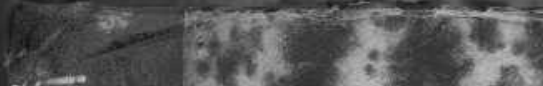

Cis

s. 48

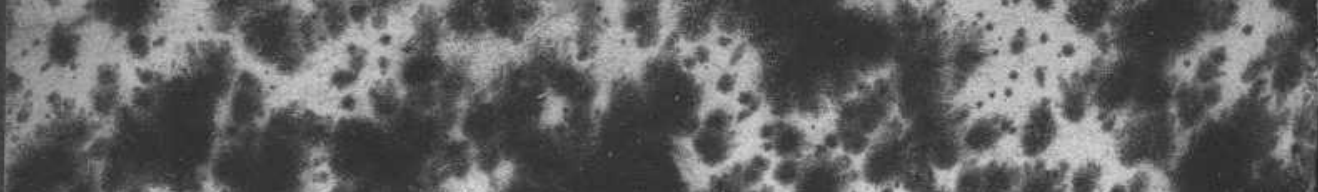

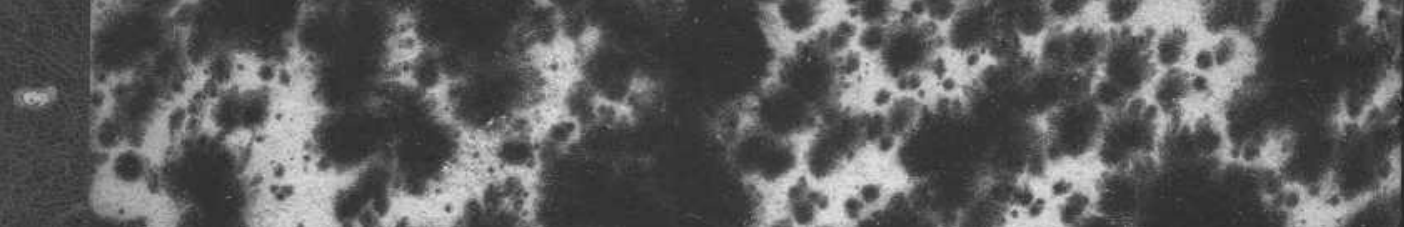

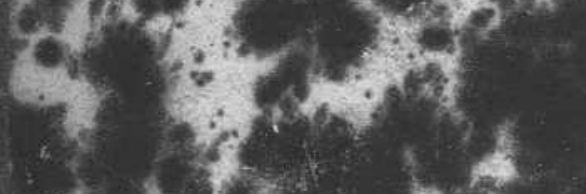

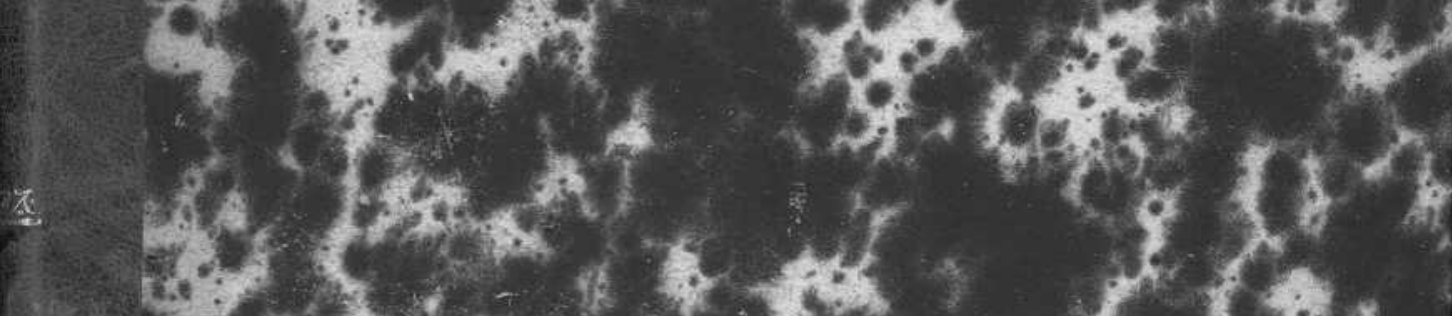

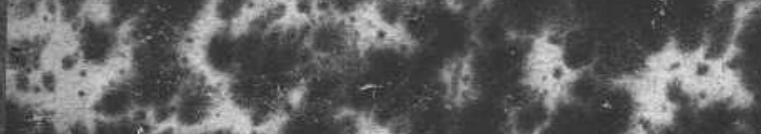

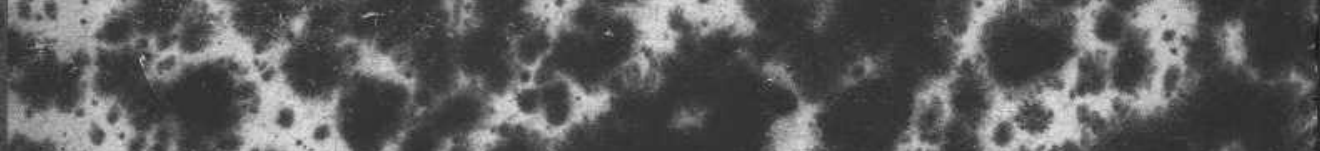

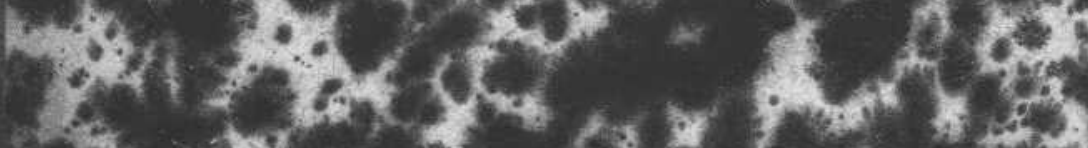
$4,2,9 * 2 \times 34$

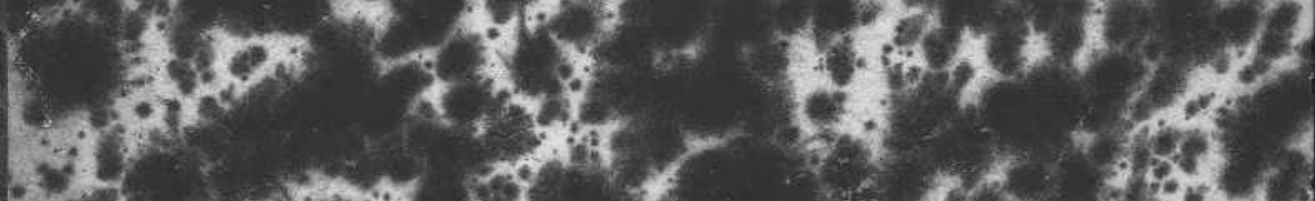

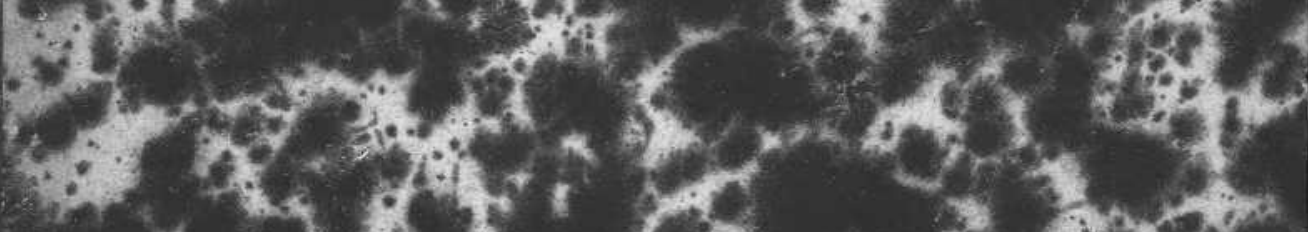

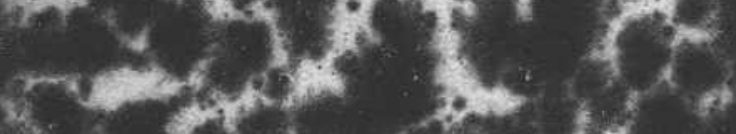

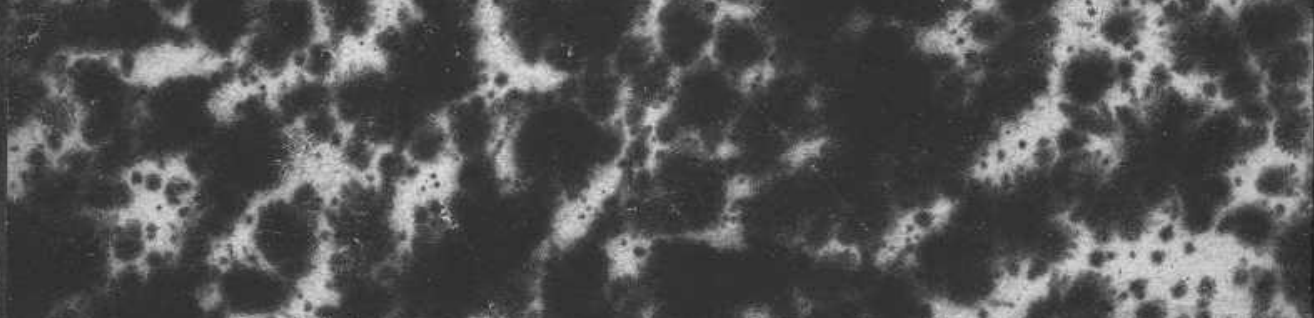

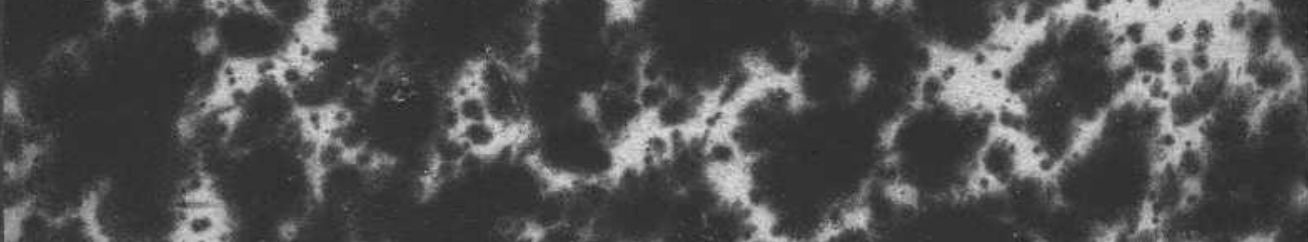

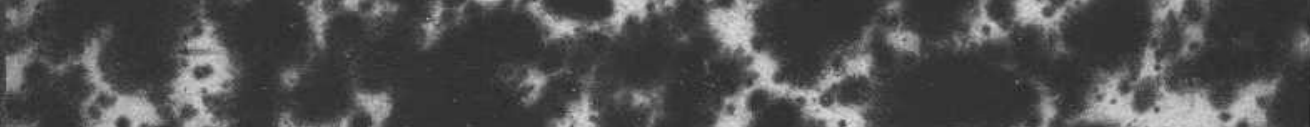

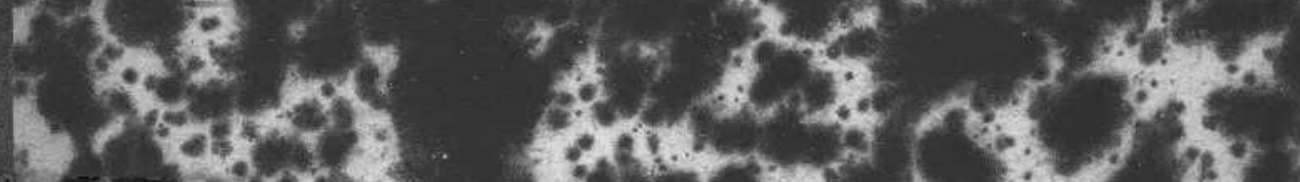

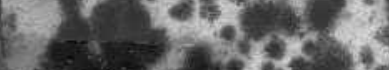

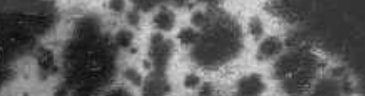

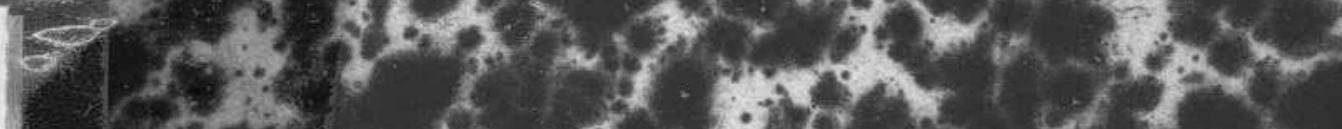

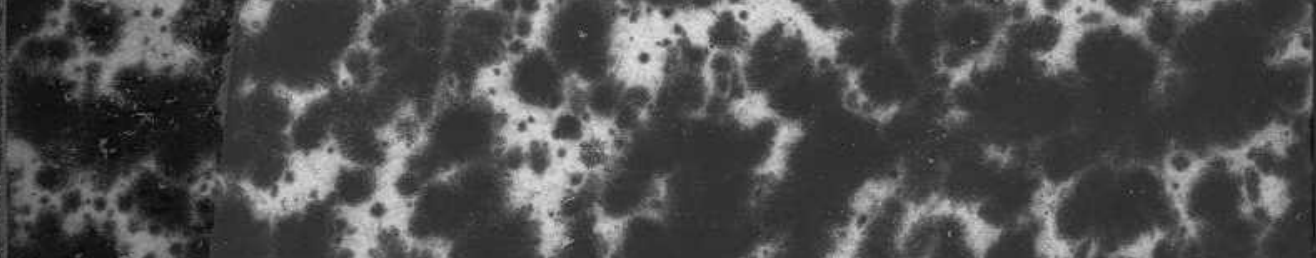

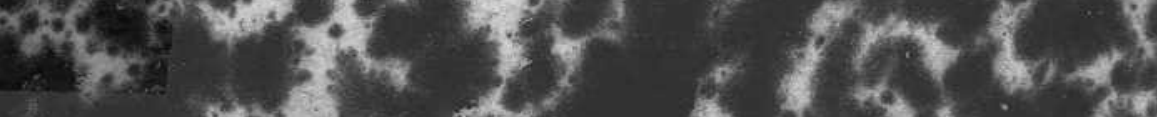

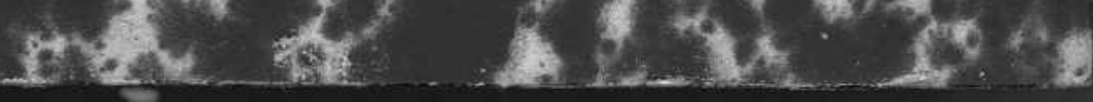




$$
6087.6087
$$




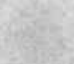

989. 
LECCIONES DE CLÍNICA MÉDICA

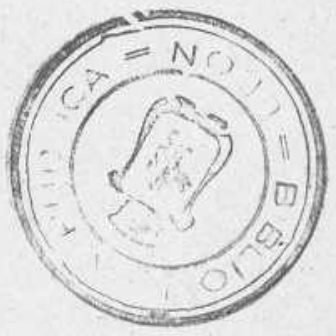





\section{LECCIONES}

DE

\section{CLINICA MÉDICA}

POR

\section{H. RENDU}

Profesor agregado á la Facultad de Medicina de París, Médico del Hospital Necker.

THADUCIDAS POR

\section{FEDERICO TOLEDO Y CUEVA}

Licenciado en Medicina y Cirugia.

\section{TOMO I}

ENFERMIEDADES GENERALES; ENFERMEDADES DEL PULMÓN Y DE LA PLEURA;

ENFERMEDADES DEL CORAZÓN Y DE LOS VASOS

\section{MADRID}

ADMIIISTRACIÓN DE LA REVISTA DE MEDICTA Y CIRUGIA PRGCTICAS

Calle de Preciados, 33, bajo.

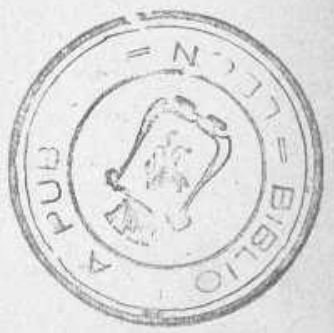





\section{Al Profesor Potain}

\section{QUERIDO MAEstro :}

Cumplo un deber sagrado de reconocimiento dedicándoos este trabajo modesto; porque siguiendo vuestras sabias lecciones es como he comprendido todo lo que puede sacarse de la observación clinica cuando la guía un espiritu investigador y un criterio sano. 



\section{Prólogo}

Los estudios clínicos que presento al público médico, son resumen de dos años de enseñanza libre inaugurada en el Hospital Necker. Emprendidos con el fin esclusivo de ser útiles á los alumnos y de hacerles analizar con todo detenimiento los casos interesantes de la clínica, no tienen más mérito que el de reproducir con la mayor fidelidad el cuadro sintomático que presentaban los enfermos. No he querido dar lecciones clásicas de patología á propósito de casos particulares, ni he pretendido tampoco hacer alarde de una erudición que muchas veces es sólo una compilación enmascarada. Mi único deseo ha sido representar con exactitud los casos patológicos observados, llevar el análisis al extremo posible con el fin de sacar todas las consecuencias prácticas. En una palabra, aunque aprovechándome de las adquisiciones recientes y admirables de la medicina experimental y de la microbiología, me he mantenido siempre en el terreno de la observación clínica convencido de que en este campo explorado tantas ve- 
ces, queda todavía mucho que descubrir, y de que el análisis del hombre enfermo, hecho con inteligencia y discernimiento, permitirá siempre sacar datos fisiológicos y terapéuticos más exactos que la experimentación en los animales.

Conseguiré por completo mi objeto, si encuentra el lector en este libro algunas ideas nuevas, algunas observaciones clínicas originales, y sobre todo indicaciones útiles para dirigir el tratamiento de los enfermos.

Me han ayudado bastante en la redacción de este trabajo, mis internos los Sres. Leflaive, Chartier y Grandhomme preparando las observaciones y notas que necesitaba y siendo siempre colaboradores eruditos y llenos de interés. Doy las gracias al Sr. Leflaive en particular, que ha recogido todas las lecciones que dí en 1888, y me ha ayudado á redactar muchas de ellas. Se las doy también á mi egregio maestro el profesor Peter, que ha tenido conmigo una benevolencia paternal y que ha puesto á mi disposición su anfiteatro del Hospital Necker. 


\section{LECCIONES}

\section{DR \\ CLINICA MÉDICA}

\section{ENFERMEDADES GENERALES}

\section{FLEBIIIS PUERPERAL SUPURADA}

Sumario: Etapas sucesivas del envenenamiento puerperal. - La flebitis es siempre una manifestación tardía y por lo general indicio de una infección atenuada.--Independencia relativa de la infección venosa y de la metritis séptica inicial. - Modos de extensión de los focos virulentos de las venas por brotes sucesivos; embolias capilares secundarias é identidad del proceso con el de la infección purulenta. - Valor pronóstico de los síntomas clínicos : posibilidad de curación con los síndromes de la piohemia.-Indicaciones terapénticas.

La enferma de que voy á ocuparme se halla hace unos dos meses en la clínica, y ha llegado al período terminal de su enfermedad, cuyas fases todas habéis seguido.

Se trata de una institutriz de dieciocho años, que se halla en la actualidad en un estado tifoideo gravísimo. Tiene de 130 á 160 pulsaciones, y es tan débil el pulso, que se asemeja á una ondulación ; la temperatura se aproxima á $40^{\circ}$, con grandes oscilaciones irregulares, como en la fiebre héctica. La mirada es lánguida y los ojos velados; tiene delirio tranquilo, que se manifiesta por indiferencia y ensueños y por incoherencia del lenguaje ; es preciso llamar mucho su atención para obtener algunas res- 
puestas cortas. La lengua está seca, pero menos que en la fiebre tifoidea, y no hay diarrea.

A pesar de este aspecto general, no se trata de una dotienentería. En efecto, el signo que llama ante todo la atención es un edema considerable de los dos miembros inferiores. Este edema es blanco, blando, algo doloroso, y se extiende hasta las regiones abdominal y lumbar.

La primera idea es la de una afección cardíaca, pero nada se nota de anormal en el corazón; la auscultación nada revela de anormal, excepto la debilidad y rapidez de los ruidos que dependen del estado general de la enferma.

Tampoco se trata de un padecimiento de los riñones, porque la cantidad de orina es normal y no contiene azúcar ni albúmina.

La historia de esta mujer demuestra que se trata de un accidente que es muy raro por fortuna, de una flebitis puerperal doble.

Dió á luz el 8 de Septiembre, hace ya dos meses. El parto fue, al parecer, normal, pero se efectuó en malas condiciones. La asistió una comadrona del barrio, cuyas torpezas hemos tenido ocasión de observar más de una vez. Quedó en el útero parte de la placenta, y no se adoptó precaución alguna para impedir la infección. A los pocos días tuvo la enferma escalofríos, y el 15 de Setiembre ingresó en la sala Delpech en un estado grave ya.

Me hallaba en dicha época ausente, y no ví á la enferma en este primer período. Pero el Dr. Hipólito Martín, encargado de la clínica en mi ausencia, me ha dado los datos más precisos sobre su estado. Presentaba entonces los signos de una metritis infecciosa. El útero, retraído de una manera incompleta y muy voluminoso, segregaba en abundancia líquidos fétidos ; la palpación y la presión eran dolorosas. Los loquios tenían el olor pútrido de la gangrena, y aunque no se notaba cuerpo extraño alguno en 
el interior de la cavidad uterina, era indudable que existían en ella fragmentos de placenta ó de membranas en descomposición.

Los accidentes se corrigieron, al parecer, por el pronto, á beneficio del único tratamiento que conviene en tales casos. Se hicieron varias veces por día inyecciones intra-uterinas de sublimado al 1 por 2000 ; los loquios tardaron poco en perder su olor, y á las cuarenta y ocho horas salió, al hacer una inyección, un trozo de placenta putrefacta. Se retrajo el útero, descendió la temperatura, y las cosas empezaron á seguir, al parecer, una marcha favorable. Los días siguientes continuaron expulsándose trozos de membranas, y el estado general de la enferma mejoró con rapidez.

El 21 de Septiembre se la hubiera creído curada por lo satisfactorio que era su estado general. Pero en esta fecha se presentó en el fondo de saco anterior de la vagina un infarto doloroso, como si principiara á formarse un abceso en dicho punto.

A los ocho días esta especie de núcleo duro se reblandeció, al parecer, y como durante este intervalo se había hecho purulenta la orina, se supuso que el flemón se abrió en la vejiga, y que la convalecencia seguiría una marcha franca.

De repente, en los días primeros de Octubre, tuvo la enferma tres escalofríos grandes de infección, con castañeteo de dientes, sudores profusos, temperatura elevada $\left(41^{\circ}\right)$ y fenómenos consecutivos de colapso.

Esto marcaba la penetración de un veneno séptico en el organismo; la infección, limitada hasta entonces al útero, se generalizó, al parecer.

Es fácil, desde este momento, rehacer la historia de la enfermedad y seguir sus diversas etapas sucesivas.

Del 8 al 20 de Septiembre, predominaron los signos de 
la retención placentaria y de la metritis; había infección de los senos del útero. Del 21 al 29 del mismo mes, se formó un flemón circunscrito peri-uterino, que, según toda probabilidad, se abrió en la vejiga. Desde entonces dejaron de estar localizados los accidentes y los escalofríos anunciaron la penetración del pus en el torrente circulatorio.

En esta fecha, nuevos signos permitieron diagnosticar la invasión del sistema venoso. El 2 de Octubre se quejó la enferma de un dolor intenso que se presentó de repente durante la noche en la fosa ilíaca izquierda, y que se propagó al poco tiempo á la pierna. Por la mañana se observó que el miembro inferior izquierdo estaba edematoso y dolorido; en el arco crural se sentía un cordón duro, que se prolongaba por el trayecto de la vena femoral. En una palabra, era el cuadro clásico de la phlegmatia alba dolens, con la diferencia de persistir la fiebre y de seguir empeorando, en vez de mejorar, el estado general.

Los días siguientes, observamos los progresos de flebitis, que, circunscrita al principio al muslo izquierdo, se propagó á la pierna, después á la excavación pelviana y, por último, al miembro inferior derecho. Esta propagación infecciosa, no se hizo en pocos días ; fue, por el contrario, lenta, y hasta fines de Octubre, tres semanas después de los primeros escalofríos, no se generalizó el edema á los dos miembros y á la pelvis.

Durante todo este período, estuvo contínuamente la enferma bajo la influencia de nuevos ataques de septicemia; vimos á cada momento reproducirse los escalofríos irregulares y el delirio, análogos por completo á los de la infección purulenta. Se afectaron también las vísceras, en particular el pulmón, que sufrió congestiones repetidas. En varias ocasiones, la respiración fue áspera en el vértice y mezclada con estertores, sobre todo en la región subclavicular izquierda, y á no haber seguido la evolución de 
los accidentes, se hubiera creído en una tuberculosis ga lopante. Estos fenómenos se agravaron de día en día; ayer mismo notamos un foco nuevo de estertores fríos en la base del pulmón izquierdo ; la respiración empieza á hacerse frecuente $y$ anhelosa, $y$ es inminente la asfixia.

La historia de esta mujer es un tipo de fiebre puerperal bastante raro y como no se ve hoy. En general, los accidentes consecutivos á la retención de la placenta ó de las membranas, siguen una marcha rápida, matan con rapidez á la enferma por septicemia ó peritonitis ; en el caso contrario, tardan poco en curar una vez que se elimina el cuerpo extraño, causa de la infección.

La flebitis sigue una marcha distinta. Es siempre un accidente tardío que corresponde, en general, á una infección atenuada. Hasta se ha considerado durante mucho tiempo la trombosis venosa como afección no séptica, y sólo se la creía resultado de una inflamación propagada á distancia y hasta de una coagulación espontánea, debida á las modificaciones de la sangre producidas por el puerperio. Es un error contra el que nunca os prevendré bastante. La phlegmatia alba dolens, aun la más ligera, que sobreviene en las paridas, es siempre resultado de una infección, por benigna que sea; y cuando se examinan de cerca las cosas, se descubre alguna complicación uterina local, una alteración del coágulo 6 algún defecto en la limpieza que originan la metritis inicial ligera. Tal es el origen, desconocido muchas veces, de la alteración venosa secundaria, la que principia casi siempre en la excavación pelviana y se propaga á la vena femoral.

En el caso actual, el proceso fue de un carácter típico singular, y es imposible considerar la flebitis doble de nuestra enferma como consecuencia de una inflamación simple. Hubo, en este caso, una causa activa de infección inicial, la retención placentaria. La herida del útero, cu- 
yos senos estaban abiertos, quedó en contacto durante toda una semana con la placenta putrefacta, en la que existían, en cantidad grandísima, micro-organismos. La infección se propagó á la mucosa uterina y á los senos, y la. metritis que existía al ingresar la enferma en el Hospital, no era una lesión puramente inflamatoria, sino, ante todo, un fenómeno séptico.

No conocemos aún por completo los agentes infecciosos. de la septicemia puerperal, á pesar de los muchos trabajos que se han publicado sobre este asunto desde la Tesis de Doléris. Parece que un estreptococo análogo, sino idéntico al de la erisipela, es uno de los factores, quizá el más importante, de la fiebre puerperal, pero no se ha demostrado que sea el único que existe ; hasta puede preguntarse si las diversas variedades clínicas de la infección corresponderán á micro-organismos distintos. Sea lo que fuere, es un hecho demostrado que la infección procede siempre de los gérmenes atmosféricos que alteran las secreciones del útero, y que la mucosa uterina primero, después los senos, sufren la acción de los microbios infecciosos.

Estos datos teóricos son en realidad muy antiguos, aunque haga sólo pocos años que se hayan aceptado. Desde 1829 admitía Dance la impregnación de los senos uterinos por un agente irritante, que producía una verdadera flebitis uterina, y sostenía, con datos suministrados por la autopsia, que el origen de la fiebre puerperal se hallaba en las venas que corresponden á la inserción placentaria. Tonnelé, al año siguiente, Boiven y Dugès, tres años después, refirieron hechos nuevos, que confirmaban la doctrina de la flebitis uterina, y en aquella época, fue creencia general que el agente irritante, no se decía aún el agente infeccioso, penetraba por la vía venosa. Los trabajos notables de Duplay y de Cruveilhier sobre las linfangitis 
uterinas supuradas, que son en definitiva las vías de propagación más comunes del veneno puerperal, hicieron olvidar las investigaciones de Dance, y la teoría de la flebitis fue relegada à segundo término hasta el día en que Béhier demostró de nuevo la realidad en sus clínicas de 1869, y Ranvier puso de manifiesto las lesiones de los senos uterinos y de las venas que les forman.

En el caso actual es indudable que existía una flebitis uterina desde la fase inicial de los accidentes. La metritis del principio no quedó aislada, y la alteración en la mucosa se propagó á los senos que quedan abiertos y preparados á la absorción de todo veneno. Recordaréis que en esta fecha, los únicos síntomas clínicos que presentaba la enferma eran aumento de volumen del útero, dolor localizado estrictamente al globo uterino, sin extenderse á las regiones laterales, $\mathrm{y}$ fetidez de los loquios. El peritoneo quedó siempre á salvo, el vientre era blando, no dilatado, indolente en absoluto, aun en las fosas ilíacas. Esta falta de peritonitis demuestra que en dicha fecha la infección estaba limitada exclusivamente al útero y á sus senos, sin linfangitis concomitante, porque las linfangitis puerperales sépticas, que supuran casi siempre, producen en pocos días peritonitis purulentas, ó cuando menos edemas flegmonosos de la base de los ligamentos anchos. En nuestra enferma nada de esto se observó, ni al principio ni después.

No nos atrevemos, sin embargo, á afirmar que los vasos linfáticos quedaran por completo á salvo, porque al parecer se formó alrededor del cuello uterino un abcesillo local, que se abrió á los pocos días en la vejiga. Pero es posible admitir también que en este caso, el proceso flegmonoso fue la consecuencia de una periflebitis (1). Lo

(1) La autopsia demostró después que existia, en efecto, un foco de supuración de origen venoso (véase la nota adicional). 
indudable es que bajo la influencia de las inyecciones intrauterinas, tardaron poco en cesar los derrames pútridos, prueba de que la mucosa del útero se reparaba y tendía á curar.

Creemos que esta curación fue completa, pero muy tardía, cuando el agente séptico había penetrado ya en las profundidades del sistema venoso intra-uterino y adquirido derecho de domicilio en el organismo. En efecto, uno de los caracteres especiales de estos fermentos animados, es quedar localizados en un punto durante algún tiempo y después germinar de repente y generalizarse. Todos los días se observa una cosa análoga en la tuberculosis : un núcleo caseoso, inofensivo en apariencia, descubre bacilos dispuestos á germinar de nuevo y á diseminarse por todo el organismo á la primera ocasión favorable.

En el caso actual no se manifestó en realidad la flebitis hasta que la lesión local uterina se hallaba al parecer en vías de regresión; de modo que hemos observado una especie de independencia de los fenómenos morbosos, porque los signos locales de la infección del útero desaparecieron cuando enfermó el sistema venoso periférico.

¿Cuál fue el mecanismo de propagación de la flebitis? En este caso, según toda probabilidad, la inflamación de la pared venosa no fue el fenómeno primitivo: hubo una trombosis, una coagulación espontánea de la sangre. Pero esta trombosis es preciso interpretarla en sentido distinto que lo hacía al principio Virchow cuando estudiaba la phlegmatia de las puérperas. No debe invocarse en este caso la composición especial de la sangre en el puerperio, ni su gran tendencia á coagularse : el estado que llamaba Vogel inopexia es sólo una fantasía. Es indudable que la sangre se coagula porque está en contacto con agentes sépticos. Los mismos organismos virulentos que determinan la metritis infecciosa continuan su obra alterando el plas- 
ma sanguíneo y formando coágulos espontáneos en apariencia, pero secundarios en realidad.-

Esta patogenia permite explicar la evolución clínica y las diferentes fases de la phlegmatia en nuestra enferma. El veneno depositado en las venas queda estacionario en ellas $\delta$ se propaga. Se forman con lentitud ciertos focos de trombosis séptica; después, pasados algunos días, en ocasiones varias semanas, producen de repente grandes coágulos que obliteran las venas en una gran extensión. Es lo que sucedió en el caso actual. La flebitis, estacionaria durante más de ocho días, se generalizó primero al miembro inferior izquierdo; luego, después de una nueva calmá, ganó las venas de la excavación pelviana y la femoral derecha, originando siempre fiebre elevada, indicio, más que del obstáculo circulatorio cada vez mayor, de la introducción de nuevas dosis de veneno en el organismo.

Esta extensión progresiva de la flebitis se manifestó por una serie de síntomas típicos.

La primera vena que se afectó fue la femoral izquierda ; vimos presentarse inmediatamente un edema difuso de la base del muslo, edema que tardó poco en propagarse á todo el miembro, y á la vez un dolor profundo, pelviano al principio, después inguinal, de irradiaciones descendentes, que señaló la marcha de la obliteración venosa. Todos estos fenómenos, que se desarrollaron con rapidez en cuarenta y ocho horas, quedaron estacionarios, hasta que un día se observó que el edema se había propagado á los grandes labios y á la región abdomino-pelviana. Este estado precedió treinta y seis horas á la invasión del miembro inferior derecho y á la infiltración de los tegumentos.

Por consiguiente, la infección venosa se hizo por etapas sucesivas, y la marcha invasora de la septicemia se reveló siempre por escalofríos y agravación del estado general. 
Estos escalofríos, que han dadoá la enfermedad de esta mujer una fisonomía tan especial, faltan de ordinario en las flebitis puerperales no supuradas, lo que tiende á hacer sospechar que las venas contienen pus, $\delta$ al menos un agente patógeno muy virulento. Es la repetición en Clínica de los célebres experimentos de Gaspard sobre la septicemia. Sabéis que este autor fue el primero que inyectó á los animales substancias pútridas. El síntoma predominante después de cada inyección era un escalofrío grandísimo, seguido de fiebre ardiente, de vómitos, diarrea y sudores profusos. A excepción de los fenómenos gastrointestinales, que jamás presentó nuestra enferma, el cuadro sintomático fue idéntico por completo. No admitimos la opinión de Hervieux, quien cree que en estas flebitis puerperales cada escalofrío corresponde á la extensión de la obliteración venosa y á la formación de un coágulo nuevo. Este puede formarse sin que haya escalofrío concomitante, y viceversa, hay escalofríos sin lesiones locales de las venas. La idea de septicemia y de infección debe predominar, en este caso, sobre la de inflamación : cada escalofrío indica una recrudescencia en los fenómenos tóxicos, cuyo sitio es la sangre.

Las pruebas de la diseminación del veneno infeccioso en esta mujer, son las lesiones viscerales secundarias que vimos desarrollarse; la flebitis séptica se asemeja en esto á la infección purulenta. Las determinaciones clínicas no son probablemente las mismas ; pero el proceso es idéntico. Se observan con menos frecuencia las supuraciones viscerales y articulares, y la ictericia infecciosa de la piohemia verdadera; pero en ambos casos se trata siempre de embolias capilares microbianas, y la única diferencia consiste en las propiedades piógenas menores del micro-organismo de la fiebre puerperal.

Es más bien una cuestión de grado que de naturaleza. 
Lo prueba un incidente ocurrido en nuestra enferma. En la primera semana de Noviembre, se quejó un día de dolor localizado en el ángulo de la escápula derecha. Nada se descubrió al examen. Al día siguiente se notaba en este sitio una pequeña elevación rojiza, dura y sensible á la presión. Dos días después se hizo manifiesta la fluctuación, y se abrió un abceso subcutáneo, indudablemente de origen embólico, idéntico por completo á los focos flegmonosos de la piohemia.

Es lógico suponer, sin afirmar que se produzcan en las vísceras supuraciones de igual índole, que estén en vías de formarse, en los pulmones de esta mujer, focos de congestión séptica; según toda probabilidad, embolias microbianas. Desde hace cerca de un mes, tiene á intervalos disnea, y se ha quejado varias veces de dolores de costado, tanto que en cierta época se pensó en la hipótesis de una tuberculosis posible. Hoy se oyen con toda claridad en varios puntos del pulmón, y en particular hacia la base izquierda, estertores finos que son indudablemente indicios de una congestión local, y quizá de un abceso metastásico en preparación.

El examen directo de la sangre de esta mujer, indica alteraciones profundas. El número de glóbulos rojos está muy disminuído, lo que se comprende dada la persistencia de la fiebre y la destrucción globular concomitante : los glóbulos blancos se hallan, por el contrario, en proporción exagerada, como sucede en todos los estados infecciosos. No ha sido posible hacer el cultivo directo del suero sanguíneo, que es muy probable hubiera dado resultados positivos; pero aunque no se ha demostrado de visu el micro-organismo patógeno, es indudable su existencia en la sangre.

A pesar de la gravedad y difusión del proceso infeccioso, resisten aún algunos órganos. Las funciones digesti - 
vas, por ejemplo, se conservan bastante bien : hasta ahora sigue en buen estado la lengua, y la enferma no ha perdido el apetito : sólo ayer ha principiado á ponerse seca la mucosa bucal, fenómeno de mal agïero. No se ha presentado diarrea, aunque es un accidente común en la septicemia. Por último, fenómeno notable, los riñones no se han interesado, la orina sigue siendo normal y no contiene albúmina. No hay, por lo tanto, indicio de nefritis, manifestación frecuente en los estados infecciosos.

Gracias á la integridad de la mayor parte de las vísceras, ha resistido hasta ahora la enferma la septicemia puerperal ; pero es dudoso que esta resistencia sea muy duradera. Desde hace cuarenta y ocho horas, accidentes de colapso indican la debilidad del corazón, y la disnea creciente hace presumir una asfixia próxima. Todo hace temer que la enferma tarde pocos días en morir.

Descartando este caso particular, de gravedad excepcional por una serie de circunstancias, no puede afirmarse como ley general que la flebitis puerperal sea siempre de pronóstico grave. Las trombosis venosas se consideran de ordinario como una forma relativamente atenuada de la infección puerperal. Son siempre tardías, y duran por término medio uno ó dos meses : la lentitud del proceso permite algunas veces eliminar el veneno cuando no se reproduce en el organismo. Además, el peritoneo queda por lo común á salvo, y cuando la septicemia puerperal interesa las venas, es raro que se presenten accidentes peritoneales, lo que no sucede en las linfangitis sépticas que se propagan en pocos días á la serosa abdominal.

En las formas graves de la flebitis puerperal, las eventualidades de más peligro son la formación de abcesos en las inmediaciones, y sobre todo la piohemia secundaria. Se cita en los casos de este género, la posibilidad del flemón pelviano; pero los abcesos de la excavación de la pelvis, 
son raros y mucho más frecuentes en relación con una linfangitis uterina. Los abcesos metastásicos de la infección purulenta, pertenecen á la historia de la flebitis supurada puerperal.

En la estadística de Tonnelé figuran en la proporción de 15 por 90 casos, 6 sea poco más de una sexta parte : en 141 casos de flebitis séptica, ha encontrado Béhier 10 abcesos del pulmón, 3 del hígado y 10 artritis supuradas. No hablo de la muerte repentina por desprendimiento del coágulo embólico, accidente siempre posible cuando hay coagulación en las venas, pero que es al parecer poco frecuente en los casos de septicemia venosa. Hervieux y Charcot han referido, sin embargo, ejemplos.

Por graves que sean los accidentes de infección y de septicemia, no debe desesperarse cuando se trata de una flebitis puerperal. He visto curar en el Hospital el año pasado una mujer que, á consecuencia de la retención placentaria, tuvo flebitis doble, abcesos subcutáneos múltiples, albuminuria y un estado caquéctico tal, que era incapaz de moverse sin vomitar y sin sentirse mal. Las inhalaciones de oxígeno, el alcohol, el café, las inyecciones de éter y el tratamiento local antiséptico, corrigieron los accidentes y curaron á la enferma.

En la clientela privada, he observado con el Dr. Polai. llon una mujer que tuvo flebitis supurada de las venas de la excavación pelviana, consecutiva á un flemón séptico de los grandes labios. Se presentaron los escalofríos de la infección purulenta, la diarrea de los estados infecciosos, y en tres ocasiones distintas, tuvo la enferma dolor de costado con estertores confluentes en la base de los pulmones. Parecía inminente la formación de abcesos metastásicos; curó después de destruir con el termo-cauterio todas las sinuosidades pelvianas, y de desaguarse esta región. La orina, lo mismo que en el caso anterior, fue albuminosa. 
Estos casos felices atenuan algo lo grave del pronóstico, pero nada quitan de su gravedad á la flebitis séptica puerperal. En muchos casos, y nuestra enferma es probable que pertenezca á este número, se concluye por morir de extenuación á los dos 6 tres meses, algunas veces á las cuatro $\delta$ cinco semanas. Puede decirse, en general, que cuanto más se prolongan los accidentes, más probabilidades hay de que cure la enfermedad. Hervieux cita casos que tardaron cuatro meses en curar.

El tratamiento de estas flebitis es el de la septicemia puerperal. Deben llenarse dos indicaciones principales : suprimir el origen de donde procede el veneno y sostener las fuerzas de la enferma.

La primera indicación es relativamente fácil de llenar, cuando se observan pronto las enfermas, y es posible oponerse á las manifestaciones iniciales de la infección puerperal. Las inyecciones intra-uterinas de sublimado al 1 por 2000, la introducción de tapones iodoformados en el interior de la cavidad del útero, la raspadura de la mucosa exfoliada y enferma, en los casos más graves, suprimen por lo general, en poco tiempo, el origen de la infección é impiden que se propague.

No sucede así cuando el agente infeccioso ha penetrado ya en el torrente circulatorio y producido trombosis venosas. En este caso, aunque es conveniente siempre continuar el lavatorio antiséptico de la mucosa uterina, no es posible afirmar que sea coronado de éxito. El caso actual prueba que puede curar con rapidez la lesión del útero, mientras tanto que el mal se propaga á las venas profundas. En tales condiciones la eficacia del tratamiento médico es muy limitada. La antipirina, recomendada recientemente, obra sólo sobre la temperatura, disminuyendo la hipertermia; el sulfato de quinina á altas dosis es, quizá, más eficaz, pero obra únicamente sobre las consecuencias 
secundarias de la fiebre sin modificar la causa primera de la flogosis. Es no obstante el agente más útil de que disponemos para disminuir, en cierto modo, las fermentaciones microbianas, y para evitar el desarrollo del agente infeccioso.

Conviene saber que la naturaleza tiende espontáneamente á eliminar los virus introducidos en el organismo. Todo tratamiento debe tener por objeto favorecer esta eliminación y activar las funciones de los emunctorios. Las bebidas calientes y alcohólicas, al favorecer la diuresis, los sudoríficos, como los polvos de Dower, las lociones vinagradas frías, al estimular las funciones de la piel, prestan servicios innegables. La leche sobre todo, como alimento completo y diurético de primer orden á la vez, es el auxiliar más eficaz de la medicación : debe combinarse con el alcohol y el extracto de carne para sostener las fuerzas.

Como en todas las enfermedades infecciosas, la profilaxis en las paridas es mucho más importante y eficaz que la terapéutica. No debe procurarse contener los estragos del veneno cuando se ha absorbido hace ya mucho tiempo y dispersado por todo el organismo, sino al principio cuando sólo ha producido accidentes locales y fenómenos de intoxicación superficial. Es indudable que si esta pobre joven, en vez de caer en manos de una comadrona ignorante y sucia, hubiera sido asistida por un médico instruído y cuidadoso, se hubiesen evitado todos estos accidentes. No hubiera habido retención de la placenta ni de las membranas, y si por casualidad hubiese quedado algo en la cavidad uterina, una irrigación antiséptica precoz habría evitado las consecuencias funestas. La omisión de estas precauciones ha puesto en grave riesgo la vida de la enferma; cuando ingresó en el hospital había producido ya sus efectos el veneno y era impotente la terapéutica. 
NOTA ADICIONAL

Como era fácil suponer, la enferma murió á los pocos días. Véanse los resultados de la autopsia practicada por mi interno el Sr. Leflaive. Confirman por completo el diagnóstico hecho en vida.

El examen de los órganos genitales demuestra que las lesiones uterinas son poco importantes. La vagina está sana; la vejiga normal, algo congestionada en su parte inferior. El cuello uterino no es grueso ni está reblandecido; no presenta ulceración alguna, La cavidad del útero se halla retraída, sin pus ni secreciones putrilaginosas. La mucosa no está engrosada ni tomentosa, es de color apizarrado liso $\mathrm{y}$ adherido al tejido subyacente. No hay, por lo tanto, indicio de metritis actual.

Al dividir el cuerpo del útero se observa que las venas están muy dilatadas; algunas contienen todavía coágulos fibrinosos. Hay en la parte anterior, en el fondo de saco vesico-vaginal, un foquillo purulento anfractuoso, que corresponde á una serie de senos venosos llenos de pus; este foco es circunscrito y está tapizado de un cascarón fibroso.

En los ligamentos anchos, en el sitio correspondiente al plexo pampiniforme, no hay islotes de supuración, pero sí coágulos fibrinosos en abundancia. El ovario está sano, lo mismo que la parte próxima del peritoneo.

Al disecar el sistema venoso abdomino-pelviano, se observa que al principio es permeable la vena cava inferior. Pero á 2 centímetros por encima de la desembocadura de las dos venas ilíacas, la pared anterior de la vena es negruzca y está reblandecida é infiltrada de un exudado putrilaginoso.

Desde la bifurcación de las ilíacas es completa la impermeabilidad de los vasos. Hay bastantes coágulos cruóricos 
que llenan por completo la vena. En la ilíaca externa derecha son cruóricos; pero en ciertos puntos se han hecho fibrinosos sin mezcla de pus. En la ilíaca interna el coágulo es indudablemente de fecha antigua, fibrinoso por completo, con una serie de estrangulaciones y de abultamientos sucesivos. El interior del coágulo está reblandecido y el centro en degeneración puriforme.

A la izquierda las lesiones son análogas, pero más acentuadas aún.La vena ilíaca externa de este lado se halla reducida á un cordón duro, fibroso, cicatricial: apenas tiene el volumen de la arteria radial. Su calibre está obliterado casi por completo. En el sitio correspondiente al arco crural forma una dilatación en forma de ampolla de gran volumen, llena de pus cremoso de la consistencia y del color de la almáciga. La supuración de la vena se continua en toda la extensión de la femoral hasta el tercio inferior del muslo; se prolonga más todavía, pero no se disecaron las venas de la pierna. La safena no contiene coágulos y se halla en estado normal.

En la excavación pelviana la vena hipogástrica izquierda está obliterada por completo y convertida en un cordón fibroso; ha debido contener pus, porque existe en un punto de su trayecto una dilatación circunscrita llena de pus caseoso como el de la femoral.

La vena femoral derecha la llena un coágulo fibrinoso antiguo, con reblandecimiento central puriforme en ciertos puntos, pero sin pus.

En resumen, resulta de este examen que, aunque la mucosa y los senos del útero han sido el punto de partida de la infección, no presentan alteración morbosa alguna, hecho que había afirmado la clínica. La flebitis interesa todas las venas de la pelvis y del muslo, y los resultados de la autopsia concuerdan por completo con los síntomas observados durante la vida, puesto que las lesiones son

Cuírica médica. - Tomo I. 
mucho más extensas y profundus en el lado izquierdo, sitio del edema inicial, y en este punto la inflamación había sido supurada.

Este es un ejemplo típico de flebitis supurada que comunicaba al principio libremente con el sistema venoso general. La alteración de la pared de la vena cava prueba que el agente séptico penetraba con facilidad en ella.

Veamos ahora los resultados de la diseminación de los productos infecciosos transportados por vía venosa.

El hígado es enorme y pesa 2500 gramos. Es graso y tiene el color moreno claro de los hígados septicémicos. El parénquima está anémico. En la cápsula de Glisson se ven estrías blanquecinas que corresponden, al parecer, á linfáticos dilatados, é islotes, blanquecinos también, que forman una serie de manchas jaspeadas. El tejido hepático es muy friable $y$ se desgarra con gran facilidad. No hay ni abcesos ni infarto.

En los pulmones existen, por el contrario, lesiones de importancia. La cavidad de la pleura izquierda contiene un derrame turbio muy purulento, próximamente un litro. El pulmón correspondiente está atelectásico y exangüe. Hacia la parte media del lóbulo inferior hay un infarto metastásico supurado del grosor de una avellana, situado debajo de la pleara y causa del derrame. La arteria pulmonar que corresponde al infarto se halla obliterada por un coágulo puriforme. En la cara interna del lóbulo superior se ve una segunda serie de infartos más recientes, unos rojos todavía, otros supurados y que han formado cavernillas gangrenosas (1). Por último, en la lengüeta anterior del lóbulo superior se encuentra un islote de bronco-pneumonía supurada, en medio del cual existen cuatro infartos de color rojo obscuro.

(1) Esta lesión fue la que simuló en vida de la enferma los signos de la tuberculosis incipiente. 
El pulmón derecho padece lesiones análogas, pero menos avanzadas. Se destacan de un fondo de bronco-pneumonía difusa infartos de dimensiones diversas y de edad variable. Al corte se descubren en ciertas arteriolas depósitos fibrino-purulentos. La pleura visceral está sembrada de manchitas equimóticas, rudimento de embolias capilares sépticas.

Los ganglios del mediastino están hinchados y vascularizados, pero relativamente sanos.

El bazo, como en la mayor parte de los estados infecciosos, es enorme y pesa 515 gramos. Su tejido es blando y friable; sobresalen en ciertos puntos de su superficie islotes de color de heces de vino que corresponden á infartos hemorrágicos. No hay indicios de focos supurados.

El corazón es blando y flácido, lleno de coágulos agónicos. El músculo cardíaco está sobrecargado de grasa y en degeneración manifiesta. Las válvulas, sin estar enfermas, se hallan engrosadas en su borde libre. Las cavidades derechas de esta víscera son delgadas y friables y contienen un coágulo de color de heces de vino pálido.

El peritoneo, aun en la excavación pelviana, no presenta lesión alguna apreciable, y lo mismo sucede con los psoas. No hemos encontrado supuración muscular. 


\section{PURPURA HEMORRAGICA INFECCIOSA}

Sumario : La púrpura no es una entidad morbosa definida.-Descripción de un caso de púrpura hemorrágica infecciosa.-Diferencias clínicas con las púrpuras de origen nervioso, la hemofilia y el escorbuto.Relaciones patógenas entre la enfermedad de Werlhof y las formas graves de púrpura tifoidea.-Lesiones embólicas comunes y presencia de micrococos en el suero sanguíneo.-Indicaciones pronósticas y terapéuticas.

Hay pocas cuestiones en clínica tan rodeada de dificultades como la púrpura. Etiología, anatomía patológica, naturaleza, todo es obscuro en esta afección; no sabemos aún si se trata de una entidad morbosa definida ó de un síndrome común á varias enfermedades. Es preciso, por lo tanto, estudiar cuidadosamente lọs casos que se presenten á la observación, hasta el día en que todos estos datos permitan hacer la historia científica de las enfermedades de la sangre. Hoy tenemos ocasión de analizar un buen ejemplo de esta enfermedad curiosa.

El enfermo ocupa el núm. 28 de la sala Chauffard, y excepto su palidez, que es extremada, tiene el aspecto de un hombre vigoroso. Es, en efecto, un joven de venticinco años, robusto y de buena constitución; pero, á causa de su enfermedad actual, se halla en un estado de anemia profunda. Sus tegumentos son pálidos y casi exangües; se oyen soplos fuertes en la base del corazón y en las yugulares; su pulso es pequeño y rápido; siente desvanecimientos en cuanto hace un movimiento brusco; fenómenos de anemia cerebral, que eran aún más pronunciados hace algunos días. Todo, en una palabra, indica que este hombre acaba de sufrir una pérdida grande de sangre. 
Voy á hacer, en pocas palabras, su historia. Hasta la edad de ventidós años jamás ha estado enfermo, ha observado una buena higiene y no tiene antecedentes de alcoholismo ni de sífilis. Pero desde hace tres años ha sufrido dos enfermedades graves, primero una fiebre tifoidea y accesos de fiebre intermitente rebelde, á los dieciocho meses de residir en Madagascar. Conviene advertir que, á pesar de la insalubridad del clima tropical, jamás revistió en él el paludismo la forma de fiebre perniciosa ni de fiebre biliosa hematúrica; pero en la última época de su permanencia en aquella isla, comenzó á sufrir anemia.

Volvió á Francia, y, al poco tiempo de desembarcar, tuvo un acceso febril durante el cual, por vez primera, se presentaron epistaxis muy abundantes. Este enfermo no era, por lo tanto, un caquéctico ni un palúdico inveterado. No tenía el color plomizo ni el edema de las piernas que se observa tan á menudo en las personas que sufren paludismo; el hígado y el bazo no estaban aumentados de volumen; la orina era clara, más bien pálida que pigmentada; nada, en una palabra, indicaba una alteración de la salud general.

En estas condiciones, buenas en apariencia, se presentaron los accidentes que voy á describir.

El 27 de Febrero último, sin causa apreciable, tuvo el enfermo por la mañana epistaxis que duró casi media hora. No prestó por el pronto atención á este fenómeno, y siguió su trabajo. Hacia las diez se reprodujo la hemorragia, pero más abundante; desde entonces hasta el día siguiente á las doce, es decir, por espacio de ventiséis horas, siguió sangrando, en más ó menos abundancia, sin el menor intervalo. La cantidad de sangre perdida excedió de 2 litros. Quedó muy débil y tuvo amagos de síncope. Al medio día fué conducido el enfermo al hospital casi exangüe $y$ en un estado de anemia grandísimo. 
$\mathrm{Al}$ día siguiente por la mañana, $1 .^{\circ}$ de $\mathrm{Marzo}$, vimos por vez primera á este hombre. La epistaxis se había contenido; pero todo el cuerpo estaba cubierto de una erupción característica. Eran manchas purpúreas, de color rojo vivo. ó violáceo, algo elevadas con relación á la epidermis, indolentes, que no desaparecían al comprimir con el dedo ni estaban rodeadas de aureola eritematosa. Era fácil conocer, por estos caracteres, una erupción de púrpura que presentaba ciertas disposiciones especiales. En efecto, en vez de las equímosis de distribución simétrica en los miembros y pliegues articulares, las manchas purpúreas estaban en este caso diseminadas con irregularidad por toda la superficie tegumentaria, y eran algo confluentes en las piernas y en los antebrazos. La cara estaba libre, pero el cuello se hallaba sembrado de ellas, sobre todo en los sitios donde roza. el cuello de la camisa y que se irritan de contínuo. Las muñecas, donde se veían vesículas de eczema, presentaban, por la misma causa, pápulas sanguinolentas mucho más numerosas, que se hacían coherentes donde se había inflamado la piel por rascamiento.

Además de las manchas de púrpura había equímosis subcutáneas más 6 menos extensas y situadas á profundidades variables : se diría que eran contusiones de fecha distinta que pasaban por matices diversos.

Hasta entonces las mucosas, excepto la nasal, habían quedado, al parecer, libres de toda lesión. No se descubrían manchas en la bóveda palatina, ni en la lengua : no obstante, dos puntos hemorrágicos que existían en la cara interna de las mejillas indicaban la invasión próxima de la mucosa bucal y, en efecto, los días siguientes se presentaron en sitios diversos de la boca equímosis numerosas.

Todos los órganos estaban sanos : no había indicio de hemorragia muscular ni de complicaciones viscerales. El corazón y los pulmones funcionaban bien; lo mismo su- 
cedía con los intestinos á pesar del aspecto melénico de las deposiciones ; parecía indudable que la sangre procedía de las epistaxis y había penetrado en el tubo digestivo, durante la hemorragia nasal. La orina no contenía indicio de sangre ni de albúmina.

Este primer ataque de púrpura que sobrevino inmediatamente después de una epistaxis abundante, fue seguido de una especie de calma, durante la cual cesaron los fenómenos hemorrágicos. En los tres días siguientes se presentaron pocas manchas nuevas, desaparecieron los vértigos, fueron más raros los desfallecimientos y mejoró el estado general. Pero de repente, el 3 de Marzo, á pesar del empleo de una medicación astringente activa, hubo una nueva epistaxis que duró más de una hora. El taponamiento de las fosas nasales con algodón empapado en esencia de trementina la contuvo por el pronto, pero siguió la pérdida de sangre por la parte posterior de la nariz. Aquella tarde hizo el enfermo una deposición negra que contenía bastante cantidad de sangre deglutida.

Dos días después (5 de Marzo) se reprodujo la hemorragia, esta vez con más abundancia; en dos ocasiones distintas duró casi dos horas, y dejó al enfermo exangüe ; cedió al fin, bajo la influencia del taponamiento anterior y posterior, y de una dosis elevada de opio y de ergotina ( 15 centígramos de extracto tebáico y 5 gramos de ergotina en poción).

Hubo un nuevo brote de púrpura en las mucosas y en la piel. Aquella tarde misma la lengua, el velo palatino, la úvula, la bóveda del paladar, el fondo de la faringe es. taban sembrados de manchas hemorrágicas, que variaban desde simples puntitos, hasta placas de más de un centímetro de diámetro. En la piel se produjo una eflorescencia idéntica : el cuello, las piernas, los brazos y el dorso se cubrieron de petequias y de equímosis. 
La situación del enfermo se agravó. Observamos por vez primera un movimiento febril notable. El termómetro marcó $38^{\circ}, 5$ y el pulso era pequeño y casi imposible de contar. El paciente no podía hacer el menor movimiento sin que sobrevinieran náuseas : su vista se nubló ; á cada instante se veía amenazado de síncopes y sentía horribles dolores de cabeza. Cada tres horas se le hicieron inyecciones subcutáneas de éter, y se le dió té con ron : se continuó la poción opiácea, alternando con ácido sulfúrico en forma de agua de Rabel.

Por la noche cesaron las hemorragias y disminuyó la fiebre : al día siguiente expulsó el enfermo sangre con las deposiciones, pero es probable que fuera la deglutida la víspera. No hubo ni hematuria ni albuminuria.

Desde aquel momento fueron raros los brotes de manchas purpúreas en los miembros ; no se reprodujeron las hemorragias de las mucosas, y la temperatura se hizo inferior á la normal $\left(36^{\circ}, 3\right)$. La convalecencia fue rápida y observamos de día en día que el enfermo recobraba fuerzas y se atenuaban los síntomas funcionales. Hoy está conjurado, al parecer, todo peligro, y excepto la anemia excesiva que persiste por necesidad, parece que ha terminado de una manera definitiva la crisis hemorrágica que acaba de atravesar el paciente.

He aquí una afección aguda que ataca á un joven que ha sufrido antes paludismo, pero que se halla en plena salud ; esta afección es ante todo hemorrágica ; apirética al principio, se hace febril á cada brote nuevo, y durante cada recidiva origina una erupción confluente de manchas equimóticas y de sufusiones sanguíneas. Después, cuando se agrava el enfermo y parece inminente la muerte, sobreviene un período de calma, señal de una convalecencia rápida.

¿Qué nombre dar á esta enfermedad singular? Desde el 
punto de vista dermatológico, es indudablemente púrpura ; pero, como sabéis, este nombre no da idea alguna clara respecto al diagnóstico de la especie nosológica, porque comprende una serie de grupos morbosos diversos que corresponden á casos distintos.

Aunque sin pretender tratar en extenso de la patología de la púrpura, manifestaré que existen cuatro clases principales, descartando las erupciones purpúricas, consecutivas á la ingestión de ciertas substancias medicamentosas, como el ioduro potásico.

Hay primero púrpuras de origen nervioso que son quizá las más comunes de todas. En este grupo no existen lesiones vasculares ni alteraciones de la sangre; la diapedesis hemorrágica se efectua en virtud de trastornos congestivos vaso-motores. Esta variedad de púrpuras se observa en dos circunstancias diferentes. Unas veces es sintomática de una lesión de los nervios ó de la médula espinal, y se la ve sobrevenir á consecuencia de una neuritis ó en el curso de la ataxia locomotriz (Straus); otras, por el contrario, es sintomática y constituye la mayor parte de los casos de púrpura simple.

El cuadro clínico es en este caso el siguiente. La erupción principia de pronto á consecuencia de un enfriamiento $o ́$ de una impresión moral. Va precedida por lo común de pródromos que consisten en hormigueo, picor, sensación de adormecimiento ó de quemadura en los miembros inferiores; después se presenta edema agudo de los tegumentos, que precede inmediatamente á la aparición de manchas purpúreas y se repite siempre que hay un nuevo ataque fluxionario. El rasgo característico de esta variedad de púrpura es presentarse en forma de punteado finísimo, sin elevación papulosa de la piel y sin equímosis subcutáneas. Los sitios predilectos de la erupción son los miembros inferiores ; nunca, 6 casi nunca, invade las mucosas 
ni produce hemorragias viscerales. Las manchas están dis tribuídas por la piel con una simetría perfecta, no sólo respecto al conjunto, sino también al detalle de su repartición; se observan á la vez, por lo común, trastornos de la sensibilidad, de ordinario hiperestesia, pero en ocasiones también anestesia.

Es indudable que esta definición no corresponde á los síntomas clínicos que observamos en nuestro enfermo. En éste la extensión y confluencia de las manchas hemorrágicas, su asimetría, su propagación á las mucosas, y sobre todo, la fiebre de que iban acompañadas las recrudescencias del exantema, no permiten suponer que se trate de una púrpura simple.

Otra segunda categoría de púrpuras, que debemos también eliminar en el caso presente, la constituyen las sintomáticas de las enfermedades generalas. La aparición de manchas hemorrágicas en los miembros, es frecuente durante varias afecciones crónicas y constituye casi siempre un signo pronóstico grave. Estas púrpuras se observan de preferencia en los tuberculosos y en los cancerosos, aun antes del período de caquexia final, $y$ he tenido ocasión de demostraros varias veces el valor sintomático de las equímosis espontáneas de la región dorsal, de las manos y de las muñecas como indicio de una tuberculosis latente en los viejos. Los diabéticos, los albuminúricos y los pelagrosos las padecen también á menudo.

Esta variedad de púrpura es por lo común fácil de diagnosticar. Además de lo grave del estado general de los enfermos, tiene caracteres especiales fáciles de conocer. La erupción se limita casi siempre á los miembros inferiores, de preferencia á las piernas y los pies. Presenta cierta simetría de conjunto y está constituída por manchas equimóticas extensas y de forma irregular en vez del punteado lenticular de la púrpura simple. Las equímosis casi nunca 
interesan el tejido celular subcutáneo ni las mucosas, aunque el año anterior vi un ejemplo notable de esta generalización en una tuberculosa. No es preciso discutir este diagnóstico.

Llegamos á otra categoría de púrpura, cuyo origen es mucho más obscuro, y que dependen al parecer de una alteración primitiva de la sangre. Constituyen este grupo dos enfermedades principales, la hemofilia y el escorbuto, y necesitamos discutir la posibilidad de accidentes de este género en nuestro enfermo.

La hemofilia constituye una predisposición especial original y transmisible por herencia en ciertas familias, en virtud de la que la sangre carece al parecer de sus propiedades plásticas normales y se coagula con mucha dificultad. Casi siempre se necesita una circunstancia particular que origine una hemorragia, para revelar la existencia de la hemofilia. Un traumatismo insignificante, una cortadura, la extracción de un diente, van acompañados de una hemorragia abundantísima, que cuesta mucho trabajo contener. Entonces se sabe que existe esta predisposición en varios individuos de la misma familia. Otras veces los ataques de hemofilia son menos típicos y se presentan en el curso de una enfermedad intercurrente. Conozco una familia de hemofílicos, dos de cuyos miembros murieron á causa de hemorragias sintomáticas de afecciones muy diferentes al parecer. El hijo murió de hemorragia intestinal durante una fiebre tifoidea, su hermana de hemorragia cerebral acompañada de apoplegía retiniana, hallándose padeciendo nefritis. $\mathrm{El}$ año anterior estuvo expuesta á morir de metrorragia que sobrevino en el período menstrual. Pero además de este dato fundamental de la herencia, que falta por completo en nuestro enfermo, los caracteres clínicos de la hemofilia son muy diferentes. Pocas veces, por no decir nunca, se manifiesta esta enfermedad por púrpura verda - 
dera ; las hemorragias se presentan en una gran extensión por las mucosas, ó son viscerales, faltan las manchas cutáneas diseminadas, excepto las equímosis subcutáneas que producen los roces más ligeros.

El escorbuto, por el contrario, se parece más al cuadro clínico que presentaba nuestro enfermo. En las formas ligeras se observan manchas purpúreas en los miembros inferiores, á la vez que los signos de anemia general, fenómenos que van acompañados en ciertos casos de hemorragias por las mucosas. Pero las manchas tienen la forma de elevaciones papulosas, ocupan el sitio de los folículos pilo-sebáceos, y no son máculas planas diseminadas indistintamente por los tegumentos. Este carácter, sobre el que insistió Lasègue y que asemeja la erupción escorbútica al acné hemorrágico, no se observa en nuestro enfermo. En las formas graves, el cuadro es aún más diferente. Además de las pápulas sanguinolentas diseminadas por los tegumentos, existen extensas placas equimóticas, cutáneas y subcutáneas, $\mathrm{y}$ hemorragias intra-musculares que forman verdaderos tumores dolorosos en la continuidad de los miembros. Las encías se afectan siempre y tienen la forma de rebordes fungosos, violáceos, que cubren el cuello de los dientes y exudan un líquido sanguinolento fétido. En estos casos se observan trastornos tróficos graves, alteraciones óseas, separación de las epífisis, accidentes todos que indican la debilidad profunda del organismo.

El caso actual no es indudablemente de naturaleza escorbútica. A pesar de la confluencia de la erupción purpúrea bucal, las encías están sanas ; únicamente se observan en ellas algunos puntitos hemorrágicos. Además, el escorbuto sólo se desarrolla en condiciones especiales de alimentación defectuosa : es una enfermedad de hambre que tiende á desaparecer cada vez más, y aunque la salud de nuestro enfermo durante su permanencia en Madagas- 
car se resintió á causa del paludismo, no creemos que esta influencia telúrica fuera capaz de desarrollar en él tendencia al escorbuto.

Queda un último grupo de púrpura, que comprende los exantemas hemorrágicos de las enfermedades infecciosas. Pertenecen á esta clase, no sólo las fiebres eruptivas, por ejemplo, la viruela, y en casos más raros el sarampión y la escarlatina, sino las enfermedades microbianas como la endocarditis ulcerosa, que se revelan muchas veces por embolias sépticas cutáneas, de determinación purpúrica. El reumatismo merece quizá ser incluído en esta categoría, porque hay reumatismos infecciosos que van acom. pañados de hemorragias cutáneas y mucosas, y por otra parte, la púrpura espontánea coincide muchas veces, como sabéis, con manifestaciones articulares y endocarditis. Según la doctrina actual del Hospital de San Luis, la púrpura llamada reumática es una enfermedad infecciosa más bien que un reumatismo clásico. Me limito á indicar esta hipótesis, de la que no participo en absoluto, y cuya discusión me conduciría demasiado lejos.

$\mathrm{El}$ caso de púrpura que estudiamos hoy pertenece á la clase, mal conocida todavía, de las púrpuras infecciosas. Es, en efecto, el tipo de la púrpura hemorrágica primitiva, de la enfermedad maculosa de Werlhof.

Recordaré, en pocas palabras, el carácter de esta afección. Principia de repente en plena salud, y sin pródromos. Los enfermos tienen á la vez hemorragias por las mucosas y manchas purpúreas en la piel, sin que la distribución del exantema afecte una simetría rigurosa. La fiebre falta de ordinario en las manifestaciones primeras de la enfermedad; pero se presenta en las recrudescencias nuevas, detalle indicado por el profesor Lasègue (1) en un trabajo publicado hace varios años, pero que es de exac-

(1) Lasègue, Archiv. gén. de méd., 1877. 
titud maravillosa. Después de una serie de ataques congestivos, principia la convalecencia, aunque dejando muy debilitado al enfermo. ¿No es este, rasgo por rasgo, el cuadro que hemos observado?

Tal es la púrpura hemorrágica benigna, la enfermedad de Werlhof curable. Pero además de este tipo, que representa la forma ligera de la infección, hay una serie de formas graves descritas, en 1883, por A. Mathieu y Gomot con el nombre de púrpura tifoidea. En este caso, el principio no sólo es brusco y caracterizado por la aparición en plena salud de hemorragias múltiples, sino que éstas van acompañadas del cortejo de síntomas malignos que caracterizan la invasión de las grandes pirexias; la fiebre se inicia con cefalea persistente, quebrantamiento grandísimo, sequedad de la lengua, albuminuria y raquialgia, como en la viruela. El enfermo pierde á la vez el apetito, y cae en un estado de colapso : es un verdadero principio de tifus.

Estos síntomas generales van precedidos $\delta$ acompañañados de hemorragias ; son á la vez cutáneas, mucosas y viscerales, y de ellas, las más frecuentes y abundantes, son las hematurias. Fenómeno notable, á pesar de estas hemorragias, es raro ver que descienda la temperatura en el momento de las crisis de púrpura, lo mismo que sucede en otra enfermedad infecciosa, la fiebre tifoidea, en la que, cuando hay hemorragia intestinal grave, el termómetro suele marcar $40^{\circ}$ después de la pérdida de sangre.

Más todavía: en ciertos casos, se ve en las manchas equimóticas formarse placas gangrenosas, testimonio irrecusable de la naturaleza séptica del proceso hemorrágico. Potain y Martin de Gimard, han observado casos de este género.

En el fondo, parece lógico suponer que estas formas benignas y graves no son entidades morbosas distintas. Los síntomas fundamentales que se observan son los mismos, 
atenuados en el primer caso, exagerados en el segundo. Resulta, al parecer, de la marcha y de la evolución de estas púrpuras, que los gérmenes infecciosos penetran en la piel y en las mucosas por vía embólica, según toda probalidad, y que las embolias capilares sépticas producen fluxiones sanguíneas locales y equímosis. El que la reacción sea variable y la gravedad diferente según los individuos, puede ser debido á la virulencia diversa del contagio $o ́$ á la resistencia mayor ó menor del sujeto contaminado. No debe hacerse clases distintas de las púrpuras, según que sean ó no febriles $\delta$ que vayan acompañadas de hemorragias más $\delta$ menos difusas. Estas divisiones, tienen un valor desde el punto de vista pronóstico, mas no así desde el nosológico, porque sólo indican grados de una misma afección. Es probable que en estos diversos casos sea la misma la patogenia, y que tanto las púrpuras benignas, como las graves, reconozcan una etiología común.

Confieso que esto es una hipótesis que necesita confirmación más decisiva, pero se funda en hechos bien observados. Se ha demostrado por completo la naturaleza infecciosa de estas púrpuras. En 1876, descubrió Hayem, en un caso de púrpura mortal, lesiones del hígado idénticas á las de la septicemia é infección purulenta, á saber : manchas anémicas y abcesos miliares ; descubrió también colonias de leucocitos aglomerados en la dermis cutánea, cerca de las manchas hemorrágicas. Balzer prosiguió estas investigaciones; no sólo descubrió las mismas masas de glóbulos blancos, sino que demostró la presencia de micrococos, pero no se atrevió á afirmar su influencia patógena. Klebs, en Alemania, y Wickham Leg, , en Inglaterra, obtuvieron resultados análogos.

Un médico italiano, Petrone, completó estos datos por la experimentación. Descubrió en la sangre tomada de una mancha de púrpura, bacilos y micrococos que logró culti- 
var. Los líquidos de estos cultivos, inoculados á los conejos, produjeron hemorragias. Un interno de los hospitales, Martin de Gimard, ha repetido estos estudios (1888), sacando de ellos conclusiones análogas. En varios casos mortales de púrpura, ha observado siempre foquillos miliares de leucocitos en la piel y en el parénquima renal, y en el centro de estos abcesillos, islotes de micrococos ; jamás los ha visto asociados con bacilos. Los cultivos han permitido multiplicar el micrococo y hacer inoculaciones sucesivas.

Mi interno Grandhomme, ha examinado la sangre de nuestro enfermo; ha visto desarrollarse á las cuarenta y ocho horas una colonia de micrococos análogos á los descritos por Gimard; pero como no se han hecho experiencias de contraprueba inoculando los líquidos de cultivo, no es posible afirmar la identidad de los dos microbios. El hecho tiene un gran interés, porque prueba la existencia de un micro-organismo infeccioso en las formas ligeras de púrpura hemorrágica, lo mismo que en las variedades tifoideas.

¿Es idéntico el microbio patógeno? Se presume, pero es imposible afirmarlo. Lo que parece indudable, es que las manchas purpúreas dependen de pequeñas embolias microbianas, y que estas embolias son sépticas en cierto modo. En cuanto á saber de dónde proceden los microbios que circulan así en la sangre, es una cuestión desconocida aún, respecto á la que se tienen pocos datos. Se supone que en la mayor parte de los casos, el germen procede del exterior; ciertos hechos que me ha referido el Dr. Champetier de Ribes, autorizan á creer que se produce algunas veces una auto-infección ; en efecto, este médico distinguido ha visto sobrevenir la púrpura en una mujer embarazada, que conservaba en el útero el feto macerado. 
Es indudable que otros agentes microbianos patógenos son capaces de producir hemorragias cutáneas y viscerales, y están dotados de virulencia mucho mayor. Basta recordar lo que sucede en la viruela hemorrágica, en la que la aparición de equímosis y de pápulas sanguinolentas es indicio de una malignidad excesiva y hace el pronóstico casi desesperado. En la endocarditis infecciosa, la presencia de manchas purpúreas diseminadas por la piel es de un augurio funesto, y anuncia la muerte próxima. En la púrpura hemorrágica, por el contrario, la aparición de manchas sanguíneas numerosas, $y$ hasta de hemorragias múltiples de las mucosas, no indica por necesidad un estado grave, y el caso actual basta por sí sólo para demostrar que las propiedades sépticas del agente infeccioso son mucho menores, porque el enfermo curó en poco tiempo. Es indudablemente un micro-organismo distinto del de la viruela y del de la endocarditis infecciosa; el hecho de que la púrpura hemorrágica nunca es contagiosa, prueba bien á las claras que, aunque el proceso embólico es común á estas enfermedades diversas, la naturaleza del microbio patógeno es muy diferente.

Hasta aquí llegan las nociones de patogenia que poseemos; todo lo demás es hipótesis pura. Si queremos saber por qué se desarrolló la púrpura en el caso actual, sólo encontraremos indicios vagos. Puede preguntarse si la fiebre tifoidea anterior, y sobre todo el paludismo, habrán obrado como causas predisponentes. Esto es verosímil si se recuerda que durante su acceso último de fiebre intermitente, tuvo el enfermo dos epistaxis bastante abundantes, que fueron como la primer advertencia y el esbozo de los accidentes actuales. El resto ha debido hacerlo el trabajo fatigoso que puso al organismo en un estado vulnerable grandísimo. Estas consideraciones se aplican á todas las enfermedades infecciosas, pero nada prueba que sean verdaderas. Clínica médica. - Tomo I. 
Nada más difícil que diagnosticar la púrpura infecciosa. La gravedad real de los accidentes no se halla siempre en relación con la intensidad de los pródromos y de los fenómenos febriles; una púrpura que principia de un modo insidioso y que, al parecer, es benigna, se complica de pronto y se hace grave, sólo por la abundancia y la repetición de las hemorragias; otra que parecía ser al principio grave, cesa y desaparece sin dejar rastro. Deben considerarse, en general, como indicios desfavorables la existencia de una fiebre alta y de una gran hipertermia; la presencia de albuminuria y de hematurias (este síntoma último por alarmante que sea, no entraña siempre un pronóstico desfavorable, porque he visto curar dos enfermos en quienes se presentó con caracteres de importancia); por último, las complicaciones como la congestión pulmonar y la miocarditis.

En toda púrpura hay una doble fuente de peligro; la infección de la economía y la pérdida de sangre que puede ser'excesiva. El peligro primero no tiene tanta gravedad como el segundo; por consiguiente, lo confieso, he abrigado grandes temores por la suerte de nuestro enfermo, cuando vi repetirse por tercera vez las epistaxis que duraban días y que ocasionaban una pérdida de varios litros de sangre. Por fortuna es joven y ha rehecho sus glóbulos con gran rapidez, á semejanza de las mujeres paridas, quienes después de hemorragias uterinas abundantísimas, se reponen en pocas semanas.

En el tratamiento de la púrpura hemorrágica hay que llenar una indicación doble : oponerse á la infección de la sangre y contener la tendencia á la difusión hemorrágica. La primera de estas indicaciones es difícil de llenar, porque no disponemos de un agente antiséptico capaz de destruir los gérmenes que circulan con la sangre ni sabemos que exista. Puede suponerse, por analogía, que el sulfato 
de quinina llena en parte esta indicación, por sus propiedades anticimóticas. Además, por su acción astringente y vaso-constrictora es útil para contener las hemorragias, y mi antiguo maestro Gueneau, de Mussy, le prefería á todos los demás hemostáticos en los casos graves.

Nuestro enfermo ha tomado todos los días un gramo de sulfato de quinina en dos dosis, y cuando se presentaban la fiebre y las epistaxis, combinada con el opio á altas dosis ( 15 centígramos de extracto tebáico), medicamento que, según Gubler, obra muchas veces cuando son ineficaces los demás. He procurado al mismo tiempo hacer más plástica la sangre por medio de los astringentes ácidos, cuyo tipo es el ácido sulfúrico, y durante más de una semana prescribí en limonada 4 gramos diarios de agua de Rabel al día. Creo que la acción de este medicamento es mucho más eficaz que la de las preparaciones de cornezuelo de centeno, y sobre todo de ergotina, que hablando con propiedad obran sólo sobre el elemento muscular, y he visto que casi nunca son eficaces en los casos de púrpura hemorrágica. Quizá sean útiles asociadas á las medicaciones precedentes. 


\section{DE ALGUNAS DIFICULTADES DE DIAGNOSTICO AL PRINCIPIO}

DE LA FIEBRE TIFOIDEA

Sumario: Las formas atenuadas de la fiebre tifoidea son las que exponen con frecuencia á errores de diagnóstico.-Formas abdominales de tipo de embarazo gástrico: caracteres sacados de la temperatura, del estado de la orina y de las condiciones epidémicas. - Fiebres tifoideas de principio faringeo : anginas precoces intensas ó ligeras. - Formas caracterizadas por predominio de los vómitos. - Fiebres de tipo torácico inicial que simulan la pulmonía, la grippe ó la tuberculosis miliar aguda ; asociación posible de la granulia y de la fiebre tifoidea.

La epidemia de fiebre tifoidea que reina hoy en París, nos permite comparar muchas formas de esta enfermedad y estudiar las evoluciones diversas. Aquellos de vosotros que asistís á la Clínica, habréis visto que muchas veces esta enfermedad, que se presenta de ordinario con un aspecto tan sorprendente, es difícil de conocer, y cuán insidioso es su principio. Voy á ocuparme hoy de estas dificultades clínicas que observáis todos los días : no hay en la práctica una cuestión cuyo conocimiento sea más útil.

Partamos, si queréis, de un tipo normal. Lo presenta un joven de dieciocho años, que ingresó hace ocho días en la sala Chauffard y ocupa el núm. 26. De buena salud habitual, se sintió, sin causa apreciable, hace doce días fatigado y débil: perdió el apetito, sintió pesadez en las piernas, náuseaś y soñolencia. A los cinco días de este malestar vago, notó de pronto una mañana cefalalgia fuerte y dolores en la nuca: hubo epistaxis durante el día y por la tarde un acceso fuerte de fiebre. A la mañana si- 
guiente se encontró abatido y sin fuerzas y acudió á la consulta del hospital.

Recordaréis el aspecto característico que presentaba aquel día : su cara bultuosa, algo cianósica, la indiferencia y el estupor con que respondía á las preguntas, su marcha vacilante indicaban el principio de una fiebre tifoidea.

Observamos por completo los tres grupos de síntomas que caracterizan esta enfermedad : síntomas cerebrales, abdominales y torácicos.

La cefalea era el trastorno funcional predominante: gravativa, contínua, iba acompañada de zumbidos de oídos y de vértigos ; durante el reposo el enfermo estaba soñoliento y postrado, aunque no podía conciliar el sueño.

La lengua, sucia y roja en la punta, estaba ya seca y pegajosa. Había diarrea de color de ocre.

$\mathrm{El}$ aparato torácico principiaba á afectarse, la respiración era bastante frecuente (35) y en las grandes inspiraciones se oía estertor sibilante bronquial.

La orina, roja y escasa, contenía una gran cantidad de albúmina.

La fiebre tenía los caracteres típicos que presenta en la dotienentería, es decir, que á una aceleración mediana del pulso correspondía una elevación grandísima de la temperatura. Las pulsaciones no excedían de 80 por minuto y el termómetro oscilaba entre $39^{\circ}, 5$ y $40^{\circ}$.

$\mathrm{He}$ aquí un caso normal de fiebre tifoidea, de mediana intensidad y cuyas manifestaciones morbosas diferentes se equilibran sin que predomine ningún grupo de síntomas. En estas condiciones el diagnóstico es siempre fácil y puede preverse con ciertas probabilidades, que la evolución de la enfermedad será regular.

Pero no siempre se observa este tipo clásico, y muchas veces se presenta la fiebre tifoidea con caracteres que la en- 
mascaran. El error es debido á dos clases de anomalías : unas veces faltan los pródromos y los síntomas habituales de invasión ; otras predominan de tal manera ciertas. manifestaciones cerebrales, pulmonares y torácicas que cambian la naturaleza del mal. Hay, por último, casos numerosos en los que la dificultad procede de la atenuación de los trastornos funcionales, y la afección se desconoce por lo insignificante y benigna.

Revisaremos estas diferentes variedades, principiando por las formas en las que predominan los síntomas abdominales. La más frecuente de todas es el embarazo gástrico. Tenemos un buen ejemplo en la joven de dieciséis años que ocupa el núm. 11 de la sala Delpech. Esta joven, después de tres días de pródromos vagos, se sintió fatigada, quebrantada. Ingresó en el hospital con inapetencia, sed insaciable, lengua sucia y fetidez del aliento; no ha tenido diarrea. A excepción de estos síntomas, nada de típico observamos : ni erupción tífica, ni hipertrofia del bazo, ni dolor ilíaco, ni gorgoteo, ni el menor síntoma cerebral, ni tendencia alguna al estupor. Hoy mismo, aunque hace cuatro días que está sometida la enferma á la observación, es imposible resolver la cuestión y afirmar si se trata de un embarazo gástrico simple $\delta$ de una fiebre tifoidea ligera.

A decir verdad, esto es únicamente una sutileza del lenguaje, porque en muchos casos el embarazo gástrico constituye por sí solo una verdadera fiebre tifoidea en miniatura. El síndrome conocido con este nombre no es, en efecto, una entidad morbosa definida en su naturaleza y siempre comparable á sí propia. Unas veces es indicio de un trastorno local del estómago, de un catarro gástrico pasajero, como el que se observa á consecuencia de la ingestión de alimentos indigestos $6 \mathrm{mal}$ condimentados, y entonces se corrige con el más ligero purgante; otras, por 
el contrario, es epifenómeno de una afección aguda, una angina 6 una pulmonía, por ejemplo. Es común como estado morboso espontáneo, independiente de toda causa apreciable y sin lesión orgánica ; en tales casos, constituye, al parecer, una enfermedad general ligera. $Y$ lo que prueba sus relaciones con la fiebre tifoidea es que durante las epidemias de dotienentería, se ven multiplicarse estas formas mal definidas, que se asemejan á simples embarazos gástricos, y que coinciden con frecuencia en una misma familia, con formas más graves.

Estas fiebres contínuas ligeras, cuya virulencia está indudablemente atenuada, bien por la resistencia del individuo, ó por la naturaleza del virus contagioso, han sido descritas recientemente con el nombre de tifoidetas. Creo que la joven á que aludía hace poco es un ejemplo de ello. Pero los caracteres clínicos que sirven para diferenciar la tifoideta del embarazo gástrico son bastante vagos y tienen sólo un valor relativo. El más importante, según Griesinger y el profesor Jaccoud, es la marcha de la curva térmica. El embarazo gástrico verdadero se caracteriza por la elevación brusca de la temperatura, á la que sigue un fastigio corto y un descenso rápido. Al contrario, la tifoideta reproduce atenuados los caracteres clásicos de la curva tifoidea ; es decir, que la temperatura se eleva progresivamente en dos 6 tres días, el fastigio presenta algunas oscilaciones, $\mathrm{y}$ el descenso es gradual, con exacerbaciones vespertinas.

Estos caracteres son importantes, pero no creo que haya derecho para formularlos como ley general. Es indudable que en los casos típicos de catarro gástrico sucede lo que dice Griesinger, y que su curva térmica difiere sensiblemente de la de las fiebres tifoideas atenuadas; pero se observan tipos intermedios de evolución idéntica. La temperatura no debe aceptarse como un criterio constante, porque se 
ven embarazos gástricos apiréticos al lado de otros febriles. Hay más : existen verdaderas fiebres tifoideas en cuya evolución no se observa elevación alguna de la temperatura. Hemos tenido en la clínica un hombre cuyos síntomas fueron clásicos por completo, que tenía diarrea, erupción de manchas rosadas, estupor y cefalea de la fiebre tifoidea, que estuvo tres semanas enfermo, principiando la convalecencia á los veinticuatro días : ahora bien; la temperatura jamás excedió de $38^{\circ}, 2$, y en el apogeo de la enfermedad se mantuvo en $37^{\circ}, 5$. Es preciso, por lo tanto, no contar en absoluto con la temperatura, aunque en general da indicaciones exactas.

Hay otros dos síntomas que hacen presumir la existencia probable de la fiebre tifoidea; me refiero á los caracteres de la orina y á la marcha de la enfermedad.

La orina, en el embarazo gástrico verdadero, es con frecuencia turbia y de color encendido; hasta contiene algunas veces indicios de pigmento biliar, pero casi nunca es albuminosa. En la tifoideta, por el contrario, aunque suele faltar la albuminuria, se la observa de cuando en cuando; de modo que la presencia de una nube albuminosa tiene en estos casos un gran valor. Sabemos, desde las investigaciones de mi maestro Gubler, cuán frecuente, por no decir constante, es la albuminuria durante la fiebre tifoidea.

En los casos dudosos es preciso tener en cuenta la duración de los pródromos. El malestar prodrómico que persiste tres días y más es una anomalía en la historia del catarro gástrico simple, en tanto que es casi la regla absoluta en las fiebres tifoideas atenuadas, en las que los fenomenos prodrómicos son casi tan acentuados como en las formas más graves. La convalecencia es diferente : el embarazo gástrico cesa de repente y de una manera definitiva; pero la tifoideta fatiga á los enfermos más de lo que 
hace suponer la benignidad de los síntomas y los deja en un estado de abatimiento durante una 6 dos semanas.

Por último, ciertos datos facilitan el diagnóstico de estas formas ligeras : muchas veces en la casa que habita el enfermo ha habido otros casos análogos parecidos al embarazo gástrico ó á la fiebre tifoidea. La noción de una epidemia domiciliaria equivale casi á la certidumbre del contagio y precisa la naturaleza de la enfermedad. Hemos observado hace poco tiempo un caso de este género. Recordaréis la mujer, nacida en Auvernia, que permaneció sólo seis días en la sala Delpech, y á la que se dió de alta á ruego suyo: la enfermedad fue diagnosticada de embarazo gástrico. Tres días después ingresó su hermana, que vivía en la misma casa, con fiebre tifoidea típica ; es indudable que este llamado embarazo gástrico era una forma atenuada de dotienentería. En dicha casa, habitada por 30 vecinos, cinco han padecido fiebre tifoidea.

Al lado de estas formas que simulan un embarazo gástrico, hay otras que inducen á error, porque se presentan con la máscara de una angina.

Las determinaciones faríngeas de la fiebre tifoidea son frecuentes, pero es fácil casi siempre conocerlas, porque se presentan en un período de la enfermedad en el que son patognomónicos los síntomas é innegable la intoxicación tífica : este faringo-tifus, como se le llama, se caracteriza unas veces por ulceraciones pterigoideas, descritas con todos sus detalles por Duguet, otras por erosiones foliculares : el diagnóstico en este caso jamás es dudoso.

El error es posible, y algunas veces casi inevitable, cuando la primer manifestación de la infección tífica es una angina eritematosa de apariencia trivial. El hecho es más frecuente de lo que se cree. Uno de mis discípulos antiguos, el Dr. Vaison, agregado entonces al Colegio de Enrique IV, estudió este asunto é hizo observaciones no- 
tables. Observó en los colegiales, de cuya asistencia estaba encargado, que de cada diez casos de fiebre tifoidea principiaba uno por angina. Heobservado esto con toda claridad en dos casos, de los que uno sobre todo nada presentaba que indicara la inminencia de la dotienentería. En 1883 fuí llamado cierto día para visitar al criado de uno de mis clientes que padecía angina de gran intensidad hacía veinticuatro horas : se temía la invasión de una difteria ; la faringe estaba roja, hinchada, tapizada de un exudado pultáceo, y la fiebre era elevada. Mi impresión primera fue que se trataba de una amigdalitis flegmonosa in. cipiente ó de la escarlatina : llamó mi atención que el enfermo padeciera tanto por un simple mal de garganta, y reservé el diagnóstico suponiendo que se trataba del principio de una enfermedad general, pero, lo confieso, sin pensar lo más remoto, en una fiebre tifoidea. Al día siguiente tuvo el enfermo una epistaxis y presentaba el aspecto de estupor característico del estado tifoideo. Las manifestaciones anginosas ocupaban un lugar secundario ; el estado general era ya el de la dotienentería, que recorrió, en efecto, todas sus fases, originando accidentes gravísimos, en particular hemorragias intestinales que estuvieron á punto de ocasionar la muerte. En este caso la faringe sirvió al parecer de puerta de entrada al microbio infeccioso, y las manifestaciones primeras de la toxemia se presentaron en las fauces lo mismo que, sucede en la erisipela. Habéis visto hace poco tiempo otro ejemplo análogo, no tan grave, pero no menos insidioso: me refieróá un hombre que, después de varios días de malestar, ingresó en el hospital con dolor fuerte en la faringe y angina eritematosa de apariencia reumática. A los cinco días se presentaron las manchas rosadas con todo el cortejo de síntomas de una tifoidea de forma mucosa.

En tales circunstancias, el diagnóstico es indudable- 
mente de los más inciertos, porque estas anginas precoces de la fiebre tifoidea no tienen carácter alguno especial que permita afirmar su naturaleza, y es imposible contar con el aspecto hipertrófico de los folículos cerrados de la faringe que se indica como signo bastante especial, pero que falta muchas veces. Debe sospecharse esta eventualidad si se observan fenómenos febriles que no guardan proporción con el estado local, sobre todo si está seca la lengua y hay cefalalgia. Pero aun en estas condiciones es muy dificil evitar el error; la marcha de los accidentes es la que indica la naturaleza verdadera. En efecto; sabéis con cuánta frecuencia se ve una angina ligera que va acompañada de un estado general grave; la amigdalitis más benigna produce en su principio escalofrío y fiebre, en ocasiones colosal, con una cefalalgia tan fuerte, que Lasègue la comparaba á la de la meningitis. Se sospechará la posibilidad de una angina tifoidea precoz cuando se vean presentarse á los pocos días pródromos de cansancio y de quebrantamiento general sin causa ocasional apreciable. La sequedad precoz de la lengua y de la faringe, la falta de adenitis concomitantes, la hipertrofia de los folículos cerrados, que presentan en ciertos casos hasta erosiones superficiales, hacen sospechar algunas veces el principio de la dotienentería ; pero en esta enfermedad ocurre lo mismo que en la erisipela : los caracteres de la angina sintomática casi nunca son bastante típicos para poderlos conocer con seguridad.

Acabo de hablar de las fiebres tifoideas de principio faríngeo-anormal : véase ahora toda una categoría de hechos en los que otro síntoma predominante, el vómito, enmascara el aspecto habitual de la enfermedad. El error es posible, sobre todo en dos circunstancias especiales : cuando se trata de niños 6 de mujeres embarazadas.

La dotienentería de los niños va acompañada siempre, 
como sabéis, de vómitos, en la de los adultos, dicho síntoma es muy raro. El predominio de dicho síntoma hace sospechar una meningitis tuberculosa en preparación, tanto más cuanto que en los dos casos la cefalalgia y el quebrantamiento general son síntomas comunes. Se comprende que haya casos dudosos. Pero los caracteres de los vómitos son distintos. Los de la fiebre tifoidea son frecuentes y abundantes y sólo se presentan después de la ingestión de las bebidas. Los de la meningitis son, por el contrario, raros y espontáneos, sin que los provoque la ingestión de alimentos, y son por lo común biliosos : coinciden además muchas veces con lentitud é irregularidad del pulso que resuelven toda duda, por indicar su origen bulbar.

En algunas mujeres embarazadas se observan en ocasiones accidentes del embarazo, mal conocidos todavía, que simulan por completo la fiebre tifoidea. Consisten en vómitos frecuentes, incoercibles en ciertos casos, que van acompañados $\delta$ no de diarrea de mediana intensidad, pero que se complican con fiebre de grandes oscilaciones y de exacerbación vespertina. El estado tifoideo es manifiesto y llega al estupor. El aborto produce, en tales enfermas, de ordinario la curación, aunque el feto que se expulsa no está siempre macerado y no ha sido, por lo tanto, causa de una septicemia intra-uterina. Se citan, no obstante, casos desgraciados que terminaron por la muerte. La esposa de uno de nuestros colegas murió así al cuarto mes de su embarazo, y después de una enfermedad de quince días. El profesor Pinard creyó que se trataba de una fiebre tifoidea verdadera, pero otros médicos, competentes también, supusieron que fueron accidentes simples del embarazo, pero jamás se aclaró el diagnóstico, prueba de las dificultades insuperables que suele haber en tales circunstancias. 
Hemos revisado hasta ahora los casos en los que el predominio de los síntomas abdominales inducen á error. Existen otros muy frecuentes, en los que la fiebre reviste, desde los primeros días, los caracteres de una enfermedad torácica. Los ejemplos de este género abundan hoy, y uno de los caracteres de la epidemia actual es presentar el aspecto de una enfermedad de las vías respiratorias. Así sucedió con la joven María B... (sala Delpech, núm. 23), que se halla convaleciente de una fiebre tifoidea bastante grave. Los accidentes simularon al principio una grippe $\delta$ una pulmonía : escalofríos, dolor de costado, tos, opresión grandísima; se pensó al principio en una brōncopneumonía, y el error duró hasta la aparición del exantema tífico, dos días después. El núm. 9 de la misma sala le ocupa una joven que padece dotienentería en condiciones idénticas. El 10 de Diciembre último, pasó la noche en su taller y se enfrió: al día siguiente tuvo escalofríos, quebrantamiento general, cefalea y tos ; al ingresar en el hospital se oían en todo el pecho estertores sibilantes. Cedieron los síntomas de bronquitis, pero siguió siendo grave el estado general, y á los ocho días se presentaron las manchas rosadas abdominales.

En otro enfermo (sala Chauffard, núm. 24) la marcha del padecimiento fue análoga. Ingresó con escalofríos, fiebre, dolor en el costado derecho, $\mathrm{y}$ al principio presentaba el aspecto de un individuo que padeciera grippe de intensidad mediana ; los estertores sibilantes eran moderados y la temperatura casi normal. Al día siguiente cambió la escena : el estado general se agravó y el enfermo estaba soñoliento y abatido; principiaba á presentarse la erupción tífica. A los diecisiete días tuvo una hemorragia intestinal abundantísima á consecuencia de la cual murió ; el intestino estaba sembrado de úlceras profundas.

Notaréis, señores, la semejanza de todos estos casos. Es 
preciso tener en cuenta la estación fría que atravesamos y los enfriamientos que son pretexto del principio de la dotienentería, porque esta evolución es excepcional en las epidemias estivales. El frío no origina la fiebre tifoidea, pero localiza sus manifestaciones en el pulmón que se resiente de preferencia. Es necesario conocer esta particularidad que hace muy difícil el diagnóstico.

La grippe, que reina también en esta estación, es una enfermedad general, lo mismo que la dotienentería, infecciosa como ella y se anuncia por pródromos casi idénticos. La cefalalgia es excesiva desde el principio, el quebrantamiento general ; la tos y la opresión no se manifiestan al pronto, $y$ algunas veces predominan en este período inicial los síntomas de catarro gastro-intestinal ; la epistaxis no es rara, nueva analogía con una fiebre contínua incipiente. El cuadro clínico de las dos afecciones es, por decirlo así, el mismo. El diagnóstico debe fundarse en síntomas poco importantes, y sobre todo, en la marcha distinta de la enfermedad. Los datos suministrados por el termómetro tienen, en general, un gran valor. En la fiebre tifoidea, excepto en casos raros, la temperatura es más elevada mientras que, por el contrario, el pulso permanece siendo lento. El profesor Jaccoud insiste con razón sobre esta especie de disociación de los elementos de la fiebre que es, en efecto, especialísima. En la grippe, el pulso es, por el contrario, bastante rápido, y la temperatura queda relativamente baja. Este es un primer carácter diferencial.

El segundo lo demuestra el análisis de los síntomas funcionales. La cefalea de la grippe es, sobre todo, frontal y constrictiva ; la de la fiebre tifoidea es más difusa y cuando se localiza predomina en la región occipital y en la nuca. La raquialgia cervical, decia Gubler, es casi tan constante en la dotienentería como la lumbar en la virue- 
la. Existen además otros signos diferenciales de ambas afecciones. En la grippe el catarro oculo-nasal es uno de los síntomas más constantes, lo mismo que al principio del sarampión ; falta siempre en la fiebre tifoidea. Los fenómenos traqueales son constantes y van acompañados de accesos de tos contínua sin expectoración notable; nada de especial se rota al auscultar; en la fiebre tifoidea sucede lo contrario. La tos en esta enfermedad es rara, pero son numerosos los extertores de bronquitis. Los dolores torácicos y articulares son mucho más fuertes que en la grippe y más ligeros los síntomas gástricos. Si es necesario, en los casos dudosos, un vomitivo puede servir de signo diferencial, porque sólo se obtiene con él poco alivio en los tíficos, mientras que en la grippe corrige casi por completo el malestar.

Hay otra enfermedad que por su localización torácica, simula por completo la fiebre tifoidea : es la tuberculosis miliar aguda. En las formas infecciosas de generalización rápida es dificil el diagnóstico, hasta el punto de persistir la incertidumbre hasta la muerte del enfermo. La tuberculosis, en efecto, procede entonces como las enfermedades infecciosas generales. Lo mismo que la fiebre contínua, tiene un período de incubación ó de preparación, largo muchas veces, y pródromos que anuncian la invasión inmediata : invade desde luego, como ésta, todos los órganos y produce en pocos días un estado general, que recuerda la adinamia de los tíficos. El cuadro clínico es más completo cuando la tuberculosis es á la vez torácica y abdominal. Recordad el enfermo cuya autopsia practicamos hace unos ocho días. Después de una semana de pródromos obscuros, durante la cual predominaron al parecer los signos de una bronquitis ligera, presentó de repente síntomas abdominales graves : meteorismo, tensión dolorosa del vientre, diarrea, nada faltaba, ni aun las manchas ro- 
sadas lenticulares que todos vísteis, y que eran de las más típicas. El estado general correspondía á estos síntomas locales, el estupor era grande, la audición torpe y la inteligencia obtusa. Tardaron poco en presentarse paresia vesical, incontinencia de orina y complicaciones de bronco-pneumonía, de las que murió el enfermo. En la autopsia, en vez de la dotienentería, que parecía indiscutible, encontramos tuberculosis miliar difusa, no sólo pulmonar, sino del peritoneo, de los intestinos y de los riñones : había á la vez dos úlceras en la válvula íleo-cecal. De modo que ni aun después de la muerte fue posible afirmar si el enfermo había sucumbido sólo de su tuberculosis, ó de una tuberculización difusa complicada con fiebre tifoidea. Se ha observado ya este hecho, y nada tiene de sorprendente la superposición de dos enfermedades infecciosas como la tuberculosis y la dotienentería. Hace algunos años, mi colega Barié presentó en la Sociedad Anatómica los ejemplares patológicos procedentes de un enfermo, en el que durante la vida había sido dudoso el diagnóstico entre la granulia y la fiebre contínua. Al hacer la autopsia se descubrieron en el intestino ulceraciones transversales manifiestamente tuberculosas, y otras verticales, diseminadas con irregularidad, que sin la existencia de las primeras se hubiera afirmado que eran de naturaleza tífica. La mayoría de los médicos que vieron las lesiones, admiraron la coexistencia de la infección tuberculosa y de la tífica.

Otras muchas enfermedades diferentes son susceptibles de confundirse con la fiebre tifoidea; y en el grupo de las dotienenterías anormales de tipo torácico, merece indicarse el pneumo-tifus, forma rara, en la que los signos iniciales del envenenamiento tífico son los de la pulmonía lobular compacta. No hemos observado ejemplo alguno de este género en la epidemia que acabamos de atravesar, $y$ ante 
todo me atengo á los hechos que habéis visto. No me ocupo, por la misma razón, de las fiebres tifoideas de principio cerebral, susceptibles de confundirse con las meningitis ó las otitis agudas y viceversa ; ni de las formas puramente febriles que simulan las grandes afecciones telúricas, como el paludismo ó las intoxicaciones espontáneas supuradas, por ejemplo, la piohemia ó la osteomielitis. La discusión de todos estos tipos morbosos me llevaría demasiado lejos, y además pertenecen á la patología general y se describen en todos los libros clásicos. 


\section{ARTERITIS TIFOIDEA}

Sumario : Evolución de un caso simple de arteritis femoral durante una fiebre tifoidea benigna.-Asociación posible de la flebitis y de la arteritis ; dificultades del diagnóstico. - El edema de la raiz del miembro es compatible con la arteritis sola, sin complicación venosa. - Mecanismo de la obliteración arterial ; no es una embolia ni una trombosis espontánea, sino una arteritis séptica que origina secundariamente la coagulación de la sangre.-Formas graves de la arteritis que producen la gangrena; lesiones anatómicas. - Propagación de las lesiones arteriales durante la fiebre tifoidea.-Pronóstico de la arteritis tífica.Tratamiento.

Tenemos en este momento en la clínica una joven de veinte años que presenta una complicación bastante rara de la fiebre tifoidea, sobrevenida durante su enfermedad.

Se ha presentado en circunstancias bastante especiales y ha principiado de una manera rara. La enferma, á consecuencia de un enfriamiento, tuvo un escalofrío, dolor en el costado izquierdo y presentó signos de bronquitis y de congestión pulmonar. Pero observamos á la vez abatimiento desproporcionado con los síntomas torácicos y sequedad de la lengua. Al día siguiente se presentó diarrea y con ella el exantema característico de la fiebre tifoidea.

Excepto este principio irregular, la evolución de la enfermedad fue normal por completo y de intensidad moderada ; la enferma jamás pareció hallarse en peligro, y el 20 de Noviembre, á los veinticinco días, podía considerársela convaleciente. El $10^{\circ}$ de Diciembre estaba al parecer curada, el 6 principib á levantarse y á andar algo por la sala, sin cansancio aparente.

Aquella tarde, el termómetro, que desde hacía una se- 
mana marcaba $37^{\circ}$, se elevó grado y medio. A la mañana siguiente procuré descubrir el origen de esta recrudescencia febril, pero no encontré la causa, la enferma se hallaba bien y todos sus órganos funcionaban normalmente.

Aquel día se levantó y paseó por la sala sin sentir dolor local ; por la tarde hubo nueva elevación térmica mayor que el día antes $\left(39^{\circ}\right)$.

Por la noche la despertaron dolores vagos en el miembro inferior izquierdo. El malestar fue creciendo ; era como adormecimiento doloroso de la pantorrilla y llegaba á la sensación de contusión de la pierna. Hubo á la vez impotencia funcional verdadera; el miembro estaba pesado y la enferma sentía al moverse dolores fuertes.

Al siguiente día por la mañana, 8 de Diciembre, observamos síntomas que explicaban la fiebre de los días anteriores.

Existía á lo largo del muslo, y sobre todo en el pliegue de la ingle izquierda, un dolor que seguía el trayecto de la arteria femoral. Era una especie de torsión permanente de esta región, más parecida á la presión dolorosa que á verdaderas punzadas; se propagaba siguiendo al cordón vasculo-nervioso del muslo. En el resto del miembro notaba la enferma sensibilidad vaga y difusa de igual naturaleza, pero menos intensa.

Los movimientos más ligeros exacerbaban el dolor ; lo mismo sucedía comprimiendo en el trayecto de los vasos. Las masas musculares, por el contrario, eran casi indolentes á la presión.

La impotencia funcional que principió á acentuarse durante la noche se hizo completa, no sólo eran dolorosos los movimientos, sino casi imposibles.

El miembro inferior estaba muy hinchado y era de forma característica ; el muslo tenía el aspecto de una pierna de carnero, cuya parte más abultada correspondía á la raiz 
del miembro; la tumefacción iba disminuyendo poco á poco desde este punto ; era nula hacia el tercio inferior del muslo. Llamo vuestra atención sobre este aspecto, porque es contrario por completo al que se observa en la flebitis; en ésta, el edema principia en el pie y llega al máximum en la parte inferior de la pierna.

Merece indicarse otro carácter; la naturaleza de este aumento de volumen que en nada se asemeja al de los miembros afectados de flebitis. Es duro, difuso é interesa el muslo en su totalidad y no los tegumentos solos; apoyando el dedo sobre la tibia, no queda huella de la presión. Hay vascularización venosa algo exagerada que indica un éxtasis sanguíneo en todo el miembro inferior; pero no se ven en él ni placas de equímosis ni sufusiones hemorrágicas.

Averiguamos la temperatura local : el termómetro marcaba $35^{\circ}, 5$ en ambos lados, fenómeno digno de citarse, porque no sucede siempre lo mismo. La regla en tales casos es la refrigeración inicial' del miembro enfermo.

Ante estos síntomas, desarrollados durante una fiebre tifoidea, acuden á la imaginación varias hipótesis.

Puede pensarse en un flemón profundo del muslo. No insisto en esta hipótesis, inadmisible en absoluto ; faltan, en efecto, en nuestra enferma los signos locales de la inflamación, rubicundez y calor de la piel, y los generales que indican la formación del pus, escalofríos y tendencia al colapso.

Otra suposición más racional, es la posibilidad de una miositis. La fiebre tifoidea ataca de una manera profunda al sistema muscular ; Zencker ha demostrado que, á consecuencia de esta enfermedad, sufren los músculos una degeneración granulo-grasosa ó cérea y se hacen friables. Obsérvase esto, de preferencia, en la pared anterior del abdomen, y algunas veces también en los músculos ad- 
ductores del muslo. Pero no se produce una miositis generalizada á todo un miembro. Atendiendo sólo al dolor espontáneo, podría sospecharse una alteración limitada á los adductores ; pero la sensibilidad á la presión permite localizar este padecimiento fuera del grupo de dichos músculos. Por otra parte, el dolor espontáneo de la miositis se presenta en forma de calambres atrocas é intermitentes ; por último, en la miositis hay siempre fiebre elevadísima y un estado general grave, lo que jamás se ha observado en nuestra enferma.

Nos vemos obligados, por exclusión, á admitir una lesión vascular, localizada en el paquete vasculo-nervioso del muslo. En efecto, los trastornos funcionales, no sólo llegan al máximum en este punto, sino que el examen físico de la región revela un signo de los más importantes. Palpando con suavidad la cara interna del muslo, es fácil sentir un cordón duro grueso, que ocupa el mismo sitio que la arteria y la vena femoral, y que, según toda probabilidad, lo forman uno ó más vasos inflamados.

La cuestión es averiguar si está inflamada la vena $\delta$ la arteria, 6 los dos vasos. Es un problema algo difícil de resolver.

Parece indudable, ante todo, que no se trata de una flebitis superficial de la vena safena interna. El cordón duro estaría mejor formado, sería más accesible al dedo y se apreciarían con más claridad los nódulos valvulares constantes en las venas subcutáneas del miembro inferior cuando están obliteradas. Además, la trombosis de la safena jamás produce, en general, aumento de volumen del miembro, porque no trastorna en alto grado la circulación de la pierna y del muslo.

Si la obliteración vascular recae en una vena, ésta sólo puede ser la femoral. La flebitis profunda de ésta es fácil de apreciar por la palpación, de ordinario, pero no siem- 
pre. Habéis visto, hace pocas semanas, un ejemplo de ello en una mujer que padecía accidentes puerperales; la vena estaba obliterada en su totalidad, y se apreciaba bastante mal el cordón femoral, á causa de la hinchazón difusa de los tejidos inmediatos.

Es poco probable que se halle obliterada en este caso la vena crural, porque no hay hinchazón excesiva de la pierna y del muslo, que jamás falta en tales circunstancias, ni la circulación venosa colateral que se desarrolla siempre cuando es impermeable el tronco venoso principal del miembro. He insistido sobre la circunscripción particular de la hinchazón del muslo, que sólo está aumentado de volumen en la proximidad del pliegue de la ingle, mientras que la pierna y el pie conservan su volumen y aspecto normales. Todo lo contrario sucedería si hubiera trombosis de la vena femoral.

El estado de los tegumentos es una prueba más. En la flebitis femoral, el edema es difuso y superficial ; la piel es blanca, lisa, tensa, y conserva la huella del dedo; en este caso, está, por el contrario, violácea, congestionada y apenas conserva la depresión digital pasajera. Esto prueba que no hay éxtasis sanguíneo notable de los tegumentos ni derrame seroso del tejido celular, análogo al que existe en las grandes obliteraciones venosas.

Llegamos á suponer, por exclusión, que el riego sanguíneo está perturbado en la arteria femoral. Véase, en efecto, un signo de gran valor que confirma la hipótesis de la arteritis. Aunque intentemos descubrir los latidos arteriales á lo largo del trayecto de la crural, vemos que faltan por completo. No se sienten ni en el pliegue de la ingle, ni en el hueco poplíteo, ni en la pedia, lo que prueba bien á las claras que no se trata de una disposición local. No hay una anomalía anatómica, porque los latidos de la arteria femoral son fuertes, en todo su trayecto, en el 
miembro inferior derecho. No es posible tampoco invocar la compresión que ejercería sobre la arteria la vena crural distendida por un coágulo, porque en este caso se notan siempre pulsaciones arteriales en el triángulo de Scarpa, allí donde el paquete vascular reposa sobre un plano óseo resistente, y es posible comprimirlo con facilidad; además, en los casos de flebitis, el cordón duro está situado por dentro de la arteria, cuyos latidos persisten.

Por consiguiente, si ha desaparecido el pulso femoral, es porque está enferma la arteria. No podemos afirmar que haya obliteración de la arteria crural, en la parte superior de su trayecto, allí donde la palpación es dolorosa, y que la obliteración se extienda quizá más abajo. La ilíaca se halla, al parecer, sana; la presión del dedo por encima del pliegue de la ingle no es dolorosa, y el edema cesa hacia el arco crural ; es probable, por lo tanto, que sean permeables la ilíaca externa y la hipogástrica.

¿Cómo explicar, admitiendo la hipótesis de una obliteración de la arteria femoral, la hinchazón de la raiz del muslo que observamos en este caso? La objeción a priori parece bastante capciosa para que haya derecho á preguntar si á la vez que una lesión arterial no habrá también flebitis local. Las venas de esta región se encuentran, en efecto, más distendidas y dilatadas que en estado normal en relación con las del lado sano.

Pero no es necesario invocar una lesión vascular doble, que no justifican en modo alguno los signos suministrados por la exploración directa de la zona enferma. Siempre que se oblitera la arteria de un miembro, se trastorna bastante la circulación venosa correspondiente, por suspenderse la tensión arterial y la vis à tergo. La primera consecuencia de esta supresión es el éxtasis sanguíneo en las venillas, lo que explica la rubicundez violácea y la tumefacción de los tegumentos. A estos fenómenos se agre- 
ga también cierto grado de parálisis vaso-motora, que contribuye á aumentar la dilatación pasiva de las venas, que es lo que observamos en este caso. La abundancia aparente de su red venosa tegumentaria no depende de la obliteración de un tronco grueso que rechaza de una manera mecánica la sangre en las vías colaterales : es sólo cuestión de paresia vaso-motora y de éxtasis sanguíneo. Además, aunque dilatadas, las venas no presentan el aspecto que presentarían si fuera impermeable la vena femoral.

Insisto sobre este punto, porque es el único argumento que puede oponerse, en casos análogos, á la hipótesis de una arteritis. La hinchazón del miembro y la vascularización anormal de los tegumentos son, vuelvo á repetir, compatibles en absoluto con la idea de una obstrucción arterial. Por paradógico que esto parezca, ¿no vemos todos los días, en los experimentos y en la clínica, embolias arteriales que producen infartos, cuyo carácter anatómico es precisamente la infiltración sanguínea venosa llevada hasta el último límite, y que termina por la sufusión hemorrágica? En este caso, la arteria se ha obliterado con lentitud, así que sólo se observa dilatación de las venillas, pero no hemorragias : el mecanismo es, no obstante, el mismo.

Resulta de lo que antecede, que, en nuestro caso, durante una fiebre tifoidea benigna, se obstruyó más 6 menos por completo la arteria femoral, pero de una manera bastante gradual para no trastornar la vitalidad, la sensibilidad y modificar sólo la calorificación. La lesión se produjo casi sin provocar reacción general.

Estudiemos ahora el mecanismo de esta obliteración arterial.

Puede explicarse por tres hipótesis : la embolia, la trombosis $\mathrm{y}$ la arteritis. 
Algunas particularidades de la historia clínica de nuestra enferma podrían hacer sospechar una embolia. El principio brusco del dolor, la aparición rápida de la hinchazón, concuerdan bastante con esta hipótesis, que justifica la frecuencia de las manifestaciones cardiacas de la fiebre tifoidea. La analogía de la dotienentería con las grandes enfermedades infecciosas, como la difteria, la viruela, la endocarditis ulcerosa, en las que los micro-organismos sépticos forman algunas veces embolias en los capilares, hace muy verosímil esta hipótesis. Aunque en teoría puede sostenerse la idea de una embolia séptica arterial, nada hay que lo demuestre. La enferma, durante todo el curso de su fiebre tifoidea, jamás padeció síntomas que hicieran sospechar una complicación cardíaca; no hemos observado en ella ni debilidad de los ruidos del corazón, ni desigualdad de las pulsaciones, ni disminución de la energía del pulso, nada, en una palabra, que se asemejara á la miocarditis. La aorta y las arterias han estado siempre sanas, al parecer. Añadiré que los fenómenos embólicos son, por lo común, más bruscos é inmediatos : el dolor en nuestra enferma se presentó por la tarde y duró toda la noche, y el miembro no apareció hinchado hasta por la mañana. Una obliteración instantánea de la arteria hubiera producido la impotencia repentina y trastornos más intensos y persistentes de la calorificación.

Es más admisible el mecanismo de la trombosis. Es de suponer, en efecto, que desde hace algunos días se preparaba en la enferma los elementos de una coagulación, que terminó con rapidez, porque durante dos noches consecutivas tuvo algo de fiebre antes de aparecer síntoma local alguno: este movimiento febril indicaba indudablemente el trabajo patológico que se efectuaba en la arteria femoral. Además, en la fiebre tifoidea, lo mismo que en todas las demás enfermedades caquécticas, la sangre está alterada y 
tiende á coagularse ; esto constituye el estado al que se da el nombre de inopexia.

Pueden hacerse objeciones fundadas á esta hipótesis. La trombosis marasmática es una complicación de las enfermedades crónicas, excepcional por completo en las pirexias agudas. Además, recae casi de una manera exclusiva en el sistema venoso, aunque el Profesor Charcot cita casos raros de trombosis arterial. Por último, se manifiesta por síntomas diferentes, mucho más localizados si se me permite la frase. Cuando un tuberculoso $\delta$ un canceroso sufre una trombosis de esta clase, se presenta en la vena obliterada un dolor circunscrito, y el infarto apenas si se extiende más allá de los límites de la región afectada.

En nuestra enferma la tumefacción, aunque menos difusa que en la flebitis general, interesa la mayor parte del muslo y ocasiona la impotencia casi absoluta. Los estados que predisponen á estas coagulaciones marasmáticas no existían en ella, porque precisamente se la consideraba como curada, y su anemia era ligera, puesto que la fiebre había sido muy benigna.

La hipótesis más verosímil en este caso es la de una arteritis primitiva. La causa ocasional fue, al parecer, la marcha: en efecto, el primer día que la enferma paseó por la sala, tuvo un acceso febril. Es probable que los movimientos de flexión y de extensión del muslo ocasionaran la irritación local de la arteria, porque se ha observado muchas veces en Clínica que las lesiones arteriales que se desarrollan en el curso de las enfermedades infecciosas, están localizadas siempre en los sitios donde se encorvan los vasos, allí donde la elasticidad de la pared arterial entra en juego más á menudo. Pero es indudable que no hubiera podido influir una causa tan trivial, si no hubiese estado enferma ya la arteria, ó al menos en estado de inminencia. 
morbosa : y esto nos obliga á examinar el papel respectivo del coágulo y de la lesión parietal.

Es difícil siempre conocer cuál es la lesión inicial en tales casos. ¿ Se forma el coágulo espontáneamente é inflama por su presencia la pared arterial? ¿O se coagula la sangre en el sitio en que la pared enferma ya ha perdido su epitelio? Pueden sostenerse una y otra teoría, pero creo más probable la segunda.

Me explico de la manera siguiente el mecanismo de esta lesión compleja. Es indudable que durante el período de estadio de la fiebre tifoidea, la sangre sirve de vehículo á gérmenes infecciosos, sobre todo al bacilo de Eberth. Estos gérmenes, arrastrados por la circulación, tienden á fijarse en los sitios donde la corriente sanguínea se hace más lenta por una causa cualquiera : las corvaduras arteriales son una de las condiciones favorables para estos éxtasis sanguíneos. En cuanto se adhieren á las paredes arteriales, se desarrollan y multiplican, exfolian el epitelio y producen la arteritis local. La consecuencia de esta arteritis es la formación de un coágulo que oblitera el vaso.

En este proceso irritativo obran los tres factores patógenos cuya influencia hemos descrito. El transporte embólico de los gérmenes infecciosos es el acto morboso inicial : la arteritis hace el resto y la trombosis determina los accidentes que dan por resultado la obliteración vascular.

Es posible explicar, por medio de experimentos, la facilidad con que se altera la pared arterial por la causa de irritación más ligera, para comprender cuán fácil debe ser la coagulación de la sangre. Zahn y Pitres han demostrado que basta comprimir durante un momento la arteria de una rana y hacer en ella más lento el curso de la sangre por espacio de algunos segundos, para que se hinche el epitelio y se acumulen los leucocitos en el punto comprimido, produciéndose á la vista del experimentador una 
trombosis rudimentaria. Bajo la influencia de los microbios patógenos debe efectuarse un proceso idéntico.

Es verdad que no conocemos la anatomía patológica de estas arteritis ligeras, porque no ocasionan la muerte. Pero la clínica y la experimentación están de acuerdo en demostrar su existencia.

Es probable que en los vasos del calibre de la femoral sea pocas veces completa la obliteración, y que la lesión predominante, si no exclusiva, sea la hinchazón de las paredes arteriales. Es preciso, además, tener en cuenta la pérdida de la elasticidad de la túnica media, fenómeno concomitante en la arteritis. En efecto; aunque es rápida la desaparición de las pulsaciones de la arteria, no lo es menos el restablecimiento de la permeabilidad vascular en los casos simples. A los pocos días se presentan de nuevo los latidos; así ha sucedido en nuestra enferma, porque hoy, seis días después del accidente inicial, principian á notarse algunas pulsaciones obscuras en la femoral. Es verosímil, por lo tanto, que el trombo que obstruye en parte la arteria, esté destinado á disgregarse y á liquidarse con rapidez, fenómeno que jamás se observa en las embolias secundarias.

Al lado de esta forma benigna de arteritis tifoidea, de la que nuestra enferma representa el tipo clásico, existen otras mucho más graves, pero por fortuna más raras, que ocasionan la gangrena del miembro inferior. Estos hechos son bien conocidos, y desde 1839 , en cuya época refirió Taupin el primer ejemplo, Bourgeois, d'Etampes, Patry, Trousseau y Hayem han publicado observaciones minuciosas que se citan en todos los trabajos (1).

En estas formas graves de arteritis tifoidea los síntomas clínicos revisten caracteres muy diferentes.

(1) En la Tesis de Chauveau, 1878, se hace un bnen resumen de la historia de la gangrena tifoidea por arteritis. 
Unas veces es brusco el principio. Abre la escena un dolor desgarrador, el miembro palidece, se enfría; al poco tiempo se deseca y se pone negro; es el cuadro de la gangrena seca local.

Otras reces los fenómenos iniciales son sub-agudos é insidiosos en su evolución; se asemejan más á los que presentó nuestra enferma. Se notan entonces hormigueo en el miembro inferior, dolores, entumecimiento en los dedos, después placas violáceas y enfriamiento progresivo; por último, se presenta gangrena invasora de marcha lenta como la senil.

En estos casos, algunos autores, Chauveau y Lereboullet, por ejemplo, admiten la existencia de una embolia, porque al hacer la autopsia se encuentra un cógulo fibrinoso que oblitera la arteria poplítea $\delta$ el tronco tibio-peroneo. Pero en general, en las autopsias publicadas nada se dice sobre el estado de las túnicas arteriales.

Es, en efecto, una laguna importantísima, porque á pesar de los síntomas de la embolia y de los accidentes de marcha rápida, puede, en realidad, tratarse de trombos. Es lo que se observa todos los días en las enfermedades del encéfalo, en las que los reblandecimientos debidos á una trombosis arterial principian por un ataque de apoplegía. En este caso la circulación se conserva hasta el fin, á pesar de la estrechez progresiva de la arteria, sin ocasionar ningún otro síntoma, y la obliteración se produce de repente por los progresos de la coagulación, como si el calibre del vaso fuera obstruído de pronto por un cuerpo extraño. Esto que sucede en las arterias encefálicas, puede ocurrir también en las de los miembros.

En mis investigaciones sobre la arteritis tifoidea, sólo he encontrado seis autopsias completas, en las que se hizo el examen histológico de la pared arterial. Son los casos de Barié, Guyot, Hayem, Giraudeau, Maubrac y Lan- 
douzy. En todos ellos había endarteritis y peri-arteritis; es, por lo tanto, lógico suponer, que la mayor parte de las gangrenas tifoideas dependen de una arteritis primitiva complicadas con trombosis secundarias, más bien que de una embolia.

Esta cuestión de la arteritis en la fiebre tifoidea, es algo más que una curiosidad clínica; es un hecho importante de patología general aplicable á todas las enfermedades infecciosas, y que mi colega Landouzy ha demostrado en un trabajo de gran mérito. En efecto, el veneno tífico no sólo altera las arterias periféricas y produce en ellas lesiones más 6 menos profundas, sino que ataca también las arterias viscerales y entraña secundariamente degeneraciones graves en los órganos más importantes de la economía. Landouzy y A. Siredey han demostrado que en la miocarditis de los tíficos, complicación frecuentísima y grave, hay casi siempre endarteritis de las coronarias; se han descubierto alteraciones vasculares análogas en las arteriolas del hígado, del bazo, de los intestinos y de los músculos. Puede afirmarse, por lo tanto, que la fiebre tifoidea ejerce una influencia perniciosa sobre todo el sistema circulatorio, lo que explica las complicaciones tardías hasta el presente mal interpretadas de esta enfermedad infecciosa.

Quedaba sólo por demostrar un punto: la comprobación directa del microbio patógeno. Pero un médico italiano, Rattone (de Parma), acaba de llenar esta laguna (1). En un trabajo interesante sobre la arteritis tífica, cita los estudios que ha hecho en los vasos del miocardio, donde ha encontrado el bacilo de Eberth en las túnicas medias y externas y en el endotelio. Los grabados anejos á su trabajo demuestran la situación de estos micro-organismos en la pared vascular.

(1) Rattone, Il morgagni, Ottob., 1887. 
Fenómeno notable, pero fácil de comprender, es mucho más fácil descubrir el bacilo tífico clavado en las paredes arteriales que en la sangre y en los coágulos, aunque existe en ellos. Se ha hecho la misma observación en la lepra, la tuberculosis y la endocarditis ulcerosa. Los microbios patógenos son transportados por la sangre, pero al parecer ésta no es un medio favorable para su desarrollo y multiplicación. En los vasos de poco calibre la circulación es más lenta, se estancan en ellos, se fijan en sus paredes, penetran en el interior de éstas, se desarrollan allí y producen alteraciones secundarias de las túnicas arteriales. Este proceso permite comprender bien los detalles accesorios de la historia de las arteritis. Explica por qué la lesión arterial se localiza casi siempre en la curva del vaso; por qué la marcha, al poner en juego la elasticidad de la arteria, provoca, 6 mejor dicho, despierta las lesiones parietales silenciosas hasta entonces, y por qué, por último, se desarrollan en la defervescencia de los accidentes tífcos las complicaciones arteriales preparadas en el período de estadio de la infección.

Se comprende que, en estas circunstancias, las alteraciones vasculares más comunes recaigan en los capilares $\mathrm{y}$ en las arteriolas de las víceras, en los que el microscopio revela su frecuencia grandísima. Las lesiones irritativas de las arterias de calibre mediano, como la poplítea, la femoral $\delta$ la humeral, son raras : en las arterias gruesas que nacen del corazón son más excepcionales aún. Se citan, no obstante, ejemplos de ellos. En 1884 publicó Barié un caso de aortitis desarrollada durante la fiebre tifoidea, y yo he observado otro de los más claros; en 1881, en un tífico de mi clínica del hospital Tenon, ví hacer y desarrollarse en el segundo septenario un soplo doble en el origen de la aorta, con los signos indudables de una insuficiencia sigmoidea. He observado durante dos años á 
este enfermo y la lesión ha persistido siempre : la aortitis contemporánea de la fiebre tifoidea se ha hecho definitiva. He visto después, varias veces, individuos con una afección aórtica en los que la única etiología racional era una fiebre tifoidea contraída uno ó más años antes. Creo que el día que se fije la atención en este asunto, se descubrirán lesiones aórticas numerosas debidas á dicha causa.

El pronóstico de la arteritis tifoidea es muy variable, no sólo á causa de la profundidad y del grado de la obli. teración vascular, sino también por el sitio y la importancia de la arteria afectada. Las arteritis difusas, con obliteración completa del calibre del vaso, son las más graves, porque pueden ocasionar la gangrena del miembro, y aunque no comprometan en absoluto la vida, producen siempre una deformidad irremediable.

En las condiciones ordinarias es, por el contrario, un accidente poco grave que no origina de ordinario, ni en el momento ni en el porvenir, consecuencias importantes, siempre que la obstrucción vascular sea poco duradera y se restablezca pronto la permeabilidad de la arteria. Creo poder afirmar, que en nuestra enferma, la afección no tendrá consecuencias, ni dejará rastro, porque á la semana de principiar la arteritis empiezan á sentirse los latidos arteriales.

No sucede lo mismo cuando el vaso permanece impermeable durante varias semanas, ó cuando menos, se halla estrechado su calibre hasta el punto de producir la supresión prolongada de las pulsaciones arteriales. En estas condiciones persisten á menudo trastornos circulatorios graves que comprometen en alto grado las funciones del miembro. Asistí hace ocho años á un joven, el que, á consecuencia de una arteritis tifoidea de este género, tuvo que renunciar á seguir la carrera militar en Saint-Cir, porque no podía montar á caballo ni andar 
mucho sin sentir entumecimiento que le obligaba á detenerse. En ciertos casos, la hinchazón de la pierna y la dificultad para la marcha duran varios meses, lo mismo que después de la flebitis, y tardan bastante en desaparecer. Por último, en casos excepcionales, por fortuna, sobreviene la impotencia definitiva del miembro con atrofia muscular. Conozco una señora, la que después de una fiebre tifoidea gravísima, tuvo arteritis extensa de la femoral izquierda (quizá complicada con flebitis : al menos tal fue la opinión del Dr. Dechambre que la vió en consulta). A causa de esta complicación quedó paralizado por completo durante algunos años el miembro inferior que se atrofió : høy, diez años después del accidente primitivo, sólo puede andar la enferma con muletas. ¿ Son consecuencia estos trastornos tróficos profundos de la obliteración arterial ó de una neuritis concomitante? No me atrevo á afirmarlo; pero sí es indudable que datan del día en que se inflamó la arteria femoral, y que la lesión parecía al principio exclusivamente vascular.

Por excepcionales que sean estos casos, prueban que la arteritis tifoidea no es una complicación despreciable y que es susceptible de producir consecuencias funestas. Por consiguiente, cuando se presenta una complicación de esta clase en un tífico, hay que ser reservados en el pronóstico ; todo depende del restablecimiento más ó menos rápido de la permeabilidad vascular.

El tratamiento es, por lo general, sencillísimo; consiste esencialmente en el reposo y en la inmovilidad del miembro. No son necesarias las fricciones ni el amasamiento que sólo sirven para agravar la lesión arterial ; pero pueden utilizarse los resolutivos y emplearse el ungüento mercurial como antiplástico. Las cataplasmas de la medicina antigua son las que más alivian. Conviene á la vez sostener las fuerzas de los enfermos con el hierro y la quina, en vez Chínica médica, - Tomo I. 
de debilitarles con los alcalinos á grandes dosis. No se trata en este caso de hacer más fluída la sangre; es necesario que se resuelva la inflamación séptica, cosa distinta en absoluto.

Quizá sea conveniente abstenerse de tratar la fiebre tifoidea por la ergotina, como aconseja Duboué, de Pau. Un caso reciente de arteritis que sobrevino en una fiebre tifoidea tratada de este modo, hace suponer, con fundamento, que la acción del cornezuelo de centeno influye en la génesis de la lesión arterial. 


\section{CAQUEXIA PALÚDICA}

Sumario: Comparación de los casos de caqu exia palúdica.-Condiciones patogénicas predisponentes.-La antigüedad de la infección palúdica y la agudeza de los fenómenos tóxicos la originan por igual.-Inflnencia de las condiciones de resistencia personal de los individuos contra el veneno palúdico.-Fisiología patológica : destrucción globular, hemoglobinuria, anemia secundaria. - Hipertrofia espleno-hepática. - Influencia respectiva del hígado y del bazo sobre la destrucción de los glóbulos.-Pronóstico y tratamiento.

Tenemos en este momento en nuestra clínica dos ejemplos de paludismo crónico. Desde hace algunos años, á causa de las comunicaciones más fáciles con los países cálidos, y sobre todo, por las expediciones coloniales, se observan más á menudo en París casos de este género. Puede decirse que el Tonkin es, respecto á este particular, una escuela de enseñanza tan buena como fue la Argelia para la generación médica anterior. Es preciso acostumbrarse á conocer y tratar estas formas graves del paludismo.

El primero de nuestros enfermos es un ejemplo clásico. Se trata de un polaco de veintiocho años, que formaba parte de la legión extranjera. Había estado de guarnición en Sidi-Bel-Abbés y allí contrajo la fiebre tifoidea, pero no el paludismo. Disfrutó buena salud hasta 1884 . En esta fecha fue enviado al Tonkin, donde permaneció tres años. Los dos primeros resistió bien el clima, pero no sucedió lo mismo desde 1886. En esta época, durante dos períodos, de cuatro á seis semanas cada uno, tuvo accesos de fiebre intermitente de tipo cotidiano al principio $\mathrm{y}$ después terciario. Al principio de 1887, se hizo irregular la fiebre; volvía de cuando en cuando durante dos 6 
tres días, y dejaba al enfermo quebrantado y anémico. Regresó éste á Marsella, y de aquí se trasladó á Nimes, donde padeció bronquitis por espacio de dos meses. Al salir del hospital vino á París por jornadas, casi siempre á pie, y en el mayor estado de miseria ; á su llegada, hace ocho días, tuvo que ingresar en el hospital.

Este enfermo es, ante todo, un caquéctico. No tiene fiebre ; su temperatura oscila entre 36,5 y $37^{\circ}$, y no es influída ni por las comidas, ni por la noche. Lo que más. llama en él la atención es la anemia profunda y la decoloración grandísima de la piel y de las mucosas. Las encías y las conjuntivas son casi blancas, lo que contrasta con su color amarillento algo sub-ictérico. Esta coloración bronceada es debida á una pigmentación anormal de los tegumentos, más acentuada en las partes descubiertas. Es efecto, no sólo del sol de los países cálidos, sino también de la caquexia palúdica : los puntos del cuerpo expuestos al aire no son los únicos coloreados de este modo; lo están también el tronco, el abdomen y el escroto. Dicho color no es el primitivo de este hombre, porque es rubio y la piel fue blanca al principio. Han producido la pigmentación todas las causas de irritación local ; las cicatrices de úlceras de origen traumático están rodeadas de una aureola negruzca, y á causa también de la miseria, casi todo el cuerpo se halla jaspeado de manchas pigmentarias.

Otra cosa es el tinte sub-ictérico añadido á esta pigmentación anormal. El día que ingresó el enfermo la mucosa de las conjuntivas era amarilla, como en la ictericia más franca ; hoy principia á palidecer, pero el tinte amarillento es perceptible aún.

Necesitamos resolver el problema siguiente : El tinte ictérico de los tegumentos, ¿es debido á una ictericia verdadera de origen biliar? El análisis de la orina permite 
contestar en sentido negativo. En la ictericia verdadera de causa hepática, el líquido urinario contiene pigmentos biliares fáciles de descubrir por los reactivos ordinarios. Bastan algunas gotas de ácido nítrico para dar á la orina el tinte verdadero, que tan bien conocéis, que pasa sucesivamente del amarillo al rojo: la reacción en este caso es distinta por completo. La orina de nuestro enfermo es de color obscuro, caoba subido, sin los reflejos verduzcos de las orinas biliosas; el ácido nítrico la hace tomar una coloración negruzea, debido al índigo urinario y á los productos de combustión hibrocarbonados. Es el tipo de las orinas pigmentadas por exceso de materias colorantes sanguíneas, á las que llamaba Gubler orinas hemaféicas. No se trata, por lo tanto, en este caso de una ictericia biliar, sino de una impregnación accidental de la piel por pigmentos de origen globular : es una ictericia hemaféica.

Al examinar los órganos de este hombre se descubre una lesión visceral doble : el hígado y el bazo están muy hipertrofiados.

El bazo, sobre todo, es característico por completo. Basta descubrir al enfermo para observar la deformación del hipocondrio izquierdo, que está muy abombado. El abombamiento se extiende por el hipocondrio y el epigastrio. Al palpar se siente un tumor duro, en forma de torta extensa, redondo y oblongo, que llega más allá de las costillas falsas y desciende hasta cerca del ombligo, casi sobre la línea media. Es de consistencia dura y fibrosa; su superficie parece lisa y no se notan en ella desigualdades ni abolladuras : su borde es romo, redondo y se palpa con facilidad la cara interna por una escotadura que corresponde al hilio del bazo. Al percutir se nota macicez en una extensión de 15 centímetros en la línea axilar visceral, y de 21 en el sentido oblícuo que representa el diámetro mayor del órgano. Fenómeno notable; este bazo, 
hipertrofiado en alto grado, no desciende directamentepor la cara lateral del abdomen haeia la fosa ilíaca, como. sucede en la leucocitemia; se dirige en sentido oblícuo. hacia el ombligo, y ocupa una extensión de 12 á 15 centímetros. Esta forma aplanada y casi orbicular es bastante característica del paludismo crónico, y se observa también en el segundo enfermo.

Esta esplenomegalia no es dolorosa : hasta es indolente cuando descansa el enfermo. La palpación del bazo despierta una sensibilidad bastante viva, sobre todo á lo largo del borde interno del órgano : este síntoma indica cierto grado de congestión activa del parénquima esplénico, o más bien una peritonitis circunscrita concomitante, porque en tales casos es la regla la peri-esplenitis, como lo es. la peri-hepatitis en la cirrosis.

Se observan en el hígado lesiones análogas. Aunque en proporción, es menos voluminoso que el bazo; se halla, no obstante, hipertrofiado y se extiende tres traveses de dedo por debajo del borde de las costillas; es liso, unido, indolente á la palpación, el borde libre conserva su forma y no está engrosado. Las venas cutáneas hipogástricas no están dilatadas, y el abdomen se halla algo aumentado de volumen. No hay, al parecer, ascitis; al menos no se nota la sensación del choque del líquido; pero en la región hipogástrica se observa timpanitis hidro-aérea, de manera que, según toda probabilidad, hay acumulación de líquido en la excavación pelviana.

Los órganos restantes se encuentran sanos, al parecer. La orina es abundante y no contiene albúmina; el corazón está sano, excepto un soplo ligero que se oye en la base y que es consecuencia de la anemia. La respiración es normal.

El segundo enfermo, que se asemeja por muchos conceptos al primero, es un joven de veinte años, que ingresó 
el 20 de Febrero en la sala Chauffard, con un dolor de costado que nos hizo temer se tratara de una afección torácica aguda. Tenía escalofríos, opresión, tos seca, dolor á la inspiración, en una palabra, todos los síntomas de una pleuresía diafragmática incipiente. Reconociendo con cuidado el pecho, no descubrimos indicios de pleuritis, pero sí peri-esplenitis manifiesta y un bazo enorme con macicez de 14 centímetros en dirección vertical y de 17 en el diámetro oblícuo. La palpación de la zona esplénica era dolorosa, y rechazando el bazo hacia el diafragma, tenía el enfermo accesos de tos. Lo mismo que en el caso anterior, era fácil palpar debajo de la pared del abdomen el tumor esplénico en forma de una torta grande que descendía hacia el ombligo.

En este caso la causa es el paludismo, y sin embargo, el enfermo jamás ha salido de Francia; pero ha residido durante mucho tiempo en Brenne, región contigua á la Sologne, y donde reinan, como en ésta, las fiebres intermitentes. En 1872 tuvo fiebres de tipo cotidiano que duraron seis semanas, y que le obligaron á ingresar en el hospital de Châteauroux. Desde entonces ha sufrido varias recaídas, $\mathrm{y}$ aun hoy, tres años después de abandonar su país y de vivir en Paris, padece de tiempo en tiempo accesos febriles irregulares que dependen indudablemente del paludismo.

Su facies, como la del enfermo anterior, es la palúdica. Está muy anémico y sus encías y conjuntivas son de color pálido; no hay ictericia, pero se observa en alto grado la pigmentación especial tan notable en el otro paciente; aunque jamás se ha expuesto al sol de la India, está también amarillento y tiene el tinte terroso de los que padecen afecciones palúdicas. Aunque la caquexia no es tan acentuada como en el caso anterior, está, no obstante, débil y flaco, y la debilidad aumenta por las epistaxis fre- 
cuentes que padece, síntoma que, según sabéis, se considera desde la antigüedad más remota como complicación ordinaria del paludismo. La pérdida rápida de glóbulos sanguíneos se indica también por el aspecto de la orina de color moreno obscuro. El líquido urinario, lo mismo que en el otro enfermo, no contiene albúmina, pero sí una gran cantidad de uratos y de substancias hidrocarbonadas á medio oxidar; el ácido nítrico forma un disco negro del aspecto del carbón, y sin embargo, esta desasimilación excesiva no es resultado de la fiebre, porque el termómetro jamás ha ascendido á $38^{\circ}$ desde que observamos á este joven.

Estos dos casos de paludismo, tan completamente análogos, merecen compararse y estudiarse con todo detenimiento, porque permiten explicar las condiciones que crea, $\delta$ al menos que favorece el estado caquéctico de los palúdicos.

El fenómeno clínico predominante en estos dos individuos es la anemia, el empobrecimiento de la sangre. Contribuyen varios factores á dificultar la formación de glóbulos y á acelerar su destrucción.

La antigüedad de la intoxicación palúdica es sin duda alguna la causa patógena preponderante de la caquexia. Basta la estancia prolongada en un país donde reine el paludismo, para ocasionar la debilidad y la anemia, independiente de toda manifestación febril. El veneno palúdico no despierta en este caso una reacción violenta en la economía, pero no por eso deja de impregnar el organismo, y el resultado primero de esta intoxicación es el retardo funcional de la hematopoiesis, después la alteración de los órganos que contribuyen á formar los glóbulos. Las lesiones del bazo se desarrollan de un modo insensible y resulta la esplenomegalia antes de manifestarse el menor acceso febril. Los niños, cuyas madres viven en 
una comarca palúdica, nacen con infarto del bazo, y á las pocas semanas del nacimiento presentan ya el tinte pálido y la decoloración de las mucosas de los anémicos confirmados. Este hecho es frecuente no sólo en Sologne, en Limousin y en Bresse, sino en los países donde se observa accidentalmente el paludismo, como sucede, por ejemplo, en los alrededores de París. Traté hace algún tiempo á un niño de cinco años, cuyos padres vivían en el valle de la Bièvre, y que presentaba todos los caracteres de la anemia palúdica, incluso la hipertrofia excesiva del bazo.

Uno de los primeros puntos que deben tenerse presentes en la historia de la caquexia palúdica es el siguiente: no es necesario en modo alguno, para hacerse anémico y caquéctico, padecer accesos repetidos de fiebre intermitente : basta residir durante mucho tiempo en un país donde reine el paludismo. El segundo enfermo se halla en este caso. En dieciséis años sólo ha padecido fiebre una vez y los accesos fueron poco graves y de corta durción; pero pasó toda la infancia en la Brenne y su bazo se ha infartado tanto como si hubiera padecido fiebres intermitentes rebeldes.

El primer enfermo presenta, por el contrario, el tipo inverso y demuestra cómo es posible hacerse caquéctico en poco tiempo. En este caso, la intensidad y la repetición frecuente de los accesos crearon las condiciones de una anemia rápida. En tres años de permanencia en el Tonkin, este hombre que no tenía la menor predisposición al paludismo, que resistió bien el clima los dos primeros, se hizo caquéctico en alto grado á los tres meses de fiebre casi contínua.

El tipo de los accidentes febriles importa poco, porque todos conducen por igual á la caquexia; pero no con la misma frecuencia. Los más graves son los que no van acompañados de remisión y revisten el carácter pseudo- 
contínuo. Estos matan con rapidez, y cuando curan dejan una anemia precoz y profunda. Los más comunes son las fiebres intermitentes, tercianas ó cotidianas, y en nuestros climas son las que ocasionan con bastante rapidez el estado anémico. Más lentas, pero más tenaces, son las fiebres cuartanas, que obedecen peor al tratamiento y recidivan muy á menudo : en el Mediodía de Francia, todo individuo que padece esta forma de fiebre está condenado casi con seguridad á la caquexia á los pocos meses. El proceso es idéntico en el fondo : tal vez sean diferentes la intensidad de acción del veneno y el modo de penetrar en la economía.

Es imposible negar la influencia del clima y del calor. En los países tropicales se ve en pocas semanas, en ocasiones en pocos días, presentarse síntomas de caquexia aguda caracterizados por edemas difusos del tronco, de la cara y de los miembros, sin albuminuria; ictericia, infarto del bazo y del hígado, postración enorme y pérdida completa de fuerza. Esta forma, descrita recientemente por Fayrer, se observa en el Tonkin, en Madagascar y en toda la zona tropical : cuando los enfermos, por volver á su patria, se libran de esta anemia sobreaguda, cesa la infiltración, pero persiste el tinte pálido, el aspecto terroso y la hipertrofia espleno-hepática de los palúdicos crónicos.

En nuestro país, la caquexia se desarrolla con más lentitud, y cuanto más nos aproximamos á las zonaz frías, más crónico es el paludismo y mejor se tolera relativamente. No obstante, á la larga se presenta siempre la anemia.

Es preciso tener en cuenta un elemento, cuya apreciación se nos escapa, pero que es de importancia etiológica grandísima : me refiero á la receptibilidad individual de las personas expuestas al paludismo. Un individuo resiste la intoxicación palúdica, mientras que enferma otro 
colocado en las mismas condiciones. En general, todas las causas debilitantes ocasionan la anemia y predisponen al paludismo; el alcoholismo, los excesos venéreos, la sífilis, ejercen sobre este particular una influencia desastrosa. Lo mismo sucede con las malas condiciones higiénicas, cuyo influjo es innegable; el primero de nuestros enfermos se nutría mal, y se hallaba en un estado las. timoso: es indudable que la intensidad de su caquexia aumentó por lo defectuoso de la alimentación. Es lo que se observa en grande escala en las comarcas pantanosas : he visto en la costa oriental de Córcega, país esencialmente palúdico, que no padecían la anemia palúdica los que se alimentaban bien y bebían vino; el resto de la población, pobre y mal nutrida, que bebía sólo agua, pagaba todos los años un tributo grandísimo á la caquexia.

En resumen, puede afirmarse en principio, que la anemia palúdica se desarrolla con tanta más facilidad, cuanto mayor es la cantidad de miasma infeccioso que se absorbe y más largo el período de absorción ; es preciso, además, tener en cuenta su virulencia variable y las condiciones de resistencia $\delta$ depresión que opone el organismo.

Para apreciar todas estas circunstancias patógenas, sería necesario conceer la naturaleza del veneno telúrico que produce el paludismo ; á pesar de los trabajos numerosos é importantísimes que se han publicado sobre dicho asunto, no se ha aclarado aún por completo este punto capital. Sin entrar en detalles, respecto al particular, lo que nos conduciría demasiado lejos, recordaré, en pocas palabras, las fases por que ha pasado la historia del microbio del paludismo.

Hace veinte años, creyó haber encontrado Salisbury el elemento generador del paludismo en unas algas pequeñas que se desarrollan en los terrenos húmedos donde reina dicha enfermedad. Estas palmelas, que consigu ió cultivar 
y que según dicho autor transportaban con ellas la fiebre, se ha visto después que son inofensivas. Lo mismo ha sucedido á los organismos vegetales descritos por Magnin en los Dombes, y álos encontrados por Ecklund, en Suecia, en el limo de las confervas. La inoculación de todos estos parásitos jamás ha producido resultado alguno, y su desarrollo en las comarcas pantanosas es, al parecer, una simple coincidencia.

La cuestión ha entrado en la vía científica en estos años últimos. Klebs y Tommasi Crudeli, han descrito un bacilo especial, el Bacillus malarice, descubierto en la tierra pantanosa de los sitios infectos y que existe en el agua potable de los países donde reina la fiebre. Dicen que al examinar la sangre de los enfermos palúdicos en el momento de los accesos, en particular la esplénica, han encontrado el mismo parásito ; pero los cultivos artificiales obtenidos con este bacilo, no han reproducido hasta ahora la enfermedad, de modo que la cuestión dista mucho de estar resuelta.

Laveran ha dado á conocer un parásito especial que sólo existe en la sangre de los enfermos en el momento de los accesos febriles. Son algas pequeñas, de estructura rudimentaria que pertenecen á la clase de las oscilatorias y que están formadas por una masa protoplásmica en forma de media luna, ó por un núcleo rodeado de filamentos móviles. Estos cuerpos flagelados son los agentes del paludismo y su desarrollo produce los accesos febriles. En Italia, Marchiafava y Celli, han confirmado hace poco tiempo la existencia de estos corpúsculos.

Sea lo que quiera, parece un hecho demostrado, que la condición primera del paludismo es la introducción en la sangre de un microbio infeccioso que se esparce por todos los órganos y produce fermentaciones febriles. Pero nada sabemos del papel que desempeña en el paludismo cróni- 
co. Todo induce á creer que el fermento infeccioso se destruye pronto, pero que sus efectos duran mucho tiempo. El examen de la sangre, en los palúdicos caquécticos no febriles, ha sido siempre negativo. Nuestros dos enfermos no son excepciones de esta regla. El Dr. Chartier, mi interno, ha hecho el examen histológico de la sangre de estos individuos sin descubrir cuerpos flagelados ni aun acumulaciones de pigmento ; sólo ha observado disminución bastante grande de los glóbulos rojos $\mathrm{v}$ aumento apreciable de los blancos.

Es, en efecto, el resultado más notable que confirman los estudios histológicos y la observación clínica. La destrucción de los glóbulos es el fenómeno capilar del paludismo crónico, y coincide con la hipertrofia de los órganos hematopoiéticos, el hígado y el bazo. Estos dos procesos siguen una marcha paralela, cualquiera que sea la forma clínica que revista la intoxicación palúdica.

En las formas agudas febriles, la demostración es palpable. Kelsch ha hecho sobre el particular observaciones interesantísimas. En una serie de palúdicos aislados en el hospital de Sétif, comprobó, por medio de la numeración globular, que en el momento del acceso hay una destrucción colosal de hematíes. Esta destrucción se manifiesta al microscopio, no sólo por la disminución del númerode glóbulos, sino por la acumulación de corpúsculos pigmentarios que circulan con la sangre, y que se fijan en parte por los leucocitos. Hay un trabajo de fagocitosis activísimo, en virtud del cual los detritus pigmentarios son absorbidos inmediatamente por los glóbulos blancos, cuyo número aumenta como es natural ; esto no impide que el exceso de pigmento impregne los parénquimas viscerales, hígado y bazo, y hasta los tegumentos. Una vez que se fijen en los tejidos estos corpúsculos pigmentarios, permanecen sin alterarse en ellos, casi de una manera inde- 
leble, y sobreviven á la fase aguda del paludismo que les origina. A éste se debe la persistencia de la pigmentación de la piel en los palúdicos y el tinte amarillento especial que adquieren poco después de una serie de accesos febriles.

El hecho clínico que indica esta destrucción sobre-aguda de los glóbulos es la hemoglobinuria. En los accesos intensos de paludismo, que revisten el carácter pernicioso y pueden matar desde luego á los enfermos, la orina es unas veces roja como la sangre, otras negra como la infusión de café ; la materia colorante de los glóbulos destruídos se elimina siempre por la vía renal, y los nombres de fiebres hematúricas ó melanúricas corresponden á formas de paludismo sobre-agudo, en las que llega al máximum la destrucción globular. En las formas febriles de intensidad mediana que observamos en nuestras clínicas, el síntoma es menos acentuado, pero cada acceso febril va seguido también de la emisión de orina roja, parecida á la cerveza negra, y muy hemaféica, por exceso de pigmento hemático.

Hasta en las formas crónicas siguen destruyéndose los glóbulos sanguíneos y manifestándose la destrucción por síntomas palpables. A pesar de la palidez de los tegumentos y de la anemia profunda, la orina es de color encendido, y contiene en abundancia más substancias decolorantes que lo que podía suponerse, á juzgar por la palidez de la mucosa. Obsérvase esto con toda exactitud en nuestros enfermos, sobre todo en el primero. Este exceso de substancias colorantes en la orina, á pesar de la falta de fiebre, demuestra con toda claridad que prosigue la desorganización de la sangre, y que la destrucción globular supera á la reparación.

El examen directo de la sangre en estas formas crónicas caquécticas, lo prueba con exceso. La proporción de los glóbulos rojos desciende al mínimum : á 1.500 .000 ó 
2.000.000 por milímetro cúbico, en vez de 4 á 5.000 .000 - cifra normal. - Los glóbulos están, al parecer algo alterados; son más pálidos y más pobres en hemoglobina. Los leucocitos son, por el contrario, más numerosos que de costumbre, aunque en los palúdicos crónicos no se observa, de ordinario, la leucocitosis aguda que existe después de los accesos febriles; están menos pigmentados, pero este carácter es variable, y más de una vez se han visto numerosos pigmentos impregnando los glóbulos blancos en las formas clásicas del paludismo.

Estas alteraciones de los glóbulos sanguíneos no son, según toda probabilidad, las únicas alteraciones de la sangre ; es de suponer que la composición del suero no sea la normal ; á esto se debe la tendencia marcada á las trasudaciones que existe en todos los palúdicos crónicos y la facilidad con que sobrevienen hemorragias. Recordaréis que el primero de nuestros enfermos tenía edematosas las piernas, y que el segundo padecía epistaxis.

Prosigamos este análisis, y averigüemos por qué mecanismo se produce la hipertrofia del hígado y del bazo concomitante siempre del paludismo. Se han emitido varias hipótesis.

Puede sostenerse, no sin razón, que el agente infeccioso del paludismo es transportado directamente por la sangre al seno del parénquima esplénico, y que le irrita por su presencia. Es una ley común á todas las enfermedades infecciosas; según parece, el bazo y el hígado tienen la facultad de retener en sus tejidos y de almacenar en cierto modo los microbios patógenos ; todos los días se ven ejemplos de ello en la fiebre tifoidea, la disentería y la tuberculosis. En las formas agudas del paludismo, durante el acceso febril, se congestiona el bazo, hasta el punto de inflamarse algunas veces y de romperse en ciertos casos; se han visto formarse, á consecuencia de una serie de accesos 
de este género, verdaderos abcesos. En las formas crónicas primitivas $\delta$ en las que se hacen crónicas después de cierto número de crisis febriles, la repetición de la congestión esplénica concluye por producir un estado inflamatorio que origina la esclerosis, de la misma manera que degenera en cirrosis la hiperemia habitual del hígado provocado por el alcohol. La realidad de este proceso se demuestra anatómicamente por la existencia de placas constantes de peri-esplenitis, y en clínica por la frecuencia de los puntos dolorosos subdiafragmáticos que indican cierto grado de peritonitis, circunscrita alrededor del bazo. El segundo de nuestros enfermos era un buen ejemplo de estos ataques peritoneales, que, por su sitio y sintomatología, se asemejan bastante á la pleuresía diafragmática incipiente.

Esta hipótesis no es admitida por todos. El microbio del paludismo, dicen los adversarios de la doctrina, no permanece en el bazo suficiente tiempo para producir en él fenómenos inflamatorios durables; se destruye con demasiada rapidez para ocasionar lesiones parenquimatosas durables. Pero como durante los accesos se destruyen los glóbulos en cantidad grandísima, sus detritus pigmentarios se acumulan en el parénquima esplénico y forman otras tantas embolias que dificultan la circulación del bazo y originan la hipertrofia permanente de este órgano.

Según esta hipótesis, el hígado y el bazo desempeñan un papel pasivo, y se limitan á interceptar el paso de los fragmentos pigmentarios y de los otros detritus procedentes de la alteración de la sangre.

Otros médicos creen, por el contrario, que, aunque la sangre se empobrece por la destrucción excesiva de hema. tíes, esta destrucción, más que efecto de la acción directa del microbio sobre los glóbulos, es consecuencia de la sobre-actividad funcional del hígado y del bazo, agentes de la transformación y desintegración globular. 
Nos hallamos respecto á dicho asunto en pleno terreno hipotético, porque es imposible resolver esta cuestión de una manera exacta hasta que conozcamos las leyes íntimas de la hematopoiesis y el papel respectivo que desempeñan el hígado y el bazo en la renovación de los glóbulos. A pesar de las investigaciones perseverantes de los fisiólogos quedan aún por demostrar varios puntos.

Se admite, en general, que el bazo fabrica los glóbulos blancos y los globulinos, rudimentos de los glóbulos rojos futuros, y que el hígado contribuye á destruir estos últimos según van envejeciendo.

Ranvier considera la hematopoiesis como una función general. Para él los leucocitos se forman en todos los sitios donde existen células conjuntivas : son, según su frase, células del tejido conjuntivo movilizadas. El bazo contribuye en alto grado á su formación, pero no tiene el privilegio exclusivo de ello. Por otra parte, á causa de las condiciones anatómicas de su circulación intersticial, desempeña el papel de un receptáculo en el que se acumulan los resíduos de la destrucción globular; hasta es posible que contribuya en cierto modo á esta destrucción, hipótesis defendida por fisiólogos competentes. Nada hay, por lo tanto, más inseguro que su papel exacto como órgano hematopoiético.

Respecto del hígado, destruye, con seguridad, los glóbulos rojos, porque si se hace un análisis comparado en la sangre de las venas supra-hepáticas y de la vena porta, se encuentra la primera menos rica en glóbulos. Esta destrucción fisiológica de los hematíes permite á la glándula, en ocasiones normales, elaborar las substancias colorantes de la bilis á expensas del pigmento sanguíneo, y todo cuanto sabemos de las alteraciones funcionales del hígado confirma esta hipótesis. Si funciona mal y de una manera insuficiente, la orina se hace al momento hemaféica, porClínica médica. - Tomo $I$. 
que el pigmento biliar destinado á colorar la bilis, no lo utiliza la secreción biliar. Lo mismo sucede cuando la destrucción globular es excesiva, aunque el hígado esté sano, lo que ocurre siempre en el período agudo y hasta en el sub-agudo de las fiebres intermitentes.

No insisto sobre los síntomas concomitantes de la caquexia palúdica; dependen todos de la destrucción globular exagerada que existe en todos los órganos, pero sobre todo en el hígado. Los edemas, los derrames serosos, la ascitis, son consecuencia de la hidremia y de la falta de glóbulos en el plasma sanguíneo.

Conviene llamar la atención sobre un punto interesante; á pesar de la alteración de la sangre, rara vez son acentuados en los palúdicos los trastornos circulatorios; lo son mucho menos, por ejemplo, que en la clorosis, aunque el número de glóbulos en esta enfermedad suele ser muy elevado. La razón de esta diferencia es la disminución de hemoglobina en los glóbulos de los cloróticos, mientras que en los de los palúdicos los pocos que persisten son abundantes en hemoglobina, y bastan para transportar el oxígeno. No se observan, por lo tanto, en nuestros enfermos las palpitaciones, los desfallecimientos, las apatías especiales de las cloróticas; al auscultar el corazón y los vasos no se oyen soplos, lo que justifica la observación de Potain, respecto á la rareza de los soplos vasculares en las falsas clorosis; por último, las funciones digestivas son buenas, circunstancia importante, desde el punto de vista del pronóstico.

Esta integridad de las vías digestivas y la falta de albuminuria, nos hace esperar que, á pesar del estado caquéctico en que se hallan nuestros enfermos, adquirirán fuerzas y recobrarán poco á poco la salud. La anemia palúdica es siempre rebelde, pero pocas veces incurable, cuando los pacientes se alejan del foco de su paludismo y 
se trasladan á un clima saludable. Por lo tanto, aun en la hipótesis más favorable, no debemos negar que quedarán siempre en nuestros enfermos rastros de la intoxicación palúdica. Hagamos lo que hagamos subsistirá el infarto del bazo. En las formas agudas es posible pronosticar la desaparición rápida de la esplenomegalia, una vez cortado el acceso, pero en las crónicas la esclerosis del bazo es un hecho realizado, definitivo: puede disminuir el volumen del órgano, pero sin recobrar sus dimensiones primitivas. La hematopoiesis está siempre alterada á causa de esta lesión anatómica y quizá también por otros motivos; es siempre defectuosa y lenta. Conviene saber, por último, que aunque el enfermo recobre por completo la salud, no están conjuradas las recidivas del paludismo; la causa más ligera ocasiona un traumatismo, un enfriamiento, una inflamación local benigna, despierta el paludismo, que se revela por verdaderos accesos intermitentes.

Sucede algunas veces que, á pesar de todos los esfuerzos de la terapéutica, no se modifica la caquexia palúdica y reviste los caracteres de la anemia perniciosa progresiva. Se ve entonces perderse el apetito, presentarse diarrea é infiltrarse los tejidos; los enfermos están desanimados, sin fuerzas, les es imposible nutrirse, y sobreviene la muerte por síncope con coagulaciones cardíacas finales. Es por fortuna una eventualidad que no ocurrirá en nuestros enfermos.

¿Cuál es el mejor tratamiento en el período caquéctico de la intoxicación palúdica?

El sulfato de quinina, medicamento por excelencia de las fases agudas de la fiebre intermitente, es poco eficaz cuando se trata de combatir los accidentes de la caquexia palúdica : sólo está indicado si hay accesos febriles irregulares, lo que ocurre pocas veces. Es preferible administrar la quina en forma de polvo, á dosis algo elevada como 
aconsejaba Trousseau ; la cantidad diaria debe elevarse á 6 ú 8 gramos. Conviene emplear á la vez vinos ricos en alcohol y tanino que contribuyen á tonificar el organismo. Los médicos de la marina usan con el mismo objeto una mezcla de quina ( 30 gramos), de café y de cacao tostados (aa. 15 gramos) macerado todo en 100 gramos de aguardiente, y que se añade á un litro de vino.

Sucede algunas veces, que á pesar de estos medios, persiste la caquexia y los enfermos no recobran el apetito ni las fuerzas. Entonces se impone la indicación del arsénico solo ó combinado con el hierro y la quina. Una de las preparaciones mejores es la disolución de arseniato de sosa, 5 centígramos por 100 gramos de agua, fácil de dosificar y bien tolerada en general por los enfermos; si persiste la atonía gástrica, conviene emplear también la tintura de nuez vómica (10 á 12 gotas) y las aguas ferruginosas. Si el arsénico es mal tolerado por el estómago, se recurre á. la vía endérmica, y se inyectan debajo de la piel 6 á 7 gotas de licor de Fowler.

Pero el medio más heróico, con el que suelen obtenerse éxitos inexperados, es la hidroterapia. La ducha fría con manga es uno de los modificadores más poderosos del estado caquéctico : obra á la vez solure la piel, cuyas funciones excita, sobre el sistema nervioso que estimula, y sobre las vísceras que descongestiona. Se ve en ocasiones, bajo su influencia, disminuir de un modo notable el volumen del bazo, aunque la esplenomegalia sea antigua, y Fleury ha referido ejemplos concluyentes. Se aconsejan con el mismo objeto las inyecciones subcutáneas de clorhidrato de quinina ó de ergotina, practicadas en la región esplénica; pero este método, eficaz algunas veces en las formas agudas del paludismo, cuando sólo hay congestión del bazo, fracasa siempre en los accidentes crónicos del paludismo, cuando existe ya la esclerosis de este órgano. 


\section{GOTA SATURNINA}

Sumario: Congestión pulmonar precedida de dolores articulares y seguida de un acceso de gota aguda franca. - Interpretación de este hecho. - Diagnóstico con el reumatismo articular. - Fluxiones viscerales de los gotosos : ison de origen gotoso $\delta$ dependen de las manifestaciones diatésicas? - Etiología de la gota en el caso particular : influencia del saturnismo. - Influencia patógena del plomo en la producción de los accidentes gotosos. - Pronóstico y tratamiento.

Las manifestaciones viscerales de las enfermedades constitucionales que simulan afecciones comunes, suelen desconocerse, y dificultan bastante el diagnóstico. Una prueba de ello es el ejemplo siguiente :

Ocupa el núm. 21 de la sala Chauffard un hombre de sesenta y cuatro años, pintor, que ingresó el 12 de Mayo con accidentes de congestión pulmonar. La enfermedad principió de una manera insidiosa hace diez días, por dolores vagos, reumatoides, en la rodilla y pie izquierdos, que no le impedían continuar su trabajo; después se interesó de repente el pecho, y entonces decidió venir al hospital.

En esta fecha, los síntomas de la enfermedad eran exclusivamente torácicos. Disnea intensa (40 respiraciones), tos frecuente, expectoración viscosa y rara, dolores intercostales y ansiedad respiratoria, todo indicaba una afección pulmonar aguda. El estado general era malo, la temperatura excedía de $39^{\circ}$. Se oían en la base del pecho estertores finos, más confluentes en el lado izquierdo, y la respiración era débil en ambos lados; en el izquierdo el murmullo vesicular estaba reemplazado por soplo velado, de timbre agudo, parecido al soplo pleurítico. Persistían 
las vibraciones torácicas, pero estaban atenuadas desde el ángulo de la escápula. La voz no era temblorosa, pero sí más agudo su tono.

Los demás órganos eran normales : nada se descubría en el corazón ni en las articulaciones, pero la orina contenía una gran cantidad de albúmina.

El diagnóstico anatómico era claro en este caso : el enfermo padecía congestión pulmonar. La significación clínica del padecimiento era dudosa. Parecían plausibles por igual varias hipótesis.

Podíamos pensar en una grippe de determinaciones articulares iniciales. El hecho no es raro al principio de esta. afección, que, como sabéis, se comporta como una enfermedad general infecciosa, y empieza casi siempre por quebrantamiento, acompañado de artralgia. Es, además, una enfermedad estacionaria que reina en París durante todas las primaveras.

Podíamos pensar también en una congestión pulmonar sobrevenida como afección intermitente en el curso de un reumatismo articular ó como manifestación del mismo reumatismo.

El examen de la orina, al revelar la existencia de la albuminuria, aumentaba las dificultades. ¿Cuál era el papel de los riñones en este caso y qué relaciones había entre las lesiones torácicas y los trastornos renales funcionales? Sabéis las relaciones íntimas que existen en patología entre el aparato renal y el pulmonar. Debíamos preguntarnos : $1 .^{\circ}$, si nuestro enfermo padecía nefritis antigua complicada con accidentes pulmonares ; $2 .^{\circ}$, si la albuminuria sería la causa patogénica de la congestión pulmonar y si se trataría de una de esas bronco-pneumonías de los albu minúricos, tan bien descritas por Lasègue ; $3 .^{\circ}$, por último, sin ver en esta asociación de las lesiones una relación causal, era posible admitir una causa única, por 
ejemplo, un enfriamiento que hubiera influído á la vez sobre el riñón y el pulmón. Era imposible resolver tantas cuestiones el día mismo de ingresar el enfermo.

La evolución ulterior de la enfermedad no tardó en esclarecer estos puntos diversos. Los fenómenos torácicos se corrigieron á beneficio de algunas ventosas escarificadas y de un vomitivo. El soplo desapareció ; los estertores de las bases se hicieron más gruesos, la expectoración más fácil y menos viscosa ; el pulmón recobró su permeabilidad en cuatro días. La albúmina disminuyó y desapareció á la vez que la orina se hizo más clara y abundante. Este hecho basta por sí sólo para descartar la hipútesis de una enfermedad inicial con complicaciones pulmonares, porque la albuminuria hubiera persistido después de desaparecer los fenómenos torácicos. Es preciso, por el contrario, invertir la proposición y admitir que la presencia de la albúmina en la orina era consecuencia de la dificultad respiratoria producida por la congestión pulmonar, ó de una hiperemia renal concomitante que seguía una marcha paralela y era debida á la misma causa, el frío. Tenemos en la actualidad en la clínica un epiléptico que, por exponerse dos horas al frío á causa de una de sus crisis, padeció á la vez un dolor pneumónico y una hematuria, prueba de la realidad clínica de este proceso.

A pesar de estas semejanzas, dudo que en nuestro enfermo fuera debida á dicha causa la congestión pulmonar. Nada, en la historia de su padecimiento, demuestra la intervención del frío como circunstancia determinante, $\mathrm{y}$ fenómenos nuevos probaron que esta congestión, fortuíta en apariencia, tenía relaciones estrechas con un estado constitucional.

En efecto, según desaparecían los síntomas torácicos, volvían los dolores de las articulaciones con caracteres particulares y de un tipo especial por completo. El vier- 
nes último, 16 de Marzo, después de pasar una buena noche, sintió por la mañana, sin pródromos y sin causa apreciable, un dolor agudísimo en la rodilla derecha. Encontramos la región articular algo edematosa, sobre todo delante de la rótula. La piel en este sitio estaba roja, tensa, muy sensible al contacto más ligero, y formaba un abultamiento circunscrito, como si fuera á desarrollarse un flemón de la bolsa serosa pre-rotuliana.

La temperatura local, bastante elevada en este sitio, era superior á la de la rodilla izquierda, y la impotencia funcional completa por el dolor que despertaban los movimientos. No estaba interesada la articulación; comprimiendo en la interlínea articular y en los lados de la rodilla, no sentía el enfermo dolor alguno; el padecimiento estaba localizado sólo en la región pre-rotuliana. Había una especie de higroma agudo, pero sin fluctuación verdadera : la bolsa serosa y los tegumentos inmediatos estaban más bien edematosos que invadidos por un derrame : era una fluxión verdadera que interesaba los tejidos fibrosos peri-articulares, sin que participara de ella la sinovial. Las demás articulaciones, las bolsas serosas similares del codo, del calcáneo, de la pata de ganso, eran indolentes por completo.

Dos días después se observó una fluxión análoga en el dedo gordo del pie derecho. Los tegumentos de la región metatarso-falángica se pusieron lisos, brillantes, de color rojo vivo y muy dolorosos : el contacto más ligero hacía prorrumpir en gritos al enfermo. Todo el dedo gordo estaba aumentado de volumen, é indudablemente había padecido de igual manera ya otras veces, porque la cabeza del metatarsiano era gruesa, rugosa y desigual. Este ataque fluxionario, que llegó ayer al máximum, persiste hoy to davía, pero va decreciendo ; el dedo gordo del pie izquierdo y la rodilla correspondiente se han hinchado á su vez, 
y lo mismo que en el miembro inferior derecho, se ha interesado la bolsa serosa pre-rotuliana, quedando á salvo la articulación tibio-femoral. Esta segunda fluxión ha sido menos intensa que la primera, y hoy se encuentra en vías de resolución.

Habréis reconocido por estos síntomas un acceso de gota con todos sus caracteres típicos, que ocupaba su sitio electivo en los dedos de los pies, é invadía de preferencia las bolsas serosas y los tejidos fibrosos peri-articulares. Como esta afección se observa pocas veces en los hospitales, y tiene grandes afinidades con el reumatismo, al que suele asemejarse y con el que se confunde en ocasiones, hay motivos para hacer con todos sus detalles el diagnóstico diferencial entre ambos padecimientos. Todos los autores que se han ocupado de la gota han visto, en efecto, casos de este género, en los que la fisonomía de la enfermedad era idéntica á la de un ataque de reumatismo; Garrod, Todd, Budd y Charcot han señalado estas formas híbridas, cuyos límites son difíciles de marcar. Creo, por lo tanto, útil recordaros los caracteres de los tipos diversos de reumatismo capaces de simular la gota.

Las localizaciones habituales del reumatismo agudo clásico son bien conocidas. La afección invade de preferencia las grandes articulaciones, primero la sinovial, después sucesiva 6 simultáneamente los tejidos fibrosos peri-articulares y las vainas tendinosas. A esto se debe la hinchazón difusa, por lo común grande, considerable, complicada casi siempre con hidrartrosis que falta en el período agudo de la gota, y una deformación de la conjuntiva mayor en la interlínea articular. Las manifestaciones reumáticas son á la vez más móviles y más múltiples; la fluxión invade casi al mismo tiempo los cuatro miembros, pero es poco duradera; por último, los tegumentos, aun que edematosos, casi nunca tienen la rubicundez intensa 
ni el aspecto brillante de la gota, ni se descama la piel.

Hay una variedad de reumatismo agudo que simula mejor el acceso de gota ; es el que interesa las articulaciones pequeñas, en particular las del pie. Pero examinando las cosas de cerca se observan diferencias. Casi nunca se afecta sólo el dedo del pie; se interesan también los demás dedos y los metatarsianos; además, en estos casos se afectan las grandes articulaciones primitiva $\delta$ secundariamente. Es lo que sucedió al reumático que se halla actualmente en nuestra Clínica y que tuvo un ataque articular agudo durante un reumatismo crónico deformante.

El reumatismo blenorrágico es más fácil de conocer, aunque tiende á localizarse en las bolsas serosas y en las vainas de los tendones, como la gota ; sus caracteres varían, es por lo común sub-agudo y poco doloroso, rebelde en sus manifestaciones, y sólo en casos raros va acompañado de coloración roja de los tegumentos.

No insisto sobre estas diferencias, que son clásicas, y resumo los síntomas que, en nuestro enfermo, demuestran de una manera perentoria la naturaleza gotosa de los accidentes.

Las determinaciones articulares en él, están, ante todo, limitadas con exactitud á los miembros inferiores, sin propagarse á los superiores, circunstancia relativamente rara en el reumatismo agudo. La localización especial en el dedo gordo del pie, el aspecto de la piel, que en este punto está caliente, roja, tensa y brillante, y que principia á descamarse en el dedo izquierdo; el edema difuso del dorso del pie, que no se limita á la zona de las vainas de los tendones extensores, y que es mucho mayor que en el reumatistno verdadero ; todo esto justifica la idea de que se trata de un acceso de gota franca. Agregad á estos caracteres la particularidad de haberse afectado la bolsa serosa pre-rotuliana sin participación de la sinovial de la rodilla, fenó- 
meno anormal en el reumatismo, y por el contrario, constante en la gota, y la convicción será completa.

La marcha, la evolución de los accesos es la de la gota, y los antecedentes del enfermo son demostrativos respecto á este particular. En 1872 sintió por vez primera los ataques del mal. Principió entonces la crisis por el dedo gordo del pie y á los tres días de padecimiento invadió el otro dedo: el ataque duró una semana. Después, al principio de la primavera, se repitieron los ataques, que empezaban siempre por los dedos de los pies y persistían diez ó doce días. Bajo la influencia de estos ataques repetidos, concluyeron por deformarse los metatarsianos, hipertrofiándose y haciéndose rugosos : hay cierto grado de sub-lujación hacia afuera de la falange, pero sin la desviación correspondiente de los otros dedos del pie, que es la regla en el reumatismo crónico.

Por vez primera fue invadida este año la rodilla, y el edema del pie tiende á propagarse á la pierna ; la crisis es también más larga y la fase de agudeza menos persistente. La gota manifiesta tendencia á instalarse en nuestro enfermo y á generalizarse; y como sucede siempre en tales casos, se hace menos dolorosa al adquirir el carácter crónico.

Hasta ahora, los accidentes han sido relativamente benignos en este enfermo, y los estigmas de la gota, los tofos, faltan casi por completo. No hay ni deformación de los dedos, ni endurecimiento de las vainas tendinosas, ni engrosamiento de las bolsas mucosas olecraneanas; pero en el pabellón de la oreja derecha, en el sitio de la concha se ve una elevación blanca pequeña, del grosor de un grano de mijo, que me parece una incrustación urática. La presencia de este tofo, por pequeño que sea, precisa el diagnóstico y nos permite afirmar que el enfermo es verdaderamente un gotoso. 
Queda ahora por interpretar la naturaleza de los accidentes pulmonares que precedieron á este último ataque de gota, y para ello volveremos á ocuparnos de los síntomas iniciales que caracterizaron el principio de la enfermedad.

El enfermo notó los síntomas primeros de su mal el 1. ${ }^{\circ}$ de Marzo : se despertó con dolores en las piernas y rigidez articular en los miembros inferiores, fenómenos tan poco acentuados que no le obligaron á interrumpir su trabajo. Duró este estado una semana, con persistencia de los dolores en el pie y en las rodillas. El día 8 se presentaron fenómenos congestivos graves en el pulmón y se observó albuminuria ; el 14 desaparecieron los síntomas de fluxión visceral á los que sucedió un ataque de gota franca.

Basta reflexionar en la marcha de estos accidentes para convencerse de que los dolores articulares del principio, aunque atenuados, eran ya la gota, y que la fluxión de pecho intermitente, se halla intercalada entre dos manifestaciones gotosas francas.

La conclusión se impone por sí misma. ¿ No era de naturaleza gotosa esta congestión pulmonar y no debe verse en este caso un ejemplo de las metastasis viscerales, cuya existencia han señalado Sydenham y Scudamore?

Esta idea hubiera sido aceptada sin la menor duda en el siglo xvin. Un ataque fluxionario del pulmón, que se presenta sin causa provocadora evidente después de dolores articulares y que desaparece de un modo brusco, á la vez que se inicia un acceso de gota franca, se hubiera considerado como un ejemplo típico de metastasis gotosa, de gota pulmonar. Hoy somos más escrupulosos desde el punto de vista científico, $y$ antes de aceptar como verdadera esta interpretación, debemos discutir el pro y el contra de la teoría y responder á las objeciones que pueden hacérsela. 
No olvidemos, ante todo, que nos hallamos en el mes de Marzo, es decir, en la época intermedia entre la primavera y el invierno que, en el clima de París, es la más fértil en afecciones pulmonares de todas clases. Es por lo tanto lógico suponer, que los dolores de gota y la fluxión pulmonar fueran en este hombre una simple coincidencia, y que en realidad las influencias climatéricas desempeñaran el papel preponderante. A esto responderé que no obró al parecer el enfriamiento; el enfermo es muy afirmativo respecto á este particular : no recuerda haberse enfriado ni de exponerse á coger frío. Por consiguiente, aunque no es posible desechar a priori la posibilidad de esta causa patógena, tampoco tenemos prueba alguna de ella.

Las manifestaciones patológicas que interesan aparatos orgánicos diversos, no dependen necesariamente de una causa morbosa común. Pueden superponerse la fiebres eruptivas de naturaleza diferente: se ve presentarse á la vez en un mismo individuo la viruela y el sarampión : una bronquitis aguda que se desarrolla en un tuberculoso no es por esto de naturaleza tuberculosa : cura y persisten las lesiones bacilares. ¿Por qué no ha de suceder lo mismo con la gota, y por qué un gotoso ha de estar exento de una congestión pulmonar intercurrente?

Hay más todavía : puede admitirse, como ley de patología general, que de dos manifestaciones morbosas superpuestas, la mayor suprime la otra y la anula en cierto modo ; lo que dice el aforismo hipocrático respecto al dolor, es verdadero para todo otro proceso patológico. La invasión de una bronco-pneumonía, por ejemplo, hace desaparecer los accesos de tos de la coqueluche, la aparición de una pulmonía, calma instantáneamente las convulsiones de la corea, la de una meningitis tuberculosa suprime las manifestaciones de la tisis pulmonar. Aplicando este principio á nuestro enfermo, podría decirse que la evolu- 
ción de la gota articular fue más lenta y dificil á causa de la congestión pulmonar, y que ésta no recobró sus caracteres francos hasta que desapareció la complicación torácica.

Estas objeciones son ciertamente fundadas. Pero creo que los argumentos en favor del origen gotoso en la fluxión pulmonar lo son también, y por mi parte admito la realidad de una manifestación torácica de la gota en este hombre.

¿Se comporta de este modo la congestión pulmonar clásica verdadera, consecutiva á un enfriamiento ó de origen microbiano? En nuestro enfermo no había causa ocasional apreciable ; padecía dolores reumatoides desde cinco ó seis días antes. De repente, sin dolor de costado, sin escalofrío, tuvo disnea y tos; su estado fue grave desde el principio. Los trastornos funcionales fueron grandísimos, los signos físicos, ligeros, y participaban á la vez de una pulmonía nada franca y de una bronquitis difusa; algunos estertores fríos, respiración sibilante, velada, tos $y$ expectoración ligeras, $\mathrm{y}$, por el contrario, angustia respiratoria grandísima y gravedad del estado general. La escena cambió á los pocos días y los pulmones quedaron permeables de una manera inusitada, á la vez que se presentaron los síntomas de una fluxión articular manifiestamente gotosa. Es dificil admitir en esta sucesión de accidentes una simple coincidencia, y el caso parece calcado en los que refiere Garrod, en los que se ve, en gotosos confirmados, manifestarse el ataque de gota por trastornos pulmonares, disnea, tos con ansiedad respiratoria grandísima, hasta que la tumefacción del dedo gordo del pie conjura la crisis visceral y revela su naturaleza.

Las manifestaciones pulmonares de la gota no son siempre tan típicas y muchas veces sólo es posible hacer el diagnóstico, teniendo en cuenta la evolución de la enfer- 
medad, y sobre todo, los antecedentes constitucionales del paciente. Asisto en la actualidad á una enferma que puede considerarse como gotosa, aunque faltan las manifestaciones articulares de esta diátesis. Se trata de una señora de setenta y tres años, que padece desde hace veinte eczema y arenillas, y que desde hará seis meses ha tenido alternativamente crisis de asma y cólicos nefríticos. Es de seguro gotosa, aunque jamás ha padecido fluxión en el dedo gordo del pie, y además es gotosa hereditaria, porque su padre padeció gota tofacia. Hace pocos días tuvo congestión pulmonar intensa, sin estertores, complicada con anuria y después expulsó un cálculo renal. Al principio sospeché accidentes urémicos, pero el riñón se hizo permeable, la orina no es albuminosa, y existe, por el contrario, en los pulmones, infarto grandísimo, con soplo congestivo, rayano con la hepatización, aunque la fiebre es nula. Ha desaparecido por completo el eczema que persistió de una manera permanente durante varios años. $\mathrm{Pa}$ rece lógico admitir, que la fluxión congestiva de origen gotoso que interesaba de ordinario la piel, ha variado de sitio y se ha hecho visceral.

Puede preguntarse, con razón, en estos casos muchas veces obscuros de manifestaciones pulmonares y artríticas alternas, si la congestión visceral que sobreviene en un gotoso, no bastará para despertar la diátesis y ocasionar un acceso de gota. Esta hipótesis está justificada por completo cuando se trata de un traumatismo. Un gotoso en buen estado de salud sufre un esguince; sobreviene una crisis de gota articular no sólo localizada en la articulación afectada, sino susceptible de generalizarse. ¿Por qué no ha de suceder lo mismo con una congestión pulmonar que quebranta más el organismo que un simple esguince?

No creemos exacta esta opinión en nuestro enfurmo, porque la hiperemia pulmonar no fue el accidente inicial, 
sino que se presentó después del primer ataque articular, pero no es menos cierto que un acceso de gota puede ser provocado por una congestión pulmonar. Hemos observado un ejemplo de ello hace pocas semanas. Recordad el enfermo que ocupó el núm. 24 de la sala Chauffard. Es un gotoso confirmado, cliente fiel del hospital Necker, que desde hace varios años viene cada seis meses por término medio con crisis gotosas articulares : tiene tofos en los dedos de los pies, en la mano, en las orejas y en los codos. Hace tres semanas ingresó en la clínica, no con los accidentes de costumbre, sino con un dolor de costado consecutivo á un enfriamiento; observamos los signos de una ligera congestión pulmonar que se resolvió en pocos días. Durante la convalecencia franca, se presentó un dolor en el hombro; al poco tiempo se afectaron el codo y la muñeca derecha; después las rodillas y los dedos de los pies con todos los caracteres de un ataque de gota franca, que cedió como las demás crisis, á beneficio del cólchico $\mathrm{y}$ de una dosis ligera de salicilato de sosa. Ved una flegmasía visceral de causa trivial, un simple resfriado que bastó para provocar una crisis de gota articular generalizada. He visto en la clientela privada tres veces una angina a frigore, inflamatoria y eritematosa franca, que produjo en gotosos un acceso articular. En tales casos sería exagerado decir que la angina ó la congestión pulmonar eran manifestaciones gotosas ; obraron como lo haría un traumatismo, porque en un gotoso todo es pretexto para despertar la diátesis. Deben tenerse siempre presente estas manifestaciones cuando se trata de interpretar casos de gota visceral.

No sería completa la historia de nuestro enfermo, si no a veriguáramos cómo se ha hecho gotoso y cuál ha sido el origen de su enfermedad. Sabéis que la gota es rarísima en los hospitales, y que casi se observa sólo en la clien- 
tela privada. La mayoría de los gotosos, por no decir todos, heredan su diátesis y las tendencias constitucionales de sus ascendientes : se encuentra la diátesis en las familias de artríticos, en las que alternan el eczema, la diabetes, la obesidad, el asma, las arenillas urinarias y biliares; en una palabra, todas las manifestaciones morbosas que el profesor Bouchard considera dependientes de un retraso de la nutrición.

Algunos, muy pocos, crean por completo su gota á causa de la mala higiene, de la vida sedentaria, ó de los excesos alimenticios y del abuso de bebidas fermentadas.

¿Puede invocarse esta etiología en nuestro enfermo? De ningún modo. Es un obrero sobrio, nada aficionado á las bebidas, que atiende á las necesidades de una familia numerosa, y cuya alimentación ordinaria es más bien parca que excesiva : además, nada de lo que sabe referente á su familia, justifica la idea de una herencia gotosa.

$\mathrm{El}$ origen de los accidentes gotosos en él es profesional. Es, en efecto, un saturnino, y sabéis que la intoxicación plúmbica constituye una de las causas predisponentes de la gota. Hace treinta y ocho años que este hombre es pintor y maneja el albayalde : ha padecido en tres ocasiones distintos cólicos de plomo; pero los accidentes tóxicos se han limitado á esto, sin fenómenos paralíticos ni trastornos nerviosos 6 viscerales : los únicos estigmas de saturnismo que existen son la cenefa de las encías y la dureza del pulso radial. Pero se ha hecho gotoso.

Estas afinidades notables de la gota y del saturnismo, no se han conocido bien hasta hace veinte años; pero ya en 1825 señaló con toda exactitud el hecho clínico Hillier Parry y después Todd y Garrod. La vulgarización en Francia de este dato etiológico se debe á Charcot, quien publicó, en 1863, los primeros casos de gota saturnina.

Hoy nadie niega la correlación patológica del saturnisCrínica mépica, - Tomo I. 
mo y de la gota; pero el hecho clínico se interpreta de distinta manera. Para unos es el plomo el que crea la gota ; para otros se limita á favorecer la tendencia diatésica individual.

El caso actual da, al parecer, la razón á la primer hipótesis, puesto que ni los antecedentes personales ni el género de vida del enfermo predisponían á la gota. Lo mismo acontece en casi todas las observaciones recogidas en nuestros hospitales, porque la alimentación de los obreros franceses es, en general, menos animal que la de los ingleses, y la gota es menos frecuente en ellos.

El mecanismo por el que la intoxicación saturnina produce la gota es todavía obscuro, como todo lo que se refiere á las modificaciones nutritivas íntimas. El plomo obra, al parecer, de dos maneras : amortiguando la nutrición y las funciones de desasimilación, y produciendo las lesiones de la nefritis intersticial idénticas, desde el punto de vista anatómico, á las del riñón gotoso.

Se ha demostrado al parecer en clínica, cualquiera que sea la explicación teórica del hecho, que los saturninos eliminan, en igualdad de condiciones, menos urea y ácido úrico, y que su sangre contiene más, de modo que se realizan á la larga las condiciones de la uricemia. Sabéis que esto es, para Garrod, el rasgo característico del estado gotoso. Algunos casos experimentales de saturnismo artificial, confirman estas ideas teóricas.

$\mathrm{El}$ análisis de la orina en nuestro enfermo, no dió resultados concluyentes. Al ingresar en el hospital, su carácter era el de la orina febril; contenía bastantes uratos, pocos ácidos, ninguna proporción notable de albúmina : era la época de la crisis pulmonar. Una vez corregida ésta, desapareció la albúmina del líquido urinario, disminuyeron también los uratos y el ácido úrico, fenómeno fácil de explicar por la inapetencia del enfermo y los pocos alimentos 
que tomaba. No se analizó la sangre; me es imposible decir si contenía una proporción de ácido úrico superior á la normal. Es una cuestión que merece reservarse tanto más, cuanto que la teoría de Garrod no es exacta siempre, y muchos saturninos gotosos, cuya sangre se ha analizado desde este punto de vista, no eran uricémicos. Sabéis que en materia de urea y de ácido úrico, el factor más importante es la alimentación; en las observaciones publicadas no se indica ni la cantidad ni la naturaleza de los alimentos que tomaban los enfermos, lo que quita bastante valor á los resultados obtenidos. Lecorché y Bouchard han demostrado también que los gotosos confirmados eliminan tanto ó más ácido úrico que otros enfermos, cuando siguen alimentándose en abundancia. No creo, por mi parte, que basta comprobar la disminución habitual de la excreción úrica para que se desarrolle por completo el estado gotoso.

¿Cuál es el porvenir de nuestro enfermo y cuáles son las eventualidades que le esperan?

El pronóstico de su estado de gota actual, no obstante la complicación pulmonar que ha producido, es indudablemente benigno. La congestión del pulmón y la albuminuria han desaparecido, y todo se reduce, en la actualidad, á dolores articulares subagudos, que durarán quizá algún tiempo, porque la gota principia á ser crónica en este enfermo, pero que concluirán por desaparecer.

El pronóstico del porvenir es más grave. Resulta, de la mayor parte de las observaciones de gota saturnina publicadas, que esta variedad tiende á propagarse con rapidez á las grandes coyunturas, y que se fija en ellas más bien que la gota franca. El saturnismo produce además lesiones renales mucho más precoces y profundas que la gota; èn nuestro enfermo son, al parecer, poco acentuadas; pero existe ya el pulso duro, indicio de la arterio-esclerosis y de la nefritis intersticial. Es decir, que en una época quizá 
no muy lejana, sobrevendrán los accidentes, debidos á la hipertrofia del corazón ó á la uremia.

Pero, excepto cierto grado de exageración de la tensión arterial, debo decir que, hasta ahora, el corazón parece sano y las arterias no están ateromatosas, lo que atenúa bastante la gravedad del pronóstico.

El tratamiento que debe emplearse tiene gran interés, porque plantea varias cuestiones de práctica no resueltas. Ante todo, ¿conviene tratar en este enfermo las manifestaciones articulares de la gota, ó es mejor abandonarlas á la naturaleza, por temor á despertar ó provocar repercusiones viscerales? Responderé, con Charcot, que jamás debe abandonarse á sí misma la gota, y que es necesario tratar sus manifestaciones articulares, agudas ó subagudas; pero es preciso hacerlo con prudencia y no emplear medios violentos. Admito que sea peligroso, en pleno acceso de gota franca, sumergir la pierna en agua helada; el alivio en este caso es seguro, pero la transición es brusca en demasía, y se ven presentarse, en ciertos casos, accidentes graves, aunque menos á menudo de lo que se ha dicho. ¿Quiere decir esto que debe renunciarse á los medios de refrigeración? No, y hasta los considero utilísimos. Acostumbro, en tales casos, á aplicar sobre las articulaciones, renovándolas á menudo, compresas empapadas en cocimiento frío de malvabisco, $\delta$, mejor aún, en un líquido astringente, como el agua de vegeto; envuelvo la articulación en hule de seda, y estas especies de cataplasmas frescas alivian más á los enfermos que la envoltura en algodón en rama que recomiendan muchos médicos.

Empleo á la vez el tratamiento interno, y considero el cólchico, según Garrod y Charcot, como uno de los medicamentos más útiles de que disponemos para combatir las fluxiones gotosas.

Nuestro enfermo toma 20 gotas diarias de tintura de cól- 
chico; cuando las articulaciones estaban hinchadas y dolorosas administré también el salicilato de litina, á la dosis de 3 gramos por día, y habéis visto, bajo la influencia combinada de estos dos medicamentos, disminuir con rapidez la hinchazón, y calmarse el dolor en cuarenta y ocho horas, sin consecuencia alguna funesta para el organismo.

Las manifestaciones viscerales de la gota, como las del reumatismo, son muchas veces refractarias á la terapéutica. El cólchico, y las preparaciones saliciladas, no obran, por decirlo así, sobre las complicaciones pulmonares, y la medicación sintomática es en este caso la que presta más servicios. Los revulsivos cutáneos en el pecho, las emisiones sanguíneas locales, la ipecacuana, son los medios más activos de que disponemos contra las congestiones pulmonares gotosas, lo mismo que contra las fluxiones de pecho a frigore; la sangría está perfectamente indicada cuando la disnea es fuerte é inminente el peligro de asfixia. 


\section{REUMATISMO ESPINAL}

Sumario: Ciertas formas de reumatismo agudo iprincipian como las congestiones espinales y revisten los caracteres de una parálisis ascendente aguda?-Ejemplo en su apoyo : invasión progresiva de los miembros inferiores y superiores. - Caracteres diferenciales con las mielitis agudas verdaderas. - Analogía del reumatismo y de las enfermedades de la médula : origen espinal de todos los reumatismos.-Historia de este asunto.-Reumatismos espinales y mielitis reumatoides. - Caracteres deducidos de los reflejos tendinosos. - Marcha diversa de los accidentes. - Pronóstico y tratamiento.

Voy á ocuparme hoy de un enfermo que padece una afección aguda, cuyo diagnóstico fue muy difícil al principio, y me pareció muy grave hasta el momento en que un cambio brusco en la evolución de la enfermedad, la transformó en un reumatismo articular clásico.

César T., de reinte años, es un italiano robusto que ejerce la profesión de cochero y que jamás ha padecido una enfermedad grave. El domingo último, hace tres días, condujo á un parroquiano al Bosque de Bolonia, y allí permaneció unos tres cuartos de hora sentado sobre el césped húmedo ; después hizo un viaje bastante largo hacia Montrouge; se encontraba entonces completamente bien. Al llegar á su destino quiso bajar del pescante, pero le fue imposible moverse. Tenía los miembros inferiores entumecidos, pesados y débiles ; sentía en la región lumbar un dolor fuerte. Se le llevó á su domicilio y tuvo que acostarse. Aquella misma tarde tuvo escal ofríos repetidos, fiebre y algo de delirio. El lunes por la mañana le fue imposible levantarse y mucho menos an dar. Se le condujo á la consulta del hospital, donde no pudo tenerse en pie : era un paraplégico. 
Al otro día encontramos al enfermo en el estado siguiente ; tenía fiebre bastante alta $\left(38^{\circ}, 6\right)$, y sed insaciable; la orina era escasa, de color encendido, cargada de uratos y no había dificultad en la emisión. La impotencia funcional de los miembros inferiores era completa : el enfermo no podía levantar las piernas; le costaba trabajo moverse en sentido lateral en el lecho; era incapaz de sentarse tanto á causa de la debilidad como del dolor.

Este era de dos clases. Consistía durante el reposo en una sensación de constricción penosa y permanente en las rodillas y en las caderas, con la que alternaban de cuando en cuando accesos agudos y punzantes. En la región lumbar era fijo y profundo; el enfermo le comparaba á una presión contínua sobre la columna vertebral con irradiaciones hacia las ingles y la raiz de los muslos.

El dolor á la presión variaba. Era, por decirlo así, nulo en la región lumbar y agudísimo en las rodillas y en la garganta del pie. No se descubrían signos de artritis local y las articulaciones no estaban rubicundas, hinchadas ni distendidas por líquido. Pero la interlínea articular era muy dolorosa, signo de una sensibilidad grandísima de la sinovial.

El reflejo rotuliano estaba también muy acentuado en los miembros inferiores; el plantar se hallaba bastante exagerado. Pero la sensibilidad era normal y no había fenómenos subjetivos, como hormigueo, punzadas, entumecimiento, $\tan$ frecuentes en las paraplegias.

Los riñones, el corazón y los pulmones estaban sanos.

Este cuadro clínico indicaba al parecer una enfermedad de la médula, de marcha rápida y de localización lumbar. Se empleó un tratamiento enérgico de acuerdo con esta idea : se pusieron á lo largo de la columna vertebral ocho ventosas escarificadas, y se administraron al interior 6 gramos de salicilato de sosa para obrar sobre el eje medular. 
Al día siguiente, miércoles, seguía el mismo estado, y los síntomas continuaban siendo alarmantes : eran más acentuados que la víspera. Los miembros inferiores estaban inertes por completo; los superiores, á salvo hasta entonces, se afectaron á su vez. Las muñecas, los codos y los hombros estaban dolorosos é inmóviles, y la impotencia funcional se generalizó. Apareció un síntoma nuevo que indicaba la invasión de la médula cervical : el cuello se puso rígido, doloroso y sus movimientos se hicieron difíciles. El estado de los miembros superiores era análogo por completo al que presentaban los inferiores el día anterior : había dolor fijo de constricción raquidiana en la región cervico-dorsal $y$, dolor local que se exacerbaba al comprimir las muñecas, los codos y los hombros. En los miembros inferiores, los fenómenos articulares eran más acentuados : la rodilla y la articulación tibio-tarsiana estaban hinchados y se notaba algo de derrame debajo de la rótula. La raquialgia lumbar aumentó hasta el punto de que el enfermo, no sólo no puede sentarse, sino que le es imposible ejecutar movimiento alguno para adoptar el decúbito lateral. Al moverse sentía dolores fuertes, atroc es que irradiaban de la región lumbar y se propagaban á los miembros inferiores.

Se observó á la vez un síntoma nuevo. El reflejo tendinoso rotuliano, exagerado la víspera, estaba muy disminuído y era casi nulo. El plantar era también mucho menor; la excitabilidad espinal había disminuído de un modo notable desde el día anterior.

Resulta de la exposición de estos síntomas que, durante los tres primeros días, podía dudarse entre una congestión aguda de la médula, hasta una mielitis y el reumatismo espinal de principio anormal. Las condiciones etiológicas en que se produjo la enfermedad, no permitían resolver la cuestión, porque el frío produce por igual los dos padeci- 
mientos, $y$ es indudable que el enfermo adquirió sus dolores por sentarse sobre el cesped húmedo.

Algunos caracteres hacían sospechar el reumatismo espinal : la rapidez de la fluxión en las articulaciones del miembro inferior, la forma de esta fluxión, que era la de una artritis verdadera, pero que no iba acompañada de calor ni de rubicundez locales y casi sin tumefacción inicial, con dolor fuerte á la presión. El carácter de la orina, escasa, hemafeica, cargada de uratos, era más bien sintomático de un ataque de reumatismo; por último, la falta de parálisis de la vejiga, cuando los miembros inferiores estaban al parecer impotentes por completo, indicaba también el reumatismo.

El diagnóstico era dudoso, á pesar de estas presunciones clínicas. Sorprendía el carácter singular de este reumatismo, que interesaba desde el principio de un modo simétrico los dos miembros inferiores, respetando los superiores, como sucede en la paraplegia más típica. La existencia de un dolor lumbar fijo, agudísimo terebrante, que irradiaba hacia las extremidades inferiores, al ejecutar el enfermo el movimiento más ligero, hacía sospechar una mielitis aguda en foco en las fases primeras del padecimiento.

El reumatismo verdadero está caracterizado más bien por dolores periféricos articulares, que por manifestaciones centrales : es raro además que principie exclusivamente por la forma paraplégica, sin propagarse pocas horas después á las articulaciones superiores. En este caso sucedió todo lo contrario : el dolor espinal fue muchísimo más fuerte que el de las articulaciones. La impotencia funcional, completa y desproporcionada al dolor. La mayor parte de los reumáticos que acuden á los hospitales, pueden sostenerse en pie y dar algunos pasos, aunque con trabajo : en éste, antes de toda manifestación dolorosa, el 
miembro estaba entumecido, casi paralizado, y las piernas no podían sostener al enfermo.

De todos modos el caso era anormal. Considerándose como un ejemplo de reumatismo, era extraño observar una paresia motora predominante y dolores de origen central ; si se le consideraba como una mielitis incipiente, sorprendía la existencia de dolores articulares provocados por la presión y la falta completa de parálisis vesical.

Cualquiera que fuese el diagnóstico de la enfermedad, se destacaba un hecho del conjunto de los síntomas, la participación innegable de la médula en los trastornos funcionales.

Voy á ocuparme de estos casos obscuros de reumatismo con predominio espinal.

Hace poco tiempo que se acepta la realidad de esta forma clínica, aunque es indudable que la han observado los médicos. Pero no había entrado todavia en el dominio clásico. En su artículo notabilísimo sobre el reumatismo, le admitía, con salvedades, mi maestro el Dr. Besnier, y lo consideraba como probable y casi demostrado. No se ha publicado, que yo sepa, trabajo alguno de conjunto sobre esta cuestión.

A decir verdad, es difícil trazar la línea divisoria entre el reumatismo espinal y las formas ordinarias del reumatis. mo; pero lo probable, por no decir seguro, es que la especie primera no difiere por sus caracteres fundamentales de la segunda. Analizando, sin idea preconcebida, los síntomas del reumatismo, es imposible no comprender la parte grandísima que tienen los trastornos funcionales de origen espinal en la sintomatología de la afección. Ante todo, la artritis de los reumáticos no es una verdadera inflamación, aunque se hayan descubierto muchas veces en el exudado articular fibrina y algunos leucocitos. Es una fluxión 
repentina y móvil, como las de origen nervioso, que varía de sitio de pronto y con facilidad extrema, que se resuelve sin dejar rastro, y que recidiva por la causa más ligera. Hay siempre una diferencia notable entre las determinaciones articulares y la temperatura central ; ésta es independiente de la localización articular, y no está en relación con el número de articulaciones invadidas. La sensación de cansancio general, el quebrantamiento de los miembros y los dolores articulares, aunque característicos del reumatismo, no son especiales de él ; este síndrome se observa en muchas enfermedades generales, en las que se afecta más $\delta$ menos el centro espinal; pueden citarse, como ejemplos, la viruela y la grippe.

La distribución de las artropatías reumáticas suministra también argumentos en favor de la teoría del origen espinal de la lesión. Al lado de los hechos en los que se generalizan las fluxiones articulares sin orden aparente y como al azar, ¡ cuántas veces es simétrica la invasión de las articulaciones como en los padecimientos de la médula! Es imposible comprender esta simetría morbosa sin aceptar un origen central.

Por último, los trastornos de la nutrición que acompañan á ciertas formas de reumatismo articular, son trastornos tróficos de origen nervioso.

Comparad desde este punto de vista las deformaciones de las falanges y de las muñecas de los reumáticos crónicos, y os sorprenderá su analogía, por no decir su identidad, con las que existen en ciertas enfermedades del sistema nervioso central, sobre todo en la parálisis agitante. Los mismos edemas duros, iguales atrofias musculares, idéntico trastorno de nutrición cutánea, el mismo aspecto escamoso y seco de la epidermis en ambos casos.

Hasta el tratamiento demuestra de una manera indirecta la participación de la médula en el proceso reumático. El 
salicilato de sosa cura de un modo tan maravilloso las fluxiones articulares de los reumáticos, porque es un medicamento espinal, que obra sobre los centros nerviosos. La prueba es que modifica, con el mismo éxito, los síntomas de origen central, por ejemplo, los dolores fulgurantes de la tabes.

Puede, por lo tanto, afirmarse en principio, que en todos los reumáticos se afecta más ó menos la médula, y es casi indudable que la lesión primitiva del reumatismo, desconocida aún, radica en el eje medular. El término reumatismo espinal es, por lo tanto, un pleonasmo, porque todos los reumatismos son espinales en cuanto á su origen. Pero conviene conservarle hasta nueva orden, porque responde á una variedad clínica bastante diferente del reumatismo clásico, en la que los síntomas articulares se hallan relativamente en segundo término, mientras que desempeñan el papel más importante la impotencia funcional, los fenómenos paréticos y el dolor raquidiano central.

Estos casos de reumatismo medular son raros, y sobre todo, no se les presta la atención suficiente. Se encuentran, en efecto, algunos ejemplos diseminados por la literatura, como curiosidad patológica, sin que se haya procurado sacar de ellos partido desde el punto de vista de la concepción de la naturaleza del reumatismo. Trousseau, por ejemplo, refiere en su clínica el caso de una joven, cuya observación se asemeja de una manera notable á la de nuestro enfermo ; el síntoma primero fue una parálisis completa ; á los pocos días se afectaron las articulaciones, y el reumatismo siguió su marcha clásica.

El primer trabajo preciso sobre este asunto data de algunos años. En 1878 leyó Vallin un buen trabajo en la Sociedad Médica de los Hospitales, en el que demostró que en los reumáticos alternan los fenómenos mielíticos con fluxiones articulares múltiples. El primero de sus en- 
fermos era un hombre de cuarenta y tres años, reumático, el que, á consecuencia de un enfriamiento, tuvo fiebre, escalofríos y al poco tiempo parálisis : cuarenta y ocho horas después era completa la parálisis de los miembros inferiores. Durante seis días se creyó que el enfermo padecía mielitis aguda, y como tal se le trató ; pero de repente, al séptimo día, desapareció la parálisis del miembro inferior izquierdo é invadió el brazo derecho. Se afectó á su vez el brazo izquierdo y quedó libre la pierna izquierda. A los diez días había desaparecido toda parálisis, se presentaron fluxiones articulares dolorosas, análogas por completo á las del reumatismo, que cedieron al poco tiempo á beneficio del tratamiento. Para completar la demostración, sobrevino una pericarditis durante las manifestaciones articulares, lo que demostró que la enfermedad de este hombre había sido desde el principio un reumatismo de evolución anormal.

El segundo caso de Vallin se refiere á un soldado, de treinta y tres años, quien á consecuencia del enfriamiento durante una noche de guardia, sintió cansancio febril y raquialgia. La enfermedad quedó estacionaria por espacio de una semana y mal definida, pero á los doce días se presentaron escalofríos, hiperestesia grandísima de los miembros inferiores y de la región lumbar é impotencia funcional rayana con la paraplegia. Los accidentes parecían graves, cuando se observó tumefacción de las muñecas y manifestaciones indolentes del reumatismo.

Si todos los casos fueran análogos á éstos, el diagnóstico sería relativamente sencillo. Pero lo que complica de un modo especial la cuestión, es que hay mielitis verdaderas que se asemejan á los reumatismos y que originan fenómenos articulares más ó menos generalizados. En la Sociedad Médica de los Hospitales (Bull., 1878) referí un caso de este género que observé cuando prestaba mis ser- 
vicios en el hospital Laënnec en calidad de agregado. Una lavandera, de treinta y seis años, se expuso á un aguacero frío, que mojó sus vestidos ; aquella tarde misma sintió raquialgia, hormigueo y entumecimiento de los dedos, y al día siguiente tuvo dolores en las articulaciones tibio-tarsianas, ocho días más tarde en las rodillas, y por último, en los codos. Al ingresar en el hospital, cinco semanas después de principiar estos accidentes, presentaba todos los síntomas ordinarios del reumatismo subagudo, de tendencia crónica : las rodillas, los codos y las articulaciones tibio-tarsianas estaban hinchadas y dolorosas. Pero existía además un fenómeno anormal en el reumatismo, una extensa escara en la región sacra, casi indolente, y en la que no se había fijado la enferma. La existencia de esta escara tan bien tolerada, me hizo diagnosticar una mielitis, aunque no había habido raquialgia, dolor en forma de cinturón, ni parálisis vesical, y la marcha de la enfermedad confirmó á los pocos días mi diagnóstico, porque se presentó paraplegia complicada con fenómenos de pielonefritis, que ocasionaron la muerte de la enferma. Al hacer la autopsia se descubrió meningo-mielitis supurada de focos múltiples y pus en las articulaciones.

Estos casos demuestran cuán íntimas son las afinidades que existen entre el reumatismo y las afecciones agudas de la médula, y cuán difícil es el diagnóstico algunas veces. Hace dos días todas indicaban que nuestro enfermo padecía una mielitis invasora : el principio brusco, desproporcionado á la causa provocadora, un enfriamiento ligerísimo, la fiebre y el quebrantamiento general, el dolor raquidiano fijo, la parálisis precoz ; todo hacía sospechar una afección medular : sólo faltaban en el cuadro sintomático los trastornos de la sensibilidad y la parálisis de la vejiga. Podía sospecharse también una congestión espinal, una mielitis 6 una parálisis ascendente aguda, al 
ver afectarse al otro día los miembros superiores después de los inferiores y suceder á la exageración de los reflejos rotulianos su abolición. Es verdad que en tales casos hay casi siempre una gran hiperestesia, hormigueo y entumecimiento, lo que no sucedía en nuestro enfermo, pero estos síntomas no son constantes aun en los casos confirmados de parálisis ascendente aguda, y era posible dudar.

Hoy es imposible la duda: se trata de un reumatismo. Bajo la inflencia del salicilato de sosa á grandes dosis las articulaciones han dejado de ser dolorosas, aunque siguen todavía hinchadas, el dolor lumbar se ha mitigado lo bastante para permitir sentarse al enfermo, ha desaparecido la rigidez de la nuca, y por más que persiste la impotencia funcional de los miembros inferiores, puede hacer el paciente algunos movimientos ligeros. En una palabra, su aspecto es el de un reumático que acaba de sufrir una crisis aguda y entra en convalecencia.

Llamo vuestra atención, de una manera especial, sobre las modificaciones interesantes que presentaron los reflejos rotulianos y plantar. Al principio de la enfermedad estaban muy exagerados, pero disminuyeron al segundo día y desaparecieron después : hoy son nulos por completo. Este hecho, que podría hacer sospechar una agravación del padecimiento y que consideré al principio como de mal agüero, no tiene el vaior pronóstico que creía.

La desaparición de los reflejos no indica por necesidad la invasión más profunda del eje gris, ni la desorganización de la médula: demuestra sólo que ha disminuído la excitabilidad refleja de los centros nerviosos, efecto de la medicación que obra como un analgésico. He observado ya varias veces que el salicilato de sosa disminuye el reflejo rotuliano hasta el punto de suprimirlo por completo. Nuestro enfermo tomó 6 gramos el primer día y 10 los días siguientes, dosis con la que se obtuvo un alivio rápido, pero que oca- 
sionó algunos zumbidos de oídos. Es preciso no atribuir á este fenómeno una significación más grave, pero es interesante desde el punto de vista de los efectos patológicos del medicamento y también de la teoría medular del reumatismo.

El pronóstico es hoy menos grave y el diagnóstico más claro. Es indudable que este enfermo curará y puede esperarse que cure en poco tiempo. Pero cuando el diagnóstico, y por consiguiente el pronóstico son dudosos, deben consultarse las reacciones eléctricas de los músculos. Muchas veces en las afecciones de la médụla, y sobre todo cuando participan de la lesión los nervios periféricos, como sucede en las polineuritis infecciosas, tarda poco en desaparecer la contractilidad farádica muscular, lo que no sucede en los reumáticos. Otros signos tienen una gran importancia para el pronóstico y son de mal agüero : tales son la tendencia á las escaras precoces de la región sacra, la aceleración de los latidos cardíacos sin elevación de la temperatura (variedad de taquicardia debida de ordinario á un trastorno funcional del pneumogástrico), y sobre todo la rigidez del cuello y la disfagia que indican la invasión del bulbo. El pronóstico es, por el contrario, favorable cuando se ve variar de sitio los fenómenos articulares.

En los casos dudosos importa más que el análisis de los síntomas diversos, en particular, la observación de su sucesión y de su marcha. El reumatismo espinal es móvil, superficial, brusco en sus manifestaciones: esta movilidad y rapidez indican de ordinario un pronóstico favorable. En las mielitis, por el contrario, el principio puede ser repentino y la paraplegia seguir una marcha invasora rápida, pero los síntomas dolorosos, lo mismo que las fluxiones articulares, son fijos y permanentes ; hay casi siempre fenómenos de parestesia que consisten en sensaciones de entumecimiento, de hormigueo y de picotazos. En nues- 
tro enfermo, la precocidad de las manifestaciones articulares, que se presentaron de pronto é inmediatamente después del dolor raquidiano, era un síntoma insólito en la hipótesis de una afección de la médula.

El tratamiento es importantísimo y nunca os prevendré lo necesario contra la tentación de recurrir al método expectante en el reumatismo espinal incipiente. Es imposible, en efecto, en los primeros días de la enfermedad afirmar lo que ha de suceder, y en la hipótesis de una mielitis incipiente, el retraso más ligero en la intervención terapéutica puede ser desastroso. Así es que, en los casos obscuros debe obrarse como si se tratara de una inflamación medular en su principio y emplear, sin perder tiempo, los medios antiflogísticos enérgicos. El día que ingresó nuestro enfermo se le aplicaron ocho ventosas escarificadas á lo largo de la columna vertebral ; creo que este medio estaba perfectamente indicado, aunque sólo fuera para calmar el dolor. A la vez, en la suposición lo mismo de una mielitis que del reumatismo, debe prescribirse el salicilato de sosa á dosis elevadas. Habéis visto que después de tomar una primer poción que contenía 6 gramos del medicamento, la mejoría fue casi nula; hubo que elevar la dosis á 10 gramos y provocar algunos fenómenos de salicismo para que desaparecieran los accidentes. El salicilato de sosa, aunque no produce tan buenos efectos en las mielitis francas, obra sobre la médula, disminuyendo los reflejos espinales y quizá descongestionando los centros nerviosos; no está, por lo tanto, contra-indicado.

La morfina en inyecciones hipodérmicas es útil algunas veces como paliativo contra los dolores, pero no debe constituir por sí sola la base del tratamiento.

Hammond, de Nueva York (1), recomienda el corne-

(1) Enfermedades del sistema nervioso, publicada por la Biвlioteca Eoonómica de la Revista de Medicina y Cirugía práotioas, Madrid.

Climion médica. - Tomo I. 
zuelo de centeno á dosis elevadas para disminuir la congestión espinal en todos estos casos de reumatismo 6 de accidentes medulares de tipo reumatoide. Hace tomar á sus enfermos durante el día cinco á seis cucharadas pequeñas de una solución acuosa de cornezuelo de centeno, que representan próximamente 6 á 8 gramos de ergotina. No he tenido ocasión de emplear el tratamiento del médico americano en las formas agudas de la mielitis, pero he observado muchas veces los buenos efectos de la ergotina en las enfermedades crónicas de la médula, y creo muy racional su empleo en los accidentes congestivos espinales. No dudaría emplearlo si en un caso de reumatismo espinal agudo fueran impotentes la medicación antiflogística y el salicilato de sosa. 


\section{ENFERIMEDADES DEL APARATO RESPIRATORIO}

\section{PULMONÍAS ABORTIVAS}

Sumario: Descripción de un caso de pulmonía abortiva; brotes sucesivos congestivos que fueron acompañados de erupción de herpes: defervescencia brusca al séptimo día.-Discusión de este caso: no es ni la congestión pulmonar idiopática de Woillez, ni la fiebre herpética de Parrot. - Analogía de evolución con la pulmonía verdadera, desde el punto de vista de los síntomas y de la etiología. - Algunas de estas congestiones pulmonares parecen ser de origen microbiano. - Su carácter contagioso probable. - Analogía de su evolución térmica con la de las enfermedades infeciosas. - iPueden considerarse como pulmo nías de virulencia atenuada?

Acabamos de ver en el núm. 30 de la sala Delpech una mujer de veinticinco años, convaleciente de una enfermedad aguda, que jamás ha revestido gravedad, pero que es interesante por más de un motivo. Esta joven, de constitución robusta, jamás ha estado enferma, y vino á París por vez primera hace quince días; apenas había transcurrido una semana de su llegada cuando sintió malestar, es. calofríos y fiebre; se quejó de quebrantamiento general y principió á toser. Este estado duró cinco días sin modificarse después; de repente, hace tres días, se presentó en el lado izquierdo dolor acompañado de opresión; durante el día expectoró dos esputos sanguinolentos y tubo que sus. pender su trabajo al día siguiente por sentir fatiga excesiva. En estas condiciones se vió obligada á ingresar en el hospital.

El día de su ingreso, 29 de Marzo, observamos los sín- 
tomas siguientes : la enferma tenía fiebre, 108 pulsaciones y $39^{\circ}$ de temperatura; la cara estaba animada, bultuosa en ciertos momentos, pero sin aspecto adinámico. La disnea era ligera, unas treinta respiraciones por minuto ; el dolor del costado era, por el contrario, bastante fuerte $y$ aumentaba durante las inspiraciones profundas y por los esfuerzos de tos; al comprimirse sobre la zona diafragmática izquierda se producía dolor. La tos era frecuente, sin carácter accesional, la expectoración poco abundante, tenaz y viscosa, tenía el carácter de la gelatina de manzanas y presentaba indicios de pigmento sanguíneo, pero no era posible decir que los esputos fueran herrumbrosos.

Los signos físicos eran los de una ligera congestión de la base pulmonar izquierda. La percusión en este sitio daba un sonido macizo y era algo dolorosa. Se conservaban las vibraciones, pero el murmullo vesicular estaba debilitado. La respiración parecía lejana y velada, sin indicio de soplo en punto alguno; se oían á la inspiración algunos estertores mucosos bastante finos que no tenían el carácter seco de los estertores crepitantes.

La enferma se quejaba también de trastornos gástricos, tenía inapetencia y repugnancia para el alimento, la lengua estaba saburrosa y los intestinos funcionaban mal.

En resumen, después de cinco días de pródromos más ó menos vagos, que indicaban la invasión de un estado gripal, existía un foco de congestión pulmonar. El caso parecía muy simple y me limité á prescribir una poción opiácea con kermes para favorecer la expectoración.

La marcha de la enfermedad presentó particularidades especiales. En efecto, desde el día siguiente, el cuarto á contar desde que se presentó el dolor de costado, se produjo al parecer una defervescencia marcadísima, la temperatura descendió á $38^{\circ}, 3$ y desapareció la disnea. Pero por la tarde hubo recrudescencia febril acentuada, el ter- 
mómetro se elevó á $40^{\circ}$, se presentó de nuevo el dolor de costado sub-mamario y los esputos adquirieron de nuevo un color herrumbroso. Apareció á la vez en los labios un grupo de vesículas de herpes (ventosas escarificadas, sulfato de quinina 1 gramo).

$\mathrm{Al}$ siguiente día, 24 de Marzo, las mismas oscilaciones: por la mañana descendió la temperatura á $37^{\circ}$, y por la tarde se elevó á $40^{\circ}$; el dolor de costado era supra-mamario y más fuerte que la víspera, y los esputos tenían el carácter herrumbroso (ipecacuana estibiada).

El 25 de Marzo no se reprodujo por vez primera la ascensión térmica vespertina, aunque persistía el malestar y el dolor de costado. Se oían en la axila izquierda algunos estertores puros y la respiración era áspera en la fosa sub-espinosa correspondiente. Por la mañana se presentó un brote nuevo de herpes más confluente que el primero.

Desde entonces (siete días después de aparecer el dolor de costado) la defervescencia fue franca ; marcó esta fase nueva de la enfermedad una crisis abundante de sudor y un tercer brote de herpes.

Desde entonces, la afección pudo considerarse curada, la fiebre era nula, la lengua se limpió y renació el epitelio. El único vestigio de la lesión pulmonar, era cierto grado de debilidad respiratoria en el vértice del pulmón izquierdo.

Considerando en su conjunto esta enfermedad, se observa un primer período prodrómico caracterizado por la fiebre y el quebrantamiento, inherentes á todas las infecciones. Después un principio franco de pulmonía ó de congestión pulmonar. La afección, en vez de seguir una marcha regular y de entrar en defervescencia á fines del septenario, presentó una serie de oscilaciones y sufrió al cuarto día una verdadera recrudescencia ; en dos ocasiones diferentes reaparecieron los síntomas funcionales á la vez que se presentaron erupciones de herpes; por último, la 
convalecencia se presentó de una manera franca, como en la pulmonía, y la enferma curó en pocos días.

Este caso, sencillísimo en apariencia y que jamás presentó una gravedad verdadera, puede interpretarse de varios modos.

Es posible considerarle, bien como una variedad de congestión pulmonar, que correspondería á la fluxión de pecho de los antiguos, 6 como una fiebre herpética de localización pulmonar, ó como una pulmonía franca de síntomas rudimentarios y atenuados. Revisemos estas diversas hipótesis.

En la congestión pulmonar idiopática, tal como la describe Woillez, los síntomas son análogos á los que presentó nuestra enferma, pero difieren por la evolución y la marcha del padecimiento. Véase lo que sucede en tales casos : el enfermo siente de repente, sin pródromos, dolor torácico más ó menos fuerte, fijo, que exacerban la tos y los movimientos respiratorios : la disnea está subordinada á la intensidad del padecimiento. La tos es rara, la expectoración casi nula, espesa, gomosa y pocas veces sanguinolenta. La fiebre es franca, alta de ordinario, y va acom. pañada de escalofríos, de calor grande y de quebrantamiento enorme. Pero en vez de durar casi un septenario, como en las pulmonías verdaderas, presenta entonces, por lo general, pero no siempre, el herpes labial.

Los signos físicos son sub-macicez en el sitio doloroso del pecho, disminución de las vibracionas torácicas, pero no su supresión. Al auscultar suelen oirse estertores finos, ó soplo más ó menos dudoso, y siempre debilidad del murmullo vesicular. La voz está modificada, es temblorosa, y en ocasiones se nota broncofonía. Estos signos estetoscópicos no difieren en el fondo de una manera notable de los que presentaba nuestra enferma.

Pero el caso actual difería por más de un concepto de 
este tipo morboso, aunque presentaba analogías evidentes. Ante todo, hubo verdaderos pródromos que duraron bastante tiempo, casi una semana : no sucede así en la congestión pulmonar clásica, que principia de repente, sin malestar prodrómico. En vez del dolor de costado inicial, brusco y fuerte siempre, vimos en nuestra enferma que se presentó con lentitud, de un modo insidioso, que aumentó por espacio de varios días, y que varió de sitio porque al principio era sub-diafragmático, después se hizo sub-mamario y por último mamario. La marcha de la temperatura fue distinta también. En la congestión pulmonar clásica faltan de ordinario las exacerbaciones vespertinas de la fiebre, y el herpes labial, cuando se presenta, es señal de la defervescencia ; en este caso, por el contrario, la erupción de herpes coincidió dos veces con la recrudescencia de la fiebre y el aumento del malestar. Puede deducirse, por lo tanto, de esta comparación, que las dos afecciones, aunque similares, no eran idénticas.

Parrot ha defendido la teoría de la fiebre herpética para explicar los casos de este género en los que la reacción febril general es grande y muy benignos los signos locales. Esta contradicción aparente depende, según él, de una mala interpretación de la filiación morbosa. En vez de considerar el herpes labial como un epifenómeno secundario de la congestión pulmonar, lo considera como el fenómeno predominante, á causa de la neuritis, de la que es una manifestación. La neuritis puede localizarse en la piel, en las mucosas ó en las vísceras, y la congestión pulmonar ser una de sus manifestaciones. Es la misma idea que emitió hace treinta años Cazalis en forma paradógica, y que defendió después Fernet, á saber, que la pulmonía es consecuencia de una neuritis del pneumogástrico. Pero es sólo una hipótesis y nada justifica la creación de esta entidad patológica. 
¿Es posible asimilar estos casos de congestión pulmonar entre las pulmonías verdaderas? La analogía es indudablemente grandísima, tanto desde el punto de vista de los síntomas funcionales como de los generales : puede decirse que la congestión pulmonar presenta el cuadro completo, aunque atenuado, de lo que sucede en la pulmonía : escalofríos, dolor de costado, disnea, expectoración tenaz y á veces sanguinolenta, nada falta en ella. Respecto á los signos estetoscópicos, es indudable que no pueden suministrar elementos suficientes para el diagnóstico, porque se ven congestiones simples que van acompañadas de soplo tubario y de broncofonía, y pulmonías centrales que llegan á la hepatización sin quẻ se noten al auscultar modificaciones apreciables.

¿Tiene algún valor la marcha de la temperatura? En los casos típicos de pulmonía franca no se observan grandes oscilaciones durante el período de estadio de la enfermedad; pero en las formas benignas se notan variaciones térmicas, muy acentuadas á veces de la mañana á la tarde.

En el fondo, el carácter general de la marcha de la temperatura es el mismo en la congestión pulmonar que en la pulmonía, pero con variaciones ligeras que dependen de cada caso particular. Suele ser más fácil observar en dos pulmonías indiscutibles diferencias más profundas que entre ellas y la congestión pulmonar. Habéis visto un ejemplo de ello hace pocos días. Vino á morir á la Clínica un hombre que presentaba estado tifoideo completo, adinamia profunda, temperatura elevada con remisiones matinales, la disnea era ligera y la tos nula. A pesar de estos signos de intoxicación difusa, se trataba de una pulmonía lobulillar supurada, y sin embargo, la evolución térmica hacía sospechar más bien una fiebre tifoidea.

Por consiguiente, cuando se analizan los síntomas diversos de estas congestiones pulmonares, y se compara su 
modo de evolución con las pulmonías similares, se encuentran tales analogías, que hay motivos para preguntarse si se trata de una entidad morbosa bien definida, ó si estos casos son pulmonías atenuadas.

Creo que esta cuestión merece resolverse tanto más cuanto que la pulmonía se concibe hoy de distinta manera que hace algunos años. Antes se consideraba esta enfermedad como el tipo de las flegmasías francas, y cuando quería expresarse la idea de una inflamación verdadera se invocaba la pulmonía. Hoy se tiende cada vez más á considerarla como resultado de una infección, no sólo en la variedad adinámica y contagiosa, en la que se ha demostrado la exactitud de esta idea, sino en las formas ordinarias. Se conocen varios micro-organismos de efectos nocivos sobre el pulmón, y que producen las lesiones de hepatización de este órgano. ¿ Pero son de origen microbiano todas las pulmonías benignas, y debe generalizarse esta doctrina á los casos de congestión pulmonar idiopática, como el de nuestra enferma?

Es imposible responder de una manera categórica á tal pregunta, aunque haya probabilidades favorables respecto á esta hipótesis.

Es necesario, ante todo, convencerse de que la congestión pulmonar no es un proceso constante de patogenia idéntica siempre. Es un síndrome que se presenta en circunstancias muy diversas y que difiere bastante según los casos. Tengo la seguridad de que un enfriamiento trivial, sin intervención microbiana de clase alguna, produce la hiperemia pulmonar, bien por impresión directa 6 por el intermedio de los nervios cutáneos periféricos. Weir Meitchell ha demostrado experimentalmente que basta producir un enfriamiento grande en el nervio ciático para ocasionar edema del miembro inferior y un estado congestivo permanente. No niego la realidad de la congestión a fri- 
gore, $\mathrm{y}$ creo haber observado casos típicos que presentaban la sintomatología descrita por Woillez, á saber : principio brusco, intensidad de los trastornos funcionales, seguida al poco tiempo de descenso rápido de la temperatura y de desaparición en los signos estetoscópicos.

Pero al lado de las congestiones francas, que pueden atribuirse al frío, creo que es posible invocar en otros muchos casos otra patogenia, y según toda probabilidad, la mayor parte de las congestiones llamadas idiopáticas son de origen microbiano. El aire libre, y hasta el frío, no obran como factores necesarios en la hiperemia del pulmón. Para convencerse de ello basta comparar la rareza de las afecciones pulmonares llamadas a frigore en las personas que viven en el campo y la facilidad con que estas mismas se acatarran en la ciudad, en condiciones de enfriamiento menores, pero mucho mayores de contagio.

Existen otros argumentos clínicos en favor de esta hipótesis. ¿Cómo no ha de llamar la atención que las congestiones pulmonares se presenten siempre en una época determinada del año, en primavera, precisamente la estación en que se observan las pulmonías de origen microbiano indudable? En invierno, estas pseudo-fluxiones del pecho son positivamente raras $y$, no obstante, si fueran debidas al frío, parece más racional que se multiplicaran durante los meses en los que la temperatura es más cruda. Bien sé que deben tenerse en cuenta las variaciones de temperatura, más frecuentes en las épocas de transición, y que ocasionan enfriamientos múltiples. Pero estas influencias estacionarias son sólo cuestión de coincidencia, porque en el equinocio de otoño, durante el cual son frecuentes también las vicisitudes atmosféricas, se observan pocas veces las congestiones pulmonares.

Sucede con la pulmonía algo parecido á lo que ocurre con la fiebre tifoidea. Se desarrolla una epidemia tifoidea 
y se ven entonces multiplicarse, á la par que los casos francos, embarazos gástricos sospechosos, trastornos intestinales, que en otras circunstancias pasarían inadvertidos, pero cuya significación revela la coincidencia de las formas graves concomitantes. Lo mismo acontece con las congestiones pulmonares que reinan á la vez que las pulmonías microbianas; son, al parecer, debidas á una infección atenuada, más bien que á enfriamientos muchas veces imaginarios.

Lo que viene á confirmar la idea de la naturaleza infecciosa de estas congestiones es el que, al parecer, se desarrollan por contagio directo. Hemos visto hace quince días, en nuestra sala de mujeres, una serie de hechos de este género, multiplicados en demasía para que fueran efecto de la casualidad. La pulmonía se ha presentado hace tres semanas, é ingresaron en la sala Delpech tres enfermas con grado diferente de fluxión de pecho. Después se declararon en la sala otros tres casos de congestión pulmonar rayana con la pulmonía : el primero en una joven tabética, que tuvo congestión pulmonar doble tan intensa, que fue preciso hacerla una sangría de urgencia. Otra enferma, hemiplégica, padeció accidentes análogos, con los signos de hepatización pulmonar unilateral ; por último, otra mujer, que ocupaba el núm. 7, enfermó á su vez y tuvo un soplo pneumónico de los más típicos, después de dos días de pródromos. Las condiciones de la sala no habían cambiado, no se cometieron imprudencias ni hubo enfriamiento por ser exagerada la ventilación : es verosímil, por lo tanto, que fuera el contagio la causa verdadera de esta pequeña epidemia.

Analizando el caso actual, se observan en los caracteres de la enfermedad varios rasgos propios de las pirexias infecciosas. Nuestra enferma tuvo por espacio de cinco días pródromos vagos, sin localización pulmonar, y muy 
parecidos á los que preceden á la grippe 6 á la fiebre tifoidea. Consistieron en quebrantamiento general, postración completa, que fueron acompañados de fiebre, inapetencia y embarazo gástrico. Este estado sobrevino sin causa apreciable, y fue imposible invocar la influencia del frío. Los síntomas pulmonares no se presentaron hasta después y con lentitud: durante dos días tuvo la enferma dolor de costado, pero siguió trabajando sin padecer gran cosa ; los signos estetoscópicos no fueron típicos hasta el día siguiente. En las congestiones debidas á un enfriamiento, los accidentes del principio son mucho más acentuados y la marcha de la enfermedad más rápida.

La marcha de la temperatura, con sus grandes oscilaciones, concuerda también con la idea de un estado infeccioso : cada introducción nueva del veneno producía una elevación de la misma. Es el tipo de la elevación térmica de la grippe, de la tuberculosis y de ciertas formas de erisipela ambulante. Merece señalarse también la variación de sitio del dolor de costado, que era al principio diafragmático y se hizo después sub-mamario, y por último, mamario, á la vez que se hacían más difusos los estertores. Como fenómeno concomitante, la serie de brotes de herpes que coincidieron con las elevaciones de la temperatura, pueden interpretarse también en el sentido de una manifestación infecciosa.

La defervescencia fue, por el contrario, la de la pulmonía, y precedida como ésta de crisis sudoral, que era, al parecer, un esfuerzo saludable de la naturaleza para eliminar los agentes tóxicos. Esta diaforesis duró tres días en nuestra enferma, que curó al terminar aquella.

Se deduce de lo que precede, que algunas de las congestiones pulmonares, llamadas idiopáticas, pueden considerarse como verdaderas pulmonías abortivas, y que son, como las pulmonías verdaderas, de carácter infeccioso, 
pero atenuado. Para confirmar tal idea, sería preciso descubrir el pneumococo de Frænkel, pero este descubrimiento, que intentamos hacer en nuestra enferma, no dió resultados positivos. Conviene además saber que los esputos, aun salivares, contienen dicho microbio, aunque no haya pulmonía, según demuestran los estudios de Netter y del mismo Frænkel. No basta descubrir el pneumococo para afirmar la naturaleza de la enfermedad, y es preciso además cultivarle é inocular el cultivo á los animales para producir en ellos pulmonías experimentales. Es toda una clase de investigaciones que deben hacerse.

Por el momento sólo es posible decir una cosa en nombre de la clínica: que hay motivos para suponer que las congestiones pulmonares estacionarias son pulmonías atenuadas de origen microbiano; no podemos demostrarlo, ni sobre todo probar que el microbio patógeno es el pneumococo, pero creemos plausible esta suposición. Sabemos, en efecto, que la vitalidad de este micro-organismo es bas. tante ligera, que muere hacia el séptimo día de su evolución, y que para conservarle artificialmente es necesario sembrar de nuevo los cultivos cade seis 6 siete días. Estos datos corresponden con toda exactitud á la evolución relativamente rápida de estas congestiones pulmonares, cuyas fases diversas duran una semana, como sucede en las pulmonías verdaderas.

Hay motivos para preguntar, desde el momento en que existe igualdad de origen entre estos dos estados morbosos, por qué se detienen las congestiones en el estado hiperémico sin llegar á la hepatización pneumónica. Sólo podemos responder á esto confesando nuestra ignorancia absoluta, porque este problema no es otro que el de la atenuación del virus pneumónico.

La clínica da sobre el particular algunos datos aproximados. Enseña que una pulmonía anterior disminuye, al 
parecer, en cierto modo la virulencia del pneumococo. Netter ha demostrado que una primer pulmonía confiere, por término medio, inmunidad durante tres 6 cuatro años ; pero esta regla tiene muchas excepciones.

Volviendo á nuestra enferma, no encontramos en ella motivo alguno de atenuación del virus, porque siempre ha disfrutado buena salud. Estas condiciones de resistencia son desfavorables para el desarrollo de los agentes patógenos infecciosos. Conocida es, por el contrario, la gravedad de las pulmonías en los individuos debilitados por la miseria, el alcoholismo 6 por enfermedades anteriores.

Las recaídas son raras en estas formas de congestiones pseudo-pneumónicas de pulmonías abortivas ; curan, si no siempre, casi siempre. Pero son posibles las recidivas, nueva analogía con las pulmonías verdaderas. Netter ha demostrado que los pulmoníacos conservan por un tiempo indefinido en la saliva, y quizá en sus secreciones bronquiales, pneumococos capaces de producir después efectos patógenos. Esta propiedad de recidivar es en ocasiones causa posible de errores de diagnóstico con los brotes de congestión pulmonar de origen tuberculoso. Se ven, en efecto, ciertas formas de tuberculosis principiar por una congestión franca de la base del pulmón, que sigue casi siempre una marcha irregular y sospechosa, pero que en ocasiones desaparece al séptimo ú octavo día por una crisis de defervescencia típica, aunque recidiva después. En estas condiciones es dificil convencerse de que la congestión no es simple y se desconoce la gravedad del padecimiento latente. He visto cometer este error á uno de mis maestros antiguos en un enfermo que se hallaba, al parecer, en plena defervescencia de la pulmonía, y que en realidad padecía granulia incipiente, de la que murió dos meses después.

Excepto esta causa de error el diagnóstico y el pronós- 
tico son en general fáciles. Estas congestiones pulmonares son de ordinario benignas, y se corrigen casi siempre con un poco de ipecacuana. Es el tratamiento verdadero de estas pulmonías abortivas y á la vez una piedra de toque para el diagnóstico, porque en las congestiones pulmonares sintomáticas de la tuberculosis, el alivio es, "si no nulo, pasajero. Cuando se observan grandes oscilaciones vespertinas de la temperatura, suele ser útil emplear la quinina á dosis elevadas ; lo mismo que en la grippe y en la mayor parte de las enfermedades infecciosas de las vías respiratorias, es un medicam ento eficaz con el que se obtienen buenos resultados. 


\section{PULMONAA TIFOIDEA Y PNEUMOTIFUS}

Sumario: Descripción de una pulmonía tifoidea : principio franco, signos físicos clásicos, pero desproporcionados con la gravedad de los síntomas generales : aparición precoz de la albúmina.-Aparición de accidentes intestinales en el momento en que debía principiar la deferrescencia, y atenuación aparente de los signos de la pulmonía.-Discusión de este caso.-Diagnóstico de la pulmonía tifoidea, de la grippal y de la tuberculosis miliar aguda de forma pneumónica.-La evolución clínica es más bien en este caso la de un peneumotifus. - Variedades clínicas del pueumotifus : casos en los que la evolución de los síntomas pneumónicos es distinto de la de los tíficos. - Casos en los que se superponen estas dos clases de síntomas. - El caso actual corresponde á esta variedad última y no autoriza un diagnóstico cierto.Resultados de la autopsia.

Voy á ocuparme hoy de un caso que presentó tales dificultades de diagnóstico, que sólo resolverá la autopsia. Me refiero al hombre que murió ayer tarde á los quince días de enfermedad aguda.

Este hombre, de veinticinco años, robusto y sobrio, jamás había estado enfermo. El 21 de Mayo último, después de su trabajo, sintió quebrantamiento, tuvo un escalofrío y después dolor de costado. Aquella misma noche padeció náuseas y vómitos. Al día siguiente había aumentado el dolor y tenía el enfermo disnea, pero poco marcada ; la tos era rara y la expectoración nula. Se aplicó él mismo un vejigatorio y esperó cuatro días ; aumentó el malestar, persistieron la fiebre y los escalofríos y se presentaron algunos esputos sanguinolentos. $\mathrm{Al}$ sexto día de la enfermedad se decidió á ingresar en el hospital.

$\mathrm{El}$ aspecto general era el de una pulmonía franca. El enfermo no estaba, al parecer, muy quebrantado y conser- 
vaba bastante bien las fuerzas. Tenía la cara bultuosa, las mejillas inyectadas, y color sub-ictérico ligero de las conjuntivas. La opresión no era excesiva, 30 respiraciones por minuto, la tos casi nula y la expectoración herrumbrosa : el dolor de costado había desaparecido; el pulso blando y depresible, dicroto, no excedía de 90 pulsaciones. El síntoma más notable era la hipertermia que llegaba á $40^{\circ}$, sin que el enfermo tuviera, al parecer, conocimiento ni sed ; se hallaba soñoliento y tranquilo. La lengua estaba blanca y húmeda, las vías digestivas, excepto algo de estreñimiento, parecían hallarse en estado normal.

Los signos físicos indicaban una pulmonía del tercio superior. Había sub-macicez en el vértice derecho del tórax hasta la fosa sub-escapular ; debajo de la clavícula se notaba resonancia timpánica y dolor á la percusión. Las vibraciones torácicas estaban exageradas en este sitio. En la fosa sub-espinosa se oía un soplo francamente tubario que se propagaba, disminuyendo de intensidad, por debajo de la espina escapular. Alrededor del foco de hepatización existía una zona congestiva, en la que eran numerosos los estertores finos. El pulmón izquierdo estaba sano por completo.

En resumen, se trataba de una pulmonía franca localizada en el vértice derecho y que hubiera parecido clásica sin dos caracteres algo anormales que implicaban la idea de un estado infeccioso. El primero era la desproporción que existía entre los trastornos funcionales y los signos fisicos, éstos considerables, aquéllos casi nulos ; el segundo era la temperatura elevada del enfermo y la depresión y dicrotismo del pulso. A pesar de la falta de adinamia se notaba tendencia de mal género. La orina, poco abundante, contenía una gran proporción de albúmina y de substancias colorantes, como en las toxemias, y esta albuminuria era desproporcionada á la edad y extensión de la pulmonía.

Ctinica médica. - Toxo I. 
El tratamiento consistió en aplicaciones locales de ventosas escarificadas repetidas dos días seguidos; el enfermo tomó también una poción cordial adicionada de 10 centígramos de tártaro emético y de otros 10 de extracto tebáico; como régimen, caldos y dieta láctea.

Del 28 al 30 se hicieron más extensas las lesiones pulmonares sin agravarse el estado general. El soplo principió á disminuir en el punto enfermo primero y se extendió más abajo por las regiones del pulmón, respetadas hasta entonces. La expectoración era herrumbrosa y sanguinolenta, aunque presentaba coloración verduzca, equimótica. La temperatura se mantenía en una cifra muy elevada con oscilaciones de medio grado entre la mañana y la tarde. La hepatización tendía indudablemente á propagarse como en las formas serpiginosas de la pulmonía; el lóbulo inferior principiaba á congestionarse. A pesar de tomar todos los días el enfermo un gramo de sulfato de quinina y de ponérsele por las tardes un enema con 50 centigramos de antipirina, la fiebre no disminuý́ y el termómetro fluctuaba siempre alrededor de $40^{\circ}$.

El 31 de Mayo, décimo día de enfermedad, aumentó la fiebre en vez de notarse defervescencia. Los esputos habían dejado de ser herrumbrosos y se hicieron muco-purulentos. Se presentó un síntoma nuevo, diarrea, que coincidió con meteorismo abdominal. Estos trastornos intestinales, raros por completo en la pulmonía franca, no podían atribuirse al empleo del tártaro emético, porque sólo lo había tomado el enfermo durante veinticuatro horas y no observamos, mientras se administró este medicamento, síntoma abdominal alguno. La lengua se puso saburrosa y la inapetencia se hizo absoluta.

Los días primeros no hubo trastornos funcionales del aparato digestivo, pero se presentaron después. El cuadro clínico no era el de una enfermedad de las vías respirato- 
rias, sino el de una fiebre; el enfermo no tenía el aspecto de un pulmoníaco, sino el de un tífico.

Según se agravaba el estado general en el sentido de la adinamia, se modificaban, al parecer, en el de la resolución las lesiones pulmonares. El soplo se hizo velado y lejano. Los estertores finos fueron sustituídos por otros mucosos gruesos y húmedos; en la fosa sub-espinosa se oía casi gorgoteo. Los dos pulmones presentaban, hasta en las bases, signos de bronquitis difusa.

Esta contradicción entre el estado pulmonar y la agravación de los síntomas abdominales se acentuó. El 2 de Junio (día doce de la enfermedad) el aspecto tifoideo era característico, había meteorismo abdominal grandísimo, diarrea profusa, la presión en la fosa ilíaca era dolorosa y producía gorgoteo, el bazo estaba hipertrofiado. El dicrotismo del pulso se había acentuado; se presentaron para completar el cuadro dos epistaxis con pocas horas de intervalo.

Los síntomas torácicos iban, por el contrario, disminuyendo ; se oían estertores mucosos gruesos por todo el pecho; eran signos de congestión difusa 6 de bronco-pneumonía más bien que de una pulmonía franca; los dos lados estaban afectados casi por igual.

Se modificó el tratamiento; además de seguir tomando el enfermo el sulfato de quinina, prescribí la poción de Toldd con 4 gramos de extracto blando de quina y una loción fría cada dos horas. A pesar de estos medios no se modificó la hipertermia y continuó el mismo estado.

Durante los dos días que precedieron á la muerte no varió de una manera sensible el cuadro clínico. Excepto la erupción tífica que faltaba, eran completos todos los signos de una fiebre tifoidea adinámica. Las epistaxis se repitieron y concluyeron por extenuar al enfermo, éste cayó en una soñolencia gradual, no tosía, no expectoraba, 
conservaba su inteligencia, pero estaba sordo é insensible á las excitaciones del exterior. La diarrea continuó hasta el fin. El 5 de Junio, antevíspera de la muerte, principiaron á alterarse los ruídos del corazón y el ritmo cardíaco adquirió los caracteres señalados por Stokes en los estados adinámicos, el primer ruido se hizo obscuro y confuso y el silencio mayor más corto. Por la noche se presentó delirio, el pulso se aceleró de un modo brusco, elevándose el número de pulsaciones á 144 por minuto. A los dieciséis días de principiar la pulmonía sobrevino la muerte por colapso.

En resumen, en este caso notable observamos la invasión de una pulmonía franca al principio y que empezó de la manera más regular; después, en el momento en que en los casos normales principia la defervescencia, mejoraron los signos torácicos y aparecieron síntomas abdominales. Estos reprodujeron el cuadro de la fiebre tifoidea y se acentuaron hasta la muerte, mientras que los accidentes torácicos fueron disminuyendo cada vez más en el síndrome clínico.

¿Cómo considerar este caso y cómo debe diagnosticarse esta enfermedad infecciosa de doble aspecto y de evolución tan especial?

Son posibles cuatro hipótesis.

Pudo ser una pulmonía de forma tifoidea, 6 una infección grippal, ó una tuberculosis miliar difusa, ó, en fin, un pneumotifus, es decir, una fiebre tifoidea de manifestaciones torácicas primitivas y de principio pneumónico. Analizaremos estas hipótesis.

La pulmonía de forma tifoidea es una entidad morbosa bien conocida, y su existencia innegable. Puede servir de tipo una observación de Joffroy (1) : Una joven de veinte años, recién llegada á París y sin aclimatar (como nues-

(1) Joffroy, Gaz. Hồp., 1882. 
tro enfermo), tuvo cefalea, fiebre y postración excesiva. Estaba desde el principio abatida y adinámica, con meteorismo, diarrea, gorgoteo íleo-cecal, epistaxis, algo de obscuridad en el vértice del pecho, sin trastorno funcional torácico. Se diagnosticó la enfermedad de dotienentería, considerándose grave el pronóstico á causa de la depresión de las fuerzas. El estado general fue, en efecto, agravándose, cuando de repente, al séptimo día de la enfermedad, hubo defervescencia, descendió la fiebre y se presentaron los signos típicos de una pulmonía del vértice.

Es la marcha ordinaria de la pulmonía tifoidea. Al contrario de lo que sucedió en nuestro enfermo, los fenómenos del principio simulan la fiebre contínua y enmascaran la lesión pulmonar. Esta variedad de pulmonía reviste caracteres insidiosos: pocas veces se observan el escalofrío inicial, los vómitos y el dolor de costado característico. La disnea es ligera, la tos escasa, la expectoración viscosa, casi nunca herrumbrosa. Los signos físicos son los de una bronco-pneumonía más ó menos extensa, por lo común bilateral ; suele faltar el soplo, y los estertores tienen, por el contrario, el carácter mucoso y húmedo. La adinamia es precoz y profunda; la temperatura, elevada desde los primeros días, se mantiene en unos $40^{\circ}$ con grandes exacerbaciones vespertinas; el pulso es desde el principio blando $\mathrm{y}$ dicroto, pero no muy rápido de ordinario. Se observan ya en este período síntomas abdominales; hay timpanitis intestinal, diarrea y sensibilidad en la fosa ilíaca. La orina está siempre alterada, suele ser escasa, siempre albuminosa y contiene gran cantidad de substancias colorantes.

Este cuadro es el de una enfermedad infecciosa general, en la que la localización pulmonar ocupa un sitio limitado y accesorio muchas veces. El rasgo característico de estas pulmonías tifoideas es la gravedad precoz de los fenómenos generales, en oposición del carácter poco típico 
de los signos torácicos, que se asemejan más bien á la bronco-pneumonía difusa que á una hepatización circunscrita, al menos durante los primeros días.

Las lesiones pulmonares siguen también una marcha especial. Progresan por brotes sucesivos, á la manera de los ataques serpiginosos de la erisipela ambulante; se ven presentarse de un día á otro focos nuevos de hepatización ó de congestión, que ocupan un lóbulo ó parte de un lóbulo pulmonar, mientras que los puntos antes atacados entran al parecer en resolución ; nueva analogía con lo que sucede en los ataques erisipelatosos de la piel.

Las pulmonías tifoideas son relativamente raras; sólo se observan más á menudo durante ciertas epidemias, y entonces la mortalidad es grandísima. En 1886 reinó una epidemia de este género, cuya historia trazó de una manera magistral Lancereaux, y que costó la vida á varias enfermeras y alumnos (1); la adinamia y el estado tifoideo fueron la nota predominante, los signos físicos y el infarto pulmonar apenas se acentuaron.

Hayem y Gilbert han hecho estudios interesantes sobre el estado de la sangre en estas formas graves; han observado como fenómeno constante señalado ya, la difluencia del coágulo y la falta de coagulación de la fibrina, éinsisten de una manera especial en el hecho de que, examinando los glóbulos rojos con el microscopio, se ve que han perdido su aptitud á agruparse en pilas cilíndricas. Este carácter es importante porque es precoz y manifestarse desde los días primeros de la enfermedad; demuestra que los glóbulos han sufrido modificaciones profundas en su constitución, é indica la gravedad del padecimiento. Es, por lo tanto, un signo importantísimo para el pronóstico.

Poco sabemos respecto á la etiología de estas pulmo-

(1) Véanse las Tésis de Mulette y de Helma, y los trabajos de Weichselbaum sobre esta epidemia. 
nías tifoideas y á las causas que les comunican caracteres infecciosos particulares. Además del carácter epidémico y del contagio, que desempeñan un papel preponderante innegable, deben influir las condiciones de resistencia del organismo, lo que sucede en la etiología habitual de todas las pirexias tóxicas, que ejercen con preferencia sus estragos sobre los individuos débiles, anémicos, gastados por el alcoholismo y los excesos de todo género. Pero esta clase de consideraciones son poco aplicables á nuestro enfermo, joven robusto $\mathrm{y}$ sobrio; después supimos que lo había abandonado su mujer hacía pocos días, y es lógico suponer que este disgusto doméstico influyó sobre el carácter que revistió la pulmonía desde el principio.

En el cuadro que precede encontramos con seguridad todos los elementos de la enfermedad de este hombre, y el caso actual puede entrar en la categoría de las pulmonías tifoideas, pero difiere por varias particularidades.

Ante todo, los signos del principio fueron los de una pulmonía franca : escalofrío inicial fuerte, vómitos, dolor de costado, esputos herrumbrosos, todo era clásico. El estado tifoideo se presentó bastante tarde, cuando las lesiones pulmonares entraban, al parecer, en una fase regresiva, y cuando debía haber principiado la defervescencia. Primera anomalía.

'La segunda es la marcha que siguió la temperatura. Las oscilaciones fueron ascendentes de un modo regular desde los primeros días, y el estado hipertérmico contínuo no se observó hasta el décimo día: es una marcha contraria á la normal de las pulmonías tifoideas, en las que las oscilaciones ascendentes duran poco, son seguidas de hipertermia momentánea y después de oscilaciones descendentes como en la dotienentería.

Aun sin desechar la hipótesis de una pulmonía de tipo tifoideo, creo conveniente señalar estas diferencias de evo- 
lución, y pongo en duda la realidad de este diagnóstico.

Desecho, por el contrario, en absoluto la hipótesis de una pulmonía grippal. Algunas veces, en tiempo de epidemia de grippe, es dificilísimo diagnosticar una broncopneumonía grippal de una fiebre tifoidea, pero en la actualidad no reina en Paris la grippe ; esto basta para desechar tal suposición. Además, estas grippes de síntomas tifoideos tienen caracteres especiales; principian siempre de repente, por cefalalgia excesiva, sensación de quebrantamiento general, raquialgia y dolores articulares, estado saburroso de las vías digestivas. En medio de este cortejo de síntomas amenazadores, la temperatura se conserva bastante baja y jamás excede de $39^{\circ}$. Los signos estetoscópicos son los de la bronco-pneumonía bilateral casi siempre, y por último, la mayor parte de los accidentes desaparecen con un vomitivo. Esta evolución es bastante característica para que sea posible asimilar el caso actual á la grippe.

¿Puede pensarse en una forma sobre-aguda de tuberculosis que principió con los caracteres de una pulmonía franca, y se generalizó á la manera de una enfermedad infecciosa, adinámica? La hipótesis merece discutirse, tanto más, cuanto que la tuberculosis miliar difusa ataca de preferencia á las personas jóvenes, y son muy variables sus formas clínicas.

Por insidiosa que sea la marcha de la granulia, no procede, en general, como lo ha hecho la pulmonía de nuestro enfermo. Este fue atacado en plena salud, sin pródromos ni malestar anterior. Siempre que se averigua de buena manera el pasado de los enfermos de granulia, se descubren una ó más manifestaciones tuberculosas anteriores. Jamás he visto desarrollarse de repente la tuberculosis miliar aguda y producir la muerte en quince días : he observado muchas veces casos en los que las apariencias 
eran las de una afección sobre-aguda; pero examinándolas de cerca, descubrí siempre un período de incubación anterior latente, caracterizado por cansancio cerebral ó corporal, enflaquecimiento, inapetencia, algunos accesos de fiebre errática, etc., y esta fase preparatoria precede por lo común varios meses á la invasión de los fenómenos agudos.

Estos pueden asemejarse por completo á los que presentó nuestro enfermo. Además de la forma ordinaria, cuyos signos son los de la bronquitis capilar, existe otra en la que el cuadro clínico es el de la pulmonía lobulillar. El principio es en ocasiones tan típico como el de la pulmonía más franca, pero la marcha varía : procede por invasiones sucesivas, por brotes congestivos, sin defervescencia verdadera, aunque con remisiones momentáneas. La fiebre no es contínua y la temperatura oscila bastante de la mañana á la tarde. Los signos físicos, que eran los de una hepatización masiva, tardan poco en ser sustituídos por estertores cavernosos y gorgoteo que indican la destrucción del parénquima pulmonar : esto ocurre casi sin producir tos ni expectoración.

En ciertas formas anormalmente rápidas, el pulmón se infiltra sin destruirse y hay hipertermia constante. Estos casos se asemejan más al nuestro, porque los síntomas son mucho más acentuados que los locales, y el fenómeno predominante es la adinamia. Así sucede en las formas de granulia, en las que la tuberculosis se propaga á los intestinos y á otras vísceras abdominales, y se presenta la diarrea, el meteorismo y todo el cortejo de accidentes tifoideos : de aquí las dificultades grandísimas del diagnóstico en algunos casos.

¿Pertenece nuestro enfermo á este género? No lo creo. No tenía antecedente morboso alguno como he dicho; ninguno de sus parientes ha padecido tuberculosis, y sus 
padres viven todavia. Los signos de hepatización pulmonar fueron unilaterales casi hasta el último día, y los estertores, aunque gruesos y húmedos, jamás han tenido el carácter de gorgoteo y de estertores cavernosos. Por último, el análisis histológico de los esputos no indicó la existencia del bacilo de la tuberculosis.

Queda la hipótesis de un pneumotifus. Se designan con este nombre los casos de fiebre tifoidea, de evolución anormal, que principian por accidentes viscerales pulmonares antes de que se presenten los síntomáas abdominales.

Es innegable la realidad de estas pulmonías iniciales de origen tífico, que enmascaran el desarrollo de la enfermedad principal. Aunque son raros estos casos, se han publicado observaciones bastante numerosas. Chomel (1) señaló ya el hecho en sus clínicas; Dietl volvió á ocuparse de este asunto en 1856 ; después han referido ejemplos nuevos Gehrardt, en Alemania; Barella, en Bélgica, y Potain, en Francia. Las Monografías de Girard y de Weill (2) dan una idea bastante clara de esta cuestión.

Estos ejemplos de pneumo-tifus se asemejan de una manera singular á nuestro enfermo. El principio de los accidentes varía, pero es insidioso pocas veces; reviste de ordinario los caracteres francos de una pulmonía, escalofrío inicial fuerte, dolor de costado, esputos herrumbrosos. La tos es, por lo común, rara y la disnea ligera. Los signos físicos nada tienen de particular, excepto el coincidir muchas veces con los de una bronquitis. Se observan simultánea ó sucesivamente los signos generales tifoideos, entre los que dominan el meteorismo, la diarrea, la hipertrofia esplénica, las epistaxis y la albuminuria. Es con toda exactitud lo que hemos observado.

(1) Chomel, Clinique, Obs. XI.III.

(2) Girard (Tesis de Paris, 1882). Weill (1bid., 1883). 
El rasgo característico de estos hechos es la marcha normal de las lesiones pulmonares y su tendencia á la resolución, á la vez que se inicia el estado tifoideo.

En los casos típicos hay una verdadera defervescencia pneumónica, y los signos de la dotienentería no se presentan hasta después. El caso de Heitler pertenece á esta categoría. Se refiere á una pulmonía cuya marcha fue regular hasta el décimo día; la temperatura era entonces de $39^{\circ}$, el pulso rápido, 110 pulsaciones y el abatimiento mayor que en una convalencia franca. Este estado duró una semana sin que aumentara la fiebre, pero acentuándose la adinamia ; volvió la hipertermia y apareció una erupción de manchas rosadas características. A la muerte del enfermo se encontraron úlceras intestinales y lesiones persistentes de infarto pulmonar.

Otras veces hay continuidad absoluta de evolución entre los signos de la pulmonía y los de la fiebre tifoidea, y el diagnóstico es imposible casi siempre. He observado un caso de este género, que desconocí al principio por compìtoto. Hace cinco años fui llamado para ver á un enfermo que había contraído dos días antes un dolor de costado al volver de Perigueux á París en el rigor del invierno. Observé los signos más típicos de una pulmonía lobulillar circunscrita, y á la vez adinamia excesiva desproporcionada á la extensión de la lesión pulmonar. Atribuí esta postración al cansancio del viaje y al estado moral del enfermo, que acababa de perder un hermano de fiebre tifoidea. Los accidentes persistieron, y no me expliqué esta anomalía hasta que ví presentarse á los nueve días manchas lenticulares indudables. El enfermo murió de dotienentería á los diecisiete días.

La superposición de los síntomas tíficos y pneumónicos, puede ser más íntima todavía. Morand (1) refiere el

(1) Caso citado en la Tésis de Castex, 1879. 
caso de un soldado que tuvo escalofríos y dolor de costado, á la vez que vómitos y diarrea. Se descubrió una pulmonía derecha adinámica con soplo y estertores. Murió á los diez días con síntomas de pulmonía doble y diarrea profusa, sin manchas rosadas. Al hacer la autopsia se observaron, además de las lesiones de la pulmonía, tumefacción de los folículos ciegos é hipertrofia de las placas de Peyer.

Estos hechos prueban la realidad del pneumotifus, es decir, de las fiebres tifoideas que principian por los síntomás de la hepatización pulmonar. Es preciso distinguir estos casos de aquellos otros en los que la dotienentería inicial se complica con fenómenos pulmonares precoces. Las observaciones de Lépine, Weil y Girard, pertenecen á esta última categoría y no creo que sean ejemplo de pneumotifus verdadero.

Se comprende cuán difícil es la interpretación de estos hechos á la cabecera del enfermo. En el caso actual, por ejemplo, se puede sostener con la misma probabilidad la hipótesis de una pulmonía infecciosa de carácter tifoideo, que la de una dotienentería latente de localización pulmonar, aunque faltó la erupción característica. Creo en la existencia de un pneumotifus, pero sin afirmarlo en absoluto, porque desde hace algunos días ingresan en el hospital bastantes casos de fiebre tifoidea; hecho que, entre paréntesis, coincide con la distribución del agua del Sena para la alimentación en el $\mathrm{XV}$ distrito. Además, el principio pneumónico franco, la tendencia á la resolución de las lesiones pulmonares, las oscilaciones de la curva térmica, son otros tantos argumentos en apoyo de esta hipótesis. ¿No vemos todos los días principiar la fiebre tifoidea por angina? ¿Por qué no admitir la localización inicial del veneno tífico en los pulmones?

Estas consideraciones nos conducen á preguntar cuál es 
el modo patógeno de los accidentes del pneumotifus. ¿Admitiremos que el microbio tífico de Eberth y de Gaffky se fija desde el principio en las vías respiratorias? Es posible, porque Artaud afirma haberlo encontrado en las bronco-pneumonías del segundo septenario de la fiebre tifoidea.

El hecho es hipotético. En 1886, describió Neumann un estreptococo de caracteres distintos que encontró en la pul. monía lobulillar desarrollada durante la fiebre tifoidea. Por otra parte, Polguère ha demostrado que en casi todas las complicaciones pulmonares de los estados graves hay infecciones múltiples. El bacilo de Eberth sólo se ha descubierto en los casos en los que existen en el pulmón de los tíficos lesiones difusas de espleno ó de bronco-pneumonía. En la pulmonía lobulillar se encuentran, según este autor, el pneumococo de Fränckel $\delta$ el estreptococo y el bacterium pneumonioe de Weichselbaum. Puede suceder, por lo tanto, que haya en tales casos superposición de infecciones múltiples.

Es posible también que haya afinidades germinativas entre los microbios pneumónicos y los tíficos. Barella ha llamado la atención, en un trabajo notable sobre la coexistencia de las epidemias de fiebre tifoidea y de pulmonía, y sobre el paralelo de los cuadros de mortalidad en ambos casos ; pero es sólo una hipótesis.

Resulta de esta discusión, que clínicamente no hay un solo medio de diagnosticar el pneumotifus. La marcha de los accidentes suministra presunciones ; pero sólo da seguridad la autopsia. Me habéis visto dudar siempre, y hoy mismo, después de morir el enfermo, no me atrevo á afirmar nada en absoluto.

Un punto indudable es la gravedad del pronóstico en los casos mixtos de pulmonía y de estado tifoideo. Los dos únicos ejemplos auténticos de pneumotifus que he obser- 
vado, terminaron por la muerte en poco tiempo. Girard no es de esta opinión y ha sacado conclusiones más optimistas, pero creo que se trataba de una serie favorable excepcional.

El tratamiento es sobre todo sintomático y carece de indicaciones especiales. Los baños fríos darían quizá buenos resultados si no se opusieran á su empleo las familias.

NOTA ADICIONAL

La autopsia del enfermo reveló que no existía lesión intestinal alguna imputable á la fiebre tifoidea. Los folículos ciegos y las placas de Peyer, se hallaban en estado normal y no se descubrió indicio de úlcera en la mucosa.

Había, por el contrario, lesiones pulmonares profundas. Todo el lóbulo superior y medio del pulmón derecho, presentaba hepatización gris purulenta ; el tejido era friable y estaban en vías de formación varios abcesos ; el parén-. quima pulmonar no se había destruído por completo. El lóbulo inferior se hallaba infartado, lo mismo que el pulmón derecho.

Encontramos las cavidades cardíacas dilatadas, llenas de coágulos blandos y delicuescentes, las paredes ventriculares flácidas y morenuzcas y en vías de degeneración. Había también esteatosis hepática y alteración en los riñones que eran gruesos, edematosos y congestionados. La substancia cortical había sufrido en parte la degeneración grasosa.

Se trataba, por lo tanto, de una pulmonía tifoidea y no de un pneumotifus, al contrario de lo que había creído. 


\section{ESGLEROSIS PULMONAR Y DILATACION BRONQUIAL}

Sumario: Identidad de los trastornos funcionales y de los signos físicos en la tuberculosis $\mathrm{y}$ en la dilatación bronquial, pero falto de fenómenos generales en esta última enfermedad.-Diagnóstico de las dos afecciones. - Dificultades especiales del diagnóstico cuando se forman $\nabla \delta$ micas purulentas, que son algunas veces el primer fenómeno aparente en el curso de la dilatación bronquial.-Mecanismo de la ectasia bronquial. - Es siempre complejo y no depende exclusivamente ni de la lesión de los bronquios ni de la esclerosis del parénquima pulmonar.Es por lo común resultado de una bronco-pneumonia primitiva, complicada con adherencias pleurales. - Elementos de pronóstico é indicaciones terapénticas.

Entre los muchos enfermos de nuestra clínica que padecen afecciones pulmonares, hay uno que, á pesar de la poca importancia aparente de su bronquitis, tiene un interés verdadero. Es un trabajador dedicado á transportar espuertas de tierra, de cincuenta y seis años, de buena constitución, que desde hace seis semanas tose y enflaquece. Los accidentes se han presentado de una manera insidiosa, sin causa aparente; jamás ha tenido fiebre ni dolor de costado, pero la expectoración ha sido casi desde el principio abundante y muco-purulenta ; ha observado varias veces en los esputos estrías de sangre, pero no hemoptisis verdadera. Bajo la influencia de esta tos rebelde ha perdido las fuerzas y el apetito.

$\mathrm{El}$ aspecto exterior de este hombre es bastante satisfactorio, no tiene la facies caquéctica ni el aire de un tuberculoso ; está apirético, $\mathrm{y}$ aunque suda en abundancia por la noche, el sudor no es precedido de escalofríos ni de accesos de fiebre.

La expectoración constituye el síntoma más caracterís- 
co. Es abundantísima y desproporcionada á la benignidad aparente de la bronquitis. Los esputos son de dos clases: unos, los menos abundantes, están formados por mucosidades transparentes, mezcladas con saliva. Otros, francamente purulentos, líquidos, se mezclan con el agua y no conservan la forma redonda ni el aspecto de los esputos tuberculosos. Se extienden en el fondo de la vasija á la manera del puré, y llenan la mitad de la escupidera en las veinticuatro horas.

Esta expectoración es más abundante por la mañana, no porque se vacíe entonces una vómica verdadera, sino porque el enfermo escupe en este momento en más abundancia, por acumularse las secreciones bronquiales durante la noche. Por el día expectora relativamente poco. No aqueja más padecimiento que la fatiga.

Los signos estetoscópicos no corresponden á esta apariencia de salud relativamente buena. La resonancia es normal en los dos vértices pulmonares, pero en la base del pulmón izquierdo se nota macicez completa, con pérdida casi absoluta de la elasticidad. Las vibraciones torácicas no están abolidas, pero sí disminuídas, como si hubiera un derrame en la cavidad de la pleura, reciente ó á medio absorber.

$\mathrm{Al}$ auscultar se oye respiración ruda y mezclada con algunos estertores; en la base izquierda se nota soplo de timbre anfórico en la cuarta parte del tórax. En la parte externa de esta zona los signos son cavernosos francos; más arriba y más cerca de la columna vertebral, el soplo es también cavernoso, pero de timbre más agudo y alto. En toda esta extensión el soplo está mezclado con gorgoteo, y existen indudablemente cavernas múltiples en el parénquima pulmonar. La tos y la voz resuenan en este sitio de un modo anormal, y se nota pectoriloquia afona.

En el lado derecho las lesiones son menos acentuadas, 
y todo se reduce á debilidad del murmullo vesicular en la base, mezclado con extertores lejanos. Hacia el hilio del pulmón, y debajo de este sitio, se oye el eco del soplo anfórico del lado opuesto, que al mitigarse adquiere un carácter suave y profundo.

Los demás órganos, corazón, riñones y arterias, nada presentan de anormal.

Resulta de este examen que los pulmones están intactos por delante y en los dos vértices por detrás. En la base izquierda el tejido pulmonar se encuentra infiltrado, condensado, según demuestra la disminución del ruido respiratorio, el soplo, la exageración de la voz y la tos.

Este tejido contiene además cavernas múltiples, como lo demuestran el gorgoteo y las diferencias de tono del soplo, según el sitio donde se ausculte : una caverna sola produciría ruidos más uniformes.

Es fácil comprender el estado material del pulmón, pero no lo es tanto precisar la naturaleza de la lesión.

La bronquitis simple no produce signos estetoscópicos tan intensos, y sobre todo tan localizados.

No es tampoco una pleuresía ni una pleuro-pneumonía, porque en este caso podría observarse la asociación del soplo y de los estertores cavernosos, pero sólo en el transcurso de la enfermedad, cuando principia la defervescencia. Ahora bien; en nuestro enfermo, la marcha de la afección no es en modo alguno la de un padecimiento cíclico agudo: ha revestido desde el principio caracteres crónicos y se asemeja más bien á una tisis incipiente que á una pulmonía de resolución lenta. Además, la larga duración del principio de los accidentes, excluye por completo esta hipótesis. No se trata de una lesión en vías de reparación, sino de una ulceración pulmonar creciente, y el gorgoteo, lo mismo que la abundancia de la expectoración, prueban la existencia de excavaciones supurantes múltiples. 
Ś́lo son plausibles dos suposiciones : la tuberculosis y la dilatación bronquial.

La idea de una tuberculosis es menos aceptable hoy que lleva ya el enfermo tres semanas en el hospital, y hemos seguido la evolución de su padecimiento. Pero no sucedió así á su ingreso, y entonces la probabilidad de una tisis pulmonar parececía la hipótesis más razonable. Este hombre, que tosía y enflaquecía sin motivo, que sudaba por la noche, que expectoraba mucosidades purulentas y algunas veces estrías de sangre, se asemejaba bastante á un tísico á pesar de la falta de fiebre ; además, en aquella fecha se hallaba inapetente y sin fiebre, y tenía el color terroso de los que padecen afecciones supuradas.

A pesar de esto, algunas particularidades de su afección hacían suponer que las lesiones no eran tuberculosas.

Eran, ante todo, unilaterales y estaban localizadas en la base. Esta localización es con seguridad rara, porque sabéis que en la inmensa mayoría de los tísicos principia la tuberculosis por el vértice de los pulmones; las bronquiectasias ocupan, por el contrario, de preferencia la base.

Pero este signo es sólo de presunción y de valor puramente relativo. Según resulta de una estadística importante de Barth, la tercera parte de las dilataciones bronquiales están localizadas en el vértice pulmonar, y, por el contrario, muchas tuberculosis principian por la base. Esta localización no es, por lo tanto, un signo diferencial suficiente. Tenemos en la actualidad, en el núm. 8 de la sala Chauffard, un tísico, cuyos esputos contienen el bacilo de Koch, y que presenta lesiones unilaterales predominantes en la base.

La edad del enfermo es más bien favorable á la idea de una dilatación bronquial. La tuberculosis inicial de la base del pecho es casi siempre patrimonio de los niños, y mucho 
más rara en el adulto, sobre todo después de los cincuenta años. En esta edad se observan con más frecuencia las esclerosis pulmonares de evolución lenta que producen las bronquiectasias secundarias; las tres cuartas partes de los casos que forman la estadística de Barth se refieran á hombres de cincuenta años 6 más. Es también una presunción, pero no una certidumbre.

La falta de fiebre es asimismo un argumento en favor de la dilatación bronquial, pero no decisiva, porque exis. ten tuberculosis tórpidas que destruyen con lentitud los pulmones sin producir reacción febril. Obsérvase esto de preferencia en los escrofulosos, y sobre todo, en los que han padecido lupus en su infancia. Esta forma de tuberculosis es susceptible de durar un tiempo indefinido. En 1873, siendo interno, ví en la clínica del Dr. Laillier un enfermo con lupus de la mano y tuberculosis pulmonar incipiente. Volví á verlo en 1886, trece años después : su tuberculosis había progresado y tenía una caverna extensa debajo de la clavícula ; pero estaba apirético, tosía muy poco, desempeñaba sus ocupaciones, su aspecto no era caquéctico y toleraba bastante bien su lesión.

La noción de una ó más hemoptisis anteriores se ha considerado durante mucho tiempo como un buen signo diferencial ; pero hoy sabemos que no debe tenerse en él una gran confianza: muchos tuberculosos no escupen sangre, y viceversa algunas bronquiectasias coinciden con expectoraciones sanguinolentas copiosas. Este signo no puede ayudarnos en la especie á afirmar nada en un sentido ni en otro.

Los caracteres de la expectoración tienen incomparablemente mucho más valor, y en ciertos casos puede decirse que bastan para afirmar la existencia de una bronquiectasia : así sucede cuando se ven nadar en medio de mucosidades puriformes grumos sólidos parecidos á la almáciga 
por su color grisáceo y su consistencia blanda. Estos grumos son fétidos y recuerda más el olor de los yesones enmohecidos que el de la gangrena; la fetidez es debida á la fermentación y á la descomposición de los ácidos grasos que les constituyen. Estos esputos pseudo-gangrenosos son casi un signo seguro de dilatación bronquial. Pero en el caso de que se trata, la expectoración es inodora; es puriforme y bien trabada, $\mathrm{y}$ aunque no tiene el aspecto ordinario de los productos de secreción en las cavernas tuberculosas, tampoco presenta caracteres bastante marcados para permitir hacer el diagnóstico diferencial.

El examen histológico de los esputos no quita todas las dudas, aunque se inclina más en el sentido de la bronquiectasia. Se han estudiado varias veces desde el punto de vista bacilar, y el resultado ha sido siempre negativo. Hay, por lo tanto, grandes probabilidades de que el enfermo no sea un tuberculoso y de que se trate sólo de una simple dilatación de los bronquios. Pero se comprende que, aunque la presencia del bacilo de Koch es un argumento decisivo en favor de la realidad del tubérculo, su falta no excluye la posibilidad, porque en muchos tísicos confirmados no es fácil siempre descubrir los bacilos, y no existen en muchas preparaciones.

Llegamos así por exclusión á diagnosticar en nuestra enferma una esclerosis del pulmón izquierdo, complicada con ectasia bronquial y casi exclusivamente unilateral. Digo casi exclusivamente, porque hacia la base del pulmón derecho se oyen algunos estertores y está debilitado el ruido vesicular, indicio posible de un principio de lesiones similares.

Puede objetarse á este diagnóstico la marcha de la enfermedad, que fue de rapidez excepcional, porque este hombre afirma no haber empezado á padecer hasta hace un mes. Pero revisando sus antecedentes, esta objeción 
pierde casi por completo su valor. Hace treinta años padeció una afección torácica aguda, según toda probabilidad, una pleuresía, caracterizada por dolor de costado y disnea intensa, y tuvo que permanecer dos meses en el hospital. Desde entonces, aunque curó por completo y no sentía malestar alguno, tosía á cada momento; todas las mañanas, aun en plena salud, expectoraba algunos esputos mucosos, á menudo purulentos, y esta secreción era mucho más abundante durante el invierno. Estamos, por lo tanto, autorizados para suponer que desde hace mucho tiempo tenía un núcleo de esclerosis pulmonar y dilatación bronquial, predispuestos á una hipersecreción inflamatoria por la causa más insignificante. Esta se presentó hace seis semanas en forma de bronquitis, que despertó la afección antigua y produjo los fenómenos que observamos en nuestro enfermo.

Lo que caracteriza, en efecto, desde el punto de vista clínico, este padecimiento pulmonar, es la limitación exacta de las lesiones á la base izquierda, la intensidad del soplo que indica la dureza fibrosa del parénquima pulmonar y la claridad del gorgoteo en una zona circunscrita, que corresponde á una serie de ampollas bronquiales, llenas de muco-pus.

Puede decirse que es un tipo perfecto y clásico de bronquiectasia. Se hallan reunidos, en efecto, todos los caracteres de esta afección : lesiones profundas en apariencia, pero limitadas y localizadas en una base pulmonar : expectoración purulenta abundantísima, y á pesar de esto, integridad relativa de la salud general, falta de fiebre y de diarrea. Por último, la etiología de este caso se halla conforme por completo con lo que sabemos de la historia de esta enfermedad, porque entre los antecedentes del enfermo figura una pleuro-pneumonía antigua y tendencias inveteradas al catarro bronquial 
En los casos de este género, es relativamente fácil el diagnóstico, y cuando el examen de los esputos da resultados negativos, la seguridad es absoluta. No sucede siempre así, y las dificultades son en ocasiones grandísimas, si la expectoración, en vez de ser contínua, es intermitente y se manifiesta por una serie de vómicas. Prueba de ello. es un caso reciente que habéis observado. Recordaréis el joven de diecinueve años, á quien, á petición suya, dimos de alta la semana pasada á medio curar. Dos meses antes, hallándose en buena salud, tuvo escalofríos, fiebre y dolor en el costado izquierdo. Ocho días después de estos accidentes (que no persistieron), expectoraba, con una tos violenta, media escupidera de líquido purulento, y desdeentonces expulsaba todas las mañanas una buena cantidad de serosidad verduzca, bastante fluída, mezclada con partículas fétidas. La expectoración cambiaba de aspecto durante el día, y se hacía casi exclusivamente mucosa.

No era fácil afirmar la naturaleza de estas pseudo-vómicas. El principio brusco y el dolor de costado inicial se hallaban más bien conformes con la idea de una pleuresía supurada, circunscrita ó interlobulillar; pero no había fiebre y la pleuresía supurada, en la que el derrame es deficiente, produce, en general, accidentes febriles. Por otra parte, los signos estetoscópicos no indicaban un foco purulento en la cavidad de la pleura. En efecto, en la base izquierda se conservaban las vibraciones, y el murmullo vesicular sólo estaba debilitado; no había ni soplo ni pectoriloquia afona ; lo que dominaban eran estertores gruesos cavernosos confluentes, que ocupaban el lóbuloizquierdo del pulmón.

En resumen, á pesar del modo de principiar la enfermedad y de los caracteres de estas pseudo-vómicas, había. más probabilidades en favor de la dilatación bronquial que de la pleuresía purulenta. Cuando pensaba hacer una 
punción exploradora para confirmar el diagnóstico, abandonó el hospital el enfermo y no hemos vuelto á verle.

Conviene saber, en efecto, que la bronquiectasia, lesión crónica por excelencia, es capaz, desde el punto de vista de su sintomatología aparente, de simular una afección aguda de principio brusco. El incidente inicial que indica en ciertos casos la lesión de los bronquios es una vómica. A pesar de lo paradógico que parece ser esta afirmación, es exacta por completo, y cuando era interno del profesor Potain ví un caso que no deja la menor duda respecto á este particular. Era un estudiante de medicina, operado en su infancia á causa del crup, que padeció desde entonces estrechez de la tráquea, la que le predisponía á bronquitis frecuentes. Tosía muy á menudo aun disfrutando buena salud, y el día que iba á doctorarse tuvo un acceso de tos y expectoró una bocanada de pus. Fue la manifestación primera de una enfermedad que duró ocho meses, y que le ocasionó la muerte con fenómenos de gangrena bronquial. Se trataba indudablemente, como demostraron los sucesos, de una bronquiectasia, cuyo accidente inicial fue tan brusco, que el profesor Potain creyó al principio que este individuo padecía una pleuresía supurada interlobular; el diagnóstico fue inseguro durante algunas semanas.

A pesar de este modo de principio anormal, la bronquiectasia es en el fondo una enfermedad esencialmente crónica, cuyo origen verdadero se remonta casi siempre á una afección torácica antigua, contraída muchas veces en la infancia. En los casos de este género es siempre un problema interesante resolver el mecanismo de la lesión $\mathrm{y}$ su antigüedad.

Las teorías patógenas inventadas para explicar la bronquiectasia son numerosas y no pretendo enumerarlas. Sólo llamaré la atención sobre el hecho siguiente : que las ec- 
tasias bronquiales jamás constituyen una lesión primitiva; son siempre consecuencia y fin común de procesos muy diferentes.

La bronquitis crónica es con seguridad una causa predisponente, pero no basta por sí sola para ocasionar por completo la dilatación bronquial. Si fuera así, todos los tuberculosos, todos los asmáticos, la mayoría de los enfisematosos, padecerían bronquiectasia; pero aunque es indudable que en dichos diversos estados patológicos pierden los bronquios su elasticidad y se dejan distender, es también cierto que este aumento de calibre en nada se asemeja á la dilatación bronquial ampulosa y circunscrita, tal como la que observamos en nuestro enfermo.

La verdadera dilatación de los bronquios es inseparable de las lesiones parenquimatosas pulmonares, y progresa á la par con la esclerosis, pero no todas las induraciones del pulmón originan por necesidad ectasias bronquiales ; todos los días se encuentran al hacer las autopsias pulmonías crónicas intersticiales y pneumoconiosis fibrosas sin que hayan sufrido los bronquios más modificación que el engrosamiento de sus paredes.

La condición patógena necesaria para crear la ectasia bronquial es, al parecer, compleja. La historia clínica de los enfermos revela casi siempre la asociación de una inflamación de los órganos respiratorios, que disminuye la resistencia y elasticidad de los tubos bronquiales, y de una flegmasía intersticial peribronquial, que altera la estructura del parénquima. En otros términos, la mayor parte de las bronquiectasias proceden de bronco-pneumonías que datan en ocasiones de la infancia. Visito á un niño de cinco años, en el que sigo de año en año la evolución de este proceso. A los ocho meses padeció una broncopneumonía gravísima, que le tuvo durante cuatro semanas entre la vida y la muerte : salió vivo de esta crisis, 
pero con opresión, induración pulmonar y estertores mucosos gruesos. La lesión se circunscribió después, pero acentuándose ; el pulmón se hizo esclerósico y se hundió la pared torácica correspondiente; los bronquios se dilataron ; en la actualidad, á pesar de ser satisfactorio su estado general, se oyen siempre en este punto respiración sibilante y gorgoteo ; la lesión es, al parecer, definitiva.

Las condiciones de la bronquiectasia se realizan sobre todo cuando además de bronco-pneumonía hay adherencias de la pleura. Estas lesiones son anejas y se asocian muchas veces : la pleura participa de la inflamación del parénquima subyacente, $\mathrm{y}$ se forman bridas en toda la zona alterada. A causa de estas adherencias circunscritas, los bronquios se estiran con fuerza á cada inspiración y se dilatan por un mecanismo análogo al de una ventosa. Barth había comprendido é indicado con toda exactitud esta influencia patógena, que es idéntica para el pericardio y explica la génesis de ciertos aneurismas parciales del corazón.

En nuestro enfermo es probable que la causa inicial de la bronquiectasia fuera la pleuro-pneumonía que padeció hace treinta años. En dicha fecha recuerda haber tenido un dolor de costado que le obligó á guardar cama más de un mes; es lógico suponer que después de curar este foco inflamatorio, quedaran adherencias circunscritas.

Aunque la lesión es definitiva, el pronóstico en este caso es relativamente benigno. Me fundo para decirlo en los datos siguientes :

La esclerosis pulmonar es poco extensa; ocupa sólo el cuarto inferior del pulmón izquierdo, el resto del órgano funciona bien y el pulmón derecho se halla, al parecer, sano casi por completo. Los pocos estertores que se oían en la base derecha han desaparecido en su mayor parte.

$\mathrm{La}$ intensidad del soplo y del gorgoteo no supone por 
necesidad una gran pérdida de substancia ni cavernas extensas, sino un tejido pulmonar endurecido y sembrado de vacuolas.

Las secreciones no son fétidas, por consiguiente las ampollas bronquiales se vacían bien; además, bajo la influencia del tratamiento, la expectoración ha disminuído de una manera notable desde que ingresó el enfermo en el hospital.

El pronóstico sería, por el contrario, más grave si las lesiones de la induración pulmonar en vez de quedar circunscritas tendieran á propagarse, y sobre todo si se estancara el pus en los bronquios y sufriera allí alteraciones y fermentaciones sépticas. En estas condiciones se presentan algunas veces fenómenos hécticos y accidentes de septicemia, pero con lentitud, y los enfermos resisten meses y hasta años á esta auto-intoxicación que concluye siempre por producirles la muerte.

Estos enfermos están expuestos á otro peligro, sobre todo si se prolonga su estancia en el hospital; me refiero á la tuberculosis. La bronquiectasia se complica con tuberculosis, tan á menudo, que, según el profesor Grancher, la dilatación bronquial es patrimonio de la tisis pulmonar. Creo que esta idea es exagerada, pero no niego que es frecuente la coexistencia de los dos estados patológicos. Los enfermos de esclerosis pulmonar y de ectasia bronquial se hacen tuberculosos con la mayor facilidad, y es logico suponer que el aire que respiran en los hospitales favorece bastante el contagio.

¿Cuáles son los recursos de la terapéutica en los casos de este género?

Existen dos clases de lesiones, unas permanentes contra las que nada podemos: la esclerosis y la ectasia bronquial; otras son, por el contrario, transitorias y susceptibles de tratamiento, me refiero á los ataques congestivos 
é inflamatorios que se revelan por la extensión de los fenómenos flegmásicos y el aumento del catarro.

Contra los accidentes inflamatorios pulmonares están indicados los revulsivos; la cauterización punteada ó los vejigatorios repetidos alivian bastante á los enfermos.

La medicación balsámica es eficacísima contra el catarro; deben prescribirse la trementina, la creosota, las emulsiones de tolú $\delta$ de eucaliptol, todas las substancias que suprimen en cierto modo la secreción bronquial $\delta$ que disminuyen al menos la putridez. Se han aconsejado con el mismo fin las preparaciones astringentes y los diversos taninos; pero no pueden emplearse por mucho tiempo á causa de la intolerancia del estómago y de la pérdida del apetito que ocasionan. Debe tenerse siempre presente que en una enfermedad crónica y de larga duración, conviene no alterar los órganos digestivos y proscribir todo lo que debilite á los enfermos.

Sólo me ocuparé por incidente de la intervención quirúrgica que no creo indicada en modo alguno en el caso actual. Esta operación, que data de ayer y con la que se han obtenido éxitos notables en Inglaterra, no tiene razón de ser más que cuando hay fenómenos generales graves y accidentes de septicemia, y además, cuando la dilatación de los bronquios produce una pérdida de substancia extensa, superficial y accesible. En el caso que nos ocupa sucede todo lo contrario, y la operación, en vez de remediar el mal, es probable que lo agravara. 


\section{BRONQUIECTASIA Y GANGRENA PULMONAR}

Somario : Bronquiectasia complicada con gangrena pulmonar.-Vómicas pútridas.-Dificultades del diagnóstico entre una ulceración tuberculosa, una pleuresía purulenta con fístula pleuro-bronquial y una esclerosis pulmonar.-Dificultades materiales para descubrir el foco séptico.-Resultados de la autopsia: coexistencia de la bronquiectasia y de la gangrena verdadera.-Patogenia de estas lesiones.-Evolución rápida de ciertas formas de esclerosis : influencia de la pleuresia en la producción de la esclerosis y de la bronquiectasia. - Infecciones secundarias y septicemia, localizadas primero en los bronquios enfermos, propagadas después al resto del parénquima pulmonar. - Tratamiento quirúrgico de las dilataciones bronquiales sépticas. - Necesidad de precisar el sitio de los focos pútridos y dificultades grandisimas de hacerlo.-Indicaciones y contraindicaciones de la pneumotomía.Manual operatorio.-Complicaciones y peligros de la operación.-Resultados estadísticos.

En la conferencia anterior, me ocupé de un caso simple de bronquiectasia é indiqué entonces la posibilidad de que sobrevengan complicaciones gangrenosas y sépticas cuando las secreciones bronquiales sufren la fermentación pútrida. Una mujer que ha muerto hace pocos días de septicemia gangrenosa, consecutiva á una afección de este género, va á demostrarnos las dificultades del diagnóstico y de la intervención terapéutica con que tropieza el clínico cuando no observa las fases iniciales de la enfermedad.

El 10 de Febrero último ingresó una mujer de cuarenta y cinço años, antigua enfermera del hospital de niños, con el aspecto de una tísica en el último período. Flaca, caquéctica, padecía opresión contínua, tosía constantemente y expectoraba á cada acceso de tos pus grisáceo de aspecto sanioso y de olor infecto. Desde unos días antes de su ingreso, tenía hinchadas las piernas.

A pesar de estos signos de destrucción pulmonar pu- 
rulenta, estaba apirética la enferma y formaba un contraste notable que la piel estuviera fresca y el pulso relativamente tranquilo, cuando todo parecía indicar la existencia de cavernas extensas en el pulmón. Esta anomalía primera hacía dudar de la realidad de la tuberculosis ; además, un año antes asistí á esta mujer que tenía accidentes de manía aguda, que obligaron á recluirla en Santa Ana, y en aquella fecha era robusta, fuerte, y no padecía lesión pulmonar alguna. Deseché por lo tanto a priori la hipótesis de la tisis.

Los datos que pude obtener me permitieron reconstituir en parte la evolución de la enfermedad. Trasladada de Santa Ana á Villa-Evrard, siguió agitada, y una noche que se levantó de la cama para pasear por los dormitorios sufrió un enfriamiento. Siguió á éste dolor de costado y pleuresía de evolución insidiosa y lenta. Desde entonces continuó tosiendo y se la consideró como tuberculosa, con tanto más motivo cuanto que tuvo en varias ocasiones hemoptisis.

Esta historia retrospectiva sólo nos enseña una cosa, que un año antes la enferma no padecía del pecho y que desde hace ocho meses, á consecuencia de una afección aguda, al parecer una pleuresía, empezó á toser y se puso caquéctica. No hemos podido saber en qué fecha principió á expectorar pus ni cuándo adquirió éste el carácter fétido que tenía los días últimos.

El diagnóstico en estas condiciones era difícil. Se trataba de una enfermedad de las vías respiratorias, crónica en la actualidad, pero aguda en su principio; era indudable. también que existía en el pecho un foco de supuración que se vaciaba de un modo irregular é incompleto y que sostenía el mal estado general, un verdadero envenenamiento pútrido. La cuestión era saber dónde estaba localizado este foco y cuáles eran su naturaleza y causa. 
$\mathrm{Ya}$ os he dicho que no creia que esta mujer fuera tuberculosa, no sólo porque la conocí robusta y sin lesiones pulmonares, lo que nada hubiera probado, sino porque los signos actuales no concordaban con la marcha regular de la tisis.

Merece no obstante discutirse esta hipótesis, porque se hallaban reunidas en este caso varias de las circunstancias que preceden 6 acompañan á la tuberculosis. La pleuresía precedente, la persistencia de la tos, la caquexia progresiva, las hemoptisis, eran otros tantos síntomas que justificaban la idea de la infección bacilar. Pero los caracteres de los esputos, y sobre todo, los signos que suministraba la auscultación, eran diferentes. Los esputos eran mucho más abundantes que cuando hay una caverna por extensa que sea ; no eran estrellados ni circunscritos como los tuberculosos, sino fluídos y poco consistentes ; estaban además mezclados con grumos caseosos, grisáceos, infectos, lo que se observa pocas veces en la tisis ulcerosa. Por último, su expulsión era característica ; á cada golpe de tos se producían verdaderas vómicas.

Los signos físicos tampoco eran los de las cavernas tuberculosas. En primer lugar, en un período avanzado de la tisis hubiera sido excepcional encontrar las lesiones limitadas á un sólo pulmón ; estas eran estrictamente laterales y estaban localizadas sólo en el lado izquierdo. En segundo lugar, el vértice del pulmón estaba sano, lo que constituía una nueva anomalía casi tan rara como la primera, y era la base la que se hallaba enferma. En el tercio inferior del lado izquierdo se notaba macicez y disminución de las vibraciones torácicas, mientras que en la parte superior había timpanitis sub-clavicular. Al auscultar se oía un soplo profundo y gorgoteo debajo del ángulo de la escápula; según se descendía iban atenuándose estos síntomas y se debilitaba el ruido respiratorio. En el 
lóbulo inferior del pulmón los signos eran los de induración y parecía que existían en él más bien excavaciones pequeñas que una caverna extensa. En la hipótesis de una tuberculosis ulcerosa de focos múltiples, era excepcional no descubrir estertores diseminados de arriba á abajo por el pulmón. Y además, cuando existen semejantes lesiones, se sabe que producen siempre la fiebre héctica ; nuestra enferma, según he dicho, estaba apirética. Por último, el examen microseópico de los esputos no revela la presencia de bacilos, y este signo negativo, unido al conjunto de los demás caracteres, excluía en absoluto la idea de la tuberculosis.

El diagnóstico fluctuaba sólo entre la dilatación bronquial y una pleuresía purulenta que comunicaba con los bronquios. Existían, en efecto, todos los signos de la bronquiectasia, de los que he hablado en varias ocasiones : la abundancia de los esputos, desproporcionada con la extensión aparente de la lesión, la intermitencia y la frecuencia de las vómicas, la mezcla en la misma escupidera de esputos purulentos, inodoros y de grụmos grisáceos fétidos; los signos estetoscópicos indicaban, por último, una infinidad de cavernillas más bien que una extensa pérdida de substancia del pulmón, y coincidían con la falta de fiebre. Como véis, nada faltaba al cuadro.

Podía hacerse una objeción á este diagnóstico: La bronquiectasia es una enfermedad crónica por esencia y de marcha lenta ; esta mujer, antes de su pleuresía, tenía en buen estado sus órganos respiratorios y las lesiones actuales databan cuando más de ocho meses. Era una anomalía verdadera en la historia de la dilatación bronquial y debemos tenerla muy presente.

Parecía tan poco racional suponer que en cinco $\delta$ seis meses se hubieran formado tantas vacuolas bronquiales en el pulmón que, aunque sin negar en absoluto la posibili- 
dad del hecho, me inclinaba más bien á creer que las vómicas eran en este caso consecuencia de una pleuresía purulenta que se vaciaba de un modo incompleto por los bronquios. En efecto, la enfermedad había principiado indudablemente por una pleuresía, y ésta, que jamás había entrado francamente en resolución, fue punto de partida de los accidentes de consunción ulteriores. Era por lo tanto lógico admitir que al hacerse purulento el derrame, se formó una fístula pleuro-bronquial, por la que se vaciaba de una manera intermitente. Fácil es comprender que el pus se descomponía al contacto del aire y producía la fetidez casi gangrenosa de las secreciones bronquiales.

Pero había dos particularidades clínicas que no estaban de acuerdo con la hipótesis de un derrame de la cavidad de la pleura. La primera era la falta completa de signos del pneumotórax, que hubieran existido con una fístula pleuro-bronquial. En segundo lugar, era indudable que la base del pulmón estaba adherida de una manera íntima á la pared torácica, porque el lado izquierdo del pecho se hallaba retraído y á cada inspiración se veían hundirse los espacios intercostales inferiores. Por último, la persistencia de las vibraciones torácicas en este punto, aunque estaban disminuídas, hacía dudar de la existencia de un derrame en la cavidad de la pleura.

Tampoco podía aceptarse la idea de una pleuresía interlobular supurada, porque los signos físicos observados indicaban la integridad del lóbulo medio. Había admitido, por exclusión, como más probable, un derrame pleurítico enquistado con esclerosis pulmonar concomitante y fístula bronquial. Así me explicaba el gorgoteo, los signos cavernosos y las vómicas.

Quedaba por averiguar por qué los esputos habían adquirido el olor pútrido y si se trataba de una gangrena pulmonar verdadera, $\delta$ simplemente de una alteración 
de las secreciones bronquiales, de una falsa gangrena.

Esta última suposición era la más verosímil. En efecto, el aliento del enfermo y las materias expectoradas eran fétidas de un modo desigual : unos esputos exhalaban olor repugnante y otros eran inodoros, lo que, como sabéis, es la regla en las broncorreas consecutivas á la dilatación bronquial. Además, el estado general del enfermo, aunque malo, en nada se asemejaba al colapso de que van acompañadas las gangrenas pulmonares verdaderas. No había ni fiebre, ni diarrea, ni fenómenos hécticos; sólo el pulso era frecuente y débil.

Cualquiera que fuere la interpretación que se aceptara, ya existiera una bronquiectasia 6 una pleuresía enquistada con fístula bronquial, la situación de la enferma era grave, é inminente la muerte á causa de la septicemia. Se imponía con urgencia la intervención y precisaba evacuar el foco purulento. Pero era difícil fijar su sitio. $\mathrm{Mi}$ amigo y colega Rigal, después de examinar detenidamente á la enferma, manifestó que la supuración estaba localizada en la base del pecho, hacia el noveno ó décimo espacio intercostal. Yo suponía, por el contrario, que el abceso se hallaba situado más arriba, debajo del ángulo de la escápula, hacia el octavo espacio, donde se oían con más claridad el soplo y el gorgoteo. Hicimos acto contínuo, con una jeringuilla de Pravaz, calentada de antemano á la llama de la lamparilla de alcohol, dos incisiones exploradoras en los puntos que suponíamos correspondían al foco; uno y otra fueron infructuosas. Dejamos para el día siguiente repetir la exploración, esta vez con el aspirador de Potain, después de cloroformizar á la enferma, convencidos de que e] pequeño calibre de la aguja había debido conducirnos al error, al no dejar salir un pus espeso, como es el de las secreciones bronquiales.

Aquella misma noche, la enferma, que tenía una gran Clínica médica. - Tomo I. 
opresión y estaba muy débil, murió casi sin agonía, á los cuatro días de ingresar en el hospital.

La autopsia reveló lesiones de diversas fechas, que no nos hicieron arrepentir de nuestra falta de intervención operatoria. Debajo del esternón encontramos inflamación reciente y difusa del mediastino é infiltraciones purulentas en toda la región media del tórax, desde la horquilla esternal hasta cerca del diafragma. El tejido conjuntivo, en los sitios respetados por el pus, era grueso, vascular y tenía adherencias íntimas con la cara profunda del esternón. La causa de este flemón era fácil de descubrir : procedía de un foco gangrenoso superficial situado en el parénquima pulmonar, cerca del hilio.

Había en el pulmón indicios de una doble lesión. Bajo la influencia de la pleuresía, el lóbulo superior, libre de adherencias, estaba deprimido, mientras que el inferior, adherido de un modo íntimo á la pared torácica, padecía esclerosis total. Quedaba debajo de la clavícula izquierda una cavidad libre que no comunicaba con el foco de supuración.

$\mathrm{Al}$ corte, la mitad inferior del pulmón estaba transformada en un bloc duro, con multitud de cavidades, que no eran más que ampollas bronquiales dilatadas. En el centro del parénquima se veía una caverna principal, del tamaño de un huevo de gallina, alrededor de la cual convergían todas las cavernillas restantes. Resultaba una serie de excavaciones anfractuosas, atravesadas por bridas fibro-vasculares y llenas de grumos sólidos y de exudados puriformes. Según habíamos supuesto, los bronquios dilatados contenían poco líquido seroso, lo que explicaba perfectamente el ningún resultado de las dos punciones exploradoras. Pero la aguja podía haber penetrado en el foco principal, porque éste sobresalía por detrás del pulmón y sólo estaba separado de la superficie de la pleura 
por una capa del parénquima, de 3 centímetros, cuando más.

Los exudados bronquiales exhalaban el olor pútrido que se observa de ordinario en tales casos; pero además de la alteración de las secreciones había gangrena verdadera. Debajo de la zona de esclerosis se descubrió una infiltración bronco-pneumónica difusa, y sobre este fondo de hepatización uniforme, descollaba una serie de pequeños islotes gangrenosos, que formaban úlceras negruzcas. Uno de estos focos, situado debajo de la pleura, se había gangrenado y producido el flemón del mediastino.

El pulmón derecho estaba sano, pero se veían en algunos puntos núcleos de bronco-pneumonía gangrenosa, consecutivos indudablemente á embolias capilares sépticas.

La autopsia justificaba, explicándolas, las dudas del diagnóstico. Las lesiones de la pleura estaban asociadas con las esclerosas, y además de la alteración de las secreciones bronquiales, había verdadera gangrena parenquimatosa.

La bronquiectasia era de fecha relativamente reciente, porque fue ocasionada por la pleuresía, que databa de ocho meses; pero no hubiera producido por sí sola la muerte. Esta fue debida á bronco-pneumonía infecciosa y á la gangrena séptica que se presentó en los últimos días.

Tal es el caso instructivo en alto grado que hemos observado. Insistiremos sobre algunos puntos para sacar las conclusiones necesarias.

Resulta, en primer término, que puede desarrollarse por completo en un espacio de tiempo relativamente corto una bronquiectasia considerable y muy extensa. No creía el hecho posible $y$, fundándome en la evolución lenta de este proceso, admití la idea de una pleuresía enquistada con fístula bronquial, Pero en este caso es inadmisible en 
absoluto la duda, porque por una feliz casualidad, había asistido un año antes á esta mujer y observé la integridad absoluta de su aparato respiratorio.

Este desarrollo rápido de la esclerosis pulmonar y de la dilatación bronquial confirma por completo las ideas de Barth sobre la patogenia de esta afección. Según este autor, la pleuresía tiene una influencia determinante de primer orden, no por el derrame que aplasta el pulmón contra la canal vertebral, sino por las adherencias que se fijan á las costillas. En nuestra enferma pudo observarse este doble proceso. La parte superior del pulmón estaba libre de adherencias y sólo ingurgitado, en la inferior había adherencias, esclerosis y bronquiectasia. La rapidez del trabajo de dilatación bronquial ha sido favorecido, según toda probabilidad, por los accesos contínuos de tos y por el estado de esplenización persistente del parénquima pulmonar.

Conviene averiguar cuál ha sido la filiación de las lesiones y su mecanismo. La pleuresía es capaz por sí sola de producir la esclerosis cortical : es esclerógena en cierto. modo. Pero esta pulmonía intersticial propagada se limita siempre á las capas periféricas del pulmón, y es dudoso que invada todo el parénquima. Es, por el contrario, muy verosímil que existieran en este caso lesiones pulmonares inflamatorias contemporáneas de la pleuresía, ó primitivas, y que la afección compleja, causa de la dilatación bronquial ulterior, fuera una pleuro-pneumonía. Demuestran la realidad de este proceso flegmásico las diversas hemoptisis que padeció la enferma, testimonio irrecusable de las hiperemias bronquiales.

La septicemia secundaria que se presenta en las últimas semanas de la vida se explica con facilidad. Fue ocasionada por la introducción, en las vías respiratorias, de gérmenes sépticos de varias clases. A cada inspiración pe- 
netra en nuestros bronquios un número considerable de micro-organismos. Mientras está intacto el epitelio bronquial y la circulación pulmonar es normal, la actividad celular impide el desarrollo de estos gérmenes. No sucede lo mismo cuando se lesiona el pulmón y se altera su epitelio, y con mucho más motivo si los bronquios afectados de inflamación crónica pierden su elasticidad y no pueden expulsar las mucosidades que les obstruyen. En estas con. diciones se producen cultivos microbianos múltiples : estafilococos y estreptococos de la supuración por una parte, bacilos de la putrefaccion por otra, todos viven juntos y se desarrollan á la vez en los mismos puntos secretorios.

Este desarrollo de gérmenes infecciosos no queda limitado á las ampollas bronquiales enfermas; se diseminan por las partes adyacentes del parénquima pulmonar, bien de etapa en etapa, por inoculación directa, $\delta$ por penetración á distancia, durante las inspiraciones fuertes, á la manera de las embolias. Lo prueban los caracteres de los foquillos secundarios cuyo centro es siempre un bronquio pequeño, y que destruyen el parénquima pulmonar peribronquial, y están rodeados de una zona de congestión vascular, lo mismo que los coágulos sépticos arteriales ó venosos.

Es verdad que en la práctica es rara la gangrena, y que las secreciones bronquiales se hacen fétidas muchas veces sin producir accidentes de absorción. Esto indica sólo que los micro-organismos que penetran con el aire inspirado no tienen la misma virulencia, y quizá que no encuentran un terreno igualmente propicio para su desarrollo. Pero, teóricamente, son aptos siempre para desarrollarse. Puede decirse, por lo tanto, que en cuanto los bronquios dilatados pierden su elasticidad, los enfermos están en peligro de padecer septicemia y condenados á morir fatalmente de intoxicación pútrida. 
La consecuencia racional que se saca de estos datos es la necesidad de desobstruir los bronquios y de expulsar los productos sépticos depositados en ellos. De aquí nació la idea terapéutica racional de abrir las cavernas bronquiales y tratarlas por el método antiséptico.

Las indicaciones son, en efecto, las mismas que para el empiema; pero su ejecución es mucho más dificil. Los focos purulentos pleurales se diagnostican casi siempre sin dificultad : es fácil precisar el sitio de la bolsa purulenta y llegar á ella con los instrumentos. El peligro de hemorragia durante la operación es casi nulo.

No sucede así cuando se trata de encontrar una caverna supurada intra-pulmonar y de abrir un foco bronquial pútrido; la pneumotomía es una operación no sólo delicada, sino, hasta ahora, siempre aleatoria que exige una gran habilidad quirúrgica.

La dificultad mayor es debida á la imposibilidad de precisar con exactitud el sitio del abceso. ¿Qué ejemplo más evidente que el de nuestra enferma? La autopsia demostró que el foco principal distaba casi 3 centímetros de la superficie de la pleura. Esta se hallaba en dicho punto unida á la pared torácica por adherencias compactas, inextensibles, y el tejido pulmonar se había reducido á una capa fibrosa : todas las condiciones eran favorabilísimas para la intervención quirúrgica, que hubiera sido relativamente fácil. Sin embargo, vísteis que, á pesar del concurso del Dr. Rigal, tan competente en auscultación pulmonar, quedamos en la duda, y que las dos punciones. exploradoras nada enseñaron respecto al sitio exacto del foco pútrido.

Conviene saber que no hay correlación constante entre los signos estetoscópicos y la lesión, y que ésta no corresponde siempre al punto donde al auscultar se oyen con más fuerza los ruidos. El soplo y el gorgoteo se oyen con 
más claridad en la periferia de una caverna pulmonar que en el sitio correspondiente á ésta, y se transmiten mejor al oído á través del parénquima esclerosado. No es posible afirmar, por otra parte, que el abceso está localizado en la zona del pecho, donde se nota macicez $\delta$ silencio al auscultar. La infiltración edematosa del pulmón y hasta la esclerosis producen signos de auscultación análogos, por ligera que sea la obstrucción bronquial. Pero la supresión del murmullo vesicular tiene en general más valor para el diagnóstico que la intensidad del soplo, y en el caso de nuestra enferma, el punto designado por el Dr. Rigal se aproximaba más al foco purulento que el que indiqué yo.

Para salvar estas dificultades debe recurrirse á la punción exploradora; pero aun con ella son numerosas las causas de error. La punción con la aguja de la jeringuilla de Pravaz, eficaz siempre cuando se trata de una pleuresía purulenta, es insuficiente para descubrir un foco bronquial, bien porque éste es central y muy profundo para la longitud de la aguja, 6 porque el contenido de los bronquios es siempre espeso y está mezclado con grumos que obstruyen la aguja. Para que la exploración sea útil es preciso emplear la aguja de Dieulafoy 6 el trócar aspirador de Potain, y no temer hacer varias punciones : cuando se emplean instrumentos de pequeño calibre, calentados de antemano y bañados en agua fenicada, no hay peligro de atravesar con ellos el parénquima del pulmón, y aunque le hubiera, siempre es menor que el debido á la existencia de un foco pútrido que intoxica el organismo.

Otra dificultad, que jamás se observa en el empiema, y con la que se tropieza cuando se trata de practicar la pneumotomía, es la multiplicidad de las dilataciones ampulosas bronquiales, que suele hacer insuficiente é ineticaz el desaguie pulmonar. Sucede, en efecto, algunas veces que la aguja exploradora penetra en una bolsa secundaria sin 
comunicación con el foco principal, y entonces persiste la causa de la infección, á pesar del acto operatorio. Esta objeción es tan seria, que por sí sola debería hacer renunciar, desde el punto de vista teórico, á la operación, porque no hay un caso de bronquiectasia sin una serie de dilataciones ampulosas. Pero la experiencia demuestra que, por lo común, en toda bronquiectasia existe un foco más importante que los otros, y que sirve, por decirlo así, de desembocadura y encrucijada á las cavernas inmediatas. Cuando se consigue descubrirle y desaguarle, cesa poco á poco la secreción en las demás cavernas. Pero se comprende que su descubrimiento debe ser eventual, porque la auscultación es importante para precisar el número y sitio de las ampollas bronquiales.

Todas estas dificultades y todas estas incertidumbres no bastan para desechar el principio de la intervención operatoria, y hay casos en los que considero de necesidad absoluta la pneumotomía, lo mismo que el empiema en la pleuresía purulenta. Creo que la operación está indicada en los casos siguientes :

.1. Cuando la medicación interna y las inhalaciones antisépticas son impotentes para corregir la fetidez de la expectoración, se agrava el estado general y hay síntomas evidentes de septicemia.

2. Cuando la bronquiectasia está limitada á un pulmón, hacia el lóbulo inferior, y en relación con adherencias de la pleura, y los signos estetoscópicos indican la existencia de una caverna extensa, que se vacía y se llena alternativamente.

3. Cuando no hay tuberculosis ni gangrena evidentes de los pulmones. Esto último es difícil algunas veces de precisar, como lo demuestra el ejemplo de nuestro enfermo.

La pleurotomía está contraindicada, por el contrario, 
en absoluto, si el pulmón del lado opuesto se halla muy enfisematoso, y también cuando la bronquiectasia es bilateral, lo que sucede á menudo. Lo está asimismo si la pleura se encuentra libre de adherencias, lo que acontece muchas menos veces, y es más teórico que real.

De todos modos, no debe practicarse una operación de este género, sin tener seguridad completa de encontrar la bolsa purulenta, y sin haber comprobado de antemano la existencia del pus por medio de una punción. Es posible, vuelvo á repetir, engañarse en absoluto, guiándose por los signos de la auscultación, y he visto á un cirujano de los más hábiles fracasar en una pneumotomía, hecha sin haber adoptado esta precaución indispensable.

Aunque la descripción de la técnica operatoria pertenece más bien á la cirugía que á la medicina, creo que debo deciros algunas palabras sobre el particular. Los cirujanos ingleses, que son los que tienen más experiencia en este asunto, proceden como sigue :

Cloroformizado $\delta$ no el enfermo (creo que es mejor anestesiarlo, tanto en su interés como en el del médico), se hace una punción exploradora con el trócar núm. 2 de Dieulafoy 6 de Potain, que se deja clavado hasta que salen algunas gotas de pus por la cánula. Después, utilizando ésta como conductor, se dividen, capa por capa, la piel, los músculos intercostales y la pleura, hasta el pulmón, con un bisturí estrecho ; hecho esto, se clava directamente la hoja del bisturí, siguiendo la cánula hasta que se comprende que ha llegado al foco purulento, y se sustituye inmediatamente por un tubo de desagüe más grueso que el bisturí que se extrae, sin agrandar la incisión. Se retira después la cánula, se fija bien el tubo de desagüe y se hace la cura antiséptica.

Este procedimiento operatorio, empleado con éxito en Inglaterra por Williams y Rickman Godlee, es útil cuan- 
do la bolsa purulenta es superficial y está rodeada de una delgada capa de tejido escleroso. En este caso, al contrario de lo que podía temerse, son ligeras las probabilidades de hemorragia grave, y se divide sin gran trabajo el tejido pulmonar condensado. Pero no sucede siempre así, y puede tropezarse con grandes dificultades, por ligera que sea la hemorragia que se presente, y el enfermo se sofoca entonces $\delta$ es acometido de accesos de tos. Godlee refiere un caso, en el que hizo primero tres punciones secas sin encontrar el foco purulento ; á la cuarta salieron algunas gotas de pus, y principió á operar. Al dividir la pleura sufrió el enfermo un acceso de tos fuerte, y el trócar se salió del pecho sin que fuera posible introducirlo de nuevo, ni volver á encontrar la bolsa purulenta, aunque hizo una incisión extensa. Tuvo que renunciar á la operación, y quince días después fue preciso resecar una costilla; esta vez llegó el operador hasta la caverna bronquial, después de haber clavado el trócar á 125 milímetros de profundidad y de dividir el parénquima en esta extensión.

Aunque sin derecho á criticar en este asunto, me permito decir que esta manera de proceder es temeraria $y$ aventurada; me parece que en materia de cirugía pulmonar es mejor no operar en un terreno tan estrecho como el de un espacio intercostal, y que es preferible disponer de un campo operatorio más extenso para conjurar los accidentes que se presenten. Soy de la opinión del Dr. Cérenville (1), quien aconseja no operar sobre el tejido del pulmón sin haber resecado antes un fragmento de costilla. Hecho esto, puede intervenirse, bien con el bisturí, utilizando el trócar como conductor, según hacen los cirujanos ingleses, $\delta$ mejor aún con el termo-cauterio, que tiene la ventaja de no producir hemorragia. Aunque cuan-

(1) De Cérenville, De l'intervention opératoire dans les maladies du poumon. (Revue méd. de la Suisse Romande, V, 441, 1887). 
do se presenta un derrame de sangre de origen pulmonar es posible conjurar los accidentes por el taponamiento bien hecho, sin embargo, la herida de una arteria algo voluminosa puede producir la muerte en pocos segundos.

Una vez abierta la bolsa la cura consecutiva es sencillísima. Consiste en introducir en ella un tubo grueso de goma que se deja aplicado y en cubrir la herida externa con un apósito antiséptico. Están contraindicadas en absoluto las inyecciones de todo género en la cavidad del foco ; la introducción del líquido en las vías respiratorias produciría la asfixia inmediata.

Debe también evitarse espolvorear la herida pulmonar con iodoformo 6 cubrirla con gasa fenicada por la facilidad con que absorbe el pulmón y lo fácil que sería un envenenamiento.

La pneumotomía, en los casos felices, es una operación admirable. Cuando no sobreviene complicación alguna, la tos desaparece casi inmediatamente, lo mismo que la expectoración fétida. La supuración, profusa al principio, cesa con bastante rapidez, y, fenómeno notable, las demás ampollas bronquiales que son siempre solidarias del foco principal, se secan á su vez. Se ve que no sólo cesa la expectoración, sino que disminuyen de un modo progresivo los estertores. Se verifica una verdadera resurrección del enfermo, el que una vez que se suprimen los accidentes de la absorción pútrida, duerme, deja de sudar, recobra el apetito y engorda. En estas condiciones favorables suele obtenerse la curación en cinco ó seis semanas ; Godlee (1), Rochett (2) y Cérenville, refieren ejemplos de ello.

Desgraciadamente, sobrevienen muy á menudo complicaciones secundarias más ó menos graves que compro-

(1) Godlee. Brit. med. jour., pág. 590, Marzo, 1886.

(2) Rochelt. Wien. medic. Presse, núm. 39, pág. 1264, 1886. 
meten la vida de los enfermos. Finlay (1) ha visto repetirse varias veces las hemorragias y producir la muerte á causa de una dilatación aneurismática de una rama de la arteria pulmonar. Además, cuando quedan sin vaciarse ampollas bronquiales que son otros tantos focos pútridos, persisten los accidentes septicémicos y los enfermos, como en el caso actual, mueren á consecuencia de accidentes de bronco-pneumonía gangrenosa ; así sucedió á un operado de Brookhouse (2).

Se ven sobrevenir también fenómenos singulares de colapso y de asfixia rápida, debidos á la parálisis bronquial y á la dificultad material de expectorar los esputos acumulados.

He observado un ejemplo de este género en una mujer que padecía desde algunos años antes bronquiectasia y que se hizo caquéctica á causa de la supuración bronquial interminable. Los accidentes sépticos me decidieron á recurrir á la intervención quirúrgica y la operación fue practicada con toda habilidad, por mi colega el Dr. Segond. Durante los dos primeros días fue excelente el estado general y local, la enferma apenas tosía y la herida supuraba poco. Pero al tercer día cesó de repente la expectoración y sobrevino el colapso. Supusimos que la imposibilidad de expectorar había contribuído bastante á precipitar el desenlace.

Conviene decir también que se citan, después de las operaciones de este género, casos de intoxicación por el iodoformo. Cérenville refiere varios ejemplos.

Son de temer muchos peligros á consecuencia de esta operación ; y, aun después de haber llegado con toda felicidad al foco séptico, no debe considerarse fuera de peligro al enfermo. Se ha creido muchas veces que estaba curado

(1) Finlay. Brit. med. journ., Octubre, 1888.

(2) Brookhouse. Lancet, 1888. 
porque parecían conjurados los peligros inmediatos (1) pero persistieron los fenómenos hécticos que ocasionaron la muerte á las pocas semanas. La pleurotomía practicada en los casos de bronquiectasia es en la actualidad una operación difícil, peligrosa y de resultados eventuales.

A pesar de sus muchas probabilidades de fracaso, no hay motivos para condenarla a priori ni para proscribirla cuando se han agotado los recursos de la terapéutica médica y los enfermos están condenados á una muerte cierta. Es mejor arriesgar la última probabilidad de curación que entregarles sin defensa á los progresos de la septicemia. Además, la pleurotomía es una operación moderna que no ha dado aún todo lo que puede dar de sí; la han practicado pocos cirujanos y no ha entrado hasta ahora en la práctica corriente. Tal cual es, se han obtenido con ella bastantes éxitos para legitimar nuevas y más numerosas tentativas. En el trabajo de Roswell Park sobre la cirugía del pulmón, de 23 bronquiectásicos operados, curaron 14 y murieron 9 . No debe olvidarse que estos 14 enfermos estaban condenados irremisiblemente y que debieron la vida á la intervención quirúrgica. Nuestra enferma ingresó en el hospital demasiado tarde y con accidentes de bronco-pneumonía difusa gangrenosa que excluyen toda probabilidad de éxito, pero algunas semanas antes se hubiera operado en buenas condiciones y no dudo aconsejar la operación en otro caso análogo. Es necesario decidirseá tiempo cuando es inminente la septicemia, pero antes que se desarrolle. La dificultad de precisar el momento psicológico de la evolución de la enfermedad es lo que hace $\tan$ raras las conclusiones de una intervención oportuna.

(1) Caso de Prengrueber. (Bull: Acad. méd., Octubre, 1886). 


\section{CONTUSION DEL PULMON Y TUBERCULOSIS}

Sumario: Contusión del pulmón, hemoptisis primitiva, seguida de signos de pleuro-pneumonía circunscrita. - Evolución clínica y grados de la contusión pulmonar, analogias y diferencias de la pulmonía tranmática y de la espontánea.-Influencia del terreno morboso sobre el traumatismo.-En este caso la hemoptisis, accidental en apariencia, es en realidad sintomática de una tuberculosis latente.-Pronóstico y tratamiento.-Nota adicional : evolución de la lesión dos años después del accidente.

Estos últimos días llamé vuestra atención sobre un enfermo que padecía hemoptisis. Era un hombre de cincuenta y un años que ingresó el lunes por la mañana con esputos de sangre consecutivos á un accidente ocurrido la víspera.

Este individuo se encontraba muy bien, cuando le dió un caballo un golpe con la cabeza en medio del pecho. Cayó en tierra á consecuencia del golpe y acto contínuo principió á escupir sangre.

Tal es el hecho en su materialidad.

La sangre, que era de color vivo y salía en abundancia (una escupidera próximamente al pronto), siguió eliminándose todo el día cuando tosía el enfermo.

La noche fue mala. El enfermo sentía un dolor fuerte que le impedía respirar con libertad; pero aunque muy quebrantado, estaba apirético, y al día siguiente vino sin gran trabajo al hospital.

Llamaba la atención á primera vista en el momento de su ingreso, la apirexia completa de este hombre. Su pulso era muy tranquilo y lento de una manera singular; latía de 48 á 50 veces por minuto. El aspecto general del en- 
fermo era bastante bueno, excepto la disnea especial de las afecciones torácicas dolorosas. La respiración era frecuente, anhelosa, entrecortada ; evitaba elevar el tórax y moderaba sus inspiraciones por miedo á aumentar su dolor ; tenía de 36 á 48 movimientos respiratorios por minuto.

La expectoración era coloreada, pero no tanto como la víspera; la sangre era menos abundante, más alterada, morenuzca, mezclada á un exudado de aspecto inflamatorio que recordaba el aspecto de los esputos herrumbrosos de la pulmonía.

Algunos coágulos negruzcos indicaban todavía que se había derramado sangre en los bronquios y permanecido en ellos.

Mientras permaneció inmóvil el enfermo, tosía poco ó nada ; pero en cuanto hacía un movimiento se presentaban los accesos de tos.

Los signos físicos del traumatismo eran tan poco acentuados, que sin el relato del enfermo hubiera sido imposible sospechar una contusión. No se descubría al reconocimiento alteración alguna de los tegumentos, ni aun la equimosis más ligera.

Al palpar no se notaba hinchazón, ni crepitación de fractura de las costillas, ni aun viva sensibilidad á la presión. Pero al percutir se apreciaba submacicez debajo de la clavícula derecha, submacicez que se extendía, aunque atenuándose, hasta más abajo del mamelón hacia el sexto espacio intercostal ; por detrás se notaba también el mismo signo en toda la altura del tórax, más acentuado hacia la escápula donde la elasticidad estaba muy disminuída. En la parte inferior del pecho las vibraciones torácicas no estaban suprimidas, pero eran poco fuertes.

Correspondían á estos signos fenómenos de auscultación que indicaban la existencia de una congestión pulmonar con induración; el murmullo vesicular estaba debilitado 
debajo de la clavícula; por detrás la respiración era al contrario, áspera hacia la espina escapular y por debajo estaba disminuída y se oía al parecer bastante lejos. Se notaban además dos signos particulares : $1 .^{\circ}$, una respiración entrecortada de las más típicas, durante la inspiración se oían unas veces dos, otras tres sacudidas que tenían el timbre de un soplo muy corto, sincrónicas con el principio del sístole cardíaco y en cuyo ritmo influía indudablemente el corazón ; $2 .^{\circ}$, en la parte media del tórax, hacia el esternón, roces superficiales ligeros. Existía por lo tanto, en la lengüeta pulmonar anterior, un estado patológico influído por el corazón, con seguridad pleuresía seca ligera, y probablemente también, congestión pulmonar; según indicaba uno de los soplos extra-cardíacos tan bien estudiados por mi maestro el profesor Potain.

Desde el día siguiente al traumatismo presentaba este enfermo un grado notable de hiperemia del vértice pulmonar derecho, que al parecer se propagaba más abajo por delante que por detrás ; la submacicez, la falta de elasticidad del tórax, la respiración áspera en las fosas supra é infra-espinosas eran pruebas bien claras de ello. Se oían también algunos estertores subcrepitantes en esta región, pero su valor era muy secundario, porque persistía la expectoración sanguinolenta y los bronquios contenían sangre mezclada con las mucosidades bronquiales. Eran, vuelvo á repetirlo, los únicos signos que existían entonces; no había ni soplo tubario, ni estertores crepitantes verdaderos, ni indicio alguno de hepatización propiamente dicho. El pulmón izquierdo estaba sano y sólo se notaba algo de respiración suplementaria.

$\mathrm{Al}$ día siguiente, martes, siguió el mismo estado general y local, pero la expectoración se hizo más clara y menos abundante.

Ayer, miércoles, los esputos eran sólo equimóticos, sin 
mezcla de coágulos sanguíneos; hoy son claros por completo. Se han hecho, por el contrario, más consistentes y viscosos, $\mathrm{y}$ presentan el aspecto de una disolución de goma, carácter sobre el que insistía con tanta razón Bouillaud como uno de los signos de la congestión pulmonar. En algunos puntos están mezclados con partículas mocopurulentas, indicio de un trabajo inflamatorio que se produce á la vez en los bronquios.

Durante estos tres días, se han modificado muy poco los signos físicos. La percusión indica macicez en el vértice del pulmón derecho y un poco de elasticidad. Al auscultar en las fosas supra é infra-espinosas, se oye siempre respiración áspera, sibilante, casi sin estertores; sólo se nota ligera crepitación al fin de las grandes inspiraciones.

Es, señores, un ejemplo curioso de traumatismo bastante fuerte para haber producido una lesión pulmonar, dejando intacta la pared torácica. A priori cuesta trabajo comprender cómo una contusión verdadera directa del pulmón puede producirse, sin que se encuentre el menor indicio de equimosis cutánea, ni de fractura de las costilas. No debe sorprendernos esto porque es casi la regla en la mayor parte de las contusiones profundas; la piel es, en efecto, muy resistente y muy elástica ; cede al choque sin desgarrarse. Recuerdo que, siendo interno, hice la autopsia de un individuo, al que atropelló un ómnibus, pasándole una rueda por el vientre; la muerte fue casi instantánea. No se notaba en la pared abdominal lesión alguna, ni aun equimosis, y sin embargo, los intestinos estaban divididos con tanta limpieza como con un instrumento cortante.

¿Es posible en la especie explicar por las condiciones fisicas de la contusión la integridad de los tegumentos y del esqueleto, mientras que sufre el pulmón de una ma- 
nera tan ruda la consecuencia del golpe? Analicemos lo que sucede en la fractura de la caja torácica.

Para que se rompa una costilla es necesario : $1 .^{\circ}$, un choque fuerte; $2 .^{\circ}$, que este choque se produzca sobre una superficie débil; $3 .^{\circ}$, que se encuentre la costilla en un estado de tensión especial; de lo contrario cede y no se rompe. Cuando se encuentran reunidas estas condiciones, hay fractura, y muchas veces la rotura de la pared costal, al amortiguar el choque, proteje las partes subyacentes de lesiones más graves. $\mathrm{Si}$, por el contrario, se hunde la caja torácica, es contundido el pulmón y hasta se desgarra. Creemos que sucedió así en nuestro enfermo. Cedió la pared torácica, y el pulmón fue comprimido con fuerza. Se citan ejemplos de lesiones viscerales aún más graves : un pulmón puede ser desgarrado por completo y gangrenarse al poco tiempo, quedando intacta la pared; obsérvase esto en los individuos cogidos entre los topes de los vagones del ferrocarril.

Las condiciones necesarias para que se lesione el pulmón son: $1 .^{\circ}$, que el choque sea brusco, sin que el pulmón tenga tiempo para acomodarse bien á una compresión gradual y transitoria; $2 .^{\circ}$, que el cuerpo contundente obre sobre una superficie extensa (en nuestro enfermo, según recordaréis, fue la cabeza de un caballo); $3 .^{\circ}$, y último, que sea favorable el momento del período respiratorio. Esta condición última no ha sido estudiada, que yo sepa, y se comprende que es difícil precisar el estado del aparato respiratorio en el momento de un traumatismo brusco é inesperado.

Pero en teoría parece que cuando ocurre el choque inmediatamente después de una inspiración forzada, durante el esfuerzo, debe producirse con más facilidad la lesión pulmonar. En efecto, en este momento la tensión del pulmón disminuye su elasticidad, y la oclusión de la glotis 
impide la salida del aire; de manera que el traumatismo interesa un pulmón de pared inextensible y poco compresible.

Sea lo que fuere de esta explicación y el mecanismo de la desgarradura pulmonar, es indudable que nuestro enfermo ha sufrido una contusión fuerte del pulmón y que hubo desgarradura parenquimatosa caracterizada por la solución de continuidad de algunos vasos pulmonares. Es imposible afirmar si esta rotura fue central ó cortical ; por lo común, son las porciones superficiales del pulmón las que se afectan de preferencia ; en este caso, lo que puede decirse es que, según toda probabilidad, quedó intacta la pleura.

Es fácil comprender así las fases diversas por que ha atravesado la lesión pulmonar. En la contusión de las vísceras ocurre lo mismo que en la de los tegumentos, y la marcha es análoga.

$¿ Q u e ́$ sucede cuando se recibe un golpe fuerte que interesa un músculo, por ejemplo? Primero hay desgarradura más 6 menos completa de las fibras musculares, que va acompañada de rotura vascular y de extravasaciones sanguíneas. La consecuencia inmediata de esta lesión es la impotencia funcional, la parálisis momentánea de la sensibilidad y el entumecimiento de la región, que queda como sumida en el estupor. Este último fenómeno explica por qué una herida por arma de fuego es tan poco dolorosa en el momento de producirse.

La segunda fase es mucho más dolorosa, y á la anestesia del principio sucede un dolor siempre considerable. Este fenómeno es debido á que la sangre que afluye á la región contusa despierta la vitalidad de los elementos lesionados y produce infarto y fenómenos irritativos, que son el esbozo primero del trabajo reparador. La seasibilidad llega entonces al máximum. Se producen casi á la vez trombo- 
sis vasculares, y continua el trabajo reorganizador, caracterizado por la formación de elementos nuevos : resulta una verdadera inflamación, casi siempre reparadora, pero susceptible de exceder de estos límites.

El mismo proceso se ha producido en nuestro enfermo en su pulmón lesionado. El día primero el único fenómeno de importancia fue la hemoptisis; se reprodujo á cada acceso de tos; era el período de roturas vasculares, sin irritación del tejido pulmonar.

El segundo día la hemoptisis era menor, pero había sensibilidad, dolor local espontáneo y provocado por la presión. Hallamos entonces en los signos estetoscópicos la prueba palpable de la congestión pulmonar y del raptus sanguíneo de la víspera ; se notaba macicez á la percusión, debilidad del ruido respiratorio, indicios de la impermeabilidad de los alvéolos pulmonares.

Al tercer día se hicieron los esputos exudativos ; se efectuaba un trabajo inflamatorio reparador ; la expectoración, aunque todavía herrumbrosa, estaba mezclada con mucosidades, en parte ya purulentas. El enfermo se hallaba en vías de curar de su lesión, trabajo que se producía por el mecanismo de una inflamación verdadera, de una pulmonía local. La pleura participaba también de la irritación reparadora que interesaba las regiones corticales del parénquima; las lesiones traumáticas pulmonares van acompanadas casi siempre de pleuritis desde el principio. Esta inflamación concomitante fue siempre ligera y transitoria, porque hoy, cuatro días después del accidente, ha desaparecido.

Esta cuestión de la reparación de las lesiones pulmonares, de la pulmonía traumática, como se la llama, es muy obscura. Depende, para mí, de que se han agrupado con el mismo nombre casos muy diferentes y que en nada se asemejan. 
La contusión pulmonar no es, en efecto, ni la congestión, ni la pulmonía ; es, en cierto modo, un estado intermedio de ellas. Pocas veces llega á la hepatización, lesión clásica de la pulmonía, pero en ciertos casos va más allá. No la conviene, por lo tanto, en general este nombre, y es mejor conservarla el de contusión que se aplica á todos los grados, desde el choque poco intenso, hasta la desgarradura extensa seguida de gangrena.

Nuestro caso es ligero, pero no sucede siempre así. Que un hombre sea, por ejemplo, cogido con fuerza entre dos trenes, como acontece en las estaciones de los caminos de hierro: al pronto hay pocos signos, algunas veces ni aun hay hemoptisis; los días siguientes se presenta fiebre, los síntomas de un estado adinámico, en ocasiones los de un abceso 6 una gangrena pulmonar. $¿$ Es esto la pulmonía verdadera? No. Lo mismo sucede, y con más motivo, en los casos raros en los que la contusión del tórax produce una especie de flemón difuso pulmonar, con disección de los lóbulos y de los lobulillos pulmonares y gangrena especial (como sucedió en el caso presentado por Hayem en la Sociedad Anatómica en 1874). Querer incluir en el mismo cuadro estas lesiones tan distintas, es ensanchar en demasía el campo de la pulmonía traumática y perpetuar la confusión en la historia clínica de la contusión pulmonar.

Hechas estas salvedades, comparemos la marcha de esta pulmonía traumática y la de la espontánea, que es distinta por completo.

Este paralelo lo hicieron Grisolle por vez primera y después Luton y Duplay; ha sido tema de las Tesis de Courtois (1873), Cohen (1879), y por último, de mi antiguo discípulo y amigo Proust (1884), quien le dedicó una serie de páginas notables.

Recordemos en pocas palabras la marcha y evolución 
de la pulmonía espontánea. Enfermedad de principio brusco, empieza casi siempre por un escalofrío único y fuerte; después se presenta fiebre alta, que excede desde el principio de $40^{\circ}$; el estado general es grave, $y$ el dolor de costado, que indica la lesión pulmonar, va precedido siempre de fenómenos generales.

A la auscultación se oyen primero estertores crepitantes. finos y debilidad del ruido respiratorio; pero estos signos. tardan poco en ser sustituídos por un soplo tubario. La enfermedad se propaga con rapidez á las zonas próximas. del pulmón, y á ellas se limita en los casos ordinarios. La tos es relativamente escasa y la expectoración herrumbrosa. Al séptimo ú octavo día disminuye de pronto la fiebre ; se presentan en el punto enfermo los estertores llamados de retorno y desaparecen poco á poco. La enfermedad, desde el punto de vista de la temperatura, ha evolucionado siguiendo un ciclo regular, que podría trazarse casi de antemano.

Nada de esto ocurre en la pulmonía traumática. Los fenómenos del principio son los del traumatismo; el dolor de costado es debido al choque y se mitiga según va trasncurriendo tiempo. La hemoptisis, si se produce, es el fenómeno inicial y tiene caracteres particulares distintos por completo de los que se observan en la pulmonía espontánea ; en vez de los esputos sanguinolentos, no rutilantes, combinados de una manera íntima con el exudado inflamatorio, que todos conocéis, la sangre de la expectoración en la pulmonía traumática es natural ; su abundancia varía bastante y no se hacen herrumbrosos hasta treinta y seis 6 cuarenta y ocho horas después del accidente, cuando se presentan los fenómenos de reparación y de inflamación secundarias.

En los casos graves seguidos al fin de gangrena, falta casi siempre la hemoptisis. El escalofrío inicial, que marca 
el principio de la pulmonía espontánea, no se observa en la traumática.

Los fenómenos de auscultación son también muy distintos. La contusión pulmonar se manifiesta casi siempre por los signos físicos congestivos complicados más ó menos con bronquitis y pleuresía, y esto desde el principio. Es decir, que el murmullo vesicular, débil al pronto, se mezcla después con estertores sibilantes y mucosos ; se observan desde los primeros días roces pleuríticos que van acompañados algunas veces de algo de egofonía y de soplo velado. Cuando existen á la vez signos de hepatización verdadera, el soplo está muy limitado ; no manifiesta tendencia á invadir las partes inmediatas, y la lesión se separa con rapidez, de modo que este soplo es á la vez poco extenso y poco durable. En los casos graves se ven presentarse con rapidez signos cavernosos y gorgoteo, que coinciden casi siempre con la gangrena pulmonar.

La temperatura suministra también elementos para el diagnóstico diferencial. Es raro que después de una contusión del pecho marque el termómetro un grado elevado; algunas veces hasta es inferior á la cifra normal. Es raro que exceda de $38^{\circ} 6$ de $38^{\circ}, 5$ y casi se mantiene con oscilaciones variables, bastante extensas en muchos casos. La defervescencia se hace de un modo gradual, por descenso sucesivo y lento. La marcha de las lesiones, en uno y otro caso, varía bastante, porque mientras que la pulmonía espontánea se extiende á la manera de una mancha de aceite, la traumática queda de ordinario localizada y su marcha no es invasora en modo alguno, cuando la contusión no es excesiva.

Resulta de lo que acabo de decir, que el pronóstico de la contusión pulmonar varía según la intensidad, la extensión, la localización del choque traumático. Puede decirse en general, que la contusión de intensidad mediana, 
tal como la que acabo de describir, es de ordinario benigna, y habéis visto con qué rapidez tendían á retroceder en nuestro enfermo los fenómenos de fluxión congestiva y de hepatización pulmonar circunscrita.

Pero para hacer un pronóstico racional, con conocimiento de causa, es necesario dirigirse á lo que podría llamarse el elemento personal del enfermo, y averiguar cuál es el terreno patológico en que va á evolucionar el traumatismo. No ignoraráis la importancia grandísima que ha tomado la parte médica de la cirugía, desde los trabajos notabilísimos del profesor Verneuil, sobre la influencia recíproca de los traumatismos y de las diátesis. Sabéis que gracias á los estudios perseverantes de este maestro eminente, conocemos hoy que el terreno patológico desempeña un papel importantísimo en los fenómenos de reparación de las heridas y que no es indiferente que un herido padezca escrofulosis, gota, diabetes ó albuminuria.

Dicho lo que antecede, debemos averiguar por qué con una contusión torácica, relativamente ligera, tuvo nuestro enfermo una hemoptisis abundante, cuando muchas veces golpes fuertes sobre el pecho no producen hemorragia apreciable.

Los antecedentes de familia de este hombre no resuelven el problema, porque no descubrimos predisposición diatésica alguna; sus padres viven y tienen noventa y dos y ochenta años. Ha tenido seis hermanos ; de ellos murieron tres de cólera y uno muy joven ; una hermana murió á consecuencia de una enfermedad crónica sospechosa ; la hermana que vive es robusta.

Sus antecedentes personales son algo sospechosos. Dice que jamás ha estado enfermo; pero hace cuatro años, por coincidencia singular, recibió en el pecho un golpe con la lanza de un carruaje. A los tres días tuvo un fuerte dolor de costado, y después una pleuresía que le obligó á per- 
manecer seis meses en el Hospital de la Piedad, é hizo necesarias tres punciones. Curó con cierta retracción del tórax y disminución del murmullo vesicular. Así, pues, es preciso desconfiar de las pleuresías, aunque hayan transcurrido tres años desde la desaparición del derrame.

$\mathrm{El}$ aspecto del enfermo tampoco es muy floreciente : es alto, flaco, barbudo y presenta el hábito exterior tan común en los tísicos.

Los anamnésticos indican un pronóstico favorable; pero la localización de los signos físicos es sospechosa. El enfermo recibió el golpe en la región esternal, y sin embargo, el máximum de los síntomas morbosos existe en la parte superior del pecho, en las fosas subclavicular y supra-espinosa. En este sitio resuena la tos de un modo alarmante, hay signos de induración y pueden interpretarse como crugidos sospechosos algunos de los estertores que se oyen en esta zona.

Pero existe un signo positivo que tiene, por sí solo, un valor patognomónico, y que por desgracia resuelve todas las dudas. Los esputos de este hombre contienen copitos purulentos, en los que ha comprobado mi interno, el señor Leflaive, los bacilos especiales de la tuberculosis pulmonar. En otra época se hubiera diagnosticado la enfermedad de phtisis ab homoptoe. ¡Cuántas veces no se ha hecho en clínica el razonamiento de Morton, atribuyendo á la hemoptisis lo que era debido á la enfermedad latente!

En este caso, la exactitud de las condiciones etiológicas no permite la menor duda. Este hombre estaba ya enfermo, aunque nada indicaba el peligro de que se hallaba amenazado. ¿Quién se hubiera atrevido á afirmar antes del accidente que no era perfecta su salud? Sobrevino una circunstancia fortuíta, que reveló la extensión de un mal en el que nadie podía creer. La contusión ligera, que en una persona sana hubiera producido algunos esputos sangui- 
nolentos, encontró un pulmón invadido ya por granulaciones tuberculosas y vasos más friables que de ordinario. A esto fue debida la abundancia de la hemorragia, su persistencia y la rapidez de la congestión pulmonar.

Pero es necario resolver otro problema. Este hombre sufrió hace cuatro años el primer traumatismo torácico; hay motivos para preguntar si la contusión pulmonar, seguida después de pleuresía, sería el origen primero de la tuberculosis. Aunque esto sea una pura hipótesis imposible de demostrar, me inclino á admitir, si no la probabilidad, al menos la posibilidad de esta influencia etiológica. En dicha época este individuo se encontraba sano, y es verosímil que la pleuresía no fuera tuberculosa al principio; pero por su larga duración ha podido disminuir la resistencia del enfermo, lo que constituye una predisposición á la tuberculosis, porque todo el mundo absorbe, en más 6 menos cantidad, el bacilo tisiógeno y, por fortuna, son muy pocos los que se hacen tísicos. Para explicar la infección tuberculosa se necesita casi siempre la debilidad orgánica previa : han podido provocarla esta larga pleuresía ó la estancia de varios meses en una sala de hospital. Desde este punto de vista, el traumatismo ha sido quizá en este enfermo el factor lejano de la tuberculosis : se han publicado, en efecto, algunos casos en los que el principio de la tisis coincidió con un traumatismo torácico.

¿Cuál será el pronóstico y la marcha de la enfermedad en este caso?

La contusión pulmonar curará pronto ; casi está corregida ya. ¿Pero qué sucederá con la tuberculosis?

¿Seguirá latente ó acelerará su marcha la congestion pulmonar producida por el traumatismo? ¿O seguirá su evolución lenta, pero segura, hacia la ulceración pulmonar?

Aunque sea imposible predecir nada, es de esperar que se realizará la primer solución, la más favorable. Exis- 
ten varias razones para justificar esta esperanza. Ante todo, no hay fiebre, aunque llevamos más de cuatro días de enfermedad. Las hemoptisis complicadas con congestión pulmonar, y que están destinadas á agravarse, van acompañadas siempre de un movimiento febril, que suele principiar á las cuarenta y ocho horas y persiste los días siguientes. El profesor Jaccoud ha demostrado con toda claridad lo grave de estas hemoptisis febriles, que indican la marcha invasora de la flegmasía pulmonar. En este caso, la congestión del principio se halla en retracción, y el termómetro ha marcado siempre la cifra normal. Lo mismo ha sucedido con los síntomas pleuríticos, los que se presentaron á los dos días y desaparecieron después. La res. piración entrecortada que persiste aún, y que se ha considerado durante mucho tiempo como un signo de tuberculosis, sabemos que no tiene el valor que la atribuía Fournet, y que se observa muchas veces sin que exista lesión pulmonar alguna, por poco que se afecten los latidos del corazón y las inspiraciones profundas.

Es de mal agüero, desde el punto de vista del pronóstico, observar en los esputos los bacilos tuberculosos; pero no debe afirmarse que el enfermo esté amenazado necesariamente de una tisis inminente. El bacilo tuberculoso, cuando ocupa un foco limitado del pulmón, puede quedar estacionario durante meses y años, sin progresar, y enquistarse, por último, en una especie de cascarón fibroso, donde se hace poco á poco casi inofensivo. Digo casi inofensivo, porque cualquier circunstancia es capaz de despertar la vitalidad de los gérmenes infecciosos adormeci. dos y favorecer su desarrollo rápido : en la mayoría de los individuos que mueren de accidentes de tuberculosis miliar, después de haber pasado la cuarentena, se encuentra casi siempre un foco caseoso antiguo como lesión inicial. 
Habéis visto la prueba hace algunos días en el enfermo que padeció pleuresía caseosa á los dieciocho años, y murió de granulia á los cuarenta y cinco. Las lesiones tuberculosas del pulmón, del hígado, de los riñones, eran recientes; sólo hallamos en la base de la pleura un foco enquistado caseoso, que se remontaba con toda seguridad á la pleuresía padecida veintisiete años antes.

Es siempre grave para el pronóstico del porvenir tener un foco tuberculoso, por pequeño que sea; pero no hay prueba de que deba generalizarse forzosamente, ni sobre todo en un fecha próxima.

Dos palabras antes de terminar esta Conferencia, sobre el tratamiento que creo debemos emplear en nuestro enfermo.

La primera indicación es contener la hemoptisis y calmar la tos consecutiva á la congestión pulmonar, pero cuya frecuencia aumenta los fenómenos fluxionarios.

Esta indicación se ha llenado con el opio, á la dosis de 10 centígramos, asociado á 4 gramos de ergotina. Se han aplicado con el mismo objeto revulsivos en la región del pulmón congestionado. Bastaron para aliviar al enfermo cataplasmas sinapizadas y ventosas secas: si la inflamación hubiera sido más intensa, hubiésemos recurrido á la ventosa escarificada ó al vejigatorio.

Hoy, que los fenómenos congestivos han desaparecido casi por completo, creo que ha llegado el momento de modificar el estado general, con el fin de contener, si es posible, la evolución de la tuberculosis. He prescrito con este objeto el arsénico, como medicamento de economía y el aceite de hígado de bacalao, cuyos efectos reconstituyentes son bien conocidos. 
NOTA ADICIONAL

Como suponía, las consecuencias de esta hemoptisis primera fueron benignas. El enfermo salió con alta á las tres semanas curado, al parecer, por completo, y no volví á verle más.

Dieciocho meses después, ingresó otra vez en mi clínica á causa de una nueva hemoptisis que sobrevino espontáneamente, sin el concurso de causa traumática alguna. Su estado general seguía siendo bueno, pero desde tres semanas antes se fatigaba y tosía. Hasta entonces se había encontrado bien y no perdió de trabajar un solo día desde que salió del hospital.

Al auscultar descubrí respiración áspera en el vértice derecho y espiración prolongada. Había en este sitio macicez apreciable y aumento de las vibraciones torácicas. Durante las inspiraciones profundas se oían crujidos secos, algunos de los cuales tendían á hacerse mucosos, que descendían hasta la fosa sub-escapular. La tuberculosis había hecho progresos lentos, pero innegables, porque ocupaba el cuarto superior del pulmón. Eran signos de esclerosis y de induración más bien que de reblandecimiento, y como el enfermo seguía apirético podía esperarse aún contener los progresos del mal.

En efecto, á las tres semanas de tratamiento se obtuvo una gran mejoría. Pero las hemoptisis se reprodujeron durante diez días consecutivos. El tratamiento consistió en revulsivos locales, en preparaciones de ergotina asociadas al opio, á grandes dosis ; cuando cesó la hemoptisis se aplicó un cauterio en la fosa supra-espinosa. Al abandonar el enfermo el hospital á fines de Agosto, habían desaparecido de nuevo los estertores, pero persistían en el vértice derecho signos inequívocos de induración pulmonar. 
Este enfermo es un ejemplo interesante de esas tisis, de forma congestiva, que progresan por brotes sucesivos muy lejanos á veces unos de otros y en cuyos intervalos es perfecta la salud. Esta variedad de tuberculosis es la más favorable de todas, permite esperar la curación definitiva, á condición de que se observe una rigurosa higiene y se eviten las causas ocasionales que favorecen la hiperemia pulmonar. Por desgracia, las condiciones sociales de nuestro enfermo no le permiten estos cuidados contínuos, y es de temer que se reproducirá la tuberculosis y seguirá una marcha contínua. 


\title{
PLEURESTA PURULENTA
}

\author{
CONSECUTIVA Á LA BRONCO-PNEUMONÍA
}

Sumario: Bronco-pneumonía infecciosa en un viejo alcohólico. - Persistencia después de la defervescencia de lesiones locales de interpretación dificil.-Diagnóstico diferencial de la atelectasia pulmonar, de la espleno-pneumonía y de la pleuresía.-La pleuresía purulenta consecutiva á la pulmonía sigue siempre una marcha insidiosa y produce pocas veces sintomas febriles.-Puede quedar latente hasta la autopsia, ó manifestarse por una vómica.-Pronóstico y tratamiento.

Hace un mes ingresó en mi Clínica un viejo de sesenta y siete años, con pulmonía grave, cuya marcha y evolución presentó varias particularidades raras. Voy á recordarlas en pocas palabras.

El síntoma predominante, al ingresar en el hospital, era un estado tifoideo de los más acentuados. La lengua no estaba seca, pero sí sucia, saburrosa y pegajosa; el enfermo se encontraba abatido, indiferente á todo lo que le rodeaba, soñoliento y casi comatoso ; por la noche deliraba y pronunciaba palabras incoherentes. Tenía las conjuntivas amarillas, sub-ictéricas, la orina era escasa, de color encendido y muy albuminosa. Todo indicaba una enfermedad infecciosa grave, cuyos síntomas principales interesaban el aparato respiratorio. Había, en efecto, disnea, respiración frecuente y anhelosa, y se oían en todo el pecho estertores perceptibles á distancia. La expectoración, abun. dantísima, consistía en esputos muco-purulentos viscosos mezclados con mucosidades sanguinolentas, análogas á los esputos herrumbrosos de la pulmonía franca. Pero la temperatura era relativamente poco elevada y no excedía de $39^{\circ}$, á pesar de la gravedad del estado general.

Se trataba, indudablemente, de una bronco-pneumonía 
infecciosa, pero nada más sabíamos. Las personas que llevaron á este hombre á la consulta, nos dijeron que había caído enfermo ocho días antes, pero sin poder indicar cómo empezó el mal. Según los pocos datos que nos dió el mismo enfermo, la afección se desarrolló de una manera insidiosa, sin escalofrío inicial ni dolor de costado; fue al principio un simple catarro, que revistió de repente caracteres graves. Supimos también que este individuo era alcohólico, porque su delirio se reducía exclusivamente á la bebida y pedía sin cesar vino. A esto se limitaban nuestros conocimientos.

La exploración física del tórax, al confirmar la existencia de una bronco-pneumonía, nada de nuevo enseñaba. Notamos obscuridad á la percusión en ambas bases del pecho, sin macicez absoluta en parte alguna. Se oían en los dos lados estertores mucosos y sibilantes, que indicaban un catarro bronquial generalizado, y además, en la axila derecha, soplo velado profundo más fuerte durante la inspiración. Era indudable que existía en este punto un núcleo de hepatización central.

Estos signos físicos concordaban por completo con el relato del enfermo, porque la pulmonía apenas se había desarrollado, aunque nos hallábamos en el octavo día de la enfermedad, y las lesiones del catarro bronquial habían precedido, indudablemente, á la invasión del parénquima pulmonar. Se trataba, por lo tanto, de una bronco-pneumonía y no de una pulmonía franca. El pronóstico parecía a priori gravísimo, porque los fenómenos infecciosos predominaban sobre los síntomas inflamatorios, propiamente dichos, y la albuminuria era considerable. La edad del enfermo, sus antecedentes alcohólicos, disminuían las probabilidades de curación.

A pesar de este conjunto de circunstancias desfavorables, la marcha de la afección engañó nuestras prediccio- 
nes, porque después de una serie de vicisitudes entró al fin el enfermo en convalecencia.

Durante cuatro días progresó la lesión local, y la hepatización, circunscrita al principióá la zona axilar, invadió el pulmón derecho hasta la base. Pero por una singular anomalía, á la vez que se extendían los límites de la pulmonía, descendía la temperatura y la fiebre disminuía con lentitud y sin el carácter de defervescencia brusca, que se observa de ordinario en las pulmonías francas. El estado general siguió siendo malo y la postración extremada. No era esto ni mucho menos la convalecencia, y sin embargo, el termómetro tendía á retroceder á la temperatura normal.

El 7 de Diciembre, á los trece días de enfermedad, apareció una erupción de herpes labial; la mejoría fue franca desde este momento, los estertores se hicieron menos abundantes y la respiración más libre; persistía, sin embargo, todavía el soplo en todo el lado derecho del tórax, pero había dejado de ser tubario y se hizo de timbre agudo y más suave. El estado general mejoró, desapareció el delirio, disminuyó la opresión, perdió la expectoración su carácter sanguinolento y la orina aumentó en cantidad y se hizo menos albuminosa. Los únicos síntomas que persistían eran el insomnio y la inapetencia absoluta, que mantenían una debilidad extremada.

Ocho días después podía considerarse convaleciente al enfermo. Habían vuelto el sueño y el apetito; pero el estado local del pecho era poco satisfactorio y consistía en signos locales difíciles de interpretar.

A los veintiún días del origen presunto de la enfermedad, observamos lo siguiente :

No se notaba á la inspección combadura torácica ni edema tegumentario : la pared del tórax se hallaba adelgazada y bastante retraída. En toda la región correspondiente al sitio de la pulmonia habían disminuído las vi- 
braciones y eran casi nulas en la base : sólo reaparecían desde el ángulo de la escápula. En la zona inferior la macicez era completa y la auscultación silenciosa : por encima había sustituído á la respiración un soplo profundo, tubario y casi anfórico desde la fosa sub-espinosa.

Las modificaciones vocales suministraban datos que confirmaban los de la auscultación. En las regiones infraescapular é infra-espinosa se oía un eco tubo-anfórico: debajo disminuía la intensidad de la voz y tomaba el carácter de una broncofonía lejana, sin egofonía verdadera. La intensidad de las vibraciones vocales disminuía hacia la base del pulmón.

Por delante la respiración era normal, más bien exagerada en tono y en amplitud : el sonido de la percusión era timpánico en la zona infra-clavicular.

El estado general, á pesar de estos signos persistentes de una lesión torácica, era bastante bueno : el termómetro marcaba $37^{\circ}$, la tos se había hecho escasa, la expectoración muco-purulenta, y la anorexia había desaparecido en parte.

Era indudable que la pulmonía de los días anteriores había entrado en resolución, pero no era tan fácil decir qué estado del pulmón sucedería á esta crisis. Se presentaban á la imaginación varias hipótesis, todas igualmente defendibles.

La idea más simple y racional era suponer una resolución lenta de la pulmonía y un infarto pérsistente del parénquima pulmonar. Es lo que sucede casi siempre en los viejos, sobre todo cuando han padecido bronco-pneumonía. Así como después de la erisipela los tegumentos quedan durante mucho tiempo hinchados é hiperémicos, y se renueva varias veces la descamación, indicio de un trabajo irritativo persistente de la epidermis, de igual manera el pulmón tarda bastante en recobrar su permeabilidad pri- 
mitiva. Queda lleno de exudados, que representa la descamación alveolar, y distendido por la sangre que se estanca en los capilares paralizados. Grisolle, que en todos los asuntos de doctrina clínica era de una exactitud tan escrupulosa, fijó en tres semanas, por término medio, el tiempo que tarda este órgano en volver á su estado normal, y hasta dijo que en ciertos casos dura este trabajo de resolución dos meses y más. La duración de este trabajo reparador pulmonar es muy variable : es mucho más largo cuando se trata de una persona de edad cuyos pulmones han sufrido de antemano alteraciones de senectud, sobre todo suprema. En estos casos los signos físicos se asemejan de un modo notable á los que observamos en nuestro enfermo. El murmullo vesicular está debilitado en todos los puntos del parénquima pulmonar, distantes de los bronquios; es áspero, por el contrario, en el hilio bronquial; algunas veces se nota un soplo lejano más ó menos intenso, que va acompañado de alteración de la voz.

Para completar la analogía, casi nunca falta el timpanismo sub-clavicular. La identidad es, por lo tanto, casi completa ; pero la evolución de la lesión ha sido diferente en el caso actual. Cuando se trata de una resolución lenta de la pulmonía, todos los signos que acabo de enumerar están localizados estrictamente en el punto donde radica la hepatización. En nuestro enfermo, la pulmonía invadió la fosa supra-espinosa, llegó al máximum en el ángulo de la escápula y se extendió relativamente poco hacia la base. Ahora bien, los signos imputables al infarto pulmonar eran mucho más típicos en los puntos declives que en el sitio inicial de la pulmonía, al contrario de lo que debía suceder. Sería preciso, por lo tanto, admitir que hubo una nueva lesión ó que la primitiva se propagó más allá de su origen.

Grancher ha descrito recientemente, con el nombre de 
espleno-pneumonía, un estado especial del pulmón, que participa á la vez de la congestión, de la inflamación y del edema. El término es nuevo, pero la lesión es antigua; los clínicos de principio del siglo la llamaban pulmonía congestiva, y Rommlaere (de Bruselas) la estudió con el nombre de atelectasia. Desde el punto de vista estetoseópico, la espleno-pneumonía se asemeja y se confunde con el cuadro clínico que presenta nuestro enfermo. La misma marcha, igual asociación de síntomas ; un principio más 6 menos insidioso de pulmonía, después una especie de detención en el proceso febril, durante el cual se observan los signos de un derrame de la pleura, macicez, supresión ó disminución de las vibraciones torácicas, soplo suave, skodismo subclavicular. El mérito de Grancher es precisamente el haber demostrado que la espleno-pneumonía reviste á menudo el aspecto clínico de una pleuresía tipo, y que no hay más signo diferencial entre estas dos afecciones que la conservación del espacio de Traube; pero este signo sólo es aplicable cuando la lesión recae en el lado izquierdo, lo que no sucedía en nuestro enfermo. El descenso del hígado, que se indica como carácter diferencial, sólo es de valor muy relativo, porque el obstáculo circulatorio producido por la lesión pulmonar origina éxtasis en las cavidades cardíacas derechas y congestión hepática, lo mismo que si se tratara de un verdadero infarto de la pleura.

Era lógico suponer que nuestro enfermo padeciera una lesión de este género, tanto más cuanto que la evolución de la espleno-pneumonía, según Bourdel, es siempre lenta. Se obtiene casi siempre la curación, pero después de varios meses, y, en ocasiones, á pesar de presentarse fenómenos de opresión acentuados.

Queda otra tercer hipótesis, defendible también; la de un derrame de la pleura. 
El médico que asiste una pulmonía debe contar siempre con la pleuresía, porque no hay un caso de hepatización pulmonar que no repercuta más ó menos en la pleura.

Estas pleuresías secundarias no revisten siempre los mismos caracteres clínicos.

Muchas veces son fáciles de diagnosticar y se manifiestan por un conjunto de síntomas característicos. A la declinación de la pulmonía, de ordinario, después de la defervescencia, se ve reaparecer el dolor de costado y aumentar sin causa apreciable. $\mathrm{Al}$ auscultar se oyen casi siempre roces pleuríticos, y si se abandona á sí misma la enfermedad, no es raro ver que se forma algo de líquido, á juzgar por la extensión de la macicez, la disminución del ruido vesicular y la alteración egofónica de la voz. Estos signos duran algunos días; después desaparecen espontáneamente á la vez que se hace permeable el pulmón. Tal es la pleuresía serosa que acompaña de ordinario á la pulmonía franca ; es casi siempre benigna, y no induce al error.

Los derrames pleuríticos post-pneumónicos no son siempre tan típicos como los síntomas. Falta muchas veces el dolor de costado; no hay egofonía, y el único signo estetoscópico es la falta de vibraciones y de murmullo vesicular.

¿Podemos suponer una complicación de este género en nuestro enfermo? Algunos síntomas eran favorables á esta idea, pero otros muchos eran contradictorios. La macicez, la falta de vibraciones torácicas indicaban un derrame, pero la falta de todo fenómeno doloroso, del dolor de costado, la naturaleza del soplo, que conservaba el carácter tubario en la región escapular, el de la voz que no era egofónica, sino broncofónica, parecían indicar más bien la atelectasia pulmonar. El descenso del hígado, ligero por lo demás, lo explicaba el enfisema del pulmón derecho ; 
por último, signo que explica, al parecer, en absoluto, la. idea de un derrame, la pared torácica, en vez de estarcombada, estaba retraída.

Si había pleuresía, no era una pleuresía ordinaria, porque faltaban todos los signos ó poco menos. ¿Había motivos para sospechar una pleuresía purulenta? Desde el punto de vista de los signos estetoscópicos, era posible esta hipótesis, porque los derrames purulentos de la pleura, excepto la macicez y la falta de vibraciones, no producen soplo ni egofonía. Por consiguiente, faltaban los caracteres clásicos de la existencia del pus; la pared torácica no estaba edematosa ni dolorida; no había combadura; la. temperatura local del pecho era la de costumbre; tampoco se notaba pectoriloquia afona, signo importantísimo, cuyo valor han demostrado Baccelli y Guéneau, de Mussy.

Por último, lo que acababa de desechar la idea de una pleuresía purulenta era el buen estado general del enfermo. La fiebre había descendido por completo, el termómetro marcaba desde más de ocho días antes $37^{\circ}$; el enfermo no tenía escalofríos ni sudores nocturnos, y comía con buen apetito; en una palabra, no se observaba síntoma alguno de los que anuncian de ordinario las supuraciones profundas, y nada hacía suponer una lesión tan grave como el derrame purulento de la cavidad de la pleura.

Precisamente, según hemos visto, esta hipótesis tan poco. verosímil, era la verdadera. Instruído por la experiencia de casos análogos, hice el 22 de Diciembre una punción exploradora con la aguja de Pravaz, creyendo, lo confieso, penetrar en un pulmón sólido, pero pensando que si había líquido sería purulento. Es lo que sucedió : salieron algunas gotas de serosidad turbia, purulenta; estaba hecho el diagnóstico é indicado el tratamiento. Practiqué al día siguiente la toracentesis y extraje 800 gramos de pus 
y espero los acontecimientos, decidido á practicar el empiema si, como es probable, se reproduce el derrame.

He insistido en las dificultades del diagnóstico, porque este caso es un buen ejemplo de la marcha insidiosa de esas pleuresías secundarias á la pulmonía, que no tienen, por decirlo así, sintomatología individual. El principio es siempre obscuro ; no es posible decir si son contemporáneas de la hepatización ó consecutivas á la defervescencia pneumónica; se presentan siempre al final de los fenómenos inflamatorios y cuando el enfermo se encuentra, al parecer, convaleciente. Jamás se manifiestan por dolor de costado, excepto en los casos de pulmonía cortical séptica desde el principio y de naturaleza gangrenosa, como la padecida por el profesor Dolbeau; en este caso el dolor torácico es atroz y dura mucho más que el dolor de costado de la pulmonía franca. Pero en circunstancias ordinarias la pleuresía purulenta post-pneumónica se desarrolla en silencio, y nada hay que permita preverla. Se presenta en una época en la que los enfermos están aún abatidos, inapetentes, postrados muchas veces y con aspecto tifoideo; la fiebre ha descendido y el termómetro marca la defervescencia. La pulmonía basta para explicar el estado general, y se sospecha tanto menos un derrame purulento, cuanto que, vuelvo á repetirlo, la temperatura es casi normal. Debe desecharse la idea de que todo derrame purulento es flogógeno y precedido de hipertermia, como se enseña todavía en las obras clásicas. Hace más de doce años que mi colega Sevestre refirió en la Sociedad Anatómica los primeros casos de pleuresía supurada que evolucionaron sin síntoma febril alguno, y sus observaciones han sido confirmadas después por todos los clínicos. Las supuraciones viscerales no van acompañadas necesariamente de fiebre héctica ; las de la pleura, sobre todo, son compatibles con una temperatura fisiológica. 
Los signos físicos permiten mejor que los síntomas generales sospechar, no digo afirmar, en tales casos el-derrame pleurítico. Cuando supura la pleura, no sólo persiste la macicez pneumónica, sino que tiende á propagarse. En vez de vibraciones torácicas, disminuídas muchas veces, pero perceptibles aún, se ve borrarse toda percepción vibratoria: el soplo de la hepatización se suprime también en las partes declives, pero persiste en la proximidad del hilio del pulmón y adquiere el carácter tuboanfórico. Este soplo pseudo-anfórico sin estertores es un signo importante, porque indica casi siempre un estado de condensación pulmonar por encima del derrame. A veces, pero no siempre, se observa al mismo tiempo dislocación del corazón ó descenso del hígado; entonces es seguro el derrame, pero no debe esperarse tanto tiempo para hacer el diagnóstico, porque entonces son considerables los trastornos y el pulmón se halla rechazado debajo de un caparazón inextensible.

Por lo común, estas pleuresías purulentas tienden más á enquistarse que á extenderse, lo que aumenta las dificultades del diagnóstico. Habéis visto que en nuestro enfermo, en vez de producir la combadura torácica, ocasionó una depresión parietal, signo que contribuyó más que ninguno á poner en duda el derrame. Es un fenómeno frecuente y que debe conocerse.

En ciertos casos los signos son nulos por completo y están enmascarados por el estado del pulmón : el derrame purulento enquistado es entonces un hallazgo de autopsia. En Junio último ingresó en mi Clínica una mujer de cincuenta y siete años, con bronco-pneumonía y cuyo tórax estaba deformado á causa de una antigua escoliosis. Cuatro días antes había tenido dolor de costado y hemoptisis : se le descubrieron en la parte posterior del pecho estertores crepitantes finos, sin soplo y los signos de bronquitis di- 
fusa ; el caso se asemejaba más bien á una congestión pulmonar que á una pulmonía franca. Mejoró con las ventosas escarificadas y la ipecacuana, no tenía fiebre y se levantaba, cuando después de una sedación de todos los accidentes durante ocho días, que podía considerarse como una convalecencia, tuvo la enferma una tarde un acceso grandísimo de opresión, con amenaza de asfixia : fue preciso practicar una sangría de urgencia. Al día siguiente parecía curada la disnea, había desaparecido y sólo se notaba estertor sibilante bronquial, sin localización fija.

Esta mujer murió de repente á las veinticuatro horas; al hacer la autopsia se encontró pleuresía purulenta enquistada entre el diafragma y el pulmón, consecutiva á un foco de pulmonía cortical gangrenosa. Fenómeno notable; ni la expectoración ni el aliento habían sido fétidos.

Otras veces una vómica repentina revela á la vez la existencia de un derrame y su carácter purulento.

Hace algunos años narré la historia de una pleuresía inter-lobular supurada que sobrevino durante una fiebre tifoidea, después de una complicación de bronco-pneumonía y que curó á beneficio del empiemia. He observado hace poco tiempo otro caso análogo. Ingresó en mi Clínica un individuo con signos de bronquitis generalizada y de bronco-pneumonía, cuyos síntomas generales eran bastante graves para hacer sospechar la tuberculosis miliar difusa, cuando una mañana expectoró una vómica purulenta. Se oyó entonces por vez primera soplo profundo debajo de la línea axilar en una zona donde la respiración obscura estaba enmascarada por estertores. Una punción exploradora practicada en este sitio demostró la existencia del pus y acto contínuo se practicó el empiema. El enfermo curó.

La evolución de las pleuresías supuradas post-pneumónicas es muy variable. Acabo de citaros casos en los que 
la formación del pus fue relativamente rápida : es lo que sucede casi siempre; quince días, tres semanas cuando más, después de la invasión de la pulmonía, se ha formado ya el derrame. A veces, sin embargo, los accidentes son más tardíos, y entonces son casi insuperables las dificultades del diagnóstico. Hace dos años tuve en mi Clínica un individuo que, seis semanas antes, después de una afección pulmonar aguda, sobre la que no obtuve datos, padeció una pleuresía. El Dr. Dujardin-Beaumetz, en cuya clínica del hospital Cochin se encontraba el enfermo, le había hecho una punción, y los signos estetoscópicos no indicaban la existencia de líquido alguno cuando ingresó en mi sala. Pensé en la esclerosis pulmonar, después en la tuberculosis : este individuo no tosía, pero se ponía caquéctico, comía mal y tenía edema de las piernas. A la primera punción, practicada en el centro de la zona de macicez, salió sólo sangre, lo que confirmó mi diagnóstico. Pero el enfermo se agravaba y la pared torácica estaba dolorida y algo edematosa. Seis semanas después repetía la punción y entonces salieron unas cuantas gotas de pus. Pero cuando practiqué el empiema al día siguiente, encontré una zona pulmonar esclerosada, y no me atreví á penetrar á más profundidad después de haber ensayado en vano desprender la pleura adherida por todas partes. Este hombre murió á los quince días á causa de la caquexia progresiva, y al hacer la autopsia descubrí que el derrame purulento de la pleura estaba enquistado por detrás, cerca de la canal vertebral, cubierto en los lados por la lámina pulmonar que encontré y que franqueó la aguja exploradora. En tres meses la pleuresía no había adquirido un volumen superior al de una naranja, y sólo se manifestó la existencia del pus por la anorexia persistente y la debilidad cada vez mayor.

¿Por qué la pulmonía produjo en nuestro enfermo la 
supuración de la pleura? Es una cuestión compleja y mal conocida todavía, aunque los estudios bacteriológicos modernos han contribuído á resolverla.

Podría preguntarse si la edad influiría sobre el carácter grave de la pulmonía y sus consecuencias. La clínica responde en sentido negativo. La mayor parte de las pulmonías de los viejos son, en efecto, francas, y sólo en casos raros producen complicaciones pleuríticas. Charcot y Dechambre lo han demostrado con toda claridad.

$\mathrm{El}$ alcoholismo es cuando más una causa de agravación de la pulmonía : debe atribuírsele el delirio de las primeras fases de la enfermedad, pero sería ir más allá de la verdad concederle influencia alguna sobre el proceso supurado de la pleura. El alcohol obra sólo como circunstancia debilitante.

La verdadera condición patógena del empiema es la naturaleza misma de la pulmonía, eminentemente infecciosa, y la propagación directa del agente infeccioso á la pleura. Todas las pulmonías son enfermedades microbianas ; pero no todas tienen, al parecer, las mismas propiedades virulentas. Las pulmonías grippales, que reinan epidémicamente é invaden á la vez los bronquios y el parénquima pulmonar, son nocivas en alto grado y favorecen el desarrollo de los microbios piógenos, aunque no son debidas á agentes capaces de provocar por sí solos la supuración.

Esta idea no es infundada. He hecho en dos ocasiones el examen bacteriológico del pus recogido antes del empiema, en condiciones perfectas de asepsia. Una vez se trataba de pleuresía post-pneumónica y encontré en el líquido purulento de la pleura el pneumococo. El otro enfermo era un tífico, y descubrí en el pus el microbio de Eberth. Mi colega Netter ha hecho, con su reconocida competencia, muchos exámenes de este género. $\mathrm{Ha}$ demostrado que en una cavidad, cerrada al abrigo del contacto del aire, pe- 
netran los micro-organismos patógenos, bien por inflamación de contigiiidad ó por infección sanguínea general. En el caso actual, se hizo el examen de este género ; pero fue negativo, excepto algunos diplococos raros, que según toda probabilidad, carecían de carácter patógeno, no se descubrió en el pus el pneumococo. Nada de sorprendente tiene este resultado, porque casi nunca se encuentra el bacilo de Koch en la serosidad de las pleuresías tuberculosas, aunque cuando se inyecta ésta en el peritoneo de los conejillos de Indias produce la peritonitis tuberculosa. Es indudable, por lo tanto, que en nuestro enfermo la supuración pleurítica fue debida á la propagación directa del agente infeccioso de la pulmonía, de cualquier especie que fuese.

El pronóstico de una pleuresía purulenta de este género en un hombre de sesenta y siete años, gastado por el alcoholismo, es indudablemente grave ; pero desde que se conoce mejor la historia de las pleuresías consecutivas á las pulmonías, han perdido algo de su gravedad. En efecto, es necesario tener en cuenta que este enfermo no tiene fiebre, y que ha recobrado el apetito, dos síntomas favorabilísimos ; el corazón está sano y funciona de buena manera : la orina no es albuminosa, lo que prueba que se ha eliminado la mayor parte del veneno morboso, y que los riñones están sanos.

Es un hecho de observación que las pleuresías purulentas secundarias á la pulmonía, son las que curan más á menudo y con mayor facilidad. He observado una docena de casos de este género, y me ha sorprendido siempre la sencillez y regularidad de su evolución. Como el pulmón hiperémico aún no se deja deprimir, no se aplasta después de evacuado el pus y hay mucha más tendencia á la cicatrización por existir siempre adherencias de la pleura. Sucede con la pleuresía en estas condiciones lo que con 
un verdadero abceso que cura en unas cuantas semanas.

Las indicaciones del tratamiento son claras. En cuanto se averigua la existencia del pus en la cavidad de la pleu$\mathrm{ra}$, es preciso evacuarlo, y estoy convencido de que es necesario practicar, sin perder tiempo, la operación del empiema. No lo he hecho en el caso actual porque la pleuresía purulenta de los pneumónicos suele curar después de una sola punción, y porque como el estado general era bueno, no creí urgente recurrir á medios radicales. $\mathrm{He}$ querido que el enfermo corriera la eventualidad de curar sin operación cruenta; pero tengo poca confianza de que suceda así, y estoy persuadido de que se reproducirá el líquido y entonces no dudaré en emplear el único tratamiento eficaz en tales casos, la abertura de la cavidad de la pleura.

\section{NOTA ADICIONAL}

Dí esta lección el 29 de Diciembre; siete días después, el 5 de Enero, se había reproducido el derrame. Cloroformicé al enfermo, practiqué la operación del empiema é hice la cura antiséptica de la herida con gasa iodofórmica y algodón hidrófilo, después de lavar la pleura con agua bórica. Las consecuencias de la operación fueron muy simples. El enfermo principió á recobrar el apetito y las fuerzas y á los ocho días apenas supuraba la herida. La cura se renovó todos los días hasta el 15 de Febrero. El 20 se suprimió el tubo de desagüe, y el 27 era completa la cicatrización. En el mes de Marzo le dí de alta curado. 


\section{PLEURESÍ PURULENTA METAPNEUMONICA}

Sumar1o: Comparación de tres casos de infección por pneumococos.Meningitis supurada latente en el curso de una pulmonia.-Localización pleuritica y pericardiaca de la supuración, correspondiente unas veces á casos de pulmonías graves, otras á pulmonías benignas en apariencia.-Formas diversas de la pleuresía purulenta metapneumónica, pleuresías contemporáneas de la pulmonía y pleuresías tardías; su evolución diversa. - Dificultades de diagnóstico de los empiemas tardios ; insuficiencia de los signos fisicos, de los trastornos funcionales y de las indicaciones termométricas. - Necesidad de hacer el diagnóstico con ayuda de la punción exploradora.-Eventualidades ulteriores del empiema ; fístulas pleuro-bronquiales ; enquistamiento de la bolsa supurada.-Patogenia de la pleuresía purulenta metapneumónica.Estudios bacteriológicos ; su desiderata clínicas.-Tratamiento. - Necesidad del empiema precoz.-Benignidad de la operación.

Se presenta la ocasión de ocuparnos de nuevo de las pulmonías infecciosas y de las supuraciones secundarias que determinan. Tres casos recientes que hemos observado, van á demostrarnos la facilidad con que se disemina el veneno pneumónico y la tendencia de las diversas serosas de la economía á supurar bajo su influencia.

Narraremos ante todo un caso en el que la autopsia reveló la existencia de una meningitis purulenta en el curso de una fluxión de pecho, sin que ninguno de los síntomas permitiera afirmar, ni aun sospechar, esta complicación. El hecho que hemos observado puede resumirse así en pocas palabras.

Un hombre robusto, de treinta y dos años, aficionado al alcohol, tuvo escalofrío, dolor de costado y disnea : al día siguiente se le condujo al hospital y observamos los sigños clásicos de la hepatización del lóbulo inferior del pulmón derecho. La fiebre era intensa, la opresión grandísima y la tos y los esputos nulos. 
La pulmonía progresaba al parecer de una manera regular, aunque se notaban en el enfermo locuacidad insólita y cierto grado de excitación cerebral, síntomas que atribuimos al alcoholismo. Por la tarde aumentó la agitación y se presentó delirio : la temperatura siguió siendo elevada, pero sin exceder de $39^{\circ}, 5$, cifra habitual en las pulmonías francas. Al otro día por la mañana, sucedió al delirio un estado de sopor, que se convirtió al poco tiempo en coma, y el enfermo murió aquella tarde, sin haber tenido vómitos, ni alteraciones pupilares, ni síntomas de contractura 6 de parálisis muscular.

Al hacer la autopsia se descubrieron, además de las lesiones ordinarias de una pulmonía del tercio inferior del pulmón derecho, que no había pasado del período de hepatización roja, alteraciones extensas é inesperadas de los centros nerviosos. La pia-madre, en toda la superficie convexa del cerebro, estaba engrosada, infiltrada, cubierta de exudados turbios supurados á lo largo de los vasos. En los intervalos de estas estrías purulentas, los capilares se hallaban distendidos por la sangre y muy inyectados : el examen microscópico demostró la existencia de una diapedesis abundante de leucocitos, prueba de que la supuración hubiera sido difusa algunas horas después. Las circunvoluciones cerebrales eran muy vasculares y su superficie principiaba á reblandecerse ; los ventrículos se hallaban distendidos por líquido turbio, y esta hidrocefalia, reciente según toda probabilidad, era la causa de la rapidez de los accidentes comatosos que precedieron á la muerte.

En tres días se desarrolló una meningitis supurada, anunciándose sólo por cierto grado de excitación cerebral y de delirio, análogo al de los alcohólicos, y cuyo pronőstico, aunque reservado, parecía menos grave de lo que lo era en realidad. Esta meningitis no ocasionó síntoma al- 
guno de los que suelen observarse en tales circunstancias : faltaron los vómitos: la cefalea fue tan ligera que jamás se quejó de ella el enfermo : las pupilas fueron siempre normales : el temblor de la lengua y de los dedos podía atribuirse al alcoholismo más bien que á una complicación meníngea : en una palabra, la supuración de la pia-madre se produjo de un modo insidioso, sin manifestarse por síntoma alguno característico, excepto el delirio.

Este caso es un ejemplo notable de esas meningitis infecciosas, consecutivas á un envenenamiento general, que son casi latentes por completo desde el punto de vista de los trastornos funcionales. Obsérvase esto á menudo cuan. do las serosas sufren la acción de un virus séptico: la peritonitis puerperal, tan poco dolorosa algunas veces, cuando la excavación pelviana está ya llena de pus, es comparable en absoluto, desde este punto de vista, con la meningitis pneumocócica.

Pero la mayor parte de las veces no se generaliza tanto la infección pneumónica y se limita á ganar de etapa en etapa la pleura en la proximidad del foco de hepatización pulmonar. Es lo que ha sucedido en dos mujeres, que se hallan en este momento en nuestra clínica y cuya historia comparada es muy instructiva.

La primera es una lavandera de veinticinco años, que ingresó en la sala Delpech hace veinte días, con pulmonía que databa de la víspera. El principio fue brusco y típico en absoluto. Escalofrío fuerte seguido de fiebre y de cefalalgia, insomnio, y al día siguiente dolor de costado y sensación de disnea dolorosa ; lo mismo que en el enfermo anterior no hubo vómito inicial.

Esta pulmonía de cuarenta y ocho horas se anunciaba como grave. La enferma tenía el tinte plomizo, los ojos hundidos y un estado de adinamia profunda. Padecía poco cuando estaba inmóvil, sentía dolor torácico fuerte en las. 
grandes inspiraciones, la tos era escasa y apenas expectoraba. Los esputos eran viscosos, poco teñidos y no sanguinolentos. Los signos físicos obscuros indicaban más bien la congestión pulmonar que la pulmonía verdadera. En el vértice derecho se oía espiración prolongada y sibilante lejana, el murmullo vesicular era débil y la percusión daba un sonido sub-macizo. La presión en el lado derecho del tórax era dolorosa.

Los días siguientes, á pesar de una medicación revulsiva enérgica y del empleo de los estimulantes á altas dosis, se agravó el estado general. Durante seis días la enferma pareció una tífica, estaba indiferente á cuanto la rodeaba, con la lengua seca y con fiebre de $40^{\circ}$ próximamente. Los signos físicos eran más acentuados, y el soplo del vértice se había hecho tubario. Los esputos seguían siendo escasos, pero más teñidos que al principio.

Al noveno día de la enfermedad se inició un principio de defervescencia, el termómetro descendió á $38^{\circ}$, y el soplo fue sustituído por estertores sub-crepitantes de timbre cavernoso. Pero el estado general, en vez de mejorar, siguió siendo grave. La enferma sentía opresión, ansiedad, el pulso era pequeño y débil y latía 130 veces por minuto; acabaron de aniquilarla sudores profusos que no tenían el carácter de la diaforesis de la convalecencia; era tal el colapso, que para impedir un síncope inminente fue preciso hacer cada tres horas una inyección subcutánea de éter.

Este estado de cosas duró desde el segundo al duodécimo día. La pulmonía se hallaba indudablemente en decrecimiento; el termómetro se mantenía cerca de los $38^{\circ} \mathrm{y}$ la respiración se hacía casi normal en el vértice derecho, pero la enferma estaba muy débil y era necesario sostenerla con inyecciones de éter. Aparecieron signos nuevos que indicaban un trabajo irritativo persistente en la pleura. Se había presentado de nuevo el dolor de costado, 6 
mejor dicho, no había desaparecido por completo, pero se hizo más fuerte. La enferma, que apenas tosía durante todo el período agudo de su pulmonía, tenía accesos de tos seca. Se notaba disminución del sonido hacia la base derecha y debilidad de las vibraciones y del murmullo vesicular. La voz era lejana, sin egofonía ni broncofonía; durante las inspiraciones profundas se oía soplo velado.

Todos estos signos indicaban un derrame en la cavidad de la pleura en vías de formación. Se efectuaba á la vez un trabajo análogo en el pericardio y el corazón, lo que explicaba la persistencia de la disnea y la rapidez y debilidad del pulso. La macicez precordial había aumentado, los ruidos del corazón se oían de mala manera, y se notaba, por último, en el origen de los vasos cardíacos gruesos, un roce peri-cardíaco suave. Se formaba, según toda probabilidad, una pericarditis exudativa.

Este antagonismo entre el decrecimiento de los fenómenos pneumónicos y la agravación de los signos de derrame, fue en aumento. A los quince días de principiar la pulmonía, la respiración se hizo franca en el vértice que enfermó primero, pero existían signos innegables de pleuresía, que se remontaban hasta el ángulo de la escápula. El hígado descendía dos traveses de dedo por debajo de las costillas. Se oía mal el ruido respiratorio: no se notaba ni soplo ni egofonía. Los latidos del corazón eran más fuertes y la tendencia al síncope menor; había mejoría respecto al particular. La fiebre era nula y el termómetro marcaba $37^{\circ}$. Pero la enferma seguía sin fuerzas é inapetente, y conservaba el tinte plomizo tan acentuado desde los días primeros.

A pesar de la desaparición de la fiebre y de la mejoría de los signos de la pericarditis, sospechaba que el derrame pleurítico era purulento ; porque la persistencia de la adinamia, después de la defervescencia de los accidentes pul- 
monares, tenía algo de anormal. Los sucesos justificaron esta idea, pues al hacer una punción exploradora con la aguja de Pravaz, salió líquido sero-purulento. Al día siguiente practiqué la toracentesis y extraje un litro de pus verduzco seroso, bien trabado, é inodoro. En la actualidad se encuentra la enferma mejor, el derrame se reproduce con lentitud, y el estado general es más satisfactorio. $\mathrm{Si}$ no se modifican de aquí á pocos días los signos locales de la pleuresía, recurriré á la operación del empiema.

En la segunda enferma la marcha del padecimiento fue análoga, menos la complicación de pericarditis. Es una joven de veintitres años, que dió á luz hace tres meses, y que tuvo después un abceso mamario fistuloso aún. Se encontraba por lo tanto en malas condiciones y en plena supuración cuando contrajo la pulmonía, que fue regular y de intensidad mediana ; circunscrita al lóbulo inferior derecho, entró en defervescencia á los ocho días y fue yugulada por una crisis de sudores profusos. El estado general era bueno y la convalecencia parecía que sería regular, cuando á los seis días de descender la temperatura vimos presentarse, sin causa ocasional de enfriamiento, los signos físicos de una pleuresía de desarrollo rápido. Lo notable fue que esta complicación no se manifestó por recrudescencia del dolor torácico ni de la fiebre; sólo sintió la enferma opresión é inapetencia; al averiguar la causa de la persistencia de estos trastornos funcionales, descubrimos un derrame limitado al tercio inferior del lado derecho del tórax. Este derrame aumentó con rapidez, y á los cuatro días se extendía hasta debajo de la clavícula; rechazaba á la izquierda el corazón y hacia abajo el hígado. Se practicó sin perder tiempo la toracentesis y se extrajo, no serosidad como era de esperar, sino un líquido sero-purulento, verduzco y sucio, análogo por completo al de la enferma anterior, que se reprodujo en igual cantidad á los 
tres días. En estas condiciones, no dudé en practicar el empiema. Hace ocho días que hice la operación. Después de un primer lavatorio bórico, coloqué un tubo de desagiie y un apósito antiséptico; hoy el estado general y local de la enferma, es muy satisfactorio; no tiene fiebre, ni opresión, ha recobrado el apetito y todo anuncia la convalecencia próxima.

Estos dos casos de pleuresía purulenta que se presentaron, uno después de una pulmonía grave y otro á consecuencia de una pulmonía benigna, pero agravada por el estado puerperal anterior, son buenos ejemplos de las complicaciones pleuríticas metapneumónicas y de su evolución insidiosa. Como es un asunto de actualidad, creo que debo dar algunos detalles sobre esta cuestión.

Woillez fue el primero que señaló en Francia la existencia de la pleuresía purulenta consecutiva á la pulmonía, y sobre todo, el que procuró distinguir las formas clínicas. Admitía dos variedades principales. En la una se trata de una enfermedad general, la pleuro-pneumonía, que produce á la vez supuraciones de la pleura y del pulmón y mata á los enfermos en quince ó veinte días. Separa de esta forma esencialmente grave las pneumo-pleuresías, en las que la complicación pleurítica no se presenta hasta después de terminar la pulmonía, y cuya marcha es más lenta; esta segunda especie de pleuresía purulenta es en general más grave, y cuando ocasiona la muerte lo hace en una época tardía después de varias semanas 6 de algunos meses.

Estas palabras de pleuro-pneumonía y de pneumo-pleuresía, se prestan indudablemente á la confusión ; pero la idea de Woillez merece conservarse; hay, en efecto, una diferencia notable entre las pleuresías contemporáneas á la pulmonía y las que la son posteriores.

Después del trabajo de Woillez, ha progresado la cuestión, y la pleuresía purulenta metapneumónica, que se 
diagnostica antes y mejor, no debe considerarse como una complicación excepcional ; es hasta un fenómeno relativa mente común de la pulmonía. Me atrevo á decir, aunque sin fundarme en estadística completa alguna, que según mi impresión personal, de 40 pulmonías que ingresan todos los años en esta Clínica, hay por término medio una 6 dos que van acompañadas de empiema ; entre las pleuresías purulentas que se observan en nuestras salas de medicina, las más comunes son con seguridad las consecutivas á la pulmonía. Riez, de Copenhague, ha encontrado 5 casos en un total de 15 empiemas de todas clases ; Guillon ha sacado la misma proporción en su Tésis inaugural (1883); según este observador la cuarta parte de los empiemas son de origen pneumónico, los demás dependen de la tuberculosis, de las alteraciones óseas del tórax, de los procesos sépticos generales y de los cuerpos extraños de los bronquios. Estoy convencido de que cuanto antes se diagnostiquen los derrames pleuríticos metapneumónicos, más se comprenderá que es frecuente la supuración; sólo que la evolución de estas pleuresías purulentas es siempre insidiosa y el principio de los accidentes se desconoce muchas veces.

En una de las conferencias anteriores, insistí sobre los caracteres clínicos del empiema metapneumónico. Aunque no vuelva á ocuparme por completo de este asunto, conviene recordaros la marcha y los caracteres de este epifenómeno.

Creo que merece conservarse la división de Woillez en pleuresías contemporáneas y en pleuresías consecutivas á la pulmonía.

En el primer caso, el padecimiento de la pleura evoluciona á la vez que la pulmonía ; es lo que sucedió en nues tra primera enferma. La intensidad del dolor de costado, su persistencia, su reproducción después de la deferves- 
cencia aparente de la pulmonía, la sensibilidad á la presión en los espacios intercostales, todo indicaba desde el principio la existencia de la complicación pleurítica. Observamos también casi desde los primeros días de la enfermedad, disminución de las vibraciones torácicas y del murmullo vesicular.

Cuando la pleuresía purulenta es consecutiva á la pulmonía, lo que sucede casi siempre, el diagnóstico es fácil unas veces y otras está rodeado de grandes dificultades.

En nuestra segunda enferma, observamos que en cuanto desaparecieron los signos de la pulmonía, se hicieron evidentes los de la pleuresía. En tres días se reprodujo la. opresión y la macicez; limitada al principio á la base del pecho se extendió en cuarenta y ocho horas hasta la clavícula. En este caso era indudable el derrame y sólo podía. dudarse de su naturaleza ; en efecto, nada en el estado general de la enferma permitía afirmar la existencia del pus. Este tiene relativamente poca importancia, hoy que se sabe cuán inofensivas son las punciones que se practican adoptando las precauciones antisépticas.

Pero no sucede siempre así ; es raro que la pleuresía purulenta metapneumónica siga una marcha tan rápida. Los. signos del derrame no se acentuan hasta quince días 6 tres semanas después de la defervescencia. La interpretación de los signos estetoscópicos es dificilísima antes. Se observa macicez, disminución de las vibraciones torácicas y del ruido vesicular, algunas veces hasta soplo profundo lejano; la voz es velada, bronco-fónica á menudo; casi nunca. egofónica ; en una palabra, es imposible afirmar si existe atelectasia pulmonar, tuberculosis incipiente $\delta$ derrame purulento.

La temperatura, signo tan importante de las supuraciones profundas, es en este caso de poca utilidad. $\mathrm{Y}_{\mathrm{a}}$ he tenido ocasión de insistir sobre estos casos de pleuresia pu- 
rulenta compatibles con la falta de fiebre, $y$ en los que el termómetro marca siempre $37^{\circ}$ aunque haya un litro de pus en el pecho. Nuestra segunda enferma es una prueba de lo que digo : tenía $37^{\circ}, 3$ una hora antes de practicarse la operación del empiema.

No quiere decir esto que no deban tenerse en cuenta las indicaciones termométricas; todo lo contrario. La temperatura baja no excluye la idea de una supuración posible de la pleura, pero la existencia de la fiebre es un indicio de gran valor. Wagner insistía con razón sobre la importancia de los accesos febriles que suceden á la defervescencia pneumónica aparente. La supuración es, sobre todo, casi segura cuando se suceden escalofríos irregulares, seguidos de calor y de sudor, porque esta pseudo-fiebre intermitente indica siempre fenómenos de absorción séptica y no es necesario para hacer el diagnóstico esperar al período héctico. Pero al contrario de lo que podría suponerse, los escalofríos erráticos y los accesos de fiebre héctica, son rarísimos en la pleuresía purulenta metapneumónica y sólo se presenta cuando se forma un foco de gangrena pleuro. pulmonar.

Los signos físicos no tienen para el diagnóstico un valor decisivo. Hay casos en los que la atelectasia pulmonar se presenta con los caracteres de un derrame pleurítico, y se manifiesta por macicez, supresión de las vibraciones torácicas y del soplo y debilidad del murmullo vesicular, y existen, por el contrario, otros de pleuresía purulenta con persistencia de las vibraciones (aunque éstas estén siempre disminuídas), y en los que la voz está debilitada, pero no es egofónica y bronco-fónica. Por último, casi nunca se observa el edema de la pared torácica, que se consideraba antes como el signo más constante del empiema.

Inútil es insistir sobre la inseguridad diagnóstica de los 
síntomas funcionales. La disnea es nula ó grandísima, según los casos. En nuestra primera enferma el derrame era poco abundante y la opresión extremada : es verdad que contribuía á ello en gran parte la pericarditis : en la segunda la opresión era relativamente ligera, aunque la cantidad del derrame excedía de un litro. La tos no tiene más valor : depende más del grado de irritabilidad del diafragma que de la abundancia de la colección líquida; pero su carácter de accesos secos, sin expectoración, es un signo bastante bueno de complicación pleurítica.

No me cansaré de repetirlo, la pleuresía purulenta metapneumónica carece de síntoma patognomónico : se llega al diagnóstico por una serie de presunciones; pero aun después de hecho el diagnóstico, no hay seguridad respecto á la naturaleza del derrame: se presume teniendo en cuenta la gravedad del estado general, $\delta$ las condiciones orgánicas de los enfermos que les predisponen más 6 menos á la supuración ; pero no debe confiarse en estas presunciones: se han diagnosticado muchas veces como purulentos los derrames post-pneumónicos cuando la salud de los enfermos parecía buena y las condiciones etiológicas satisfactorias.

La conclusión práctica es que siempre que se observa uno de estos casos dudosos, debe hacerse sin perder tiempo una punción capilar exploradora con la aguja de Pravaz calentada á la llama y lavada en agua fenicada. Es siempre el medio mejor, y á menudo el único, de conocer la naturaleza del líquido pleurítico.

El examen del pus, sin ser característico en absoluto, da algunas indicaciones útiles para el pronóstico. Es por lo común de color verduzco, sin mezcla de tinte grisáceo; no tiene olor; su consistencia varía según la proporción de serosidad con que está mezclado, pero es siempre bien trabado y no contiene grumos ni partículas sólidas; no se 
separa con facilidad de su suero ni deja precipitar una capa gruesa de leucocitos, de modo que conserva su color primitivo después de enfriarse. Además, como es poco fibrinoso, no manifiesta tendencia á coagularse como la gelatina, á la manera de los exudados inflamatorios. En una palabra, és un líquido sero-purulento, y en los casos de evolución rápida, como sucedió en la segunda enferma, tiene un carácter más seroso que purulento.

Si se abandonan á sí mismos los abcesos metapneumónicos, sucede una de las tres cosas siguientes:

Por lo general el derrame de la pleura no manifiesta tendencia á aumentar y sigue siendo poco abundante: se absorbe en parte y se enquista más ó menos. En estas condiciones se forman las pleuresías enquistadas de diagnóstico difícil. El estado general del enfermo indica entonces un foco de supuración persistente : la fiebre, aunque no es contínua, se presenta á menudo, el apetito es nulo, la debilidad bastante grande y se desarrolla una verdadera consunción : estos enfermos se consideran muchas veces como tuberculosos con infiltración lobular caseosa del pulmón : error deplorable que impide ensayar el único tratamiento racional, la abertura del abceso de la pleura.

Otras veces el foco sero-purulento sigue la misma marcha que un derrame pleurítico agudo y aumenta con más 6 menos rapidez y rechaza los órganos inmediatos. Es lo que sucedió en la segunda enferma. Esta eventualidad es poco frecuente, pero favorable en definitiva, porque los progresos del derrame no permiten desconocerle y obligan á recurrir á la intervención precoz que es la toracentesis. Se observa al punzar el pecho que el derrame es purulento, si no se había sospechado antes, y desde entonces se impone el empiema como una necesidad posible, ya que no próxima. 
Por último, el abceso puede evacuarse espontáneamente por las vías naturales. Las estadísticas demuestran que la cuarta parte de los casos terminan de este modo, pero esta terminación prueba simplemente cuán imperfecto es aún el diagnóstico de la pleuresía purulenta metapneumónica, porque en las condiciones ordinarias de una terapéutica racional no debe contarse con las eventualidades aleatorias en una vómica pulmonar, y es preciso dar salida al pus antes de que se abra paso por los bronquios. Además, la abertura del abceso en sus bronquios no da seguridades de curación : la mayor parte de los enfermos en los que se observan estas vómicas tienen fiebre más ó menos héctica y se debilitan y consumen poco á poco : se asemejan á tuberculosos con los que se los confunde muchas veces; y cuando se hace el diagnóstico verdadero y se les trata de la manera debida por el empiema, tardan meses y hasta años en curar.

Sólo en un caso la pleuresía purulenta metapneumónica tarda poco en evacuarse por los bronquios y con un pronóstico casi siempre favorable : cuando recae en la cisura interlobular y es consecutivo á un foco de pulmonía central. En este caso el pus se evacua pronto y de un modo definitivo: sólo conozco dos ejemplos. Pero si el derrame ocupa la parte más extensa de la cavidad pleurítica, y hasta si está circunscrita á la pleura diafragmática, es raro que cure por vómicas sucesivas, y el foco purulento supura durante un tiempo ilimitado.

Una particularidad de estos abcesos que merece señalarse, es que jamás producen por sí mismos gangrena pulmonar. Aunque ulceren poco á poco el pulmón hasta abrirse por los bronquios, siguen siendo inodoros y no originan fenómeno alguno de esfacelo. Las supuraciones fétidas de la pleura son secundarias siempre á un foco de gangrena pulmonar primordial. Cuando se trata de una pul- 
monía franca de pneumococos, la pleuresía purulenta secundaria es siempre inodora, y el pulmón se repara por completo detrás del derrame.

Resulta de esto, que el pronóstico de la pleuresía supurada metapneumónica es relativamente benigno. En una estadística de 316 casos, cita Netter sólo 47 muertes. Bouveret considera grave esta variedad de empiema. Estas divergencias de opiniones prueban sólo una cosa : que se incluyen en las mismas estadísticas casos muy diferentes. Nada más diferente, en efecto, que los empiemas precoces ó tardíos, y el modo de intervención es tan capital en este asunto, que domina por completo el pronóstico.

He hecho hasta ahora caso omiso de todas las cuestiones relativas á la naturaleza y á la patogenia de la pleuresía purulenta metapneumónica, porque son del dominio de la teoría pura. Pero los estudios recientes de patología experimental han difundido bastante luz sobre el mecanismo de esta complicación de la pulmonía. Se ha demostrado que la pleuresía purulenta es producida en tales casos por el mismo agente virulento que ocasiona la inflamación pulmonar, á saber, el pneumococo, y no por los microbios ordinarios de la supuración, en particular por el estreptococo piógeno. Así resulta de las investigaciones de Frænkel y de Weichselbaum en Alemania ; de Netter, de Talamon, y de Cornil, en Francia.

Pero el descubrimiento del pneumococo en el pus del derrame de la pleura no resuelve todas las dudas. En efecto, el microbio de Frænkel no produce supuración por su presencia en los parénquimas, no es piógeno. Hormiguea en los pulmones sin que produzca la supuración, y hasta en las pulmonías mortales, en las que la hepatización se convierte en infiltración gris, es raro descubrir un verdadero abceso. Hay motivos para preguntar por qué no supura el pulmón, aunque el pneumococo se encuentra en 
él mezclado muchas veces con los estreptococos y estafilococos, agentes ordinarios de la supuración; mientras que produce, al contrario, por su presencia la supuración de la pleura, aunque no se halle mezclado con los demás microbios piógenos.

Hasta ahora no se ha resuelto de una manera satisfactoria este asunto, y debemos atenernos al hecho material sin buscar una explicación prematura. Es indudable que las serosas se inflaman con la mayor facilidad al contacto del pneumococo, aún exento de toda mezcla con otros microbios. Las meninges cerebrales, el pericardio, se afectan con frecuencia, y se han encontrado muchas veces el líquido aracnoideo y la serosidad pericardíaca reducidos al estado de cultivos puros de pneumococos. No puede decirse que esto sea efecto de una propagación inflamatoria directa del parénquima pulmonar á su membrana de envoltura, porque Netter, de quien tomo estos datos, ha visto desarrollarse pleuresías de pneumococos en casos en que no había supurado el tejido del pulmón.

Otro punto mal resuelto es saber por qué supuran ciertas pleuresías de pneumococos, mientras que otras siguen siendo serosas. Se ha buscado y encontrado el microbio de la pneumonía en los derrames serosos consecutivos á la pulmonía : no es, por lo tanto, por sí mismo un agente piógeno necesario, y son precisas ciertas condiciones mal conocidas todavía para aumentar su virulencia y hacer purulento el líquido.

Estas condiciones se suponen, pero no se conocen con exactitud. Influyen indudablemente la intensidad y gravedad de la pulmonía, aunque no constituyen un factor indispensable. Se ven pulmonías, de extensión é intensidad moderadas, que producen empiemas, y viceversa, pulmonías difusas y graves que ocasionan, cuando más, esbozos de exudados serosos. 
Las condiciones individuales de los enfermos tienen indudablemente mucha más importancia, y la cuestión del terreno es superior en este caso á la cantidad y á la cualidad del germen morboso. Nada sabemos de las aptitudes personales de los enfermos, cuya afećción va á supurar : podemos, cuando más, adivinar ciertas circunstancias accesorias que desarrollan 6 hacen nacer estas aptitudes. La existencia de una supuración anterior, como en nuestra joven parida, tiene una influencia innegable : debe agregarse además el trabajo físico exagerado, las grandes fatigas, las preocupaciones morales, en una palabra, todo lo que debilita el organismo y le hace vulnerable : el alcoholismo obra en este sentido no sólo como causa predisponente, sino también como determinante respecto á la localización de la lesión. El enfermo de que os hablé al principio de esta conferencia, murió á causa de una meningitis pneumocócica supurada ; pero era un alcohólico, y el alcohol debió haber alterado de antemano la pia-madre.

Aún subsiste la etiología antigua á pesar de lo que ha modificado nuestras ideas el descubrimiento del microbio patógeno de la pulmonía; persisten la influencia patógena del frío y de las causas debilitantes, y aunque el agente patógeno sea un microbio, las condiciones necesarias para su desarrollo son las que la observación clínica había indicado siempre como causas eficaces de la enfermedad.

Lo que se sabe con más exactitud que antes, es que el pneumococo, una vez que se desarrolla en el organismo, disfruta una vitalidad poco activa y transitoria, y que su difusibilidad es limitada. Deben tenerse en cuenta estos datos al apreciar el pronóstico y las indicaciones del tratamiento.

Ciertos autores, como Gehrardt, en Alemania, admiten que la pleuresía supurada metapneumónica es muchas veces bastante benigna para curar espontáneamente, y acon- 
sejan limitarse á la expectación, interviniendo, si es necesario, después de varias semanas. No acepto ni aun en principio esta idea. La presencia del pus en la pleura constituye por sí sola un peligro, y por una probabilidad, entre mil de curación espontánea, se corre el riesgo seguro de ver agravarse un estado peligroso para el enfermo. En cuanto hay pus en la cavidad pleurítica, debe evacuarse.

La punción simple ha sido eficaz en ciertos casos. Al principio de mis estudios médicos, ví en la clínica del profesor Richet una joven que padecía pleuresía purulenta consecutiva á una fluxión de pecho, y que curó por completo á beneficio de una sola toracentesis. En 1883 ingresó en mi sala un hombre, que, á consecuencia de una pulmonía, tenía un derrame localizado de la base ; extraje el pus por medio de una punción, y me disponía á practicar el empiema, cuando observé que no se reproducía el líquido y que la cicatrización tendía á hacerse espontáneamente. El enfermo curó.

Esta terminación no es rara, porque Netter, en su trabajo notabilísimo, cita 32 casos de este género. Pero manifestaré que estos casos de curación se han considerado siempre como rarezas, lo que hace que se les publique de preferencia; de manera que la proporción de la estadística de Netter debe ser muy exagerada en relación al número de pleuresías purulentas clásicas que necesitan el empiema.

Hecha esta salvedad, es lógico principiar el tratamiento por una punción simple, inofensiva siempre. Lo peor que puede suceder es que se reproduzca el líquido, $\mathrm{y}$ hay motivos para suponer que con la toracentesis sea posible obtener un resultado definitivo, aunque esta esperanza sea más que problemática.

Si se reproduce el líquido, lo que sucede, por lo general, no debe recurrirse á nuevas punciones, aunque se hayan citado casos que curaron después de 10 ó 12 toracen- 
tesis. Esta práctica, eficaz algunas veces en los niños en manos de Bouchut, me parece mala; es un procedimiento largo, fastidioso y de resultados eventuales ; la reproducción incesante del líquido extenua á los enfermos, y en muchos casos es preciso decidirse á practicar el empiema después de haber perdido en tentativas varias semanas, durante las cuales la curación estaría muy adelantada 6 sería completa ya.

Mi convicción sobre el particular es absoluta. Concedo que en la pleuresía supurada, consecutiva á la pulmonía, haya derecho á ensayar una primer punción, pero esto es todo. En cuanto comprendo que existe un derrame purulento, practico lo antes posible el empiema, según los preceptos de Moutard Martin.

Cloroformizo siempre los enfermos, para evitar, no sólo el dolor, sino el espasmo involuntario de los músculos intercostales, que aproxima las costillas y dificulta la operación, y escojo, como sitio electivo, el punto más declive, asegurándome antes, por una punción capilar, de la existencia del pus. Esta última precaución es de gran utilidad, porque la pleuresía metapneumónica es de todas las pleuresías la que se complica más veces con adherencias pulmonares y me ha sucedido en varias ocasiones, después de incindir la pleura, tener que desprender con el dedo su hoja parietal para llegar al foco de la supuración. Recordaréis que sucedió así en nuestra segunda enferma, y esta maniobra, sencillísima cuando los pacientes están anestesiados, sería difícil y dolorosa sin el cloroformo.

Una vez abierto el abceso de la pleura y limpio el foco por medio de inyecciones bóricas, puede estarse seguro del éxito, porque de todos los empiemas son éstos los que curan antes y con más regularidad. Es fácil comprender el motivo de esta evolución. El pulmón tiende á recobrar con rapidez su forma y su volumen, porque no lleva mu- 
cho tiempo comprimido por el derrame y no se ha cubierto de un cascarón fibroso grueso; además, no ha tenido tiempo de sufrir la transformación esclerosa, resultado constante de las pleuresías de duración larga. En segundo lu. gar, las adherencias pneumo-pulmonares que existen siempre le impiden aplastarse y que el foco supurado adqniera grande extensión. Resulta, por lo tanto, que, desde el punto de vista de la curación, estas pleuresías purulentas se comportan como simples abcesos, sin que sea necesario, ni aun útil, repetir los lavatorios antisépticos de la cavidad de la pleura. Una cura de Lister bien aplicada, que se renueve todos los días 6 cada dos, según la abundancia de la supuración, basta para conservar en buen estado la herida torácica, y, en los casos favorables, se oblitera casi por completo el foco en tres $\delta$ cuatro semanas. Pero conviene prolongar el desagüe más tiempo, para que no se reproduzca el abceso. Siguiendo estas indicaciones, se evita toda clase de accidentes y se obtiene la curación con seguridad y rapidez.

Voy á completar en pocas palabras la historia de estas dos enfermas.

La primera, la que padecía pericarditis, acababa de ser punzada cuando hablaba de ella. Según preveía, el derrame se reprodujo al poco tiempo. Dos días después, el 12 de Abril, practiqué sin dificultad alguna el empiema. Lavatorio bórico y cura con gasa iodoformada. La enferma pasó bien el día y la noche ; al día siguiente era abundante la supuración, pero disminuyó con rapidez los días siguientes. Empezó á tener apetito por vez primera.

El 20 de Abril la supuración se había reducido á una copita de pus espeso, cremoso, que apenas manchaba el apósito. La enferma estaba apirética, se levantaba y comía con apetito.

El $1 .^{\circ}$ de Mayo la cavidad de la pleura se había oblite- 
terado casi por completo; la herida tendía á cerrarse y costaba mucho trabajo retener el tubo de desagüe en el foco que apenas supuraba. A cada acceso de tos chocaba el pulmón contra el tubo, y la enferma sentía dolores fuertes en el hombro derecho. Fue preciso disminuir la longitud del tubo.

El 10 de Mayo se suprimió por completo el tubo de desagüe y se curó la herida con un trozo de diaquilón.

La enferma salió curada el 21 de Mayo.

Las consecuencias de la operación fueron también satisfactorias en la segunda enferma. Operada el 5 de Abril salió curada por completo el 7 de Mayo; he vuelto á verla en Junio; no se resentía de su pleuresía y disfrutaba buena salud. 


\title{
EMBOLIA PULMONAR SÉPTICA : PNEUMOTORAX
}

\author{
PLEURESÍA GANGRENOSA \\ CURACIÓN POR UN EMPIEMA PRECOZ
}

Sumario : Piopneumotórax gangrenoso ocurrido en una joven á los pocos días de un aborto.-Empiema precoz: curación.-Discusión retrospectiva del diagnóstico. - No es posible pensar ni en una bronquiectasia complicada con gangrena pulmonar, ni en una bronco-pneumonía ni aun infecciosa. - La marcha de la afección es la de una embolia pulmonar que produjo un infarto séptico á causa del puerperio. - La embolia procedente de los senos uterinos, después de la muerte del feto, puede preceder á la expulsión del producto de la concepción. - Mecanismo de la infección del coágulo embólico. - Necesidad de la intervención precoz en casos semejantes : consecuencias benignas del empiema, tratado según las reglas antisépticas.

Hace algún tiempo os hablé de la pleuresía purulenta consecutiva á las pulmonías infecciosas, á propósito de un anciano que sufrió la operación del empiema, y que curó á pesar de su edad avanzada. En la Conferencia anterior me ocupé también de un enfermo en el que la pleuresía, de marcha insidiosa, se hizo con rapidez purulenta, á consecuencia de una pleuresía complicada con nefritis : en este caso se imponía también la operación ; ésta se hizo, y el enfermo se halla casi curado. Hoy continua la serie de los derrames pleuríticos graves. Esta vez se trata de un abceso pútrido consecutivo á una gangrena pulmonar, y tanto la historia clínica como las indicaciones terapéuticas del caso son bastante interesantes para merecer llamar vuestra atención.

Véase en pocas palabras la historia de nuestra enferma. Es una joven de veinticuatro años, que sólo ha padecido 
una bronquitis ligera á fin de año. Se casó en Septiembre y quedó en cinta al poco tiempo. Su embarazo siguió una marcha normal, sin accidente alguno, hasta Marzo, á pesar de que en Febrero se reprodujo la bronquitis y duró tres semanas sin caracteres graves.

A principio de Marzo tuvo, sin causa conocida, una pérdida uterina, que duró veinticuatro horas, sin provocar cólicos pelvianos ni accidentes graves. La hemorragia se contuvo al día siguiente, y no volvió á repetirse ; el embarazo siguió, al parecer, su marcha. Digo al parecer, porque creo que esta hemorragia debió ser causada por un desprendimiento parcial de la placenta, y el feto sucumbió entonces, según toda probabilidad.

Sea lo que fuere, la enferma principió á sentir desde esta época malestar, peso lumbar, dolores abdominales, cansancio permanente, aunque no tenía fiebre, y su salud general seguía siendo relativamente buena.

El 28 de Marzo cambió la escena y se presentaron accidentes agudos. Tuvo un escalofrío fuerte, seguido casi inmediatamente de dolor agudo en el costado izquierdo, sin tos ni expectoración herrumbrosa. A pesar de la falta de fiebre, el médico que la asistía diagnosticó una pulmonía incipiente, y aplicó un vejigatorio que mitigó el dolor del costado. Siguió el mismo estado durante varios días sin agravación aparente. A los siete días expulsó la enferma un feto muerto y macerado.

Desde el día siguiente al aborto, 6 de Abril, el estado general de esta mujer, en vez de mejorar, se agravó. Tuvo fiebre, aumentó la disnea y apareció de nuevo el dolor de costado más fuerte que al principio. Cuarenta y ocho horas después se presentaron dos síntomas nuevos, tos frecuente y expectoración purulenta fétida. $\mathrm{El}$ aliento adquirió un olor especial pútrido, que molestaba á la enferma ; ésta perdió por completo el apetito. En estas condiciones, 
agravadas por cuatro días de espectación, se la condujo al hospital el 11 de Abril.

Recordaréis, señores, el aspecto de esta enferma el día de su ingreso. Se encontraba en una situación gravísima, y bastaba sólo verla para comprender que padecía una enfermedad infecciosa.

La facies era terrosa, el color plomizo, la mirada brillante y ansiosa, la piel estaba cubierta de sudor. La respiración, difícil y frecuente, se elevaba á 50 por minuto; el pulso, pequeño y contraído, latía de 120 á 130 veces. La enferma estaba abatida, atormentada por la sed, con deseos contínuos de vomitar, aunque no tenía sucia la lengua, pero sí seca y árida. Existía sobre todo un síntoma que indicaba el carácter séptico de la afección : la fetidez del aliento. Era, en efecto, horrible hasta el punto de viciar el aire de toda la sala y molestar á las demás enfermas. La expectoración exhalaba también un olor gangrenoso, aunque su aspecto no era el de la verdadera gangrena. En vez de los esputos escasos, viseosos, de color obscuro ó negruzco, parecidos á la expectoración pneumónica crónica y que caracterizan la gangrena franca, había mucosidades bastante abundantes, compuestas de grumos blanquecinos, que nadaban en serosidad turbia más 6 menos purulenta. Este aspecto recordaba más bien el carácter de las expectoraciones de la bronquiectasia ó de la tisis pulmonar.

La tos, irregular y por accesos, era frecuente en ciertos momentos, rara en otros. No cesaba ni de día ni de noche, pero no iba acompañada de vómicas verdaderas, aunque la expectoración era abundantísima unas veces y nula otras.

El examen del pecho no explicaba al principio estos síntomas. El tórax era normal á la inspección y á la palpación; la opresión que sentía la enferma y la debilidad de su voz impedían en absoluto apreciar las vibraciones 
torácicas. La percusión tampoco suministraba más datos, aunque se notaba en el lado izquierdo una zona de macicez dudosa hacia la base, mientras que en la región infraespinosa el sonido adquiría un tono más elevado, sin ser timpánico. Eran signos de presunción demasiado vagos para poder afirmar la existencia de un derrame en la cavidad de la pleura.

Sólo la auscultación daba resultados decisivos haciendo hablar y toser á la enferma. A la derecha, la respiración era normal por completo; á la izquierda, era débil, pero no se oía estertor alguno. Mas durante la tos se oía debajo del ángulo inferior de la escápula un eco anfórico que iba acompañado de cuando en cuando de retintín metálico. Existía, por lo tanto, en este sitio una perforación pulmonar que comunicaba, en un espacio circunscrito, con la cavidad de la pleura, y probablemente producida por un foco de gangrena. El derrame no era abundante ni el pneumotórax extenso, porque no se notaba fluctuación al moverse la enferma. La fetidez del aliento y la gravedad del estado general, permitían afirmar que el derrame era purulento y séptico.

En vista de estos accidentes, que dependían, á mi juicio, de una pulmonía cortical séptica, prescribí el sulfato de quinina á grandes dosis, una poción cordial adicionada con 4 gramos de alcoholaturo de eucaliptus é inhalaciones fenicadas. La medicación fue ineficaz en absoluto, y el estado general siguió agravándose. La temperatura de $38^{\circ}$ se elevó el 12 de Abril por la mañana á $39^{\circ}$, y por la tarde á más de $40^{\circ}$. El abatimiento fue creciendo, la anorexia era absoluta, la lengua fuliginosa : los síntomas del pneumotórax se acentuaron cada vez más. El tratamiento médico era insuficiente, y había que abrir sin perder tiempo el abceso pútrido; ésta fue también la opinión del doctor Rigal, que vió en consulta á la enferma. Pero era di- 
fícil precisar el sitio de la perforación pulmonar. Se decidió abrir en seguida el espacio intercostal con una ó más. punciones exploradoras.

La operación se practicó aquel mismo día. Después de cloroformizar á la enferma, se introdujo el trócar núm. 2 del aspirador de Potain en la línea axilar del octavo espacio intercostal; no salió líquido alguno. Se practicó otra segunda punción más arriba, á dos traveses de dedo por debajo y fuera del ángulo inferior de la escápula ; salieron acto contínuo algunas gotas de serosidad purulenta fétida. Se practicó á continuación el empiema en este punto, dejándose al descubierto la pleura en la extensión de 5 centímetros. Pero en vez de llegar directamente al abceso como esperaba, encontré el pulmón unido á la pared costal por adherencias fuertes, y fue preciso desprender con el dedo la pleura visceral en una extensión bastante grande, después de dividir con muchas precauciones la parietal. A los pocos instantes comprendí que penetraba mi dedo en una cavidad; el abceso se abrió algo más arriba y atrás que suponía, y la aguja del aspirador había atravesado el pulmón para llegar al foco pulmonar. Excepto este accidente, la operación siguió una marcha regular. Salieron por la incisión unos 300 gramos de pus fétido, grisáceo y grumoso ; se lavó la bolsa con agua fenicada al 1 por 100, y después se hicieron lavatorios bóricos por miedo á que la enferma absorbiera ácido fénico en demasía. Se fijó en la abertura de la herida un tubo grueso de desagüe doble, y se hizo una cura antiséptica con gasa iodoformada. Durante una semana se repitieron todos los días los lavatorios fenicados, hasta que se eliminaron por completo las escaras gangrenosas y desapareció el olor.

Desde el momento de la operación cambió por completo el estado de la enferma : fue una verdadera resurrección. 
Al día siguiente descendió la temperatura casi dos grados por la mañana, aunque se elevó por la tarde; la tos y la expectoración fétida desaparecieron. El aliento siguió exhalando olor gangrenoso durante cuarenta y ocho horas, y después cesó ; renació el apetito. Por espacio de varios días salieron por la herida pus y colgajos esfacelados abundantes; hoy, cinco dias después del empiema, el pus que mancha el apósito es de olor fétido, aunque menos que antes, pero el estado general es tan satisfactorio, que puede predecirse con seguridad la curación próxima.

Tal es el ejemplo notable que hemos observado. Ahora es posible, con conocimiento de causa, discutir el diagnóstico de la naturaleza de la lesión que preparó el pneumotórax y sacar consecuencias relativas á la patogenia y al tratamiento de casos análogos.

El síntoma predominante desde que ingresó la enferma era, según hemos dicho, la fetidez gangrenosa del aliento y de los esputos. Pero la observación de este fenómeno no permitía deducir que existía en realidad en el pulmón un foco de gangrena. Debe averiguarse ante todo si se trataba de una mortificación verdadera del tejido pulmonar 6 de una simple bronquitis fétida. Suposición tanto más racional en la especie, cuanto que la enferma padeció en Diciembre un primer ataque de bronquitis y otro en Febrero, después del cual no desapareció por completo la tos.

Mas esta hipótesis era poco fundada. En efecto, la bronquiectasia es una complicación tardía de la bronquitis crónica y la alteración de las secreciones bronquiales, y el olor gangrenoso del aliento no se manifiestan de ordinario á los dos meses, sino después de varios años. Además, en el período en que principian á presentarse estos accidentes, es raro que esté alterada la salud general y durante mucho tiempo pueden ser olorosos los esputos y el aliento, sin que padezcan los enfermos. Diremos de paso, 
que uno de los signos mejores de la bronquiectasia es ver coincidir una secreción purulenta y fétida con un aspecto bueno y con la apirexia completa. Además, aunque el aspecto de los esputos recordaba por su tinte grisáceo y los grumos que contenían los caracteres de la expectoración de los bronquiectásicos, eran, al contrario, menos abundantes y de olor distinto. En la bronquiectasia verdadera, los esputos son, unos mucosos é inodoros, otros espesos, purulentos y fétidos, estos últimos recuerdan el olor del cascote y son productos de las fermentaciones. En nuestra enferma, todos los esputos eran de una fetidez horrible, verdaderamente gangrenosa. Los signos suministrados por la auscultación diferían también de un modo esencial. En la dilatación bronquial, los ruidos patológicos son siempre bilaterales y consisten en estertores y gorgoteos, pero en nuestra enferma quedó siempre á salvo el pulmón derecho y jamás oimos un solo estertor en el izquierdo.

Pero lo que acababa de resolver todas las dudas, era el pneumotórax. La perforación pulmonar es un accidente desconocido en la bronquiectasia. Aunque produzca pérdidas de substancias del pulmón y verdaderas cavernas, el proceso es lento, progresivo, y el trabajo de esclerosis concomitante permite á las neomembranas y á las adherencias fibrosas, protejer la pleura. La destrucción del parénquima pulmonar y el pneumotórax, suponen por necesidad una ulceración rápida, lo que jamás acontece en la bronquiectasia.

Debíamos, por lo tanto, deducir que los esputos de nuestra enferma procedían de un foco verdadero de gangrena, situado cerca de la pleura.

En estos casos de esfacelo circunscrito con fístula pleurítica, hay siempre, como lesión inicial, una bronco-pneumonía cortical; pero en este grupo se incluyen casos muy diferentes. 
La bronco-pneumonía tuberculosa produce ante todo, según sabemos, ulceraciones de la pleura que originan piopneumotórax. Había motivos para sospechar que sucediera así en nuestra enferma, porque era de origen tuberculoso ; su madre murió á los treinta y dos años de tisis pulmonar, y la hija, según recordaréis, tosía desde dos mesés antes de ingresar en nuestra clínica. Es verdad que era un período de tiempo muy corto y que rara vez los tuberculosos sub-pleuríticos producen accidentes de perforación tan precoces ; pero la cosa era posible. Debo, no obstante, manifestar que no es este el carácter habitual del pio-pneumotórax de los tuberculosos. En este caso sobreviene la perforación pulmonar, pero no la gangrena, y el líquido del derrame, aunque sea purulento, lo que jamás sucede, nunca.tiene los caracteres de fetidez que en nuestra enferma. Pero esta regla no es fija, y se conocen casos de tuberculosis, en los que bajo la influencia de un mal estado general, se hizo pútrido el derrame.

El examen directo de los esputos y sus reacciones microbianas resolvieron la cuestión. El Dr. Chartier no descubrió en ellos bacilos tuberculosos; pululaban, por el contrario, en el líquido y en los elementos celulares los estreptococos y los organismos habituales de la supuración. No se trataba, por lo tanto, de una tuberculosis anormal.

Queda la clase de bronco-pneumonías sépticas, que son casi siempre origen de las gangrenas pulmonares. El principio de los accidentes en nuestra enferma fue el de una pulmonía ; escalofrío, dolor de costado, disnea ; pero faltaron la tos y la expectoración, jamás hubo expuición sanguínea ni esputos herrumbrosos ; por último, fenómeno más importante todavía, la temperatura fue siempre baja. El médico que asistió primeroá esta mujer, diagnosticó su enfermedad de pleuresía incipiente, más bien que 
de una verdadera pulmonía, y en efecto, este diagnóstico parecía racional.

Era, por lo tanto, algo insólito este principio violento de los accidentes pulmonares, seguido en tan poco tiempo de una perforación de la pleura. No se comportan así las pleuresías consecutivas á una pulmonía cortical ni á una bronco-pneumonía infecciosa. En este caso el derrame es tardío, latente é insidioso en su desarrollo; las complicaciones pleuríticas sobrevienen siempre en el curso de los accidentes pulmonares, y casi nunca originan pneumotórax. Habéis observado varias veces esta evolución especialísima de la pleuresía purulenta cuando depende de una bronco-pneumonía infecciosa. Las dos enfermas, cuya historia he narrado en la Lección anterior y que curaron á beneficio de la operación del empiema, son prueba de ello.

La grippe es menos susceptible aún que la pulmonía de complicarse con pleuresía purulenta, y mi colega el doctor Gaucher, ha referido hace poco tiempo ejemplos de ello. Ignoro si se han observado en esta enfermedad pio-pneumotórax ó gangrena ; pero aunque-se admita la posibilidad del hecho, no es posible invocarla en este caso, porque nuestra enferma no tuvo síntomas de grippe ni reina en este momento una epidemia grippal.

Además, en todos los casos de pleuresía purulenta secundaria á los estados infecciosos, los caracteres clínicos son muy diferentes. La supuración propagada de una bronco-pneumonía séptica, no es por necesidad fétida, y hasta puede sentarse como principio, que lo es pocas veces. Hace dos años publiqué la observación de un caso de pio-pneumotórax, que sobrevino en el curso de una fiebre tifoidea, enfermedad séptica por excelencia; el derrame fue inodoro y jamás se observaron signos de gangrena pulmonar. Para explicar este último sintoma, es necesario una necrosis extensa del parénquima del pulmón, que exige 
para realizarse condiciones especialísimas, dada la abundancia de sus plexos vasculares.

Es dificil explicar un caso como el de nuestra enferma. La idea de una pulmonía, aun cuando sea séptica, no responde á los síntomas observados, y sobre todo á la marcha de los accidentes, cuyo origen es siempre obscuro.

En este caso interviene el puerperio como factor importantísimo.

Señalemos las fechas que han marcado las etapas sucesivas de la enfermedad. El embarazo de esta mujer siguió su marcha regular hasta Marzo; en esta época sobrevino una metrorragia que, para mí, marca el principio de los accidentes, aunque su gravedad fue pasajera. Más de tres semanas después, el 5 de Abril, terminó el aborto; en el intervalo (el 28 de Marzo) se presentaron las primeras complicaciones pleuro-pulmonares que se agravaron de una manera notable desde el día siguiente del aborto.

La significación de esta metrorragia, que duró veinticuatro horas y no volvió á presentarse, es considerable. Puede afirmarse que la placenta se desprendió á medias aquel día y que dejó de vivir el feto. El desprendimiento placentario, insuficiente para determinar la expulsión del huevo, fue causa eficaz de la muerte de la criatura; cuando, tres semanas después se produjo el aborto, el feto estaba ya macerado hacía bastante tiempo.

La enferma conservó en su útero durante estas tres semanas un feto muerto que puede calificarse, en cierto modo, de foco séptico.

Puede hacerse una objeción á esta idea. ¿Es posible considerar como causa de septicemia la presencia de un feto intra-uterino, aun macerado, mientras quedan intactas las membranas? Conozco, señores, que es un argumento fundado. Los hechos diarios prueban que la retención fetal, en los casos de desprendimiento placentario in- 
completo, es, por lo común, poco grave. Se ven casos de embarazo extra-uterino en los que el feto queda retenido un año, dos y más, sin ocasionar accidentes tóxicos; no entra en putrefacción, sino que sufre una transformación molecular, una especie de saponificación. La putridez verdadera sólo se produce cuando los fermentos orgánicoaerobios se ponen en contacto con la substancia putrescible.

Sin embargo, parece indudable que en estas condiciones suelen producirse trastornos inmediatos que preparan la vía á los accidentes sépticos. El feto obra á la manera de un cuerpo extraño; ocasiona por su presencia metritis y trombosis de los senos uterinos. Es, según toda probabilidad, lo que debió pasar á nuestra enferma ; tuvo, á consecuencia de su metrorragia, malestar, dolores lumbares, peso pelviano, síntomas todos que indican se produce en el útero un trabajo lento. No se encontraba bastante mal para permanecer en cama, pero se cansaba al menor esfuerzo. Creo que este período de vago malestar correspondió á la formación de coágulos intra-uterinos.

La trombosis de los senos del útero es una condición predisponente, y muchas veces determinante de embolia pulmonar. Esta esclarece de un modo notable la patogenia de los accidentes torácicos. Ved, en efecto, lo que pasó. El 29 de Marzo, algunos días después de padecer la enferma trastornos uterinos, tuvo de repente, sin prodromos, un escalofrío, sintió á la vez dolor torácico desgarrador $y$ disnea excesiva, sin tos ni expectoración. Notad, señores, la desproporción de los desórdenes funcionales y de la lesión. La ansiedad era excesiva, el malestar grandísimo, y, sin embargo, el médico nada observó al auscultar y la temperatura permaneció baja. ¿No es ésta la marcha y como la rúbrica de la embolia del pulmón? Una trombosis espontánea de la arteria pulmonar, además de ser una 
lesión rara dependiente casi siempre de un estado caquéctico como el cáncer $o ́$ la tuberculosis, no se comporta de esta manera. La localización cortical del foco gangrenoso basta para confirmar la idea de una embolia, porque sabemos que la mayor parte de los infartos ocupan la periferia de los parénquimas.

Podría objetarse á esta hipótesis que la embolia pulmonar se observa de ordinario después del parto, mientras que en nuestra enferma los accidentes torácicos precedieron siete días á la expulsión del feto. Responderé á esto que el desprendimiento placentario ocurrió lo menos quince días antes, lo que crea condiciones de trombosis uterina aptas para ser origen de una embolia venosa. Esta opinión no es hipotética, porque voy á referiros un ejemplo auténtico de fenómenos embólicos que precedieron al parto en circunstancias análogas. Hace dos años ví en consulta, con el Dr. Champetier de Ribes, á una señora de mi clientela, embarazada de siete meses y albuminúrica. La situación era grave, el anasarca estaba generalizado y los párpados abotagados; una cefalea persistente indicaba la inminencia de accidentes urémicos, y temiendo la eclampsia se presentó la cuestión de provocar el parto artificial. En estas condiciones tuvo la enferma escalofrío, dolor de costado y hemoptisis; descubrí estertores fríos y un foco de congestión pulmonar. Dos días después se produjo espontáneamente el aborto, con gran beneficio para la enferma, aunque observé derrame pleurítico ligero en el sitio donde existía la congestión pulmonar, la persistencia de los esputos hemoptoicos indicaba con toda claridad la existencia de un infarto pulmonar. Para completar la demostración, al día siguiente del parto se presentó flebitis en la vena femoral derecha, que era, á no dudarlo, consecutiva á una trombosis uterina.

Interpreté este hecho de la manera siguiente: el feto 
murió bajo la influencia de la albuminuria y se produjo una trombosis de los vasos uterinos que originó después la flebitis de los miembros inferiores y un infarto pulmonar embólico. Lo mismo que en nuestra enferma, el infarto precedió á la expulsión del feto.

Es indudable la realidad de este proceso $y$, lo diremos de paso, en las paridas se observan á menudo dolores de costado fugaces, accesos de opresión que duran algunas horas, acompañados ó no de un ligero movimiento febril y no son consecutivos á enfriamientos, como suele creerse, sino á embolias parcelarias procedentes de coágulos uterinos. Los accidentes son fugaces por lo general é insignificantes y casi nunca se afecta de una manera seria el pulmón.

¿Por qué, pues, evolucionaron en nuestra enferma con tanta rapidez y gravedad los accidentes? ¿Por qué, en vez de un infarto inofensivo, destinado á absorberse en poco tiempo, se produjo un foco de supuración gangrenosa y de necrosis? Es dificil responder á estas cuestiones.

Es posible que procediera el émbolo de un coágulo séptico primitivamente : el feto estaba macerado y pudieron formarse coágulos en un útero inflamado y enfermo ya. No creo que sucediera así por dos razones. Primera, hubiese habido en esta época complicaciones de metritis sépticas que no existían. Segunda, es indudable que entre el momento de aparición del dolor de costado sintomático de la embolia y el aborto, el estado general de la enferma fue relativamente bueno, circunstancia inexplicable si hubiera sido infeccioso desde el principio el coágulo pulmonar.

Creo mucho más probable que el émbolo se hiciera séptico después del aborto. El médico de la enferma me dió un dato importantísimo respecto del particular. El feto fue expulsado el 5 de Abril, pero no las membranas ni la placenta. Estas quedaron en el útero día y medio más, y 
los loquios eran ya fétidos cuando fueron expulsadas. Debo manifestar, que los accidentes por parte de los órganos genitales fueron casi nulos ; bastaron algunas inyecciones locales para destruir el foco séptico. ¡Pero no es posible que estas treinta y seis horas de retención placentaria bastaran para infectar el émbolo!

Esta patogenia no es de exactitud matemática, y no me atrevería á decir de una manera afirmativa cuál fue en este caso la puerta de entrada de los fermentos patógenos. Lo indudable es que hubo una embolia pulmonar según toda probabilidad, de origen genital. Poco importa que el coágulo se infectara primitivamente en el útero $\delta$ secundariamente á consecuencia de una septicemia genital ó tal vez por el contacto mismo del aire en los alvéolos pulmonares. Hubo desarrollo de microbios que produjeron la supuración infecciosa y la necrosis. De aquí la marcha invasora, aunque insidiosa, de la alteración pleurítica y la producción precoz del pneumotórax. De aquí también el hecho clínico interesante de que quedara localizada la lesión pleuro-pulmonar y se defendiese el pulmón por adherencias en la periferia de la zona ulcerada.

Creo que pueden hacerse respecto á este hecho clínico algunas observaciones complementarias. Recordaréis cuán difícil fue el diagnóstico del sitio de la lesión, tan indispensable porque era necesario intervenir é intervenir pronto. La macicez torácica estaba localizada en el cuarto inferiơr del pulmón y el sonido anfórico se oía con más claridad á tres traveses de dedo debajo del ángulo de la escápula. Era lógico suponer que la fístula pleurítica se hallaba en este sitio, y que el derrame ocupaba los puntos declives ; pero no sucedía así. La operación demostró que la macicez no correspondía al foco del derrame y que éste se hallaba situado más arriba y atrás, en el límite superior de la zona anfórica : prueba de la propagación de los 
sonidos bronquiales á través del tejido pulmonar condensado, y de la dificultad grandísima de precisar los focos poco extensos.

Se saca de esta observación otra enseñanza; la urgencia absoluta de evacuar sin perder tiempo el foco pútrido. $\mathrm{Si}$ en el caso actual el éxito respondió á la operación, fue porque se practicó sin perder tiempo y sólo esperé para intervenir á que los signos estetoscópicos fueran claros. En estos casos son utilísimas las punciones exploradoras con la jeringuilla de Pravaz ó con las agujas aspiradoras pequeñas de Potain : en los casos dudosos, cuando se observan accidentes graves, jamás debe titubearse en recurrir á ellas; no agravan la situación y aclaran siempre el diagnóstico.

Por una coincidencia feliz habéis observado esta misma semana la contraprueba del caso precedente y visto morir en cuarenta y ocho horas, sin que fuera posible socorrerle, á un hombre de cincuenta años, que padecía pleuresía fétida consecutiva á un infarto gangrenoso del pulmón. Pero en este caso, se trataba de un alcohólico con cirrosis en el que los accidentes pleuro-pulmonares databan de más de un mes y se habían desarrollado de una manera casi latente, sin tos ni expectoración. El enfermo deliraba y estaba casi comatoso á su ingreso, y no había la menor esperanza de sálvarlo practicando el empiema. Ocho días antes, las probabilidades de la intervención quirúrgica hu. bieran sido más graves.

Es preciso operar en cuanto se diagnostica el derrame purulento de la cavidad de la pleura, y con mucho más motivo si hay fístula pleuro-pulmonar y la expectoración es gangrenosa. En estas circunstancias, cualquier retraso puede ser fatal, y un día de contemporización producirá muchas veces resultados desastrosos, porque los fenómenos de septicemia se propagan con una rapidez prodigiosa. 
Una palabra referente á ciertas precauciones que deben emplearse en el manual operatorio. Habéis visto que, á pesar de las dos punciones exploradoras, no penetré directamente en el abceso. Esto hubiera podido tener inconvenientes graves si, una vez llegado á la pleura parietal, hubiese desbridado en gran extensión la serosa en un solo tiempo, como se aconseja de ordinario. En el caso de que se trata, hubiera dividido el pulmón y producido una hemorragia abundante, muy difícil de contener. No sobrevino este accidente, porque acostumbro á hacer una incisión muy pequeña, capa por capa, en la pleura parietal, y á introducir el dedo para que sirva de conductor, en cuanto puede penetrar en la herida. Creo más prudente obrar así, porque algunas veces se encuentran adherencias fuertes y sin esta precaución podría herirse el parénquima pulmonar. Habéis visto que así me fue posible desprender el pulmón todo alrededor de la abertura de la pleura, y llegar al abceso situado mucho más arriba y atrás. El empiema no se practicó en este caso en el sitio mismo del derrame; pero, gracias á los tubos de desagüe, fue fácil penetrar en la cavidad supurada.

El punto más importante del tratamiento es limpiar bien el foco gangrenoso. Después del empiema me limito, por lo general, á hacer en la cavidad de la pleura irrigaciones abundantes con agua bórica, y desconfio del ácido fénico, que ha producido en ciertos casos accidentes graves, y hasta una vez, según tengo entendido, la muerte del enfermo. Pero en nuestra enferma, á causa de la poca extensión de la cavidad supurada y de la fetidez excesiva de los colgajos esfacelados que la llenaban, derogué esta regla y principié haciendo lavatorios múltiples con agua fenicada al 1 por 100. Después de las primeras irrigaciones empleé las de ácido bórico, para tener seguridad de que no quedaba substancia tóxica en las anfractuosidades Cu.́ícica méptca. - Tomo I. 
de la herida pulmonar. Hice lo mismo los días siguientes, y no suspendí las inyecciones hasta que se eliminaron los últimos colgajos de tejido mortificado, y desapareció por completo el olor. No sigo de ordinario esta práctica en el tratamiento del empiema, y procuro hacer los menos lavatorios posibles ; pero no olvidéis que, en este caso, había un foco séptico que comunicaba por los bronquios con el aire exterior, y que las condiciones eran, por lo tanto, muy diferentes.

A pesar del estado gravísimo en que se encontraba la enferma, todo hace suponer que obtendremos la curación rápida y definitiva. En efecto, las dos hojas de la pleura están unidas por adherencias, que han impedido retraerse al pulmón ; la cavidad es pequeña. Cuando sea completa la reparación pulmonar (ha principiado ya, porque la enferma no tose cuando se hace la inyección), cuando esté bien limpia la herida, podemos estar seguros de que las paredes se adherirán pronto. Hoy es favorable el caso que era gravísimo hace ocho días. Es una satisfacción para el médico, porque si por vacilaciones hubiéramos dejado á la enferma intoxicarse otros cinco ó seis días más, su estado, grave ya, hubiese empeorado, se hubieran afectado los riñones, reduciéndose al mínimum las probabilidades de salvación.

\section{NOTA ADICIONAL}

Las consecuencias de la operación fueron, en efecto, muy benignas. La fiebre cesó desde el 18 de Abril, y sólo salieron con los lavatorios copos pseudo-membranosos poco abundantes. En los días últimos del mes, apenas salió líquido por el tubo ; la enferma se levantó y recobró el apetito ; pero expectoraba de vez en cuando algunos grumos fétidos, aunque su aliento había perdido todo olor. 
El 6 de Mayo se suprimíb el tubo de desagüe, y no salió con los lavatorios partícula alguna. Esta supresión fue prematura, porque en los tres días siguientes volvió á toser la enferma, y expectoró algunas mucosidades purulentas bastante olorosas. El día 10 volvió á colocarse el tubo de desaguie, aunque con cierta dificultad, y la tos y la expectoración desaparecieron desde entonces por completo. El 16 se extrajo definitivamente el tubo. La respiración era buena, los signos del pneumotórax habían desaparecido hacía bastante tiempo, y sólo se oían en el sitio correspondiente al foco algunos estertores finos de desplegamiento pulmonar.

El 20 de Mayo no se notaba signo estetoscópico alguno; la herida operatoria había cicatrizado por completo.

El 4 de Junio salió con alta la enferma curada por completo : un mes después, cuando volvimos á verla, disfrutaba buena salud. 


\section{ACCIDENTES NERVIOSOS CONSECUTIVOS AL EMPIENA}

Sumario : Los accidentes nerviosos graves no se presentan jamás al principio del tratamiento del empiema, sino cuando parece segura la curación.-Descripción de un caso de este género.-Ictus apopléctico ocurrido inmediatamente después de una inyección medicamentosa : accesos epilépticos sub-intrantes y muerte rápida : falta de lesiones cerebrales.-Discusión del caso clínico : no se trataba de un epiléptico, ni de un urémico; es inadmisible la teoria de la embolia cerebral. - Los accidentes epileptiformes pertenecen al orden de los fenímenos reflejos bulbares, y no deben atribuirse ni á la cualidad, ni á la cantidad del liquido inyectado, sino á lo brusco de su penetración.-Existencia de una zona refleja peligrosa cerca del diafragma : hechos en su apoyo. - Evolución y variedad de los accidentes reflejos del empiema. Formas siderantes, apoplécticas ó epilépticas : parálisis fugaces y durables de forma hemiplégica. - Indicaciones terapéuticas.

Los casos diversos de pleuresía purulenta que han ingresado en la Clínica desde hace algunos meses y exigido la operación del empiema, curaron todos, excepto cuando el derrame era de origen tuberculoso. Hoy, gracias á la cura antiséptica, se tiene seguridad casi absoluta de que, una vez hecha la operación, las consecuencias serán benignas y no se presentarán los accidentes infecciosos y sépticos que arrebataban los enfermos hace unos quince años.

Pero hay circunstancias excepcionales en las que puede sobrevenir la muerte mucho tiempo después de haberse salvado, al parecer, el período peligroso y cuando el enfermo parece que va á entrar en convalecencia. No son de temer entonces los fenómenos de absorción purulenta y de septicemia, aunque es posible verlos sobrevenir cuando se efectua mal el derrame y tiende á retraerse la fístula de la pleura. Son trastornos nerviosos repentinos que se mani- 
fiestan por convulsiones, crisis epileptiformes y que comprometen en pocas horas la vida. Un caso desgraciado de este género, que ha ocurrido en la Clínica, va á permitirnos estudiar esta clase de complicaciones mal conocidas aún, y sacar de él consecuencias prácticas desde el punto de vista del tratamiento que ha de seguirse.

Félix B., de treinta y siete años, ingresó en la Clínica el 30 de Junio padeciendo pleuro-pneumonía grave complicada con derrame abundante en el lado izquierdo. Con la primer punción de urgencia practicada el 7 de Julio, salieron 1700 gramos de líquido hemorrágico casi desprovisto de fibrina. Al día siguiente aumentó la congestión pulmonar y principió á reproducirse el derrame : era tan grande la ansiedad respiratoria, que fue preciso practicar una sangría : á pesar del alivio momentáneo, hubo que repetirse la toracentesis á los cuatro días. El líquido extraído, más sanguinolento aún, era algo turbio y contenía glóbulos de pus : podía suponerse que se reproducía con rapidez. En efecto, doce días después de la segunda toracentesis, aunque los accidentes eran menos agudos y había disminuído la fiebre, se hizo necesaria otra nueva punción. Esta vez el líquido del derrame no fue hemorrágico, sino francamente purulento; la urgencia del empiema se imponía.

Cloroformizado el enfermo, se practicó la operación el 2 de Agosto, y se extrajeron unos tres litros de pus. La pleura era gruesa, fibrosa y de consistencia casi cartilaginosa. Inmediatamente después de abrir el espacio intercostal, se lavó la cavidad pleurítica con agua bórica, y se curó la herida con gasa iodoformada y algodón. Como sucede siempre, la fiebre descendió desde el día siguiente y disminuyó la disnea : se oía el murmullo vesicular en el vértice del pulmón izquierdo, pero mezclado con estertores de bronquitis. 
Durante todo el mes de Agosto vimos desaparecer poco á poco los signos de la bronquitis y aumentar las adherencias pleuro-pulmonares. A fin de mes respiraba la tercera parte del pulmón, el pus era escaso, espeso y de buena naturaleza, y el estado general perfecto.

El 25 de Septiembre pesaba nueve libras más el enfermo y habían vuelto al estado normal las dos terceras partes de su pulmón. En Noviembre era casi completa la curación, y las tres cuartas partes del pulmón estaban unidas á la pleura por adherencias fuertes. Pero en la base quedaba una bolsa quística del tamaño de una naranja grande, de paredes duras, que seguía segregando pus y mantenía una fístula torácica. Se había intentado en vano. suprimir varias veces el desagüe, y el enfermo, obligado á. emprender de nuevo su trabajo, nos rogaba aceleráramos. el trabajo de cicatrización.

A principio de Diciembre consulté con mi colega y amigo el Dr. Bouilly para decidir si convenía activar la reparación de la fístula resecando una costilla. Aconsejó no practicar la operación de Estlander, sino inyectar en el foco purulento una disolución de cloruro de zinc. Desde entonces hasta principio de Febrero, es decir, durante siete semanas, se hicieron inyecciones cada tres días, primero con una disolución al 1 por 200 y después al 1 por 100 , sin accidente alguno y con gran beneficio del enfermo, porque la supuración era en esta época insignificante. En todo este período fueron siempre bien tolerados los lavatorios de la pleura, y excepto una sensación de plenitud torácica que jamás llegó á producir dolor verdadero, no. sentía el enfermo molestia alguna ni durante ni después de la operación. La bolsa pleurítica contenía aún 60 á 80 gramos de líquido, y creía yo segura la curación de este. hombre cuando sobrevino la catástrofe que voy á describiros. 
El 6 de Febrero, á las once de la mañana, se hizo la inyección en las mejores disposiciones y en buen estado de salud. Debo decir, que desde ocho días antes había cambiado el personal ; pero el externo encargado de la cura la había hecho ya dos veces sin producir molestia alguna al enfermo. ¿ Se hizo esta vez la inyección con mucha rapidez ó muy hacia abajo en dirección del diafragma? Lo ig. noro. Lo cierto es que inmediatamente después de penetrar el líquido en la bolsa de la pleura sufrió el enfermo un desvanecimiento. Apenas tuvo tiempo de advertir que se enturbiaba su vista y que notaba una sensación extraña cuando palideció, perdió el conocimiento y cayó hacia atrás. En aquel momento la cabeza estaba inclinada á la derecha, del lado opuesto al empiema, y los ojos seguían esta dirección.

Sucedió á esta fase inicial una reacción casi instantánea : la cara se puso congestionada y cubierta de sudor : el enfermo cayó en el coma con la respiración estertorosa ; todo el cuerpo se puso rígido, excepto el lado izquierdo de la cara que se hallaba paralizado: el orbicular de los labios estaba relajado y se elevaba á cada espiración ; las pupilas eran desiguales, la izquierda más dilatada que la derecha, el párpado izquierdo caido, $\mathrm{y}$ el derecho contraido. El reflejo querático abolido á la izquierda se conservaba á la derecha. Estaban abolidas todas las percepciones sensitivas y sensoriales. Las funciones respiratorias se hallaban comprometidas de una manera grave; la respiración era frecuente, difícil y ruidosa : salía de la boca una espuma sanguinolenta y se oían en todo el pecho numerosos estertores: el pulso se hizo en pocos momentos pequeño, débil, casi imposible de contar, y el número de pulsaciones excedió de 160 por minuto. El aspecto clínico era el de un ataque de apoplegía fulminante, con repercusión sobre los centros bulbares. Mi interno, el señor 
Grandhomme, cubrió, sin perder tiempo, de sinapismos el cuerpo del enfermo, y aplicó seis sanguijuelas detrás de la oreja derecha. A los veinte minutos se observaron algunos movimientos espontáneos en el brazo derecho, cesó la rigidez muscular, pero persistió el coma con resolución completa de todos los miembros, hasta la una de la tarde, sin que recobrara el enfermo un instante el conocimiento. A esta hora se presentó el primer ataque epileptiforme que fue seguido de otro al poco tiempo; se sucedieron de este modo las crisis casi sub-intrantes con elevación constante de la temperatura central : de una á tres horas hubo sesenta y un accesos.

Cada ataque se descomponía así : Se anunciaba por la dilatación de la pupila izquierda, después casi instantáneamente por la desviación conjugada de la cabeza y del cuello á la derecha. Sobrevenía á la vez contractura de la mitad derecha de la cara, del cuello y del miembro superior; seguían á esta contracción tónica una serie de convulsiones clónicas del brazo y antebrazo que terminaban por resolución total. Durante toda la duración de la crisis, que no excedía de dos minutos, quedaban inmóviles los miembros del lado izquierdo y el inferior derecho. En el momento de la relajación, la cabeza recobraba su posición normal y la actitud directa, pero los ojos seguían inclinados á la derecha ó ejecutaban movimientos rotatorios alternos.

Este período de accesos epileptiformes sub-intrantes duró toda la tarde, elevándose sucesivamente la temperatura á $39^{\circ}, 5,40^{\circ}$ y $40^{\circ}, 7$ : desde las cuatro cesaron las crisis, pero se acentuó el coma y se presentó estertor traqueal. El enfermo murió á las cinco de la mañana, diez y ocho horas después de principiar los accidentes. Las inhalaciones de cloroformo, los enemas de cloral, las emisiones sanguíneas, las inyecciones de éter fueron impo- 
tentes para calmar las convulsiones, y en nada modificaron la marcha de los accidentes.

Tal es el hecho clínico. ¿Cómo interpretarle, y cuál es su diagnóstico?

Lo primero que se pensó es que se trataba de una simple coincidencia, y que este hombre murió de una afección latente hasta entonces, cuyos efectos se manifestaron de una manera brusca. ¿Cómo admitir en efecto a priori que la inyección en la cavidad de la pleura determinara accidentes mortales en tan poco tiempo, cuando hacía dos meses que se repetían de igual manera, con la misma solución sin el menor inconveniente? ¿ No es racional suponer que este individuo tenía algo oculto y que la explosión de los fenómenos epileptiformes fue un incidente fortuíto é inexperado?

Sólo son posibles dos hipótesis, según estas ideas : $\delta$ se trataba de un epiléptico ó de un urémico.

La epilepsia, á pesar de la apariencia y la sucesión de los ataques, era á la verdad poco admisible. Los antecedentes de este enfermo eran mudos respecto á los trastornos nerviosos, y jamás presentó el menor indicio de neurosis. En segundo lugar, los accidentes que produjeron la muerte diferían de una manera notable del cuadro habitual de la epilepsia. El estado sincopal inicial, que sobrevino de repente, sin coma prodrómico, sin aura, con suspensión respiratoria y fenómenos disnéicos casi instantáneos, recuerda más bien el colapso de la apoplegía que la crisis epiléptica. Las convulsiones tónicas y clónicas, limitadas á un segmento del cuerpo, mientras quedaban en resolución completa la mitad izquierda de la cara y del tronco, son también una anomalía excepcional de la epilepsia y, por último, lo repentino del ataque, haciéndose las crisis sub-intrantes en menos de una hora después del principio de los accidentes, todo esto no concuerda, como 
sabemos, con la marcha de la neurosis ; hasta la misma rapidez de la muerte excluye casi en absoluto la idea de la epilepsia verdadera.

Conviene advertir, también, que en los epilépticos rara vez las causas exteriores obran sobre el retorno y producción de los accesos. Lasègue insistía, con razón, sobre esta especie de fatalidad que hace presentarse la crisis sin motivo apreciable, y no cuando existen causas perturbadoras verdaderas $\mathrm{y}$ activas muchas veces.

El año último vimos comprobada esta especie de ley patológica en un joven que se hizo epiléptico á causa de un traumatismo cerebral. Por una coincidencia singular, había ingresado en la clínica con una pleuresía purulenta, y practiqué el empiema. Durante unos tres meses, pude observar á este enfermo hasta su curación. Lo notable es que jamás, durante su permanencia en el hospital, despertaron las curas la menor predisposición á la repetición de las crisis, $y$, en cambio, las vimos presentarse varias veces por la noche ó á cualquier hora del día sin causa plausible ; y siempre era advertido el enfermo de la inminencia del ataque por la sensación de un aura visceral que partía al parecer del intestino.

No se trataba, por lo tanto, de una epilepsia verdadera; añadiré que tampoco era una epilepsia sintomática de un tumor del cerebro, porque á la autopsia de este enfermo no se descubrió lesión encefálica alguna, y además, según esta hipótesis, hubiera habido trastornos funcionales prodrómicos desde mucho tiempo antes, lo que jamás sucedió.

La uremia era tan inaceptable como la epilepsia. A prio$r i$, en un individuo que padece supuración prolongada, es posible una nefritis, $y$ hasta os he indicado más de una vez la frecuencia de la albuminuria consecutiva al empiema. Pero desde hacía dos meses se analizó en distintas 
ocasiones la orina de este enfermo sin descubrir el menor indicio de albúmina. Además tampoco observamos los trastornos funcionales y el malestar general que existen en las nefritis ; finalmente, último argumento perentorio, los riñones se encontraron sanos al hacer la autopsia.

No puede admitirse, por lo tanto, que el accidente fue fortuíto ; hay que aceptar á la fuerza que la inyección en la cavidad de la pleura fue la causa ocasional y, según toda probabilidad, determinante de los accidentes convulsivos, y que, sin esta desgraciada intervención, no se hubiera alterado la salud de este hombre.

Según dicha hipótesis ¿̨ cómo debe interpretarse la patogenia de esta muerte rápida y por qué mecanismo ocasiona una inyección accidentes tan formidables?

¿Deberemos suponer la penetración directa del líquido de la inyección en los bronquios? El hecho ha sido ob. servado ya, y Boinet ha referido un ejemplo de muerte rápida por asfixia en un individuo al que se le inyectó iodo en un trayecto fistuloso. Pero en este caso la lesión era muy distinta ; había fístula pleuro-bronquial, y el aire de los bronquios comunicaba directamente con el de la cavidad pleurítica. En nuestro enfermo, por el contrario, la pleura era dura, resistente, sin comunicación alguna con los bronquios, y formaba una bolsa de paredes gruesas casi inextensibles. En estas condiciones, era imposible que penetrara en los bronquios el liquido inyectado. Además, nada más distinto á la asfixia que los accidentes cerebrales que produjeron la muerte del enfermo.

¿Admitiremos la hipótesis de una embolia cerebral cuyo origen fuera el pulmón ó el corazón? El hecho nada tendría de inverosímil, porque en toda pleuresía crónica la zona del parénquima pulmonar contigua á la bolsa supurada sufre una esclerosis y pueden formarse en ella coágulos sanguíneos. Un trombo desprendido de las venas 
pulmonares y arrastrado á las cavidades cardíacas izquierdas, hubiera podido ir desde éstas á las arterias encefälicas ; y hasta sin invocar necesariamente un coágulo pulmonar primitivo, el émbolo podía haberse formado en el corazón sin producir trastorno funcional alguno prodrómico. Merece, por lo tanto, discutirse la idea de la embolia.

Los fenómenos clínicos se adaptan a priori bastante bien á esta idea. Una embolia del tronco basilar, cuando no ocasiona la muerte repentina, produce un ictus apopléctico, que va acompañado de trastornos respiratorios y circulatorios inmediatos, como en el caso actual, y se complica muchas veces con crisis convulsivas. Hasta se ven presentarse convulsiones cuando la embolia recae en las arterias de Sylvio, aunque son excepcionales las crisis epileptiformes subintrantes. Feltz ha demostrado que la inyección de los corpúsculos finísimos en las carótidas, determinando embolias capilares, produce isquemia cerebral y convulsiones epilépticas. El cuadro clínico no es en rigor opuesto á la idea de una embolia.

El hecho anatómico se ha comprobado varias veces en estos últimos años, y Vallin, Laveran y Potain, han observado obliteraciones arteriales encefálicas espontáneas en el curso de la pleuresía ó consecutivas á la operación del empiema. Debo, sin embargo, manifestar que la evolución de los accidentes es distinta en este caso. Los enfermos, ya sea mientras dura el derrame ó después de evacuarse éste, son atacados de repente, sin pródromos, de hemiplegia derecha y de afasia ; casi nunca se observa en ellos el estado de mal ni las crisis epileptiformes; por último, la duración de los fenómenos paralíticos es incomparablemente mayor, porque estos individuos tardan en morir una $\delta$ dos semanas, en ocasiones más ; al hacer la autopsia, se descubren las lesiones ordinarias y tan conocidas del reblandecimiento cerebral. 
El caso que nos ocupa no pertenece á esta categoría. No sólo fue muy diferente la evolución clínica de los síntomas, sino negativa también en absoluto la comprobación anatómica. Hicimos con el mayor cuidado la autopsia de este hombre; no descubrimos lesión alguna en los vasos del encéfalo ni en los del bulbo; no había trombosis pulmonar, las cavidades cardíacas no contenían coágulo alguno organizado, ni existía lesión valvular susceptible de producir una embolia. Es, por lo tanto, indudable que el enfermo no murió á consecuencia de la embolia del cerebro.

En vista de esta autopsia negativa, nos vimos obligados á admitir que los accidentes cerebrales que ocasionaron la muerte del enfermo, fueron de índole puramente refleja. En efecto, los centros nerviosos, las meninges, las circunvoluciones, el tejido del bulbo, no presentaban alteración alguna apreciable, ni hemorragia, ni edema, ni distensión exagerada de los pequeños vasos, ni apoplegía capilar. Unicamente los ventrículos contenían algo más exudado que en estado normal, consecuencia de las crisis violentas y de las convulsiones repetidas durante las últimas horas de la vida. En una palabra, la autopsia nada demostró. Como sucede por lo común en los epilépticos que mueren durante un ataque, la violencia de los trastornos funcionales produjo la sideración del sistema nervioso y fue suficiente para ocasionar la muerte.

Creo indudable que el reflejo que ocasionó este quebrantamiento nervioso formidable, partió de la pleura é inte resó desde luego el encéfalo y en particular el bulbo á consecuencia de uno de esos fenómenos de inhibición descritos por Brown-Séquard.

Analicemos los síntomas que se sucedieron en nuestro enfermo. Apenas tocó la pleura el líquido de la inyección cuando sufrió este hombre un verdadero ictus apoplécti- 
co ; palideció, perdió el conocimiento y se inclinó hacia atrás atacado de vértigo ; casi al mismo tiempo se aceleró y debilitó el pulso, la respiración se hizo suspirosa y anhelosá y la cara se congestionó y cubrió de sudor. Todos estos fenómenos implican la idea de un choque difuso sobre la masa encefálica, en particular, sobre el bulbo, que perturbó de una manera activa los centros respiratorios, circulatorio, torácico y vaso-motor. ¿ Se trataba de un espasmo inicial de todas las arterias cerebrales, seguido instantáneamente de un estado paralítico, ó bien el trastorno vascular fue consecutivo al quebrantamiento que sufrió la célula nerviosa? Es imposible decirlo. Pero el carácter repentino y difuso de los accidentes, prueban que la impresión sufrida fue general y que la conmoción se extendió á todo el encéfalo.

Profundicemos más el análisis y averigüemos por qué la pleura, tan tolerante hasta entonces, dejó de serlo de repente. Todo cuanto digamos sobre el particular es hipotético, pero es indispensable discutir estas hipótesis, aunque sólo sea para prevenir, si es posible, catástrofes análogas.

Debemos preguntar, ante todo, si fue la causa la naturaleza de la infección y si era irritante en demasía el lí. quido destinado á modificar la superficie de la pleura. Pero la disolución de cloruro de zinc al 1 por 100 no puede considerarse como un líquido cáustico, y todos los días emplean los cirujanos disoluciones infinitamente más concentradas, al 2 y al 5 por 100 , cuando se trata de corregir supuraciones crónicas. Además, desde un mes antes estaba el enfermo acostumbrado á estas inyecciones, y jamás había notado el más ligero malestar. No hay, pues, que atribuirlo á las propiedades cáusticas de la disolución empleada.

Tampoco creo que pueda considerarse como causa del accidente la cantidad del líquido inyectado. Ya sé que es 
dificil tener datos precisos sobre el particular; pero resulta de la información que hice, que apenas se había inyectado la mitad del contenido de la jeringa, cuando sobrevino el síncope inicial, y esta cantidad no excedia de 50 á 60 gramos. Algunos días antes, con objeto de saber la capacidad de la bolsa supurada, medí con exactitud la cantidad de líquido que podía penetrar, y pude inyectar sin trabajo 80 cent. cúb. Además, comprobamos en la autopsia que era ésta la capacidad del quiste de la pleura.

$¿$ Debemos atribuir á la proximidad del corazón y al hecho de ser la pleuresía del lado izquierdo la gravedad de los accidentes que sobrevinieron? No lo creemos. Es indudable que un choque brusco, transmitido directamente al corazón, es capaz de producir un síncope reflejo, pero los fenómenos son distintos: 6 sobreviene la muerte repentina por suspensión de los latidos cardíacos, 6 bien, después del primer estupor del ventrículo, los síntomas observados son palpitaciones, angustia precordial, dolores que recuerdan la angina de pecho, pero no fenómenos cerebrales convulsivos y comatosos, como los que presentó nuestro enfermo. Es, por lo tanto, poco probable que se interesara directamente el corazón. Además, lo que acaba de hacer desechar tal hipótesis es que las pleuresías izquierdas no son las únicas que provocan accidentes de este género ; Mauricio Raynaud y Roger han publicado casos de derrames que existían á la derecha y que no tenían relación alguna de contigüidad con el corazón. Por consiguiente, el sitio de la pleuresía es un elemento secundario.

Después de reflexionar bastante sobre las causas que debieron producir la muerte de nuestro enfermo, me inclino á atribuirla á dos más particularmente. De una parte, la brusquedad con que fue hecha la inyección y, de otra, la localización de la bolsa quística en la proximidad de la región diafragmática. 
Es indudable que el hecho material de inyectar líquido en la pleura, no constituye una maniobra imprudente. En el momento en que se practica el empiema, se inyectan diariamente grandes cantidades de líquido en la cavidad pleurítica, $\mathrm{y}$ se hacen pasar por ella de ordinario de 6 á 7 litros de agua antes de proceder á la cura definitiva. No se cita un caso siquiera, en el que se hayan presentado en estas condiciones desórdenes cerebrales reflejos, aunque no esté cloroformizado el enfermo y conserve toda su sensibilidad la pleura. Puede decirse, por lo tanto, que la inyección no constituye en sí un peligro ; es al parecer, por el contrario, inofensiva en absoluto.

Quizá suceda todo lo contrario á una pleura rígida, inextensible, como se halla la serosa á los dos ó tres meses de supuración. En estas condiciones, la bolsa quística contrae adherencias por todas partes con el pulmón, el diafragma y la pared torácica. Cuando se hace de una manera lenta y metódica la inyección, la bolsa se distiende gradualmente, sin que el enfermo note molestia alguna; pero si se inyecta de un modo brusco y de golpe la misma cantidad de líquido, el estiramiento de las adherencias pleuro-pulmonares y pleuro-diafragmáticas produce una sensación dolorosa y es causa de accidentes. Aun obrando con precaución, se halla uno expuesto á una falsa maniobra de este género, ya porque el pistón de la jeringa funcione desigualmente, ya porque el trayecto de la fístula es estrecho y tortuoso y exige esfuerzos de presión para ser franqueado. No es raro, en este caso, que el obstáculo opuesto al líquido ceda de repente y que á causa de esto penetre en la cavidad de la pleura con demasiada rapidez. Creo que debió suceder algo parecido en este caso, porque desde algunas semanas antes el trayecto fistuloso se estrechaba cada vez más y el tubo de desaguie tendía á salirse contínuamente. 
Otra causa que contribuyó para mí á ocasionar estos accidentes reflejos, fue la localización de la lesión en la región diafragmática. Toda la zona animada por las expansiones del nervio frénico está dotada de una sensibilidad exquisita, y con la mayor facilidad parten de ella reflejos terribles. Se ha visto más de una vez la exploración quirúrgica de la cara convexa del diafragma provocar crisis sincopales y lipotimias. La presencia de una sonda en este punto produce con frecuencia dolores que irradian al tronco y al hombro, y que van acompañados de una sensación de angustia por poco que durante los esfuerzos de tos toque al pulmón la extremidad del instrumento. Muchas veces se prolonga más la irradiación y origina trastornos nerviosos persistentes. Lépine ha publicado un caso en el que una inyección en la pleura diafragmática fue inmediatamente seguida de dolor intenso con entumecimiento de los miembros superiores; estos síntomas fueron seguidos de una verdadera parálisis, que duró varias semanas.

Cuaṇdo la irritación en vez de obrar sobre la cara pleurítica del diafragma obra sobre la peritoneal, se observan accidentes análogos por completo. Operaciones insignificantes sobre el hígado, son capaces de ocasionar, no sólo el dolor clásico del hombro, sino una sensación de desfallecimiento y de angustia rayana con el síncope. He visto, á consecuencia de la punción capilar de un tumor hepático que se creía un quiste, presentarse dolores atroces que irradiaban por los dos brazos é iban acompañados de una sensación de entumecimiento y de calambre epigástrico que duró varias horas. En ciertos casos hasta los trastornos funcionales son seguidos de verdaderas parálisis, con neuritis y atrofia muscular; en un enfermo cuya historia publiqué (1), la punción de un quiste hemático del hígado fue seguida de fenómenos dolorosos y después, como

(1) Revue de Médecine, 1884.

Clinica aŕdica. - Toyo I. 
en el caso de Lépine, de una parálisis braquial atrófica, que tardó más de un año en curar; jamás recobraron los músculos su integridad.

Existe, por lo tanto, una región cuyo centro se halla en el diafragma, en la que las reacciones reflejas son muy violentas y peligrosas. En los empiemas crónicos, el fondo de saco pleurítico próximo al diafragma, es el último que cicatriza siempre, y, por consiguiente, toda inyección hecha en este período de la enfermedad, tiene grandes probabilidades de excitar la zona frénica. Si en estas condiciones se hace de una manera brusca la inyección, pueden y deben producirse los accidentes.

En 1881 publicó Dumontpallier una observación de este género, que tiene, desde este punto de vista, el valor de una experiencia de laboratorio, y demuestra con toda claridad la patogenia de estos accidentes reflejos, de origen pleuro-diafragmáticos. Fue operada en su clínica de empiema una joven, $y$ todas las mañanas se hacían inyecciones antisépticas en la cavidad de la pleura. Durante algún tiempo las toleró perfectamente, pero un día, al penetrar el líquido en el pecho, sintió desvanecimiento y cefalalgia fuerte; aparecieron á la vez placas congestivas extensas en la cara y en los miembros. Estos accidentes se repitieron los días sucesivos en las mismas circunstancias. No se suprimieron los lavatorios, pero se les hizo con mucha lentitud y cuidado; desaparecieron todas las molestias. Quince días después el encargado de la cura hizo la inyección con más fuerza ; esta vez se sintió mal la enferma y tuvo un verdadero ataque sincopal del que curó por fortuna.

¿No es este caso una demostración de la influencia grandísima del modo operatorio sobre la génesis de los accidentes reflejos?

Es probable también que exista un factor de importan- 
cia capital, cuya apreciación es imposible ; me refiero á la susceptibilidad individual de los enfermos y á su reactividad nerviosa, bajo la influencia de las excitaciones periféricas. Pueden hacerse sobre estos hechos las mismas consideraciones que sobre las parálisis y contracturas de origen traumático. De un número grandísimo de traumatismos, son pocos los que producen accidentes paralíticos, y para esto se necesita una predisposición neuropática particular, individual en absoluto. Es muy probable que en los accidentes consecutivos á las inyecciones pleuríticas desempeñen también un papel importantísimo las influencias nerviosas; quizá hasta algunos de los fenómenos señalados, por ejemplo : ciertas hemiplegias repentinas y durables, entran en la categoría de las manifestaciones neuropáticas puras, aunque, en general, difieren de las parálisis de este género por el predominio de los trastornos motores y la falta de anestesia. Pero la mayor parte de las veces, los trastornos nerviosos graves, convulsivos y apoplectiformes, nada tienen que ver con el histerismo, y en nuestro enfermo no se descubrió antecedente neurósico alguno antes de la catástrofe de los últimos días. Es, no obstante, indudable que para que se presenten efectos reflejos de esta intensidad se necesita un sistema nervioso predispuesto de una manera particular.

El caso que acabo de analizar no es un hecho aislado, y aunque la mayoría de los médicos ignoran hasta la posibilidad de accidentes reflejos durante el empiema, en la literatura médica de estos últimos años se citan bastantes observaciones de este género, para que el Dr. Bouveret, en un capítulo completísimo de su notable obra, haya reunido 26 casos auténticos. Aunque sin hacer la historia de este asunto, os recordaré que las primeras investigaciones sobre el particular se han hecho en Francia. Mi antiguo maestro, el Dr. Roger, refirió, en 1864, en la Socie- 
dad Médica de los hospitales, la historia de una niña, la que tuvo un síncope á consecuencia de una inyección en la cavidad de la pleura, y algunos momentos después convulsiones y delirio. Diez años más tarde, otro médico del Hospital de Niños, el Dr. J. Simon, publicó un caso análogo en la Gazette des Hôpitaux, y al año siguiente (1875) leyó Mauricio Raynaud un trabajo célebre, que se hizo clásico, sobre un caso desgraciado seguido de muerte, en circunstancias análogas por completo á las de nuestro enfermo. Se han ocupado después de este asunto Cayley y Goodhart, en Inglaterra, y Von Dusch, en Alemania.

Todos estos hechos, por una coincidencia singular, son idénticos en cuanto á su origen. Se refieren siempre á enfermos operados hacía mucho tiempo y casi curados, y los accidentes se presentaron á consecuencia de una inyección intra-pleurítica 6 al tocar la pleura con una sonda. Dichos accidentes difieren de intensidad y gravedad.

En ciertos casos, excepcionales por fortuna, la muerte fue casi repentina. Mi colega el Dr. Kirmisson me ha referido un ejemplo que observó siendo interno. Un individuo iba á ser operado de toracentesis : en vez de aspirar el líquido, el instrumento se hallaba, por desgracia, dispuesto de modo que rechazó el aire al pecho ; á los cuatro ó cinco golpes de émbolo, el enfermo palideció y murió : la consecuencia de la distensión de la pleura fue un síncope fulminante. En este caso hubo pérdida repentina del conocimiento, cesaron la respiración y el pulso, y se abrieron los párpados: la muerte fue debida más bien á la suspensión de las funciones bulbares que á la parálisis cardíaca.

Los accidentes no son, por lo común, de una gravedad tan inmediata. Principian por lipotimia ó por un ictus apopléctico, al que sigue una fase de hiperemia cerebral. Se ven presentarse entonces convulsiones más ó menos 
generalizadas, como en nuestro enfermo, después parálisis de extensión y persistencia variables.

La evolución de estos trastornos funcionales es muy diversa.

Por fortuna, sólo en casos raros se ven presentarse después de la primer convulsión crisis epileptiformes subintrantes, como en nuestro enfermo. Por lo general, el acceso es único y no se repite; $\sigma$ si se reproduce, es de tarde en tarde y cada vez con menos violencia. Una vez pasado el ataque, queda entumecimiento y estupidez y con frecuencia también parálisis parciales de predominio hemiplégico. Fenómeno notable: la parálisis corresponde casi siempre al lado del empiema: así al menos se deduce de la estadística de Bouveret, y nuestro enfermo no es una excepción de la regla, porque presentaba resolución paralítica de la mitad izquierda de la cara y de los miembros.

Estas parálisis, fugaces de ordinario, desaparecen sin dejar rastro ; pero otras veces duran mucho tiempo y hasta se hacen permanentes.

Hay en la actualidad en la sala de Cirugía del Profesor Le Fort un enfermo, el que, á consecuencia de una inyección pleurítica hecha después de practicar la operación de Estländer, tuvo una parálisis de este género. Hace más de un año que ocurrió el accidente, y persiste la hemiplegia. Puede preguntarse si en este caso dependen los fenómenos paralíticos de una lesión orgánica del cerebro; pero lo que sabemos de la duración indefinida de ciertas parálisis histéricas, hace dudar de la realidad de una alteración material.

Es decir, que el pronóstico de estos accidentes, grave en general, es imposible afirmarlo a priori, y depende de una multitud de circunstancias. En la mayor parte de los casos, todo se limita á un gran cuidado por parte del enfermo y del médico : otras veces, por el contrario, hay que lamentar verdaderos desastres. 
Respecto al tratamiento, no se halla aún bien determinado, y en las formas graves han fracasado todas las medicaciones empleadas. La indicación primera, en las formas sincopales, es estimular la sensibilidad cutánea por todos: los medios posibles, flagelación, aspersión de agua fría, sinapismos, fricciones, inyecciones de éter ; debe recurrirse simultáneamente á la faradización del frénico y colocaral enfermo con la cabeza algo baja, para oponerse á la isquemia cerebral.

En la fase congestiva, y cuando se presentan convulsiones epileptiformes, las indicaciones son distintas por completo y el tratamiento es muy parecido al de la eclampsia. Es decir, que deben emplearse las inhalaciones de cloroformo y los enemas de cloral á grandes dosis, para. moderar la excitabilidad del cerebro. Quizá sea útil una sangría abundante, y siento que no se empleara este medio en nuestro enfermo durante las crisis sub-intrantes : la emisión sanguínea local que se hizo desde los primeros momentos del accidente, no ejerció al parecer una influencia notable sobre su evolución.

El verdadero tratamiento, en este caso, es profiláctico. El día que se sepa cuál es la causa verdadera de estas. manifestaciones reflejas terribles, será fácil combatirlas.

Por ahora puede sentarse como principio que, excepto. los primeros lavatorios antisépticos de la pleura, que son indispensables casi siempre en el momento de la operación, es necesario abstenerse en lo posible de recurir á inyecciones ulteriores. Cuanto menos se toque una pleura que se halla en vías de reparación, más pronto y con mäs seguridad cicatriza.

A medida que la cavidad de la pleura se va llenando, es preciso aumentar la prudencia para evitar todo lo que puede distenderla é irritarla, y no olvidar que cuando la curación parece sólo cuestión de días es cuando pone en 
peligro la vida del enferino una medicación intempestiva. Creo que deben proscribirse, si no en absoluto, poco menos, las inyecciones intra-pleuríticas, si sólo se trata de activar una cicatrización segura : es mejor que se retrase la curación un día ó dos que comprometerla por agentes modificadores, cuyos efectos pueden ser peligrosos.

Si hay necesidad de recurrir á las inyecciones para terminar el trabajo de reparación de la cavidad pleurítica, debe adoptarse siempre todo género de precauciones para que el líquido inyectado penetre de un modo lento y regular en la cavidad de la pleura. Por no haber observado esta regla, tenemos que deplorar la muerte de un hombre; y para evitar la repetición de estos desastres en el porvenir, he elegido este caso desgraciado como tema de discusión, con el fin de sacar de él toda la enseñanza posible. 


\section{DIAGNOSTICO DE LA CANTIDAD DE LOS DERRAMES PLEURITICOS}

Sumak10: Signos físicos casi idénticos pueden corresponder á derrames de cantidad diferente; dos ejemplos en su apoyo. - La intensidad de los trastornos funcionales nada indica respecto á la proporción del liquido derramado. - El estado del pulmón subyacente es la verdadera dificultad del diagnóstico. - Valor de los diversos signos estetoscópicos ; palpación, percusión y medición.-Importancia de la dislocación de los órganos y causas de error al apreciarla.-Signos de auscultación, medios de apreciar el estado del pulmón, valor de la difusión del soplo.-Causas de error debidas al enfisema y á las adherencias de la pleura.-Resumen.

Hay en clínica cuestiones sobre las que es preciso insistir contínuamente, y que, á pesar de su carácter trivial, 6 mejor dicho á causa de esta trivialidad, son de aplicación práctica diaria. Tal es la pleuresía, con seguridad nada más común ni mejor estudiada que esta enfermedad, y sin embargo, en la práctica, ¡ cuántas veces se cometen errores de interpretación sobre la existencia y cantidad del derrame!

Dos ejemplos recientes van á demostraros cuán difícil es á menudo formarse una idea aproximada respecto al particular. Hace algunos días ingresaron dos enfermos con pleuresía, que presentaban en apariencia signos estetoscópicos idénticos. A pesar de esto, uno de ellos tenía un derrame abundante y el otro mediano. Lo ocurrido después, vino á darme la razón; porque con la toracentesis se extrajeron al primer enfermo más de dos litros de líquido, y al segundo medio litro escaso. La diferencia fue, como véis, considerable, aunque el cuadro clínico era idéntico ; esto me ha inducido á estudiar hoy los signos que permi- 
ten calcular con cierto grado de exactitud la cantidad de los derrames pleuríticos.

Veamos cuál es la historia de estos dos enfermos.

El primero era un cochero de treinta años, que padecía pleuresía de principio típico. El 14 de Abril último lo mojó la lluvia y se enfrió ; aquella misma tarde tuvo dolor en el costado, escalofríos erráticos y fiebre. Persistió este estado con poca intensidad, durante ocho días, el enfermo sentía ligera opresión, estaba abatido y muy fatigado. El 22 se descubrió la existencia de un derrame pleurítico izquierdo y se condujo al paciente al hospital. Observamos los signos estetoscópicos siguientes :

No había combadura torácica, pero los espacios intercostales eran poco móviles, sobre todo, por delante. En todo el lado izquierdo, desde la base al vértice, se notaba macicez; lo mismo sucedía por delante hasta debajo de la clavícula ; no se descubrió timpanitis en parte alguna. Las vibraciones parietales eran nulas en las partes anterior $y$ posterior del tórax, se oían aunque atenuadas á lo largo de la columna vertebral y hacia el hilio del pulmón. En toda la extensión de la zona de macicez se oía un soplo suave más amplio y profundo en la parte superior y posterior del pulmón. La voz resonaba con timbre bronquial y egofónico á la vez, al hablar el enfermo en voz baja, se notaba pectoriloquia afona.

Al examinar órganos inmediatos, se descubrió dislocación notable de las vísceras adyacentes. El corazón estaba desviado y su punta chocaba contra el esternón; la macicez de las cavidades cardíacas derechas se apreciaba á dos traveses de dedo por fuera del borde esternal. El límite superior de la sonoridad gástrica era más inferior que en estado fisiológico, pero se conservaba el espacio de Traube.

A pesar de que estos signos indicaban un derrame re- 
lativamente considerable, la disnea era ligera, el número de inspiraciones no excedía de 30 por minuto, el enfermo tosía poco, conservaba el apetito y podía adoptar sin inconveniente el decúbito dorsal. La fiebre era nula, por decirlo así, pero el pulso latía 100 veces por minuto y las orinas eran de color encendido.

He aquí un tipo de pleuresía franca con derrame rápido. En efecto, al día siguiente de este examen practicamos la toracentesis y extragimos 1700 gramos de serosidad hemorrágica, sin vaciar por completo la pleura. A pesar de esta precaución, el derrame se reprodujo con rapidez, porque á los seis días fue preciso repetir la toracentesis, con la que se extrajo litro y medio de serosidad menos sanguinolenta. Desde entonces perdió su agudeza la afección y la pleuresía siguió una marcha descendente.

Nuestro segundo enfermo, de cuarenta años, sufrí un enfriamiento hace ocho días al descargar unos sacos de carbón. Aquella misma tarde tuvo escalofríos, fiebre, do. lor de costado y siente un intenso dolor submamario. Al ingresar en el hospital, el síntoma predominante era tos seca, frecuente y muy penosa ; se hallaba en decúbito lateral izquierdo, $y$ al hacer el menor esfuerzo para moverse, se presentaban los accesos de tos; la respiración era rápida y anhelosa.

Los signos estetoscópicos eran los siguientes :

No había combadura torácica, como en el otro enfermo. Macicez absoluta, que se elevaba por detrás hasta la espina de la escápula : por delante llegaba hasta la clavícula, y algo por fuera de la línea media del esternón. Las vibraciones eran nulas por delante y por detrás, pero reaparecieron en la parte media del omoplato; se exageraban en la fosa sub-espinosa : se oían también en los tres primeros espacios sub-claviculares.

$\mathrm{Al}$ auscultar se oía en todo el pulmón izquierdo un so- 
plo lejano de timbre agudo bastante fuerte; este soplo se oía también por delante hasta el tercer espacio intercostal; en la base del pecho era menos fuerte. En toda la zona en la que se oía este soplo, la voz era broncofónica, pero no había egofonía excepto arriba, hacia la espina escapular. Lo mismo que en el caso anterior, era bastante característica la pectoriloquia afona.

Por último, para completar la analogía, se notaba también una ligera desviación del corazón, cuya punta latía en el borde external derecho; pero la sonoridad gástrica no había descendido de una manera notable, llegaba hasta una línea que pasaba por el apéndice xifoides, y no descendía por debajo del límite normal. Se conservaba el espacio de Traube.

He aquí dos casos en los que los signos físicos presentaban identidad casi absoluta, y sin embargo, las lesiones eran muy diferentes, porque mientras que en el primer enfermo el pecho contenía cerca de dos litros de líquido, en el segundo sólo se extrajo por la punción medio litro escaso, y sin embargo, la macicez persistió después de la toracentesis lo mismo que antes.

Se saca de la comparación de estos dos hechos una primera enseñanza : los trastornos funcionales que padecen los enfermos no están en relación con la cantidad del derrame, ni sirven para apreciar su abundancia. Nuestro primer enfermo no tenía disnea, ni fiebre, tosía poco, comía con apetito, y sin embargo, el derrame era abundante. El segundo padecía más : tenía opresión, tos, ansiedad precordial, no podía adoptar el decúbito dorsal ni el lateral derecho, y á pesar de esto, su derrame era insignificante.

Es que deben tenerse en cuenta dos factores cuyo papel respectivo no es fácil de demostrar siempre. El primero, la rapidez con que se reproduce el derrame; el segundo, 
el estado del pulmón, que enmascara el foco pleurítico.

Hay grandes derrames que pasan casi inadvertidos y no producen malestar de importancia, siempre que se formen de una manera insidiosa, sin traumatismo pleuro-pulmonar. Al contrario, todo foco purulento agudo, por insignificante que sea, que se desarrolla con rapidez y cambia de pronto las condiciones de la circulación pulmonar, se convierte en origen de trastornos funcionales desproporcionados con la lesión inicial. Esta es una primera causa de error.

La dificultad verdadera del diagnóstico consiste en conocer el estado del pulmón. Es, en efecto, difícil siempre precisar la parte que corresponde á la congestión pulmonar concomitante en los trastornos funcionales y en los signos físicos.

Debe sentarse como principio, que toda pleuresía aguda es en su origen una enfermedad pulmonar. Aun en las condiciones etiológicas más clásicas, el primero que se afecta es el pulmón : la pleura se interesa de un modo secundario, y lo más que puede admitirse es que el proceso morboso se desarrolle al mismo tiempo en ambos. Un enfriamiento torácico influye á la vez sobre el pulmón y sobre la pleura, pero el pulmón, órgano vascular y mucho más sensible, reacciona el primero y con más violencia. De aquí la hiperemia inicial, la fluxión sanguínea activa que se produce siempre en este caso. La pleura obedece á las leyes de todas las serosas y sigue las fluctuaciones patológicas de la víscera que envuelve : lo mismo hace la pia-madre con el encéfalo, el peritoneo con el hígado, el intestino y el útero. En casos rarísimos, por no decir nunca, es la pleuresía un acto morboso primitivo: cuando existe un derrame pleurítico debe buscarse siempre la lesión parenquimatosa subyacente, inflamatoria, séptica ó parasitaria.

En estas condiciones, pueden presentarse dos eventuali- 
dades : ó bien el pulmón, poco infartado, se deja aplastar por el líquido y se forma un derrame abundante en la base del pecho, en el sitio de la víscera rechazada; en este caso se cree algunas veces que el foco es poco abundante y se desconoce su importancia ; sucede esto con más frecuencia en los bríghticos edematosos y en ciertos cardíacos que padecen derrame pleurítico. Por el contrario, un derrame poco abundante coincide muchas veces con un pulmón indurado y condensado, que se sumerje en el seno del líquido y lo rechaza en todas direcciones : á causa de esto, el nivel del líquido se eleva y hay, al parecer, un derrame abundante cuando, en realidad, casi exclusivamente el pulmón es el que está enfermo.

Toda la dificultad del diagnóstico de la pleuresía consiste en determinar, entre los signos observados, cuál depende del pulmón y cuál del derrame concomitante.

A decir verdad, el diagnóstico algo exacto de la cantidad de líquido data sólo de la época de vulgarización de la toracentesis, la que ha permitido comprobar de un modo directo los signos estetoscópicos y compararlos con los resultados de la función. Antes de esta época, los clínicos más expertos sólo contaban con la inseguridad de los medios de exploración del pecho para resolver esta cuestión, y médicos del valor de Chomel, Damoiseau, Trousseau y Woillez, insistían en sus obras sobre la imposibilidad de conocer de una manera cierta la cantidad verdadera de un derrame pleurítico. Por consiguiente, es justo decir que Laënnec, con su genio observador, había conocido á primera vista los signos de presunción más seguros y dictado las primeras leyes que nos guían aún en estos estudios.

Analicemos los diversos signos estetoscópicos que nos permiten conocer una pleuresía.

La percusión suministra, ante todo, una indicación capital : la macicez. Según Laënnec, es el signo más inme- 
diato y menos infiel de los derrames pleuríticos. La gene ración médica posterior á Laënnec participó de su opinión, porque Damoiseau y Grisolle afirmaban sin titubear que era posible diagnosticar con este signo la existencia de 100 gramos de líquido en la cavidad de la pleura, lo que es indudable si el derrame se extiende alrededor de un pulmón hiperemiado. Y, sin embargo, veinte años después, Woillez sostenía, fundándose en piezas anatómicas, ante la Sociedad Médica de los Hospitales, que existen derrames abundantes que no producen macicez alguna, y que el enfisema pulmonar basta para enmascarar, en ciertos casos, derrames hasta de más de un litro de líquido.

Por consiguiente, este signo, casi patognomónico para Laënnec y sus discípulos, falta algunas veces por completo : hay derrames sin macicez.

Abundan, por el contrario, los ejemplos de macicez sin derrame : siempre que por una razón $\delta$ por otra se hace sólido el parénquima pulmonar, hay macicez al percutir : obsérvase esto en la pulmonía masiva, la atelectasia, la congestión pulmonar, los tumores sólidos del pulmón, los quistes hidatídicos, etc.

No basta observar macicez torácica para afirmar la existencia de un derrame; es necesario además que la macicez tenga ciertos caracteres que la dan entonces un valor casi absoluto.

El dedo que percute debe notar una sensación de dureza, con pérdida completa de la elasticidad : cuando persiste ésta, indica casi siempre infarto pulmonar más bien que un derrame pleurítico.

Merece también tenerse en cuenta la extensión de la zona de macicez.

Si es abundante el derrame, se extiende la macicez á la parte anterior del pecho: cuanto más se aproxima á la clavícula, mayor es su abundancia, aunque en la parte 
posterior no se aprecie este signo por encima de la espina del omoplato. La macicez sub-clavicular puede depender en rigor de una induración tuberculosa del vértice, pero es un signo que engaña pocas veces y con el que es posible contar casi siempre para apreciar la cantidad del derrame.

El skodismo es, por el contrario, un indicio falaz, aunque mi maestro Roger le atribuía cierta importancia. Según este observador, el ruido hidro-aéreo indica la existencia de derrames abundantes, y el timpanismo ordinario un derrame de mediana abundancia. Grancher ha vuelto á estudiar este asunto desde el punto de vista del diagnóstico de la naturaleza de la pleuresía, combinando las indicaciones que suministra el tono del sonido con las suministradas por las vibraciones vocales y la intensidad respiratoria. Pero no temo afirmar, que en la práctica es un medio de diagnóstico poco fiel, porque el skodismo está relacionado con la misma frecuencia con la condensación del parénquima pulmonar que con la pleuresía : se observa muchas veces en la pulmonía y en la congestión pulmonar con los mismos caracteres y la misma marcha. Puede, por el contrario, faltar en pleuresías muy diferentes desde el punto de vista de la abundancia del derrame : nuestros dos enfermos son prueba de ello, porque ni en uno ni en otro se observó timpanismo sub-clavicular, aunque el derrame era abundante en el primero y mínimo en el segundo. No debe, por lo tanto, contarse en absoluto con este signo.

La palpación es un medio de investigación utilísimo que nos permite apreciar la falta de las vibraciones torácicas en el punto que corresponde al derrame. Este signo, sobre el que Monneret fue uno de los primeros en llamar la atención, es tan importante como la macicez, y hasta diré que de más valor, porque las condiciones en que se 
observa son relativamente más raras. En efecto, excepto en algunos casos excepcionales, en los individuos de tórax delgado y de voz muy sonora, las vibraciones se apagan siempre que hay líquido en la cavidad de la pleura, y su reaparición indica con toda exactitud el límite del derra. me. Sería, por lo tanto, un error creer con Monneret que es exacta la ley inversa y que persisten las vibraciones torácicas siempre que hay condensación ó induración del parénquima pulmonar. Sabemos hace mucho tiempo que. en ciertos casos desaparecen las vibraciones, aunque no haya indicios de derrame torácico; Woillez indicó el hecho, á propósito de la congestión pulmonar, y Granchez ha insistido de nuevo sobre este asunto en sus estudios notabilísimos sobre la pulmonía compacta y la esplenopneumonía. Cuando en la pulmonía están obstruídos los. bronquios por tapones fibrinosos, son algunas veces tan completas como en las pleuresías más francas la macicez. y la falta de vibraciones torácicas.

Es decir, que al apreciar este signo deben hacerse restricciones, pero éstas nada le quitan de su valor. Es posible afirmar, en general, que la falta de las vibraciones es uno de los signos de presunción del derrame de más importancia, y que cuando se observa en las regiones anteriores del pecho y debajo de la clavícula, puede afirmarse casi siempre que existe un derrame abundante.

En estas condiciones suele notarse, al palpar el pecho, una sensación de plenitud general y de tensión de los espacios intercostales, que es prueba segura de un derrame abundante, pero este signo sólo se observa cuando existen ya los demás, lo que prácticamente le quita parte de su valor.

El examen de los órganos inmediatos suministra indicaciones mucho más constantes, sobre todo cuando la pleuresía es izquierda, si se descubre dislocación progre- 
siva de los pulmones, del corazón y de las otras vísceras.

Se observa, ante todo, extensión insólita en los limites de la macicez pleurítica que se extiende en ciertos casos hasta 2 centímetros más allá del borde external derecho, mientras que el pulmón está rechazado en la canal vertebral, y sólo en este sitio persiste el sonido.

La dislocación del corazón hacia la derecha es un signo bien conocido, sobre el que no necesito insistir; manifestaré, no obstante, que para que tenga valor, desde el punto de vista de la cantidad del derrame, es preciso que la punta del ventrículo se halle más allá del esternón, porque la hepatización pulmonar, al aumentar el volumen del pulmón, basta para dislocar el corazón hacia el mediastino. La dislocación cardíaca en este caso se aprecia, más que por la palpación, por la auscultación, que permite precisar el sitio donde llegan al máximum los ruidos cardíacos.

La disminución de la sonoridad gástrica es un signno bastante bueno, cuando se observa varios días consecutivos y en diferentes períodos del día ; sin estas condiciones tiene, en realidad, poco valor, porque nada más variable que el grado de distensión del estómago, y la presencia ó falta de gases ocasionan errores de importancia.

Pero cuando se ve de una manera regular descender el límite superior de la sonoridad gástrica al noveno 6 décimo espacio intercostal, y sobre todo cuando se borra el espacio de Traube, es posible afirmar con seguridad la existencia de un derrame abundante, que deprime la cara convexa del diafragma.

Estas consideraciones son aplicables también al hígado, pero con más reserva. En efecto, la disminución de la macicez hepática tiene sólo un valor relativo : la hipertrofia del órgano, la laxitud de su ligamento suspensor, hacen que descienda en ciertos casos su borde libre más abajo de las costillas, sin que haya el menor derrame pleurítico, y 
por el contrario, ciertos tumores hepáticos rechazan el diafragma hasta el punto de simular derrames pleuríticos abundantísimos. El descenso del hígado no es un buen signo más que cuando coincide con otras pruebas del derrame, y sobre todo, con la extensión de la macicez á la zona sub-clavicular. En estas condiciones indica, con seguridad, un gran derrame.

No insisto sobre las indicaciones que se sacan por la inspección del tórax, porque son mucho más inseguras. La dilatación del pecho y la combadura no existen siempre, ni aun en los casos de derrame abundantísimo; por otra parte, una mala conformación del tórax puede dar origen á la falta de derrame. Respecto á la medición, es un signo infiel, difícil de aplicar, y no da los resultados prácticos que creyó Woillez; porque el líquido, antes de rechazar los espacios intercostales, rechaza el mediastino y deprime el diafragma, de modo que los derrames serosos abundantes producen, cuando más, una ampliación de 1 á 2 centímetros, de significación siempre dudosa, porque se ignora el perímetro anterior del pecho.

Todos los signos que hemos estudiado hasta ahora son característicos de los grandes derrames ; pero no indican, en manera alguna, cuál es el estado del pulmón que se encuentra detrás del derrame; en las condiciones ordinarias es precisamente el punto que más conviene determinar. Para ello es preciso recurrir á la auscultación.

La auscultación suministra tres signos principales : falta del murmullo vesicular, soplo y egofonía. Cada uno de ellos, considerado aisladamente, no indica necesariamente la presencia del líquido. El murmullo vesicular desaparece por completo en las pulmonías compactas y en la esplenopneumonía : el soplo se oye, en la mayor parte de los casos de congestión pulmonar, con su carácter velado, lejano, y su tono agudo; por último, la egofonía, signo más fiel, 
no es patognomónico, porque hace poco tiempo le oimos en un individuo, en el que la punción capilar demostró la falta del líquido.

Pero si cada uno de estos caracteres es insuficiente por sí sólo para hacer un diagnóstico exacto, su asociación tiene un valor inapreciable y suministra elementos de presunción, que equivalen casi á la certidumbre.

Puede asegurarse que hay un derrame abundante, cuando desaparece por completo el murmullo vesicular en toda la extensión del pulmón, y coexiste la supresión del ruido respiratorio con la macicez anterior sub-clavicular, con la falta de vibraciones torácicas y con la dislocación del corazón. En estas condiciones es fácil observar que el pulmón está rechazado en la canal vertebral, y es posible calcular con exactitud la cantidad del derrame en dos litros, cuando menos.

Las dificultades son mayores si se trata de un derrame menos abundante. En este caso, se asocian de la manera siguiente los signos estetoscópicos : Desde la base del pecho hasta casi el ángulo de la escápula, es nula la respiración y están suprimidas las vibraciones torácicas; por encima de este punto se oyen soplo y egofonía, y vibraciones atenuadas pero sí, perceptibles. Se observa en general cierto grado de desviación del corazón; pero la punta no está rechazada por debajo del pezón derecho; late hacia el borde derecho del esternón ó algo más allá. Cuando se observan estos caracteres reunidos es posible diagnosticar, con bastante probabilidad, un derrame de un litro á litro y medio.

Al contrario, cuando el pulmón congestionado ó hepatizado se sumerge en el líquido pleurítico, es posible evitar el error de creer que existe un derrame abundante, funđándose en los caracteres siguientes :

La macicez, en este caso, es siempre mucho más ex- 
tensa por detrás que por delante : llega muchas veces hasta la espina del omoplato y hasta la región supra-espinosa, mientras que en la parte anterior apenas llega á la línea. mamilar. Es un carácter importantísimo relacionado con la. localización habitual de la hiperemia pulmonar que ocupa. la parte posterior del pulmón.

Las vibraciones torácicas están disminuídas por detrás. en una gran extensión, pero no suprimidas en absoluto; persisten en cierto grado; por poco que la voz del enfermo sea fuerte y de tono bajo, no desaparecen más que en los puntos declives.

El corazón está en su sitio ó se halla algo dislocado; el espacio de Traube se conserva siempre.

La auscultación es, sobre todo, característica. Se oye en toda la extensión del pulmón correspondiente á la macicez, un soplo más ó menos velado 6 más ó menos duro, según los casos, pero de ordinario muy intenso : la voz resuena con un carácter mixto egofónico y broncofónico á la vez; pero en algunas ocasiones hasta se nota el eco de los estertores pulmonares. Esto indica dos cosas : primera, que el pulmón sigue siendo buen conductor del sonido, á pesar de la presencia del líquido, ó en otros términos, que está condensado ó indurado; segunda, que la capa líquida interpuesta es ligera. Además, en este caso, los trastornos funcionales son siempre más acentuados que los derrames exclusivamente pleuríticos; lá tos y el dolor torácicos son más fuertes y duran más tiempo, lo mismo que la fiebre y la disnea : en ciertos casos se descubren, al comprimir, puntos dolorosos á lo largo de los espacios intercostales.

Puede afirmarse, como ley general, que la difusión del soplo, en una gran extensión, casi nunca es compatible con un derrame abundante é indica la existencia de lesiones pulmonares concomitantes.

Pero esta regla tiene una excepción importante. Cuan- 
do el pulmón, aunque condensado y sólido, es rechazado hacia atrás por un derrame abundante, sucede entonces que persiste el soplo y que las vibraciones sonoras se transmiten por el intermedio de la columna vertebral y de las costillas con un timbre bajo casi anfórico. Fundándose en esto, sostenían Béhier y Rilliet y Barthez que el soplo pseudo-cavernoso indica siempre un derrame pleurítico abundante. No creo que sea exacta esta opinión, excepto en el caso especial que acabo de indicar. Prueba de ello es que después de punzar un foco pleurítico, se ve aparecer siempre el soplo anfórico en cuanto no queda líquido en el pecho. Landouzy ha definido perfectamente la naturaleza de este ruido, al llamarlo soplo de la atelectasia pulmonar.

Existe otro elemento de apreciación que debe tenerse en cuenta al calcular la cantidad del líquido pleurítico : es la edad de la pleuresía.

En las pleuresías recientes el pulmón está siempre congestionado : así es que persiste el soplo, aunque el derrame no sea abundante.

El mejor medio de apreciar los progresos, rápidos algunas veces, del derrame, es averiguar el grado de dislocación de los órganos, en particular del corazón, y también seguir la marcha de la macicez en la parte anterior del pecho. Cuando llega á la región sub-clavicular, es raro que la cantidad del derrame no sea de dos litros, y en estas condiciones es más fácil el cálculo.

Si se trata, por el contrario, de una pleuresía antigua, el cálculo es más difícil y las causas de error más numerosas. En este caso el soplo es de ordinario poco pronunciado 6 falto por completo, aunque el derrame sea mediano, porque el pulmón está poco infartado y el derrame se halla enquistado en neomembranas gruesas. Pero conviene tener presente que en las pleuresías antiguas puede haber 
derrames abundantes y manifestarse sólo por los mismos. signos. El error es en este caso perjudicial para el enfermo, porque se diagnostica un derrame poco abundante, cuando. en realidad es enorme. Sucede esto cuando el derrame: pleurítico se encuentra debajo del pulmón sujeto por adherencias, de manera que al acumularse rechaza el diafragma $y$ el mediastino. Bouilly ha referido un ejemplo. demostrativo de esta variedad de pleuresías insidiosas. Un enfermo de la Clínica de Bucquoy padecía disnea excesiva. aunque el derrame al parecer era escaso : la macicez no. excedía del tercio inferior del pulmón, al auscultar se oían hasta abajo soplo y egofonía, y á pesar de esto se extrajeron por la toracentesis dos litros y medio de líquido. $\mathrm{El}$ enfermo murió algunas semanas después, y al hacer la. autopsia se descubrió que el derrame estaba enquistado. entre el diafragma y el pulmón fijo por adherencias.

En los casos de este género se oyen también estertores. finos y roces en la base, que hacen creer en la falta del derrame cuando este es abundantísimo. El hecho es raro, pero no excepcional : se observa de preferencia en los cardíacos y en los bríghticos.

Este capítulo de patología pleuritica se extendería indefinidamente, si se tratara de todos los casos que se observan en clínica. Me contentaré con resumir, en algunas proposiciones sumarias, los medios principales de apreciar la. cantidad de los derrames de la cavidad de la pleura.

Aunque sin seguridad absoluta, es posible hacer un cálculo bastante aproximado, teniendo en cuenta los treselementos siguientes : dislocación del corazón y de los órganos inmediatos; extensión de la macicez pulmonar, sobre todo por delante, debajo de la clavícula y desaparición correspondiente de las vibraciones torácicas ; y, por último, signos de auscultación que indican 6 no el estado de condensación pulmonar. El soplo difuso indica por lo común 
el infarto del pulmón y un derrame pleurítico poco profundo; pero el silencio respiratorio completo es el único signo decisivo para calcular la cantidad del líquido.

Es preciso también tener en cuenta que la exactitud absoluta en el diagnóstico no es tan necesaria hoy, que son inofensivas por completo las punciones exploradoras del tórax. A pesar del análisis más minucioso de los signos estetoscópicos, se observan todos los días casos en los que es dudosa la apreciación del volumen de un derrame. En estas circunstancias no debe titubearse en punzar, adoptando las precauciones antisépticas indispensables, en cuanto se agravan los síntomas funcionales y el estado general ó cuando se estaciona, al parecer, la marcha del derrame, siempre que haya inconveniente en que se comprima el pulmón. 


\section{PLEURESIA DIAFRAGMATICA TUBERCULOSA}

Sumario: Frecuencia de las formas atenuadas de la pleuresía diafragmática : estado latente de los síntomas. - El único fenómeno constante es el dolor frénico en el sitio de elección. - Dificultades de diagnóstico de estas formas ligeras con la pleurodinia, las congestiones circunscritas de la base del pulmón y las peritonitis sub-diafragmáticas. - Hecho que demuestra la estrecha analogía de los síntomas de una pleuresía purulenta sub-frénica y de una hepatitis. - Pleuresias diafragmáticas de repetición : son casi siempre sintomáticas de tuberculosis, cualquiera que sea su forma clínica y la duración del período que separa las recidivas. - Indicaciones terapéuticas.

Tenemos en este momento en nuestras salas dos enfermos con pleuresía diafragmática. Aunque esta afección es menos rara de lo que se ha dicho, dista mucho, sin embargo, de ser común, y hay un verdàdero interés en comparar, desde el punto de vista de los síntomas y de la marcha, estos dos casos, que presentan además ciertas particularidades especiales que conviene conocer.

La primera es una mujer que ocupa el núm. 11 de la sala Delpech. Aunque tiene sólo cuarenta y seis años, se la creería una sexagenaria; tan consumida, quebrantada y flaca se halla. Hace dos meses vino otra vez al hospital con dolor pleurítico y ha ingresado de nuevo con la misma afección. Recordaréis en qué condiciones se presentó este dolor de costado, tan característico como sitio y como intensidad, que bastó para diagnosticar desde luego una pleuresía diafragmática. Después de un día de trabajo, la enferma sintió, sin causa conocida, un dolor punzante, cuyo máximum correspondía á la región epigástrica, pero que se propagaba á toda la base derecha del tórax y co. rrespondía con exactitud á las inserciones del diafragma. 
Este dolor era bastante fuerte para arrancar espontáneamente gritos y para imposibilitar casi en absoluto todo movimiento: la enferma estaba anhelosa, suspendía su respiración, no se atrevía á sentarse ni á bajarse y permanecía en decúbito dorsal sin adoptar el lateral derecho.

Este dolor se exacerbaba y adquiría un carácter más agudo durante ciertos movimientos provocados. Comprimiendo sobre una superficie extensa del abdomen, de manera que fueran rechazados los intestinos hacia el diafragma, notaba la enferma una sensación de desgarradura en la base del pecho. La palpación directa de los últimos espacios intercostales producía el mismo resultado. Pero en ningún punto era el dolor tan fuerte como en el sitio que llamaba Noël Gueneau de Mussy botón diafragmático. Este sitio se encuentra, como sabéis, en la intersección de la prolongación de la décima costilla y de una línea vertical que sigue á lo largo del borde del esternón, y es importante conocerle, porque ciertas formas atenuadas de pleuresía diafragmática se limitan á esta localización dolorosa. En nuestra enferma, los signos eran más completos, y la sensibilidad de los nervios frénicos se manifestaba no sólo por dolor epigástrico, sino también cervical, que se despertaba con seguridad apoyando el dedo entre los dos cabos inferiores de inserción del músculo esternomastoideo.

A estos síntomas funcionales se limitaba casi toda la enfermedad de esta mujer, porque los signos físicos eran casi nulos. El lado derecho del tórax era á la verdad menos móvil que el izquierdo, y las últimas costillas no ejecutaban su movimiento de expansión natural; pero este fenómeno tiene poca importancia, pues implica sólo la idea de un dolor localizado en la base del pecho, sea cual fuere su causa y su sitio. Lo mismo sucede con los otros dos signos que se han indicado en tales casos, que observamos, 
en efecto, en nuestra enferma, pero que, en realidad, son de un valor muy secundario: me refiero á la debilidad del murmullo vesicular, á la disminución de las vibraciones torácicas y la obscuridad del sonido á la percusión. Cierto grado de macicez noindica necesariamente que el pulmón esté congestionado, y con más razón que haya derrame pleurítico. Puede ser simplemente consecuencia de una. contracción refleja de los músculos torácicos bajo la influencia del dolor. Todos los días, en los enfermos que se sospecha padecen tuberculosis, véis variar los resultados de la percusión del vértice del pecho, según la posición que ocupen los miembros superiores y el estado de contracción ó de relajación de los músculos supra-espinosos. En este caso, los músculos abdominales y torácicos están contraídos de un modo instintivo para inmovilizar las costillas y disminuir el dolor; es necesario, por lo tanto, no atribuir una gran importancia á la disminución del sonido. La debilidad del murmullo vesicular es debida á la. falta de ampliación del pulmón y al modo de respiración de la enferma, que respira sólo con sus costillas superiores. Basta muchas veces una inyección de morfina, que calma el dolor, para quedesaparezcan estas diferencias de auscultación. Por último, la disminución de las vibraciones torácicas se halla también en relación con el estado de contractura refleja de las paredes musculares, y aunque tenga quizá más valor que los signos precedentes, no puede considerarse como patognomónica de la pleuresía diafragmática.

En resumen, los signos físicos sólo dan resultados negativos. Casi nunca se oyen roces. Su presencia es un síntoma decisivo, é indica la propagación del proceso inflamatorio pleurítico á la gran cavidad serosa, y la pleuresía no es entonces sólo diafragmática. En nuestra enferma no se oyen roces, ni egofonía, ni timpanitis por encima de 
la zona que ba perdido su sonoridad. Gueneau de Mussy, que estudió tan á fondo todo lo que se refiere á la pleuresía diafragmática, indicó este tono agudo y timpánico como signo frecuente, perceptible inmediatamente por encima de la zona dolorosa : bien que las partes próximas á la región lesionada respiren más bien por una especie de trabajo suplementario, 6 porque en este punto es menor la tensión aérea intra-pulmonar, es la teoría del ruido de Skoda aplicable á todas las lesiones congestivas y fluxionarias del pulmón.

El mismo autor ha señalado el descenso del hígado en las pleuresías diafragmáticas derechas. En resumen, que conviene no olvidar que el diagnóstico de la pleuresía diafragmática se hace casi exclusivamente por la apreciación de los puntos dolorosos y los fenómenos disnéicos, porque falta casi siempre la fiebre, como sucedía en nuestra enferma. Es, por lo tanto, fácil desconocerla muchas veces.

En la pleurodinia se observa un cuadro sintomático bastante análogo. En esta afección el síntoma preponderante es un dolor fuerte de costado, que se exagera al comprimir y al respirar, y va acompañado á menudo de disnea y casi nunca de fiebre. El diagnóstico se funda en los signos siguientes : En la pleuresía diafragmática son dolorosas á la presión las inserciones del diafragma, y principalmente el punto epigástrico ; en la pleurodinia lo son los espacios intercostales. En esta última afección, el dolor provocado por los movimientos inspiratorios es mucho más agudo que el que despierta la presión; en la pleuresía diafragmática sucede lo contrario. Por último, el punto frénico cervical es un signo excelente que resuelve todas las dudas ; pero falta muchas veces en las pleuresías diafragmáticas confirmadas, aunque exista el punto epigástrico; no debe contarse con este signo, que no es constante. 
La marcha de las dos enfermedades da también indicaciones de gran valor: la pleurodinia no dura más que veinticuatro ó treinta y seis horas, mientras que la pleuresía dura cuando menos tres días ; por último, la pleurodinia va acompañada casi siempre de otros dolores musculares de la misma naturaleza, es decir, erráticos, fugaces y móviles, que se presentan de ordinario bajo la influencia de una causa evidente, á saber : un enfriamiento en una persona reumática.

No me ocuparé del diagnóstico de la pleuresía diafragmática con la neuralgia intercostal y la pericarditis ; no hay motivo de error. Pero la congestión de la base del pulmón se la asemeja en ocasiones bastante, tanto más cuanto que esta última enfermedad se complica en ciertos casos con un elemento pleurítico. En una y otra afección predominan el dolor y la disnea; pero la congestión principia casi siempre con más intensidad y va acompañada de escalofríos y de fiebre, mientras que la pleuresía pura es, casi siempre, apirética, al menos en sus formas ligeras. Los mejores signos diferenciales son los que suministra la auscultación. En la congestión pulmonar es raro no oir estertores más ó menos finos, á menudo crepitantes; hay, además, esputos característicos, algunas veces sanguinolentos, siempre adherentes, viscosos, parecidos á una disolución de goma. La tos de la pleuresía diafragmática, mucho más dolorosa, es seca, contenida y sin expectoración. Pero estos signos dejan al clínico en la duda si hay combinación de síntomas que hagan sospechar una lesión pleuro-pulmonar y si los enfermos no saben expectorar.

Tenemos un ejemplo de estas dificultades de diagnóstico en la enferma que ocupa el número 3 de la sala de Santa Teresa; ingresó la semana pasada con dolor de costado, que databa de tres días, y fiebre ligera; el único signo físico era una pequeña disminución del ruido respiratorio al 
auscultar. En realidad, padecía una congestión pulmonar, como demostraron algunos estertores finos que se oyeron al día siguiente; no oimos roces hasta cinco días después. Se trataba, por lo tanto, de una fluxión pulmonar primitiva que se complicó, como sucede casi siempre, con ligera pleuritis secundaria.

Los síntomas diafragmáticos son debidos también á lesiones de proximidad que interesan el peritoneo sub-frénico; tal sucede, por ejemplo, con la peritonitis espontánea que se desarrolla entre el hígado y el diafragma, 6 con la que rodea un quiste hidatídico, $\delta$ con la tuberculosis peritoneal localizada. El diagnóstico es entonces dificilísimo, porque los síntomas son casi idénticos; resultado fácil de comprender, porque es el diafragma el que se interesa, aunque, á decir verdad, por la cara opuesta. En este caso, los vómitos y el hipo son síntomas que pueden ayudar al diagnóstico; son raros en la pleuresía diafragmática y relativamente frecuentes en la peritonitis sub-frénica. En estas condiciones complejas es indispensable averiguar el estado del peritoneo abdominal; si el vientre está de ordinario doloroso y timpanizado, es poco probable que sea la causa la pleura diafragmática. La exploración minuciosa del abdomen revela, en ciertos casos, la existencia de una peritonitis tuberculosa, ó de lesiones viscerales que han producido una inflamación más ó menos circunscrita de la serosa peritoneal.

Es preciso tener presente que algunas veces en el mismo individuo se propagan las lesiones al mismo tiempo á la pleura y al peritoneo, y resulta una sintomatología compleja que participa de las dos afecciones.

Las hepatitis subagudas, complicadas con perihepatitis, simulan la pleuresía diafragmática hasta el punto de confundirse casi con ella. He observado en la clientela privada un caso de este género, en el que era permitida la 
duda. Me consultó hace algunas semanas un oficial de Marina, á causa de un dolor que sentía en el costado derecho. Había padecido disentería en el Senegal, y además, un ataque de hepatitis; á pesar de cierto estado de anemia persistente, quedo, al parecer, completamente bien durante dos años. Cuando le ví, padecía, desde quince días antes, dolor fijo epigástrico y diafragmático, y fiebre irregular de oscilaciones vespertinas; estaba pálido y de color terroso. El hígado no parecía muy grueso, pero era dolorosa la región infra-diafragmática ; la respiración difícil y anhelosa exacerbaba el dolor; la tos era seca y por accesos. ¿ Se trataba de una pleuresía diafragmática ó de una recidiva de la hepatitis, complicada esta vez con abceso del hígado? No me atreví al pronto á decidirme en favor de una $\delta$ de otra hipótesis, pero después de algunos días, deduje que se trataba de una pleuresía, tuberculosa ó purulenta, á causa de algunos fenómenos de auscultación que observé en el pulmón derecho (respiración áspera y espiración prolongada en el vértice, debilidad del murmullo vesicular y estertores lejanos en la base). Quince días más tarde, un edema limitado al octavo espacio intercostal indicaba la existencia de un derrame purulento y el empiema demostró que el abceso era, en realidad, pleurítico.

Resulta de estos hechos, que sería fácil multiplicar, que en ciertas condiciones es dificil el diagnóstico de la pleuresía diafragmática. Conviene también añadir que no termina el trabajo del clínico con reconocer la afección pleurítica, sino que necesita también averiguar la naturaleza y la marcha ulterior de esta pleuresía, cuestiones dificiles en alto grado y sobre las que no hay unanimidad de opiniones entre los médicos.

Es curioso, en efecto, conocer las divergencias tan grandes que hay respecto al pronóstico de la pleuresía diafrag- 
mática. Andral y Guéneau, de Mussy, la consideraban como una enfermedad rara, siempre grave, y con tendencia casi fatalmente á la supuración. Laënnec, á quien llamó la atención la frecuencia con que encontraba, al hacer las autopsias, adherencias pleuro-diafragmáticas, la consideró como un accidente común y benigno en la mayor parte de los casos.

Aunque sin pretensión de terciar en esta contienda, me inclino á colocarme al lado de Laënnec. Creo, como él, que la pleura diafragmática se afecta muy á menudo, y casi siempre primitivamente en relación á las otras regiones de la serosa : la extensión y la localización ulteriores en el diafragma de una pleuresía general al principio es un hecho excepcional. La pleuresía diafragmática supurada es, por el contrario, un accidente rarísimo ; sólo he visto dos casos, y Gueneau de Mussy tenía razón al considerar grave su pronóstico. Pero son, vuelvo á repetir, dos modalidades morbosas diferentes por completo.

La pleuresía diafragmática simple ó exudativa, la más común de todas, es, repito otra vez, una forma inicial de la pleuresía : muchas veces se localiza en la región frénica sin extenderse á otras : en otros casos se extiende y generaliza. En un gran número de casos es seca y adhesiva y produce la sínfisis parcial del pulmón : además, va acompañada de derrames serosos, que casi nunca quedan limitados á la concavidad del lóbulo inferior del pulmón, sino que llegan á la gran cavidad pleurítica.

En ciertos casos coexisten estas dos formas, como lo demuestra el hecho que sigue, referente á nuestra segunda enferma, María F., que ocupa el núm. 17 de la sala Delpech.

Esta mujer, de treinta y cinco años, al principio fuerte y robusta, es una de mis antiguas clientes, y he tenido ya ocasión de asistirla hace tres años. En aquella fecha, in- 
gresó en el hospital Necker con pleuresía diafragmática de las más típicas, dolorosa en exceso. Durante una semana observamos todos los signos de la neuralgia del frénico, incluso el dolor cervical, y en todo este tiempo la pleuresía quedó limitada estrictamente al diafragma, después se mitigaron los dolores á la vez que se presentaban los signos de un derrame, que se hizo tan abundante, que exigió la punción. Extraje de la cavidad pleurítica litro y medio de líquido cetrino: el resto se absorbió, y las consecuencias de la operación fueron normales, porque á las seis semanas salió esta mujer curada por completo, y desde entonces no ha tenido la menor recidiva. Hoy, excepto un grado ligero de debilidad del murmullo vesicular en la base, el pulmón izquierdo es normal por completo.

Por una singular coincidencia, este año, á principio de Abril, ha vuelto la enferma, presentando en el lado derecho los mismos signos de pleuresía diafragmática que presentó en el izquierdo hace tres años. Esta vez la pleuresía es seca, muy dolorosa, con irradiaciones abdominales é hiperestesia difusa de todo el lado del tórax y sin derrame.

Los signos físicos eran mucho menos acentuados que la vez primera, y á pesar de lo cual, desconfiaba de esta pleuresía recidivante. Llamó mi atención que la enferma, aunque no sintió malestar alguno en el intervalo de las dos pleuresías, había enflaquecido bastante y perdido su aspecto de salud. Tosía poco y expectoraba de cuando en cuando esputos algo purulentos. Al auscultar, se oía en el vértice del pulmón derecho respiración áspera y algunos crugidos secos : por último, lo que resolvió todas las dudas fue el que los esputos contenían bacilos. Esta mujer era, por lo tanto, tuberculosa, y el origen probable de la tuberculosis fue la pleuresía diafragmática contraída tres años antes, aunque tan franca y regular en apariencia.

A pesar de la naturaleza más que sospechosa de esta se- 
gunda pleuresía, siguió una marcha rápida hacia la curación, yá las tres semanas pidió el alta la enferma por encontrarse sin dolor en el costado y respirar con libertad. Pero esta vez fue poco duradera la remisión. A fin de Mayo volvió con un tercer brote de granulaciones tuberculosas, no en la pleura, sino en el peritoneo. En la actualidad tiene sensibilidad difusa en el abdomen y dolores fuertes infra-umbilicales, acompañados de disuria. Vomita, digiere mal y presenta facies peritoneal; los signos del vértice derecho se han acentuado, el pulmón principia á reblandecerse y la enfermedad ha entrado en su fase terminal.

La observación de esta mujer pone en claro dos puntos importantes de la historia de la tuberculosis.

El primero es que la tuberculización puede principiar por las serosas, y en particular por la diafragmática, antes de toda otra manifestación morbosa y con los caracteres de una inflamación franca. El segundo, que en las serosas, lo mismo que en los parénquimas, las lesiones proceden por brotes, separados por intervalos de calma que simulan curaciones completas. Inútil parece decir que esto es sólo una apariencia clínica, y es muy posible que en realidad la aparición de las granulaciones se efectue de una manera contínua, preparando en silencio la invasión general de la economía. Pero á la cabecera del enfermo no se observa esta marcha regular, sino más bien una serie de congestiones sucesivas $\delta$ de inflamaciones sintomáticas mezcladas con períodos de remisión. En nuestra enferma la calma duró dos años y medio, y después de la primer crisis de pleuresía diafragmática hubiera sido imposible sospechar la tuberculosis; después de la segunda no era posible la duda, y menos un mes más tarde, cuando se interesaron de una manera irremediable el peritoneo y los parénquimas viscerales. 
Esta evolución, de brotes por accesos, existe también en la primer enferma de que me he ocupado, porque su pleuresía actual es recidivante y la precedió otra ligera ; en la actualidad han desaparecido los síntomas pleuríticos, pero se oyen en el vértice del pecho crujidos; es indudable que existe una tuberculosis latente, aunque progresa de una manera sensible.

Se saca de estos hechos la conclusión clínica de que debe desconfiarse de las pleuresías diafragmáticas recidivantes, porque son de ordinario sintomáticas de la tuberculosis.

$¿$ Existen otros indicios que hagan sospechar, desde que enferma la serosa, la naturaleza del mal? Puede pregun. tarse si la forma anatómica, en la pleuresía diafragmática, influye desde el punto de vista del pronóstico. En teoría parece que deberían ser más temibles las formas secas, porque la tuberculización pleurítica produce casi siempre roces sin derrame. Pero la historia de nuestra segunda enferma, cuya tuberculosis principió por una pleuresía con derrame tan abundante, que exigió la toracentesis, prueba que no hay regla fija alguna respecto al particular. $\mathrm{He}$ observado la contraprueba del caso anterior, á saber : una pleuresía frénica grave, que fue siempre seca y terminó por la curación. Se trataba de una enfermera del hospital Tenon, agregada á mi clínica, la que durante la epidemia de fiebre tifoidea de 1882, á consecuencia del trabajo excesivo, contrajo una pleuresía diafragmática doble, con fiebre elevadísima y angustia indecible. Este estado persistió cerca de un mes, se oían frotes ásperos en los dos lados del pecho y todo hacía temer una tisis aguda inminente. A beneficio de los calmantes y de los revulsivos curó al fin, y hoy es vigilanta en uno de los hospitales de París y no conserva rastro alguno de su enfermedad antigua. No es posible, por lo tanto, fundar el diagnóstico en la presencia ó falta de un exudado. 
En materia de pleuresía es siempre muy difícil hacer un pronóstico lejano, y la interpretación de los hechos se presta bastante á la controversia. Nuestra segunda enferma curó, al parecer, por completo de su pleuresía izquierda y de su derrame. En rigor, podía sostenerse que su segunda pleuresía, la derecha, era independiente de la primera y que marcó el principio de la tuberculosis. Por otra parte, el que cure por completo una pleuresía diafragmática sin dejar rastro seis años después, como en mi antigua enfermera, no permite afirmar que sea inverosímil en absoluto toda sospecha de tuberculosis en este caso. Es posible y hasta probable, pero no cierto. La tuberculosis del diafragma puede comportarse, en efecto, como una tuberculosis local, aislarse, enquistarse, y dejar de ser una amenaza y un peligro para el organismo, al menos durante mucho tiempo, hasta que una circunstancia fortuita despierta su virulencia.

El año pasado he tenido ocasión de hacer una autopsia de las más instructivas desde este punto de vista, y os pido permiso para resumir el caso en pocas palabras : Un joven de veintidós años, borgoñés, no alcohólico, ingresó en el hospital con todos los signos de la tuberculosis miliar aguda y murió á las cuatro semanas. No encontramos, ni en su herencia ni en sus antecedentes, causa alguna plausible para explicar la invasión de esta tuberculosis ; jamás había estado enfermo y sólo sabía que á los cinco años de edad padeció, durante varios meses, una afección indeterminada. La autopsia nos reveló una serie de granulaciones tuberculosas recientes esparcidas por todos los órganos y además una lesión inesperada de tuberculosis antigua. A la parte derecha del diafragma se veía una placa caseosa de 2 centímetros de grosor, dura como la almáciga, de consistencia fibro-cartilaginosa, que inmovilizaba el pulmón hacia su lóbulo inferior; el examen histológico 
reveló la existencia de bacilos. Este cascarón grueso estaba formado por la pleura diafragmática. Es probable, por no decir seguro, que esta lesión se remontaba á la primera infancia y debió quedar latente durante quince años, hasta el día en que causas triviales, el enfriamiento ó el exceso de trabajo, reanimaron el foco tuberculoso y originaron la infección general.

Debéis tener siempre presente estos casos, cuando se trate de pronosticar la suerte futura de una pleuresía diafragmática, y es prudente hacer ciertas reservas sobre las. eventualidades ulteriores. Pero no creáis que la pleuresía diafragmática se tuberculiza con facilidad y que todas las pleuresías frénicas sean sintomáticas. Lo son muchas veces, y me sorprende que este hecho clínico no llamara la atención de un observador tan sagaz como Gueneau de Mussy; pero no lo son siempre. Se observa durante el curso del reumatismo muscular, como manifestación reumática sobre las serosas ; el año pasado ví un ejemplo típico en una joven. En este caso, la evolución es diferente y la marcha de la afección característica ; es á la vez más aguda y más. fugaz, como todas las manifestaciones reurnáticas ; se forma con rapidez el derrame, y es casi siempre doble. Por último, la absorción del derrame y la desaparición del dolor son rápidas, y no quedan los roces de las pleuresías fibrinosas francas.

Se observan también pleuritis diafragmáticas durante las afecciones cardíacas, muchas veces, á consecuencia de un infarto del lóbulo inferior del pulmón ; hace pocas semanas tuvimos en nuestras salas un ejemplo de este género. Por último, todas las afecciones irritativas del pulmón, y en particular las pulmonías, van acompañadas casi siempre de pleuresías localizadas, que revisten en ciertos casos. los caracteres de la pleuresía diafragmática.

En resumen, señores, he procurado demostrar en esta 
conferencia que existe una forma de tuberculosis cuya manifestación inicial es la pleuresía diafragmática. Recordad que, en los niños, la tuberculosis pulmonar compacta principia más á menudo por la base que por el vértice; la pleura diafragmática se afecta entonces de una manera aguda 6 crónica, y sufre la degeneración caseosa. En los adultos, el hecho es raro, pero se observa algunas veces. Por lo general, en ellos son las serosas las que se afectan en primer término, $\mathrm{y}$ al parecer las que padecen de una manera predominante. Pero en esta forma última es raro que la enfermedad progrese de una manera contínua, y se observa de ordinario una serie de brotes pleuríticos, separados por remisiones engañosas.

Las indicaciones terapéuticas se sacan del conocimiento de la naturaleza y de la marcha de la pleuresía diafragmática. En las fases agudas de la afección se combate con eficacia el dolor por las inyecciones de morfina, á las que deben asociarse los revulsivos, de preferencia las ventosas escarificadas $\delta$, en su defecto, los vejigatorios. Después de algunos días, cuando la enfermedad entra en el período subagudo, conviene envolver la base del pecho con esparadrapo de Vigo, que suprime la respiración cutánea y mantiene una atmósfera húmeda, á la manera de una cataplasma, y obra además como alterante local. Es de la mayor importancia ocuparse del estado general, sobre todo en los casos sospechosos. Creo que el arsénico es uno de los mejores medicamentos que pueden emplearse en tales casos, bien solo ó en combinación con el tratamiento cloro-iodurado, según el método de mi maestro el profesor Potain. Sabéis en qué consiste : se administra todas las mañanas, durante semanas, leche, á la que se añade una cucharada de una mezcla de ioduro (5 gramos), de bromuro potásico (10 gramos) y de cloruro de sodio (40 gramos) por 300 de agua. 
Algunos enfermos, en particular los niños, mejoran con el fosfato de cal á la dosis de 2 á 4 gramos por día. Es necesario recomendar el régimen, la higiene y las precauciones contra los enfriamientos, que son la causa ocasional más frecuente de las recidivas de la pleuresía diafragmática. 


\section{CANCER PRIMITIVO DE LA LARINGE}

DIFICULTADES DE DIAGNÓSTICO CON LA PERICONDRITIS CRÓNICA

Sumario : Discusión de un caso de huélfago crónico y de marcha progresiva.-Posibilidad de la compresión de las víss respiratorias por un tumor intra-torácico ó un epitelioma del esófago: signos que indican que la causa primitiva reside en la laringe.-Diagnóstico de las laringitis crónicas que van acompañadas de huélfago : en este caso los síntomas son los de un tumor intra-laríngeo, y el laringoscopio confirma estas presunciones.-Formación brusca de un abceso de la laringe á expensas del tejido celular profundo del cuello.-Valor diagnóstico y pronóstico de este flemón cervical. - i Se trata, en este caso, de una pericondritis supurada, primitiva ó secundaria?-Caracteres, evolución y marcha de la pericondritis : influencia probable del traumatismo en . este caso. - Sólo la terminación de la enfermedad indica que la pericondritis era consecuencia de un epitelioma de la laringe.-Resultados de la autopsia.

Voy á ocuparme hoy de un enfermo cuyo padecimiento, médico y quirúrgico á la vez, ha seguido una evolución insólita, y cuyo diagnóstico es, en la actualidad, difícil. Se trata de un hombre, de cincuenta y nueve años, que ingresó el 4 de Mayo, en la sala de Chauffard, con accidentes de opresión y de huélfago.

La enfermedad se inició de un modo muy obscuro hace ocho meses. Empezó por una sensación de dolor sordo, pero fijo, en la parte anterior del cuello, sin dificultad para respirar ni alteración de la voz. Esta sensación se localizó, asemejándose á un cuerpo extraño que obstruía las fauces; en el mes de Febrero último, principió á tener disfagia y dificultad respiratoria durante las inspiraciones profundas.

Este estado duró dos meses: el enfermo siguió entregado á sus ocupaciones ; pero como la deglución era dolorosa, renunció á tomar alimentos sólidos. La consecuencia de este régimen fue un gran enflaquecimiento. 
A mitad de Abril, cambió el aspecto de la enfermedad. El dolor se mitigó de repente, pero no la disfagia, que aumentó de una manera notable. La voz, clara é inalterada hasta entonces, principió á ponerse ronca. La dificultad respiratoria se acentuó cada vez más, y el 17 de Abril, al caminar algo deprisa, tuvo el enfermo un acceso de sofocación muy alarmante.

En los últimos días del mes se repitieron varias veces los accesos, y en los intervalos se hizo permanente la disnea.

Entonces se decidió á ingresar en el hospital.

Recordaréis el estado en que se encontraba en aquella fecha. Alto, flaco, pálido, de aspecto ansioso é inquieto y con una manera especial de respirar. La respiración era fuerte y ruidosa y se oía á bastante distancia ; este fenómeno se exageraba mucho al menor esfuerzo $\delta$ durante los accesos de tos, que era sonora. La inspiración, en particular, era dificil ; la respiración, aunque dificultada, se efectuaba con alguna más facilidad. A pesar de estos síntomas laríngeos, que recurdaban los del edema de la glotis, la voz se conservaba bastante bien y era sonora; pero de carácter desigual y se sostenía mal; en ciertos momentos se hacía velada y ronca, mientras que en otros seguía siendo clara.

El huélfago, así se llama este modo respiratorio, no tiene en clínica una significación muy exacta. Indica una compresión de las vías respiratorias, bien en la laringe, en la tráquea ó en la bifurcación bronquial. Debemos averiguar, ante todo, cuál era el sitio del obstáculo al paso del aire.

$\mathrm{Al}$ pronto, sospechamos una compresión intra-torácica. Algunos indicios confirmaban, al parecer, esta hipótesis. La conservación de la voz, el timbre sonoro de la tos, su sequedad, la falta de expectoración, á pesar de los accesos frecuentes, estaban de acuerdo con la idea de un obstáculo 
localizado más abajo de la laringe. Observamos además, en este enfermo, una tumefacción notable del cuello, dilatación de las venas yugulares y edema de las regiones supra. claviculares; por último, la exploración minuciosa de las partes laterales del cuello permiten descubrir, por encima de la clavícula derecha, un ganglio duro y voluminoso. Sabéis que es un signo importante de los tumores del mediastino. Pero faltaban muchos signos para que fuera posible afirmar este diagnóstico. El dolor retro-esternal, tan característico, de las neoplasias intra-torácicas, faltaba por completo, y el enfermo sentía molestias en la laringe. Además, no observamos la dilatación de los vasos subcutáneos pre-esternales, que anuncia siempre con mucha antipación la presencia de un obstáculo en la circulación venosa profunda del mediastino ; no había macicez precordial ni debilidad de los ruidos del corazón : estos signos son constantes en los casos de tumores mediastínicos.

La hipótesis de un aneurisma del cayado de la aorta merecía estudiarse más detenidamente.

Una lesión de este género puede quedar en ciertos casos latente durante mucho tiempo, y sólo produce fenómenos de compresión á distancia : el huélfago, la alteración de la voz, la hinchazón del cuello, podían hacer sospechar una ectasia aórtica que comprimiera la tráquea y el nervio recurrente. Mas la falta completa de fenómenos de auscultación en la zona de dicha arteria, la conservación del pulso radial en ambos lados, la integridad completa del corazón, nos hacía dudar. Sin embargo, como presentaba el enfermo un grado notable de ateroma no era irracional admitir una lesión análoga de la aorta : como piedra de toque del diagnóstico creí conveniente prescribir el ioduro potásico, que mejora tan á menudo las condiciones de la circualción aórtica.

El resultado fue distinto del que esperaba. Los síntomas 
de edema glótico y de sofocación se acentuaron casi inmediatamente, á la vez que'se presentaron fenómenos de iodismo, congestión de las mucosas nasal y ocular; á los cuatro días suprimimos la medicación, y los accidentes mejoraron. Este resultado, sin demostrar la falta de lesiones aórticas, indicaba, cuando menos, una intolerancia completa para el medicamento ; conviene advertir que esta intolerancia se observa rara vez en los aórticos verdade. ros, los que toleran, por lo general, muy bien el ioduro.

A los pocos días de examen deseché por completo la idea de una compresión de la tráquea, y me convencí de que era de origen laríngeo. Pero necesitábamos precisar si se trataba de una lesión extra 6 intra-laríngea.

Entre las causas de compresión de la laringe, dos sobre todo producen síntomas análogos á los que presentaba nuestro enfermo; los abcesos retro-faríngeos y el cáncer del esófago.

La idea de un abceso retro-faríngeo era poco verosímil en este caso. Es, de ordinario, como sabéis, una enfermedad rápida, de principio brusco, francamente febril, y produce, en algunos días, todos los accidentes de la disfagia y del edema retro y peri-laríngeo. No existía en el caso actual esta forma clínica. Pero, además del flemón agudo faringeo, hay una forma crónica de evolución obscura, y que corresponde á la adenitis subaguda de los ganglios de la pared posterior de la faringe. En estas condiciones, el diagnóstico suele ser difícil, y el cuadro clínico se asemeja, por más de un concepto, al que observamos en nuestro enfermo. La disfagia es el síntoma predominante, $\mathrm{y}$ además hay ronquera y dificultad á la inspiración. Pero, en este caso, la voz presenta caracteres especialísimos ; es á la vez gangosa y resonante, con un timbre que se ha comparado, con razón, á la voz del pato. Además, al reconocer con cuidado la faringe, deprimiendo con fuerza la base 
de la lengua, se observa combadura de la mucosa faríngea ; por último, aplicando el dedo sobre el punto saliente, se nota renitencia seguida de un choque de retorno brusco, que indica la existencia de un foco líquido. Nada de esto observamos en nuestro enfermo.

La idea de un epitelioma del esófago era mucho más defendible. En efecto, aunque se ve muchas veces desarrollarse esta enfermedad, produciendo signos de inanición progresiva y vómitos contínuos, existen también casos en los que el cuadro clínico se asemeja tanto al de nuestro enfermo, que se confunde con él. Obsérvase esto cuando el neoplasma se propaga directamente desde el esófago á la laringe, y provoca los fenómenos de edema de la glotis y alteración de la voz. En ciertos casos, es distinto el mecanismo : una placa epitélica del esófago poco extensa y casi insignificante infecta los ganglios próximos que comprimen el recurrente y producen afonía y parálisis de la glotis. En 1869 publiqué un caso de este género, en el que se cometió un error de diagnóstico, confundiendo un epitelioma del esófago con un linfadenoma primitivo de los ganglios cervicales.

En nuestro enfermo, la evolución del padecimiento y la asociación de los síntomas, justificaban por completo, en apariencia, esta hipótesis. La duración larga de los fenómenos prodrómicos, el dolor sordo y profundo en el cuello, el predominio de la disfagia, que fue el primer trastorno funcional que vimos aumentar y complicarse con accesos de opresión laríngea ; por último, y sobre todo, el descubrimiento de un ganglio duro supra-clavicular, que tenía todos los caracteres de un ganglio canceroso, constituían otros tantos signos de presunción, que hacían verosímil esta hipótesis.

Mas podían hacérsela objeciones fundadas. La primera y la más importante, que con el cateterismo esofágico no 
se descubría estrechez ni induración alguna, lo que probaba la integridad del esófago. Además, aunque la disfagia era el síntoma predominante, sólo se observaba al deglutir los líquidos, porque la deglución de los sólidos era relativamente fácil; en la estrechez cancerosa del esófago, sucede lo contrario. En segundo lugar, había contradicción aparente entre el sitio del dolor laríngeo y la situación del ganglio infartado, que ocupaba el hueco supra-clavicular, mucho más abajo que el punto donde notaba el enfermo una sensación de constricción penosa.

Era, por lo tanto, poco probable, á pesar de que las apariencias hacían sospechar una afección orgánica, que padeciera este hombre un epitelioma del esófago. La causa del huélfago debía buscarse en la laringe. Quedaban por revisar las diversas lesiones susceptibles de producir este síntoma.

¿Debíamos admitir la hipótesis de una laringitis crónica francamente inflamatoria, complicada con edema de la glotis? Era indudable que estaban hinchados los pliegues ari-epiglóticos. No había de ello la menor duda. La manera de respirar el enfermo, el predominio de la disnea durante la inspiración, el carácter ruidoso de la respiración y los accesos de sofocación que se presentaban al producirse el espasmo laríngeo, lo probaban bien á las claras. Pero faltaban los síntomas propiamente dichos de la laringitis. La voz, en vez de ser afónica, como en las flegmasías verdaderas de la laringe, era sólo ronca; además, la disfagia tan acentuada en nuestro enfermo no existe en el cuadro clínico ordinario de las laringitis. Por otra parte, el edema de la glotis es casi siempre un epifenómeno tardío de las laringitis crónicas, cuya invasión puede predecirse casi con seguridad por los progresos que hacen la afonía y la dificultad respiratoria en la laringe. En nuestro enfermo, la marcha de los accidentes fue muy distinta. 
Además, entre las causas de la laringitis crónica, las dos más comunes, la tuberculosis y la sífilis, no figuraban, al parecer, en la etiología de la enfermedad. La salud de este hombre había sido hasta ahora excelente, y la auscultación del tórax no revelaba indicio alguno de tisis pulmonar. Bien sé que en estos casos el descubrimiento de los signos físicos es difícil y muchas veces dudoso, porque los ruidos pulmonares están enmascarados por el eco del soplo laríngeo : así sucedió en nuestro enfermo; pero la expectoración era nula, lo mismo que la tos, y jamás hubo hemoptisis ; por último, no se oía estertor alguno en el pecho. No era, por consiguiente, admisible la tuberculosis, tanto más, cuanto que los síntomas funcionales y la marcha de los accidentes diferían de los de la tisis laríngea. Los tuberculosos principian por tener afonía, sus padecimientos laríngeos son insignificantes y la disfagia no se presenta en mucho tiempo, hasta que existen á la vez lesiones de la epiglotis, de la basede la lengua y de la faringe.

Tampoco se trataba de una sifilis laringea. Nuestro enfermo areguró no haber padecido accidentes específicos ni presentaba estigma alguno. Por lo demás, excepto ciertas formas de laringitis sifilítica hipertrófica, que deja las cuerdas vocales relativamente intactas, y cuya marcha es lenta, en la mayor parte de los casos domina también la afonía, y los síntomas funcionales son muy distintos.

La hipótesis más plausible, y al parecer la verdadera, era la de un tumor de la laringe, muy probablemente, un epitelioma. Observamos, en efecto, casi todos los síntomas que corresponden á este género de lesión : disnea de principio gradual y lento, con crisis de sofocación y de espasmo glótico, huélfago, desproporcionado al grado de afonía y á los trastornos vocales ; por último, disfagia, que existe muchas veces en tales casos y que falta de ordinario en las afecciones inflamatorias $\delta$ ulcerosas de la 
laringe. Como este hombre se había depauperado, había enflaquecido y se nutría mal, era poco probable que padeciera un pólipo simple de la laringe, y era más racional suponer se trataba de un epitelioma, á juzgar por la fijeza del dolor, la precocidad de la disfagia y los efectos de la lesión local sobre la salud.

Puede objetarse á esta hipótesis que el edema del cuello, observado en este enfermo, no correspondía á la laringe, sino que se hallaba más abajo, hacia las regiones supraclaviculares; que no había infarto de los tejidos peri-laríngeos, y que no se observó tumefacción alguna de los ganglios laterales de la laringe que se escalonan á lo lar. go de los esterno-mastoideos. Pero los estudios notabilíisimos de Krishaber han demostrado que en la mayor parte de los epiteliomas primitivos de la mucosa laringea faltan las adenopatías; sólo se presentan cuando el neoplasma se propaga al esófago y al tejido celular retro-laríngeo, y hasta faltan entonces algunas veces.

Por lo demás, la existencia en este caso de un infarto ganglionar en la región supra-clavicular, aunque rara con relación á un padecimiento de la laringe, tenía cierto valor desde el punto de vista del diagnóstico de la naturaleza del mal. Śblo las afecciones cancerosas producen colonizaciones ganglionares á distancia, y era posible admitir una relación de causa á efecto entre la adenopatía supra-clavicular y la afección laríngea.

De este modo, por exclusión, y teniendo en cuenta sólo el análisis de los síntomas funcionales y de la marcha de los accidentes, deducimos que nuestro enfermo padecía un epitelioma primitivo de la laringe, complicado con edema de la región supra-glótica y generalizado quizá al esófago, en razón de que la disfagia fue uno de los síntomas predominantes desde el principio de la enfermedad.

El examen laríngeo directo con el laringoscopio era el 
único que podía resolver la cuestión. Lo hice varias veces, y mi colega y amigo el Dr. Luc confirmó mi apreciación, apoyándola con su gran experiencia. Al inspeccionar la laringe, descubrimos lo siguiente : Los pliegues ari-epigló. ticos y la epiglotis estaban rojos, hinchados y obstruían en parte el orificio superior de la glotis. Había también implantado en la pared izquierda de la laringe, sobre el cartílago tiroides, un tumor voluminoso, del tamaño de una avellana, casi del de un huevo de paloma, de base bastante ancha y sin pedículo. Este tumor no estaba ulcerado, parecía vascular, pero no se notaba en él exudación hemorrágica alguna.

La opinión del Dr. Luc, de más valor sobre el particular que la mía, fue que se trataba de un tumor epitélico primitivo de la laringe; se fundaba en tres razones principales : la edad del enfermo, que se aproximaba á los sesenta años, la inmovilidad de la lesión, y, por último, su limitación á un lado de la laringe.

Este diagnóstico se aceptó sin titubear, porque correspondía mejor al conjunto de los sintomas y á la marcha de la afección. Parecía inadmisible, en efecto, que la induración laríngea fuese de naturaleza flegmonosa : el desarrollo lento de la enfermedad y la falta de fiebre excluían, al parecer, toda idea de abceso. Tampoco había indicio alguno de infiltración local, ni dolor al comprimir la laringe, y el aspecto caquéctico y pálido del enfermo era el de una afección orgánica.

$\mathrm{Y}$, sin embargo, la marcha de los accidentes demostró que esta hipótesis, inverosímil en apariencia, era en realidad la verdadera.

Recordaréis que en los días que siguieron al descubrimiento del tumor por medio del laringoscopio, se agravaron bastante los síntomas funcionales. La angustia respiratoria era permanente y el huélfago se hizo excesivo ; va- 
rias veces los accesos de sofocación pusieron en peligro la. vida del enfermo. Se imponía la traqueotomía como recurso último, cuando de repente, la noche del 23 de Mayo sobrevino un accidente que cambió por completo el aspecto del cuadro clínico.

Durante un acceso de tos, sintió el enfermo que se rom. pía algo en su laringe : principió á la vez á arrojar esputos sanguinolentos, mezclados con substancias purulentas. Cuando lo ví, al hacer la visita por la mañana, tenía la escupidera medio llena de una expectoración morenuzca, sanguinolenta, más 6 menos mezclada con moco pus. En vez de encontrarse fatigado por estos accesos de tos y esta especie de vómito, se sentía mucho mejor; su voz era más clara y el huélfago excesivo de la víspera, había desaparecido de repente. La disfagia era la única que no se había modificado.

Si bien la respiración era más fácil, se había presentado un síntoma nuevo. El enfermo tenía un dolor agudo á lo largo del externo-mastoideo derecho, y al mover la cabeza sentía mucho dolor. La piel en este punto nada presentaba de anormal, pero la compresión á lo largo del borde interno del músculo era dolorosa.

Aquella tarde misma, observamos una zona de rubicundez y de infarto en el lado derecho del cuello en el sitio. del dolor. Al día siguiente, se propagó el edema desde la laringe á la clavícula y al munón del 1 onibro derecho. La piel estaba tensa, como si fuera á formarse un flemón eritematoso, pero á pesar de esta apariencia alarmante, la fiebre era nula, la voz clara y la respiración mejor que había sido desde un mes antes. La disfagia persistía sin modificarse.

Era indudable que se trataba de un abceso del cuello en vías de formación, con tendencia á ganar la vaina celulovascular contigua al externo-mastoideo. Era indudable 
también que había coincidencia estrecha entre su formación y la desaparición del huélfago. Debía deducirse que el tumor laríngeo, abierto bruscamente, derramó su contenido en el tejido celular peri-laríngeo.

Pero esta hipótesis ponía en duda el diagnóstico que se hizo de la afección orgánica de la laringe, y la significación clínica de este abceso era susceptible de interpretaciones diferentes. ¿ Podía admitirse una complicación flegmonosa producida alrededor de un tumor epitélico ó el tumor considerado hasta entonces como canceroso, era simplemente de naturaleza inflamatoria? El caso de la enfermedad del anterior Emperador de Alemania, demuestra que eran admisibles las dos suposiciones, porque ambas habían sido defendidas por los médicos que lo asistieron, hasta el momento en que se formó el flemón que hizo necesaria la traqueotomía.

Sea lo que fuere, esta complicación inflamatoria agravó bastante el pronóstico, y la vida corrió un peligro inminente, durante varios días, á causa del flemón invasor del cuello que se extendía desde la laringe á la clavícula. La apirexia de los primeros días fue sustituída por fiebre elevada, y aunque la voz siguió siendo clara, volvió á presentarse la disnea á causa del edema del cuello y de la compresión consecutiva de la tráquea. El 28 de Mayo se hicieron incisiones múltiples á lo largo de la vaina del externo-mastoideo y en la región supra-clavicular, con las que se contuvo la marcha invasora del flemón y, gracias á las irrigaciones fenicadas, al desagüe y á la cura antiséptica, tardó poco en cesar la supuración.

Hoy, doce días después de la operación, está transformado nuestro enfermo y cuesta trabajo conocerlo, tan grande es la mejoría del estado local y del general. La respiración es normal por completo, no hay indicio de huélfago ni ronquera: la disfagia que había persistido Cíínica mídica. - Tomo I. 
más que los otros síntomas, ha desaparecido y el enfermo come con apetito substancias sólidas y líquidas, sin sentir el dolor local más ligero. La curación parecería completa, si el examen directo de la laringe no demostrara que subsisten aún lesiones. Queda en el lado izquierdo del cartílago tiroideo un abultamiento de base ancha, mucho menos voluminoso que cuando el primer examen, pero persistente y vascular. ¿Qué significa esta callosidad? ¿Es una simple induración inflamatoria, reliquia del flemón, que procedente de la laringe invadió el tejido celular circunvecino? ¿O se trata de un epitelioma de desarrollo lento, complicado con un abceso intercurrente? La marcha de la enfermedad nos lo dirá de aquí á pocas semanas.

He aquí un caso que estudiamos con el mayor cuidado desde hace un mes, y que á pesar de la intervención de un laringólogo competente, es aún indeciso y obscuro. Nuestro diagnóstico ha sido dudoso durante mucho tiempo; al principio, por espacio de algunos días, creímos posible una lesión intra-torácica que comprimía la tráquea, después, cuando se hizo evidente que la causa única era la laringe, se impuso la idea de un epitelioma laríngeo : una complicación inesperada, un flemón supurado del cuello, pone en duda la realidad de este diagnóstico y hace pensar en là posibilidad de un abceso crónico de la laringe.

Esta eventualidad de una lesión inflamatoria primitiva de la laringe entraña varias cuestiones interesantes.

Ante todo, ¿ cuál fue el sitio original de la flegmasía? No pudo ser la mucosa laríngea, porque en estas condiciones el abceso hubiera sido mucho más precoz, y en pocos días hubiéramos observado una laringitis sobreaguda edematosa que hubiese necesitado la traqueotomía de urgencia. En véz de ser esto así, el huélfago y la disfagia siguieron una marcha paralela lenta, pero contínua, durante varias semanas ; el volumen del tumor, más bien que la infiltra- 
ción de los pliegues ariepiglóticos, era la causa de la opresión que sentía el enfermo.

El abceso tampoco nació en el tejido retro-laríngeo que separa la laringe del esófago, porque aunque la precocidad de la disfagia pudo hacer pensar en esta localización, la constitución anatómica de la región se opone en absoluto á ello. Un flemón desarrollado en este tejido conjuntivo laxo, que desempeña el papel de una serosa, se hubiera difundido inmediatamente en vez de tardar semanas en desarrollarse. Lo prueba la rapidez con que se propagú el proceso inflamatorio en esta región, una vez abierto el ab. ceso laríngeo.

Llegamos á suponer, por exclusión, que el pus quedó retenido mucho tiempo por paredes duras, gruesas é inextensibles. El revestimiento fibroso de los cartílagos reune precisamente estas condiciones. Es, por lo tanto, casi indudable que el abceso fue en su origen pericóndrico.

Hasta es posible precisar más su localización primitiva.

El abceso debió estar localizado por dentro y detrás del cartílago tiroides, hacia su borde posterior y superior. En efecto, el enfermo sentía, desde algunos meses antes, un dolor fijo en el hueso hioides, por arriba y á la izquierda de la laringe, y desde entonces deglutía con dificultad los alimentos sólidos. Además, la voz quedó inalterable durante varias semanas, y aun en la fase más grave de la enfermedad no hubo afonía. Es, por lo tanto, indudable que las cuerdas vocales inferiores quedaron á salvo de la flegmasía y no se hincharon. Por último, la falta de signos precoces de edema de la glotis demuestra también que los pliegues ari-epiglóticos quedaron indemnes hasta el último momento, porque el huélfago desapareció á los pocos minutos de abrirse el abceso traqueal.

Todo concurre, por lo tanto, á hacer admitir la existencia de una pericondrițis crónica inicial en nuestro enfer- 
mo, y esta hipótesis explica perfectamente los síntomas y la marcha de la afección; la lentitud del principio, el dolor cervical profundo, sordo, pero fijo; el desarrollo lento del huélfago á medida que engrosaba el tumor laríngeo y maduraba el abceso; por último, el enflaquecimiento y el estado caquéctico, consecutivos á la insuficiencia de la alimentación y á la inanición progresiva, dependientes de la disfagia.

Queda por averiguar la causa de la pericondritis; debo decir que sólo tengo presunciones sobre el origen de la lesión. Es indudable que no pueden invocarse ni la sífilis ni la irritación producida por el abuso del tabaco. El alcoholismo es dudoso, aunque el enfermo haya hecho más de un exceso. Pero entre sus antecedentes hemos descubierto una causa que puede haber influído sobre el desarrollo del mal. Hace cinco años, al entrar en su casa, fue asaltado este hombre por vagabundos que le comprimieron con fuerza la garganta, pretendiendo estrangularlo. A consecuencia de esta agresión, tuvo durante varios meses dolor laríngeo, persistente, localizado á la izquierda del cartílago tiroides, en el sitio donde fue más fuerte la compresión. Es lógico suponer que este traumatismo grave influye sobre la localización del padecimiento de la laringe. Lo que ignoramos, en absoluto, es la causa que despertó los síntomas adormecidos en apariencia, porque tres años después no se acordaba de este accidente cuando se presentaron el dolor cervical, la disfagia y el huélfago.

Creo, con las salvedades inherentes á un hecho tan complejo, que se trataba de una pericondritis laríngea crónica, debida á un tra umatismo antiguo. Es una enfermedad rara cuya descripción se remonta á 1827, en cuya época Albers, de Bona, publicó las primeras observaciones. Aunque sin hacer una exposición didáctica de este padecimiento, recordaré en pocas palabras los principales caracteres : 
La pericondritis empieza unas veces por el cartílago, otras por la mucosa, pero sea cual fuere el origen de la inflamación, origina siempre el infarto y el desprendimiento ulterior del pericondrio, y, por último, su ulceración $\delta$ desgarradura. En este caso se ven producirse, como sucedió en nuestro enfermo, infiltraciones purulentas por dentro ó por fuera de la laringe, que ocasionan flemones cervicales 6 fístulas laringo-esofágicas. Sucede muchas veces que el cartílago se necrosa primitiva 6 secundariamente, y mantiene de un modo indefinido el huélfago, hasta el punto de exigir la traqueotomía; Krishaber ha referido tres casos de este género.

Clínicamente, los síntomas de la afección están calcados en los que observamos en nuestro enfermo. El carácter más importante es lo insidioso del padecimiento y su marcha lenta; se ve conservarse mucho tiempo la salud en un estado de integridad relativa. Los trastornos funcionales son poco acentuados durante bastante tiempo; el dolor es ligero, pero fijo, y no se exacerba por la compresión; la tos es poco frecuente, casi nula. La disfagia varía y rara vez es $\tan$ acentuada como en el caso actual. La voz se altera de ordinario, pero casi nunca hay afonía completa. $\mathrm{Al}$ examen laringoscópico se descubre un abultamiento de base ancha sin ulcerar, que forma un tumor más 6 menos voluminoso y en ciertos casos mamelonado.

Lo que complica sobremanera el diagnóstico es que la pericondritis se desarrolla á menudo, como lesión secundaria, en la tuberculosis y hasta en el cáncer. Obédénare, en su Tesis ya antigua (1866), refiere ejemplos de este género, y Krieg (1) ha publicado un caso de pericondritis pustulosa de tres años de antigïedad en una tísica. A esto se debe la dificultad en el caso actual; es casi indudable que nuestro enfermo ha padecido pericondritis, y quizá la

(1) Krieg, Arch. f. phat. An. u. Phys., Bd. LXXII, pág. 92, 1879. 
lesión se reduzca por completo á esto y que su origen sea. traumático; pero es probable que haya á la vez una afección orgánicạ de la que es un epifenómeno.

De todos modos, el pronóstico de estos casos es grave. La curación no se obtiene hasta que se necrosa el cartílalago : es una eventualidad afortunada, que no se presenta casi nunca. En un enfermo á quien, siendo interno, practiqué la traqueotomía, en 1869 , á causa de una pericondritis necrósica, jamás pudo eliminarse el cartíląo enfermo, y hasta 1884, fecha de su muerte, tuvo que llevarconstantemente una cánula traqueal. Cuando se presenta la pericondritis como complicación de una lesión tuberculosa $\delta$ de un epitelioma, el pronóstico es más grave, y tal vez suceda así en este caso.

El tratamiento médico en estas condiciones es sólo paliativo. Al principio, durante el período preparatorio del abceso, fueron útiles los emolientes y los antiflojísticos. El enfermo se alivió con las pulverizaciones de cocimiento de adormideras y con los toques con la cocaína : bajo la influencia de esta medicación, disminuyó el espasmo laríngeo. La aplicación de un vejigatorio á la parte anterior de la laringe, mitigó bastante los dolores durante varios días.

Recordad, por el contrario, la influencia que ejerció el i oduro potásico sobre la marcha de la enfermedad. Sólo fue posible administrarlo por espacio de cuatro días : los accidentes de sofocación y de edema de la glotis se hicieron tan alarmantes, que parecía inminente la urgencia de la traqueotomía : la aparición de cierto grado de coriza hizo sospechar que el iodo no era extraño á estos fenómenos; y, en efecto, la supresión del medicamento fue seguida de remisión de los síntomas. Mi colega Huchard ha referido casos de este género.

La verdadera cuestión terapéutica que debe resolverse en este caso es la siguiente : ¿Hay motivos para practicar 
la traqueotomía preventiva con el fin de intentar después una operación directa sobre la laringe, la extirpación de todo el cartílago tiroides $\delta$ de la mitad, por ejemplo? Tal fue la opinión de varios colegas que examinaron al enfermo, y quizá era la verdadera, desde el punto de vista quirúrgico. Es indudable que una operación de esta gravedad tiene tantas más probabilidades de éxito, cuanto antes se practica, en un período en el que no ha perdido fuerzas el paciente y no se ha alterado su estado general. Pero los resultados de la extirpación de la laringe, aun parcial, son tan problemáticos y el trastorno funcional que resulta es tan considerable, que no creo conveniente, en este caso, la intervención quirúrgica. Además, en nuestro enfermo es quizá ya demasiado tarde para intentarla, á causa de su enflaquecimiento y debilidad, no obstante la mejoría que ha tenido. Una de estas dos cosas : $\delta$ se trata de una pericondritis simple, con ó sin necrosis del cartílago, y en este caso este individuo puede vivir mucho tiempo, sin traqueotomía $\delta$ con una cánula si se hace necesaria la operación, ó, por el contrario, la pericondritis va asociada á una lesión orgánica de la larínge, y entonces, hágase lo que se haga, están contados los días del enfermo. Con seguridad que en esta última hipótesis hay más probabilidades de prolongar la vida practicando la traqueotomía, que si se intenta una operación radical de extirpación de la laringe.

\section{NOTA ADICIONAL}

Según supuse, la mejoría observada en nuestro enfermo fue de corta duración. Antes de los quince días, volvieron á presentarse nuevos signos de estenosis laríngea y de huélfago y á la vez una impresionabilidad anormal de la laringe. La inspección laringoscópica se hizo dificil , y sólo pudo practicarse, anestesiando antes con cocaína la muco- 
sa. El 28 de Junio me escribió lo siguiente el Dr. Luc, que había reconocido en su domicilio al enfermo : « La ) tumefacción de la pared lateral izquierda de la laringe, ) ha vuelto á hacerse tan voluminosa como la primera vez. ) Sospechando que existía un nuevo abceso en este punto, „) me disponía á sajar la región afectada, guiándome con el es๖ pejo; pero se ha opuesto el enfermo. Por otra parte, basta ) introducir en la laringe un pincel mojado en cocaína, para ) que se presenten espasmos tan fuertes que creo que, en ) caso de amenaza de astixia, debe preferirse la traqueoto„) mía á todo otro género de intervención operatoria ».

Las previsiones de mi colega no tardaron en realizarse. Hacia el 8 de Julio el enfermo, que había salido del hospital, volvió de nuevo asfixiándose, con los signos de un edema de la glotis creciente de un modo progresivo. El mismo día de su ingreso practiqué la traqueotomía que fue seguida como siempre, de mejoría notable de todos los síntomas y del estado general. El enfermo pudo dormir y comer, pero sin el apetito que caracterizó su primera convalecencia.

Desde el mes de Agosto, aunque los signos locales siguieron en el mismo estado, se hizo evidente que progresaba la caquexia. El enfermo estaba abatido, se nutría mal, tosía y expulsaba por la cánula materias muco-purulentas : pero los esputos jamás fueron şanguinolentos. Esta depauperación progresiva aumentó durante el mes de Septiembre y el paciente murió á principios de Octubre á consecuencia de bronco-pneumonía.

Autopsia (1). - Al examinar la laringe por su parte superior, se ve que la glotis’está estrechada y desviada á la derecha por un tumor del tamaño de una nuez, abolsado y duro, situado en la región lateral izquierda del órgano.

(1) Mi interno Grandhomme me comanicó los resultados de la autopsia, á la que no pude asistir. Los copio casi textualmente. 
Este tumor, examinado después de dividir por medio la laringe, se halla limitado hacia fuera por el cartílago tiroideo, hacia detrás por el aritenoides, hacia dentro por el ventrículò y las cuerdas vocales, las que están hinchadas y aumentadas de volumen, sobre todo, la superior. Asciende hacia arriba por el espesor de los pliegues ariteno-epiglóticos que ha separado: en este punto forma una gran elẹvación y oblitera, en parte, el espacio glótico ; por abajo no llega más allá de la glotis, y deja á salvo por completo las cuerdas vocales inferiores.

La mucosa laríngea está sana, pero hipertrofiada é inyectada en toda la superficie del tumor. En el ventrículo, hacia el sitio de implantación de la cuerda vocal superior, se ve una úlcera tomentosa y vellosa que comunica por un trayecto fistuloso con un desprendimiento extenso del cartílago tiroides : introduciendo por el orificio de la fístula un estilete, se llega al cartílago denudado; es una prueba de la pericondritis cuyos síntomas se observaron en vida.

La región subglótica de la laringe está sana. Los cartílagos se hallan osificados, pero no los ha invadido el tumor.

En la cara anterior de la tráquea, en el sitio donde se apoyaba la extremidad de la cánula, se ve una ulceración estrecha, transversal que llega hasta el cartílago.

No hay indicio alguno de adenopatía de vecindad á lo largo del trayecto de los externo-mastoideos. El tejido celular de la región es escleroso, como sucede siempre después de los flemones. El ganglio supra-cervical observado en vida del enfermo, es duro y voluminoso, pero, al parecer, no lo ha invadido el cáncer, y no tiene aspecto lardáceo. El cuerpo tiroideo es duro y resistente al corte.

En los pulmones hay focos diseminados de broncopneumonía supurada. Los demás órganos están sanos. 
Examen histológico del tUmor. - A simple vista, el tejido del tumor es duro, de aspecto escirroso, no da jugo al rasparse sino grumos blancos amarillentos. EI corte histológico es de aspecto alveolar muy marcadó en ciertos puntos. Los alvéolos están limitados por bridas de tejido conjuntivo que se subdividen y circunscriben alvéolos más pequeños. Los islotes alveolares están constituídos por células de forma variable, epitélicas en unos puntos, epiteloides en la mayor parte de ellos.

La abundancia relativa del estroma y del elemento celular varía bastante, según los puntos que se examinan. En ciertos cortes el tejido fibroide es muy compacto y sólo se descubren algunas células de forma tubular. Por el contrario, el tejido conjuntivo es laxo y las células hipertrofiadas tienen el aspecto de los elementos del carcinoma encefaloide, incluso la degeneración granulo-grasosa que se observa en varios grupos de células epitélicas.

Los vasos del tumor están todos contenidos en el estroma conjuntivo. Acá y allá, los capilares penetran hasta en los tabiques conjuntivos que subdividen los alvéolos.

En resumen : se trata de un epitelioma cuya disposición alveolar se asemeja á la estructura de los carcinomas. Aunque las células del tumor no presenten los caracteres suficientes para permitir incluirlas en una variedad bien definida de epitelioma, es probable, dadas las relaciones del tumor, que naciera en las glándulas de las muoosas más bien que en su epitelio. 


\title{
ENFERMEDADES DEL APARATO CIRCULATORIO
}

\author{
PERICARDITIS AGUDA CON DERRAME
}

Sumario : Descripción de un caso de pericarditis aguda reumática con derrame, complicada con pleuresia. - Muerte repentina la víspera del día en que iba á practicarse la paracentesis del pericardio. - Resultados de la autopsia. - Reflexiones sobre este caso. - Relaciones reciprocas de la pleuresía y de la pericarditis. - Dificultades del diagnóstico de los derrames pericardíacos en los adultos. - Valor negativo de los síntomas funcionales y de la curva térmica, por oposición al carácter del pulso paradógico, que es casi patognomónico. - Valor de los signos físicos, en particular de la percusion, mueho menos infiel que la auscultación: persistencia de los roces, aunque el derrame sea abundante.-Indicaciones de la punción del pericardio y necesidad de practicarla á su debido tiempo.-Sitio electivo de la punción, por fuera y por debajo de la punta del corazón. - Resultados estadísticos de la operacion.

Acabamos de observar un caso desgraciado, pero muy instructivo. Un joven de veinte años ha muerto casi de repente en el curso de una pericarditis aguda con derrame, la víspera del día en que iba á practicarle la paracentesis del pericardio. Una intervención más rápida, hubiera podido salvarle, y por no habernos decidido veinticuatro horas antes, tenemos que lamentar una muerte que nada hacía sospechar iba á ser tan repentina.

Voy á recordaros las circunstancias que prepararon este inesperado desenlace. Este joven, de aspecto robusto, sólo había padecido cinco años antes una fiebre tifoidea.

El $1 .^{\circ}$ de Febrero, á consecuencia de un enfriamento, se sintió mal de la garganta. Esta angina, intensa y febril, 
fue la manifestación primitiva de un reumatismo que invadía cuarenta y ocho horas después las articulaciones de los miembros inferiores, y luego las de los superiores. En este estado ingresó el enfermo en el hospital.

$\mathrm{El}$ aspecto general en aquella fecha (8 de Febrero) era el de un reumatismo articular agudo franco: las coyunturas estaban hinchadas y dolorosas, la fiebre era elevada, el pulso rápido, 130 pulsaciones, y la temperatura oscilaba entre $39^{\circ}$ y $39^{\circ}, 5$. El corazón principiaba á afectarse, y oimos en la punta un soplo sistólico suave, sintomático de una endocarditis mitral. La macicez precordial no había aumentado y nada hacía sospechar la invasión del pericardio; el pulso era duro, lleno y vibrante, á pesar de su frecuencia. Pero la respiración era corta, y al auscultar se oían en las dos bases extertores de congestión pulmonar. La orina era escasa y encendida, pero no albuminosa. El enfermo estaba abatido, pálido y algo abotagado, y parecía hallarse muy grave.

A pesar de un tratamiento activo ( 6 gramos diarios de salicilato de sosa en una poción cordial), las manifestaciones articulares del reumatismo fueron las únicas que desaparecieron ; las fluxiones viscerales se agravaron. Desde el 10 de Febrero, los codos y las muñecas quedaron libres y el dolor de las rodillas disminuyó, pero persistía la opresión. Los ruidos del corazón eran sordos y deficientes; las pulsaciones cardíacas principiaban á ser desiguales; había tendencia manifiesta á la aritmia. Hacia la base del corazón se oía un roce superficial ligero.

Se aplicaron sobre la región precordial ventosas escarificadas, se administraron los calomelanos á dosis refractas : todo fue inútil. El 15 de Febrero, la pericarditis se hallaba en pleno desarrollo y era indudable que se formaba un derrame en la serosa. El choque de la punta del corazón había desaparecido, los ruidos valvulares eran sor- 
dos; el soplo sistólico mitral casi imperceptible. Desde la víspera se había presentado un signo nuevo importantísimo. La percusión, que hasta entonces no indicaba aumento alguno del volumen del corazón, reveló de repente macicez precordial considerable : 15 centímetros desde la base del corazón al diafragma, y 13 de macicez transversal en la línea mamaria. El roce se oía con toda claridad.

En el pecho se habían presentado complicaciones análogas y era indudable que se formaba un derrame abundante en la cavidad de la pleura izquierda. Se oían soplo y egofonía en la base del pulmón, y se notaba macicez en el tercio inferior de la cavidad torácica.

Del 16 al 23 de Febrero observamos los progresos lentos y poco acentuados del doble derrame pleurítico y pericardíaco. Hasta el 22 fue moderada la disnea, 30 movimientos respiratorios por minuto : el enfermo padecía poco, apenas tosía, y sudaba en abundancia ; 100 pulsaciones y $38^{\circ}, 5$. Los purgantes repetidos de aguardiente alemán y 60 centígramos de maceración de digital fueron seguidos de diuresis abundantísima, y el estado general no se agravó, al parecer. Pero algunos indicios demostraban que el derrame del pericardio no había disminuído. La macicez precordial conservaba los mismos límites y el pulso tendía á adquirir el ritmo paradógico; había á cada tres pulsaciones una interrupción regular. La egofonía y el soplo llegaban al ángulo de la escápula, pero la respiración se oía hasta la base, lo que hacía suponer que el derrame se extendia alrededor del pulmón congestionado y que su cantidad era relativamente pequeña.

El 22 de Febrero aumentó de una manera notable la disnea, y el número de movimientos respiratorios se elevó de repente de 30 á 40 : la macicez torácica se extendió hasta la espina de la escápula; los signos de pericarditis 
no variaron. Principió á formarse un derrame ligero en la cavidad de la pleura derecha.

Como el peligro mayor era debido, al parecer, al derra me pleurítico, practiqué la toracentesis y extraje un litro de serosidad obscura algo hemorrágica ; después de esta evacuación, el enfermo tuvo un acceso de tos convulsiva que sólo cedió con una inyección de morfina ; el alivio no fue tan grande como era de esperar. Había indudablemente, detrás de este derrame pleurítico doble, una congestión pulmonar bastante intensa.

Al día siguiente, 23 de Febrero, era mejor el estado general y menor la disnea. El derrame pleurítico no había vuelto á reproducirse en el lado izquierdo; en el derecho era insignificante, pero persistía el soplo pulmonar congestivo.

En la región precordial seguía siendo considerable la macicez, aunque sin haber aumentado gran cosa desde algunos días antes (16 centímetros por 13). Al auscultar se veían roces, no sólo en la base del corazón, sino en una gran zona de la superficie ventricular; el derrame no había progresado, al parecer. Pero el carácter del pulso era paradógico franco ; á cada 2 ó 3 pulsaciones radiales regulares, pero poco marcadas, seguía una pausa que correspondía á un número igual de pulsaciones abortadas ; estas intermitencias eran debidas á la disminución de la tensión arterial, porque no se observaban al auscultar el corazón. Esta dificultad de la circulación arterial no iba acompañañada de trastornos venosos; no había ni cianosis, ni edema de las piernas, ni distensión de las yugulares; los ri. Ĩones seguían funcionando bien y la orina era abundante. En una palabra, no se notaba signo alguno de desfallecimiento ni de insuficiencia cardíaca.

Al día siguiente, después de una noche regular, el estado general era el mismo, pero los signos físicos pulmo- 
nares demostraban que el derrame pleurítico izquierdo principiaba á reproducirse y que el derecho seguía estacio. nario. En vista de esta situación, que siguió siendo grave sin modificarse de una manera franca, rogué á mi colega el Dr. Rigal, me indicara su parecer sobre la conducta que debía seguirse. Observamos ambos que la macicez precordial era extensa, pero no más que los días anteriores ; medía 16 centímetros y medio de altura vertical y 14 de anchura al nivel del pezón. La sonoridad gástrica había disminuído á causa de la depresión del diafragma, pero menos que antes de la punción de la pleura. $\mathrm{Al}$ auseultar se oían siempre numerosos roces, que se extendían desde la base de la aorta hasta la proximidad de la punta del corazón; había motivos para dudar del derrame si la extensión de la macicez y el carácter sordo de los ruidos vasculares no demostraran bien á las claras su existencia; había, además, cierto grado de combadura precordial mayor que en los días anteriores. Por último, no se descubrió edema de la pared torácica ni distensión de las venas yugulares, ni tendencia á las lipotimias ; la respiración era algo difícil (36) y el número de pulsaciones se mantenía entre 110 y 120 . Ambos estuvimos conformes en que se imponía la indicación de la paracentesis del pericardio, pero que no era de urgencia inmediata. Se fijó para el día siguiente por la mañana.

Hacia las cinco de la tarde, fue acometido de repente el enfermo de tos convulsiva, análoga á la que se presentó después de la toracentesis, y expulsó en pocos momentos cierta cantidad de serosidad albuminosa. Mi interno el Sr. Chartier, llamado con urgencia, que le auscultó sin descubrir síntoma alguno nuevo, le hizo aplicar 20 ventosas secas y calmó la disnea por medio de una inyección de medio centígramo de morfina. El enfermo pudo respirar con libertad y se quedó dormido. Pero durante la no- 
che, se presentó de repente otra crisis nueva de sofocación, seguida á los pocos segundos de muerte por asfixia más bien que por síncope.

Tal es el hecho sensible que hemos observado. Véanse las piezas anatómicas, instructivas en alto grado, procedentes de la autopsia de este hombre.

Antes de abrir la cavidad torácica, comprobamos de nuevo los límites de la macicez pericardíaca, y obtuvimos. las cifras siguientes :

Altura del vértice del cono pericardiaco al diafragma. 16 c. 1/2 Anchura de la base diafragmática............... 18 cent.

Anchura media de la región mamaria........... 14 cent.

Estas dimensiones son casi las mismas que las observadas en vida del enfermo. Ahora bien; este pericardio, en el que se oían la víspera roces considerables, perceptibles en los 2/3 de la extensión de la macicez, contiene 750 gramos de serosidad sanguinolenta, análoga á la gelatina de grosella, y coágulos cruóricos acumulados en los puntos declives, detrás del ventrículo. La serosa pericardíaca, en sus dos caras, está roja, violácea, equimótica. Tanto la hoja parietal como la visceral se encuentran tapizadas de neomembranas vellosas de más de un milímetro de altura; son más confluentes en el ventrículo derecho y delante de las aurículas, hacia el sitio de reflexión en la serosa, en el origen de los vasos del corazón. Están empapadas por la serosidad sanguinolenta que llena la cavidad del pericardio ; en algunas se descubren hemorragias intersticiales, prueba de su estructura vascular. Debajo de ellas, la serosa está sin brillo, rugosa y sembrada de equimosis. El corazón mismo es pequeño y se halla contraído; presenta algunas vegetaciones de formación reciente en el borde libre de la válvula mitral; el ventrículo izquierdo contiene un coágulo fibrinoso, que se prolonga hacia el orificio aórtico : 
La pleura izquierda contiene casi un litro de líquido no hemorrágico; el pulmón correspondiente está congestionado y atelectásico; el derecho tiene en su base un núcleo de pulmonía congestiva; no se encuentra, sin embargo, infarto ni trombosis vascular.

Los riñones y el hígado están sanos.

Este caso es notable por más de un concepto. Desde el punto de vista anatómico, tiene un interés verdadero, porque suministra la ocasión, bien rara por cierto, de ver, en el vivo, las lesiones viscerales del reumatismo agudo.

Se dice, como sabéis, que las alteraciones reumáticas son exclusivamente de naturaleza fluxionaria y congesti$\mathrm{va}$, sin que tome parte en ellas la inflamación, por decirlo así. Este caso prueba lo erróneo de semejante afirmación. Es indudable que las flegmasías reumáticas se manifiestan de preferencia por exudaciones serosas, que se absorben pronto sin dejar rastro, pero van acompañadas también de verdaderos procesos inflamatorios; la abundancia de las neomembranas pericardíacas, la existencia de vegetaciones mitrales, la gran proporción de fibrina en el líquido del derrame, todo indica en este caso la realidad de una inflamación llevada á los límites últimos de la agudeza y una diapedesis hemorrágica considerable.

La pulmonía misma, no fue exclusivamente congestiva, aunque turo este aspecto clínico. Hay en la base del pulmón derecho un núcleo de hepatización de los más típicos, y con el microscopio se descubre en él un exudado de naturaleza fibrinosa. Es inexacto, por lo tanto, decir que la pulmonía reumática es una falsa pulmonía, exclusivamente fluxionaria ; es indudable que supura raras veces y que se resuelve siempre con rapidez, pero el proceso anatómico es el mismo; sólo difiere el agente patógeno, y esto basta para imprimir á la marcha de la afección un carácter especial.

Clinica médica. - Tomo $\mathrm{I}$. 
Merecen discutirse también las relaciones recíprocas de la lesión pericardíaca y de las alteraciones pulmonares, porque su patogenia es susceptible de interpretarse de varias maneras, y tiene una importancia clínica grandísima. La regla en estos casos es la coexistencia de una pericarditis y de un derrame pleurítico, y esta asociación de las lesiones se indicó hace mucho tiempo en el trabajo de Roger sobre la pericarditis infantil y en las Monografías de Claisse y de Picot sobre el reumatismo de la infancia. Pero aunque es indudable la influencia reumática sobre esta doble lesión, no basta para explicarlo todo. Duroziez ha observado el hecho interesante de que el reumatismo visceral rara vez da origen á la pleuresía cuando se localiza en el endocardio ; si ataca, por el contrario, el pericardio, es muy raro que quede á salvo la pleura, y entonces se desarrolla de preferencia una pleuresía izquierda. Hay en esto algo más que una influencia constitucional : hay también una cuestión de localización morbosa particular. Según toda probabilidad, las relaciones íntimas de las serosas pericardíaca y pleurítica explican la facilidad con que se propaga la inflamación de una á otra; la irritación procedente del pericardio se transmite á la pleura adyacente por simple contiguiidad. Es necesario también tener en cuenta la acción recíproca de los derrames pericardíaco y pleurítico sobre la circulación pulmonar. Es indudable que un derrame seroso abundante del pericardio no dificulta de una manera grave el juego del corazón, ni favorece la producción de congestiones pasivas en el seno del parénquima pulmonar. Es preciso también no olvidar que el pulmón está casi siempre enfermo, primitiva ó secundariamente, cuando se afecta la pleura, y que las lesiones parenquimatosas pulmonares provocan y sostienen las alteraciones pleuríticas. Hay, por lo tanto, en este caso una serie de influencias recíprocas que obran unas sobre otras, 
y muchas veces es difícil poner en claro la filiación patógena, pero es indispensable conocer por qué agravan de tal modo el pronóstico y aumentan considerablemente las dificultades del diagnóstico.

No creáis, en efecto, que el diagnóstico de un derrame pericardíaco, y sobre todo la apreciación de la cantidad del líquido derramado, sea cosa fácil. No temo afirmar que hay pocos problemas clínicos más difíciles de resolver, y que la descripción clásica de la pericarditis con derrame no responde, ni mucho menos, á lo que se ve á la cabecera del enfermo.

Los resultados del análisis de los síntomas funcionales son, ante todo, tan variables, que es imposible sacar conclusiones ni aun aproximadas. El dolor falta casi siempre, no sólo en los derrames ligeros, sino en los abundantes; es más bien característica de la pericarditis seca, $\mathrm{y}$ aun en ésta no es constante desde el principio del mal. Nuestro enfermo, cuya lesión vimos nacer y desarrollarse, jamás acusó dolor alguno en la región precordial ; sólo notaba una sensación de opresión, que fue aumentando con el derrame.

La disnea, que debía tener, al parecer, más valor, es también un síntoma infiel, y depende más bien de las altera. ciones pulmonares y pleuríticas que de las del pericardio ; tiene, no obstante, caracteres algo especiales que indican la participación del corazón; aumenta bajo la influenci: del más ligero esfuerzo, y va acompañada muchas veces de una sensación de desfallecimiento y de angustia; pero estos fenómenos son muy variables, porque aunque nuestro enfermo tenía un derrame de $\%$ de litro, jamás observamos tendencia alguna á las lipotimias, y el número de inspiraciones no excedía de 36 por minuto, circunstancia que contribuyó á inspirarnos una seguridad engañosa.

Un signo que dista mucho de ser constante, pero que 
creo tiene cierto valor cuando se observa, es la palidez y el abotagamiento de la cara. Era tan acentuado en nuestro enfermo, que la primer impresión del Dr. Rigal fue que se trataba de un albuminúrico. He observado ya muchas veces la palidez y el abotagamiento del semblante, sobre todo en un joven á quien hice en 1881 la paracentesis del pericardio, y jamás he visto que sean tan acentuados como cuando es considerable el derrame de la serosa; es, por lo tanto, un buen signo de presunción, pero nada más, porque falta en las verdaderas pericarditis, $y$ se observa, por el contrario, en otros estados patológicos de los que no participa el pericardio.

El pulso tiene caracteres de importancia grandísima, sobre los que no insistiré lo bastante. No sólo es pequeño, rápido, miserable, lo que indica una tensión débil de la sangre y disminución de la onda sanguínea ventricular, sino de un ritmo particular, que basta casi para afirmar la existencia de un derrame intra-pericardíaco. Este ritmo, que caracteriza el pulso llamado paradógico, fue señalado en 1883 por vez primera por Kussmaul, quien le consideraba como sintomático de las adherencias pericardíacas y de la mediastinitis callosa : después lo estudiaron Baümler y Traube, y demostraron su constancia en los derrames abundantes del pericardio. Consiste en lo siguiente : Aplicando el dedo sobre la arteria radial, se notan tres 6 . cuatro pulsaciones precipitadas, después una detención y una supresión de todo latido arterial durante el mismo tiempo. El esfigmógrafo marca con toda claridad estas alternativas. El período de desaparición del pulso corresponde exactamente al fin de la inspiración : durante la espiración aparece de nuevo y dura casi el mismo tiempo. Esta pausa rítmica es sólo aparente, porque auscultando el corazón durante ella, no se nota interrupción alguna de los ruidos cardíacos. 
La teoría del pulso paradógico es deficiente : es posible que esta supresión de la pulsación radial sea debida á la compresión de la aorta en el momento en que los pulmones adquieren su volumen máximo ; puede depender también del descenso de la presión arterial durante la inspiración, cuando la tensión sanguínea se ha reducido al mínimum á causa del obstáculo cardíaco. Sea lo que fuere, es un signo diagnóstico y pronóstico de importancia, que indica casi con seguridad un derrame abundante : en nuestro enfermo se presentó de una manera muy marcada en dos ocasiones : la víspera de la toracentesis y en los últimos días de su vida; desapareció, en parte, después de evacuarse el derrame pleurítico.

Es preciso distinguir estas irregularidades rítmicas del pulso, de las verdaderas irregularidades del corazón debidas á un trastorno de la inervación cardíaca ó á la miocarditis. Este último signo se observa también, pero no está en relación con el derrame del pericardio : indica por lo común una complicación endo-cardíaca ó valvular.

Conviene manifestar que la hipertermia y la fiebre para nada figuran en la sintomatología de la pericarditis con derrame, porque es muy raro observar una temperatura superior á $39^{\circ}$ : en nuestro enfermo debía atribuirse la elevación termométrica á la existencia de una fluxión reumática concomitante.

Por consiguiente, ni los síntomas funcionales ni la fiebre nos conducen al diagnóstico de los derrames del pericardio : del análisis del pulso se sacan signos de presunción importantes, pero sólo se tiene certidumbre investigando con cuidado los signos físicos.

Pero no creáis que éstos se descubren con facilidad. Todo lo fácil que es diagnosticar en el niño la presencia de un derrame pericardíaco, es posible la duda en el adulto. La combadura torácica, por ejemplo, tan característica 
en los niños, casi nunca se observa después de los veinticinco años. Nuestro enfermo, que apenas había salido de la adolescencia, sólo presentó este signo la víspera de su muerte : el derrame se hizo en él á expensas del diafragma y del mediastino posterior, y se disimuló completamente sin rechazar las costillas.

Las indicaciones más seguras son las que suministra la. percusión. Esto indica, de un día á otro, aumentos considerables de la macicez. En nuestros enfermos aumentó un doble en veinticuatro horas. La extensión rápida de la macicez es, por consiguiente, un buen signo de derrame, pero. no es, sin embargo, un signo cierto. Puede inducir al error una dilatación rápida del corazón. Pero la forma diferente de la zona de macicez precordial resuelve todas las dudas. Como es un punto práctico de importancia grandísima, os ruego me dispenséis si insisto sobre este asunto.

La macicez debida á un derrame pericardíaco, tiene la forma de un cono. El vértice de éste ocupa un punto constante, situado á unos cinco centímetros por debajo de la horquilla del esternón en el segundo espacio intercostal : corresponde al límite de la reflexión de la serosa pericardíaca sobre los vasos gruesos. Desde allí se dirige de un modo simétrico á derecha é izquierda hasta el diafragma, donde llega al máximum de su amplitud. Cuando se trata, por el contrario, de una dilatación cardíaca, la macicez es globulosa y sube mucho menos : el máximum de amplitud corresponde, no al diafragma, sino á la línea mamaria, 6 mejor dicho, al tercer espacio intercostal izquierdo.

A bajo, en la punta del corazón, el sonido reaparece. Esta zona sonora, interpuesta entre el corazón y el diafragma, basta para poder afirmar que no hay en la serosa pericardíaca derrame abundante, y viceversa. Es, por lo tanto, un 
signo de importancia grandísima que utilizaremos para discutir las indicaciones de la paracentesis del pericardio.

Otro signo paralelo al anterior, pero mucho más infiel, es la desaparición del choque precordial. No tiene en sí valor alguno, porque basta para producirlo la debilidad del ventrículo; adquiere más importancia cuando después de haber observado durante varios días la integridad de la contracción cardíaca, se la ve disminuir de repente y desaparecer luego; es lo que sucedió en nuestro enfermo.

Prácticamente es difícil algunas veces limitar el borde izquierdo de la macicez pericardíaca, sobre todo cuando se confunde y continua con el sonido obscuro, debido á un derrame pleurítico ; pero estas condiciones físicas, que hacen más delicada la intervención quirúrgica, contribuyen á precisar el diagnóstico, á causa de la coincidencia de los derrames pleuríticos y pericardíacos de que os hablaba hace poco.

Un signo poco estudiado y de gran valor, es el descenso de la zona sonora gástrica y la disminución del espacio de Traube al percutir, porque es el único medio de apreciar el grado en que está rechazado el diafragma hacia la cavidad abdominal. En estado normal, el estómago lleno de gases da un sonido timpánico hasta la quinta 6 sexta costilla ; cuando el pericardio distendido por líquido gravita sobre el diafragma, desciende la zona sonora ; con mucha más razón sucede esto si hay á la vez, como en nuestro enfermo, un derrame pleurítico. Recordaréis que después de la toracentesis, la sonoridad gástrica se elevó de repente 4 centímetros, aunque no varió el derrame pericardíaco. Es, pues, un signo que debe buscarse siempre.

En los derrames pericardíacos abundantísimos se ha señalado la existencia de un edema circunscrito de la pared torácica, que coincide con dilatación de las venas sub- 
cutáneas superficiales. Es un excelente signo cuando existe, pero su falta no prueba que el pericardio no esté distendido por una gran cantidad de líquido; en nuestro enfermo no hubo edema, $y$, sin embargo, el derrame excedió de 700 gramos.

La auscultación, al contrario de lo que podría suponerse, suministra indicaciones mucho menos exactas que la percusión. Se dice que la falta de ruidos cardio-pericardíacos tarda poeo en observarse, en cuanto se acumula líquido en la cavidad de la serosa. Este hecho es exacto respecto á los ruidos valvulares, que disminuyen, se obscurecen y desaparecen con rapidez relativa; pero como esta desaparición de los ruidos se observa en todas las miocarditis, por debilitarse la contractilidad cardíaca, es un signo de presunción, pero no de certidumbre.

En cuanto á los ruidos de roce producidos por el pericardio inflamado, es un error creer que desaparecen, y no es posible deducir de su existencia ó falta si hay derrame en la serosa. El caso de nuestro enfermo es, bajo este concepto, del todo demostrativo.

El 24 de Febrero por la mañana observamos roce pericardíaco extenso y fuerte: seis horas después murió el enfermo, y encontramos en su pericardio casi un litro de derrame.

He insistido sobre este punto, porque se halla en contradicción con lo que se enseña y hasta con los datos racionales de la fisiología patológica. Aunque estaba convencido de la existencia del derrame, no lo creí amenazador por la claridad con que oía el vaivén pericardíaco; este error de apreciación costó quizá la vida al enfermo. Persuadios de la verdad de esta paradoja clínica : el roce pericardíaco es compatible con la existencia de un derrame abundante, y la auscultación es impotente para permitirnos apreciar su abundancia. 
Se comprende esto si se reflexiona en las condiciones de fijeza del corazón y en sus relaciones con el pericardio. El corazón está íntimamente unido al diafragma por el intermedio de la vena cava inferior, y la auricula derecha es el eje fijo de suspensión del órgano. Cuando se forma un derrame se acumula por debajo y detrás del ventrículo en los puntos más declives. El corazón se sumerge de una manera incompleta en el líquido; como está libre por su punta, tiende á sobrenadar y, en esta posición, su cara ventricular anterior queda aplicada contra la pared torácica sobre una superficie extensa, aunque el derrame sea abundante. Por poco inflamadas.y ásperas que estén las hojas de la serosa, producen roces que se oyen á pesar del líquido.

Resumiendo esta discusión, sacamos las conclusiones siguientes, que deben servir de regla clínica para apreciar la existencia y la cantidad de los derrames pericardíacos:

Los únicos signos con los que puede contarse son : la macicez precordial de marcha rápida y de forma especial : el descenso del diafragma y de la sonoridad gástrica; los signos de compresión del corazón y la disminución de la tensión arterial (pulso paradógico); por último, los que indican la compresión pulmonar. Algunas veces se observa en este caso un ruido sonoro skódico posterior, independiente de todo derrame pleurítico, debido, al parecer, á que el pulmón es rechazado por el pericardio distendido.

Conviene conocer todos estos detalles, puesto que en materia de derrame pericardíaco es necesario decidirse y obrar pronto, porque el peligro que corren los enfermos es múltiple é inminente. Peligro de asfixia pulmonar á causa de la abundancia del derrame, y, sobre todo, de su coincidencia frecuente con un foco pleurítico. Peligro de muerte repentina por síncope cardíaco, ó de muerte muy rápida por formación de una trombosis ventricular. Esta 
causa, lo diremos al paso, es la que ocasionó la muerte á nuestro pobre enfermo; al hacer la autopsia, encontramos un coágulo fibrinoso de gran volumen, formado indudablemente durante la vida, que llenaba todo el ventrículo izquierdo y se extendía hacia la aorta. Dicha lesión produjo una asfixia rápidamente progresiva y un síncope final.

¿Qué conducta debe seguirse cuando existen accidentes. amenazadores de pericarditis reumática con derrame?

Habéis visto cuán ineficaz fue en nuestro enfermo el tratamiento médico, propiamente dicho, aunque se empleó con energía y perseverancia. El salicilato sódico, de actividad tan maravillosa contra las manifestaciones articulares del reumatismo agudo, es impotente para modificar los fenómenos viscerales. Al contrario de Lebreton, que lo cree eficaz en las fluxiones torácicas reumáticas, le considero como inactivo casi en absoluto en ellas, lo mismo que en las localizaciones peri y endocardíacas. Los diuréticos y los tónicos del corazón, como la digital y el café ; los alterantes, como los calomelanos; los drásticos, como el aguardiente alemán, llenan sólo indicaciones particulares y no hacen más que aliviar por el pronto á los enfermos. Por último, los revulsivos locales, por ejemplo, las ventosas escarificadas y los vejigatorios, aunque de acción más enérgica y directa sobre los accidentes inflamatorios, no contribuyen muchas veces más que á retrasarlos momentáneamente, sin contenerlos de un modo verdadero. Exceptúo la sangría, que mi maestro el Dr. J. Bouley aconsejaba en los reumáticos que padecen congestiones y fluxiones viscerales, y con la que el año último obtuve un efecto maravilloso en una joven que padecía pericarditis reumática con derrame pleurítico doble y opresión grandísima. Pero, á pesar de esto, dicho medio heróico no es eficaz siempre y en e! joven del hospital Tenon, al que tuve que practicar 
la paracentesis del pericardio, la sangría previa no contuvo la marcha del mal.

Es preciso, por lo tanto, en tales casos recurrir á la punción del pericardio y decidirse pronto, en cuanto se conoce que existe un derrame abundante, sin esperar á que los accidentes se hagan alarmantes. Lo repito hasta la saciedad : por haber tenido confianza absoluta en la abundancia del líquido, y haberme fiado en la benignidad aparente de los síntomas funcionales y del estado general, dejé pasar la ocasión única de salvar la vida de este enfermo.

La paracentesis está resuelta. ¿Dónde conviene practicarla?

Si se consultan sobre el particular las estadísticas y los libros, la perplegidad es grandísima, porque las divergencias de los autores son innumerables. En las 80 operaciones referidas por Hindenlang la punción se practicó sucesivamente en todos los espacios intercostales, desde el tercero al octavo, y que con todos los procedimientos se obtuvieron éxitos y fracasos. ¿Quiere decir esto que sea indiferente el sitio de la punción? Todo lo contrario : prueba sólo que cuando el pericardio está muy distendido por líquido es posible penetrar en él por puntos múltiples y agrandar, sin mucho peligro, el campo operatorio. Pero se correría el riesgo de sufrir grandes fracasos si se obrara así al azar, y si no se supieran de antemano las ventajas y los inconvenientes de la punción practicada en tal ó cual región determinada.

El sitio de elección habitual, el que recomendaban Trousseau y Roger, está situado á 4 centímetros á la izquierda del esternón, en el cuarto $\delta$ quinto espacio intercostal. De este modo se evitan la aurícula y la arteria mamaria interna, $y$ se llega al derrame sin necesidad de hundir mucho el instrumento. 
A pesar de la autoridad de estos maestros eminentes, no temo decir que, en general, es un mal punto de elección, porque aunque se evita la arteria mamaria interna, se corre, por el contrario, el riesgo de herir el ventrículo derecho. He visto á mi maestro Roger, en un caso que publicó con la lealtad de un verdadero sabio, introducir el trócar en el ventrículo de un niño que se ahogaba á causa de una enorme dilatación cardíaca, que se confundió con un derrame del pericardio. La operación no tuvo consecuencias funestas, pero el enfermito corrió un gran peligro.

Tengo la convicción completa de que el mejor medio de llegar con seguridad y sin peligro hasta el derrame, es punzar debajo y por fuera de la punta del corazón, en la base del saco pericardíaco. Según hemos dicho hace un momento, el corazón está fijo por las dos venas cavas, la aorta y la arteria pulmonar, y flota en el líquido. Hay, si no seguridad absoluta, al menos probabilidades fundadas de que la punta de este órgano no descienda á un nivel inferior al de costumbre ; punzando en el séptimo espacio intercostal, y mejor todavía en el octavo, debajo y por fuera de la línea mamaria, no lejos de los límites de la macicez, se llega con seguridad al foco líquido sin riesgo de herir el corazón. A lo sumo se atraviesa la hojilla en reflexión de la pleura, ó, en casos excepcionales, una lámina delgada del parénquima pulmonar, accidente menos peligroso que la herida del ventrículo. Debe, sin embargo, tenerse presente, que la distensión del pericardio rechaza el pulmón hacia atrás y afuera, y que es, por lo tanto, casi seguro no herirle.

Me habéis visto repetir la experiencia en el cadáver. Antes de abrir la cavidad torácica, clavé el trócar en el séptimo espacio intercostal, á 15 centímetros á la izquierda de la línea media, debajo de la punta del corazón. Introduciéndolo en sentido directo y no oblícuo, por temor á que se 
deslizara por la hoja parietal de la serosa, penetró la punta del trócar en el saco del pericardio sin tocar la punta del corazón ni el borde ventricular. En 1881, practiqué en las mismas condiciones, en el vivo, la paracentesis del pericardio en un joven que curó y cuya historia publiqué en el Boletín de la Sociedad de los Hospitales.

La punción del pericardio ¿̇es realmente un medio curativo, ó sólo un paliativo destinado á impedir por el pronto que se ahoguen los enfermos? Las estadísticas operatorias de Hindenlang van á respondernos. En 65 casos que ha seguido hasta el fin, hubo 44 fracasos y 21 curaciones, ó sea una tercera parte de éxitos, lo que en resumen es una proporción poco elevada. Pero es necesario no olvidar que son cifras que se refieren á la totalidad de los casos de paracentesis, buenos $\delta$ malos, sintomáticos $\delta$ no de tuberculosis, supurados 6 no supurados. No es posible hacer comparaciones entre estos elementos tan dife rentes.

Comparando las variedades de pericarditis, la proporción mejora. De todas ellas, en la reumática es en la que se obtienen más éxitos, porque de diez punciones hechas en esas circunstancias, curaron 8 enfermos. Es racional, por lo tanto, suponer que si hubiera habido tiempo de intervenir en nuestro desgraciado enfermo, la curación hubiese sido no sólo posible, sino probable. Es verdad que las complicaciones pleuro-pulmonares eran extensas y graves; que el pulmón influyó mucho en el desenlace fatal, y que con la paracentesis del pericardio no se hubiera corregido el infarto pulmonar; pero el caso no era ni con mucho desesperado y debía intentarse la operación.

Termino repitiendo lo que decía al principio de esta Lección : La pericarditis aguda exudativa, es una de esas enfermedades raras en las que puede salvarse la vida del 
enfermo por una decisión médica tomada á tiempo y ejecutada en el momento oportuno. Por esta razón, tienen una importancia grandísima los signos por los que puede apreciarse la cantidad de derrame pericardíaco y el manual operatorio que permite evacuarlo con seguridad y sin peligro. 


\section{SINFISIS CARDIACA (1)}

Sumario: Signos fundamentales de la sínfisis cardíaca; exageración de los latidos del corazón que contrasta con la falta de expansión de las costillas durante los movimientos respiratorios. - Depresión sistólica de la punta del corazón ; elevación diastólica de la base. - Interpretación fisiológica de estos signos. - Sintomas secundarios; pequeñez del pulso y debilidad del impulso ventricular. - Influencia de las adherencias pleuriticas concomitantes. - Consecuencias relativas al estado del corazón ; frecuencia de las complicaciones valvulares y de las dilataciones de las cavidades cardíacas. - Resultados de la autopsia.

Voy á tratar hoy, del enfermo que ocupaba el núm. 7 de la sala Chauffard.

Es un hombre de treinta y tres años, guarda municipal, al que he asistido ya otras veces. Ha tenido varios ataques de reumatismo, $y$ hoy se halla padeciendo, por décima vez, dolores articulares. Cuando lo ví por vez primera, hace cuatro años, presentaba ya fenómenos cardíacos muy acentuados. Tiene en la región precordial señales numerosas de ventosas escarificadas. Ultimamente le curó el doctor Peter una pleuresía derecha, desarrollada durante un ataque de reumatismo.

En la actualidad, ha ingresado en la clínica con un nuevo ataque, de tipo subagudo esta vez. La hinchazón de las articulaciones ha desaparecido hoy ; la fiebre es nula, y lo que llama en él la atención son los fenómenos cardíacos.

El enfermo está pálido, anémico, pero no tiene el aspecto caquéctico.

Los signos funcionales predominantes, son de dos clases :

(1) Esta Lección ha sido redactada por mi interno el Sr. Chartier. 
1. Disnea constante, que aumenta la forma de accesos en cuanto hace el enfermo el menor esfuerzo.

2. Dolor precordial espontáneo, que cesa bajo la influencia del reposo, pero que se presenta algunas veces de un modo casi repentino en forma de opresión ó de constricción torácica.

Hay, además, dolor á la presión á lo largo del trayecto del frénico en el cuello y en la región diafragmática.

Es lo que llamaba Guéneau de Mussy botón diafragmático. Existe, por lo tanto, en este caso un nervio frénico dolorido.

A pesar de la palidez de nuestro enfermo, no hay signo alguno de anemia cerebral, ni edema de las piernas, ni cianosis ; pero el ahogo continúa, las palpitaciones y el dolor impiden en absoluto el trabajo.

Es indudable que se trata de una afección cardíaca. Queda por determinar su naturaleza y conocer á qué variedad pertenece.

Al examinar el tórax, lo primero que llama la atención es la combadura de la región precordial, que forma un re. lieve, marcado, sobre todo, en los espacios intercostales. tercero y cuarto. Se observa, además, otro fenómeno : la locomoción de toda la pared torácica del lado izquierdo, que se eleva en masa en el momento del sístole.

Los movimientos respiratorios están, por el contrario, disminuídos de amplitud en el lado izquierdo; expansión ligera de las costillas, descenso pequeño del diafragma, que se revela por una especie de aspiración del hueco subdiafragmático y del epigastrio.

Hay, por lo tanto, á primera vista antagonismo entre la exageración del impulso cardíaco y la disminución de la locomoción respiratoria.

Analizando con más detenimiento estos fenómenos, se observan otros signos. 
Sabemos que en estado fisiológico el choque precordial coincide con el sístole. En nuestro enfermo parece, por el contrario, que está invertido el ritmo. Falta el choque de la punta en el momento del sístole, y se observa, en cambio, una ligera depresión. El choque se produce durante el diástole, y lo que lo prueba es que alterna con el pulso radial.

Independientemente de la depresión en la punta del corazón, depresión poco acentuada, existe otra también sistólica en los espacios intercostales tercero y cuarto y á lo largo del borde externo del esternón. Pero no se observa movimiento ondulatorio general desde la base á la punta, como ha sucedido en otros casos análogos.

A la palpación, se nota debilidad del choque sistólico. Cuesta, en efecto, trabajo precisar el sitio donde late la punta. Durante las palpitaciones se la siente debajo y fuera del pezón, á 15 centímetros de la línea media. El choque alterna con el pulso radial. No hay estremecimiento catario.

Por la percusión se nota aumento de la macicez precordial, sobre todo á expensas de las cavidades cardíacas derechas. La macicez llega á unos 4 centímetros más allá del esternón. La aurícula derecha se halla, por lo tanto, dilatada de una manera notable. La distancia del borde de esta aurícula á la punta es de 18 á 19 centímetros; la del mismo borde al lado izquierdo del corazón, en dirección transversal, de 12 á 14 .

La aorta mide 5 centímetros y medio.

Esta macicez no se modifica en modo alguno por los cambios de posición ni por los movimientos respiratorios.

La auscultación suministra signos típicos. En la punta se oye un soplo sistólico profundo, lejano, de timbre suave, pero no de silbido, que se propaga poco hacia la axila $y$ nada hacia la base.

Clínica médica. - Tomo I. 
En la región del esternón y del apéndice xifoides se oye también un soplo sistólico más fuerte, pero de timbre suave. Hay, por consiguiente, á la vez insuficiencia mitral y tricúspide.

El segundo ruido del corazón es sordo, deficiente. Nada se oye en la aorta, ni se notan roces pericardíacos.

¿Cuál es el valor clínico de estos diversos signos?

Como acabamos de indicar, hay insuficiencia doble mitral y tricúspide.

Lo prueban los latidos sistólicos de las yugulares dilatadas, el infarto y las pulsaciones del hígado.

Pero no es esto todo, y nuestro enfermo tiene además adherencias generalizadas del pericardio; en una palabra, padece sínfisis cardíaca.

Recapitulemos algo, y expliquemos los diferentes síntomas que hemos observado.

La sínfisis cardíaca es siempre difícil de conocer en el vivo. Es latente muchas veces y sólo se descubre al hacer la autopsia cuando no hay trastornos cardíacos concomitantes, $\delta$ las lesiones se desarrollan con gran lentitud. Pero, en bastantes casos, se manifiesta por trastornos funcionales graves y signos físicos más ó menos apreciables.

Es posible dividir las sinfisis cardíacas en dos clases: las que son bien toleradas y las que se toleran mal. El diagnóstico de las primeras es difícil, las segundas se diagnostican con facilidad.

Mas, antes de discutir este asunto, permitidme deciros algunas palabras sobre las funciones del pericardio.

El pericardio es un órgano de deslizamiento y de protección, gracias á su hoja elástica que limita los movimientos cardíacos.

Desempeña, además, otro papel importante por su acción sobre la circulación cardíaca. En efecto, gracias al 
vacío intra-pericardíaco, se facilita la repleción de las cavidades cardíacas en el momento del diástole.

También la sínfisis trastorna las funciones del pericardio y origina consecuencias graves, desde el punto de vista funcional del corazón.

Morell-Lavallée ha insistido, en su Tesis (1885), sobre las consecuencias de las adherencias pericardíacas, que se manifiestan :

1. Por dificultad en la expulsión de la sangre, es decir, por sístole insuficiente á causa del estiramiento é inmovilidad de las hojas del pericardio;

2. Por dificultad en la repleción de las cavidades cardíacas, es decir, por diástole insuficiente debido á la disminución $o ́$ desaparición del vacío pericardíaco.

Estas explicaciones nos dan fácilmente la clave de los síntomas observados en nuestro enfermo.

La elevación sistólica expansiva total es debida á la falta de deslizamiento. A causa de sus adherencias fibrosas con los órganos inmediatos, el pericardio se eleva á la vez que la pared torácica, y arrastra con él el corazón.

La depresión sistólica de la punta del corazón y de los espacios intercostales es más dificil de interpretar.

De todos los signos de la sínfisis cardíaca es el más antiguamente conocido. Lo describió por vez primera Kreisig, contemporáneo de Corvisart.

Su mecanismo difiere para la punta, para la base y para los espacios intercostales.

Para la punta es de admitir una brida parcial que sujeta el corazón por detrás. Pero en los casos de adherencia generalizada, debe haber depresión en todo el órgano y rio de la punta sola.

Se han referido también casos (Raynaud, Morell-Lavallée) en los que existía este signo, á pesar de la enfermedad del corazón. 
Merece citarse, además, por su gran influencia, las parálisis de los espacios intercostales y la acción de la presión atmosférica.

En los costados y en la base del corazón, la causa de la depresión es debida sobre todo á la falta de resistencia de los espacios intercostales, exagerada por las adherencias. pleuro-pericardíacas.

Es un fenómeno raro. Como ha demostrado Marey por medio del esfigmógrafo, en toda contracción cardíaca normal hay presión negativa. Se desconoce á causa de la tensión y de la resistencia elástica del pericardio.

La depresión sistólica es debida á una exageración de esta presión negativa.

La prominencia que forma la punta en el momento del diástole depende de los mismos fenómenos, á saber : de la debilidad paralítica de la pared, de la que resulta una distensión brusca de las cavidades cardíacas que ya no son sostenidas por la elasticidad del pericardio.

Estos signos varían según el estado del corazón, del miocardio, del grado de dilatación, del adelgazamiento ó de la hipertrofia del órgano. Estas variaciones dependen bastante de los individuos, y explican las dificultades del diagnóstico.

Los signos secundarios de la sínfisis cardíaca son la debilidad del impulso del corazón y, por consiguiente, del choque precordial; la pequeñez del pulso resulta de la tensión débil de las arterias, como lo prueba el trazado esfigmográfico.

Resulta con toda claridad del análisis que precede que existen en nuestro enfermo adherencias cardio-pericardíacas. ¿Es posible profundizar más y saber si hay á la vez adherencias de la pleura?

Puede decirse, en general, que existen cuando se observan los signos siguientes: 
1. Depresión de los espacios intercostales y de la punta ;

2. Disminución de la elevación de la parte izquierda del tórax durante la inspiración y dificultad de locomoción de los espacios intercostales ;

3. Debilidad del murmullo vesicular en esta región.

Respecto al estado del corazón, parece que en nuestro enfermo no hay hipertrofia, como lo indica la elevación en masa de la región precordial.

¿Qué significan las lesiones mitral y tricúspide?

¿Son lesiones fijas debidas á alteraciones de las válvulas, ó sólo dilataciones de los orificios?

Es difícil muchas veces resolver esta cuestión. Por lo común, hay lesiones valvulares concomitantes, debidas á la endo-pericarditis reumática; pero en otros casos están sanas las válvulas. Los Dres. Jaccoud y Fournier han publicado observaciones en las que no se descubrió al hacer la autopsia lesión valvular alguna, aunque se observaron con toda claridad estos signos durante la vida.

Quizá suceda así en nuestro enfermo, á juzgar por las razones siguientes :

1. ${ }^{\mathrm{a}}$ No hay estremecimiento catario ;

2. ${ }^{a}$ Los soplos son de timbre suave, sin carácter alguno de aspereza ;

3. ${ }^{a}$ Hay falta de expansión y de propagación de los soplos ;

4. ${ }^{\mathrm{a}}$ No se observa, por último, lesión aórtica alguna.

Es preciso resolver otro problema : ¿padece nuestro enfermo una lesión antigua ó un proceso flegmásico del momento, que contribuye á aumentar más aún las adherencias?

Existen ambas lesiones á juzgar por el estado de los frénicos, que son indolentes en las adherencias antiguas.

De todos modos, la aorta y el plexo cardíaco están sanos. 
La pericarditis ha quedado localizada y no se ha propagado, como en los casos que refiere el Dr. Peter.

El pronóstico depende de la extensión y generalización. de la lesión pericardíaca, del estado de las alteraciones. valvulares y del miocardio.

Las dos primeras condiciones producen lesiones profundas é inveteradas. La tercera es más importante.

En nuestro enfermo, el miocardio se halla aún en buen estado; este hombre tiene sólo treinta y tres años, y no. padece asistolia, edema ni hidropesía. Tampoco hay albuminuria ni congestión pulmonar.

Sin embargo, ciertos indicios demuestran que empieza á llegar á su fin el período de tolerancia; el enfermo tiene opresión rápida y accesos de sofocación. La intervención de las cavidades cardíacas derechas y la insuficiencia tricúspide agravan más el pronóstico.

Es necesario, por último, saber que la sínfisis cardíaca. expone á la muerte repentina 6 á la asfixia rápida. Según el Dr. Brouardel, en muchas autopsias de individuos que murieron de repente, se ha encontrado la sínfisis del corazón.

El tratamiento consiste, sobre todo, en sostener la energía de la fibra cardíaca. Para esto se recurre á la digital. Contra los fenómenos inflamatorios se empleará la revulsión local. Será útil añadir algo de ioduro potásico.

Contra las crisis dolorosas se darán las preparaciones. opiáceas, que son más útiles que la antipirina y el salicilato sódico, porque no tienen los inconvenientes de estos. medicamentos.

\section{NOTA ADICIONAL}

El enfermo murió en los días primeros de Agosto : he aquí los resultados de la autopsia :

Las cavidades pleurítica y abdominal contienen en 
abundancia serosidad teñida de amarillo por la bilis. (En los últimos días de su vida padeció el enfermo ictericia intensa $\mathrm{y}$ anasarca).

El corazón, muy voluminoso, está unido á los pulmones por adherencias bastante laxas, más numerosas á la izquierda que á la derecha. Sus dimensiones son las siguientes :

De la punta á la base........... $19 \%$ centimetros.

Lateralmente................ 16

Pesa, vacío de coágulos, pero incluso el pericardio, 960 gramos.

Las dos hojas del pericardio están íntimamente unidas en toda su extensión y es preciso disecarlas para separar unas de otras. A pesar de esta precaución, se lesionó el miocardio, sobre todo hacia la base del corazón y en la parte anterior del ventrículo derecho. Estas adherencias son secas, fibrosas, poco vasculares, indudablemente de fecha antigua. Son algo más laxas hacia la punta del corazón y en la parte posterior del ventrículo derecho : adquieren su máximum de espesor y de consistencia en la pared anterior de los ventrículos derecho é izquierdo. Hacia la base, las neomembranas están edematosas é infiltradas. En este sitio, los ganglios cardíacos se hallan muy hipertrofiados y rodeados de tejido conjuntivo de nueva formación.

La aurícula izquierda es enorme : cabe en ella el puño de un adulto. $\mathrm{El}$ orificio mitral está muy abierto y tiene la forma ovalada no semilunar : sus bordes son romos y gruesos, á causa de la retracción de la válvula mitral y del acortamiento de los tendones papilares. La pequeña válvula de la mitral ha desaparecido casi por completo y está reducida á un rodete. La mayor es gruesa, bastante ancha; pero sus funciones se han anulado, en parte, por la retracción de los tendones papilares. 
El borde libre de la válvula mitral tiene próximamente centímetro y medio de espesor.

$\mathrm{El}$ orificio mitral mide 13 centímetros de contorno, la pared ventricular está muy hipertrofiada y tiene cerca de tres centímetros de espesor.

Las cavidades derechas están también enfermas. Hay enorme dilatación de la aurícula y del ventrículo, lo que da al corazón una forma general de zurrón.

La válvula tricúspide conserva su flexibilidad y no se halla alterada, al parecer. Pero el orificio auriculo-ventricular está muy dilatado y mide más de 13 centímetros de contorno. Esta dilatación del orificio era causa de la insuficiencia valvular.

$\mathrm{El}$ orificio aórtico está ensanchado. Las válvulas sigmoideas, engrosadas, han perdido su flexibilidad; tienen en los bordes vegetaciones verrugosas y son algo insuficientes; es lo que se observó en vida del enfermo. La insuficiencia es debida, sobre todo, á la adherencia lateral de las válvulas, que origina una especie de fruncimiento anormal y deja un orificio entre ellas.

Hígado grueso, que presenta la alteración conocida con el nombre de hígado moscado, y un grado notable de cirrosis.

Riñones congestionados, algo esclerosos, pero no granulosos. La congestión llega al máximum en las pirámides.

Bazo pequeño y escleroso.

Los pulmones presentan lesiones interesantes. En la parte inferior del derecho se ve un tumor voluminoso, que sobresale debajo de la pleura. Al corte se descubrió un abceso anfractuoso lobulado, cuyo centro está reducido al estado de detritus puro-sanguinolentos. En la periferia existen abcesillos miliares confluentes, agrupados en medio de infartos hemorrágicos antiguos. Su conjunto tiene 
el volumen de un puño. El resto del tejido pulmonar está exangüe y atelectásico. En ciertos puntos, en el seno del pulmón izquierdo, se ven islotes diseminados de broncopneumonía.

Esta lesión, que se asemeja á un abceso metastásico, no procede de una ulceración de las vías biliares, porque la vesícula está sana por completo y contiene poca bilis. Dichas vías están intactas, y no existe en el parénquima hepático foco alguno de supuración.

Es probable, por lo tanto, que la supuración pulmonar sea debida á la introducción directa de gérmenes atmosféricos en los alveolos pulmonares enfermos y alterados por infartos hemorrágicos preexistentes. 


\section{SINFISIS CARDIACA}

(Conclusión).

Somario : Comparación de un caso de sínfisis cardiaca diferente del anterior. - Falta de la combadura precordial y del impulso cardíaco; retracción del lado izquierdo del pecho; falta de ruidos que indican lesiones valvulares. - Diagnóstico diferencial con las hipertrofias y las dilataciones del corazón sin alteraciones de los orificios. - Valor de ciertos signos físicos en los casos obscuros de sinfisis cardiaca : situación de la punta del corazón debajo y por dentro de la línea mamaria, á pesar de la hipertrofia del órgano. - Desaparición del choque sistólico ventricular y de la expansión diastólica, pero aparición de estos signos en el hueco epigástrico, por trasmisión á distancia de los movimientos cardíacos. - Discusión del estado del corazón, que presenta signos pasajeros de insuficiencia mitral por dilatación ventricular, pero que, al parecer, no está interesado de un modo grave.-Duración larga de ciertos casos de sínfisis cardíaca sin trastornos funcionales de importancia.

Voy á hablaros de nuevo de la sínfisis cardíaca, porque el diagnóstico de esta afección es siempre difícil y los signos físicos que permiten conocerla varían de un enfermoá otro. El caso que voy á tratar hoy tiene pocas analogías con el que describí hace algunas semanas.

José M., de cuarenta y ocho años, que ocupa el núm. 20 de la sala Chauffard, es un individuo caquéctico, flaco, de pómulos rojos y salientes, que tiene opresión y tos. Su aspecto es más bien el de un tísico que el de un cardíaco: no presenta indicio alguno de edema, ni soplos, ni palpitaciones, ni dolores precordiales. Es, sin embargo, un cardíaco, y hasta un cardíaco antiguo, porque conserva la señal de dos cauterios que se le aplicaron hace doce años en la región precordial.

Los signos físicos no responden á lo que podría espe- 
rarse encontrar en un hombre que padece una cardiopatía tan antigua. No sólo no hay combadura precordial, sino que el lado izquierdo del tórax ha sufrido un especie de retracción y es menos amplio que el derecho. No se ve el punto donde late la punta del corazón; sólo al palpar se aprecia de un modo imperfecto el sitio del choque precordial, que es débil, atenuado y late en el sexto espacio intercostal, por dentro y debajo del pezón.

A la auscultación se oyen los ruidos cardíacos sordos y lejanos, pero regulares. El primero es muy débil. No hay alteración del ritmo, ni ruido de galope, ni descomposición del primer ruido, ni acentuación del segundo tono aórtico, ni soplo. De tarde en tarde, y de un modo pasajero, se oye hacia la punta un soplo suave, superficial, sistólico, que no tiene la claridad ni el timbre del soplo de la insuficiencia mitral.

El único signo típico y positivo es la macicez precordial, mucho más extensa que en estado fisiológico; excede de 12 centímetros cuadrados.

Estos signos físicos no tienen carácter típico alguno, y la lesión cardíaca, que existe indudablemente, merece discutirse.

¿ Se trata de una afección orgánica con lesión valvular? A creer al enfermo, es el diagnóstico que se ha hecho en las clínicas donde ha permanecido : su afección se ha diagnosticado de insuficiencia mitral; $y$, en efecto, los días en que hemos oído un soplo al auscultar, era sistólico y estaba localizado en la punta del corazón. Pero, á pesar de esto, dudo que exista una lesión de la mitral. Las afecciones orgánicas cardíacas verdaderas se comportan de otro modo. Los ruidos anormales se atenúan y desaparecen por el momento; pero recobran su intensidad bajo la influencia del reposo y de la digital. En este caso, ha sido nula la influencia del tratamiento : el soplo se observó por casualidad y de 
una hora á otra dejó de ser perceptible. Además, los verdaderos soplos de insuficiencia mitral son de timbre más áspero y más fuertes, en relación con la energía de la contracción ventricular, que se manifiesta por un choque precordial brusco y duro. En nuestro enfermo, por el contrario, el ruido morboso ha sido siempre fugitivo, superficial y suave, y no ha coincidido con un impulso cardíaco violento.

Tampoco hay estrechez mitral. Esta lesión queda algunas veces casi latente, y los fenómenos que se observan al auscultar son obscuros; habéis visto en este curso varios ejemplos, y, en la actualidad, se encuentra en la clínica una mujer que padece embolia cerebral con afasia, en la que la estenosis mitral no se ha manifestado por signo alguno apreciable durante casi una semana. Pero, observando con cuidado los enfermos y auscultándoles varios días consecutivos, se descubren siempre algunos indicios que permiten afirmar la existencia de la lesión : un soplo breve presistólico, $\delta$ un ruido diastólico, y sobre todo una división permanente del segundo ruido, independiente de los movimientos respiratorios. En nuestro enfermo jamás se ha oído ruido alguno de éstos, y nada recuerda en él los signos de la estrechez aurículo-ventricular.

Tampoco es probable que se trate de una hipertrofia del corazón sin lesiones de los orificios. Estas hipertrofias ventriculares son consecutivas casi siempre á la nefritis intersticial, á la arterio-esclerosis generalizada ó á trastornos gastro-hepáticos. Esta última suposición es infundada, porque el enfermo jamás ha padecido dispepsia ni afección alguna del hígado. Las cardiopatías dependientes de la esclerosis renal tienen caracteres que no permiten desconocerlas, aunque falte el ruido de galope á la auscultación. Se observa, en efecto, siempre en estos casos exageración del impulso ventricular y del choque precordial y aumento 
de la tensión arterial. Precisamente en el caso de que tratamos predominan los caracteres contrarios; el pulso es pequeño y los latidos cardíacos casi nulos. Además, los trastornos funcionales no son los de la nefritis intersticial; el enfermo no tiene poliuria, jamás se levanta por la noche, y la cantidad de orina es más bien inferior que superior á la normal. En ciertos intervalos contiene indicios de albúmina; pero este fenómeno, como sabéis, se observa siempre que está congestionado el riñón, y no tiene nada de especial con la nefritis intersticial.

Por último, la idea de una dilatación del corazón sin hipertrofia, que podría sospecharse fundándose en la debilidad del impulso cardíaco y en la extensión de la macicez precordial, no concuerda en modo alguno con lo que sabemos de los antecedentes del enfermo. La dilatación primitiva del corazón es excepcional por completo. Es secundaria casi siempre á las afecciones pulmonares ó á las enfermedades generales infecciosas; pero, á excepción del reumatismo, no se encuentra en los antecedentes de este hombre fiebre infecciosa alguna. La bronquitis y la opresión que padece son fenómenos consecutivos á la cardiopatía, y no primitivos; este enfermo no es un enfisematoso: tose porque su circulación cardio-pulmonar está trastornada.

Por consiguiente, ni la hipótesis de una afección orgánica del corazón con alteración valvular, ni la de una hipertrofia $\delta$ una dilatación ventricular sin lesiones de los orificios corresponden al cuadro clínico que observamos. Llegamos á suponer, en este hombre, por exclusión, una sínfisis cardíaca, fundándonos para ello en dos clases de consideraciones.

Primera : las circuntancias etiológicas son las que predisponen á este género de lesiones. Encontramos entre los accidentes de nuestro hombre el reumatismo como enfer- 
medad de familia. Su padre y su madre fueron los dos reumáticos. El enfermo padeció su primer ataque cuando apenas tenía catorce años. Esta primera crisis duró seis semanas y se generalizó á todas las articulaciones. Dos años más tarde, nuevo ataque de reumatismo poliarticular, que se complicó con fenómenos cardíacos, porque se le aplicó un vejigatorio en la región precordial. Por último, á los veinte y veinticuatro años tuvo otros dos ataques de reumatismo agudo, á la vez articulares y viscerales, porque se afectó siempre el corazón. Después, aunque no padeció crisis violentas, estuvo sujeto siempre á ligeras manifestaciones reumáticas, y desde hace algunos años empezó á sentir cierto grado de opresión habitual y dificultad grandísima para todos los movimientos que necesitan esfuerzos.

Se trata, indudablemente, de un reumático y de un reumático antiguo. Es una ley patológica que el reumatismo articular, cuando principia en la infancia, se complica con endocarditis y pericarditis, más á menudo que el de los adultos. Puede afirmarse en principio, que todo reumatismo algo rebelde en esta edad, ocasiona la endo-pericarditis exudativa; tal era al menos la opinión de mi maestro Roger, confirmada por los trabajos notabilísimos de Claisse y de Picot sobre el reumatismo infantil. Hay, por lo tanto, grandes probabilidades, por no decir seguridad, de que nuestro enfermo ha padecido desde hace mucho tiempo lesiones complejas de este género que han originado adherencias del pericardio.

Sin embargo, esto no es más que una conjetura. Existen, no obstante, signos afirmativos que confirman casi por completo esta idea :

La inspección del tórax suministra indicaciones características, pero, debo decirlo, difieren bastante del tipo clásico. Así, en vez de la combadura precordial que se observa de ordinario en tales casos, y que en el enfermo de que os 
hablé hace poco era de los más pronunciados, existe aquí aplanamiento general del tórax y de las costillas á la izquierda del esternón, y retracción acentuadísima de los espacios intercostales. Haciendo respirar con fuerza al enfermo, vemos que están abolidos los movimientos parciales de las costillas de esta región; no se elevan durante la inspiración y quedan inmóviles.

Los movimientos del diafragma están también reprimidos. El hueco epigástrico presenta una combadura muy incompleta, que contrasta de una manera notable con la elevación de la región hepática correspondiente. Es necesario deducir de esto, no la parálisis del diafragma, sino la insuficiencia mecánica de sus funciones. Este músculo está adherido de un modo íntimo al pericardio y al corazón por su trebol aponeurótico, y la resistencia de estas adherencias dificulta su locomoción.

Resulta de este hecho anatómico un tipo respiratorio especial, que sorprende en cuanto se examina al enfermo. Su tórax se eleva en masa, como si formara una sola pieza, y á la vez está disminuída la amplitud respiratoria.

Un punto sobre el que llamo vuestra atención de un modo especial, y del que, en los casos obscuros puede hacer sospechar, y casi afirmar, la existencia de una sínfisis cardíaca, es la situación que ocupa la punta del corazón. Habéis visto que en nuestro enfermo late en el sexto espacio intercostal, debajo $\mathrm{y}$ por dentro del pezón; al menos es el sitio donde se oyen las pulsaciones con más claridad al auscultar. Dado el volumen del órgano y la extensión de la macicez precordial que existe, esta situación es una anomalía, porque la punta del ventrículo debería inclinarse hacia la región axilar y hallarse por fuera del pezón. Por lo tanto, si á pesar de la hipertrofia del corazón la punta de éste se halla tan próxima al esternón, es porque está fija y sostenida de una manera in- 
mutable; en otros términos, porque hay adherencias.

El estudio de la locomoción cardíaca confirma estas primeras indicaciones, $\mathrm{y}$ he procurado insistir sobre los signos capitales que se deducen. Los recordaré en pocas palabras.

En los casos típicos de sínfisis cardíaca se observan tres síntomas : disminución del choque sistólico de la punta del ventrículo; hundimiento del espacio intercostal que coincide con el sístole; por último, aparición de un choque diastólico que se propaga de la base del corazón á la punta y produce una especie de ondulación especial.

Estos tres fenómenos son solidarios unos de otros y dependen de la falta de resistencia del pericardio y de su adherencia al corazón. La adherencia dificulta el sístole ventricular que es débil é incompleto, y de aquí la disminución del choque precordial. La falta de resistencia pericardíaca deja que se ejerza sin obstáculo la presión atmosférica, de donde resultan la depresión de los espacios intercostales durante la inspiración, y, al contrario, su encorvamiento bajo la influencia de la repleción del ventrículo. El pericardio es pasivo por completo, en vez de ser resistente, como en las condiciones fisiológicas.

En nuestro enfermo los signos físicos no tienen, ni con mucho esta claridad, pero existen, en parte. El choque sistólico de la punta es nulo y no se nota ni aunque se incline el paciente hacia adelante. Por el contrario, la depresión sistólica del espacio intercostal en la proximidad del corazón falta por completo, lo mismo que la expansión diastólica. Pero se observan estos signos con toda claridad más abajo, en la región epigástrica, particularidad sobre la que llamo de una manera especial vuestra atención, porque creo que no se ha señalado todavía. Si examináis el hueco epigástrico en este hombre, véis deprimirse los tegumentos de un modo brusco en un punto 
situado inmediatamente por debajo del apéndice xifoides, y esta depresión corresponde al sístole ventricular. En el momento del diástole se forma una combadura del epigastrio, y se nota con toda claridad un choque. En el fondo son los signos clásicos de la sínfisis cardíaca observados en la región epigástrica en vez de su sitio de producción. Esta transmisión á distancia de los movimientos cardíacos, creo que es un signo excelente de las adherencias pericardíacas, porque prueba la solidaridad íntima que existe entre el corazón, su serosa y el diafragma.

$¿$ Cuáles son las consecuencias de este estado de cosas, desde el punto de vista de la estructura del corazón? Varían bastante según los casos, y sabéis que la sínfisis cardíaca va acompañada: unas veces de hipertrofia ventricular, otras de dilatación con adelgazamiento de las paredes y otras, por último, de atrofia general del órgano.

En este caso es posible eliminar, desde luego, esta última hipótesis, porque la macicez precordial es una tercera parte más extensa que en estado fisiológico. El diagnóstico se circunscribe entre la hipertrofia y la dilatación del corazón y no deja de ser bastante difícil. Pero me inclino más á creer que hay dilatación ventricular. Una hipertrofia cardíaca notable produciría combadura precordial más acentuada, $y$, sobre todo, un impulso más fuerte : se oiría al auscultar un choque difuso fuerte que elevaría la pared torácica en una gran extensión, mientras que en este caso los fenómenos son negativos. Además, la poca energía de la tensión arterial y la pequeñez del pulso no indican en este caso la asistolia, porque no hay edema ni complicación visceral, sino que dependen más bien de la debilidad normal de la contracción ventricular; es precisamente el carácter que presenta la dilatación cardíaca simple, con ó sin adelgazamiento de las paredes. Por último, esta hipó- 
tesis explica mucho mejor el soplo intermitente que hemos observado en nuestro enfermo.

Este soplo es susceptible de interpretarse de diversas maneras, y conviene discutir su naturaleza.

Manifestaremos, ante todo, que no se trata de un soplo extra-cardíaco, aunque no se le oye de una manera permanente : no tiene ni el carácter ni la localización de estos soplos. Se oye en la punta del corazón y es sincrónico por completo con el sístole ventricular, en vez de ser postsistólico y de oirse en el silencio menor, como sucede á la mayor parte de los soplos extra-cardíacos. Es, por consiguiente, un soplo que parece orgánico y está localizado en el foco de los ruidos morbosos del corazón izquierdo : al oirle, se piensa en una insuficiencia mitral; y recordaréis que este es el diagnóstico que se ha hecho en las diversas clínicas donde ha estado el enfermo.

Podría preguntarse, á causa de la importancia y de la variabilidad del soplo, si se produce en las cavidades izquierdas del corazón, y si no es más bien sintomático de una insuficiencia tricúspide.

A pesar de la frecuencia de esta complicación, siempre que es difícil la circulación cardíaca, no creo admisible la hipótesis. Hemos observado de cuando en cuando, en este enfermo, distensión de las venas yugulares, indicio de éxtasis sanguíneo de las cavidades derechas; pero jamás hemos observado pulso venoso ni reflujo hepático, coincidiendo con un soplo de localización esternal ó xifoidea. Nos ha parecido, por el contrario, que cuando eran más acentuados los fenómenos de éxtasis venoso desaparecía por completo el soplo, para aparecer de nuevo en condiciones inversas, cuando recuperaba su energía la contractilidad cardíaca. Creo, por lo tanto, que nuestro enfermo padece insuficiencia no tricúspide, sino mitral ; sólo que ésta es intermitente y pasajera, lo que excluye casi con 
seguridad la hipótesis de una lesión valvular permanente. Me parece probable que bajo la influencia de las adherencias que dificultan la contracción ventricular, se produce de cuando en cuando una insuficiencia funcional del orificio aurículo-ventricular, á causa de la dilatación anormal del ventrículo y de la separación de los pilares de los músculos papilares, consecuencia de esta dilatación. Aunque sea difícil demostrar este hecho, creo que es la hipótesis más racional, porque explica perfectamente la variabilidad del soplo y su carácter suave, que en nada se asemeja al silbido clásico producido por las asperezas de la válvula mitral.

En resumen, saco de esta discusión, que nuestro enfermo tiene el corazón dilatado, debilitado, y que sus funciones son difíciles, pero que no se halla afectado aún de una manera grave : no creo que exista una lesión mitral, y tengo la convicción de que tampoco se trata de una insuficiencia tricúspide.

Así se explica cómo, durante veinte años, ha podido este hombre desempeñar sus ocupaciones con actividad, aunque es probable que su lesión se remonte á esta época. Los trastornos funcionales no se presentaron hasta el día en que empezó á fatigarse el corazón. Entonces apareció la disnea, y es casi el único síntoma que indica la existencia de la lesión cardíaca.

El origen de esta disnea es, por lo demás, complejo : depende del estado del corazón y de los pulmones.

Las adherencias generalizadas del pericardio crean para el corazón condiciones especiales, y es indudable que las cavidades cardíacas se llenan y vacían de una manera insuficiente. Así se explica la frecuencia insólita de los latidos del corazón, que exceden de 90 en pleno reposo : el ventrículo se contrae más á menudo, porque se llena y vacía mal. Por la misma razón es el pulso pequeño y frecuen- 
te, porque á cada sístole es lanzada á la circulación una onda sanguínea insuficiente que necesita renovarse á menudo para mantener la hematosis. Esta consideración tiene cierta importancia desde el punto de vista del pronóstico, porque es necesario distinguir esta pequeñez del pulso, fisiológica en cierto modo, de la dependiente del desfallecimiento del ventrículo y de la contractilidad cardíaca poco enérgica. El estado actual es, indudablemente, menos. grave y el porvenir menos amenazador.

El estado de los pulmones tiene también una gran influencia sobre la producción de la disnea. La lesión del pericardio se extiende, en efecto, á la pleura, y es posible afirmar que la serosa pleurítica ha sufrido varios ataques inflamatorios, que han dejado señales indudables de su. paso. El examen del tórax demuestra la existencia de adherencias pleuro-pulmonares antiguas. En el lado izquierdo del pecho, las costillas están aplanadas hacia atrás, y los espacios intercostales correspondientes se hunden á cada inspiración, de modo que, en vez de la ampliación normal de la base del pecho, se observa retracción. Además, al auscultar la región axilar izquierda, se oyen extertores finos de crepitación subpleurítica, y roces superficiales que indican que el trabajo irritativo persiste aún en la pleura y va acompañado de cierto grado de infarto pulmonar.

Tenemos ya todos los elementos de apreciación necesarios para hacer un diagnóstico y un pronóstico exactos. Nuestro enfermo es un reumático antiguo, que padece aún en la pleura y en el pericardio flegmasía desarrollada en las adherencias antiguas. La sínfisis cardíaca es completa; pero, al contrario de lo que se observa por lo común en tales casos, no hay lesiones viscerales profundas. El corazón no está hipertrofiado ni enfermas las válvulas : los pulmones, aunque con lesiones de atelectasia y de con- 
gestión crónica, no padecen, al parecer, esclerosis; el hígado es normal y apenas desciende por debajo de las costillas : por último, los riñones funcionan bien y la orina no contiene albúmina.

Resulta de lo que antecede, que la situación de este hombre, aunque grave para el porvenir, no es alarmante por el pronto. El único síntoma penoso es la disnea, y aun ésta disminuye mucho durante el reposo. El peligro verdadero, en el caso actual, es debido al trabajo excesivo de un corazón fatigado ya é incapaz de soportar un trabajo sostenido. Por pocos esfuerzos que haga el enfermo ó si ejecuta un movimiento algo brusco, siente accesos de opresión. Es indudable que, en estas condiciones, se halla á merced de la circunstancia ocasional más ligera : un enfriamiento, una enfermedad intercurrente, son susceptibles de producir accidentes de asistolia y de poner en peligro la vida. El tratamiento debe ser ante todo higiénico, y consistir en el reposo del corazón, lo más absoluto posible, $\mathrm{y}$ en mantener en buen estado los riñones por medio de algunos diuréticos, haciendo predominar la leche en la alimentación. Las indicaciones relativas á la digital, al café y á los otros medicamentos cardíacos, están subordinadas al estado del corazón ; creo intempestiva, por el pronto, toda medicación activa. Exceptuo, sin embargo, los revulsivos, que me parecen indicados á causa de la persistencia de los roces recientes pleuro-pericardíacos; $\mathrm{y}$, á ejemplo de Gendrin, voy á aplicar un cauterio sobre la region precordial, no para remediar las adherencias antiguas, porque es imposible, sino para impedir las congestiones nuevas, que prueban que subsisten aún las tendencias inflamatorias locales. 


\section{AFECCION CARDIACA Y RESPIRACION DE CHEYNE-STOKES}

Sumario : Insuficiencia mitral en un ateromatoso. - Ritmo respiratorio. de Cheye-Stokes que se presentó después de cesar la crisis de asistolia, y duró sin modificarse tres semanas. - Análisis del fenómeno: caracteres del pulso y de la circulación cerebral durante el periodo de apnea y el de disnea.- Condiciones clínicas en las que se observa este tipo respiratorio; historia del asunto; frecuencia de su aparición como síntoma de uremia: diferencia con la respiración de meningíticos. Patogenia del fenómeno: á la disnea corresponde un aumento en tensión arterial y de anemia cerebral : á la apnea disminución de la tensión sanguinea y congestión bulbar. - Mecanismo de la excitación y de la depresión alternativas del bulbo.-Papel que desempeñan la fibra cardíaca (Stokes) - las arterias cerebrales y el ateroma basilar (Traube, Filehne)-el estado dela sangre y de gases que contiene.-Para Traube, es efecto de la acumulación de ácido carbónico; para Sachi es consecuencia de la falta de oxígeno.- Es probable que el fenómeno de Cheyne-Stokes sea sólo exageración del automatismo del bulbo.

Señores, voy á ocuparme hoy de un enfermo que padece una afección trivial, pero cuyo tipo respiratorio singular ha llamado más de una vez vuestra atención durante las seis semanas que hace que está en la clínica. Estudiaré con vosotros este ritmo respiratorio particular, conocido con el nombre de fenómeno de Cheyne-Stokes.

Recordemos en pocas palabras los antecedentes de este enfermo. Hasta 1885 carece de historia patológica ; en esta fecha era un hombre robusto, que sólo había padecido eczema varicoso de las piernas. En 1886 observó por vez. primera algunos trastornos circulatorios, que se caracterizaron por vértigos y una sensación de vacío en el cerebro. Al año siguiente, principió á tener disnea, opresión, todos los signos de un padecimiento cardíaco; lo asistí en un ataque de asistolia, con edema de las piernas y anasarca, y á los tres meses abandonó el hospital, casi curado. Desde- 
el mes de Enero de 1888 ha vuelto varias veces, quejándose de opresión y con más frecuencia de debilidad y de quebrantamiento general. A principios de Marzo ingresó en la clínica, donde permanece.

Es un hombre alto, ancho de hombros, robusto al principio, pero hoy pálido y anémico. En vez de hinchado é infiltrado como el año anterior, está seco y flaco y sin indicio alguno de edema. Los síntomas que aqueja son principalmente vértigos y desvanecimientos, que siente en cuanto varía de posición; no tiene ni cefalalgia ni vómitos. La disnea es intermitente; sólo se presenta cuando hace el enfermo algún esfuerzo; durante el reposo no siente opresión alguna, el sueño es tranquilo, y no necesita dormir con la cabeza alta, como sucede á la mayoría de los cardíacos. Lo que llama la atención en este individuo es un estado cerebral extraño, que se caracteriza por apatía, ofuscación intelectual y falta absoluta de la voluntad. Tarda mucho en comprender las cosas, y habla con lentitud y dificultad; es imposible obtener de él datos sobre lo que ha pasado y sobre las circunstancias que le han conducido al estado en que se encuentra, fenómeno notable, porque cuando estuvo por vez primera en el hospital, respondía con exactitud á las preguntas.

La impresión general que resulta de este conjunto sintomático es la de una afección cardíaca, según toda pro. babilidad, aórtica, complicada con anemia del cerebro. Pero la auscultación no justifica esta idea. Los latidos del corazón son sordos é irregulares; en la punta se oye un soplo sistólico de insuficiencia mitral. Mas en la base el ruido es sigmoideo, típico, claro, apergaminado, é indica á lo sumo ateroma arterial, pero sin insuficiencia aórtica. El corazón no está hipertrofiado, al parecer, si bien no puede afirmarse, porque el pulmón es enfisematoso y traspasa la región precordial. 
El pulso es amplio, algo fuerte, y la tensión sanguínea no se halla, según parece, exagerada. Las arterias radiales, aunque algo sinuosas, no son duras ni gruesas, ni presentan signos de ateroma pronunciado. Pero el círculo senil de la córnea está bastante acentuado. En resumen, hay indudablemente lesiones cardio-vasculares, pero nada tiene esto de extraordinario en un hombre de más de sesenta años.

Los demás órganos están sanos, excepto los riñones, que están congestionados. La orina es roja, de color encendido, cargada de sales y de materias colorantes; contiene una proporción pequeña de albúmina, 15 á 20 centígramos por litro. Pero su cantidad se eleva de 1000 á 1200 centímetros cúbicos diarios, lo suficiente para excluir toda idea de uremia.

El diagnóstico anatómico en este caso no presenta dificultad alguna : es indudable que existe una lesión cardíaca, y que esta lesión es una insuficiencia mitral. Pero no es tan fácil afirmar si es primitiva 6 secundaria, si depende de una arterio-esclerosis generalizada $\delta$ de una afección renal bien definida. Los antecedentes del enfermo no justifican en modo alguno la hipótesis de una nefritis primitiva; no ha tenido poliuria nocturna, ni cefalea, ni trastornos vesicales. Los caracteres de la secreción urinaria son los de la orina cardíaca, más bien que los de la enfermedad de Bright; por último, al auscultar el corazón no se oye ruido alguno de galope. Parece, por lo tanto, racional atribuir la albuminuria á la lesión del corazón, aun teniendo en cuenta cierto grado de ateroma arterial.

Suponiendo que este hombre padecía insuficiencia mitral y cierto grado de senectud arterial, administramos durante varios días la digital á alta dosis (15 decígramos de hojas en maceración en veinticuatro horas). Bajo la influencia del medicamento, los latidos del corazón se hicie- 
ron más regulares y fuertes, aumentó la cantidad de orina y la albúmina desapareció á los ocho días. El enfermo, curado de esta crisis, se hallaba, al parecer, en plena convalecencia, y se encontraba, en efecto, mucho mejor, cuando vimos aumentar un síntoma que era casi insignificante á su ingreso - me refiero á esta forma singular de disnea intermitente, que se conoce con el nombre de fenómeno de Cheyne-Stokes, y que dura en la actualidad sin interrupción ni modificación desde hace tres semanas.

Este modo respiratorio notable, que constituye hoy el único síntoma objetivo que presenta el enfermo, consiste en lo siguiente :

Después de una larga pausa respiratoria, se presentan movimientos del tórax, lentos al principio, y luego más profundos; al poco tiempo adquieren una amplitud gradual creciente y se hacen más rápidos. La respiración es viva y tumultuosa; después, sobreviene una fase decreciente gradual, y la calma se hace cada vez mayor; las oscilaciones torácicas lentas y débiles concluyen por suspenderse y aparece la apnea; está dura, casi tanto como la disnea. Durante medio minuto próximamente, queda el enfermo insensible, sin movimiento, sin respiración, y se diría que es un cadáver. Pasado este período, principia de nuevo la respiración, que sigue las mismas fases, y asi consecutivamente. Estas modificaciones se producen con un ritmo regular. La apnea dura de veintitrés á treinta segundos ; el período de ascensión, de cinco á seis; la disnea, de dieciséis á veinte, $\mathrm{y}$ el período de calma de cinco á seis. La revolución total tarda un minuto próximamente en efectuarse.

Es curioso ver cuán poco influyen sobre este ritmo las condiciones diversas que modifican de ordinario la respiración. Durante el sueño, el período de apnea, después el de ansiedad respiratoria, se suceden con regularidad 
perfecta; el de pausa apenas es más largo, y la disnea es: tan pronunciada como hallándose despierto el enfermo. El despertar bruscamente, no influye tampoco; cualquiera. que sea la fase respiratoria durante la cual sorprende al enfermo, la deja cumplirse con exactitud matemática sin interrumpir ni cambiar la duración ó periodicidad. Si el enfermo ejecuta movimientos espontáneos; si se sienta en su lecho; si se baja ó se levanta, la opresión se acentua más, pero persiste la pausa respiratoria ; únicamente va acompañada de mayor cianosis y de malestar más acentuado. durante el período de disnea consecutivo.

Los caracteres del pulso varían según las fases del ritmo respiratorio y sufre modificaciones alternativas que os he hecho observar muchas veces. Durante el período de disnea el pulso es tranquilo, regular y muy lento; late 50 660 veces por minuto; durante la apnea, por el contrario, se acelera y se cuentan de 70 á 80 pulsaciones; hay, por lo tanto, una diferencia de 20 pulsaciones entre las dos fases respiratorias, y, cosa curiosa, la rapidez de los latidos cardíacos se halla en oposición absoluta con el número de movimientos respiratorios, haciéndose más lentos cuando éstos se aceleran y viceversa. Es un carácter constante, que no debe confundirse con la apariencia del pulso dicroto que presentaba nuestro enfermo en la primer semana de su estancia en el hospital. Este ritmo de las pulsaciones radiales, que consiste en la sucesión regular y alternativa de una pulsạción fuerte con otra débil, no depende del fenómeno respiratorio de Cheyne-Stokes, sino del uso de la digital, aunque no sea fácil explicar el fenómeno. Habéis visto desaparecer el pulso dicroto cuando se suspendió la administración del medicamento.

La circulación del cerebro se modifica de una manera notable durante las alternativas de disnea y de apnea, y resulta el estado intelectual extraño y especialísimo sobre 
el que insistiré más adelante. Desde el principio de los accidentes $\mathrm{y}$ antes de que se presentara la disnea intermitente, domina la soñolencia y el atontamiento, de la que es * difícil sacar al enfermo. Hoy, estos síntomas están mucho más caracterizados. Durante la fase de apnea, hay embotamiento absoluto; el enfermo se queda adormecido y sigue con trabajo el curso de las ideas; estimulándole, se consigue que responda ; durante la fase de disnea, es, por el contrario, locuaz y habla en demasía. La diferencia es mayor aun durante el sueño. El período apnéico es la imagen de la muerte ; hay movilidad, embotamiento cerebral absoluto. A medida que reaparecen los movimientos respiratorios, se ve á nuestro hombre balbucear palabras ininteligibles, delirar después, pronunciar frases incoherentes, que se convierten en seguida en un murmullo confuso según van haciéndose más lentos los movimientos respiratorios. El contraste es, en ocasiones, más notable. Los enfermos que durante el período de apnea están inmóviles como cadáveres, se agitan en cuanto se presenta el período de disnea ; se vuelven violentos, lanzan gritos, tienen alucinaciones y visiones terroríficas, $\mathrm{y}$ es preciso sujetarlos como á verdaderos maníacos; después esta agitación se calma de pronto, es seguida á los pocos segundos de inercia, y vuelve á empezar al minuto siguiente. He visto estas alternativas dramáticas producirse durante cinco días consecutivos, en un profesor distinguido de la Universidad que murió con accidentes urémicos.

En nuestro enfermo no hay escenas de delirio violento, pero sí esbozo de estos accidentes, á juzgar por ciertos desórdenes intelectuales que habéis observado. Más de una vez, lo mismo que los paralíticos generales, ha ejecutado actos inconscientes, automáticos, se ha acostado en otra cama, se ha equivocado de sala, se ha orinado en el pavimento, y ha perdido por completo el recuerdo de 
estos actos. Se da cuenta de estas lagunas cerebrales y comprende que pierde la memoria ; conserva, por lo tanto, en el fondo, la razón; por poco que se estimule y fije su atención, se obtienen respuestas sensatas ; no padece, por consiguiente, delirio verdadero, ni se halla sujeto á alucinaciones, pero su inteligencia está trastornada por las modificaciones circulatorias de su cerebro.

Hemos procurado, en vano, descubrir los trastornos vesicales y las alteraciones pupilares que suelen existir en tales casos; volveré á ocuparme de este asunto.

Hoy, seis semanas después de ingresar el enfermo en el hospital, ha cambiado bastante el cuadro clínico. La respiración ha conservado durante un mes el tipo de CheyneStokes sin modificación alguna, pero, en la actualidad, la salud es relativamente buena y el corazón está tranquilo. Hemos visto disminuir poco á poco los fenómenos de disnea intermitentes; en diez días se han corregido casi por completo. De cuando en cuando se observa tendencia á la lentitud y después á la aceleración de los movimientos respiratorios, pero en estado incipiente y sin apnea verdadera. Estas modificaciones se presentan de preferencia durante el sueño. El estado cerebral ha mejorado también y el enfermo contesta á lo que se le pregunta y no ejecuta actos incoherentes.

La evolución de la enfermedad hacia la convalecencia es de las más típicas, y el fenómeno de Cheyne-Stokes, que era el síntoma predominante, ha seguido la misma marcha. ¿Tenemos derecho para atribuir á nuestra terapéutica este resultado feliz? Es una pregunta difícil de contestar, pero creo que resulta la siguiente del estudio de este caso.

Durante la primera semana se combatieron con éxito los accidentes cardíacos por medio de la digital á alta dosis, se restableció la secreción urinaria, pero en vez de me- 
jorar el enfermo, principiaron á acentuarse los fenómenos de disnea intermitente. La supresión de la digital no modificó este estado.

Suponiendo que los trastornos respiratorios estaban en relación con el ateroma, y sobre todo con el ateroma bulbar, empleé la medicación alterante y prescribí primero el ioduro potásico á dosis creciente de medio á 2 gramos por día, después el ioduro asociado al bromuro; los resultados, desde el punto de vista de la salud general, fueron buenos ; nulos respecto á la disnea. Por el contrario, los fenómenos disnéicos y los trastornos cerebrales se acentuaron, durante este período del tratamiento. Lo mismo sucedió con las inhalaciones de oxígeno; este agente terapéutico, que en teoría parece que debería modificar la anemia del bulbo, fue ineficaz en absoluto.

Los únicos medicamentos útiles, según creo, han sido. el cloral y el opio. Administrados al principio con el fin exclusivo de calmar el insomnio y la excitación intelectual, produjeron los efectos más benéficos. Tardé poco en suprimir el cloral, y el efecto sedante persistió bajo la in fluencia de medio centígramo de morfina inyectado mañana y tarde. Esta medicación se continuó durante quince dias, $y$ hemos visto mejorar de una manera progresiva el estado intelectual y los trastornos respiratorios sin que se modilicara de un modo sensible la secreción urinaria; el enfermo estuvo sometido á la vez al régimen lácteo parcial. En la actualidad, se ha suprimido la morfina y la mejoría persiste; es lógico, por lo tanto, suponer que el opio ha contribuído á restablecer en este caso la función regular del bulbo.

$\mathrm{T} u \mathrm{l}$ es el hecho clínico que acabáis de observar. Debemos aprovecharlo para estudiar de cerca este fenómeno de Cheyne-Stokes, que constituía el síntoma predominante en nuestro enfermo y para discutir el valor diagnóstico y 
pronóstico. Veréis de paso cuántos puntos obscuros quedan aún por exclareeer en este estudio.

En 1816, un médico irlandés, Cheyne, fue el primero que señaló este tipo respiratorio en un hombre que padecía esteatosis cardíaca y que fue acometido de apoplegía. Al hacer la autopsia, se descubrieron corazón grueso y hemorragia cerebral.

En 1854, Stokes, de Dublin, estudió de nuevo este asunto é hizo de la disnea intermitente un signo de la degeneración grasosa del corazón. Este síntoma tiene, para dicho autor, un valor patognomónico cuando coincide con el pulso lento y la debilidad de los latidos cardíacos.

Trece años más tarde, von Dusch, en Alemania, se ocupó de nuevo de este asunto, y demostró que el síntoma de Stokes no corresponde á todos los casos de degeneración del miocardio, y que se observa, por el contrario, en otras afecciones, entre ellas la pericarditis, y sobre todo ciertas enfermedades cerebrales, en particular la meningitis y los tumores del cerebro. Traube, en 1871, fue más lejos : añadió á la lista de las enfermedades conocidas ya, la nefritis y los accidentes urémicos, en los que se observa el tipo respiratorio intermitente. Desde entonces, se han publicado en todos los países trabajos numerosos sobre el particular ; entre las Monografías más completas citaré la Tesis de Biot, de Lyon, y la de Saloz, de Ginebra, y los trabajos de Murri (1) y de Sachi (2), en Italia.

Las condiciones patógenas del fenómeno son, en efecto, muy complejas y susceptibles de agruparse en varias clases.

Se incluyen en la primera categoría las enfermedades del corazón y de la aorta. El sitio y la naturaleza de la lesión no tienen, al parecer, influencia alguna. Se ha observado,

(1) Murri, Rivista clin. de Bologna, 1883.

(2) Sacchi, 1bid., Février, 1877. 
lo mismo en los casos de miocarditis con esteatosis indicados por Stokes, que en los de lesiones del orificio. Nuestro enfermo padece una insuficiencia mitral; Traube y Filehne han referido ejemplos análogos. Se ha observado también en la estrechez mitral. He visto un ejemplo en el curso de una insuficiencia aórtica; Sachi ha publicado el caso de un enfermo que padecía aneurisma de la aorta. Todas las enfermedades del corazón son capaces de ocasionar la disnea intermitente; pero debemos decir que es un accidente raro, respecto á la gran frecuencia de las afecciones cardíacas.

Las enfermedades del encéfalo forman el segundo grupo natural. El fenómeno de Cheyne-Stokes se observa en ellas á menudo, sobre todo en las lesiones basilares que interesan de cerca ó de lejos el bulbo. La meningitis, la hidrocefalia, los tumores cerebrales con derrame ventricular, y los tubérculos del cerebelo, son las afecciones en las que se observa de preferencia; en ciertos casos, sólo se descubre, al hacer la autopsia, ateroma arterial sin lesiones encefálicas localizadas.

Las enfermedades infecciosas ocasionan también la disnea intermitente. La difteria es, de todas ellas, la que presenta más á menudo esta sintomatología ; en muchos niños que padecen crup ó angina maligna, se observa este tipo respiratorio pocas horas antes de la muerte; he observado dos ejemplos de ello, y Huttenbrenner cita otros varios; es un signo pronóstico de gran valor, porque indica con seguridad un fin próximo. En la fiebre tifoidea es mucho más raro, pero Klein ha publicado un ejemplo; quizá en este caso la respiración intermitente esté en relación con las complicaciones renales.

De todas las intoxicaciones patológicas, la uremia es, en efecto, la que realiza más á menudo las condiciones patógenas de la respiración de Cheyne-Stokes. Tan cierto es 
esto, que puede decirse que, en clínica, la observación deI fenómeno debe hacer sospechar, en seguida, que existe una afección renal, que ha llegado á la fase de los accidentes. urémicos. Traube, de Berlín, fue el primero que notó esta. coincidencia; pero el mérito de haber vulgarizado la idea y de haberla hecho pasar al dominio de la clínica diaria, pertenece á Potain y á su discípulo Cuffer, por sus admirables trabajos sobre la nefritis intersticial. El tipo clásico de la disnea intermitente se ve de ordinario en la forma crónica de esta variedad de nefritis, pero no está exenta la uremia aguda, la que se observa, por ejemplo, en ciertos. escarlatinosos. No deja esto de tener importancia, porque se ha querido atribuir al ateroma cerebral, observado tan á menudo en los bríghticos crónicos, la producción del fenómeno cuando se produce perfectamente en personas. jóvenes cuyas arterias bulbares están sanas por completo. He observado varias veces accidentes urémicos complicados con la respiración de Cheyne-Stokes, en saturninos cuyos vasos se hallaron sanos al practicar la autopsia.

No me ocupo de nuevo de la sintomatología del fenómeno, porque la descripción de nuestro enfermo es un ejemplo típico. Voy únicamenteá poneros en guardia contra un error de semeiótica, que es fácil cometer al confundir la respiración de Cheyne-Stokes con la meningítica.

En esta última se observan irregularidades, pausas, y decuando en cuando, suspiros profundos; pero estos fenómenos no siguen un ritmo regular, y el período de apnea jamás es tan pronunciado. Hay, además, siempre en tales casos, irregularidades del pulso, que no existen en la respiración verdadera de Stokes, y que no se asemejan á las fases de aceleración y de lentitud isócronas que he descrito. En ciertos casos se ve asimismo, á consecuencia de ciertas intoxicaciones, sobre todo la asfixia, por el vapor de carbón, alternar 465 respiraciones aceleradas con 465 
lentas, pero no hay pausa verdadera. El mecanismo de este modo respiratorio es quizá análogo al que estudiamos, pero no es idéntico.

Ocupémonos de la fisiología patológica del síntoma y de los fenómenos de que va acompañado; y analizemos ante todo lo que pasa durante el período de apnea.

El fenómeno predominante que se observa entonces es la exageración del sueño que se convierte en estupor. La tensión arterial está siempre disminuida de un modo notable. Hemos comprobado este hecho en nuestro enfermo y los trazados cardiográficos y esfigmográficos publicados por Biot, Blaise y Murri, no dejan la menor duda sobre la realidad de dicha modificación. Como consecuencia de este descenso de la presión vascular se acelera el pulso y hemos visto que el número de pulsaciones excede en una veintena al del período disnéico correspondiente. Las pupilas están casi siempre contraídas y punctiformes, como en estado fisiológico durante el sueño: en ciertos casos raros se ha observado desviación conjugada de los globos oculares. El aspecto de los tegumentos no indica esta tendencia congestiva, porque la piel y las mucosas quedan pálidas ; las conjuntivas son las únicas que presentan cierto grado de vascularización.

Durante el período de disnea los fenómenos son contrarios por completo. La tensión arterial aumenta, y la consecuencia es la lentitud del pulso; las pupilas no están contraídas, sino normales y hasta dilatadas muchas veces : en vez del sueño y del embotamiento cerebral hay agitación, delirio y locuacidad. Las condiciones de la circula. ción cerebral y bulbar parecen opuestas diametralmente : á la fase de apnea corresponden fenómenos congestivos intra-cefálicos, mientras que en el período disnéico predomina la anemia. Después veremos qué debe pensarse de la teoría; por el pronto, nos limitaremos á exponer el hecho. 
En ciertos casos excepcionales el aparato muscular y el sistema nervioso sensitivos sufren las consecuencias de este antagonismo funcional. Robertson (Lancet, 1888), ha publicado un ejemplo de respiración de Cheyne-Stokes, en el que durante la fase de disnea se producía una verdadera contractura tónica de los músculos, mientras que en la pausa respiratoria había relajación completa.

Lo mismo sucede con la sensibilidad cutánea. Muchas veces hay anestesia, ó cuando menos percepción defectuosa del contacto y del dolor durante la fase de apnea : y exaltación de la sensibilidad en el período de disnea, pero la observación de estos síntomas es delicada siempre.

Resulta de este análisis que la disnea intermitente consiste esencialmente en la alternativa de fenómenos de excitación y de depresión bulbares. Pero el problema no está resuelto con esto, y las dificultades son grandísimas cuando se trata de explicar el mecanismo de esta alternativa.

Stokes invocaba el estado de la fibra cardíaca y la insuficiencia de la contracción ventricular. Esta explicación no es defendible. Cae ante el hecho clínico de que las fases del ritmo respiratorio no son influídas en modo alguno por las contracciones del corazón. A cada momento se ve presentarse la asistolia sin producir apnea ni irregularidades respiratorias, y, al contrario, se observa la disnea intermitente en individuos cuyas contracciones cardíacas son fuertes y enérgicas, ó que acaban de tomar la digital, como sucedió á nuestro enfermo.

El estado de las arterias cerebrales desempeña, al parecer, un papel esencial en la producción del fenómeno. Según Traube es la condición anatómica indispensable. La respiración de Cheyne-Stokes se produce siempre que es insuficiente el riego arterial del bulbo, bien por lesión directa de los vasos ó de los centros nerviosos, 6 por una alteración cardíaca. 
Esta teoría es especiosa, y tal vez verdadera en parte. Debe tenerse en cuenta la alteración del tronco basilar y de sus ramas en el mecanismo del fenómeno, y en nuestro enfermo, á causa de su edad, es de suponer que no fue extraña al cuadro clínico. Pero sólo es quizá una causa predisponente ; porque, por una parte, no se explica que una lesión fija y definida produzea trastornos funcionales pasajeros é intermitentes, y por otra los hechos desmienten la correlación necesaria de los dos términos. ¡Cuántas veces se encuentran ateromatosos los vasos en la base del cerebro en personas que jamás han padecido la respiración de Cheyne-Stokes, y, al contrario, conocemos casos en los que este fenómeno coincidió con integridad perfecta de las arterias bulbares!

Pero sería inexacto negar toda importancia á las lesiones locales de los vasos del bulbo. Hace ya mucho tiempo que Filehne (1), procurando resolver el problema por la vía experimental, demostró claramente la influencia capital de la circulación sanguínea local sobre el fenómeno. Este ilustre experimentador pasó un hilo por debajo de la arteria subclavia y del tronco braquio-cefálico de un conejo, de modo que fuera posible modificar á voluntad, por el grado de tensión del lazo, el calibre de los vasos. Estrechando la arteria se producían fenómenos disnéicos; abandonando el hilo sobrevenía la pausa respiratoria. La isquemia del cerebro corresponde á la fase de disnea, y. la apnea á la congestión experimental. Estas condiciones de experimentación son indudablemente teóricas, pero ponen, no obstante, de manifiesto ciertos aspectos del fenómeno.

Es indudable también que debe tenerse en cuenta el estado de la sangre y ciertas condiciones discrásicas susceptibles de impresionar de una manera directa el bulbo. El

(1) Filehne, Berl. Kl. Woch, 1875. 
hecho es cierto porque vemos, á falta de toda lesión cardíaca $o ́$ arterial, que las toxemias, como la difteria y la uremia, producen la disnea intermitente y que ocasionan el mismo fenómeno intoxicaciones más sencillas, por ejemplo, la asfixia por el vapor de carbón (Bernheim). Pero sobre este asunto estamos reducidos á conjeturas. ¿Cómo obran las modificaciones de la sangre? ¿Estimulando ó paralizando los elementos del bulbo, ó produciendo de una manera indirecta trastornos circulatorios locales? Es imposible decirlo.

Hemos dicho que, para Traube, el fenómeno fundamental del ritmo respiratorio de Cheyne-Stokes, es la disminución de la excitabilidad del centro bulbar debida al riego arterial insuficiente. Cree que como el ácido carbónico es el excitante natural de este centro nervioso, se necesita, en las condiciones nuevas del bulbo, una cantidad mayor de dicho ácido para que funcione. La pausa respiratoria corresponde, según este autor, á la acumulación de ácido carbónico en la sangre y cuando ésta se halla saturada lo suficiente, se deja sentir de nuevo la necesidad de respirar, tanto más imperiosa cuanto más próxima está la asfixia.

A esto se debe la respiración entrecortada y precipitada que marca el principio del período de disnea. Al contrario, á medida que el oxígeno penetra en la sangre, disminuye la excitabilidad del bulbo y del pneumogástrico y concluye por desaparecer. A esta fase corresponden los movimientos respiratorios cada vez más lentos y débiles, después la pausa respiratoria, cuyo principio marca el apogeo de la oxigenación de la sangre.

La teoría de Traube supone la integridad del pneumogástrico; según él, este nervio sufre la primer influencia excitante del ácido carbónico y la calmante del oxígeno. Es una hipótesis que contradicen los hechos experimen- 
tales. Filehne ha demostrado, en efecto, que después de la sección de los nervios vagos se produce aun el fenómeno de Cheyne-Stokes; es lógico, por lo tanto, suponer que existe en el bulbo el origen de su incitación, sin el intermedio de los pneumogástricos, y que estos nervios no son indispensables para transmitir las impresiones reflejas de la mucosa pulmonar.

Un médico italiano, Sacchi, interpreta de distinta manera el fenómeno. Según este observador, la causa de la disnea intermitente no es la acumulación de ácido carbónico, sino más bien la falta de oxígeno. Se funda para creerlo en los buenos efectos terapéuticos de las inhalaciones de oxígeno que combaten la anoxemia y hacen desaparecer algunas veces la apnea. Pero, por desgracia, para la teoría, los hechos clínicos no responden á estas afirmaciones y por mi parte puedo afirmar, por haberlo experimentado varias veces, que estas inhalaciones no son tan eficaces como pretende Sacchi. Más diré : en la mayor parte de los casos, el oxígeno en nada modifica la respiración de Cheyne-Stokes, ni aun disminuye la tendencia asfíxica de los enfermos.

Queda por exponer una teoría compleja, defendida por Murri en un trabajo extenso que publicó en 1883 en la Revista clínica de Bolonia. Según este autor, el centro respiratorio está formado, desde el punto de vista fisiológico, por una serie de zonas que funcionan sucesivamente según el carácter venoso más ó menos pronunciado de la sangre; en otros términos, las menos sensibles son las últimas que funcionan. En el fenómeno de Cheyne-Stokes disminuye la excitabilidad general del bulbo de modo que las zonas que responden á las condiciones de la respiración normal, se hacen insuficientes $y$ es necesario que entren en juego las suplementarias del centro respiratorio. Para este autor, lo mismo que para Traube, la causa patógena de la perio- 
dicidad del fenómeno es la composición variable de los. gases de la sangre.

En el fondo, es una variante de la teoría del profesor de Berlín y las condiciones secundarias del fenómeno se asemejan bastante, según Murri,á las que admite Traube. Este cree en un trastorno funcional del pneumogástrico; Murri va más lejos : considera como muy verosímil que en todos los que padecen disnea intermitente hay siempre una enfermedad del bulbo complicada con neuritis del nervio vago ó desorganización de su núcleo de origen. Algunas autopsias justifican, al parecer, esta creencia : en 1884, publicó Tizzoni (1) un caso en el que había alteraciones del pneumogástrico. Pero el descubrimiento de una lesión primitiva no basta para fundar una teoría general. Es, para mí, muy poco probable, que esta neuritis del pneumogástrico sea una condición patógena esencial ; porque se observan casos que curan con rapidez, como ha sucedido á nuestro enfermo. Creo que se trata más bien de un trastorno funcional del bulbo, resultado, por ejemplo, de una acción electiva de ciertos venenos, tales como los que se forman durante las enfermedades de los riñones y que producen accidentes urémicos.

Además, para comprender el mecanismo intimo de la respiración de Cheyne-Stokes, sería necesario, ante todo, conocer la teoría exacta de la función normal del centro respiratorio. Pero esta cuestión es una de las más controvertidas de la fisiología, porque no todos admiten el centro respiratorio único, el nudo vital bulbar de Flourens. Algunos fisiólogos, Langendorff y Rosenthal sobre todo, admiten varios, y describen, al lado del centro bulbar único, otro medular que, especialmente en los gatos, funciona á pesar de la sección de la médula oblongada. Pero. aun limitándose al centro bulbar único, la cuestión dista

(1) G. Tizzoni, Arch. ital. de Biol., fasic. II., 1884. 
mucho de estar resuelta, porque este centro, según los experimentos más modernos, funciona, al parecer, de una manera automática independiente de las condiciones del riego vascular, de la presión sanguínea y de la contracción cardíaca; es independiente también de las sensaciones sensitivas periféricas, que desempeñan un papel tan importante en el reflejo respiratorio. Todos estos elementos obran de un modo indudable en el estado fisiológico, pero el bulbo puede funcionar sin su concurso. Si decimos, además, que para Marckwald y Kronecker existen otros dos centros bulbares, uno inspiratorio y otro espiratorio, se comprenderá cuán complejo es el problema y de qué maneras tan diversas le consideran los fisiólogos.

Pero resulta de estas investigaciones divergentes que existe en realidad el automatismo del bulbo, y es probable que el fenómeno de Cheyne-Stokes sea sólo una exageración de este automatismo. Basta asfixiar una rana sumergiéndola en agua, 6 impidiendo el aflujo de sangre al cerebro por una ligadura de la aorta, para ver presentarse la disnea intermitente, con fases de apnea, análogas en un todo al fenómeno patológico. Este experimento, hecho por Luchsinger, prueba, al parecer, que, colocando al bulbo en condiciones de riego anormal, se exageran sus funciones. Es una ley general, para todos los órganos, que su excitabilidad fisiológica aumenta por el reposo y se anula por su actividad. El fenómeno de Cheyne-Stokes es quizá sólo resultado de una excitación bulbar exagerada que ocasionó la extenuación nerviosa. La disnea, según esta hipótesis, es consecuencia de la excitabilidad anormal del bulbo, cosa contraria á las conclusiones de Traube; y así se explica la utilidad de los narcóticos, tan evidente en nuestro enfermo.

Esto me conduce á hablaros de las indicaciones terapéuticas de la respiración de Cheyne-Stokes. No es posi- 
ble formular regla fija alguna, porque las condiciones en que se presenta este síndrome, son muy variables. Puede decirse, en términos generales, que la terapéutica tiene poca influencia sobre la disnea intermitente. Ni los medicamentos que hacen más lenta la circulación y aumentan la tensión sanguínea, como la digital, ni los que la aceleran, como el café, obran, al parecer, de un modo eficaz.

Los que obran sobre la circulación local del bulbo, como el nitrito de amilo, suelen ser más eficaces, pero no siempre; el año pasado empleé, sin éxito, este medicamento en un caso. Otro tanto puede decirse de la ergotina.

Los que modifican la composición de la sangre tienen alguna más eficacia. Sacchi, por ejemplo, ha obtenido buenos resultados con las inhalaciones de oxígeno: os he hablado de un caso en el que no obtuve éxito alguno. No creo que sean eficaces más que los sedantes directos del sistema nervioso, y en particular la morfina y el cloral. Pero tened presente que no debe emplearse indistintamente la morfina en todos los casos, y que es un medicamento que por disminuir la secreción urinaria, puede ser peligroso para los urémicos. 


\section{AORTITIS AGUDA}

Sumario: Congestión pulmonar aguda en el curso de una crisis de aortitis. - No tiene ni los caracteres de la congestión inflamatoria, ni los de las congestiones sintomáticas de la albuminuria. - Estos son los sintomas más notables de la aortitis aguda. - Son siempre apiréticos y no van acompañados de accesos dolorosos análogos á la angina de pecho. - Mecanismo de estas crisis accesionales é influencia del sistema nervioso. - Influyen poco sobre el estado del corazón. - Etiología de la aortitis aguda : influencia eada vez más preponderante de las enfermedades infecciosas sobre la génesis de las lesiones vaseulares.Indicaciones terapénticas.

El núm. 7 de la sala Chauffard la ocupa un hombre de cuarenta y tres años. Hoy su pulso es tranquilo, lento y algo duro; no tiene fiebre y respira bien. Pero cuando le vimos llegar á la consulta, hace dos días, presentaba el aspecto de un enfermo gravísimo. Tenía la cara pálida y ansiosa, la respiración era difícil ; al movimiento más ligero sentía angustia precordial excesiva. Tosía poco, por accesos; le era imposible bajarse 6 levantarse, sin sofocarse.

Notaba una sensación penosa de peso en el epigastrio : el vientre estaba hinchado como al principio de una cirrosis, las piernas se hallaban algo edematosas y había, al parecer, ascitis. Todos estos accidentes, según indicó el enfermo, databan de la víspera y durante la noche creyó ahogarse.

Lo primero en que se pensaba era en una congestión pulmonar aguda, cuyos signos físicos llegaban al máximum. Observamos, en efecto, en la base del pecho, macicez y disminución de las vibraciones torácicas.

El murmullo vesicular estaba debilitado en toda esta 
región, y se oían en ella infinidad de extertores finos, sobre todo, á la izquierda.

Era difícil auscultar el corazón, á causa de la intensidad de la disnea y de la confluencia de los ruidos pulmonares: no había, al parecer, soplo orgánico ni lesión valvular.

El hígado, que traspasaba las costillas falsas, era doloroso y estaba congestionado y el abdomen, distendido por gases, presentaba en los puntos declives ascitis. ligera.

El principio brusco de los accidentes, unido á estas congestiones múltiples, hacia verosímiles varias hipótesis.

Podía creerse, ante todo, en una de esas congestiones. pulmonares que sobrevienen con rapidez y adquieren en seguida una intensidad grandísima bajo la influencia del frío. Pero en nuestro enfermo no existía esta causa ocasional, y además era distinta la marcha de los accidentes. Las congestiones pleuro-pulmonares debidas á los enfriamientos principian casi siempre por dolor de costado, escalofríos, expectoración hemoptoica ó cuando menos espesa y viscosa. Nada de esto sucedió aquí. El enfermo no ha tenido dolor de costado, tose poco y no expectora: la disnea tiene también otro carácter. En vez de los movimientos respiratorios precipitados que existen en los enfermos que padecen dolor torácico, la respiración es lenta, y va acompañada de una sensación de angustia precordial indecible. Por último, en este enfermo los extertores están diseminados por todo el pecho, mientras que en las congestiones pleuro-pulmonares, a frigore, los signos estetoscópicos son casi siempre unilaterales, y corresponden al lado doloroso.

Un edema brusco que se presenta en el curso de una albuminuria, produce algunas veces un cuadro clínico análogo. Pero aun, en este caso, predominan los fenómenos de disnea y los signos de una congestión pulmonar aguda, á los que se unen complicaciones pulmonares y derrames 
serosos. Pero difiere por completo el estado de las funciones renales, y este carácter basta por sí solo para desechar la idea de una enfermedad de Bright. La orina, en vez de ser escasa, roja-albuminosa 6 sanguinolenta, como sucede de ordinario en las nefritis que van acompañadas de edemas viscerales, es en nuestro enfermo normal por completo como cantidad y no contiene albúmina.

Queda la hipótesis de una congestión pulmonar de origen cardíaco. En las enfermedades del corazón se observan dos variedades de accidentes congestivos. La hiperemia pulmonar es casi siempre pasiva y va acompañada de edema del pulmón : en este caso se observa en un período avanzado de la enfermedad, mucho tiempo después de estar ya infiltradas las piernas y de ser indudables los signos racionales de la afección cardíaca. Otras veces son congestiones activas, y entonces el cuadro clínico recuerda por completo el que acabamos de observar en nuestro enfermo. De pronto, en medio de una buena salud aparente, sobreviene una crisis de disnea con angustia precordial, sensación de ahogo y de desfallecimiento, silbido traqueobronquial, tos escasa y expectoración difícil, á menudo hemoptoica. Al mismo tiempo hay meteorismo, la orina se suprime por completo ó disminuye su cantidad, y el pulso pequeño, desigual é irregular indica la dificultad cardíaca y los trastornos de inervación.

Estos accidentes bruscos de disnea cardíaca, que interesan siempre á la vez los pulmones y el corazón, y que son debidos, al parecer, á una parálisis funcional del pneumogástrico, tienen la particularidad de adquirir en pocas horas una intensidad grandísima, hasta el punto de poner de la mañana á la tarde en peligro la vida del enfermo : en los casos típicos es completo el trastorno del corazón, y el pulso imperceptible; es el ataque de asistolia con toda su gravedad. 
En nuestro enfermo faltaron los fenómenos cardíacos, propiamente dichos, $\mathrm{y}$ los accidentes pulmonares fueron mucho menos agudos. La disnea jamás excedió de 36 respiraciones por minuto; el corazón ha latido siempre con regularidad, sin aritmia, aunque la opresión tenía el carácter cardíaco, en el sentido de que el esfuerzo más ligero la exacerbaba y producía una sensación de angustia precordial excesiva.

La auscultación, incierta el primer día, permite hoy resolver el problema, porque suministra la prueba evidente de la existencia de una lesión cardíaca. El volumen del corazón parece que no está aumentado, porque la macicez precordial absoluta no excede de 5 centímetros y la relativa es sólo de 10 . Los latidos son regulares y no están exagerados en modo alguno; el primer ruido mitral es fisiológico. Pero en la base, hacia el segundo espacio, se oyen dos ruidos morbosos : el primero sistólico, caracterizado por un soplo tenue y algo áspero; el segundo diastólico, de timbre suave y aspirador. Este soplo doble se propaga por toda la región del cayado de la aorta, y se oye lo mismo á la derecha que á la izquierda del esternón ; pero, al parecer, el máximum corresponde al segundo es pacio derecho.

La lesión es, por lo tanto, indudablemente aórtica, y de los caracteres de la auscultación se deduce que están enfermas las válvulas sigmoideas, y que la alteración se extendía por parte del cayado de la aorta.

El hecho de existir en el orificio un soplo sistólico áspero prueba que las válvulas están induradas, apergaminadas y rugosas : el soplo diastólico demuestra que estas válvulas no se aplican con exactitud por sus bordes y dejan pasar cierta cantidad de sangre al ventrículo. Pero puede afirmarse que la insuficiencia aórtica no es considerable, porque no produce trastorno vascular periférico al- 
guno. El pulso radial no tiene el carácter de salto; es, á lo sumo, algo más amplio y duro que en estado normal. No se ve la pulsación arterial en el cuello, ni hay indicio de pulso capilar visible en la frente ni en los dedos de la mano. Estos fenómenos concuerdan con la falta de trastornos funcionales circulatorios; el enfermo no siente ni desvanecimientos, ni vértigos, ni sensación de náuseas, en una palabra, ningún síntoma de anemia cerebral.

Lo que domina es, indudablemente, la lesión de la aorta. En las alteraciones limitadas de las válvulas sigmoideas, el soplo nace in situ y tiende poco á propagarse, excepto cuando la insuficiencia es considerable; pero, aun entonces, se propaga más bien hacia la punta del corazón. En nuestro enfermo, por el contrario, el soplo falta en la punta, se propaga por toda la región del cayado aórtico y su máximum corresponde al segundo espacio intercostal derecho, es decir, á la inflexión de la arteria. Puede, por lo tanto, afirmarse que hay arteritis del cayado.

¿Quiere decir esto que la aorta está dilatada por igual en toda su extensión? No lo creo. Porque no se la siente latir deprimiendo con el dedo la horquilla esternal, y el examen de la región supra-clavicular, tanto á la derecha, como á la izquierda, no revela que las arterias subclavias estén situadas más arriba que en estado normal, signo importante de la dilatación aórtica. Por último, percutiendo la región pre-esternal, se nota macicez aórtica en la extensión casi de 6 centímetros ; esta extensión es superior á la media fisiológica, pero no llega al máximun. En algunas aortas dilatadas así, la macicez transversal excede de 7 á 8 centímetros.

Parece indudable, por lo tanto, según el análisis de estos signos físicos, que existe en la porción ascendente del cayado de la aorta una ectasia ampollosa, que principia en las válvulas sigmoideas y cesa en la proximidad de la 
parte superior de la curva, de 7 á 8 centímetros de longitud próximamente. Se trata, por lo tanto, de una aortitis verdadera.

Este descubrimiento de una inflamación de la aorta esclarece bastante la naturaleza de los accidentes que hemos observado. Es indudable, en efecto, que hay una estrecha relación entre la aortitis y la congestión pulmonar especialísima que ha padecido nuestro enfermo.

Estas crisis congestivas, cuya significación no ha sido bien conocida hasta hace unos quince años, son el síntoma más notable y más dramático de la aortitis aguda. Se presentan á menudo sin causa apreciable, en medio de un buen estado de salud aparente, y revelan desde luego, por los accidentes gravísimos, la existencia de lesiones vasculares latentes, desconocidas hasta entonces. Otras veces se producen en el curso de una aorcitis confirmada, y entonces se anuncian desde mucho tiempo antes por malestar, que son el esbozo y la expresión atenuada del ataque: una sensación pasajera de sofocación y de peso torácico, respiración anhelosa, que dura algunos minutos $\delta$ varios segundos. Por último, constituyen uno de los epifenómenos más comunes y habituales de la dilatación crónica de la aorta y de los aneurismas de este vaso.

Los caracteres de estas crisis accesionales han sido descritos de una manera magistral por mi inolvidable colega y amigo Léger en su Tesis inaugural (1877).

El primero, y uno de los más importantes, es la apirexia que existe siempre en tales casos. Cualquiera que sea la intensidad de los accidentes, la temperatura es siempre baja y el número de pulsaciones excede pocas veces de 80 á 90. Es un fenómeno tanto más importante, cuanto que contrasta de una manera extraña con lo que sabemos de las congestiones pulmonares agudas en general. El más ligero enfriamiento que obre sobre el pulmón, produce de 
ordinario una elevación térmica bastante notable, aunque los signos estetoscópicos son casi nulos ; el pulso se acelera de un modo paralelo. En el caso de que tratamos, nada de esto se observa. El pulso siguí́ siendo lento, duro y amplio. Esta amplitud, por decirlo de paso, no indica por necesidad un aumento de la fuerza de los latidos cardía$\cos$, ni una hipertrofia ventricular concomitante ; parece más bien hallarse en relación con el eretismo vascular. No hay correlación necesaria entre la energía de la acción cardíaca y la intensidad del pulso : asisto en la actualidad á una señora que padece aortitis, en la que, durante las crisis, las pulsaciones radiales son duras y vibrátiles, pero el choque de la punta es débil y la contracción ventricular poco enérgica. Existe, al parecer, en tales casos cierta independencia vascular, como sucede en la enfermedad de $\mathrm{Ba}$ sedow, en la que se ha observado á menudo el fenómeno.

La naturaleza de la opresión que sufren los enfermos es también característica. No aumenta el número de movimientos respiratorios ; oscilan entre 30 y 40 por minuto, pero son muy penosos y laboriosos. La inspiración es larga y difícil, como si hubiera un obstáculo mecánico al paso del aire; la espiracion es relativamente más libre. No es el tipo de la disnea de los asmáticos en la que la espiracion se prolonga en demasía, ni la de los pulmoníacos, en la que el número de respiraciones aumenta en proporción á la disminución del campo respiratorio. Parece que, á causa de la dilatacion de la aorta, es comprimida de una manera momentánea la tráquea y el plexo nervioso que la rodea; á esto se debe la dificultad real de la inspiración.

Lo que prueba bien á las claras que se produce en tales casos una especie de espasmo de las vías respiratorias, es la escasez de signos que se notan al auscultar. Todos los médicos que han visto y descrito estos accesos, llaman la 
atención sobre la falta de concordancia que existe entre los trastornos funcionales y los signos físicos. El enfermo se sofoca y tiene necesidad de aire; le parece que va á ahogarse, y á pesar de esto se oyen relativamente pocos extertores, con seguridad bastantes menos que en muchas bronquitis en las que apenas hay disnea. Pero esta regla no es absoluta, porque precisamente habéis visto que en nuestro enfermo se oían á su ingreso bastantes extertores en ambas bases de los pulmones, extertores que desaparecieron en los días siguientes, á la vez que los fenómenos disnéicos.

El dolor es uno de los síntomas más constantes de las crisis aórticas. Se manifiesta casi siempre por una sensación de peso localizada en la región retro-esternal, en el trayecto de la aorta 6 más abajo hacia el epigastrio; así sucedió en nuestro enfermo, quien se quejaba de dolores constrictivos en el hueco del estómago. Otras veces, de este fondo de padecimiento fijo, que es más bien un malestar permanente que un dolor verdadero, se destacan punzadas fuertes, que irradian por fuera del esternón, á la base del cuello, hacia el hombro izquierdo, y recuerdan por su intensidad y su carácter brusco y grave, los ataques de angina de pecho. Los enfermos notan, en efecto, una sensación grandísima de angustia y comprenden que esta ansiedad no puede continuar impunemente, sin producir ${ }^{\text {th }}$ al poco tiempo la muerte.

Cuando se repiten los accesos de este género, no es raro ver presentarse trastornos circulatorios que se manifiestan por la aparición de edemas en los miembros inferiores.

Excepto el dolor, que en nuestro enfermo fue ligero y no tuvo los caracteres de una crisis de angina de pecho, se encuentran, en el caso que estudiamos, la mayor parte de los rasgos de esta descripción de la aortitis aguda; de aquí lo intenso y brusco de los accidentes y su mejoría 
rápida. La evolución de las congestiones pulmonares verdaderas jamás es tan rápida.

¿Cuál es el mecanismo de estas crisis accesionales? Es todavía muy obscuro.

Un punto que creo indudable, desde el punto de vista clínico, es la realidad del proceso congestivo en tales casos. Para el pulmón, el hecho es innegable. No sólo se nota disnea, dificultad respiratoria que va acompañada de congestión torácica, sino que los signos estetoscópicos cuando se les observa, corresponden por completo á este dato: hay macicez, obscuridad del ruido respiratorio, extertores bronquiales más ó menos numerosos. La demostración es más palpable algunas veces, porque la fluxión pulmonar se manifiesta por esputos sanguinolentos, verdaderas hemoptisis. Tuve hace algún tiempo, en la clientela privada, un enfermo de sesenta años, gotoso antiguo, que padecía angina de pecho y que presentaba crisis muy violentas. Cada vez que era algo fuerte el ataque, se presentaban accesos de tos seguidos de hemoptisis, y durante algunas horas se oían, al auscultar, infinidad de extertores finos. Los signos estetoscópicos tardaban de ordinario dos días en desaparecer.

En el hígado se observan fenómenos análogos. Es frecuente, durante los accesos de angina de pecho, ver que esta víscera aumenta de volumen y se pone dolorosa. Es precisamente lo que ha sucedido á nuestro enfermo, y recordaréis que á su ingreso dudábamos si la congestión hepática sería el preludio de la cirrosis.

¿Para qué, y por qué, se producen estas congestiones viscerales y cómo la irritación procedente de la aorta repercute en tales casos?

A esta cuestión sólo es posible responder hoy por hipótesis.

Parece verosímil que la aparición de las crisis corresCrinaca médzca. - Tomo $\mathrm{I}$. 
ponde á una dilatación brusca y repentina de la ampolla aórtica que se distiende por la onda sanguínea. Quizá bajo la influencia de esta distensión son comprimidos los órganos inmediatos, la tráquea y los bronquios gruesos; quizá, y es lo más probable, se trate sólo de una parálisis momentánea de los nervios del plexo aórtico, cuyas consecuencias son trastornos vaso-motores é isquemia cardíaca. Así se explican los síntomas de angina de pecho tan frecuentes en estos casos, los fenómenos de hiperemia del hígado y el meteorismo intestinal, porque sabemos que el pneumogástrico y el simpático que forman el plexo cardíaco envían filetes nerviosos á las vísceras abdominales.

¿Mas de dónde procede la dilatación aórtica causa primera del proceso morboso? ¿ Es activa 6 pasiva, directa ó refleja? Son otros tantos problemas que se plantean, pero que no se resuelven. Es indudable que una inflamación aguda de la aorta, de origen reumático ó traumático, es capaz de producir la dilatación paralítica pasajera del vaso ; es probable que influyan de este modo sobre la aorta una multitud de influencias lejanas; el frío, las emociones morales, los trastornos dispépsicos, figuran como causas determinantes.

Un punto que merece señalarse, respecto á la fisiología patológica de esta crisis, es la influencia muy variable que ejercen sobre el corazón. Esta influencia es por lo común casi nula, mucho menor que lo que podría suponerse. En pleno apogeo del acceso, los latidos cardíacos no son irregulares ni tumultuosos, sino relativamente lentos y fuertes; es lo que habéis visto en nuestro enfermo. Por consiguiente, cuando se producen fenómenos de angina de pecho, la sensación de tumefacción, de plenitud cardíaca que notan los enfermos, demuestran con toda claridad que no es indiferente el corazón á la crisis aórtica. No necesito insistir sobre la gravedad de estas complicaciones cardíacas, 
porque la consecuencia puede ser la muerte por síncope.

Volviendo á nuestro enfermo, es necesario resolver un problema, averiguar la edad de sus accidentes de aortitis. $\Varangle$ Se trata de una lesión incipiente $\delta$ de un estado patológico ya antiguo, latente durante más ó menos tiempo y que despertó por una circunstancia ocasional?

Las causas ordinarias de la aortitis son de varias clases. A excepción de los traumatismos directos, cuya influencia patógena es indiscutible, la mayor parte de las lesiones irritativas de la aorta dependen de estados generales diatésicos, por ejemplo, el reumatismo y la gota, $\delta$ de intoxicaciones como el alcoholismo y el saturnismo. Es preciso agregar, además, las enfermedades infecciosas, cuya influencia, desconocida durante mucho tiempo, tiende á hacerse preponderante á medida que se conoce mejor la etiología de las lesiones vasculares. La fiebre tifoidea, la viruela, la difteria y la sífilis, son ejemplo de ello.

En nuestro enfermo, no descubrimos herencia constitucional alguna; ni él ni sus padres, han padecido reumatismo; tampoco parece que ha tenido sífilis. Pero en su juventud padeció sucesivamente dos enfermedades graves, la viruela y la difteria. ¿Debe atribuirse á esta etiología lejana el origen de la aortitis actual, que ha quedado latente más de veinte años? No lo creo ; sería una incubación de duración anormal. Cuando las enfermedades infecciosas interesan la aorta, producen en ella con rapidez lesiones que no esperan años para dejar sentir sus efectos nocivos. Tal es al menos la conclusión que saca Landouzy de sus notabilísimos trabajos sobre la aortitis tífica, y tal es también mi opinión fundada en los casos que he observado.

Verdad es que podría sostenerse, con ciertos visos de fundamento, que la aortitis actual es la primer manifestación de un reumatismo visceral. El hecho clínico no es imposible 
y el año anterior he observado un caso de este género. Se trataba de un hombre de treinta y dos años, el cual permaneció veintiocho días de maniobras como reservista, durante los cuales estuvo expuesto á la humedad, y volvió con fiebre, angustia precordial y todos los signos de una aortitis ; pocos días después se presentaron dolores articulares francos. Pero no deben forzarse las analogías y nada prueba que nuestro enfermo padezca una arteritis reumática verdadera.

Sólo hemos encontrado en él una causa predisponente legítima, el alcoholismo. Este enfermo ha hecho excesos frecuentes en la bebida y tiene todas las mañanas la pituita de los bebedores. Excepto esto, su salud era buena, no sentía fatiga respiratoria alguna y se dedicaba á trabajos de fuerza ; es, por lo tanto, poco probable que este estado patógeno baste para explicar los accidentes actuales.

Citaremos un incidente sobre el que ha insistido de una manera especial el enfermo y que quizá ha influído algo en el desarrollo de su aortitis. El 4 de Enero, hallándose ocupado en cargar trozos de hielo, se hizo una cortadura profunda en un dedo de la mano derecha. Fue poca cosa, porque pudo seguir trabajando hasta el día 20. En esta fecha, se presentó una linfangitis que degeneró en flemón y que le obligó á ingresar en la clínica del profesor Lefort, quien le hizo varias incisiones. Desde el punto de vista quirúrgico, la mejoría progresó con rapidez ; pero hallándose en tratamiento, se presentaron de repente una noche accidentes de opresión y de angustia precordial que fueron acompañados de palpitaciones ; tuvo que pasar varias horas sentado, sufriendo una disnea excesiva. A la noche siguiente, se presentó otra crisis análoga algo menos fuerte y después todo entró en orden. A las cuarenta y ocho horas de abandonar el enfermo el hospital, sufrió otro tercer ataque más fuerte y prolongado que los anteriores; 
entonces se decidió á ingresar en una Sala de medicina.

Resulta de esta historia clínica que, hasta la época de su linfangitis, jamás tuvo este enfermo accidente alguno por parte del corazón $\delta$ de los pulmones, y que desde entonces presentó los síntomas característicos de una aortitis aguda. ¿ Debe deducirse de esto que hay una relación causal entre la linfangitis y la lesión de la aorta? La cosa es posible, pero no me atrevo á afirmarlo. Decir linfangitis, supone penetración en el organismo de un fermento patógeno de naturaleza infecciosa; estas condiciones son quizá suficientes para producir la irritación de la aorta, sobre todo si se reflexiona que el alcoholismo habrá debido preparar ya las lesiones.

Pero nada prueba en absoluto que sea ésta la etiología verdadera, porque el enfermo jamás tuvo fiebre desde que se sajó el flemón. Es verdad que los trastornos arteriales pueden desarrollarse de una manera secundaria sin despertar manifestaciones febriles; ejemplo de ello es la marcha insidiosa de las aortitis tíficas.

En resumen : trátese de un reumatismo visceral en su principio 6 de una aortitis consecutiva á una linfangitis infecciosa, los accidentes son, al parecer, de fecha reciente, y aunque se admita la influencia predisponente del alcoholismo, no es posible afirmar que la lesión de la aorta sea antigua.

Es dificil indicar con exactitud el pronóstico en este caso. La lesión no es, al parecer, ni considerable ni inveterada, pero los trastornos viscerales son intensos, y aunque la salud de este enfermo sea relativamente buena en los intervalos de las crisis, nada prueba que éstas no puedan reproducirse y hacerse más graves. No conozco medio alguno de apreciar la verdadera gravedad del padecimiento aórtico, porque no hay paridad entre la lesión y los síntomas y una lesión importante de la aorta, 
hasta un aneurisma, puede pasar inadvertido en ciertos. casos.

Lo que sí puede afirmarse, es que las crisis congestivas. son siempre graves, sobre todo cuando existen á la vez sintomas de angina de pecho. Sin embargo, aun en estas condiciones no entrañan un pronóstico inexorable, y se observan en su evolución períodos de calma larga. Veo de cuando. en cuando á una señora, á quien asistí en 1886 por accesos anginosos graves, sintomáticos de una aortitis, y desde entonces no ha vuelto á padecer trastorno funcional de la aorta. Pero este caso es una excepción afortunada, y la regla es ver reproducirse los accidentes algunas veces bajo. la influencia de causas triviales. Un enfriamiento, un esfuerzo, una mala digestión, una emoción moral, bastan para despertar los accesos; con más razón son de temer en un obrero que no puede dedicarse al descanso, y que por su profesión está condenadoá trabajos penosos. Es necesario, por último, no olvidar que la aortitis es una de las enfermedades que producen en ocasiones la muerte repentina.

Aunque el pronóstico es inseguro, las indicaciones del tratamiento son, por el contrario, precisas. El hecho fundamental en estas crisis accesionales es una fluxión cardiopulmonar, como he procurado demostraros.

Lo primero que debe hacerse, es combatir estos accidentes congestivos y emplear los antiflogísticos. Considero, como Peter, las emisiones sanguíneas locales, sanguijuelas y ventosas, utilísimas en tales casos ; las prescribí en nuestro enfermo. Aunque los accesos pierdan su agudeza, deben continuar empleándose los revulsivos; los vejigatorios, las cauterizaciones punteadas, los cauterios, contribuyen á sostener una derivación saludable, y es, según creo, el medio más eficaz para prevenir la reproducción de los accesos.

Conviene emplear á la vez los agentes modificadores de 
la circulación, y en particular el ioduro potásico, el más activo de los medicamentos llamados alterantes. La acción del ioduro sobre los gruesos vasos es innegable, sea cual fuere el origen de la endarteritis; no es necesario que sea sifilítica la aortitis, para observar sus buenos efectos. La dosis diaria debe ser de medio á un gramo; no creo indispensable recurrir, desde luego, á las grandes dosis ; es útil emplearlo á menudo y con perseverancia, con intervalos de reposo de quince días. Nuestro enfermo toma ahora un gramo diario ; si los accidentes mejoran, disminuiré dentro de poco la mitad de la dosis. Por poco acentuados que sean el eretismo vascular y el estado nervioso, es necesario asociar al ioduro cierta cantidad de bromuro; de este modo se corrigen con más facilidad la disnea y la angustia precordial. El valerianato amónico presta servicios verdaderos en las personas nerviosas.

En el momento de las crisis accesionales el tratamiento debe ser paliativo. El medio más eficaz de obtener la mejoría rápida es hacer una inyección de morfina $\delta$ mejor todavía de éter, si hay teudencia al síncope. Con las inhalaciones de nitrito de amilo, á la dosis de 6 á 10 gotas, se obtienen también efectos excelentes, $\mathrm{y}$ al descongestionar el pulmón producen un descenso instantáneo de la presión arterial. Si los accidentes son gravísimos y comprometen la vida, no debe titubearse en practicar una sangría, con la que se obtienen algunas veces éxitos inesperados.

La higiene debe vigilarse muy de cerca, sobre todo en lo que se refiere á la alimentación. En muchos de los enfermos que padecen aortitis sin exceso del régimen, origina la recidiva de los accesos: y sabemos cuantas veces aparece la angina de pecho durante una mala digestión. Es necesario, por lo tanto, vigilar el estado de las vías digestivas y prevenir, por la elección cuidadosa de los alimentos todo cuanto puede despertar los accidentes cardíacos. 


\section{AORTITIS CRONICA}

Somario : La aortitis crónica, á pesar de los sintomas parecidos á los de la aguda, tiene una fisonomia clínica por completo diferente.-Predominan los signos en una dilatación difusa del cayado: levantamiento en masa de la base del cuello, latidos vasculares en la horquilla esternal, elevación de las arterias subclavias; soplo doble á lo largo del trayecto de la aorta. - Los trastornos funcionales no están siempre en relación con la intensidad de las lesiones. - Valor del dolor retro-esternal y de los fenómenos vertiginosos : alteraciones oculo-pupilares. - Caracteres diferenciales de la dilatación crónica de la aorta y de los aneurismas : evolución diferente de estas dos clases de lesiones.

En la Conferencia anterior, hemos estudiado un caso que se desarrolló, por decirlo así, á nuestra vista. Hoy encontramos la misma enfermedad, en una fase más avanzada de su evolución. La sintomatología fundamental es análoga, pero los caracteres clínicos de los dos casos son muy diferentes.

El enfermo de que voy á hablaros, es un carpintero de cuarenta y dos años, robusto, sobrio, que no ha padecido sífilis ni reumatismo, ni es alcohólico. Hasta los treinta y nueve años ha disfrutado de buena salud. En esta época, sufrió un accidente grave. Al hacer un esfuerzo violento para elevar un gran trozo de madera, notó dolor retro-esternal y una sensación de desgarradura en el pecho. Inmediatamente después escupió sangre, y la hemoptisis se repitió varias veces seguidas. Tuvo que renunciar por completo al trabajo durante tres meses, sin notar cambio en su estado. Ingresó entonces en la Caridad, en la clínica del Dr. Peter, quien diagnosticó insuficiencia aórtica por rotura valvular, y aplicó sobre la región precordial una serie de revulsivos enérgicos. Después de una mejo- 
ría pasajera, se hallaba seis meses después en la clínica de Ferrand, en Laënnec, por accesos de angina de pecho, y, por último, ingresó hace un año en las salas de mi colega Rigal, quien le aplicó un cauterio y le sometió al uso del ioduro potásico.

Se trata, como véis, de un enfermo que padece una afección esencialmente crónica, casi de un inválido. Las lesiones del sistema circulatorio han adquirido en él una enorme importancia.

$\mathrm{El}$ aspecto exterior de este hombre, llama la atención. Alto, seco, flaco, pálido en extremo, de color blanco mate, sin venas varicosas ni placas congestivas, $y$ sin indicio de edema en los miembros inferiores.

La parte superior del tórax y la base del cuello, se elevan por movimientos de expansión rítmimos, sincrónicos con los latidos cardíacos. Parece, á primera vista, que hay un aneurisma enorme. Pero examinando con más detenimiento al enfermo, se ve que el sitio casi exclusivo de esta elevación expansiva es la base del cuello ; los espacios intercostales superiores apenas se hallan encorvados y quedan inmóviles ; no hay combadura ni deformación circunscrita del tórax ; la región precordial es, al parecer, normal por completo. No sucede así en los casos de aneurisma verdadero del cayado aórtico. En éstos se elevan los espacios intercostales, y los latidos expansivos se transmiten al cuello de una manera atenuada.

A pesar de estas diferencias, es posible afirmar desde luego que se encuentra enferma la aorta, y el examen físico de la región confirma esta idea. Aplicando la mano sobre los dos primeros espacios intercostales, se siente una doble vibración, isócrona, con los movimientos de expansión y de contracción de la arteria. Fenómeno notable : el estremecimiento catario es mucho más fuerte en el momento del diástole ventricular, es decir, durante la contracción 
de la arteria que en el del sístole, al contrario de lo que se observa por lo general. Volveremos á ocuparnos de este fenómeno insólito.

La percusión suministra la prueba directa del aumento de calibre de la arteria. Hay en la región pre-external una macicez que se extiende á tres traveses de dedo más allá del borde del esternón. Si se recuerda que en estado normal el seno aórtico llega precisamente al borde derecho, se comprende la dilatación enorme que ha sufrido la arteria. En cifras exactas, la macicez transversal mide 7 centímetros; es, por consiguiente, casi el doble del calibre fisiológico, porque la macicez aórtica varía de 3 centímetros y medio á 4 (Peter).

Esta dilatación continúa á todo lo largo de la porción ascendente del cayado aórtico, porque la macicez persiste desde el tercer espacio intercostal al primero, con variaciones insignificantes. Es posible afirmar también que está afectada la porción transversal de la curva, porque deprimiendo con el dedo la horquilla del esternón, se siente latir la aorta, lo que no sucede jamás fisiológicamente á la edad de este hombre. El contacto directo de la arteria produce las mismas sensaciones que la palpación torácica, se nota un choque sistólico expansivo que corresponde á un estremecimiento vibratorio suave, mientras que, al contraerse el vaso, la vibración se hace ruda y áspera.

La auscultación de la zona aórtica confirma los datos que suministra la palpación. Se oyen dos soplos, uno sistólico y otro diastólico. El primero, que corresponde á la fase expansiva de la arteria, es suave, filiforme, de timbre grave y prolongado: su máximum se oye en el segundo espacio intercostal derecho, en la parte media y hacia el borde del esternón. El segundo, que principia en el segundo tiempo del corazón y se prolonga durante todo el silencio mayor, es un soplo vibrante, áspero, de intensidad 
extraordinaria y de timbre musical. Es más bien un pio, una especie de ruido de cepillo de carpintero, duro y áspero, que desgarra el oído. No es necesario, para oirle, aplicar la cabeza sobre el pecho: se nota á distancia. El enfermo le oye de día y de noche, y esta especie de ronquido perpetuo es para él un verdadero suplicio y una causa permanente de insomnio. Este soplo se halla localizado en el segundo espacio intercostal derecho, y se propaga lo mismo hacia el cayado de la aorta que hacia el corazón; pero se oye con más intensidad en la porción ascendente del cayado que en el orificio de las válvulas sigmoideas. Disminuye de una manera notable, á medida que se aproxima á la punta del corazón. Se le oye en todo el pecho, y casi tan claramente lo mismo en la región posterior que en la anterior.

Es posible deducir, desde ahora, de este análisis, que la aorta está muy dilatada, y que su superficie interna, desigual, se halla tapizada, según toda probabilidad, de asperezas ateromatosas y de placas calcáreas.

El corazón, aunque menos enfermo, padece lesiones innegables. Está indudablemente hipertrofiado, porque su punta late al nivel de la sexta costilla, á 13 centímetros de la línea media del esternón. El choque ventricular es fuerte y duro, la macicez precordial se halla aumentada ; los ruidos valvulares se oyen mal, están enmascarados por los soplos aórticos.

Las cavidades cardíacas derechas no han sufrido las mismas lesiones hipertróficas que las izquierdas. No están dilatadas de una manera sensible, no hay distensión de las venas yugulares, ni se nota tendencia congestiva por parte del hígado.

Todo el sistema arterial, por el contrario, ha sufrido las consecuencias de la dilatación de la aorta. Las carótidas son enormes y sus latidos expansivos contribuyen á 
dar al cuello el aspecto de un aneurisma extenso. Las subclavias, cuya exploración es, como sabéis, muy difícil en estado normal, se sienten inmediatamente debajo del dedo y llegan á un centímetro más allá de las clavículas, lo que prueba cuánto se ha elevado su punto de inserción con relacion al estado fisiológico. Uno de mis antiguos colegas, Faure, ha demostrado en un trabajo interesantísimo (Arch. gen. de méd., 1893) el valor de este signo.

Las arterias periféricas han sufrido modificaciones análogas. La humeral está ateromatosa y aumentado su calibre; las radiales son sinuosas y el pulso es duro, rebotante; es el pulso de Corrigan típico, con su ascensión brusca y su gancho especial en el trazado esfigmográfico. Las femorales son también voluminosas y duras. En una palabra, todo el árbol circulatorio participa de las lesiones de la aorta.

Volvamos á la interpretación de estos signos físicos, y analicemos lo que sucede en la ectasia aórtica.

El soplo sistólico es fácil de explicar. La columna sanguínea, lanzada por la contracción ventricular, encuentra á su paso las asperezas de las válvulas y de la túnica interna de la arteria y vibra lo mismo que la pared; nada más fácil de comprender.

El soplo del segundo tiempo, de una intensidad excepcional, es más difícil de explicar. No puede negarse que hay insuficiencia aórtica. La presencia simultánea del pulso de Corrigan, y la del pulso capilar que se observa con toda claridad en la frente y debajo de las uñas, prueban de un modo innegable que existe una onda sanguínea recurrente. Pero la insuficiencia depende de varias causas : unas veces coincide con una lesión valvular, otras depende del ensanchamiento del orificio aórtico, aunque queden sanas las válvulas.

¿Es posible precisar, en este caso, la lesión anatómica 
que origina la insuficiencia? En la mayor parte de los casos la causa reside en las válvulas, y el ateroma que las deforma se extiende al resto de la arteria. Es probable que suceda así en nuestro enfermo; pero, sin embargo, no me atrevo á afirmar que es ésta la única lesión, porque el calibre de la aorta se halla dilatado de una manera tan marcada, que el orificio ha debido sufrir una ampliación paralela. Según toda probabilidad, existen los dos estados anatómicos y producen una lesión compleja en la que la ectasia del orificio desempeña un papel tan importante quizá como la deformación valvular. Lo que prueba, al parecer, que las válvulas sigmoideas no son el sitio exclusivo de la insuficiencia, es la localización del soplo diastólico, cuyo máximum se oye á la derecha del esternón y no á la izquierda, como sucedería si fuera producido por el roce de la sangre sobre las válvulas.

Respecto á la causa del timbre musical del soplo, estamos reducidos á hipótesis. Puede afirmarse que, para que se produzcan vibraciones tan ruidosas é intensas, es necesario que la sangre encuentre á su paso una ancha membrana, dura y rígida. Los soplos diastólicos de timbre musical son excepcionales por completo, porque la onda sanguínea no tiene de ordinario bastante tensión para producir vibraciones sonoras. Los ruidos de pio corresponden casi siempre al sístole ventricular y dependen entonces de condiciones anatómicas variadas. Unas veces son las válvulas sigmoideas calcificadas cuyo borde rígido vibra: otras la cretificación no reside en la válvula, sino debajo de ella, y forma una especie de espolón hacia el punto donde se inserta; he observado esto en un caso. Puede haber también una placa de ateroma incrustada de sales calcáreas, que se eleva á cada sístole, ó un fragmento pediculado de válvula, ó un tendón aberrante de la mitral que flota en la corriente sanguínea, pero en estos casos el 
soplo se oye mucho más abajo, hacia la punta. En nuestro enfermo parecen poco probables todas estas suposiciones, aun la de la rotura de la válvula sigmoidea, admitida con reserva por el Dr. Peter á causa de las condiciones en que se inició la enfermedad. Si fuera así, no se comprende, en efecto, que el fragmento de válvula, causa de las vibraciones, no produzca algún ruido en el momento del sístole, cuando llega al máximum la corriente sanguínea. El pio es diastólico con toda claridad.

La historia de estos ruidos musicales del segundo tiempo es más conocida. En un caso, en el que pude hacer la comprobación anatómica, sólo encontré orificios de las válvulas sigmoideas que explicaran el ruido que se oyó en vida : pero el pio era mucho menos intenso que el de nuestro enfermo. En éste, la única suposición racional es admitir la existencia de una incrustación calcárea de la pared, dispuesta de modo que se deprime bajo la influencia de la corriente sistólica de la sangre, pero que se eleva y convierte el orificio en un tubo rígido en el momento en que la onda retrógada refluye hacia el ventrículo. Es, por lo demás, una cuestión secundaria de interés puramente anatómico.

Hemos visto, al estudiar hace poco tiempo un caso de aortitis aguda, que el fenómeno más notable de la afección consiste en crisis cardio-pulmonares, de naturaleza congestiva, casi siempre de origen reflejo, en el intervalo de las cuales se disfruta buena salud. Es interesante comparar estos síntomas con los que presenta nuestro enfermo actual, cuyas lesiones son infinitamente más considerables.

Presenta tres categorías de síntomas : cardíacos, aórti$\cos$ y cerebrales.

Los síntomas cardíacos no tienen carácter especial alguno : son los trastornos funcionales ordinarios que se ob- 
servan siempre que hay dificultad circulatoria. $\mathrm{El}$ enfermo tiene disnea, ligera ó casi nula cuando se halla en reposo, muy fuerte, por el contrario, en cuanto hace el menor esfuerzo : le es imposible andar deprisa, subir una escalera, bajarse para levantar un objeto. De aquí la incapacidad absoluta para el trabajo. Además, como la mayoría de los cardíacos, no puede conservar el decúbito horizontal, y se encuentra mal, casi se ahoga, cuando se acuesta boca arriba y con la cabeza baja. Por último, tiene palpitaciones fuertes algunas veces que originan crisis dolorosas.

Estas palpitaciones que tienen ya el carácter de ansiedad precordial, forman la transición entre los síntomas puramente cardíacos y los trastornos funcionales especialmente aórticos. Estos son muy típicos en nuestro enfermo. Consisten en dolor fijo, constante, situado detrás del esternón ; parece como si tuviera un peso permanente delante del pecho y esta sensación jamás desaparece. Si ejecuta el esfuerzo más ligero, siente además dolores neurálgicos angustiosos que parten de la base del pecho é irradian hacia el brazo y hombro izquierdos ; en una palabra, este individuo tiene verdaderos ataques de angina de pecho, de ordinario poco intensos, pero que se presentan siempre bajo la influencia de la más ligera excitación cardíaca.

Estos trastornos circulatorios influyen sobre el cerebro y producen desórdenes funcionales muy penosos. El enfermo siente á cada instante desvanecimientos, aturdimientos y vértigos. Si está acostado no puede sentarse $\delta$ po. nerse en pie sin ver girar los objetos á su alrededor, su marcha es vacilante é insegura á causa de estas sensaciones vertiginosas. Tiene también cefalea permanente con exacerbaciones dolorosas ; nota latidos en su cerebro, zumbidos contínuos de oídos, rítmicos con las pulsaciones 
cardíacas ; y esto, unido al ruido de su soplo aórtico que le persigue constantemente, contribuye á aumentar su estado de vértigo. Por último, estos fenómenos de anemia cerebral van acompañados muchas veces de náuseas, que jamás han sido seguidas de vómitos.

Todos estos síntomas son consecuencia de los cambios bruscos de presión en las arterias cerebrales durante las fases alternativas de expansión y de contracción de la aorta. Como el impulso ventricular es fuerte y la onda retrógrada voluminosa á causa de la dilatación excesiva del árbol aórtico, estas oscilaciones de la tensión sanguínea llegan al máximum. Añadid á esto la falta absoluta de elasticidad de la arteria, que forma un tubo rígido que transmite íntegro al cerebro el choque de la onda sanguínea, sin atenuarlo como en las condiciones fisiológicas, y comprenderéis por qué los trastornos cerebrales tienen en la sintomatología tanta importancia como los desórdenes cardíacos propiamente dichos. Tenemos á la vista el cuadro de la insuticiencia aórtica, pero agravada de un modo singular por las condiciones especiales de induración de todo el árbol arterial.

Fenómeno notable, á pesar del volumen enorme de la aorta, son nulos los síntomas de compresión torácica.

La vena cava, tan contigua á la aorta, parece que debería estar comprendida ; pero no se observa ni éxtasis en las yugulares, ni dilatación de las venas superficiales del cuello, ni indicios de edema. Es, no obstante, probable que las condiciones de la circulación venosa sean defectuosas, pero la abundancia de las anastomosis colaterales restablece el curso de la sangre y la circulación se mantiene gracias á la derivación que se produce por las venas raquidianas y la azygos. El edema, en tales casos, significa casi siempre la existencia de una trombosis venosa; y para que se produzca, se necesita que esté obliterada, si no la 
vena cava, al menos los troncos venosos braquio-cefálicos, lo que casi nunca sucede en la dilatación aórtica.

No existen fenómenos de compresión nerviosa. Jamás, excepto en los momentos de las crisis de angina de pecho, nota este enfermo las sensaciones de entumecimiento, de hormigueo, de neuralgia braquial, $\tan$ frecuentes en ciertos casos de aneurisma de la aorta. Tampoco hay huélfago, este signo tan típico que indica la compresión de la tráquea 6 de los bronquios : el enfermo no está ronco, y aunque tiene la voz algo velada desde hace casi un año, hoy no observamos trastorno funcional alguno de la laringe, ni nada que haga sospechar la compresión del nervio recurrente. Lo mismo sucede respecto al pneumogástrico. Faltan por completo los fenómenos que indican la compresión de este nervio, á saber, la taquicardia y la aritmia cardíaca : es también curioso observar cuán lentos y regulares son los latidos del corazón.

Hay, no obstante, un síntoma bastante especial que tiene, al parecer, en este hombre íntima relación con el estado de la aorta; es una estrechez particular de las pupilas. Existe miosis doble, análoga por completo á la que se observa en los atáxicos; las pupilas son punctiformes y la sensibilidad refleja á la luz, está, al parecer, si no abolida, al menos bastante disminuída. La visión se halla alterada de un modo notable en el lado izquierdo y empieza á alterarse en el derecho. El principio de estos accidentes: oculares se remontan á más de dos años, porque el médico que le asistía en esta época, le llamó la atención sobre la estrechez de su pupila.

Os decía, hace un momento, que yo admitía una relación causal entre los trastornos pupilares y la dilatación aórtica. Hace, en efecto, mucho tiempo que se han observado fenómenos oculo-pupilares en el curso de las lesiones de la aorta. Trousseau habla de ellos en su clínica, y antes 
que él, Banks y Williamson, en Inglaterra, habían hecho la misma observación. Ogle después, en 1869 , ha estudiado estos trastornos oculares desde el punto de vista de su valor semeiótico.

En general, se nota en tales casos más bien desigualdad pupilar que miosis, y la pupila más dilatada es de ordinario la izquierda. Según Ogle, esta midriasis es debida á la excitación del simpático que hace contraer las fibras radiadas 6 dilatadoras del iris, y esta explicación parece bastante racional, puesto que se observan á la vez trastornos vaso-motores análogos á los que produce la irritación experimental del simpático cervical, á saber : palidez de la cara y del pabellón de la oreja. Podría creerse, al contrario, cuando hay miosis, en una parálisis doble del simpático, fenómeno indicado en algunos casos, consecutivo á la compresión del tronco nervioso ó á una inflamación, á una neuritis verdadera como admite Peter. En nuestro enfermo no parece racional la idea de una compresión bastante fuerte para paralizar los dos troncos del simpático cervical ; tanto más, cuanto que las conjuntivas y las orejas en vez de congestionadas están pálidas, más bien exanguies, y no existe ningún otro signo de compresión torácica. Quizá sea necesario admitir un reflejo que, partiendo de la aorta, influya sobre el centro cilio-espinal de la médula cervical, pero es una hipótesis imposible de demostrar.

Los diversos síntomas que acabo de analizar, dan una idea exactísima del cuadro clínico de la dilatación de la aorta, que se llama también, no sin motivo, aneurisma total, por oposición á los aneurismas ampollosos 6 sacciformes que constituyen los aneurismas verdaderos. La analogía sintomática de las dos lesiones es evidente en el fondo ; los trastornos funcionales son casi los mismos, y los signos físicos, soplo y elevación pulsátil del tórax pueden 
ser idénticos. Pero lo que caracteriza la dilatación total de la aorta es la falta de fenómenos de compresión localizada que se observan casi siempre en los aneurismas verdaderos y la influencia menor sobre la salud general, de lesiones mucho más considerables en apariencia.

La aortitis crónica, tal como la presenta nuestro enfermo, no está, en efecto, limitada exclusivamente á la aorta. Es una enfermedad general de todo el sistema arterial; lo prueba el aumento de calibre de todas las arterias, desde las colaterales inmediatas á la aorta, hasta las ramas más lejanas. La lesión es difusa é invasora; es una inflamación crónica de todo el árbol arterial que conduce al ateroma, á la degeneración grasosa ó á la infiltración calcárea, pero casi sin tendencia al adelgazamiento de las paredes y á la ectasia ampollar. En la aortitis crónica hay siempre espesor enorme de las túnicas vasculares y del tejido conjuntivo peri-aórtico, al contrario de lo que sucede en los casos de aneurismas verdaderos. La ectasia ampollar y circunscrita de la aorta tiene el carácter de una lesión más localizada é influye, necesariamente, menos sobre el corazón y los otros vasos.

Las arterias pueden ser elásticas y normales en los casos de aneurisma, pero nunca en los de aortitis crónica. Se ven también morir de cuando en cuando enfermos de aneurisma cuyo corazón es pequeño y las válvulas sigmoideas sanas; cuando se trata de una dilatación uniforme de la aorta, la hipertrofia ventricular y el aumento de todas las cavidades cardíacas son la regla.

El límite que separa las lesiones del ateroma generalizado y del aneurisma, es sin duda algo ficticio, porque en ambos casos es idéntico el proceso, ya que no la causa inicial; pero subsisten las diferencias clínicas y merecen indicarse desde el punto de vista de la marcha y del pronós tico de las dos afecciones. 
¿Es posible remontarse á la filiación de las lesiones y encontrar el punto de partida? A creer el relato del enfermo, la influencia traumática desempeñó en este caso. el principal papel : los esfuerzos musculares repetidos han predispuesto á la aorta á dilatarse; un esfuerzo más violento produjo, quizá, una rotura valvular. Esta etiología nada tiene de imposible, y estoy dispuesto á aceptarla, pero con una salvedad, y es que el sistema arterial del enfermo debía ser poco resistente y con tendencia constitucional al ateroma, porque sus arterias no estaban lesionadas por el alcohol ó la sífilis. Hay individuo cuyo sistema. vascular es poco resistente por herencia, y se hacen espontáneamente varicosos 6 ateromatosos á una edad no muy avanzada; es posible ser senil de una manera precoz por sus arterias, y es de suponer que ha sucedido así en este caso, porque para que un esfuerzo muscular rompa una válvula aórtica, es necesario que se halle ésta enferma; así al menos resulta, al parecer, de los casos que se conocen hasta ahora.

No hay necesidad de decir que el pronóstico es grave y que las lesiones aórticas tan extensas deben producir, en un plazo más ó menos corto, accidentes numerosos.

Es de temer el desarrollo de trombosis y de obliteraciones arteriales á causa de la difusión de las lesiones ateromatosas ; pero es una eventualidad poco probable, porque se observa con menos freeuencia en el curso de la aortitis crónica que en los aneurismas verdaderos. No sucede así con la embolia, accidente relativamente común, porque los trozos de fibrina y de papilla ateromatosa, los fragmentos desprendidos de las paredes de la arteria pueden ser lanzados al torrente circulatorio y obstruir vasos importantes. Hace poco tiempo he hecho la autopsia de un individuo el que á consecuencia de una aortitis de este género tuvo hemiplegia repentina, y encontré una embolia 
que obstruía el tronco de la arteria cerebral posterior. Dicha eventualidad es tanto más verosímil en este caso, cuanto que el soplo musical fuerte que se oye, prueba la existencia de una placa ateromatosa vibrante en el seno del líquido, susceptible, por consiguiente, de ser desprendida cualquier día por la onda sanguínea.

No insisto sobre los peligros á que se halla expuesto el enfermo á causa de los ataques de angina de pecho; en estos casos se está siempre á merced de un síncope posible aunque, preciso es decirlo, muchos enfermos toleran durante largo tiempo una lesión de este género y hasta sin tener consecuencias funestas. Por último, como todos los cardíacos, nuestro enfermo puede hacerse caquéctico, minado por una larga lucha, y sucumbir á los progresos de una infiltración gradual.

Son, como véis, eventualidades peligrosas, y aun suponiendo que no progrese la lesión, es imposible que viva mucho tiempo este hombre. Pero hay un accidente que no creo compatible con su género de lesión, y es la rotura de las paredes arteriales, al contrario de lo que sucede con tanta frecuencia en los casos de aneurismas. Tampoco es de temer el desgaste progresivo de las paredes torácicas, consecuencia de las dilataciones ampollares de la aorta.

La terapéutica es casi impotente en este caso y en las lesiones de fecha antigua, son ineficaces todos los modificadores de la circulación. No podemos esperar aquí atenuar los síntomas, como si se tratara de una aortitis aguda. Se han ensayado sucesivamente todos los revulsivos incluso el cauterio que empleó el Dr. Rigal : desde hace dos años toma el enfermo, casi sin intervalo, el ioduro potásico á dosis relativamente considerables ; gracias á este medicamento, la lesión ha seguido una marcha lenta, pero no se ha podido contenerla. Las crisis de angina de pecho han 
mejorado de un modo notable por las inhalaciones de ni-trito de amilo, y este síntoma se halla, al parecer, en decrecimiento.

La indicación dominante, en el grado en que se encuentran las lesiones, es normalizar en lo posible las funciones cardíacas y disminuir el eretismo cardio-vascular. Creo que esta indicación se llena perfectamente con el opio. á pequeñas dosis. Todas las tardes inyecto al enfermo medio centígramo de morfina, y gracias á ella las noches son mejores, el sueño más tranquilo y la circulación cardíaca. más regular. Añadiré que el dolor retro-external ha disminuído de un modo notable desde que se emplea esta medicación con el mismo objeto. Le hago tomar durante el día cuatro píldoras de á centígramo de extracto de belladona la que además de un efecto sedante, tiene la propiedad de disminuir la tensión arterial. He visto, cuando tenía la honra de ser discípulo del profesor Axenfeld, un caso notable de curación, al menos momentánea, de aneurisma aórtico por la belladona administrada á dosis crecientes. Es verdad que no podemos esperar que cure este hombre, pero sí aliviarse y mantenerse en una situación relativamente tolerable por espacio de semanas y hasta de: meses. 


\section{AORTITIS - ANGINA DE PECHO}

Sumario: Aortitis crónica limitada á la aorta y complicada con insuficiencia sigmoidea : falta de ateroma en el resto del sistema vascular. -El trastorno funcional predominante es una angina de pecho precoz, de irradiaciones dorsales y cervicales. - Relaciones de la angina de pecho y de la aortitis. - Clasificación de las anginas de pecho. - Anginas verdaderas, caracterizadas por la lesión de las arterias coronarias : sintomatología de estos casos. - Anginas sintomáticas de una periaortitis y de una neuritis del plexo cardiaco. - Anginas neurosis : posibilidad de diagnosticarlas: sintomas diferenciales sacados de su modo de principiar, de las irradiaciones dolorosas predominantes, de la marcha de los accesos y de su causa provocadora.-Casos de angina de pecho híbridos, orgánicos y neurósicos á la vez : su frecuencia y dificultad de diagnóstico. - Indicaciones pronósticas y terapéuticas.

Tenemos hoy ocasión de completar la historia de la aortitis y de las complicaciones que produce. El enfermo de que voy á hablaros, Juan B..., de treinta y nueve años, es un cardíaco que desde hace ya quince meses experimenta la opresión y los síntomas propios de una enfermedad del corazón. Basta observar su pecho, para descubrir levantamiento de la base del cuello y ligera combadura de la región precordial : al ausculsar se oye en el foco de los ruidos aórticos un soplo diastólico suave, aspirador; es indudable, por lo tanto, que este hombre padece insuficiencia aórtica.

Analicemos con más detención los síntomas. El corazón no está, al parecer, hipertrofiado de una manera notable. La punta late sin violencia en el quinto espacio intercostal; las pulsaciones cardíacas son lentas y regulares; la macicez precordial normal; el enfermo retiene con facilidad la respiración sin sentir ahogo.

La lesión es, con toda seguridad, aórtica. No sólo se oye 
en el tercer espacio izquierdo el soplo diastólico de que he hablado, sino que es más fuerte en toda la región del cayado aórtico. En un punto situado á lo largo del borde derecho del esternón, se oyen dos soplos, el primero breve $\mathrm{y}$ suave, el segundo largo y algo áspero, de tono alto. No se nota, en punto alguno, estremecimiento catario á la palpación.

Se deduce de estos signos que las válvulas sigmoideas, aunque enfermas, no han sufrido la degeneración cretácea ni están lesionadas de un modo grave, porque conservan en parte su elasticidad; además, se halla tan alterado el cayado de la aorta como las válvulas, y en una gran extensión. Encontramos, en efecto, las pruebas habituales de la dilatación aórtica : levantamiento en masa de la base del cuello, sensación directa de los latidos del vaso en la horquilla esternal, elevación de la arteria subclavia, que llega casi 2 centímetros más allá de la clavícula derecha. La lesión es, por lo tanto, más arterial que cardíaca.

A pesar de esta propagación al cayado de la aorta, la arteritis no se ha generalizado, $y$, al contrario de lo que suele observarse en tales casos, el sistema arterial general ha quedado, al parecer, intacto. Las arterias no están dilatadas, ni duras, ni flexuosas; no hay indicio de ateroma periférico. No se ve latir la facial en el ángulo de la mandíbula, y la radial es blanda y depresible, por más que el pulso tiene una amplitud exagerada, que recuerda los caracteres del pulso de Corrigan. Pero aunque el impulso es brusco, la relajación es menos instantánea que en la mayor parte de los casos de insuficiencia aórtica, fenómeno debido á la conservación de la elasticidad arterial : gracias á ésta, se conserva en cierto modo la tensión sanguínea y no presenta las variaciones bruscas tan características cuando la lesión de la aorta coincide con ateroma general. Así, no observamos, por ejemplo, el pulso capilar, 
que indica las oscilaciones de la presión sanguínea hasta en los pequeños vasos.

Los síntomas funcionales corresponden á estos signos físicos. Excepto el ahogo que siente el enfermo cuando hace esfuerzos prolongados, el estado general es excelente. No sólo no hay indicio de edema de las piernas ni trastornos circulatorios graves, sino que faltan en absoluto los signos de anemia cerebral. Jamás ha padecido este hombre vértigos, ni desvanecimientos, ni tose, ni siente molestias en el estómago, y puede sin ningún inconveniente acostarse horizontalmente; en una palabra, apenas se resiente de su lesión aórtica.

Pero existe un síntoma grave que se ha presentado desde el principio de la afección y que es más peligroso que la lesión misma : me refiero á las crisis de angina de pecho. Son contemporáneas de los primeros malestares y datan de catorce meses : principiaron á manifestarse al hacer esfuerzos respiratorios. Cuando subía una escalera con cargas pesadas sentía un dolor precordial punzante, como si su pecho fuera comprimido dentro de un estuche. Los accesos tuvieron desde el principio el mismo carácter y casi igual intensidad que hoy, pero eran raros y producidos siempre por la fatiga muscular. En la actualidad se presentan á cada momento, casi sin causa apreciable, y estallan de ordinario en pleno reposo, fuera de toda provocación, durante el sueño. El carácter nocturno de estos accesos anginosos da á la afección de este enfermo un aspecto muy particular.

Estas crisis de angina de pecho se producen de la manera siguiente: Empiezan casi siempre á media noche, de repente y sin pródromos. Se presenta un dolor constrictivo hacia la punta del corazón, dolor que va acompañado de una sensación de presión y de angustia torácica indescriptible; á los pocos segundos, se extiende más allá de 
su foco de origen é irradia en direcciones muy diversas.

De estas irradiaciones dos son constantes y acaban de caracterizar el acceso. La primera es un dolor dorsal fijo, localizado en el espacio inter-escapular, cuyo máximum se halla á lo largo del borde izquierdo del raquis, hacia el tercio superior del tórax. La segunda es anterior y cervical : llega unas veces á la laringe y produce una sensación de ahogo, otras se extiende hasta el ángulo de la mandíbula, que queda como comprimido en un estuche. Estos dolores irradiados no son siempre muy fuertes, pero. tienen un carácter angustioso que influyen de una manera notable sobre la moral del enfermo: se encuentra amilanado y es incapaz de obrar ni de pensar. Si se presenta el ataque durante el día, el enfermo queda inmóvil sin atreverse casi á respirar; si es por la noche, se levanta de repente sobre su asiento y espera con ansiedad en esta posición el fin de la crisis : jamás, ni aun en los accesos más fuertes, ha perdido el conocimiento ni observado tendencia al síncope. No ha padecido tampoco las náuseas, los sudores fríos, la palidez y la dilatación de las pupilas que caracterizan los grandes ataques de angina de pecho. Falta, por fortuna, esta parte dramática del cuadro del angor pectoris.

Falta asimismo otro síntoma : los dolores irradiados al hombro y al brazo izquierdos.

Este fenómeno, que es tan frecuente y figura en la. descripción clásica de los ataques de angina, jamás se ha. observado en este enfermo, ni tampoco el entumecimiento. ni el hormigueo del brazo y de la mano. Toda la escena patológica pasa en el cuello y en el pecho.

El acceso doloroso que acabo de describir dura poco, algunos minutos á lo sumo; pero no desaparece con la rapidez que se presenta; los padecimientos disminuyen de una manera gradual y durante mucho tiempo queda el 
enfermo bajo la influencia de la sensación de opresión precordial y de angustia que le han despertado de repente. En ocasiones, toda la crisis no excede de un cuarto de hora, en otras dura más de una hora y deja al paciente quebrantado. Jamás es yugulada por la aparición de síntomas críticos de orden visceral, por ejemplo, hipo, eructos, poliuria, sudores profusos.

A pesar de esta marcha algo insólita y de las particularidades especiales, el cuadro de la angina de pecho, es en definitiva imposible de desconocer. Pero ¿̨cuál es la naturaleza y la gravedad de este síntoma, y hasta qué punto se relaciona con la lesión aórtica observada en el enfermo? Es lo que vamos á examinar.

A primera vista, el problema parece fácil de resolver. La dilatación aórtica y la angina de pecho suelen marchar tan á la par, que su asociación es, al parecer, natural por completo; la primer impresión es considerar los accesos dolorosos como una consecuencia inmediata de la aortitis y deducir, por lo tanto, un pronóstico grave. Pero es preciso no juzgar á la ligera en este asunto, porque por intima que sea la relación entre la angina de pecho y la lesión aórtica, no son por necesidad solidarias una de otra. No todas las enfermedades de la aorta producen crisis anginosas, y éstas se presentan en individuos cuyo sistema vascular es normal por completo.

Hoy se considera la angina de pecho, no como una entidad morbosa, sino como un síndrome patológico, y los estudios de mi maestro Potain, confirmados por los de Huchard, han demostrado con toda claridad que hay anginas de pecho y no una especie sola comparable siempre á sí misma.

La tendencia actual es disociar hasta el infinito este grupo morboso, y, por así decirlo, creo que se va demasiado lejos por este camino. La reciente obra de Géli- 
neau, en la que se describen más de treinta variedades de angor pectoris, demuestra el abuso de este trabajo de análisis etiológico, que si se convierte en método general, nos hará volver de pronto á la nosología de Sauvage.

Sin entrar en todas estas subdivisiones, que se fundan muchas veces en sutilezas, creo que es necesario distinguir dos grandes categorías de angina de pecho: las que van acompañadas de lesiones de la aorta ó del plexo nervioso cardíaco y las que son puras neurosis.

En general, cuando hay lesión aórtica, el mecanismo del dolor anginoso es el siguiente : Una placa de ateroma estrecha ú oblitera el orificio de las dos arterias coronarias 6 de una de ellas, siguiendo de aquí trastornos circulatorios graves en las paredes del corazón é isquemia del músculo cardíaco. Esta isquemia ventricular es la causa inmediata del dolor precordial, de la sensación de angustia que notan los enfermos; por poco que se prolongue, produce un síncope mortal. Tal es la teoría defendida por Potain y Huchard y aceptada por la mayor parte de los clínicos; debo decir que, en los casos, raros por fortuna, en que he visto sobrevenir la muerte á consecuencia de un acceso de angor pectoris, he encontrado siempre esta lesión de las coronarias. Creo que el hecho anatómico y clínico es cierto.

En estos casos, las condiciones patógenas del acceso son muy típicas y la sintomatología bien conocida.

La crisis anginosa se presenta casi siempre á consecuencia de un esfuerzo muscular que exige la actividad ventricular y necesita una circulación parietal más abundante. Este es el momento en el que, á causa de la estrechez de las coronarias, el aflujo de sangre en el músculo cardíaco se reduce al mínimum, y hay escasez de riego sanguíneo, precisamente en el instante en que el corazón necesita de toda su energía funcional. Es el mismo fenómeno que origina 
la claudicación intermitente en los caballos que padecen aneurisma de la aorta abdominal, y esta ingeniosa comparación, hecha por Potain, explica perfectamente la repetición accesional de los ataques en circunstancias determinadas, cuando el enfermo levanta un fardo, anda contra el viento, sube de pronto una pendiente, en una palabra, siempre que hace un esfuerzo sostenido. Lo mismo sucede con las emociones morales que perturban de una manera violenta el aparato cardíaco y aceleran en alto grado la circulación sanguínea. Todas las impresiones vivas, y en particular la ira, que originan la contracción brusca del corazón, obran en el mismo sentido y son factores frecuentes de la angina de pecho.

Los síntomas de estos accesos son fijos. Principian por dolor en la punta del corazón, que va acompañado de sensación constrictiva de toda la región precordial; parece al enfermo que se juntan el esternón y la columna vertebral. Después se presentan á la vez el dolor irradiado, característico, que se propaga al hombro y brazo izquierdos, y desciende algunas veces hasta los dos últimos dedos de la mano, siguiendo el trayecto del nervio cubital. En casos más raros se observan irradiaciones cervicales y maxilares.

Los síntomas generales son á la vez muy acentuados: el enfermo es acometido de terror y tiene el presentimiento de una muerte inminente: está pálido, cubierto de sudor, con amenazas de desfallecimiento y de síncope, $\delta$ al contrario, se ahoga, y después del acceso escupe sangre rutilante lo mismo que en las congestiones pulmonares más francas. He visto producirse este accidente más de 20 veces en uno de mis clientes, en los dos años últimos de su vida, á cada crisis de angina de pecho.

Comparando este cuadro clínico con el de nuestro enfermo, se notan muchas diferencias. El dolor es más bien precordial desde un principio, con la sensación de compresión 
y de angustia; pero faltan las irradiaciones escapulares y predominan, por el contrario, las del dorso y de la mandíbula, relativamente excepcionales en los casos de angina clásica.

La etiología difiere más aún que la sintomatología. La crisis anginosa verdadera reconoce por causa provocadora un esfuerzo muscular ó una emoción moral, pero en nuestro enfermo se presenta en pleno reposo, durante el sueño de la noche, y por una anomalía más singular aún, este individuo puede andar, hacer movimientos bruscos, subir una escalera, sin sentir el menor indicio de angor.

No se trata, por consiguiente, en este caso, de un acceso de angina de pecho clásica, tal como se observa de ordinario en las afecciones aórticas.

Además, quizá la lesión de la aorta produzca la crisis anginosa por un mecanismo diferente. Peter ha demostrado que toda aortitis va acompañada de periaortitis, y la inflamación de la atmósfera celulosa de la arteria interesa entonces casi con seguridad el plexo nervioso cardíaco. De aquí las variedades diferentes de anginas de pecho, según que haya congestión pasajera y desórdenes vaso-motores de este plexo 6 neuritis verdadera. Pero entre ésta y la neuralgia la transición es fácil y difícil de marcar las líneas divisorias. Se comprende, por lo tanto, que sea imposible en ciertos casos decir si la angina de pecho, aun asociada á una lesión de la aorta, se comporta como una neurosis simple, 6 si depende de una lesión indeleble de las arterias coronarias.

La cuestión clínica se plantea de la manera siguiente: ¿Es posible conocer, por los síntomas, estas anginas neurosis y diferenciarlas de las anginas lesiones?

En ciertos casos típicos, no sólo es posible la distinción, sino relativamente fácil.

Tomemos, como ejemplo, los ataques de angina de pecho 
que se observan en el histerismo ó en el curso de la enfermedad de Basedow. Se ve un conjunto de síntomas que difieren, de una manera sensible, del cuadro clínico que describí hace poco.

Ante todo, las circunstancias en medio de las cuales se presenta el acceso no son las mismas. La crisis sobreviene sin causa provocadora apreciable, en ocasiones por una contrariedad ó una emoción, casi siempre sin sacudida física 6 moral, mientras duerme, por ejemplo, el enfermo. La mayor parte de las anginas de principio nocturno son anginas neurosis; es el primer carácter y de los más importantes.

El principio del ataque es también diferente. El dolor precordial no es el primer síntoma que se presenta. Hay en ciertos casos un aura periférica braquial, caracterizada por entumecimiento, hormigueo en los dedos de la mano izquierda, y muchas veces también por trastornos vasomotores concomitantes; así es que se ve la cianosis de los dedos y hasta un estado sincopal de las extremidades preceder al ataque, $\delta$ presentarse de una manera permanente. En una enferma histérica, observada por mi colega Marie, existía esta sensación de entumecimiento perpétuo, aunque su corazón funcionaba de un modo regular en los intervalos de los accesos anginosos.

En el período paroxístico del ataque se notan también caracteres diferenciales. Los dolores de irradiación son mucho más extensos y difusos. Se les observa, no sólo en la región precordial, sino en el hombro, en el cuello y en el brazo á la vez. Coinciden con una hiperestesia excesiva de la piel, penosísima para los enfermos, pero de pronóstico más bien tranquilizador; se observan también puntos histerógenos, cuya compresión produce crisis verdaderas. Estos puntos dolorosos faltan casi siempre en las anginas de pecho dependientes de las lesiones coronarias ; pero, según 
Peter, se descubren en el curso de las neuritis del plexo. cardíaco. Por último, durante estos accesos anginosos neurósicos tienen los enfermos palpitaciones frecuentes y vio-

- lentas que suelen ir acompañadas de tendencia al síncope; se agitan, respiran con violencia y hacen para ello grandes esfuerzos. No sucede así en los que padecen angina verdadera: en éstos late el corazón con lentitud y queda tranquilo en las crisis más violentas; en vez de hacer movịmientos desordenados, permanecen inmóviles, aterrados, y no se atreven á respirar; el cuadro es distinto por completo. Lo es también el fin del ataque. En la angina neurosis, el acceso termina muchas veces por pérdida del conocimiento, por desvanecimiento momentáneo, una crisis de llanto $\delta$ una abundante emisión de orina; en los anginosos verdaderos el dolor desaparece poco á poco ó de repente, y deja al enfermo la impresión de un gran peligro terminado, pero que puede volver.

En fin, la marcha de los accesos no es comparable. Las crisis anginosas verdaderas son relativamente raras; algunas veces matan al enfermo al segundo ó tercer ataque; en ciertos casos se repiten á causa del esfuerzo más ligero. Pero jamás se ve en los aórticos repetirse estas series de crisis incesantes que en los neurópatas duran todas las noches por espacio de varias semanas ó meses. La enferma á quien visito en la actualidad por un bocio exoftálmico y ataques de angor nervioso, acaba de pasar tres semanas en un sillón sin poder casi acostarse; Bernheim ha publicado la historia de un histérica en la que las crisis nerviosas ocasionaron el insomnio durante dos meses. Inútil es decir que, en tales casos, cualquier emoción aumenta de una manera especial la repetición de las crisis, y que éstas son más frecuentes é intensas durante los períodos menstruales.

La auscultación suministra nuevos elementos de diagnóstico diferencial ; la aortitis verdadera es en general fá- 
cil de reconocer por los signos físicos de que va acompañada ; en las anginas puramente neurósicas faltan los signos estetoscópicos. Se observan, no obstante, en la enfermedad de Basedow casos confusos cuando el eretismo cardio-vascular es considerable y al auscultar se oyen soplos inorgánicos, fenómeno frecuente.

Existen, por lo tanto, elementos de diagnóstico diferencial posible en la mayor parte de los casos, y teniendo en cuenta estos diversos caracteres, puede conócerse en muchos enfermos si la angina de pecho pertenece á la clase de las neurosis ó si es consecuencia de una lesión de la aorta $\delta$ de las arterias coronarias.

Conviene saber, sin embargo, que en la práctica no es siempre fácil el diagnóstico, y que además de los casos bien definidos se observan en clínica otros híbridos en los que la lesión coexiste con la tendencia neuropática. Nada más difícil entonces que indicar la parte de esta doble influencia.

Tengo en mi clientela una enferma que por sus ascendientes es gotosa, y cuya madre, abuela y una de sus tías han muerto de angina de pecho. Esta señora empezó á sentir, hace tres años, dolor precordial al montar á caballo; desde entonces las crisis han tomado cada vez más el carácter anginoso, ha tenido que dejar de subir escaleras, andar contra el viento; á pesar de estas precauciones, persisten los accesos y se presentan bajo la influencia de las causas morales más insignificantes, $\mathrm{y}$ hasta por la noche durante el sueño. Este caso es, al parecer, muy sospechoso desde el punto de vista de la realidad de una lesión aórtica, tanto más, cuanto que la aorta se ha dilatado de un modo evidente. Pero esta señora es á la vez nerviosa, ha tenido ataques de histerismo y conserva una impresionabilidad exagerada. Sus ataques anginosos tienen también algunos caracteres insólitos : van acompañados de entumeci- 
miento permanente del brazo y de puntos dolorosos situados, no en el foco de la región aórtica, sino debajo de la clavícula derecha; los dolores irradian hacia el dorso y el hombro, y producen tendencia al síncope, que recuerda algo de lo que se observa después de los grandes ataques. En una palabra, hay una mezcla de histerismo y de aortitis que hace difícil el diagnóstico y menos grave el pronóstico que si se tratara exclusivamente de la aortitis franca.

Estos casos híbridos son mucho más comunes de lo que se supone, y en las mujeres, sobre todo, la sintomatología de la aortitis se complica muchas veces con un aparato nervioso que reviste los caracteres del angor pectoris. De igual modo, en los que padecen la enfermedad de Basedow, suele ser muy dificil afirmar que los trastornos anginosos no dependen de una dilatación de la aorta, porque se observan con frecuencia, durante el curso de esta neurosis, fases de ectasia cardíaca y aórtica que van acompañadas de verdaderas crisis de asistolia. Mi colega y amigo Landouzy ha referido casos instructivos de histerismo que coexistieron con afecciones cardíacas y revistieron caracteres especiales.

Por el contrario, la ascciación de fenómenos neuropáticos es susceptible de conducir á otro género de error, y aunque antes las lesiones de aortitis aparente disimulaban el elemento nervioso, éste puede ser considerado como preponderante cuando la causa verdadera de la angina de pecho es una lesión grave de la aorta. Uno de los ejemplos más notables de esta causa de error es el caso siguiente, referido por Huchard. Ingresó en el hospital un individuo con crisis violentas de angina de pecho; se le reconoció sin descubrir lesión alguna, y al saberse que era un gran fumador, se diagnosticó la enfermedad de angina tabáquica esencial. El enfermo murió á los pocos días y su aorta se encontró sana. La autopsia confirmaba, al pare- 
cer, el diagnóstico, cuando el examen de las arterias coronarias demostró una estrechez, no en su origen aórtico, sino en su trayecto intra-muscular. Sin la casualidad, que hizo descubrir el estado de las arterias intrínsecas del corazón, se hubiera desconocido el caso y se le hubiese considerado, aun después de la muerte, como un ejemplo de angor neurósico.

Las condiciones patógenas de los accesos, no dan más que presunciones, y no permiten afirmar la naturaleza de la angina de pecho. La mayor parte de los ataques anginosos, consecutivos á los trastornos dispépsicos, son de índole puramente nerviosa; pero, en ciertos casos, dependen de lesiones graves de la aorta. He referido una observación á Huchard, quien la publicó en su trabajo, y que demuestra la realidad del hecho. Un gotoso con angina de pecho presenta la particularidad de que sus accesos no aparecen cuando anda $\delta$ hace ejercicio; pero sí siempre que la digestión es penosa. $\mathrm{Y}$ sin embargo, al auscultar el corazón se oye un doble soplo, y es innegable la lesión ateromatosa de la aorta y de las válvulas sigmoideas. Es, por lo tanto, casi indudable que el angor pectoris en este individuo es consecuencia de dichas alteraciones degeneradoras, y que los trastornos digestivos obran sólo como causas ocasionales.

Es preciso, pues, en los casos dudosos, pensar en la superposición posible de una lesión orgánica y de una neurosis, y analizar con el mayor cuidado los síntomas anginosos imputables á esta doble condición patógena. Es necesario, sobre todo, analizar con todos sus detalles los datos que suministra la etiología, porque aunque no son elementos seguros de diagnóstico, constituyen presunciones fundadas. El enfermo es, por ejemplo, un ateromatoso que padece arterio-esclerosis, un sifilítico antiguo; se ha probado que tiene un aneurisma ó una lesión de insu- 
ficiencia aórtica, y es casi seguro que la angina de pecho. es sintomática de una lesión de las coronarias. La existencia de un reumatismo es también una presunción plausible, pero más discutible. Al contrario, el conocimiento de una herencia neuropática ó de antecedentes nerviosos, como el histerismo, la epilepsia, la enfermedad de Basedow; el dato de una intoxicación habitual, como el nicotinismo ó el teismo, deben hacer sospechar á primera vista. la naturaleza neurósica del angor pectoris; pero aun en este caso es necesario siempre explorar con el mayor cuidado la aorta, porque el intermedio entre la neurosis y el síntoma, es casi siempre un trastorno circulatorio, quizá una dilatación momentánea del vaso.

Estos datos van á permitirnos averiguar cuál es el valor diagnóstico y pronóstico de los accesos anginosos que sufre nuestro enfermo. A pesar de los caracteres insólitos de sus crisis, y aunque no ha padecido ni sífilis ni reumatismo, aunque no es ni ateromatoso ni alcohólico, no me atrevo á decir que la angina de pecho sea en este caso un trastorno funcional puramente nervioso. Hay dilatación de la aorta, y aunque esta dilatación parece una lesión limitada y accidental del sistema circulatorio general, es casi indudable que va acompañada de coronaritis y de neuritis del plexo aórtico. Hasta es probable que la aortitis se extienda hasta cerca de la aorta descendente, y esto explica quizá la irradiación y la fijeza del dolor dorsal que siente el enfermo. Basta con esto, para comprender que el pronóstico es grave porque no hay esperanza alguna de ver retroceder la lesión aórtica.

Mas podemos obrar sobre los fenómenos fluxionarios y congestivos que se producen alrededor de la aorta enferma, y que son quizá los factores indirectos de las recidivas de las crisis. Los revulsivos deben figurar con este objeto en primera línea. En la fase aguda de los acciden- 
tes hice aplicar seis ventosas escarificadas en la región preesternal : recurro á la cauterización punteada cada diez 6 doce días ; si persisten las crisis, no dudaré en aplicar un cauterio. Empleo á la vez el tratamiento clásico de la arteritis crónica, á saber, la indicación iodurada, reservando, para el momento de los accesos, las inyecciones de morfina y las corrientes contínuas. 
ATEROMA Y ANEURISMA AORTICO

Sumario: Variedades del ateroma arterial y de sus localizaciones : asociación frecuente de las cardiopatias y de las lesiones vasculares. Análisis de un caso de este género con síntomas complejos : dilatación aórtica, latidos carotideos unilaterales. - Extasis crónica de las yugulares, supresión completa del pulso radial izquierdo, incompleta del derecho.-Falta de signos estetoscópicos cardio-aórticos.-Discusión de este caso. - No es una cardiopatía primitiva ni secundaria : hay, según toda probabilidad, un aneurisma del cayado de la aorta. - Valor de la supresión del pulso radial é hipótesis sobre este particular.Diagnóstico del sitio y del estado anatómico del aneurisma.-Pronóstico y tratamiento.

No hay lesión más frecuente que las degeneraciones del sistema arterial ; no la hay tampoco que revista caracteres más distintos á la cabecera del enfermo. Los síntomas. varían por completo, según su grado, su sitio y su localización ; nada se asemeja menos al ateroma aórtico que la endarteritis de las arteriolas $\delta$ de los capilares, aunque en el fondo sea el mismo el proceso; según la manera que se haga el riego sanguíneo de las vísceras, la nutrición general se conserva íntegra, 6 se perturba de un modo rápido y por completo ; á esto se deben las consecuencias diversas que imprimen á la enfermedad caracteres tan variables, que es imposible á primera vista encontrar el origen común.

$\mathrm{El}$ ateroma arterial es casi siempre una lesión latente que se desarrolla de una manera sorda, con lentitud, sin producir el menor trastorno funcional. Un día se descubre que las arterias accesibles á la exploración se han hecho más gruesas, más tortuosas, que su superficie es desigual y rugosa ; han cambiado de dirección, de consisten- 
cia y perdido su elasticidad; pero las vísceras por las que distribuyen la sangre siguen funcionando con regularidad. La alteración de los conductos no influye sobre la nutrición de los órganos, y este estado persiste largos años.

Un tipo más frecuente y de gravedad singular es aquel en el que la endarteritis generalizada va acompanada de esclerosis cardíaca ó renal. La mayor parte de los casos de nefritis intersticial que se observan todos los días en la clínica reconocen como causa patógena primera la irritación de las arterias y de los capilares, y el rastro del proceso doble, inflamatorio y degenerativo, se encuentra en la tendencia de las vísceras á sufrir á la vez la esteatosis y la proliferación fibrosa.'

Otras veces las alteraciones arteriales influyen sólo sobre la nutrición de las vísceras y producen la necrobiosis 6 la degeneración funcional á través de una serie de oscilaciones circulatorias; obsérvase esto en el cerebro que concluye por sufrir lesiones irremediables á consecuencia de una serie de ataques congestivos 6 de fases da anemia.

Por último, casi nunca están enfermas sólo las arterias, y el corazón participa de ordinario de sus lesiones. Los dos sistemas se influyen desde el punto de vista patológi$\mathrm{co}$, aunque tienen cierta independencia funcional. Resulta de aquí que los síntomas pueden revestir por completo los caracteres de una cardiopatía, aunque el corazón no sea, al parecer, la causa directa. Obsérvase esto con toda claridad en el enfermo de que voy á ocuparme :

Este individuo, que ocupa el núm. 1 de la Sala Chauffard, es un hombre robusto, de cincuenta y tres años, natural del Jura, el cual, durante veinte años, se ha dedicado á subir á domicilio sacos de carbón. Después, por espacio de otros cuatro, dejó este oficio rudo y se hizo carretero. Apenas notaba alguna dificultad al respirar, consecuencia natural de la edad, cuando se presentaron de re- 
pente, hace dos meses, los accidentes graves que le obligaron por completo á suspender el trabajo.

Una noche, sin causa conocida y sin pródromos, tuvo un ataque de asma, que duró dos horas. Pero no se trataba del asma clásico, con estertor sibilante y expectoración mucosa final; era más bien una sensación de opresión y de ahogo, una angustia precordial inexplicable. Creyó morir aquella noche. Después, ha vuelto á tener varias veces crisis análogas, aunque menos intensas, $y$ siempre ha notado la coincidencia de trastornos dispépsicos y de dolor epigástrico en el momento del acceso. Desde esta época, su respiración ha sido difícil; y se ha hecho habitual en cierto modo el ahogo; no puede andár deprisa, y mucho menos llevar el menor fardo.

Cuando ingresó el enfermo en la Clínica, tenía, desde quince días antes, el aspecto de un cardíaco. Durante el reposo, respiración libre y opresión casi nula ; anhelación inmediata al menor esfuerzo ; imposibilidad de conservar el decúbito horizontal sin tener elevada la cabeza ; tos y expectoración nulas é integridad completa del aparato respiratorio.

El examen del corazón da los resultados siguientes : la punta late en la sexta costilla, algo más abajo del quinto espacio; el choque precordial es normal, sin exageración ni debilidad. No hay ni combadura torácica ni estremecimiento catario. La auscultación no revela lesiones valvulares; el primer ruido es algo sordo; el segundo duro y muy acentuado, sin apariencia de soplo.

Puede, pues, suponerse en este enfermo cierto grado de hipertrofia ventricular, pero esta lesión, que no excede del término medio, que se observa con tanta frecuencia después de los cincuenta años, no explica de un modo suficiente los trastornos funcionales observados.

Es, por otra parte, poco probable que el estado del co- 
razón dependa en este caso de un padecimiento renal. La orina es normal en cantidad y en calidad; no contiene indicio de albúmina, y aunque este hombre haya orinado en abundancia, en cierta época, no puede deducirse que hubiera verdadera poliuria; no es posible, por lo tanto, afirmar la existencia de una nefritis intersticial, de la que no se observa el menor síntoma.

El estado del sistema vascular, da la clave de todos estos fenómenos presentando anomalías arteriales importantes.

Examinando la base del cuello, llamó la atención un primer síntoma. Se notaban pulsaciones en la zona supraclavicular, amplias y bruscas, rítmicas como los latidos del corazón y seguidas, á cada diástole, de una depresión brusca de los tegumentos. Esta dilatación es producida, indudablemente, por la ampliación de la aorta y de la carótida primitiva bajo el impulso de la contracción ventricular.

Pero, por una extraña anomalía, la elevación de la región supra-clavicular sólo se observa en el lado derecho; en el izquierdo, la expansión es nula y no se nota latido alguno en la región cervical correspondiente. Tiene á primera vista la apariencia singular de un choque pulsátil que eleva la mitad de la base del cuello hasta la línea media y deja inmóvil casi por completo la otra mitad.

Por otra parte, el examen directo de la región animada por los latidos no deja duda alguna sobre la realidad de la dilatación aórtica. Se siente latir la aorta inmediatamente debajo del dedo aplicado sobre la horquilla esternal, y la arteria subclavia derecha está mucho más elevada que de costumbre en el triángulo supra-clavicular. No insisto sobre estos signos, cuyo valor desde el punto de vista del diagnóstico de la ectasia aórtica he indicado ya.

Para terminar lo referente á estas pulsaciones arteria- 
les, indicaré un detalle que tiene su importancia en la especie. Palpando á la vez con las dos manos la zona pulsátil del cuello y la punta del corazón, se nota que los latidos del cuello se retardan de una manera sensible en relación al choque precordial, mucho más que en las condicionas fisiológicas de transmisión de la onda aórtica. Este retraso es bastante apreciable para dar la sensación de dos choques alternativos y no superpuestos. Es un fenómeno importante, de cuya significación me ocuparé más adelante.

$\mathrm{He}$ aqui, pues, un primer punto conseguido: el cayado aórtico traspasa los límites normales y la arteria subclavia está situada más arriba de su inserción habitual.

El examen de las venas yugulares suministra también dos signos físicos importantes.

El primero es una elevación en masa de la yugular derecha, con repleción brusca del tronco venoso, isócrona con la expansión de la arteria. Este fenómeno, que simula á primera vista el pulso venoso, no es debido á una insuficiencia tricúspide, como podría creerse ; es sólo consecuencia de la propagación del choque de la aorta dilatada ; son latidos de impulsión que siguen las fases del choque precordial y del diástole arterial.

El segundo signo, mucho más importante que esta elevación intermitente, es la repleción persistente de las venas yugulares que no se limita, esta vez, á la región supra-clavicular derecha, sino que es común á los dos troncos venosos del cuello. Quiere decir esto que hay éxtasis sanguíneo permanente debido á un obstáculo en la circulación de retorno. Como este obstáculo no reside en la aurícula derecha y no depende de una lesión valvular, es preciso admitir que se encuentra en el mediastino y que es debida á la compresión de los dos troncos venosos braquio-cefálicos, los que, como sabéis, están situados en un 
plano superficial entre el esternón y los vasos arteriales gruesos que nacen del corazón.

Este doble descubrimiento, de una dilatación del cayado de la aorta y de un éxtasis venoso yugular, despierta al punto la idea de un aneurisma y conduce á explorar con cuidado la región pre-esternal. Pero al contrario de lo que podía preverse, el examen en esta región da resultados casi negativos.

No hay ni latidos visibles ni se nota impulsión de la pared torácica, ni estremecimiento vibratorio : la macicez del cayado aórtico se extiende á 6 centímetros, casi las dimensiones normales. La auscultación nó es más decisiva. Se oyen por propagación los dos ruidos cardíacos : el primero atenuado y apenas imperceptible; el segundo claro y más sonoro. Se nota también un soplo suave sobreañadido, que principia algo después de la expansión arterial, pero es, al parecer, un ruido inorgánico debido al cambio de sitio del aire de las vesiculas pulmonares. Es un ejemplo de los soplos extra-aórticos que existen con igual motivo que los extra-cardíacos, y cuya frecuencia han señalado Potain y Balfour. Lo que acaba de demostrar la naturaleza inorgánica de este soplo, es la coexistencia de sacudidas respiratorias típicas, cuando se ausculta ó se hace respirar al enfermo; este fenómeno, como sabéis, es debido á la misma causa; las sacudidas son rítmicas por los latidos del coraźn.

Nada, al explorar la región aórtica, permite afirmar la existencia de un aneurisma : pero los latidos supra-claviculares son un signo positivo que tiene por sí sólo más valor que los negativos y no permite poner en duda la existencia de una ectasia de la aorta.

Otros indicios, á falta de la auscultación, imponen la certidumbre de una lesión aórtica. Me refiero á los datos que suministra el examen de las arterias colaterales de la aorta. 
Hemos visto que las carótidas laten de un modo des. igual en el cuello, pero las dos son normales, al parecer : funcionan con regularidad porque el enfermo no acusa trastorno funcional alguno cefálico.

Las arterias subclavias son ya más desemejantes. La derecha está algo más elevada que la izquierda por encima de la clavícula, late también mucho más fuerte. Es posible, por lo tanto, que su calibre sea algo diferente en su origen.

Explorando las arterias radiales se observa un fenómeno inesperado. El pulso radial es muy débil en el lado derecho, apenas se siente : en el izquierdo es nulo por completo : la onda sanguínea si llega al antebrazo, es tan atenuada, que no se nota.

Buscando el punto donde la arteria parece que deja de ser permeable, se saca la conclusión de que la obliteración, $\delta$ al menos la estrechez del calibre arterial, está localizado entre la subclavia y la axilar : por encima de la clavícula son muy fuertes los latidos; por debajo son nulos.

Este fenómeno es tan típico, y tan imprevisto por otra parte, que hay motivos para preguntar cómo puede efectuarse en tales condiciones la circulación de los miembros superiores. Es innegable que no existe en este hombre trastorno circulatorio grave. No se queja de entumecimiento ni de hormigueo, ni de sensación de peso 6 de paresia del brazo: los trastornos funcionales son nulos y el fenómeno pasaría completamente inadvertido si no se investigara con detenimiento el estado del sistema arterial.

Existe, sin embargo, una disposición anatómica particular que explica esta curiosa inmunidad funcional. Las arterias acromio-torácicas de este individuo han adquirido un desarrollo insólito. Salen del hueco supra-clavicular, 
se dirigen en sentido oblícuo por delante de la clavícula y desde allí descienden hacia el surco pecto-deltoideo, describiendo sinuosidades flexuosas. Sirven de anastomosis amplias entre las arterias musculares del brazo y el sistema de la subclavia. Es una anomalía arterial, porque el tronco acromio-torácico nace por lo común de la axilar debajo de la clavícula, pero en su distribución general sigue el mismo trayecto y tiene igual fin fisiológico; es un conducto de desviación. En nuestro enfermo, á causa de haberse obliterado la arteria axilar, ha adquirido un desarrollo enorme y el mismo calibre que la radial. Es probable que las demás arterias anastomóticas profundas, las circunflejas y las escapulares, hayan sufrido un desarrollo correspondiente, y de este modo es como se mantiene la circulación del miembro sin trastorno alguno. Así se explica también el hecho paradógico de que mientras que en la arteria axilar derecha no hay latido alguno, es perceptible el pulso radial correspondiente ; la circulación se ha restablecido más adelante por anastomosis.

Respecto al pulso radial, os haré la misma observación que para las pulsaciones aórticas. Estas se retrasan de un modo manifiesto con relación al sístole ventricular y aquel se retrasa á su vez en relación á la pulsación de la subclavia, de manera que entre el choque precordial y la elevación de la subclavia transcurre bastante tiempo, un cuar. to á un quinto de segundo. Más adelante indicaremos el valor de este fenómeno.

Las lesiones arteriales no se limitan á la esfera de los miembros superiores, se extienden á los vasos de los inferiores. Las femorales son enormes, duras y como cartilaginosas; las tibiales y las pedias se marcan en forma de cordones flexuosos duros. El ateroma es, por consiguiente, general. Pero lo particular es que el pulso femoral y hasta el de la pedia se retardan en relación al sístole cardíaco 
mucho menos que el radial ; nueva prueba de que existe en la aorta una lesión importante interpuesta en el sistema arterial.

Es inútil, después de esta exposición de síntomas, insistir sobre el diagnóstico diferencial. No es admisible la existencia de un tumor del mediastino; la única hipótesis racional es la de una dilatación aórtica fusiforme. He insistido ya varias veces, ante vosotros, sobre los diferentes caracteres de esta afección. Aunque es verdad que origina latidos del cuello y una elevación anormal de la subclavia como en nuestro enfermo, determina, por el contrario, rara vez fenómenos de compresión de las venas yugulares. Además, al auscultar se oye siempre en este caso un doble soplo más ó menos áspero que falta en nuestro enfermo ; por último, las pulsaciones radiales son duras, amplias y rebotantes, en vez de abortadas y nulas como en el caso actual.

Todo concurre, por el contrario, á demostrar que se trata de un aneurisma de la aorta, á pesar de lo poco acentuado de los trastornos funcionales y de la falta de tumor pulsatil-torácico. La realidad de los fenómenos de compresión mediastínica, la localización especial de los latidos del cuello, la existencia de los signos de éxtasis venoso, son otras tantas pruebas. Hace mucho tiempo demostró Stokes que la falta de signos estetoscópicos en la región de la aorta, no prueba en modo alguno la integridad de la arteria ; aneurismas muy voluminosos no producen fenómeno estetoscópico alguno apreciable, y, como en este caso, se caracterizan exclusivamente por el eco del segundo ruido sigmoideo transmitido. Por otra parte, la clínica ha hecho además justicia á la ley experimental de Marey, según la cual, todo aneurisma aórtico al exagerar la presión sanguínea por detrás de la bolsa arterial, origina la hipertrofia cardíaca y lesiones valvulares secunda- 
rias ; se han referido bastantes ejemplos de aneurisma ampular de la aorta que coexiste con integridad absoluta del orificio y de las válvulas sigmoideas. La objeción fundada en la falta de signos estetoscópicos carece, pues, de valor.

No es posible objetar tampoco que la pobreza de los trastornos funcionales excluye la idea de un aneurisma. ¡Cuántas lesiones de este género, aun considerables, pasan inadvertidas! No porque no observemos afonía, huélfago, angina de pecho ó neuralgia braquial, vamos á deducir la falta de tumor aneurismático ; estos síntomas faltan muchas veces. Por otra parte, ¿no padece nuestro enfermo, además de la disnea y de la opresión permanente, crisis de asma sintomático, cuya significación como fenómeno precursor del aneurisma ha sido demostrada por Trousseau?

El carácter del pulso y el retraso en las pulsaciones subclavias y radiales son argumentos nuevos y decisivos. Marey y F. Franck han probado por medio de experimentos que una bolsa extensible, al suprimir la elasticidad arterial, disminuye la tensión sanguínea y hace más lento el curso de la sangre. Por esto es tan importante dicho signo; el pulso, detrás de la ampolla aneurismática, está siempre exagerado, mientras que por delante es mucho menos amplio y más lento. En nuestro enfermo se observan con toda claridad estos caracteres.

La supresión del pulso radial es dificil de interpretar. En una nota leída hace poco tiempo en la Sociedad Médica de los Hospitales, he demostrado el valor de dicho signo como indicio de los aneurismas latentes del cayado aórtico, y creo que el caso actual confirma esta regla. En efecto, la desaparición del pulso radial depende de ordinario de la obliteración de la arteria subclavia por los coágulos que tapizan la bolsa aneurismática. Pero esta patogenia no es constante y se comprende perfectamente que 
una placa ateromatosa formada en el punto de nacimiento de las colaterales de la aorta, las estreche y concluya. por obliterarlas. He observado dos casos de este género, en los que faltaba el pulso radial durante la vida, y la causa anatómica era una degeneración ateromatosa localizada. en el espolón de la subclavia. Esta lesión es, como sabéis, frecuente en la coronaria y puede existir también en el sitio de nacimiento de las arterias gruesas de los miembros superiores.

En el caso actual el mecanismo es más complejo, porque la obstrucción vascular se halla situada, no en el origen aórtico de las subclavias, sino más abajo, hacia el punto donde éstas se continuan con las axilares. El hecho es innegable, porque se siente latir con toda claridad los dos troncos subclavios, mientras que las pulsaciones desaparecen en la región axilar. Queda por interpretar esta curiosa particularidad, y en nuestro enfermo, lo confieso, estamos reducidos á hipótesis.

Esta extraña localización puede interpretarse de tres maneras. Es de suponer que por delante del punto de la estrechez se ha formado una trombosis que ha invadido paso á paso el calibre de la arteria deteniéndose en la desembocadura de la primer colateral, representada por la arteria acromio-torácica.

Es difícil explicar por esta hipótesis la simetría de las lesiones en dos puntos similares del trayecto de la arteria axilar; pero sabemos también desde los estudios de $\mathrm{Bi}$ zot y de Lobstein, que el ateroma interesa á menudo puntos simétricos del sistema arterial. En este caso ha podido suceder algo parecido.

Es posible también que exista una anomalía arterial de fecha muy antigua, quizá hasta congénita. La arteria acromio-torácica en vez de nacer, como de costumbre, en la axilar, nace mucho más arriba de la subclavia. La estrechez 
espontánea de ésta, á causa de un vicio de conformación congénita, explicaría los fenómenos ; en este caso, habría más bien apariencia de trombosis que trombosis verdadera. Creo poco fundada esta hipótesis.

Queda la suposición de una embolia que es inverosímil. No porque no puedan formar émbolos los detritus y los fragmentos de coágulos procedentes de la cara interna de un aneurisma; hace pocos días habéis visto un ejemplo en un individuo que murió de reblandecimiento cerebral de origen embólico, debido á una dilatación de la aorta. Pero, además de que es casi imposible admitir la coincidencia de un émbolo doble localizado simétricamente en las dos arterias axilares, los accidentes han seguido una marcha muy distinta. Toda embolia supone un proceso brusco, y en este caso, la interrupción del riego sanguíneo ocasiona siempre síntomas característicos, dolores agudos, entumecimiento, cianosis de los miembros, hasta gangrena si la obliteración recae en un vaso voluminoso.

En resumen, aunque el mecanismo de la obliteración arterial queda obscuro, es probable que se trata de un aneurisma de la aorta desarrollado en un individuo que padece ateroma general.

Debemos profundizar más el diagnóstico y resolver los dos problemas siguientes: ¿Cuál es el sitio exacto del aneurisma? ¿Cuál su estado anatómico?

El primer problema es relativamente muy fácil de resolver, aunque no hay seguridad absoluta respecto al particular. Puede preguntarse, en efecto, si en razón de hallarse las pulsaciones cervicales limitadas á la región supra-clavicular derecha, el aneurisma interesa la aorta ó el tronco braquio-cefálico. Creo poder afirmar, en este caso, que reside en la aorta. En efecto, el pulso radial no sólo está disminuído en el lado derecho, como sucedería si la lesión recayera en el tronco braquio-cefálico, sino que es tamClínica médica. - Tomo I. 
bién nulo el pulso radial izquierdo, lo que supone una lesión propagada á la subclavia de este lado, y por lo tanto, dependiente del tronco de la aorta. Hecha esta salvedad, es indudable que el aneurisma aórtico debe estar situado en las inmediaciones del nacimiento del tronco braquio-cefálico, porque el retardo del pulso es más apreciable en el lado derecho, signo que, según F. Franck, indica con exactitud la localización del aneurisma en la primer porción de la curva aórtica.

Respecto á saber cuál es el estado material de la bolsa aneurismática, si es antigua $\delta$ reciente, tapizada de coágulos estratificados ó permeables, sólo podemos hacer conjeturas. Creo probable que el saco del aneurisma debe es-, tar obliterado en parte por coágulos, á causa de los signos negativos en absoluto que suministra la exploración de la región pre-external. La falta de latidos expansivos de estremecimiento (thrill), de soplo, el carácter sordo de los ruidos del corazón, todo concurre á hacer verosímil esta creencia. Además, la persistencia del éxtasis yugular á los quince días de reposo, demuestra que hay en el mediastino un tumor sólido, inextensible, que comprime el tronco venoso braquio-cefálico; estos signos son propios de los aneurismas consolidados. Se puede, pues, asegurar, que el aneurisma se halla en vías de obliteración progresiva y es muy probable que date de una época lejana, porque excepto los fenómenos disnéicos, que se han corregido á beneficio del reposo, los signos físicos siguen en el mismo estado que cuando ingresó el enfermo en el hospital.

La etiología de este aneurisma es la del ateroma. La tendencia á las degeneraciones arteriales es casi siempre constitucional y hereditaria ; aumenta por las enfermedades intercurrentes y las faltas de higiene. En nuestro enfermo, existe la influencia hereditaria ; su padre murió á los sesenta y tres años, á consecuencia de una hemorragia 
cerebral. Aunque este hombre no ha padecido gota, ni reumatismo, ni sífilis, los tres grandes factores de la arteritis, ha fatigado su sistema vascular de dos maneras distintas : abusando de las bebidas alcohólicas y además por la profesión penosa que ha ejercido durante veinte años de su vida. No olvidéis, en efecto, que pasaba todo el día subiendo sacos de carbón á domicilio; no hay con seguridad otro ejercicio que aumente más la tensión sanguínea en la aorta. Estos enfuerzos sostenidos y prolongados, repetidos todos los días durante años, han debido, con seguridad, forzar esta arteria y producir el aneurisma ; la frecuencia de las lesiones cardíacas y aórticas en mozos de cuerda, prueba la realidad de esta influencia patógena.

Queda por averiguar cómo con una lesión muy probablemente antigua, y con seguridad preparada por las fatigas profesionales, no se han manifestado los síntomas del aneurisma de un modo progresivo por dificultad respiratoria creciente. Las manifestaciones de la enfermedad se presentaron, al parecer, de una manera inesperada en forma de un acceso de asma violentísimo; este accidente fue el primer indicio en la alteración de la aorta, que según toda probabilidad, databa de muy lejos, porque el enfermo tuvo que cambiar de oficio hace cinco años, al encontrarlo muy pesado para sus fuerzas. Es posible que si se le hubiera reconocido en aquella época, se hubiese descubierto la lesión aórtica. Le ha sucedido lo que ocurre en las enfermedades del corazón; hay tolerancia mientras que el corazón, vigoroso aún, se adapta á las condiciones nuevas que le crea la lesión; el día en que flaquea por una circunstancia ocasional, fatiga, emoción, enfriamiento, se presentan accidentes formidables muchas veces.

Volviendo á nuestro enfermo, aunque su estado general parece bueno, y por el momento tiene poca opresión, el pronóstico es grave. Va á entrar en la fase en que el cora- 
zón flaquea, y en la que se presentan con facilidad complicaciones circulatorias. No creo que está amenazado por ahora de que se extienda su aneurisma; hasta parece que se encuentra en vías de efectuarse el trabajo de coagulación de la bolsa aneurismática ; pero, además de los peligros de embolia 6 de trombosis, siempre posibles en tales. casos, me parece que se halla amenazado de un modo más directo por la debilidad del corazón.

Así que, al contrario de los demás enfermos de aortitis que me habéis visto tratar desde el principio por los alterantes y por el ioduro, creo que en este caso conviene emplear desde luego la digital á pequeñas dosis y con prudencia, porque me parece que la indicación primera es restablecer la energía ventricular. Desde que se encuentra en la clínica este hombre, ha mejorado bastante; el reposo sólo ha sido suficiente para corregir todo el malestar y para restablecer el equilibrio circulatorio. Los latidos del cuello son menos fuertes; las yugulares son las únicas que siguen distendidas como el primer día. El enfermo toma diariamente, desde hace dos semanas, 40 gotas de tintura de digital; está también sometido al régimen lácteo parcial. Después de algún tiempo, cuando se normalice la respiración, emplearé el ioduro asociado á la trinitrina, que creo preferible para disminuir la presión arterial. Pero todos estos medios son puramente paliativos, porque la lesión aórtica ha llegado á una fase que hace poco probable la mejoría duradera.

NOTA ADICIONAL

Después de tres estancias sucesivas en el Hospital, durante los años 1888 y 1889, volvió este individuo á principios de Marzo de 1890 con síntomas mucho más graves. Esta vez estaba hinchado y presentaba todos los caracte- 
res de la asistolia ; la orina era escasa y albuminosa; el corazón se hallaba dilatado, aunque no se oía ningún soplo. A pesar del empleo de la digital y de la cafeína, no se modificaron los accidentes asistólicos, y el enfermo murió á causa de los progresos de su caquexia, el 30 de Abril de 1890 . Autopsia, el $1 .^{\circ}$ de Mayo, veintiséis horas después de la muerte.

El corazón y los gruesos vasos, separados de la cavidad torácica, presentaban las lesiones siguientes :

La aorta estaba dilatada ; en toda la porción ascendente del cayado formaba una ampolla gruesa, que podía contener un huevo de gallina. La dilatación se prolongaba por todo el cayado, hasta la arteria subclavia izquierda. Desde este punto se hacía de nuevo normal su calibre. En toda la parte correspondiente á la ampolla dilatada, era relativamente sana la túnica interna de la aorta. Sólo se descubrieron tres engrosamientos formados por placas de ateroma incipiente, sin incrustaciones calcáreas ni ulceración de la túnica arterial.

El tronco braquio-cefálico nacía en una región de la aorta relativamente sana $y$ sin placas ateromatosas.

En el origen de la arteria subclavia izquierda había, por el contrario, una placa de ateroma con incrustación calcárea, que estrechaba de un modo notable el calibre de la arteria ; pero ésta era ancha y dilatada en los 4 centímetros primeros de su trayecto. Se estrechaba de repente en el sitio de nacimiento de la acromio-torácica que tenía casi el calibre de la subclavia, mientras que ésta quedaba reducida á un cordón fibroso obliterado casi por completo á causa del aplastamiento de sus paredes, porque se necesitaba un estilete para separarlas.

La obliteración era casi completa en un trayecto de $\mathbf{1 6}$ centímetros y es indudable que debía haberse suprimido, casi en absoluto, la corriente sanguínea. 
La obliteración era completa en el origen de la arteria humeral.

En el espolón formado en el sitio de nacimiento de la acromio-torácica, había placas ateromatosas calcáreas del mismo aspecto que las que existían en la primer porción del trayecto de la subclavia.

El tronco braquio-cefálico era relativamente poco ateromatoso, pero debajo del nacimiento de la arteria acromio-torácica existían lesiones análogas á las del lado izquierdo, que disminuían de una manera notable el calibre de la arteria que era casi tan gruesa como una de las radiales y estaba obliterada por completo en una extensión de 5 á 6 centímetros.

La lesión de este lado era idéntica á la del opuesto, es decir, que las placas ateromatosas y las incrustaciones calcáreas, ponían en contacto las paredes convertidas así en una especie de cordón fibroso.

El resto de la aorta presentaba lesiones ateromatosas difusas, pero algo confluentes.

El corazón era voluminoso, con el ventrículo izquierdo hipertrofiado y dilatado. La pared muscular tenía 3 centímetros de espesor. Las válvulas mitrales y aórticas estaban sanas. Los orificios de las coronarias se encontraban abiertos y no presentaban más que algunas placas ateromatosas.

Higado. Moscado.

Riñones. Congestionados. Aspecto de riñón cardíaco con cierto grado de nefritis intersticial. Disminución de la substancia cortical, desaparición de las pirámides. Transformación en tejido conjuntivo del parénquima renal.

Pulmones. Bazo. Normales.

Esta autopsia confirma por completo el diagnóstico hecho en vida del enfermo. 


\section{ANEURISMA DE LA AORTA TORACICA DESCENDENTE}

Sumario: El síntoma predominante, casi único, del aneurisma de la aorta torácica descendente es el huélfago. - Diagnóstico diferencial con los tumores del mediastino, el cáncer del pulmón y la adenopatía traqueobronquial. - Signos accesorios de esta variedad de aneurismas: dilatación de la vena yugular izquierda y situación más elevada de la arteria subclavia correspondiente ; debilidad del pulso radial izquierdo.-Signos de auscultación pulmonar concomitantes : soplo anfórico sin estertores, localizado en el hílio del pulmón : valor de este soplo desde el punto de vista de la localización del aneurisma.- Errores de diagnóstico posibles : casos de aneurisma de la aorta descendente tomados por accesos de asma, por tuberculosis aguda 6 crónica. - Indicaciones etiológicas y terapéuticas.

El enfermo sobre el que voy á llamar hoy vuestra atención es un hombre de sesenta y tres años, alto y robusto, que desde hace más de doce meses padece accesos de opresión intermitentes y disnea de carácter particular en los intervalos de las crisis. Aun durante el reposo respira con trabajo y dificultad, y la inspiración es mucho más difícil que la espiración, al contrario de lo que sucede en los enfisematosos, cuya espiración es más prolongada y en ocasiones sibilante. No tiene el color congestivo ni el tórax combado de los enfisematosos, sino que está por el contrario muy pálido, $\mathrm{y}$ su pecho no presenta deformación apreciable. Si á este aspecto general se agrega el que desde hace algunos días tiene edema de los maleolos y palpitaciones provocadas por el más ligero esfuerzo, se comprende que este hombre padece una afección del corazón.

Presenta, no obstante, un síntoma particular que es raro en los cardíacos, el huélfago. Cuando se halla el en- 
fermo en reposo absoluto, apenas se nota ; la respiración se hace ronca, sonora y estridente : hay al mismo tiempo tirantez supra-clavicular y depresión de los tegumentos de la base del cuello.

El huélfago es un signo de gran valor, porque indica siempre la existencia de un obstáculo en la parte superior de las vías respiratorias. Se trata, por lo común, de una compresión que estrecha la glotis y la tráquea. Todas las lesiones localizadas de la laringe que obstruyen el calibre del conducto, por ejemplo, un flemón, el cáncer, los pólipos, producen el huélfago: los cuerpos extraños, situados en las vías respiratorias, los tumores del cuello y del mediastino que aplastan y deforman la tráquea, ocasionan también este síntoma.

La primera cuestión que debe resolverse en tales casos, es averiguar el sitio del huélfago, si es laríngeo, traqueal ó bronquial. En nuestro enfermo es imposible la duda: el huélfago es indudablemente de origen traqueal. En efecto, la voz es clara, bien timbrada, no hay ronquera ni dolor localizado laríngeo, y la laringe es, por por lo tanto, normal, en absoluto. Además, el enfermo nota una sensación penosa en el vértice del pecho : siente en este sitio cosquilleo continuo, que compara á la titilación de las barbas de una pluma, que provoca golpes de tos seca, sin expectoración. Se queja además de un dolor fijo retro-external que corresponde á la segunda pieza del esternón. Agregando estos síntomas al huélfago de que van acompañados se comprende que la lesión, sea la que quiera, comprime la parte inferior de la tráquea cerca de su bifurcación. Debemos averiguar qué afecciones son capaces de producir este fenómeno.

Hay cuatro principales : los tumores del mediastino, el cáncer del pulmón, la adenopatía traqueo-bronquial y los aneurismas de la aorta. Veamos estas diversas hipótesis: 
Es poco probable, a priori, que se trate en este caso de un tumor del mediastino. Nuestro enfermo ha pasado la edad en que es frecuente esta afección ; porque los linfadenomas mediastínicos se presentan de preferencia en la juventud, de los veinte á los treinta años. Sin embargo, no debe desecharse, desde luego, esta suposición, porque se han referido casos de tumores tardíos del mediastino en personas de más de cincuenta años ; pero la sintomatología en tales casos es diferente. El huélfago, sobre todo, no se observa más que cuando los trastornos funcionales son extensos y la lesión ya difusa, en vez de ser un fenómeno inicial y casi exclusivo como en el caso de que se trata. Se observan entonces signos físicos que indican un obstáculo profundo para la circulación y que faltan en el caso actual. Las venas superficiales de la región pre-esternal se dilatan y forman una red análoga á la de la región supra-hepática en la cirrosis ; la base del cuello está hinchada, edematosa, la cara vultuosa á causa del éxtasis venoso yugular, la macicez precordial se halla aumentada, y sobre todo se extiende á la región aórtica en proporciones insólitas; hay, por último, casi siempre síntomas de derrame pericardíaco y pleurítico. La marcha de los accidentes varía también. Los linfadenomas del mediastino siguen de ordinario una evolución rápida : ocasionan la muerte en pocos meses, algunas veces en pocas semanas. En nuestro enfermo, los accidentes se han desarrollado con lentitud y presentan, al parecer, poca tendencia á aumentar.

Nada indica, por lo tanto, una neoplasia invasora que se comporte como un cáncer.

Lo que acabo de indicar de los tumores del mediastino se aplica, casi lo mismo, al cáncer del pulmón. Pero nuestro enfermo presenta ciertos síntomas que pueden hacer pensar en este padecimiento : la edad, el color pálido, el 
aspecto anémico y el tinte amarillento recuerdan el de los cancerosos. Por último, los trastornos funcionales son casi idénticos : el huélfago, la disnea accesional, los dolores torácicos sordos unas veces, neurálgicos otras, la imposibilidad del decúbito dorsal, y la dificultad grandísima de respirar bajo la influencia de los esfuerzos más ligeros. Tales son las analogías.

Véanse ahora las diferencias.

En nuestro enfermo la tos es corta, seca, constituída por una sacudida espiratoria brusca; se siente que los bronquios son permeables y que no hay hipersecreción glandular.

En el cáncer del pulmón, por el contrario, la tos es muy intensa y frecuente, se presenta por accesos de apariencia coqueluchoide, expulsa con dificultad y á costa de grandes esfuerzos pequeños esputos mucosos estriados de sangre $\sigma$. parecidos á la gelatina de grosella.

Los signos físicos, sobre todo, son muy diferentes. La macicez pulmonar en el cáncer es absoluta, como leñosa, no sólo preesternal, sino subclavicular, y se observa en la parte superior del pecho cuando el neoplasma está localizado en el lóbulo superior del pulmón. La pared torácica, al nivel del tumor, suele estar retraída y dolorosa, y los murmullos vesiculares suprimidos siempre ; no se oyen estertores, y sólo en casos raros soplo. En nuestro enfermo, por el contrario, la respiración, aunque débil, es buena, y la percusión sonora ; el parénquima es, al parecer, permeable por completo, pero en el hílio pulmonar se oye un soplo anfórico, de cuya significación me ocuparé más adelante. Por último, en el cáncer, al explorarse los ganglios supra-claviculares, suele descubrirse una adenopatía especial, formada por núcleos duros, poco móviles, indolentes ; y cuando se encuentra este signo, es posible diagnosticar casi con seguridad la existencia de una neoplasia 
maligna. En este caso nada de esto se observa, y los ganglios del cuello son imperceptibles.

$\mathrm{La}$ adenopatía traqueo-bronquial, aunque rara en el adulto, no es una enfermedad tan excepcional que no deba tenerse en cuenta, y Fonssagrives y Lionville han publicado ejemplos hasta en los viejos. Pero casi siempre pasa inadvertida, y se desarrolla sin síntomas. Cuando produce trastornos funcionales, se presentan crisis de tos coqueluchoide, con 6 sin expectoración, y no la tos seca y corta de nuestro enfermo. Se observan también á la vez, casi siempre, signos de congestión pulmonar y laringitis, debidas á la compresión del recurrente. Existe igualmente huélfago, pero es raro; lo que domina es la rudeza habitual de la inspiración al auscultar la zona supra-clavicular.

A esto se limitan casi los únicos signos físicos, porque nada más excepcional que encontrar en el adulto la macicez pre-esternal y retro-vertebral señaladas por Guéneau de Mussy como característica de la adenopatía bronquial. Es un cuadro clínico muy diferente, en realidad.

Además, en nuestro enfermo las presunciones etiológicas no son favorables á la idea de una adenopatía, que supone una bronco-pneumonía específica anterior ó bronquitis repetidas. En los antecedentes de este hombre no se encuentran enfermedad infecciosa alguna, ni accidentes profesionales susceptibles de originar la esclerosis del pulmón.

Es mucho más racional atribuir en este caso el huélfago á un aneurisma de la aorta. No sólo es la hipótesis más probable en este hombre, que ha pasado de los sesenta años, y cuyo sistema arterial es por lo mismo sospechoso, sino que el examen detenido de los signos físicos demuestra bien á las claras el origen aórtico de la lesión. En efecto, la macicez es mayor en la región del cayado de la aorta : mide $6 \frac{1}{2}$ centímetros de diámetro, ó sea próxima- 
mente una tercera parte más que de ordinario. El examen de los vasos del cuello suministra otra prueba. La vena yugular derecha se encuentra hinchada y distendida, lo que indica un obstáculo local al curso de la sangre, mientras que en el lado derecho nada de esto se observa : este signo se ha señalado hace mucho tiempo como caracterís. tico de ciertos aneurismas de la aorta, porque ya en 1835 indicó Green su valor. La palpación del hueco supra-clavicular demuestra también que la arteria subclavia izquierdo está más elevada que de costumbre, y he tenido ocasión, al ocuparme de otro enfermo, de recordaros la importancia de este signo. No sólo está elevada, sino que es, al parecer, más voluminosa que su congénere, y parece dilatada. En las pulsaciones radiales se nota una diferencia inversa : en el lado izquierdo el pulso es más débil que en el derecho, y esta desigualdad es un signo de gran valor, porque prueba la existencia de una lesión directa del sistema arterial. Un tumor que comprimiera la aorta no produciría síntomas de este género, porque las arterias, por su elasticidad, se libran casi siempre de las causas de compresión : las diferencias notables en las pulsaciones arteriales derechas é izquierdas indican por necesidad 6 $u n$ aneurisma, $\delta$ placas ateromatosas situadas en el origen de las subclavias, y que estrechan más 6 menos su calibre.

Este conjunto de signos demuestra, por consiguiente $y$ de un modo absoluto, que se halla enferma la aorta, pero quedan aún por esclarecer algunos puntos. ¿ Se trata de una dilatación total del cayado aórtico ó de un aneurisma ampular, y, en este último caso, cuál es su sitio, cuáles son sus consecuencias respecto á los órganos inmediatos?

Ya he tenido ocasión, á propósito del enfermo anterior, de discutir el diagnóstico diferencial del aneurisma y de la 
dilatación aórtica, y no quiero repetirlo en detalle. Me limitaré á deciros cuáles son los motivos que, en la especie, me hacen desechar la idea de una dilatación uniforme de la arteria.

En este último padecimiento los síntomas de la auscultación son por lo general muy típicos, y se oye en toda la longitud del cayado de la aorta un soplo más ó menos áspero, casi siempre doble. En nuestro enfermo faltan en absoluto los soplos; hasta es un fenómeno notable que la resonancia de los ruidos del corazón sea ligera, que esté disminuída con relación al estado normal. Esta es la primer diferencia.

La segunda la suministra la exploración de la aorta, que es posible hacer deprimiendo con el dedo la horquilla external. Cuando el cayado aórtico está dilatado en toda su extensión, su curva llega al borde superior del esternón y hasta más arriba; se le siente latir inmediatamente debajo del dedo; en este enfermo falta dicha sensación. Todas las arterias colaterales de la aorta siguen en tales casos el movimiento de ascensión del tronco, y se observa la elevación simétrica de las dos subclavias por encima de la clavícula, mientras que las dos venas yugulares se hallan también distendidas á causa de la compresión simultánea de los troncos braquio-cefálicos venosos. Habéis visto que no sucede así en nuestro enfermo : que sólo la arteria subclavia izquierda es la que está situada en un plano más elevado que de costumbre; que únicamente la vena yugular izquierda se halla distendida por la sangre. El obstáculo á la circulación, sea el que quiera, se encuentra localizado, y este hecho basta para afirmar que la aorta no está dilatada en toda su extensión. Por último, lo prueba el mismo huélfago. Este síntoma es rarísimo en las ectasias verdaderas de la aorta torácica, y supone siempre una compresión ejercida sobre la tráquea por una lesión circunscrita. 
Deducimos, por consiguiente, de esta discusión que se trata de un aneurisma verdadero y no de una dilatación difusa del cayado de la aorta.

Prosigamos el análisis de los síntomas : ellos van á permitirnos diagnosticar el sitio de la lesión aneurismática.

Ante todo, el síntoma capital que presenta el enfermo, el huélfago, suministra una indicación importante respecto al sitio donde está localizado el padecimiento: demuestra que la tráquea se halla comprimida en su parte inferior ó hacia su bifurcación. Esto supone una dilatación aneurismática, situada en las partes laterales del cayado aórtico, casi ciertamente por detrás.

Es poco probable que el aneurisma se halle en la parte anterior al nivel de la porción ascendente, porque faltan la mayor parte de los signos de los aneurismas de esta región. No se notan ni latidos expansivos en el segundo espacio intercostal, ni estremecimiento catario á la palpación : no hablo de la auscultación, que es negativa, porque sabemos que los aneurismas verdaderos no se manifiestan á veces por soplo ó ruido anormal alguno. Tampoco se observa el menor signo de éxtasis venoso que indique obstáculo en los troncos braquio-cefálicos, ni están dilatadas las venas subcutáneas de la región pre-esternal. Todo concurre, por consiguiente, á demostrar que la ampolla aneurismática no se halla localizada en la parte anterior del cayado de la aorta.

Es, por el contrario, lógico suponer que la lesión ocupa la parte descendente del cayado, el sitio de la curva aórtica. Varios indicios lo prueban, además de los signos negativos que demuestran la integridad de la aorta ascendente.

El hecho que os he indicado del nacimiento más elevado de la subclavia izquierda, indica que la ectasia ampulosa interesa el origen de esta arteria, es decir, el punta donde principia la reflexión de la aorta. 
La estancación venosa de la yugular izquierda es un fenómeno de la misma clase. Se explica, según creo, por la dirección del tronco venoso subclavio, que está situado á la izquierda en un plano más profundo que su congénere de la derecha, y, por lo tanto, en relación más inmediata con la ampolla arterial.

La auscultación pulmonar suministra también datos de importancia. Por delante, debajo de las clavículas, la respiración es normal por completo : todo lo más, á la izquierda se halla algo disminuída. Por detrás, no se nota macicez al percutir; pero en el punto correspondiente al hílio pulmonar, hay soplo tubario fuerte, casi anfórico. Este soplo se oye lo mismo á la derecha que á la izquierda; $y$, fenómeno notable, no va acompañado de estertor alguno. Es, por consiguiente, un soplo de compresión bronquial, que nada tiene que ver con una induración del parénquima pulmonar, y que representa para el oído la reproducción y la exageración del huélfago traqueal. Dicho signo tiene un gran valor, porque puede existir independiente del huélfago y basta por sí solo para hacer sospechar la existencia del aneurisma.

Hay más : es posible deducir de los caracteres de este soplo el sitio verosímil de la bolsa aneurismática. Es indudable que ésta comprime directamente la tráquea, porque si comprimiera el bronquio izquierdo debajo de la bifurcación traqueal, sólo se oiría el soplo en un lado, ó cuando menos sería más fuerte á la izquierda : ahora bien, el soplo es bilateral y se oye con la misma claridad á la izquierda que á la derecha. Por otra parte, el murmullo vesicular, debajo del punto comprimido, sería indudablemente menor, y se notaría una diferencia notable en la intensidad respiratoria de los dos pulmones, lo que no sucede.

Podemos, por lo tanto, deducir que el aneurisma es pro- 
bable que esté localizado en el punto de inflexión del cayado de la aorta ó en el sitio donde éste cruza la tráquea, lo que explica la falta de los signos habituales observados en la región pre-esternal.

¿Es posible apreciar el volumen de la dilatación aneurismática?

Es una cuestión difícil de responder, porque los síntomas funcionales no están en modo alguno en relación con las dimensiones de la bolsa aneurismática, sino con su sitio. Un aneurisma enorme puede permanecer latente y pasar inadvertido, mientras que ectasias aórticas pequeñísimas producen desórdenes considerables, por poco que compriman órganos importantes y les inmovilicen adherencias resistentes.

Todo lo que podemos decir, en este caso, es que los accidentes dependen sólo de la compresión de la tráquea : no hay síntoma alguno que indique invasión ni trastorno del nervio recurrente $\delta$ del pneumogástrico. El esófago se halla, al parecer, libre, la deglución es fácil : no se notan dolores irradiados raquidianos que indican la compresión de los nervios prevertebrales y el desgaste de las vértebras, ni las neuralgias lumbo-abdominales, tan rebeldes algunas veces en ciertos aneurismas de la aorta torácica. En una palabra, todo se reduce al huélfago y á los fenómenos disnéicos, que son la consecuencia. Es, por lo tanto, lógico suponer que el aneurisma no tiene un gran volumen, pero que, según toda probabilidad, se halla enclavado cerca de la tráquea y fijo á las vías respiratorias por adherencias fibrosas, lo que explica la rebeldía é intensidad del huélfago.

A pesar de su pequeño volumen probable, el aneurisma de este enfermo produce consecuencias bastante graves. Aunque el corazón no está hipertrofiado, al parecer, de un modo sensible, y sus válvulas son normales, se observan 
trastornos de la circulación general que demuestran que se ha debilitado la energía ventricular. Las piernas están edematosas y el edema llega hasta la parte inferior del abdomen. La circulación pulmonar se ha trastornado también: se oyen estertores mucosos diseminados por las dos bases, y la respiración es débil como en los casos de edema del pulmón. Por último, el hígado es grueso, doloroso y congestionado : lo mismo sucede con los riñones, cuya secreción es poco abundante y contiene indicios de albúmina. Todas estas alteraciones viscerales son las que se observan en los padecimientos confirmados del corazón, cuando principia el período de asistolia, y las que, más que la lesión aneurismática propiamente dicha, deben preocuparnos desde el punto de vista del pronóstico.

He dejado á un lado la cuestión etiológica : ya es tiempo de que tratemos de ella. ¿Es posible descubrir la causa del aneurisma? No puede invocarse la herencia de una predisposición ateromatosa, porque los antecedentes de este hombre son buenos : su madre murió á los sesenta y ocho años, su padre á los setenta y siete; el enfermo ha sido toda su vida robusto y sobrio y nunca ha padecido reumatismo. Ha vivido bastantes años en Argelia como soldado, y jamás ha padecido más enfermedades que las heridas de arma de fuego (tiene en la pierna izquierda las cicatrices de dos balazos).

No encontramos más que dos circunstancias etiológicas que hayan podido influir sobre su estado actual : la repetición de los esfuerzos musculares fuertes, y la sífilis. Este hombre era maestro de armas en su regimiento, y la esgrima es indudablemente uno de los ejercicios que necesita más fatiga respiratoria y más trabajo muscular. Además, ha padecido quizá sífilis. Digo quizá, porque no recuerda haber tenido chancro ni erupciones secundarias : pero en 1887 ingresó en el hospital de San Luis con una 
úlcera en la pierna izquierda, que después de resistir mucho tiempo á los tópicos locales, curó bajo la influencia del ioduro potásico y de un emplasto de Vigo. Es, por lo tanto, posible que esta úlcera fuera la manifestación tardía de una sífilis desconocida hasta entonces, pero no hay seguridad de ello. De todos modos, como la influencia de la sífilis sobre el estado de las arterias no es dudoso, y como por otra parte este enfermo no es ateromatoso en alto grado, á pesar de sus sesenta y tres años, dicha etiología concuerda con la existencia de un aneurisma y suministra algunas indicaciones terapéuticas.

Antes de estudiar el tratamiento que debe emplearse en estos casos, insistiremos sobre el aneurisma y las particularidades que dependen de su sitio especial.

Estos aneurismas de la porción descendente del cayado aórtico sin ser comunes, se observan de cuando en cuando y suelen desconocerse porque sus signos son de ordinario obscuros. Si se reflexiona que en estos enfermos el dolor pre-esternal no es tan fuerte como en los aneurismas de la porción ascendente, que las palpitaciones y los trastornos cardíacos son en general poco acentuados y que la disfagia es excepcional, se comprende que queden latentes por completo y sólo se descubran al hacer la autopsia.

Los trastornos funcionales más comunes que caracterizan esta variedad de aneurisma, son la disnea accesional y sobre todo el huélfago que indica la compresión de la tráquea; el signo físico correspondiente es un soplo traqueo-bronquial posterior de timbre anfórico sin estertores; existen además algunas veces fenómenos de compresión del mediastino, pero que casi nunca dificulta la circulación venosa ni dilata los vasos cutáneos. En una época más avanzada de la enfermedad, se observan en ciertos casos latidos expansivos y levantamiento de la región dorsal, pero es raro que las lesiones lleguen á este grado. 
La sintomatología de los aneurismas de la porción des. cendente del cayado aórtico, es, por lo tanto, especial, poco característica y susceptible de ocasionar numerosos errores de diagnóstico. En ocasiones no presentan los enfermos más que un aspecto enfisematoso y los ataques de disnea se atribuyen al asma. Otras veces llaman la atención trastornos generales de aspecto cardíaco y se diagnostica una enfermedad del corazón, con ó sin lesiones valvulares, sin comprender que la causa es el aneurisma. Popham (Arch. gen. de Méd., 1858) y Douglas, han publicado ejemplos de errores de este género ; Vallois, 1885, ha referido algunos en su Tesis inaugural (1885).

Puede sospecharse también la tuberculosis, y el diagnóstico diferencial es algunas veces muy dificil. Jean ha referido en la Sociedad anatómica la historia de un individuo que padecía disnea progresiva, tos, hemoptisis repetidas y soplo tubario limitado al vértice del pulmón izquierdo. Se le consideraba como tísico ordinario, cuando murió de hemoptisis. Al practicar la autopsia se descubrió un aneurisma de la parte descendente del cayado que había ulcerado el bronquio izquierdo. He observado un caso análogo que publiqué en los boletines de la Sociedad anatómica. Una mujer, asistida antes en el hospital de la Piedad y considerada como tuberculosa, ingresó en mi clínica con tos y hemoptisis ; descubrí soplo cavernoso sin estertores en el sitio del pulmón y supuse que existía un aneurisma que comprimía la tráquea ; á los pocos días murió de repente esta mujer y se descubrió una bolsa aneurismática ulcerada, abierta en la tráquea.

Otras veces el aneurisma no sólo simula la tuberculosis aguda de forma congestiva, sino la forma crónica ulcerosa de la tisis ordinaria. Chandeleux ha publicado un caso en el que estaban reunidos todos los síntomas de la consunción laríngea tuberculosa, ronquera, accesos de tos, ex- 
pectoración muco-purulenta, respiración bronquial en ambos vértices, enflaquecimiento progresivo; al hacer la. autopsia se descubrió un aneurisma de la aorta descendente, cuya existencia no se sospechaba. Se han citado asimismo casos en los que los síntomas eran los de una pleuresía crónica (Lebert) ó de un pneumotórax (Coyne); se han visto otros más raros en los que se presentaron de cuando en cuando vómicas pulmonares ; el pus procedía de una erosión vertebral debida á un aneurisma de este género. Estos últimos casos sirven de transición á las paraplegias que ocasionan los aneurismas al desgastar poco á poco la columna vertebral, y que se consideran como mielitis crónicas. Detallar estos modos de terminación, sería separarme de mi objeto.

Las eventualidades que esperan á nuestro enfermo son, según toda probabilidad, menos complejas. Es probable que los accidentes venideros dependan de los progresos de la debilidad del corazón y de las congestiones viscerarales, y que este hombre muera con todos los síntomas. de una asistolia creciente. Es posible también que sobrevenga la muerte por síncope imprevisto ó por una hemoptisis fulminante, si el aneurisma se abre en la pleura ó en la tráquea. Puede suceder, por último, que, bajo la influencia del reposo, deje de progresar la lesión aórtica y se regularice la circulación; por desgracia, esta eventualidad favorable, es la que tiene menos probabilidades de realizarse.

Sea lo que fuere, se impone la medicación iodurada, no sólo porque el enfermo padece un aneurisma aórtico, sino porque, según toda probabilidad, es sifilítico. En estos casos, suelen obtenerse con el ioduro potásico curaciones inesperadas. He observado un ejemplo de este género, que no lo creería á no haberlo visto. Un cochero de Levallois-Perret, que padeció desde bastante tiempo antes 
un aneurisma aórtico y era sifilítico antiguo, me llamó para asistirlo en Noviembre de 1875 ; le encontré moribundo, anasárquico, con ansiedad terrible $\mathrm{y}$ un tumor pulsátil grueso, del tamaño del puño á la derecha del esternón. La situación de este enfermo parecía desesperada, y me limité á prescribir inyecciones de morfina y el ioduro á dosis elevadas (4 gramos por día), no creyendo posible ni aun la mejoría parcial. ¿Cuál no sería mi sorpresa al volverlo á ver en 1877 , no diré curado por completo, pero sí sin el menor trastorno funcional y respirando como todo el mundo? El tumor pulsátil había desaparecido, y en su lugar quedaba una dureza circunscrita, maciza á la percusión é indolente por completo. Este individuo murió de pulmonía en 1882 .

Aunque no me atrevo á esperar este resultado, tengo idea de seguir el mismo plan, es decir, hacer tomar al enfermo 3 gramos diarios de ioduro potásico, y calmar su disnea por medio de una dosis cotidiana pequeña de opio. Mantendré á la vez, en la parte anterior del pecho, una revulsión moderada pero repetida á menudo, y procuraré facilitar la diuresis con el régimen lácteo. Respecto á la digital, que parece indicada en este caso á causa de los síntomas de desfallecimiento cardíaco, no me atrevo á emplearla por miedo á aumentar de un modo demasiado brusco la tensión arterial en una bolsa aneurismática, cuya resistencia desconozco. Prefiero recurrir á los medicamentos que disminuyen la presión sanguínea, y si continúan los accesos de disnea, emplearé las inhalaciones de nitrito de amilo 6 la ingestión, mañana y tarde, de tres gotas de una disolución de trinitina al 1 por 100. Creo llenar así las dos indicaciones principales del tratamiento, que son : calmar el eretismo cardio-vascular y restablecer la permeabilidad renal. 


\title{
ANEURISMA DE LA AORTA TORACICA DESCENDENTE
}

\author{
QUE QUEDÓ LATENTE HASTA SU ROTURA
}

Sumario : Observación de un enfermo con palpitaciones, enfisema y retracción antigua de la pared torácica izquierda. - Desarrollo de una bronco-pneumonía especial, que fue acompañada de esputos hemoptoicos abundantísimos; muerte repentina por hemorragia pulmonar. - Descripción de la autopsia ; aneurisma de la porción descendente de la aorta torácica con desgaste de las últimas cinco vértebras dorsales y lesiones de esclerosis y de apoplegía pulmonar. - Concordancia de los síntomas y de las lesiones; mecanismo de la disnea, de las palpitaciones y de la expectoración hemoptoica. - Falta de hipertrofia del corazón á pesar de la lesión aórtica ; carácter latente de los síntomas. - Valor de la retracción del pecho en ciertos aneurismas de la aorta.--Influencia de la grippe sobre la evolución de los accidentes últimos.

La historia de los aneurismas abunda en sorpresas y son muchos los casos en los que una lesión, aun considerable, evoluciona durante varios años sin producir trastorno funcional alguno apreciable, y sin llamar la atención del clínico por el menor fenómeno insólito. Un caso de este género hemos tenido en nuestra clínica; no he sospechado la dilatación aneurismática hasta el momento de la hemoptisis final que arrebató al enfermo. Aunque desconocí en absoluto el diagnóstico durante la vida, el caso no deja de ser instructivo porque este hombre había permanecido bastante tiempo en nuestras salas en dos ocasiones distintas y se le reconoció con cuidado. Tenemos, por lo tanto, datos retrospectivos que nos permiten comprender por qué desconocimos la lesión y cuáles eran los signos que hubieran podido evitar el error.

Arturo C., de cuarenta y cinco años, de aspecto más: bien mediano que robusto, ingresó por vez primera en el 
Hospital Necker, en la clínica de mi colega el Dr. Rigal en Enero de 1888. Se quejaba entonces de opresión y de palpitaciones fuertes; se diagnosticó afección cardíaca más bien funcional que orgánica. En efecto, bastaron dos semanas de reposo para que desapareciera todo malestar y se le dió de alta, curado al parecer. Carezco en absoluto de datos precisos respecto á esta primer estancia.

Cuatro meses después se presentó este individuo en mi consulta é ingresó en la clínica. El síntoma predominante era un dolor de costado, situado en la base del pulmón derecho, y que duraba casi sin interrupción dos meses y medio. Era, a priori, probable que se tratara de una neuralgia, porque el enfermo ni tenía ni había tenido fiebre. El aspecto general, á primera vista, era el de un cardíaco. Sentía opresión al menor esfuerzo, respiraba con trabajo y con fuerza y presentaba cierta tendencia á la cianosis : tosía poco y cuando se presentaban de tarde en tarde los accesos de tos, no eran seguidos de expectoración.

Tenía, como la vez primera, intensas palpitaciones que le impedían dedicarse al trabajo sostenido, síntoma que databa de muy lejos, porque desde su infancia afirmaba no haber podido jamás correr ni hacer el menor ejercicio violento. A excepción de esto había disfrutado siempre buena salud, nunca padeció sífilis ni recordaba haber tenido reumatismo.

Durante el reposo y cuando se tranquilizaba el corazón, la respiración se normalizaba, cesaban las palpitaciones y todo entraba en orden; sólo persistía el dolor de costado que era molesto por su constancia más que por su intensidad.

Estos trastornos funcionales eran los de una cardiopatía, y desde luego, lo mismo que el Dr. Rigal, no dudé en considerar al enfermo como un cardíaco. Sin embargo, el examen de los signos físicos no concordaba con esta pri- 
mera impresión ni conducía al diagnóstico de una lesión orgánica. La inspección del tórax nada enseñaba : había quizá una ligera combadura precordial, pero era debida, al parecer, más bien al enfisema que á la hipertrofia del corazón. En el momento de las crisis y de las palpitaciones el impulso cardíaco era fuerte y brusco, los chasquidos valvulares durós y vibrantes, pero no se oía ruido morboso alguno y los signos observados eran sólo exageración de los fenómenos normales. La punta del corazón latía en el quinto espacio y la percusión, aunque bastante difícil á causa del enfisema, no indicaba aumento de volumen de este b́rgano (12 centímetros de longitud á lo largo del borde derecho, y otros 12 en sentido transversal). No había ni aritmia, ni ruido de galope : era imposible deducir con exactitud que estaba enfermo el corazón.

El examen del pecho tampoco era más concluyente. Por delante, debajo de las clavículas, el sonido era timpánico, el murmullo vesicular débil ; eran signos indudables de enfisema, pero insuficientes para explicar la disnea y las palpitaciones. Por detrás, la respiración era amplia y áspera á la derecha, en el lado de la neuralgia intercostal : la compresión sobre el sitio de salida de los nervios, producía dolor. A la izquierda y por debajo, el sonido estaba disminuído á la percusión y atenuadas las vibraciones vocales. La respiración en este sitio era obscura y el murmullo vesicular débil, sin indicio de estertores.

Supuse que la base del pulmón izquierdo estaba infartada ó atelectásica, lo que, unido á un grado notable de enfisema, explicaba en cierto modo los accesos de opresión. Esta hipótesis parecía tanto más plausible, cuanto que la pared torácica, en el sitio correspondiente á la macicez, estaba retraída y aplastada como cuando hay adherencias de la pleura. Esta retracción era tan acentuada que no dudé en admitir una pleuresía antigua, aunque el 
enfermo no recordaba haber tenido en su infancia una afección de este género. Sólo parecía obscuro un punto : no comprendía por qué el dolor torácico se dejaba sentir en el lado derecho, allí donde al parecer estaba sano el pulmón, mientras que el izquierdo, sitio de lesiones apreciables, era indolente por completo. Además, no tuve tiempo de averiguar la causa de esta anomalía, porque el caso se comportó de la manera más sencilla. Lo mismo que la vez primera, el reposo y algunos calmantes bastaron para que desaparecieran casi inmediatamente las palpitaciones y la opresión. La neuralgia cedió con más lentitud después de la aplicación de ventosas escarificadas y de un vejigatorio. A los quince días pidió el alta el enfermo y no volvimos á oir hablar de él.

Este caso, en resumen, parecía de los más vulgares; el enfisema y la pleuresía son lesiones comunes que se asocian á menudo en un mismo individuo, y nada se apartaba de lo ordinario en nuestro enfermo. Pero me habían sorprendido dos particularidades clínicas, que debieron llamar más mi atención; me refiero al carácter de las palpitaciones y á su influencia sobre la salud de este hombre.

El valor de las palpitaciones es de por sí muy relativo; son un síntoma trivial, de origen exclusivamente nervioso, que se observa con la misma frecuencia, y aún más, en personas que no padecen lesiones del corazón, que en el curso de las afecciones cardíacas verdaderas. El abuso del alcohol, y sobre todo del tabaco, el uso inmoderado del té, del café, los excesos genitales, los trastornos gástricos, son sus factores habituales; ni su frecuencia, ni su intensidad indican su verdadera gravedad. Pero en todos estos casos de palpitaciones, puramente funcionales, la crisis se presenta espontáneamente, lo mismo por la noche que por el día, igual durante el reposo que después de los movimientos; la mayor parte de las veces debidas á trastornos 
digestivos simples. En nuestro enfermo los ataques de palpitaciones se presentaban siempre después de los esfuerzos ; si andaba algo deprisa, si quería subir una escalera, levantar un fardo, etc., inmediatamente adquirían una gran intensidad los latidos cardíacos y sólo cesaban con el reposo absoluto. Se producía un fenómeno análogo $a ́$ las crisis de angina de pecho que provocan la marcha $\delta$ los esfuerzos musculares en las personas que padecen lesiones aórticas.

El enflaquecimiento de este enfermo era también una particularidad insólita que debió despertar mis sospechas. Notaba desde dos años antes, que sus fuerzas disminuían $y$ sin enfermedad intercurrente, sin fatigas exageradas se demacraba de un modo notable. El enfisema sólo, era incapaz de producir estas consecuencias. La mayoría de los enfisematosos tienden, por el contrario, á la obesidad, á causa de la falta de ejercicio que les impone su disnea habitual.

Sea de esto lo que fuere, habíamos perdido de vista al enfermo cuando volvimos á verlo el 27 de Diciembre de 1889; padecía desde cinco días antes influenza, que reinaba en aquella época en forma epidémica.

Su aspecto exterior había cambiado bastante. Pálido, los labios cianósicos, eon accesos de opresión grandísima y de tos que le producían sudores copiosos, parecía un cardíaco llegado al período de asistolia, con la diferencia de que no presentaba el menor indicio de edema. Su pulso era frecuente, pequeño, desigual é irregular; los latidos del corazón fuertes y tumultuosos; la auscultación, casi imposible, no revelaba más que aritmia y un ensordecimiento pronunciado de los ruidos valvulares sin lesiones orgánicas manifiestas; el volumen del órgano parecía aumentado, sin que fuera posible afirmar que habia hipertrofia verdadera. La fiebre era bastante intensa, y la temperatura se mantenía á unos $39^{\circ}$. 
El examen del pulmón no correspondía á la gravedad de los trastornos funcionales. Se oían estertores sibilantes diseminados por el pecho, $\mathrm{y}$ algunos estertores mucosos en las dos bases, pero no soplo ni foco de estertores finos pneumónicos francos. A la izquierda observamos submacicez y obscuridad de la respiración, fenómenos notables antes, pero sin modificaciones apreciables. En resumen, lesiones de bronquitis, quizá cierto grado de congestión pulmonar, pero nada más. La tos era escasa, los esputos tenaces, blancos, poco aireados y menos abundantes.

Diagnostiqué una grippe agravada por el antiguo enfisema y una afección cardíaca, según toda probabilidad una hipertrofia ventricular sin lesiones de los orificios; la violencia de las palpitaciones y la aritmia indicaban, al parecer, una lesión orgánica del corazón. Prescribí al enfermo una poción de 30 gotas de tintura de digital y 10 centígramos de extracto tebáico.

Bajo la influencia de este tratamiento y del reposo se obtuvo una mejoría rápida. La opresión disminuyó, los latidos del corazón recobraron su regularidad y se hicieron menos tumultuosos, la fiebre cesó casi por completo, y el termómetro descendió á $37^{\circ}, 5$ por la mañana, y á $38^{\circ}$ por la tarde.

Pero á la vez que estos síntomas de defervescencia, se presentaba un fenómeno nuevo que estaba, al parecer, en discordancia con la mejoría observada por el enfermo. La expectoración, mucosa y escasa al principio, había cambiado de carácter. Los esputos eran más abundantes y estaban teñidos de sangre; se asemejaban á los esputos pneumónicos, hasta el punto de confundirse con ellos. La disnea era menor, no había dolor torácico, ni indicio alguno del de costado; por último, la auscultación más minuciosa no revelaba el menor foco de hepatización pulmo- 
nar ; los estertores de bronquitis disminuían, y los de la base conservaban el carácter mucoso de los primeros días.

Insisto sobre dicha particularidad, que ha sido la nota clínica personal del enfermo, y sobre los caracteres de esta lesión pulmonar extraña que no se asemejaba ni á la pulmonía franca ni á la bronco-pneumonía grippal. Desde el punto de vista de la consistencia y del dolor, los esputos eran los de la pulmonía más legítima; el mismo aspecto herrumbroso, el mismo carácter viscoso, igual combinación íntima de la sangre y del exudado alveolar. Sólo que en vez de ser escasos, como sucede en la mayoría de los pulmoníacos verdaderos, su abundancia en este caso era verdaderamente excesiva; todas las mañanas encontrábamos la escupidera llena en su tercera parte ó en su mitad de estas mucosidades sanguinolentas; lo que acabó de diferenciar este caso de una pulmonía verdadera, fue su persistencia anormal por completo. Durante quince días, desde el 31 de Diciembre al 14 de Enero de 1890, conservó la expectoración los mismos caracteres ; sólo que su color de rojo obscuro que era al principio, pasó por todos los tintes del equimosis desde el amarillo azafranado hasta el verduzco, como cuando un derrame sanguíneo se absorbe poco á poco. Añadid á esto que, durante todo este período no tuvo el enfermo ni disnea verdadera, ni fiebre, que la tos se había hecho blanda y fácil, como en el período de cocción de la bronquitis, y que la auscultación indicaba la desaparición casi completa de los estertores sibilantes. Nada menos parecido á la evolución de una pulmonía fibrinosa.

Tampoco era posible asimilar este caso á las broncopneumonías grippales. Hemos tenido ocasión muchas veces, en la epidemia actual, de observar caracteres especialísimos de esta variedad de pulmonía infecciosa : en nada 
se asemejaron á los síntomas que presentaba nuestro enfermo. Jamás hemos observado en él la expectoración grisácea, purulenta, análoga por completo á la de los tuberculosos llegados al tercer período; ni los estertores mucosos gruesos mezclados al soplo lejano, comparables al gorgoteo, que constituyen los signos de auscultación más comunes de la influenza y asemejaban estas pneumonías á verdaderas bronquitis purulentas. La grippe parecía en este hombre muy benigna; no ocasionaba ni fiebre, ni disnea ; sólo la expectoración sanguinolenta, con sus caracteres de abundancia y persistencia inusitada, difería de lo que observábamos en los demás pnenmónicos de la sala.

Pero á pesar de la poca intensidad de la bronquitis, el estado general de este hombre era mediano, se sentía débil, sin apetito, cansado y seguía enflaqueciendo. Digería mal, y una diarrea rebelde atestiguaba la persistencia de los fenómenos infecciosos.

El 20 de Enero, á la visita de la mañana, se quejaba de vago malestar y de náuseas, pero sin dolor en parte alguna : la respiración era buena y la fiebre lenta. Pasó bien el día, sin accidente, y durmió con toda tranquilidad. Se despertó de repente por la noche con una sensación de angustia ; arrojó por la boca una cantidad grande de sangre y murió en pocos segundos.

Este desenlace imprevisto aclaró la situación y probó que el diagnóstico hecho en vida había sido incompleto. Sólo un aneurisma podía ocasionar una hemoptisis tan considerable, porque en el medio minuto que tardó en morir el enfermo, arrojó más de dos litros de sangre arterial.

La autopsia demostró, en efecto, que había un aneurisma de la aorta, localizado precisamente en el único sitio donde podía desarrollarse sin producir ningún síntoma, 
es decir, en su porción torácica descendente, entre la inserción del bronquio y la región diafragmática.

Es fácil comprender que los aneurismas localizados así son de todas las ectasias aórticas las que pasan más á menudo inadvertidas. Un aneurisma de la porción ascendente $\delta$ transversal del cayado produce siempre fenómenos de compresión visceral y se manifiesta por signos estetoscópicos por lo común palpables: los de la aorta descendente, aunque difíciles de descubrir, tienen también su sintomatología característica, porque comprimen el hilio del pulmón y van acompañados muchas veces de huélfago y de soplos cavernosos, que simulan la tuberculosis pulmonar. Hace pocas semanas tuve ocasión de analizar en vuestra presencia un caso de este género. Por último, los que ocupan la región correspondiente del orificio diafragmático tienen, á pesar de estar profundamente situados una fisonomía notable, que hace su diagnóstico relativamente fácil : provocan crisis gastrálgicas en extremo dolorosas, vómitos é irradiaciones testiculares.

Por el contrario, en la porción de su trayecto intermediaria entre el bronquio izquierdo y el diafragma, la aorta no está en relación con órgano importante alguno; se extiende á lo largo de los cuerpos vertebrales y no se halla en contacto más que con el esófago y el pulmón; este contacto es además mediato, porque el tejido celular del mediastino posterior se interpone de modo que fija los órganos, aunque permitiéndoles su locomoción respectiva. Una bolsa aneurismática desarrollada en este punto (caso raro), no encuentra por delante obstáculo alguno, y puede adquirir un volumen relativamente considerable, sin manifestar su presencia por trastornos funcionales sensibles. El esófago se libra de la compresión formando una curva lateral, de modo que la disfagia es nula ; el pulmón es rechazado poco á poco hacia adelante, sin que se tras- 
tornen gran cosa las funciones respiratorias, y sólo después de mucho tiempo se observan síntomas de la disminución gradual del campo respiratorio. La pieza anatómica que os presento, demuestra con toda exactitud lo que acabo de indicar.

En este caso, las lesiones realmente son grandísimas, y cuesta trabajo comprender á primera vista cómo se han desconocido trastornos tan considerables. La bolsa aneurismática mide 13 centímetros de diámetro vertical y 6 á 7 en sus dimensiones antero-posteriores; es decir, que es casi tan voluminosa como la cabeza de un feto de término. Corresponde á las seis últimas vértebras dorsales, á las que está íntimamente adherida con fuerza por tractus sólidos, y se extiende por ambos lados, casi por igual, hasta los anales costo-vertebrales. El esófago se halla desviado á la izquierda y relativamente poco comprimido.

Las paredes del saco aneurismático son muy desiguales, delgadas y elásticas en unos puntos ; gruesas, rigidas é incrustadas de concresiones calcáreas en otros; pero son en todas partes muy resistentes y no presentan solución alguna de continuidad aparente.

Abriendo el saco por uno de sus lados, se observa que está casi lleno de coágulos cruóricos negruzcos y recientes; la pared anterior es la única que se halla tapizada de una capa de estratificaciones fibrinosas de 2 centímetros de espesor.

Los orificios de comunicación del saco aneurismático con el resto de la aorta están dispuestos de distinta manera, según que se examine el superior ó el inferior. Por arriba, el saco no se continúa directamente con la porción descendente del cayado de la aorta, como podría suponerse a priori; los separa una especie de espolón valvular de 2 á 3 centímetros de altura, resistente y rígido, que forma un semi-tabique de dirección transversal. 
Esta disposición debía dificultar en cierto modo el curso de la sangre, y amortiguar algo el choque de la onda sanguínea á su llegada á la bolsa aneurismática. Por encima de esta especie de válvula, y casi á la altura del bronquio izquierdo, se halla muy estrechado el calibre de la aorta, hasta el punto de ser dificil introducir el dedo índice; nuevo obstáculo que encontraría la columna sanguínea antes de penetrar en el aneurisma.

El orificio inferior es mucho más simple : no presenta ni estrechez ni onda valvular, se abre directamente en la. parte inferior $y$ posterior del saco aneurismático, $y$ se continúa sin cambio de calibre con la aorta diafragmática y abdominal.

Esta dilatación aórtica, enorme, se efectúa á expensas de la pared anterior del vaso : por detrás, el aneurisma, colocado en contacto con la vértebra, no ha podido desarrollarse; pero los movimientos de expansión del saco han producido una doble consecuencia : desgastar á la larga la pared de la arteria y destruir el tejido óseo vertebral.

El cuerpo óseo denudado de las vértebras forma la pared posterior de la bolsa aneurismática : el saco no existe por detrás, y la sangre baña con toda libertad la substancia ósea. Las cinco últimas vértebras dorsales están desgastadas por completo $\mathrm{y}$ ahuecadas de modo que forman una concavidad anterior: las aponeurosis y los ligamentos prevertebrales han desaparecido; sólo subsisten los discos intervertebrales, pero desgastados en parte y desprendidos casi en la mitad de sus inserciones. Un grado más de esta lesión, y la sangre hubiera penetrado en la cavidad raquidiana.

Conviene advertir que las vértebras dorsales están mucho más desgastadas en su cara lateral derecha que en la izquierda, á pesar de las relaciones normales más inme- 
diatas de la aorta en este lado. Esto explica, sin duda, por qué la neuralgia intercostal de que se quejó tanto tiempo el enfermo fue siempre derecha; dependía de la irritación del sexto, séptimo y octavo par dorsal, porque en este sitio llegaban al máximum las lesiones óseas.

Estudiemos ahora las relaciones del aneurisma con los órganos inmediatos y el mecanismo de la hemoptisis terminal.

La pared anterior corresponde al mediastino posterior, cuyo tejido celular se halla condensado y ha adquirido la textura fibrosa. Es la parte más resistente de la bolsa aneurismática, está íntimamente adherida á la atmósfera celulosa adyacente, y no presenta fisura ni pérdida alguna de substancia susceptible de haber dado salida á la sangre.

Por sus caras laterales, el saco aneurismático está en contacto con la interna de los pulmones, y las lesiones difieren de un modo notable en ambos lados. A la derecha, la pared es resistente, gruesa, y en su interior hay una serie de capas de coágulos fibrinosos estratificados. El pulmón correspondiente, defendido contra la invasión de la sangre, está sano, muy poco congestionado, y no presenta lesiones de atelectasia.

A la izquierda, la situación varía por completo. La pared aórtica no existe, por decirlo así : es una especie de membrana delgada, que no tiene en ciertos puntos un milímetro de espesor, y que ha perdido su elasticidad. Incompletamente protegida por detrás por los exudados fibrinosos, mezclados con coágulos recientes, se halla en contacto inmediato con el pulmón por su parte anterior, y los dos están adheridos de modo tan íntimo, que es preciso, para separarlos, un disección cuidadosa. Puede decirse que, en este sitio, la pared del aneurisma la forma el tejido pulmonar.

Esta condición anormal modifica de una manera notaClínica médica, - Tomo I. 
ble la estructura del pulmón. El parénquima pulmonar presenta induración crónica y una alteración intermedia entre la esclerosis fibrosa verdadera y la atelectasia. Al corte aparece carnificado é infiltrado de sangre en su totalidad. Esta infiltración no es debida á una desgarradura brusca y reciente, sino que se ha producido, al parecer, con lentitud; ha habido repleción completa de los alvéolos por la sangre, con induración previa de su tejido, lesión muy parecida á la apoplegía pulmonar. Pero no es una simple sufusión hemorrágica producida en un pulmón sano: el parénquima pulmonar está indudablemente inflamado desde mucho tiempo antes. Esta lesión interesa todo el lóbulo inferior y parte del medio : por abajo es sustituída por hepatización verdadera, idéntica á la de la pulmonía franca.

Otra prueba de la antigüedad de las lesiones irritativas del pulmón es el estado de la pleura, que se halla en toda su extensión engrosada, indurada é íntimamente adherida al tejido pulmonar. En la bifurcación de la tráquea se ven también ganglios hipertrofiados, endurecidos y negruzcos, que indican el carácter crónico de la pulmonía, producida por el aneurisma.

Esta lesión compleja del pulmón, apopléctica é inflamatoria á la vez, explica los caracteres singulares de los'esputos durante la vida del enfermo.

La persistencia de los esputos herrumbrosos, equimóticos, fue debida á la infiltración sanguínea del lóbulo pulmonar y la falta de fenómenos febriles demostraba que no se trataba de una pulmonía ordinaria. Es indudable que se produjo una primer exudación sanguínea del aneurisma en el seno del parénquima pulmonar, que originó la infiltración intersticial sin ocasionar una hemorragia abundante.

¿Cómo se produjo la hemoptisis enorme que ahogó al 
enfermo en pocos segundos? El estudio detenido de las lesiones permite explicar el mecanismo. Es indudable, al parecer, que no hubo rotura directa del saco aneurismático; la fisura se formó, evidentemente, en el pulmón izquierdo. El parénquima cedió por el sitio donde se había producido ya la primer hemorragia intersticial, en el punto que oponía menos resistencia á la presión sanguínea. Pero á pesar del examen más minucioso, fue imposible descubrir la menor solución de continuidad de la pared aneurismática. La rotura se hizo por el intermedio del tejido pulmonar hepatizado é infiltrado. Es probable que ocurriera cerca de un bronquio grueso, porque al disecarlos los hemos encontrado llenos de sangre, y uno de ellos se continuaba, al parecer, con un seno pequeño lleno de coágulos recientes; es posible, por lo tanto, que la hemorragia principiara en una gran extensión del parénquima pulmonar y que se abriera después paso por los bronquios.

Cualquiera que haya sido el mecanismo de la hemorragia, es indudable que se produjo con mucha rapidez y con gran fuerza, como lo prueba la abundancia de la sangre arrojada en pocos segundos. La muerte fue, por decirlo así, instantánea, á causa de la asfixia debida á la penetración de la sangre en las vías respiratorias. Sabéis que para producir este resultado no se necesita una hemorragia considerable; se ven morir algunos tísicos con aneurisma de la aorta pulmonar, después de haber arrojado una cantidad insignificante de sangre.

Para terminar la relación de esta autopsia, me queda que decir algunas palabras respecto al estado de los otros órganos.

Al contrario de lo que podría suponerse, el corazón, del que padecía constantemente el enfermo desde tres años antes, no estaba aumentado de volumen, sino que sus dimensiones eran más bien inferiores á las normales. Las 
válvulas se hallaban sanas, el ventrículo no hipertrofiado. izquierdo y sin dilatar las aurículas. Sólo se descubrieron lesiones insignificantes en todo el trayecto de la aorta; excepto algunas placas amarillentas de ateroma diseminadas, sin induración ni incrustación calcárea, estaba sana en toda su extensión, lo mismo por arriba que por abajo de la bolsa aneurismática. No se encontró alteración alguna en el hígado, el bazo y los riñones.

Insistiré sobre algunas particularidades clínicas de este caso, convencido de que un error de diagnóstico de este género es la mejor de las enseñanzas.

Una lesión enorme, un saco aneurismático del tamaño de una cabeza de feto de término, escapa á la investigación más minuciosa, y esto no una vez sino tres en el espacio de dieciocho meses, aunque parece elemental haber observado de la manera más exacta los progresos de la enfermedad.

$¿$ Hubiera podido evitarse el error y había indicios suficientes para sospechar el diagnóstico verdadero?

Conviene advertir que los signos funcionales que presentaba este hombre, eran los de una afección cardíaca, porque al auscultar sólo se notaban lesiones de enfisema. He insistido ya sobre el carácter especial de la disnea intermitente, aumentada por los esfuerzos y sobre las palpitaciones excesivas que se presentaban al ejecutar un movimiento brusco. Esto, unido á la integridad absoluta de los ruidos del corazón y á la falta de hipertrofia cardíaca, hubiera debido hacernos sospechar que existía alguna lesión en el trayecto de la aorta, porque, por grande que sea la dificultad respiratoria de los enfisematosos, nunca cesa de repente bajo la influencia del reposo, y los enfermos son siempre incapaces de acostarse con la cabeza baja; en este, caso era fácil el decúbito horizontal. Además, cuando no hay lesiones valvulares 6 miocárdicas confirmadas, el en- 
fisema no produce palpitaciones tan fuertes como las que eran el síntoma predominante en nuestro enfermo.

Con la noción del aneurisma, los trastornos funcionales se interpretaban y encadenaban de la manera más lógica.

La poca expansión de los movimientos respiratorios, en este enfermo, se explican por el volumen del tumor aneurismático, que ocupaba la quinta parte de la cavidad torácica y rechazaba á los lados los pulmones.

El aumento de la disnea en el momento de la marcha y bajo la influencia de los esfuerzos, era consecuencia natural de la interposición del saco aneurismático en el trayecto de la aorta. Marey ha demostrado que esto aumenta siempre la tensión de la columna sanguínea por encima de la ampolla aneurismática; $y$, por otra parte, el exceso mismo de esta tensión y el aumento mismo de los latidos cardíacos, hacen más voluminosos el saco del aneurisma y exageran su distensión. En igualdad de proporciones, sucede en este caso algo parecido á lo que acontece cuando se comprime con demasiada rapidez y energía la bolsa de goma de un pulverizador de Richardson; la ampolla que sirve de recipiente al aire, y que en la especie representa el saco aneurismático, se distiende á cada golpe de pistón, porque la entrada del aire es superior á la velocidad de su salida. Cuando el enfermo, por una causa ó por otra, aceleraba los latidos del corazón, hacía penetrar en el saco aórtico una cantidad de sangre exagerada en relación á la que salía en el mismo tiempo. Quizá intervenía en este mecanismo la disposición del orificio superior del aneurisma que he descrito en detalle.

Esta especie de espolón, que formaba una brida en la parte superior de la bolsa aórtica, debía, probablemente, contribuir á estrechar el calibre de la arteria y á aumentar la tensión sanguínea en el interior del aneurisma; la 
consecuencia era, según toda probabilidad, un aumento. de volumen de la bolsa, y por consiguiente disnea.

El mismo mecanismo explica la violencia singular de las palpitaciones cardíacas que había llamado mi atención, y la de mi colega el Dr. Rigal, siempre que se auscultaba al enfermo. La energía de las contracciones ventriculares era debida á la existencia del obstáculo, y aunque en los períodos de calma circulatoria latía el corazón de una manera normal, se veía, por el contrario, obligado á funcionar de un modo exagerado en cuanto cesaba el reposo. completo del enfermo.

Con seguridad que si la exageración en las contracciones cardíacas bastara para producir la hipertrofia ventricular, hubiésemos encontrado al hacer la autopsia de este enfermo un ventrículo izquierdo enorme. $\mathrm{Y}$ sin embargo, recordaréis que las dimensiones del órgano eran más bien inferiores al término medio. Llamo vuestra atención sobre este resultado de la autopsia que se halla en contradicción absoluta con los datos deducidos por el razonamiento y la experimentación fisiológica. No ignoráis, en efecto, que Marey, en sus célebres experimentos sobre la circulación cardio-arterial, ha erigido, como ley absoluta, la doctrina de la hipertrofia cardíaca proporcionada á la resistencia de la arteria; y que, además, ha demostrado por medio de su aparato esquemático la realidad del aumento de la tensión sanguínea por encima de las bolsas aneurismáticas. Es la mejor prueba que puedo daros de la superioridad de la observación sobre el razonamiento de los fisiólogos; porque mucho antes que Marey, un médico que no hizo experimentos, pero que había analizado de un modo maravilloso todo cuanto se relaciona con las enfermedades del corazón, Stokes, observó que la existencia de un aneurisma no produce siempre la hipertrofia ventricular. « Una bolsa aneurismática, por voluminosa que sea, influye muy 
poco sobre el desarrollo ulterior de la hipertrofia del corazón ». Para que se produzca, se necesitan condiciones morbosas que modifican la circulación intersticial y la nutrición íntima de la fibra cardíaca ; siempre que coincide el aneurisma con hipertrofia ventricular, puede afirmarse que hay á la vez endoarteritis y esclerosis de este órgano.

Creo que se deducen de este hecho clínico otras consideraciones interesantes desde el punto de vista de la sintomatología de los aneurismas torácicos.

¿No es notable que se destruyeran casi por completo cinco cuerpos vertebrales sin dolor, por decirlo así, y sin más trastorno funcional que una neuralgia intercostal?

Esta falta del dolor, aunque observada en ciertos enfermos, no es, debo decirlo, un fenómeno constante. Hay casos en los que los pacientes sienten un dolor fijo, terebrante en la profundidad del pecho, con sensación de peso ó de constricción torácica. Algunas veces se hacen tan intolerables estas sensaciones, que producen actitudes especiales ; ciertos individuos descansan sólo sentados ó acostados sobre el vientre, $\delta$ mejor todavía, con el pecho encorvado hacia adelante, para disminuir el peso que los oprime. Recuerdo haber visto en 1868 en el hospital de San Antonio, clínica del Dr. Axenfeld, un pobre enfermo que permaneció así varias semanas sentado en una silla, con la cabeza apoyada sobre el lecho, presa de sofocaciones en cuanto variaba de posición. Sin embargo, debo manifestar que estos casos de dolor aneurismático excesivo no corresponden por necesidad al desgaste de los cuerpos vertebrales, y cuando se descubre esta lesión al hacer la autopsia, no es posible afirmar que haya sido origen de los dolores que sentía el enfermo. En nuestro caso, con seguridad, el tejido óseo y los ligamentos prevertebrales se destruyeron en silencio; la compresión de los nervios intercostales fue la única que debió ocasionar los síntomas. 
No necesito manifestaros que este desgaste progresivo de las vértebras no va acompañado de supuración alguna ; la osteítis rarificante que se produce en tales casos, jamás se complica con accidentes de este género, lo que se comprende porque la bolsa no comunica con el aire ni contiene micro-organismos piógenos. Notad de paso que el tejido óseo, á pesar de ser más duro y consistente, es atacado con más facilidad que el fibroso; los discos intervertebrales han resistido allí donde están destruídas las vértebras en sus tres cuartas partes.

Voy á ocuparme de un síntoma, del que hablé al principio y que contribuyó á inducirme al error ; me refiero á la retracción de la pared torácica en el sitio correspondiente al aneurisma. Recordaréis que el enfermo tenía, en el lado izquierdo y por detrás, hundido el pecho en tres sitios, lo mismo que se observa después de una pleuresía crónica $\delta$ de un enfisema. Es un signo interesante observado en Inglaterra por Mayne y sobre el que insistió con razón Stokes; se halla, al parecer, en relación con el estado atelectásico del pulmón en la proximidad de la bolsa aneurismática, $\mathrm{y}$ con las adherencias pleuríticas que existen siempre en la atmósfera celulosa del aneurisma. Este aplastamiento del pecho, cuando coincide como en nuestro enfermo, con los síntomas del enfisema, debe hacer sospechar al clínico ; pero conviene decir que no es un signo bastante demostrativo para tener importancia verdadera. Son tantas las causas que contribuyen desde la infancia á deprimir la pared torácica (bronco-pneumonías, esclerosis pulmonares, pleuresías adhesivas, etc.), que á falta de datos precisos sobre los antecedentes patológicos de los enfermos, no es posible atribuir á este signo valor patognomónico.

El examen del sistema arterial ¿ pudo suministrar algunos datos diagnósticos más claros? La exploración de las 
dos radiales nada enseñó, lo que no debe sorprender porque la lesión aneurismática estaba situada más allá de su origen. No se exploraron, por desgracia, las femorales. Es posible, y hasta probable, que se hubiera notado retraso significativo de la pulsación arterial con relación al pulso radial, pero este descubrimiento es siempre delicado y exige, para ser demostrativo, el empleo de aparatos registradores.

Insisto en la falta absoluta de signos estetoscópicos del aneurisma durante la vida del enfermo. Este silencio de la auscultación se explica por el sitio de la bolsa aneuris. mática que, situada á bastante profundidad en el trayecto de la aorta descendente, era poco accesible á los medios de investigación : se explica también por el volumen y las dimensiones del saco del aneurisma. Puede, en efecto, sentarse como principio, que cuanto más gruesa es la ampolla aórtica, menos ruidos morbosos típicos produce : se comporta á la manera de los aneurismas difusos que no se manifiestan por soplo alguno perceptible. Los soplos se producen en los sitios donde está estrechado el calibre de la aorta 6 en las asperezas de la endarteritis. En este caso había estrechez aórtica por encima del orificio superior del aneurisma, pero, según toda probabilidad, las condiciones de la onda sanguínea que la atravesaba eran especiales, porque jamás observamos soplo vascular.

No insisto sobre el carácter hemático de la expectoración del enfermo que se asemejaba á la de una pulmonía, pero con diferencias notables. Sólo voy á hacer resaltar su valor pronóstico. Esta expectoración significaba, en efecto, que el límite de la tolerancia respectiva del pulmón y del aneurisma iba á ser pronto vencido, y era el signo revelador de la primer hemorragia á través del parénquima pulmonar. No es raro, como sabéis, ver presentarse hemoptisis parciales en los días y hasta en las semanas que 
preceden á la hemotipsis definitiva. Si hubiéramos diagnosticado de antemano un aneurisma, esta expectoración equimótica nos hubiera hecho temer la inminencia de una rotura probable. Pero la expectoración se presentó en plena epidemia de grippe, cuando la quinta parte de nuestros enfermos padecían bronco-pneumonía y parecía racional, á pesar de sus caracteres especiales, atribuirla á la enfermedad reinante.

Estas consideraciones me obligan á estudiar la influencia de la grippe sobre la evolución de la lesión aneurismática. Creo posible afirmar, sin temor de equivocarme, que la grippe contibuyó bastante á precipitar la marcha de los accidentes. Los esfuerzos de tos repetida, la bronquitis extensa, los fenómenos congestivos pulmonares, contribuyeron, sin duda alguna, á limitar el campo respiratorio y á exagerar sobre manera el trabajo del corazón. Estos fenómenos aumentaron de un modo permanente la tensión del aneurisma, y produjeron, probablemente, un estiramiento continuo de las adherencias que unímn el pulmón con la bolsa sanguínea. El desenlace era de todos modos inevitable, pero lo aceleró la grippe intercurrente. Hemos observado muchas veces este fenómeno durante la epidemia última en todos los enfermos de afecciones cardíacas ó pulmonares crónicas ; la invasión de la bronquitis infecciosa agravaba al momento su estado y producía en pocos días accidentes asistólicos $\delta$ asfíxicos. 


\section{ANEURISMA DE LA AORTA ABDUMINAL}

Sumario: Observación de un caso complejo de aneurisma de la aorta abdominal, complicado con insuficiencia aórtica y un derrame pleurítico izquierdo. - Etapas diversas del aneurisma : persistencia de un dolor sordo lumbar, con crisis neurálgicas accesionales.-Desarrollo brusco de un aneurisma falso á consecuencia de un traumatismo. - Descripción del tumor aneurismático sub-diafragmático. - Dificultades de diagnóstico. - Se consideró al principio como una cirrosis hipertrófica expleno-hepática, como una leucocitemia y como un flemón perinefrítico. - Caracteres fundados en los latidos expansivos del tumor y posibilidad de confundirlos con los latidos transmitidos á las pulsaciones de los tumores telangiectásicos. - Consecuencias del aneurisma relativamente al estado de la pleura. - Relaciones con la afección cardiaca : modificaciones de la insuficiencia aórtica debidas al aneurisma. Consecuencia respecto á la circulación periférica. - Pronóstico y tratamiento.

La conferencia anterior la dediqué á éstudiar un caso de aneurisma de la aorta torácica descendente, que quedó latente hasta el momento de su rotura, é indiqué las grandísimas dificultades clínicas del diagnóstico en tales casos. Hoy se presenta ocasión de completar esta serie de estudios sobre las enfermedades aórticas, y voy á ocuparme de un aneurisma de la aorta abdominal.

Pablo G., de cuarenta y seis años, que ocupa el número 4 de la sala Chauffard, ingresó hace sólo dos días en el hospital Necker. Este hombre, de bastante inteligencia, no pertenece á la categoría ordinaria de los enfermos que acuden á los hospitales; ha ejercido una profesión liberal, y por reveses de fortuna se vió obligadoá dedicarse á corredor de vinos. Ha disfrutado hasta ahora buena salud y carece de herencias morbosas importantes; no es reumático ni sifilítico, ni ha padecido enfermedades generales infec- 
ciosas, causa frecuente de las lesiones arteriales. No es, al parecer, alcohólico, aunque por su oficio tiene que probar á menudo las bebidas alcohólicas, al menos no presenta síntoma funcional alguno del alcoholismo. Pero encontramos en su familia antecedentes patológicos que explican, quizá, una predisposición á las enfermedades cardio-aórticas; su madre murió de una enfermedad del corazón y su padre de hemorragia cerebral.

El principio de las molestias precursoras de su enfermedad actual se remonta á 1887. Era por esta época aficionadísimo á los ejercicios corporales y en particular á la equitación; había observado que siempre que montaba bastante á caballo, sentía un dolor sordo en la región lumbar. Tuvo que suspender la equitación; los síntomas dolorosos se mitigaron, pero no desaparecieron; los despertaban la marcha, la carrera, los esfuerzos violentos; el reposo los calmaba por completo.

El dolor era sordo, fijo y contuso; estaba localizado á bastante profundidad en la parte inferior del dorso, y jamás sintió el enfermo punzadas ó latidos. Se exacerbaba de cuando en cuando, y producía crisis punzantes que irradiaban al abdomen y le obligaban á permanecer en reposo algunos días. En los intervalos de estos accesos, muy raros, el estado general era bueno.

Este estado duró dos años sin obligar al enfermo á abandonar sus ocupaciones activas; pero observó que se fatigaba con la mayor facilidad, que el ahogo se presentaba rápidaménte y que no podía hacer esfuerzos sostenidos ni andar sin que se presentaran los dolores lumbares.

Hace cuatro meses, un traumatismo accidental agravó de repente su situación. Cayó por una escalera y sufrió una contusión grave en la región lumbar. El golpe y el dolor fueron bastante fuertes para ocasionar la pérdida del conocimiento; se formó casi instantáneamente una 
equimosis enorme, y á los dos días se descubrió fractura de las costillas que tardó tres semanas en curar.

$\mathrm{El}$ estado del enfermo cambió por completo desde este momento. El dolor lumbar se hizo mucho más agudo y permanente y mayor en el flanco derecho. La marcha era penosa y casi imposible. Apenas andaba unos cuantos pasos se veía obligado á detenerse de pronto, no por fatiga muscular y entumecimiento de los miembros, sino por exceso del dolor dorsal, éste se mitigaba después de algunos instantes de reposo y era posible la marcha ; pero los accidentes se repetían tantas veces cuantas renovaba la tentativa. En una palabra, había una verdadera claudicación intermitente relacionada con la aparición del dolor abdomino-lumbar. El enfermo se vió obligado á suspender toda ocupación activa.

Llegamos al último episodio de la enfermedad que pre. cedió quince días al ingreso de este hombre en nuestra clínica.

El 19 de Enero último le fue preciso hacer una caminata algo larga por negocios urgentes, sintió dolores más fuertes que de costumbre, tuvo que regresar á su casa en carruaje y meterse en cama en cuanto llegó. La noche fue mala, pero tolerable el día siguiente. Se quedó en su habitación y guardó el reposo más absoluto. Al medio día, sin causa conocida, sin haber hecho esfuerzo ni movimiento exagerado, se presentó de nuevo la crisis más fuerte que nunca. Sintió en el flanco izquierdo un dolor repentino, atroz, que comparó á un garfio de hierro que le arrancaba las entrañas. A los pocos segundos la sensación de desgarro, localizada primero en la región infra-diafragmá. tica, se propagó al flanco izquierdo, luègo á la fosa ilíaca, á la ingle, á la raiz del muslo, y por último al testículo, haciendo sufrir al enfermo de una manera espantosa. Tuvo un síncope. Cuando recobró el conocimiento, estaba páli- 
do, cubierto de sudor, tenía náuseas y vértigos, y sobre todo un estado absoluto de impotencia de los miembros inferiones. Las dos piernas estaban como paralizadas, y eran incapaces del menor movimiento. El entumecimiento duró varios días, concluyó al fin por desaparecer, pero la marcha fue incompleta, vacilante $y$ dolorosa. En tales condiciones, se presentó este hombre á la consulta el lunes último, 10 de Febrero.

Recordaréis su actitud general y su aspecto característico. Pálido, el dorso inclinado, apoyándose con trabajo sobre un bastón, tenía el modo de andar de un paraplégico y parecía un individuo afectado de mielitis crónica. Sentía á la vez anhelación y dificultad respiratoria. Su color era amarillo terroso como el de los caquécticos, pero sin el tinte cetrino de las conjuntivas de los ictéricos verdaderos.

La disnea era un síntoma tan predominante, que indicaba al parecer, á primera vista, una afección torácica.

El examen del pecho demostró, en efecto, deformaciones torácicas de varias clases. El enfermo habrá sido probablemente raquítico en su infancia, á juzgar por la combadura del esternón y la proyección desigual de las costillas ; éstas son aplanadas á la derecha y angulosas á la izquierda. Además de esta deformación antigua había otra reciente; una combadura notable de la mitad inferior izquierda del tórax que quedaba casi inmóvil durante los movimientos respiratorios. Toda la región infra-diafragmática estaba más ensanchada y saliente, sobre todo, hacia el hipocondrio izquierdo. Este aspecto recordaba á primera vista la deformación producida por el hígado y el bazo aumentados de volumen en la cirrosis hipertrófica.

Era fácil observar la existencia de un derrame en la cavidad pleurítica izquierda. Toda la región correspondiente á la combadura torácica daba un sonido macizo al 
percutir y no vibraba cuando se hacía hablar al enfermo. El murmullo vesicular era débil y estaba sustituído por un soplo lejano; la voz resonaba con un timbre egofónico. Era indudable, por lo tanto, la presencia de líquido ; hasta podía afirmarse que existía en bastante abụndancia, porque el corazón se hallaba dislocado y su punta latía por dentro del pezón, cerca del esternón. Estos signos físicos contrastaban con la falta total de trastornos funcionales. El enfermo jamás había padecido dolor en el pecho ; no tosía y adoptaba con la misma facilidad cualquier decúbito; el único indicio del derrame de la pleura era la poca expansión respiratoria, sobre todo, cuando pretendía hacer algún esfuerzo.

Señalemos un signo que no es propio de las pleuresías con derrame y que era bastante acentuado en este enfermo. Comprimiendo los espacios intercostales en la región dorsal inferior correspondiente al derrame, se despertaba una sensibilidad muy viva, desproporcionada al carácter indolente de los movimientos respiratorios. Esta anomalía se explicaba mal á primera vista, y más adelante tendré ocasión de insistir sobre ella.

El corazón presentaba lesiones innegables. Aunque el enfermo no había tenido ni palpitaciones ni trastornos funcionales, el órgano se hallaba aumentado de volumen; su punta latía en el sexto espacio intercostal y elevaba la pared torácica con un choque brusco. $\mathrm{Al}$ auscultar se oía un soplo diastólico y predominante en la base, en el tercer espacio derecho y que tenía todos los caracteres del de la insuficiencia aórtica; era suave, aspirador, principiaba de repente en el momento del segundo ruido del corazón y disminuía durante el silencio mayor. La lesión de las válvulas sigmoideas era, por consiguiente, indudable; pero no ocasionaba, cosa curiosa, trastornos funcionales como los que existen de ordinario en los casos de dicha insuficien- 
cia. El pulso era pequeño, débil, regular, sin desigualdad de tensión y $\sin$ ser rebotante, y el enfermo no tenía ni vértigos, ni desvanecimientos, ni fenómenos de anemia cerebral, á pesar de su palidez ; todo se reducía á la comprobación fisica en la alteración valvular sin otro síntoma. Llamaba la atención, además, que pareciera sano el cayado aórtico, no obstante la lesión sigmoidea; no se oía en su trayecto ni soplo, ni acentuación anormal en los ruidos cardíacos ; se le sentía latir en el fondo de la horquilla del esternón y las arterias subclavias no eran perceptibles por encima de las clavículas, como en los casos de ectasia aórtica confirmada. Faltaban por completo los latidos de las carótidas y la dilatación sistólica de los vasos del cuello; era lógico, por lo tanto, suponer que la aorta torácica, al menos en su porción ascendente y transversal, conservaba su volumen y calibre normales.

En resumen, el examen del aparato torácico indicaba un derrame pleurítico izquierdo de mediana abundancia y una hipertrofia notable del corazón que coincidía con insuficiencia aórtica; los pulmones estaban, al parecer, sanos. por completo.

Prosigamos el examen de las otras vísceras; existen en ellas lesiones complejas.

Os he señalado la combadura infra-diafragmática, que producía un ensanche tan característico de la mitad superior del abdomen. El aspecto, á primera vista, era idéntico al que presentan los enfermos que padecen cirrosis hipertrófica y llamaba desde luego la atención sobre el estado del hígado y del bazo.

El hígado era voluminoso y ocupaba la mayor parte del hipocondrio derecho ; descendía casi tres traveses de dedo más abajo de las costillas y medía 16 centímetros de macicez vertical en la línea mamilar. Su superficie era desigual, dura y abolsada ; el borde anterior parecía romo é 
irregular; en una palabra, daba la sensación de un hígado afectado de esclerosis con retracción fibrosa. La palpación era poco dolorosa, pero comprimiendo con fuerza se despertaba cierto grado de sensibilidad.

La región esplénica estaba todavía más deformada y la combadura del hipocondrio izquierdo era mayor que el del derecho; pero este aspecto no dependía sólo de la hipertrofia del bazo. Es verdad que se palpaba bien este órgano que se continuaba, al parecer, con el borde cortante del hígado y que llegaba más allá de las costillas ; pero era fácil observar que no ocupaba él sólo toda la región infra-diafragmática. El bazo no tenía un gran volumen; era móvil y accesible con facilidad, porque lo rechazaba hacia el abdomen la colección líquida de la pleura y se apoyaba por detrás sobre una masa que le servía de plano resistente.

Esta especie de tumor difuso constituía el hecho más interesante de la historia patológica de nuestro enfermo. Se notaba, en efecto, un abultamiento considerable en toda la región lumbar que se extendía más allá del hipocondrio izquierdo. Rechazaba hacia arriba el diafragma y se prolongaba por debajo hasta cerca de la espina ilíaca anterior superior. Sus límites eran indecisos y su circunscripción imperfecta. Al percutir, se notaba en toda su extensión submacicez que se convertía en macicez verdadera en la región lumbar; hacia los límites inferiores de la tumefacción había sonoridad intestinal, pero atenuada, y con tono menos claro que en el lado derecho.

La palpación suministraba datos más precisos. La sensación que daba el tumor no era igual en todos sus puntos. Consistía en una especie de renitencia profunda y difusa que comunicaba la impresión de una bolsa tensa llena á la vez de masas sólidas y de partes líquidas; en ciertos puntos se palpaban verdaderos núcleos duros, en otros Clínica médica. - Tomo I. 
era apreciable la fluctuación; aplicando una mano sobre el riñón izquierdo, y otra sobre el borde inferior del bazo se enviaba una onda líquida indudable. Esta exploración era indolente y sólo despertaba sensibilidad en la parte posterior.

Al examinar con detenimiento la región enferma, se descubrió un signo inesperado y decisivo á la vez. Palpando el tumor, de delante á atrás, se sentían con toda claridad movimientos de elevación rítmicos, expansivos, que distendían ó deprimían alternativamente la pared del abdomen. Estos movimientos correspondían á latidos profundos localizados en el tumor, porque daban la sensación de una ampliación general que se efectuaba en todos sentidos y no de pulsaciones comunicadas. Palpando el hígado, se apreciaba la diferencia de estas dos impresiones; este órgano, que recibía el impulso del tumor pulsátil subyacente se elevaba de pronto y la mano que le exploraba sentía un choque típico, sin movimiento expansivo; la región espleno-lumbar se distendía, por el contrario, á cada sístole ventricular, y el aumento de volumen que resultaba era visible examinando en dirección oblícua la pared del abdomen.

Este signo es casi patognomónico é imponía desde luego la convicción de un aneurisma de la aorta abdominal. Era, en efecto, la hipótesis que estaba más de acuerdo con los síntomas funcionales y podía reconstituirse con este dato toda la historia patológica del enfermo desde el principio del padecimiento.

La lesión aórtica era indudablemente antigua y, como siempre, se desconoció en sus primeras fases. Los dolores sordos dorso-lumbares que sentía el enfermo desde dos años antes, las crisis de neuralgia profunda que sobrevenían de cuando en cuando al andar ó hacer un esfuerzo, eran indicio de la dilatación vascular y de los progresos 
lentos, pero contínuos del aneurisma. En esta fecha no hubo trastornos generales, ni desórdenes de la circulación local.

La ectasia aórtica se hizo mayor y se formó el aneurisma. En este período se hicieron permanentes los dolores $y$ las crisis accesionales aumentaron de frecuencia y de intensidad. Entonces se presentó un síntoma nuevo que, cuando es típico, tiene un valor casi patognomónico, aludo á la claudicación intermitente. El enfermo refiere, en efecto, que en esta fase de su padecimiento andaba algunos pasos bien, después se presentaban de repente dolores accesionales que iban acompañados de impotencia funcional relativa ; le era preciso entonces detenerse, y á los pocos minutos desaparecían todos los trastornos funcionales.

El traumatismo marca una etapa nueva en la evolución del padecimiento aórtico. Hasta entonces los síntomas observados eran los de una dilatación vascular sin rotura parietal. Desde que sufrió el enfermo la contusión lumbar, puede afirmarse que los límites primitivos del aneurisma aumentaron de repente. Las crisis de dolores atroces que se presentaron algunos días después, fueron debidas á una rotura arterial que produjo en pocas horas un aneurisma falso consecutivo. La sensación de desgarradura que sufrió este hombre, la irradiación casi instantánea de los dolo. res á la ingle y al testículo, indican el derrame de la sangre que después de desprender el tejido conjuntivo periférico se infiltró á lo largo del psoas hasta el arco crural.

Por último, lo que completa el cuadro es la concomitancia de los signos que anuncian las grandes hemorragias viscerales. $\mathrm{El}$ enfermo, al adquirir su máximum de intensidad los dolores, estaba pálido, bañado en sudor, anheloso y desfallecido, casi con síncope y con pulso filiforme. Una crisis dolorosa, por violenta que sea, produce pocas veces síntomas tan graves. 
Podemos afirmar que nuestro enfermo tiene una bolsa: sanguínea voluminosa, que ocupa toda la región lumboabdominal profunda. Esta bolsa, según toda probabilidad, está llena de una gran cantidad de coágulos blandos cruóricos, que principian á sufrir la transformación fibrosa en ciertos puntos; á esto se debe la impresión que se nota al palpar el tumor: en unos sitios es fluctuante, en otros duros y en todos blando y' renitente. Es probable que principien á organizarse los coágulos, y que por el momento haya un período de calma en la marcha de la lesión aórtica; es, al menos, lo que parece deducirse de la falta. de dolores y de la desaparición actual de las crisis accesionales; en efecto, el enfermo nota sólo tensión sorda, alguna sensación de tirantez en los testículos, y el síntoma predominante es una debilidad excesiva.

La evolución de los accidentes y el análisis de los síntomas presentes, permite afirmar que se trata de un aneurisma de la aorta abdominal complicado con derrame sanguíneo difuso en el flanco izquierdo. El diagnóstico parece, pues, incontestable, y los puntos obscuros que quedan se refieren á la causa primitiva que determinó en este enfermo la aortitis inicial ; porque la influencia del traumatismo, como agente propagador de la lesión primitiva, es indudable.

Pero la idea de un aneurisma no se ha impuesto desde el principio, y los que asistís á la Clínica recordaréis las dudas que tuvieron los primeros observadores que examinaron al enfermo.

Recordad, en efecto, que el médico que nos le recomendó, y que es un buen clínico, creyó que padecía una afección crónica del hígado, probablemente, una cirrosis. Y en efecto, nada tenía de inverosímil esta hipótesis, dado el aumento de volumen del hígado y la combadura infra-diafragmática. La glándula hepática era más 
gruesa y dura que en estado normal ; presentaba desigualdades y abolsamientos análogos á los de la hepatitis intersticial. Era por lo tanto lógico admitir, en vista de estos signos, una esclerosis, y cuando menos afirmar la congestión crónica del hígado, con tanto más motivo, cuanto que el oficio de corredor de vinos que ejerce este hombre hace verosímil la presunción del alcoholismo. La falta de ascitis no basta para desechar la idea de la cirrosis, porque hace pocos días practicamos la autopsia de un individuo que padecía cirrosis atrófica típica, el cual jamás presentó durante su vida el menor indicio de derrame en el peritoneo. La hipótesis de una cirrosis no era por lo tanto infundada, y se comprende que un examen superficial, y sin la noción de un tumor pulsátil del abdomen, haya hecho pensar en ella.

Se pensó también por un momento en la posibilidad de la leucocitemia, á causa de la hipertrofia aparente del hígado y del bazo, en un individuo caquéctico y anémico. Pero esta suposición se desechó en seguida, al reconocer que el bazo no era voluminoso y que la sangre no contenía una proporción de leucocitos superior á la normal. Además, no se podía, racionalmente, atribuir á la leucocitemia, enfermedad indolente y crónica esencialmente, las crisis accesionales y los fenómenos de neuralgia lumboabdominal que habían sido el síntoma predominante de este caso.

Varios de vosotros emitísteis la idea de un abceso perinefrítico, diagnóstico que hizo el interno de la Clínica, después de un reconocimiento muy minucioso.

Debo manifestar que muchos de los signos observados en nuestro enfermo respondían á esta idea y le daban apariencias de realidad. Había, en efecto, tumefacción difusa de la región circunrenal, y, como sucede de ordinario en los flemones subagudos perinefríticos, se sentían en me- 
dio de una renitencia difusa, algunos puntos de fluctuación obscura. Comprimiendo en la región lumbar, cerca del canal vertebral, se despertaba un dolor sordo contuso, bastante análogo al de los abcesos inflamatorios. profundos. Por último, el traumatismo ocurrido dos meses antes, y que debió provocar accidentes, estaba de acuerdo con la idea de un flemón, porque es una etiología frecuente en la historia de las inflamaciones perinefríticas. Hasta las crisis dolorosas sufridas por el enfermo, parecían confirmar el diagnóstico ; porque el carácter agudo de losdolores, sus irradiaciones ilíacas é inguinales, la apirexia, la retracción concomitante del testículo, eran otros tantos. síntomas que hacían pensar en los cólicos calculosos; ahora bien, la litiasis renal origina tan á menudo el abceso perinefrítico, que hacía verosímil el diagnóstico. Podría reconstituirse la historia del enfermo. Era un calculoso que padecía, desde dos años antes, crisis nefríticas obscuras ; éstas se habían exacerbado á causa del traumatismo y se complicaron secundariamente con una inflamación difusa del tejido celular circunrenal.

La objeción más importante á esta hipótesis era la falta de fiebre, que no se observó en período alguno del padecimiento, y que fue nula desde que ingresó el enfermo en la Clínica. Pero conviene saber que las verdaderas flegmasías perinefríticas no van acompañadas siempre de elevación notable de la temperatura, sobre todo cuando siguen una marcha subaguda y tardan mucho tiempo en desarrollarse. He observado en la ciudad un caso de este género, en el que el diagnóstico fue dudoso durante mucho tiempo, á causa de la apirexia. Se trataba de un hombre de cincuenta años, que tenía aplicado un vendaje herniario inguinal, cuyo resorte era duro y había magullado la región lumbar. Durante mucho tiempo sólo sintió el enfermo dolor sordo en los riñones y dificultad para andar y perma- 
necer en pie ; los trastornos funcionales, los dolores y la impotencia se acentuaron después ; se presentó, por último, edema de la región, que fue acompañado de tumefacción profunda, pero sin escalofríos ni fiebre. La punción exploradora en el tejido perinefrítico no dió salida á una gota de pus, y el Dr. Tillaux, que vió al enfermo, sospechó, aunque sin atreverse á afirmarlo, el desarrollo de un sarcoma de mal género, precisamente á causa de la falta de los signos racionales de la supuración. Nueve semanas después de los accidentes tuvo el enfermo escalofríos y fiebre, y la tumefacción lumbar adquirió proporciones considerables. Era un flemón perinefrítico, como yo había sospechado al principio, que curó en poco tiempo á beneficio de una incisión.

En nuestro enfermo era racional creer en una nefritis de origen calculoso. Pero no aceptamos este diagnóstico, á causa de la marcha y evolución de los accidentes morbosos.

Cuando se desarrolla un flemón perinefrítico, sigue una marcha rápida $\delta$ lenta; en el primer caso es difícil desconocerlo, porque los escalofríos, la fiebre, la inapetencia, el insomnio, son casi constantes é indican un trabajo de supuración profunda. En el segundo caso, el edema local es uno de los signos precoces que indican la existencia del abceso, y dicho edema jamás adquiere las proporciones que tenía en nuestro enfermo, sin alterar de un modo grave el estado general. En segundo lugar, el cólico nefrítico, aunque muy doloroso, no es comparable á la crisis atroz que se declaró al penetrar la sangre en el tejido celular circunrenal. Por último, la orina de los que padecen arenilla está siempre alterada en su cantidad ó en su composición, lo que no se ha observado en el caso actual. En éste, la orina es, en efecto, de color encendido, hemaféica, pero no contiene albúmina ni arenilla, 'aunque sí un 
exceso de pigmento sanguíneo, pero nada que justifique una lesión renal.

De cualquier modo que se considere el caso, se vuelve á la idea de un aneurisma aórtico, y la existencia de pulsaciones en el tumor constituye un signo casi patognomóco de la ectasia vascular.

Digo casi patognomónico, porque son posibles los errores, aun existiendo este síntoma, y se cree en un aneurisma cuando se trata de lesiones diferentes.

Los tumores esplénicos, elevados por las pulsaciones de la aorta, pueden considerarse como verdaderos aneurismas, y yo conozco un joven, en el que un quiste del bazo, punzado varias veces, tiene latidos comunicados. Es fácil siempre distinguir estos casos de las ectasias vasculares verdaderas; el impulso que tacta la mano es brusco y breve, y no da la sensación de un tumor espontáneamente pulsátil y expansivo.

Más difícil es distinguirlos de los tumores malignos telangiectásicos, cuyos latidos son difusos y dan la impresión de un aneurisma pulsátil ; obsérvase esto de preferencia en los sarcomas y carcinomas encefaloideos, cuya blandura es tal, en ocasiones, que simula una fluctuación verdadera, hasta el punto de confundirse con ella. Pero en tales casos, además de los sintomas generales de caquexia, más acentuados de ordinario, la marcha es muy diferente. Los progresos de la afección son continuos, y más ó menos rápidos los dolores incesantes y no intermitentes; por último, no se ve aumentar de repente el volumen del tumor de un día á otro, como sucedió en nuestro enfermo, después del traumatismo. Además, ciertos signos locales demuestran que no se trata de un foco sanguíneo circunscrito, sino de un neoplasma invasor; por ejemplo, la dilatación venosa colateral de los tegumentos, es siempre mayor cuando existe un tumor encefaloide y la tempera- 
tura de la región es más elevada; la ascitis es constante, mientras que falta siempre en los casos de aneurisma; casi siempre hay roces peritoneales ó pleuríticos, lo que no sucede en este caso. Por último, los fenómenos de auscultación en el sitio del tumor difieren bastante ; en los tumores encefaloides nada se oye ó, á lo sumo, se nota soplo vasculár; en nuestro enfermo se observa, por el contrario, en el sitio donde son más claras las pulsaciones, un murmullo doble, suave y profundo, perceptible lo mismo en la región peri-nefrítica que en la proximidad del bazo.

¿Es posible circunscribir más el diagnóstico y precisar el sitio de la ectasia aórtica?

Parece indudable que el aneurisma ocupó, en su origen, la región subyacente del diafragma, y que, según toda probabilidad, se hallaba situado debajo de la inserción de los pilares de este músculo. En efecto, cuando un aneurisma ocupa el trayecto diafragmático de la aorta, se manifiesta casi siempre por crisis gástricas atroces y por vómitos repetidos. Nuestro enfermo jamás ha vomitado ni ha tenido gastralgia. La ley, formulada ya por Stokes, es exacta en todas sus partes; los aneurismas de la aorta abdominal producen dolores tanto más fuertes, cuanto más elevado es el sitio de la lesión ; en este individuo, la crisis de dolores atroces que siguió á la rotura parcial del saco, los cuales han sido más bien sordos y contusos.

Es probable que la lesión aórtica se halle localizada en la proximidad inmediata del tronco celíaco, por encima ó por debajo de su origen. Este sitio es, como sabéis, el electivo de las ectasias de la aorta abdominal, y así se comprende, porque el saco aneurismático se desarrolla hacia el diafragma y la región perinefrítica sin interesar el riñón ni las arterias renales. Es casi seguro que en este caso la fisura parcial de la bolsa ocupa la parte posterior, y que la sangre se derramó por detrás y separó el tejido celular 
que rodea el riñón, siguiendo el psoas y la aponeurosis ilíaca. Así se explica la situación del bazo rechazado sobre un plano anterior con el resto de la masa intestinal.

Debemos ahora averiguar la significación del derrame pleurítico y sus relaciones con la bolsa aneurismática.

Es indudable que hay sólo coincidencia entre las dos lesiones, porque recordaréis que la pleuresía de este hombre jamás ha presentado los síntomas de una enfermedad inflamatoria, y el derrame de la pleura se produjo, al parecer, de una manera independiente de toda irritación previa del parénquima pulmonar, marcha rara en la pleuritis. Puede, por lo tanto, preguntarse de qué modo influyó sobre la pleura el aneurisma infra-diafragmático. ¿ Hay motivos para admitir la penetración directa de la sangre del aneurisma en la cavidad pleuritica, $\delta$ se trata simplemente de una trasudación serosa por irritación de vecindad?

Para resolver el problema, hicimos una punción exploradora capilar con la jeringuilla de Pravaz aséptica, y salieron de la cavidad pleurítica unas cuantas gotas de serosidad sanguinolenta, pero no sangre pura. La segunda hipótesis parecía, por consiguiente, la verdadera; hubo trasudación, al menos de la substancia colorante sanguínea, por proximidad del aneurisma falso consecutivo. Es poco verosímil que penetrara de repente sangre en la pleura, porque la consecuencia de este accidente es casi siempre la muerte repentina ó rápida, y nuestro enfermo jamás ha padecido crisis de sofocación, como hubiera sucedido en tal caso.

Queda por exclarecer un punto final del diagnóstico referente al estado del raquis en nuestro enfermo. La proximidad de la bolsa aneurismática á los cuerpos de las vértebras lumbares, autoriza á creer que pueden estar enfermas; sabemos, en efecto, con qué facilidad se desgasta la 
substancia ósea al contacto de un tumor pulsátil. Creemos que es imposible responder con exactitud á esta cuestión. Habéis visto, hace poco tiempo, que las vértebras se desgastaron sin que se presenten dolores ni trastornos funcionales apreciables. No es posible afirmar ni negar que el dolor profundo, fijo y terebrante de que se queja constantemente el enfermo, esté localizado en el aneurisma 6 en las vértebras subyacentes.

Antes de terminar este asunto, creo conveniente llamar vuestra atención sobre algunas particularidades que, desde el punto de vista clínico, tienen interés verdadero.

Es notable, ante todo, que una lesión tan importante sea tolerada por el organismo sin producir trastornos funcionales graves. Cuándo se encuentra en reposo, este hombre no padece, por decirlo así ; todas sus funciones se ejecutan con regularidad, el apetito es bueno, el sueño tranquilo; el malestar sólo se presenta bajo la influencia de la marcha 6 de los esfuerzos. Stokes llamó ya la atención sobre esta integridad absoluta del estado general en tales casos. Este observador admirable insistió sobre el hecho de que los aneurismas de la aorta abdominal se desconocen con frecuencia durante mucho tiempo, porque no producen más fenómenos que las crisis neurálgicas ; este síntoma único nada tiene de característico y se interpreta de ordinario en el sentido de un dolor visceral de origen gástrico, renal 6 hepático.

Merece también señalarse en esta observación otro punto : la coexistencia de una afección cardíaca con el aneurisma de la aorta abdominal. Al contrario de lo que podría creerse, esta coincidencia es rara, y en la mayor parte de los casos publicados de aneurisma abdominal, se ha observado la integridad del corazón. Conviene advertir que la hipertrofia ventricular en este enfermo es, al parecer, una lesión secundaria consecutiva á la alteración del 
orificio aórtico : por consiguiente, la endarteritis es primitiva. A pesar de esto, no parece que la aorta sufra lesiones difusas ni generalizadas : no se oyen en punto alguno de su trayecto los ruidos ásperos y fuertes que indican la degeneración ateromatosa y calcárea : el cayado aórtico no está dilatado y no se observa síntoma funcional alguno que haga sospechar lesiones de la porción torácica descendente del vaso. Es, por lo tanto, una localización curiosa del ateroma la que presenta nuestro enfermo; la lesión se halla localizada, si no de una manera exclusiva, al menos predominante, en las dos extremidades de la aorta ; en su origen ventricular y en la proximidad del tronco celiaco.

Las consecuencias de la enfermedad de la aorta sobre el estado del corazón no dejan de ser interesantes. En efecto, la insuficiencia sigmoidea reviste una fisonomía y caracteres especialísimos, y no se manifiesta por sus sínto. mas ordinarios. Excepto al soplo diastólico que tiene el carácter clásico y corresponde á la destrucción valvular, faltan todos los demás síntomas de la enfermedad de Corrigan. El pulso, en vez de ser duro, rebotante y depresible es débil de una manera notable y la tensión arterial inferior á la normal. Este fenómeno es debido, no á la pequeñez de la lesión valvular, sino á la existencia en el trayecto de la aorta de una bolsa aneurismática voluminosa que suprime en parte la reacción elástica de la arteria y atenúa los efectos del impulso cardíaco. La mayor parte de la contracción ventricular se pierde en las paredes del tumor sanguíneo, y la tensión de la sangre se mantiene baja sin pasar por las alternativas de exageración y de depresión.

Este descenso de la tensión arterial tiene, por lo demás, una ventaja ; gracias á él, no padece el enfermo trastornos cerebrales tan frecuentes en la insuficiencia aórtica. Jamás 
desde el principio de su enfermedad ha tenido aturdimientos, ni vértigos, ni cefalalgia, aun cuando la pérdida de sangre ocasionada por la formación del aneurisma falso consecutivo del abdomen fue considerable, y la anemia grandísima. Esto prueba, digámoslo de paso, que las molestias que se atribuyen á la anemia del cerebro, son debidas más que al riego arterial insuficiente, á los cambios bruscos de presión que sufren los vasos encefálicos.

Acabamos de indicar los efectos del aneurisma sobre la circulación cardíaca : sus consecuencias sobre la periférica no son menos interesantes. Explorando las arterias femorales, se nota dureza ateromatosa de sus paredes; pero en vez del impulso brusco de la sangre, que era de suponer había de encontrarse en arterias tan rígidas, se notan pulsaciones débiles apenas perceptibles : indudablemente la presencia del saco aneurismático por encima de las arterias ilíacas intercepta parte del impulso primitivo de la onda arterial. Existe otro signo no menos decisivo : entre los latidos del corazón y el choque de las femorales, media un intervalo notabilísimo, mucho más largo que en estado fisiológico. Este retraso del pulso femoral es perceptible sin auxilio de aparatos registradores, no sólo por comparación con el choque precordial, sino con el pulso radial. Sabéis que, según Marey, es uno de los signos más seguros en la existencia de una bolsa aneurismática en el trayecto de la aorta.

La disminución de la tensión arterial que hemos observado en las femorales, es más acentuado aún en las arterias de la pierna y del pie : en las pedias no se sienten los latidos. La circulación sanguínea no está trastornada, al parecer; el enfermo no siente hormigueo ni entumecimiento en las extremidades : sólo se enfría con la mayor facilidad, fenómeno debido principalmente á la necesidad en que se encuentra de no hacer ejercicio. 
Después del análisis minucioso que acabo de hacer, es casi supérfluo decir que el estado de este enfermo es grave y el pronóstico funesto. El descubrimiento de un aneurisma de la aorta abdominal es una amenaza de muerte inmediata, sobre todo cuando el saco ha cedido ya su parte y la sangre se ha abierto paso por una fisura parietal, por mínima que sea. En nuestro enfermo se ha producido con seguridad un derrame sanguíneo secundario, un aneurisma falso consecutivo. En tales condiciones hay poquísimas probabilidades de que se retraiga el saco y se obliteren poco á poco los coágulos fibrinosos.

Son posibles varias eventualidades. La primera, y la más feliz, sería que dejara de progresar la lesión y que se formasen coágulos sólidos. He dicho que es la menos probable, pero no imposible. Puede suceder también, que después de un período de calma relativa dé salida la bolsa aneurismática á cierta cantidad de sangre, que se enquistaría como la vez primera y aumentaría el volumen del aneurisma consecutivo. De todos modos, la lesión terminará por la muerte, lenta por extenuación progresiva, 6 repentina por rotura del saco y derrame de la sangre en la cavidad abdominal. Esta última eventualidad es la más probable, porque ha faltado poco ya para realizarse.

Las indicaciones terapéuticas son claras. Es indispensable, ante todo, conseguir la calma absoluta de la circulación. Sólo por este medio puede esperarse que se active la formación de los coágulos y que precipite la fibrina. El enfermo debe ser sometido al reposo completo, permanecer en inmovilidad absoluta durante varias semanas, y después, si no sobreviene accidente alguno y se atenúan, al parecer, los desórdenes locales, se le permitirá hacer poco á poco movimientos ligeros ordenados con mucha prudencia, algunos ensayos tímidos de marcha y permanecer sentado. La alimentación debe ser muy moderada, 
reduciendo la bebida al mínimum, para no aumentar la tensión sanguínea; las comidas, sobre todo, conviene que sean frugales. No es menos necesario mantener libre el vientre por medio de enemas y de laxantes, tanto con el fin de que no haya sobrecarga intestinal, como para evitar los esfuerzos de defecación, durante los cuales podría romperse el aneurisma. Por último, es perjudicialísima para la salud del enfermo toda emoción moral, toda contrariedad susceptible de acelerar la circulación y de aumentar el impulso cardíaco.

Los medicamentos ocupan en este caso un lugar secundario en relación con la higiene. Conviene, no obstante, ensayar algunos remedios que producen una relajación en los vasos y disminuyen la presión arterial. Pertenece á esta clase el ioduro de sodio ó el de potasio, que se ha prescrito ya, pero por desgracia tolera, al parecer, mal el enfermo : tengo idea de emplearlo de nuevo, principiando por pequeñas dosis que aumentaré poco á poco. He empleado á la vez la trinitina á la dosis de 3 gotas mañana y tarde de una disolución al 1 por 100, según aconseja Huchard.

Se presenta una cuestión de práctica especial en este enfermo. Hay un derrame pleurítico sero-hemorrágico que no comunica con el foco hemático, pero que está bastante próximo para que sea una trasudación de la substancia colorante de la sangre. ¿Qué conducta debe seguirse respecto á este derrame? ¿Debemos punzarlo ó respetarlo? Por el pronto, seguiré este último partido, reservándome intervenir si se presentan algunos accidentes imprevistos, ó fenómenos de opresión torácica alarmantes. Por ahora, nada de esto sucede, $\mathrm{y}$ no me parece que se adelantaría gran cosa con evacuar el líquido de la pleura. Una punción, en estas circunstancias, quizá no produjera efecto funesto alguno, pero no me atrevo á afirmarlo; podría suceder, por el contrario, que la substracción de cierta can- 
tidad de líquido en la proximidad del aneurisma tuviera consecuencias funestas al suprimir una compresión conveniente para que se formen los coágulos y al activar en demasía la circulación de la bolsa aneurismática. Creo, por lo tanto, que es más prudente dejar que se absorba pocoá poco el derrame pleurítico.

Con más motivo considero contraindicada en absoluto toda intervención directa sobre la bolsa aneurismática. Se ha aconsejado para acelerar la transformación en los coágulos cruóricos en fibrinosos, la electro-puntura. Estas tentativas se han ensayado de preferencia en los aneurismas del cayado aórtico que sobresalían por fuera del esternón y amenazaban romperse ; he visto á mi maestro el Dr. Bucquoy, obtener un verdadero éxito en un caso de este género. Pero en una región tan profunda como la lumbar, con una bolsa aneurismática, incompletamente circunscrita y de límites difusos, temía, al obrar así, hacer poco, muy poco. Con la electro-puntura no se obtendría una coagulación suficiente para evitar el derrame sanguíneo, y, por otra parte, sería quizá susceptible en producir en el electrodo negativo fenómenos inflamatorios que costaría trabajo moderar.

Creo que es preferible esperar la resolución espontánea y la retracción de la bolsa sanguínea inmovilizando al enfermo é insistiendo en una higiene severa.

\section{NOTA ADICIONAL}

Bajo la influencia del reposo absoluto, favorecido con algunas inyecciones de morfina y el uso del ioduro de sodio ( 50 centígramos por día) se consiguió una mejoría sensible. El hígado disminuyó con rapidez de volumen y perdió parte de su dureza; es indudable que su apariencia de cirrosis se hallaba en relación con el estado del corazón y dependía de la congestión crónica. 
En el aneurisma se obtuvo igual mejoría, pero más lenta. La combadura infra-diafragmática disminuyó de una manera indudable; los latidos del tumor, aunque perceptibles, eran mucho menos ámplios y menos extensos ; la consistencia de la tumefacción aumentó, al parecer, y la fluctuación no se notaba con la misma claridad que al principio. Por último, el estado general mejoró, el sueño, regularizado con la morfina, fue mejor que antes y el dolor dorsal desapareció casi por completo.

Hoy, 15 de Marzo, se ha concedido al enfermo permiso para levantarse y pasear por la sala ; cojea mucho menos y padece poco andando con lentitud y descansando con frecuencia; se le ha prohibido bajar las escaleras y pasear por el jardin. En resumen, se encuentra lo mejor posible, dada una lesión tan grave, pero no puede asegurarse que la bolsa aneurismática se halle protegida por estratificaciones fibrinosas sólidas, y el peligro para el porvenir es tan amenazador como antes.

Durante algunas semanas, persistió la mejoría observada y el enfermo, deseoso de volver de nuevo á su trabajo, salió del hospital á principios de Abril.

El día 26 se presentó de nuevo en la consulta en un estado alarmante. Desde la víspera habían aparecido otra vez los dolores fuertes en el abdomen y en la columna vertebral y se sentía muy débil. Le costó un trabajo ímprobo subir á la sala. En el momento en que se desnudaba y se disponía á meterse en la cama, se puso de repente muy pálido y cayó al suelo bruscamente ; á los pocos segundos expiró.

Al día siguiente, 27 de Abril por la mañana se hizo la autopsia (1).

(1) El Sr. Buscarlet, interno de la clínica, redactó el resultado de la autopsia y presentó la pieza patológica á la Sociedad Anatómica.

Clínica médica. - Tomo 1. 
Al abrir la cavidad abdominal, salió una gran cantidad de sangre negruzca y se descubrió al momento una masa de coágulos parecidos á la gelatina de grosella adherentes al epiploón, delante del cual se encontraban ; se continuaban con otros coágulos que obstruían la excavación pelviana. La masa de coágulos extraídos pesó 550 gramos.

Levantando el epiploón y el intestino delgado se encontró un tumor enorme que llenaba las tres cuartas partes de la cavidad del abdomen y ocupaba principalmente la región lumbo-abdominal izquierda, salvaba la línea media y se extendía desde el diafragma hasta la fosa ilíaca izquierda. El bazo, de volumen normal, ocupaba su sitio ordinario y era distinto por completo del tumor por fuera y delante del cual estaba situado.

Aplicados inmediatamente, sobre esta masa encontramos el colon descendente y el estómago, adheridos íntimamente, sobre todo este último en toda la extensión de su curva mayor. Estaba rechazado hacia adelante y dirigido en sentido casi vertical. Al separar el hígado, que conservaba su posición normal, se encontró entre las dos hojillas del epiploón gastro-hepático un derrame sanguíneo reciente, situado entre el lóbulo izquierdo del hígado y la curva menor del estómago; había desprendido la hojilla peritoneal de la cara anterior del estómago y se había derramado en parte sobre esta última.

El riñón derecho aparecía en su sitio normal contra el raquis.

El izquierdo, oculto por el tumor, no se veía en aquel momento.

Extrayendo todos los órganos de la cavidad abdominal de arriba á abajo, se comprendía que la masa estaba íntimamente adherida á la columna vertebral por delante, y á la izquierda de la cual se hallaba situada; no había desvia- 
ción ni alteración alguna de los cuerpos vertebrales. Se disecó con cuidado y pudo verse entonces que se continuaba por arriba directamente con la aorta torácica; era una dilatación aneurismática de la aorta abdominal que se extendía desde el orificio diafragmático hasta el origen de las arterias renales. Pero la bolsa descendía mucho más aplicada por delante de la aorta, de la que se separó por disección y de la vena cava inferior; de manera que la aorta, que se había dilatado de una manera fusiforme para formar la parte superior del tumor, salía, al parecer, algo por debajo de la parte media, donde era muy estrecho su calibre. En este sitio se encontraron la arteria renal derecha bastante voluminosa y dos arterias renales izquierdas pequeñas. Siguiendo estas últimas se llegó al riñón izquierdo que formaba cuerpo con el tumor. Este riñón estaba aplanado y hubo necesidad de descortezarlo para reconocerlo; fue imposible separar su cápsula propia del tumor. Las dos arterias renales se dirigían una á la parte media del hilio y otra á su parte inferior; eran de poco calibre y existían dos venas correspondientes. Había en la superficie del riñón infartos numerosos que se revelaban por manchas violáceas. $\mathrm{Al}$ corte se encontró anémico este órgano.

Disecando el tumor por la cara porterior, se descubrió cerca del borde derecho, por encima del punto de salida de la aorta, una desgarradura irregular y extensa por la que salían coágulos; correspondía á la cara posterior del estómago. Las paredes del saco eran muy delgadas y friables en este punto.

Dimensiones. - La aorta mide 4 centímetros de diámetro en el orificio diafragmático.

Debajo del saco tiene sólo 2 centímetros.

La altura total del tumor es de 26 centímetros y llega 
10 más allá del nacimiento inferior de la aorta. Tiene en. su parte más ancha 18 centímetros; en la superior del ovoide 11 y medio y junto al riñón 13 .

En sentido antero-posterior mide 7 centímetros.

Forma.-Ovoide irregular, con dilataciones secundarias irregulares.

Paredes. - Abriendo el tumor por su cara anterior se observa que, mientras ésta se halla formada por una pared gruesa de 7 centímetros constituída por capas de fibrina estratificadas 6 por tejidos próximos rechazados de manera que es difícil conocer qué se ha hecho de la pared aórtica, la cara posterior del aneurisma es, por el contrario, delgada, friable, distendida de un modo irregular, sin cubrir por coágulos organizados, es la pared misma de la arteria. La rotura se ha producido en este sitio, y algún tiempo antes debió haber en el mismo punto otra rotura incompleta, porque se ven coágulos antiguos infiltrados en la pared.

Por encima del aneurisma, la pared aórtica está sembrada de placas ateromatosas hasta el orificio cardíaco; el vaso tiene 5 centímetros de diámetro desde el diafragma. hasta el tronco braquio-cefálico; desde este punto se dilata. de un un modo considerable, y el cayado mide 7 centímetros de diámetro.

Las válvulas sigmoideas están sanas, lo mismo que el endocardio del ventrículo izquierdo.

El corazón está poco hipertrofiado, y nada presenta de particular.

Contenido. - Masa de coágulos considerable; el tumor, incluso el riñón izquierdo, el corazón y la aorta torácica, pesan 3000 gramos.

Examinando las demás vísceras, se encuentra en la cavidad torácica un derrame seroso de unos dos litros en la 
pleura izquierda; en la derecha, adherencias pulmonares locales. Los pulmones presentan lesiones de bronquitis crónica.

El riñón izquierdo, aplastado, anémico, mide 13 centímetros de longitud por 7 de anchura. El derecho pesa 170 gramos, y tiene 13 centímetros de longitud, 7 y medio de anchura y 3 y medio de espesor; está muy congestionado. El hígado pesa 1600 gramos, y tiene el aspecto del hígado moscado tipo.

El bazo pesa 255 gramos, y no presenta particularidad alguna. 



\section{INDICE DE MATERIAS DEL TOMO PRIMERO}

\section{ENFERMEDADES GENERALES}

FLEBITIS PUERPERAL SUPURADA

Etapas sucesivas del envenenamiento puerperal. - La flebitis es siempre una manifestación tardia, y, por lo general, indicio de una infección atenuada. - Independencia relativa de la infección venosa y de la metritis séptica.inicial. - Modos de extensión de los focos virulentos de las venas por brotes sucesivos; embolias capilares secundarias, é identidad del proceso con el de la infección purulenta. - Valor pronóstico de los síntomas clínicos; posibilidad de curación con los sindromes de la piohemia.Indicaciones terapéuticas..............................

\section{PÚRPURA HEMORRÁGICA INFECCIOSA}

La púrpura no es una entidad morbosa definida. - Descripción de un caso de púrpura hemorrágica infecciosa.-Diferencias clinicas con las púrpuras de origen nervioso, la hemofilia y el escorbuto. - Relaciones patógenas entre la enfermedad de Werlhof y las formas graves de púrpura tifoidea. - Lesiones embólicas comunes y presencia de micrococos en el suero sanguíneo. - Indicaciones pronósticas y terapéuticas.........................

DE ALGUNAS DIFICULTADES DE DIAGNÓSTICO AL PRINCIPIO DE LA FIEBRE TIFOIDEA

Las formas atenuadas de la fiebre tifoidea, son las que exponen con frecuencia á errores de diagnóstico. - Formas abdominales de tipo de embarazo gástrico: caracteres sacados de la temperatura, del estado de la orina y de las condiciones epidémicas. - Fiebres tifoideas de principio faríngeo: anginas precoces intensas $\delta$ ligeras. - Formas caracterizadas por predominio de los vómitos. Fiebres de tipo torácico inicial que simulan la pulmonía, la grippe $\delta$ la tuberculosis miliar aguda; asociación posible de la

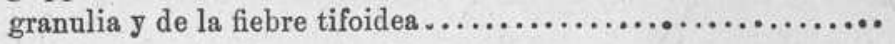




\section{ARTERITIS TIFOIDEA}

Evolución de un caso sımple de arteritis femoral durante una fiebre tifoidea benigna. - Asociación posible de la flebitis y de la arteritis; dificultades del diagnóstico. - El edema de la raiz del miembro ¿es compatible con la arteritis sola, sin complicación venosa? - Mecanismo de la obliteración arterial; no es una embolia ni una trombosis espontánea, sino una arteritis séptica que origina secundariamente la coagulación de la sangre. - Formas graves de la arteritis que producen la gangrena; lesiones anatómicas. - Propagación de las lesiones arteriales durante la fiebre tifoidea. - Pronóstico de la arteritis tifica. - Tratamiento .....

\section{CAQUEXIA PALÚDICA}

Comparación de los casos de caquexia palúdica. - Condiciones patogénicas predisponentes. - La antigüedad de la infección palúdica y la agudeza de los fenómenos tóxicos, la originan por igual. - Influencia de las condiciones de resistencia personal de los individuos contra el veneno palúdico. - Fisiologia patológica: destrucción globular, hemoglobinuria, anemia secundaria.Hipertrofia espleno-hepática. - Influencia respectiva del hígado y del bazo sobre la destrucción de los glóbulos. - Pronóstico y

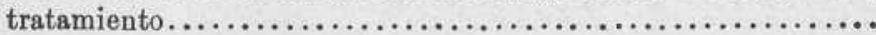

GOTA SATURNINA

Congestión pulmonar precedida de dolores articulares y seguida de un acceso de gota aguda franca.-Interpretación de este hecho. Diagnóstico con el reumatismo articular. - Fluxiones viscerales de los gotosos: $i$ son de origen gotoso ó dependen de las manifestaciones diatésicas? - Etiologia de la gota en el caso particular: influencia del saturnismo. - Influencia patógena del plomo en la producción de los accidentes gotosos.-Pronóstico y tratamiento.

\section{REUMATISMO ESPINAL}

Ciertas formas de reumatismo agudo iprincipian como las congestiones espinales y revisten los caracteres de una parálisis ascendente aguda? - Ejemplo en su apoyo: invasión progresiva de los miembros inferiores y superiores. - Caracteres diferenciales con las mielitis agudas verdaderas. - Analogia del reumatismo y de las enfermedades de la médula : origen espinal de todos los reumatismos.-Historia de este asunto.- Reumatismos espinales y mielitis reumatoides. - Caracteres deducidos de los reflejos tendinosos. - Marcha diversa de los accidentes. - Pronóstico y

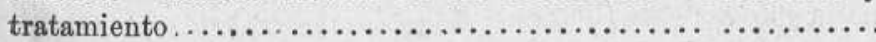




\section{ENFERMEDADES DEL APARATO RESPIRATORIO}

\section{PULMONIAS ABORTIVAS}

Descripción de un caso de pulmonía abortiva; brotes sucesivos congestivos que fueron acompañados de erupción de herpes: defervescencia brusca al séptimo día. - Discusión de este caso: no es ni la congestión pulmonar idiopática de Woillez, ni la fiebre herpética de Parrot. - Analogia de evolución con la pulmonía verdadera, desde el punto de vista de los sintomas y de la etiologia. - Algunas de estas congestiones pulmonares parecen ser de origen microbiano. - Su carácter contagioso probable. Analogia de su evolución térmica con la de las enfermedades infecciosas. - ¿Pueden considerarse como pulmonias de viru-

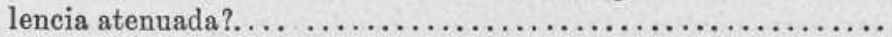

\section{PULMONIA TIFOIDEA Y PNEUMOTIFUS}

Descripción de una pulmonía tifoidea: principio franco, signos físicos clásicos, pero desproporcionados con la gravedad de los síntomas generales: aparición precoz de la albúmina. - Aparición de accidentes intestinales en el momento en que debia principiar la defervescencia, y atenuación aparente de los signos de la pulmonía. - Discusión de este caso. - Diagnóstico de la pulmonía tifoidea, de la grippal y de la tuberculosis miliar aguda de forma pneumónica.-La evolución clínica es más bien en este caso la de un peneumotifus. - Variedades clínicas del pueumotifus: casos en los que la evolución de los síntomas pneumónicos es distinto de la de los tíficos. - Casos en los que se superponen estas dos clases de síntomas. - El caso actual corresponde á esta variedad última y no autoriza un diagnóstico cierto.-Resultados

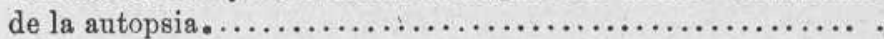

ESCLEROSIS PULMONAR Y DILATACIÓN BRONQUIAL

Identidad de los trastornos funcionales y de los signos físicos en la tuberculosis y en la dilatación bronquial, pero falto de fenómenos generales en esta última enfermedad. - Diagnóstico de las dos afecciones. - Dificultades especiales del diagnóstico cuando se forman vómicas purulentas, que son algunas veces el primer fenómeno aparente en el curso de la dilatación bronquial. Mecanismo de la ectasia bronquial. - Es siempre complejo y no depende exclusivamente ni de la lesión de los bronquios ni de la esclerosis del parénquima pulmonar. - Es, por lo común, resultado de una bronco-pneumonía primitiva, complicada con adherencias pleurales. - Elementos de pronóstico é indicaciones

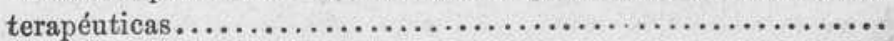




\section{BRONQUIECTASIA Y GANGRENA PULMONAR}

Bronquiectasia complicada con gangrena pulmonar. - Vómicas pútridas. - Dificultades del diagnóstico entre una ulceración tuberculosa, una pleuresía purulenta con fístula pleuro-bronquial y una esclerosis pulmonar. - Dificultades materiales para descubrir el foco séptico. - Resultados de la autopsia: coexistencia de la bronquiectasia y de la gangrena verdadera. - Patogenia de estas lesiones.-Evolución rápida de ciertas formas de esclerosis: influencia de la pleuresía en la producción de la esclerosis y de la bronquiectasia. - Infecciones secundarias y septicemia, localizadas primero en los bronquios enfermos, propagadas después al resto del parénquima pulmonar. - Tratamiento quirúrgico de las dilataciones bronquiales sépticas.-Necesidad de precisar el sitio de los focos pútridos y dificultades grandísimas de hacerlo. Indicaciones y contraindicaciones de la pneumotomía. - Manual operatorio.-Complicaciones y peligros de la operación.-Resul-

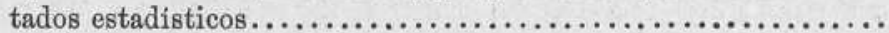

\section{CONTUSIÓN DEL PULMÓN Y TUBERCULOSIS}

Contusión del pulmón, hemoptisis primitiva, seguida de signos de pleuro-pneumonia circunscrita. - Evolución clínica y grados de la contusión pulmonar, analogias y diferencias de la pulmonía traumática y de la espontánea. - Influencia del terreno morboso sobre el traumatismo.--En este caso la hemoptisis, accidental en apariencia, es en realidad sintomática de una tuberculosis latente. - Pronóstico y tratamiento. - Nota adicional: evolución de la lesión dos años después del accidente.. ..............

\section{PLEURESIA PURULENTA CONSECUTIVA Á LA BRONCO-PNEUMONÍA}

Bronco-pneumonía infecciosa en un viejo alcohólico.-Persistencia después de la defervescencia de lesiones locales de interpretación difícil. - Diagnóstico diferencial de la atelactasia pulmonar, de la espleno-pneumonía y de la pleuresía.-La pleuresía purulenta consecutiva á la pulmonía sigue siempre una marcha insidiosa y produce pocas veces sintomas febriles. - Puede quedar latente hasta la autopsia, ó manifestarse por una vómica.-Pronóstico y

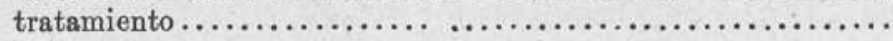

\section{PLEURESÍA PURULENTA METAPNEUMÓNICA}

Comparación de tres casos de infección por pneumococos.-Meningitis supurada latente en el curso de una pulmonia. - Localización pleuritica y pericardíaca de la supuración, correspondiente unas veces á casos de pulmonias graves, otras á pulmonías be- 
nignas en apariencia. - Formas diversas de la pleuresía purulenta metapneumónica, pleuresías contemporáneas de la pulmonía y pleuresías tardías; su evolución diversa. - Dificultades de diagnóstico de los empiemas tardíos: insuficiencia de los signos físicos, de los trastornos funcionales $y$ de las indicaciones termométricas. - Necesidad de hacer el diagnóstico con ayuda de la punción exploradora. - Eventualidades ulteriores del empiema ; fístulas pleuro-bronquiales; enquistamiento de la bolsa supurada Patogenia de la pleuresía purulenta metapnenmónica.-Estudios bacteriológicos; su desiderata clínicas. - Tratamiento. - Necesidad del empiema precoz. - Benignidad de la operación........

\section{EMBOLIA PULMONAR SÉPTICA : PNEUMOTÓRAX}

Pleuresia gangrenosa curada por un empiema precoz.

Pi opneumotórax gangrenoso ocurrido en una joven á los pocos días de un aborto. - Empiema precoz: curación. - Discusión retrospectiva del diagnóstico. - No es posible pensar ni en una bronquiectasia complicada con gangrena pulmonar, ni en una broncopneumonia ni áun infecciosa. - La marcha de la afección es la de una embolia pulmonar que produjo un infarto séptico á causa del puerperio.-La embolia procedente de los senos uterinos, después de la muerte del feto, puede preceder á la expulsión del producto de la concepción. - Mecanismo de la infección del coágulo embólico. - Necesidad de la intervención precoz en casos semejantes: consecuencias benignas del empiema, tratado según las reglas antisépticas....................................

\section{ACCIDENTES NERVIOSOS CONSECUTIVOS AL EMPIEMA}

Los accidentes nerviosos graves no se presentan jamás al principio del tratamiento del empiema, sino cuando parece segura la curación.-Descripción de un caso de este género.-Ietus apopléctico ocurrido inmediatamente después de una inyección medicamentosa: accesos epilépticos sub-intrantes y muerte rápida: falta de lesiones cerebrales. - Discusión del caso clínico: no se trataba de un epiléptico, ni de un urémico; es inadmisible la teoria de la embolia cerebral. - Los accidentes epilectiformes pertenecen al orden de los fenómenos reflejos bulbares, y no deben atribuirse ni á la cualidad ni á la cantidad del líquido inyectado, sino á lo brusco de su penetración. - Existencia de una zona refleja peligrosa cerca del diafragma: hechos en su apoyo.-Evolución y variedad de los accidentes reflejos del empiema. - Formas siderantes, apoplécticas $\alpha$ epilécticas : parálisis fugaces y durables de forma hemiplégica. - Indicaciones terapénticas.............. 
diagnóstico DE LA CANTIDAD DE LOS DERRAMES PLEURíticos

Signos físicos, casi idénticos, pueden corresponder á derrames de cantidad diferente; dos ejemplos en su apoyo.-La intensidad de los trastornos funcionales nada indica respecto á la proporción del líquido derramado. - El estado del pulmón subyacente es la verdadera dificultad del diagnóstico. - Valor de los diversos signos estetoscópicos: palpación, percusión y medición.-Importancia de la dislocación de los órganos y causas de error al apreciarla. - Signos de auscultación, medios de apreciar el estado del pulmón, valor de la difusión del soplo.-Causas de error debidas al enfisema y á las adherencias de la pleura. - Resumen .........

\section{PLEURESÍA DIAFRAGMÁtica TUBERCULOSA}

Frecuencia de las formas atenuadas de la pleuresía diafragmática: estado latente de los sintomas. - El único fenómeno constante es el dolor frénico en el sitio de elección.-Dificultades de diagnóstico de estas formas ligeras con la pleurodinia, las congestiones circunscritas de la base del pulmón y las peritonitis sub-diafragmáticas. - Hecho que demuestra la estrecha analogia de los síntomas de una pleuresía purulenta sub-frénica y de una hepatitis. -Pleuresías diafragmáticas de repetición: son casi siempre sintomáticas de tuberculosis, cualquiera que sea su forma clinica y la duración del período que separa las recidivas. - Indicaciones terapéuticas....................................

\section{CÁNCER PRIMITIVO DE LA LARINGE}

Dificultades de diagnóstico con la pericondritis crónica.

Discusión de un caso de huélfago crónico y de marcha progresiva. - Posibilidad de la compresión de las vías respiratorias por un tumor intra-torácico ó un epitelioma del esófago: signos que indican que la causa primitiva reside en la laringe. - Diagnóstico de las laringitis crónicas que van acompañadas de huélfago: en este caso, los sintomas son los de un tumor intra-laríngeo, $\boldsymbol{y}$ el microscopio confirma estas presunciones. - Formación brusca de un abceso de la laringe á expensas del tejido celular profundo del cuello. - Valor diagnóstico y pronóstico de este flemón cervical. - iSe trata, en este caso, de una periconditis supurada, primitiva ó secundaria?-Caracteres, evolución y marcha de la pericondritis: influencia probable del traumatismo en este caso. - Sólo la terminación de la enfermedad indica que la pericondritis era consecuencia de un epitelioma de la laringe. - Resultados de la

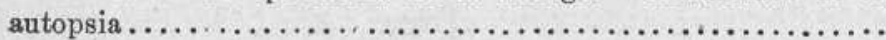




\title{
ENFERMEDADES DEL APARATO CIRCULATORIO
}

\author{
PERICARDITIS AGUDA CON DERRAME
}

Descripción de un caso de pericarditis aguda reumática con derrame, complicada con pleuresia. - Muerte repentina la vispera del día en que iba á practicarse la paracentesis del pericardio.Resultados de la autopsia. - Reflexiones sobre este caso. - Relaciones recíprocas de la pleuresía y de la pericarditis.-Dificultades del diagnóstico de los derrames pericardíacos en los adultos.- Valor negativo de los sintomas funcionales y de la curva térmica, por oposición al carácter del pulso paradógico, que es casi patognomónico. - Valor de los signos físicos, en particular de la percusión, mucho menos infiel que la auscultación: persistencia de los roces, aunque el derrame sea abundante. - Indicaciones de la punción del pericardio y necesidad de practicarla á su debido tiempo. - Sitio electivo de la punción, por fuera y por debajo de la punta del corazón. - Resultados estadísticos de la

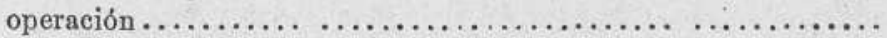

\section{SINFISIS CARDIACA}

Signos fundamentales de la sinfisis cardiaca; exageración de los latidos del corazón, que contrasta con la falta de expansión de las costillas durante los movimientos respiratorios. - Depresión sistólica de la punta del corazón; elevación diastólica de la base. - Interpretación fisiológica de estos signos. - Síntomas secundarios; pequeñez del pulso y debilidad del impulso ventricular. - Influencia de las adherencias pleuriticas concomitantes. Consecuencias relativas al estado del corazón; frecuencia de las complicaciones valvulares y de las dilataciones de las cavidades cardíacas. - Resultados de la autopsia....................

\section{SÍNFISIS CARDIACA}

(Conclusión).

Comparación de un caso de sínfisis cardiaca diferente del anterior. - Falta de la combadura precordial y del impulso cardíaco; retracción del lado izquierdo del pecho; falta de ruidos que indican lesiones valvulares.-Diagnóstico diferencial con las hipertrofias y las dilataciones del corazón sin alteraciones de los orificios. Valor de ciertos signos físicos en los casos obscuros de sínfisis cardíaca: situación de la punta del corazón debajo y por dentro de la línea mamaria, á pesar de la hipertrofia del órgano. Desaparición del choque sistólico ventricular $y$ de la expansión 
diastólica, pero aparición de estos signos en el hueco epigástrico, por trasmisión á distancia de los movimientos cardiacos. Discusión del estado del corazón, que presenta signos pasajeros de insuficiencia mitral por dilatación ventricular, pero que, al parecer, no está interesado de un modo grave. - Duración larga de ciertos casos de sínfisis cardiaca sin trastornos funcionales de importancia.......................................

\section{AFECCIÓN CARDIACA Y RESPIRACIÓN DE CHEYNE-STOKES}

Insuficiencia mitral en un ateromatoso. - Ritmo respiratorio de Cheye-Stokes que se presentó después de cesar la crisis de asistolia, $\mathrm{y}$ duró sin modificarse tres semanas. - Análisis del fenómeno: caracteres del pulso y de la circulación cerebral durante el período de apnea y el de disnea. - Condiciones clínicas en las que se observa este tipo respiratorio; historia del asunto; frecuencia de su aparición como síntoma de uremia : diferencia con la respiración de meningiticos. - Patogenia del fenómeno: á la disnea corresponde un aumento en tensión arterial y de anemia cerebral: á la apnea disminución de la tensión sanguinea y congestión bulbar. - Mecanismo de la excitación y de la depresión alternativas del bulbo. - Papel que desempeñan la fibra cardíaca (Stokes) - las arterias cerebrales y el ateroma basilar (Traube, Filehne) - el estado de la sangre y de gases que contiene. - Para Traube, es efecto de la acumulación de ácido carbónico; para Sachi es consecuencia de la falta de oxígeno. - Es probable que el fenómeno de Cheyne-Stokes sea sólo exageración del automa-

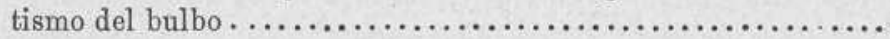

\section{AORTITIS AGUDA}

Congestión pulmonar aguda en el curso de una crisis de aortitis.No tiene ni los caracteres de la congestión inflamatoria, ni los de las congestiones sintomáticas de la albuminuria.-Estos son los sintomas más notables de la aortitis aguda. - Son siempre apiréticos y no van acompañados de accesos dolorosos análogos á la angina de pecho. - Mecanismo de estas crisis accesionales é influencia del sistema nervioso.- Influyen poco sobre el estado del corazón.-Etiología de la aortitis aguda : influencia cada vez más preponderante de las enfermedades infecciosas sobre la génesis de las lesiones vasculares. - Indicaciones terapéuticas.........

\section{AORTITIS CRÓNICA}

La aortitis crónica, á pesar de los sintomas parecidos á los de la aguda, tiene una fisonomía clínica por completo diferente.Predominan los signos en una dilatación difusa del cayado: 
levantamiento en masa de la base del cuello, latidos vasculares en la horquilla esternal, elevación de las arterias subclavias; soplo doble á lo largo del trayecto de la aorta. - Los trastornos funcionales no están siempre en relación con la intensidad de las lesiones. - Valor del dolor retro-esternal y de los fenómenos vertiginosos : alteraciones oculo-pupilares. - Caracteres diferenciales de la dilatación crónica de la aorta y de los aneurismas: evolución diferente de estas dos clases de lesiones ............

\section{AORTITIS - ANGINA DE PECHO}

Aortitis crónica limitada á la aorta y complicada con insuficiencia sigmoidea : falta de ateroma en el resto del sistema vascular. El trastorno funcional predominante es una angina de pecho precoz, de irradiaciones dorsales y cervicales. - Relaciones de la angina de pecho y de la aortitis. - Clasificación de las anginas de pecho.-Anginas verdaderas, caracterizadas por la lesión de las arterias coronarias: sintomatologia de estos casos. - Anginas sintomáticas de una peri-aortitis y de una neuritis del plexo cardiaco. - Anginas neurosis : posibilidad de diagnosticarlas: sintomas diferenciales sacados de su modo de principiar, de las irradiaciones dolorosas predominantes, de la marcha de los accesos y de su cansa provocadora. - Casos de angina de pecho híbridos, orgánicos y neurósicos á la vez: su frecueneia y difieultad de diagnóstico. - Indicaciones pronósticas y terapéuticas........

\section{ATEROMA Y ANEURISMA AÓRTICO}

Variedades del ateroma arterial y de sus localizaciones : asociación frecuente de las cardiopatías y de las lesiones vasculares. Análisis de un caso de este género con sintomas complejos: dilatación aórtica, latidos carotideos unilaterales. - Extasis crónica de las yugulares, supresión completa del pulso radial izquierdo, incompleta del derecho. - Falta de signos estetoscópicos cardio-aórticos. - Discusión de este caso. - No es una cardiopatia primitiva ni secundaria: hay, según toda probabilidad, un aneurisma del cayado de la aorta. - Valor de la supresión del pulso radial é hipótesis sobre este particular. Diagnóstico del sitio y del estado anatómico del aneurisma.-

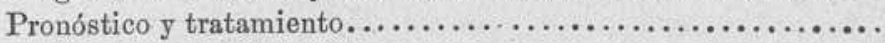

\section{ANEURISMA DE LA AORTA TORÁGICA DESGENDENTE}

El sintoma predominante, casi único, del aneurisma de la aorta torácica descendente es el huélfago. - Diagnóstico diferencial con los tumores del mediastino, el cáncer del pulmón y la adenopatía traqueo-bronquial.-Signos accesorios de esta variedad de aneu- 
rismas: dilatación de la vena yugular izquierda y situación más elevada de la arteria subclavia correspondiente; debilidad del pulso radial izquierdo. - Signos de auscultación pulmonar coneomitantes : soplo anfórico sin estertores, localizado en el hílio del pulmón: valor de este soplo desde el punto de vista de la lócalización del aneurisma. - Errores de diagnóstico posibles : casos de aneurisma de la aorta descendente tomados por accesos de asma, por tuberculosis aguda ó crónica.-Indicaciones etiológicas $\mathrm{y}$ terapéuticas.$\ldots \ldots \ldots \ldots \ldots \ldots \ldots \ldots \ldots \ldots \ldots \ldots \ldots \ldots$

\section{ANEURISMA DE LA AORTA TORÁCICA DESGENDENTE}

que quedó latente hasta su rotura.

Observación de un enfermo con palpitaciones, enfisema y retracción antigua de la pared torácica izquierda. - Desarrollo de una bronco-pneumonia especial, que fue acompañada de esputos hemoptoicos abundantísimos; muerte repentina por hemorragia pulmonar.-Descripción de la autopsia; aneurisma de la porción descendente de la aorta torácica con desgaste de las últimas cinco vértebras dorsales y lesiones de esclerosis y de apoplegia pulmonar.-Concordancia de los síntomas y de las lesiones; mecanismo de la disnea, de las palpitaciones y de la expectoración hemoptoica. - Falta de hipertrofia del corazón á pesar de la lesión aórtica; carácter latente de los síntomas.-Valor de la retracción del pecho en ciertos aneurismas de la aorta. - Influencia de la grippe sobre la evolución de los accidentes últimos ...........

\section{ANEURISMA DE LA AORTA ABDOMINAL}

Observación de un caso complejo de aneurisma de la aorta abdominal, complicado con insuficiencia aórtica y un derrame pleurítico izquierdo. - Etapas diversas del aneurisma : persistencia de un dolor sordo lumbar, con crisis neurálgicas accesionales. - Desarrollo brusco de un aneurisma falso á consecuencia de un tranmatismo. - Descripción del tumor aneurismático sub-diafragmático.-Dificultades de diagnóstico.-Se consideró al principio como una cirrosis hipertrófica expleno-hepática, como una leucocitemia y como un flemón perinefritico.-Caracteres fundados en los latidos expansivos del tumor y posibilidad de confundirlos con los latidos transmitidos á las pulsaciones de los tumores telangiectásicos.-Consecuencias del aneurisma relativamente al estado de la pleura. - Relaciones con la afección cardíaca : modificaciones de la insuficiencia aórtica debidas al aneurisma. Consecuencia respecto á la circulación periférica. - Pronóstico

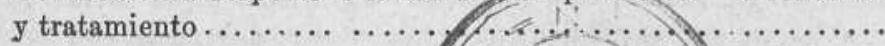




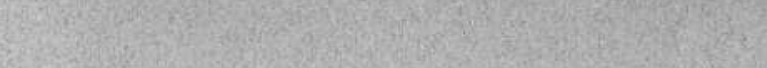






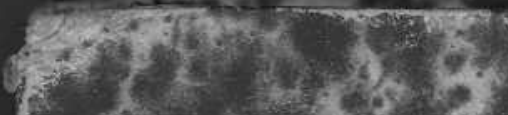

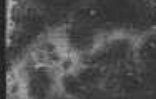

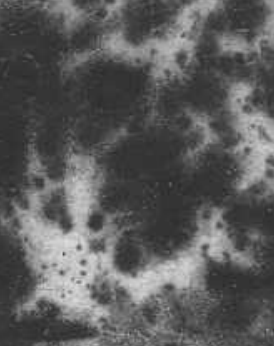

(e) $x x^{2}$

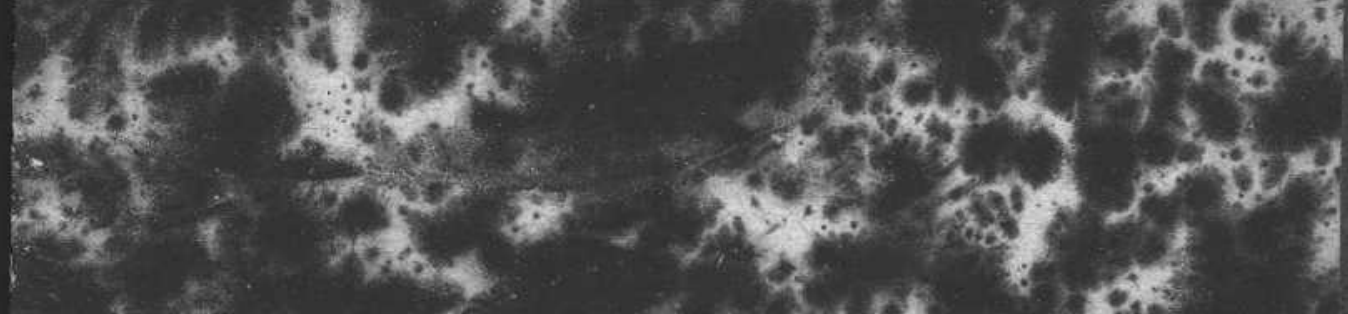

the

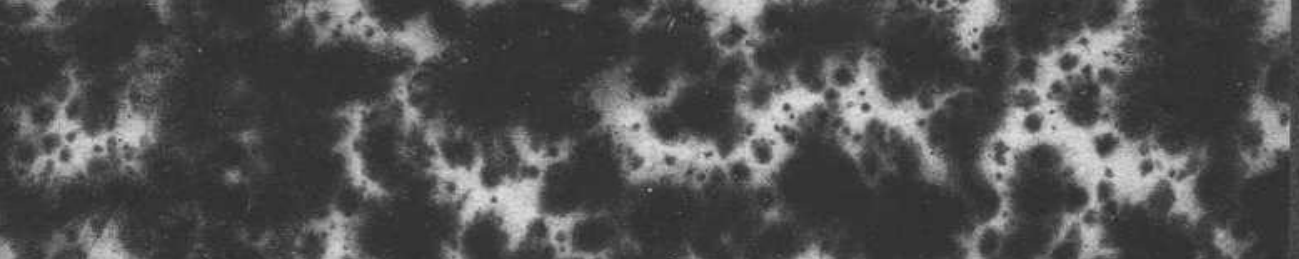

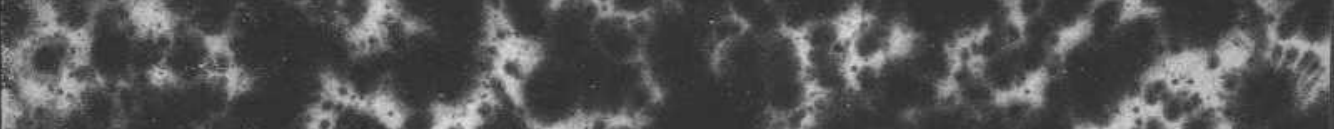

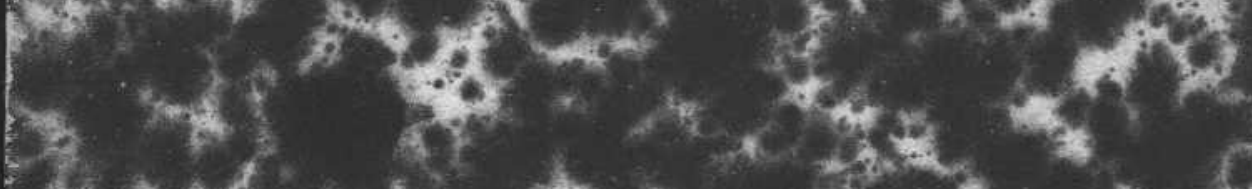

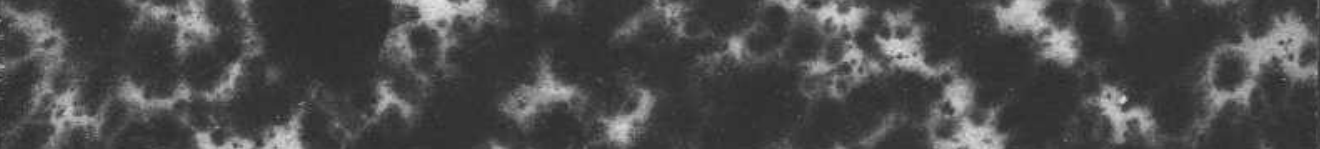

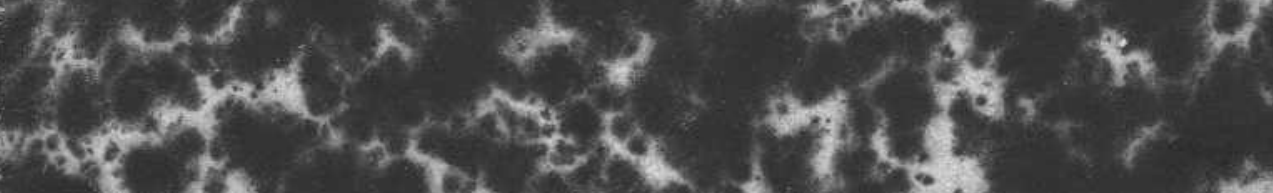

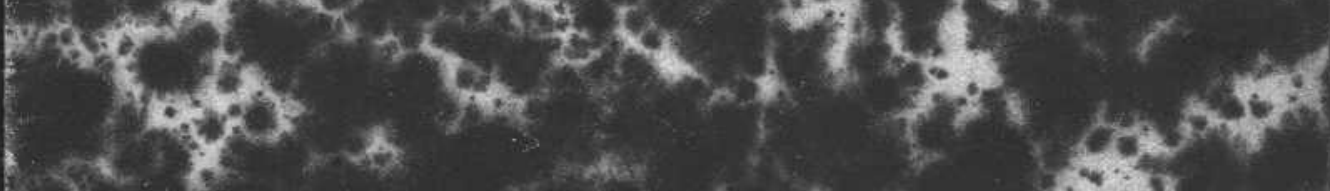

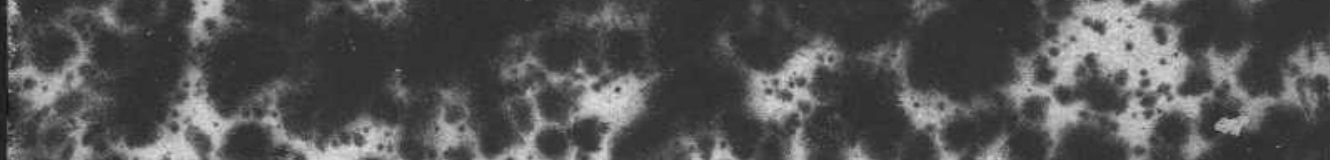

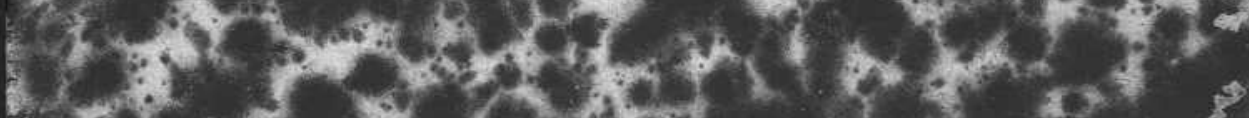

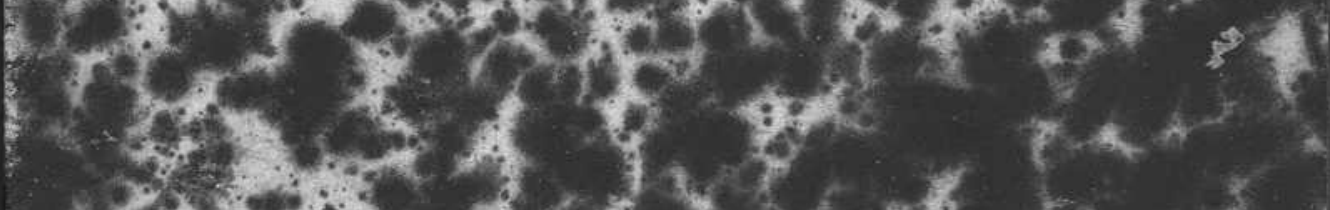
x $5.7,4 \times 2 \times$

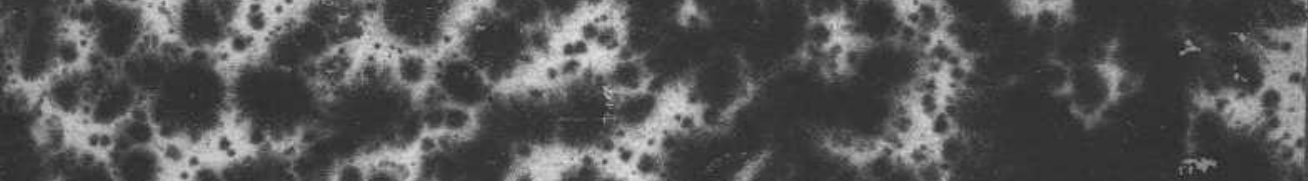

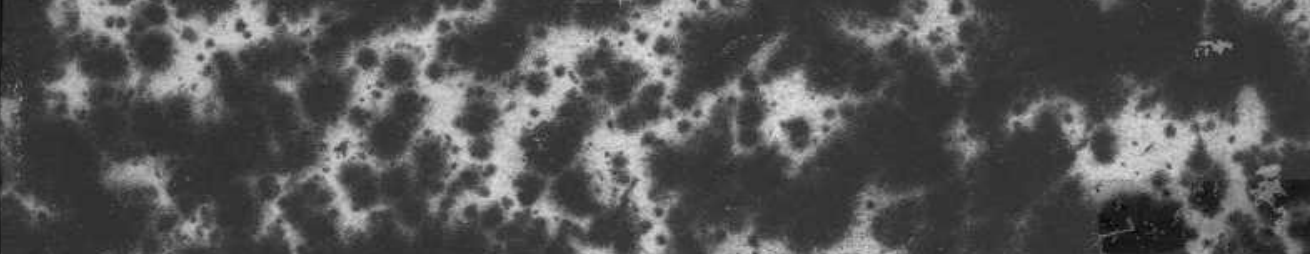

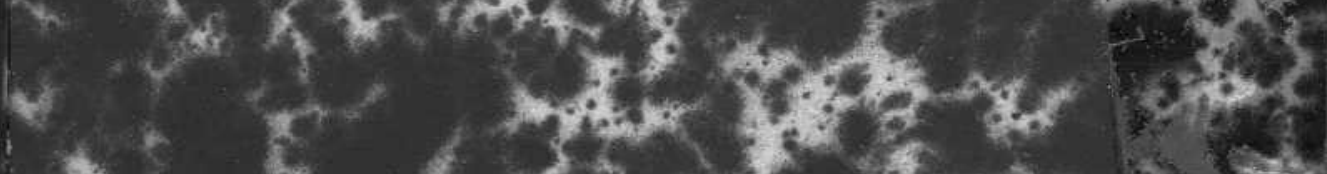

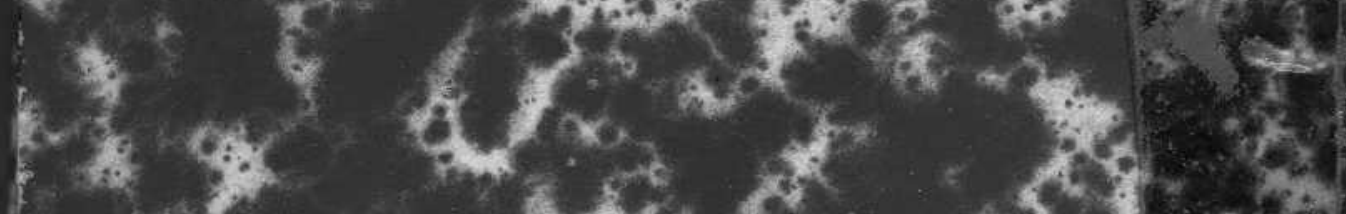
at क से की or ${ }^{2}-x^{2}$ m. in $x^{2}$ 


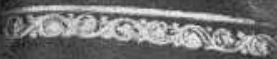

IIมบก

sesoseroro:man 6

HHica vedig

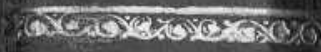

1

1895

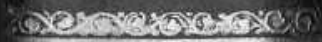

6087 